\title{
Towards a comprehensive dispute settlement system in a China-EU bilateral investment treaty
}

Citation for published version (APA):

Zhao, C. (2020). Towards a comprehensive dispute settlement system in a China-EU bilateral investment treaty. [Doctoral Thesis, Maastricht University]. ProefschriftMaken.

https://doi.org/10.26481/dis.20201214cz

Document status and date:

Published: 01/01/2020

DOI:

$10.26481 /$ dis.20201214cz

Document Version:

Publisher's PDF, also known as Version of record

\section{Please check the document version of this publication:}

- A submitted manuscript is the version of the article upon submission and before peer-review. There can be important differences between the submitted version and the official published version of record.

People interested in the research are advised to contact the author for the final version of the publication, or visit the DOI to the publisher's website.

- The final author version and the galley proof are versions of the publication after peer review.

- The final published version features the final layout of the paper including the volume, issue and page numbers.

Link to publication

\footnotetext{
General rights rights.

- You may freely distribute the URL identifying the publication in the public portal. please follow below link for the End User Agreement:

www.umlib.nl/taverne-license

Take down policy

If you believe that this document breaches copyright please contact us at:

repository@maastrichtuniversity.nl

providing details and we will investigate your claim.
}

Copyright and moral rights for the publications made accessible in the public portal are retained by the authors and/or other copyright owners and it is a condition of accessing publications that users recognise and abide by the legal requirements associated with these

- Users may download and print one copy of any publication from the public portal for the purpose of private study or research.

- You may not further distribute the material or use it for any profit-making activity or commercial gain

If the publication is distributed under the terms of Article $25 \mathrm{fa}$ of the Dutch Copyright Act, indicated by the "Taverne" license above, 
Towards a Comprehensive Dispute Settlement System in a China-EU Bilateral Investment Treaty 
(C) 2020 Chunlei Zhao, Maastricht

Published by ProefschriftMaken || www.proefschriftmaken.nl ISBN 978-94-6423-086-4 
Towards a Comprehensive Dispute Settlement System in a China-EU Bilateral Investment Treaty

\author{
Dissertation
}

\begin{abstract}
to obtain the degree of Doctor at Maastricht University, on the authority of the Rector Magnificus,

Prof.dr. Rianne M. Letschert

in accordance with the decision of the Board of Deans, to be defended in public on
\end{abstract}

Monday 14 December 2020 at 13.00 CET

by

Chunlei ZHAO 


\section{Supervisor}

Prof. dr. P.L.H. van den Bossche

\section{Co-supervisor}

Dr. M.D. Prévost

\section{Assessment Committee Members:}

Prof. dr. J. Vidmar (Chair)

Prof. dr. H. Ruiz Fabri, Director of the Max Planck Institute Luxembourg for International, European and Regulatory Law, Luxembourg

Prof. dr. Z. Yuejiao, Professor of Law, Tsinghua University and Shantou University, China

Dr. I. Alexovicova

The research conducted for this dissertation is supported by the Chinese Scholarship Council. 


\section{Table of Contents}

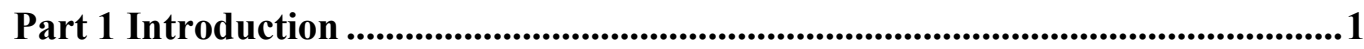

Chapter 1 Introduction.....................................................................................................1

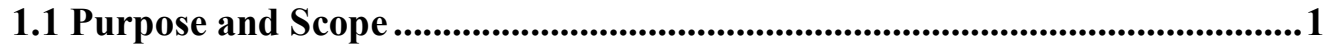

1.1.1 Background Information: Respective Status of China and the EU in

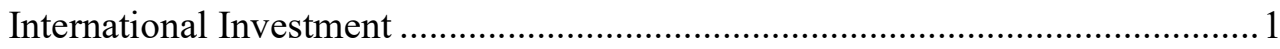

1.1.2 Purpose

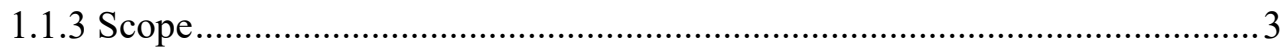

1.2 Research Questions and Structure .....................................................................4

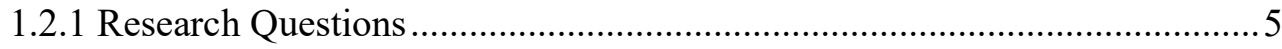

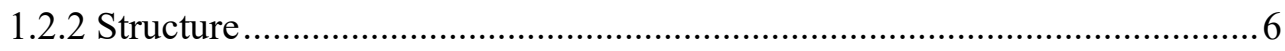

1.3 Methodology ............................................................................................................

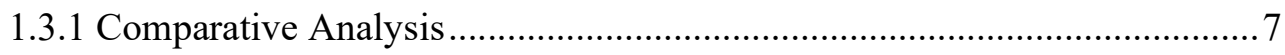

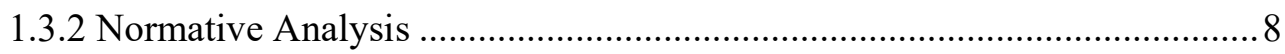

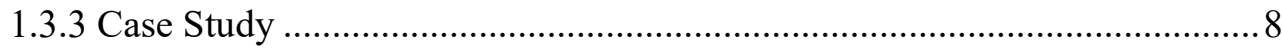

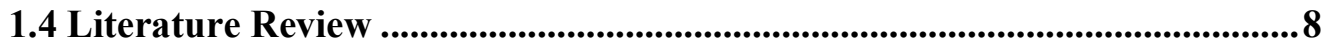

1.4.1 Literature on the Legal Framework of the China-EU Investment

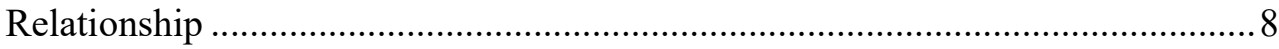

1.4.2 Literature on Investment Dispute Settlement .........................................

1.5 Innovative Character..................................................................................10

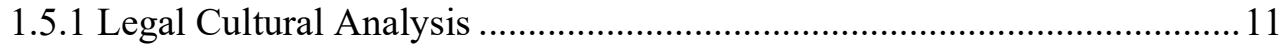

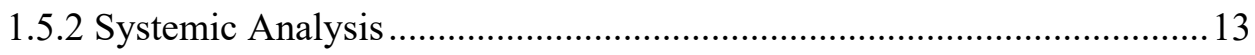

1.5.2.1 Systemic Examination of International Economic Dispute Settlement

1.5.2.2 Systemic Examination of Investment Dispute Settlement

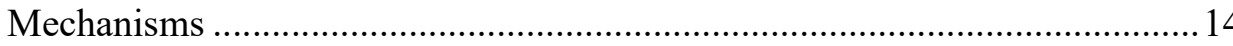

Chapter 2 Background and Context: International Investment and Investment Dispute Settlement Systems .............................................................................................15

2.1 Legal Frameworks for International Investment and International Investment Dispute Settlement .....................................................................................15

2.1.1 The Legal Framework for International Investment................................. 15

2.1.2 The Legal Framework for International Investment Dispute Settlement ... 16

2.2 Dispute Settlement Systems under International Investment Agreements 18

2.2.1 State-State Dispute Settlement Systems ................................................. 19

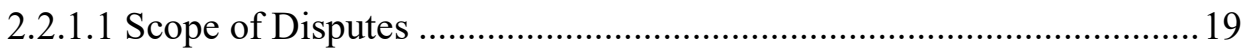

2.2.1.2 Acceptable Claims ...................................................................... 19

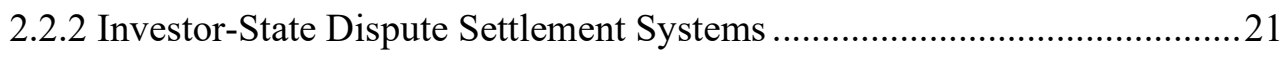

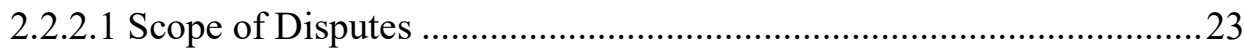

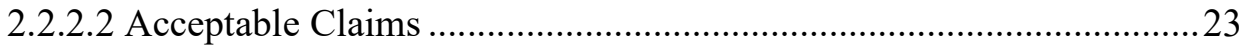

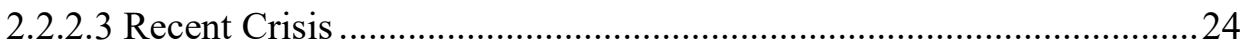

2.2.3 The Relationship between State-State Dispute Settlement Systems and Investor-State Dispute Settlement Systems ...................................................26

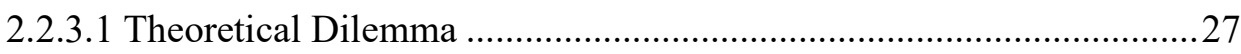


(i) Inter-related Disputes and Correlated Interests

(ii) Co-existence of State-State Dispute Settlement Mechanisms and Investor-State Dispute Settlement Mechanisms 27

(iii) Shared Interpretive Authorities of State-State Tribunals and Investor-

State Tribunals 29

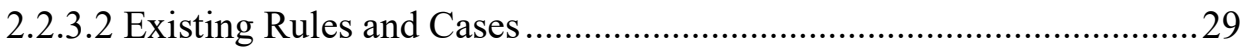

(i) Rules in the ICSID Convention and International Investment Agreements

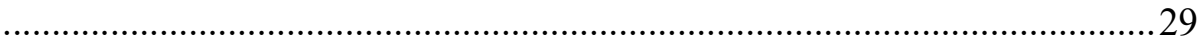

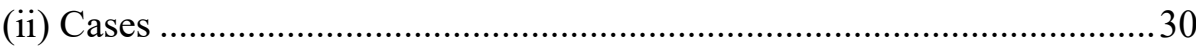

2.3 International Investment Dispute Settlement Mechanisms ...........................34

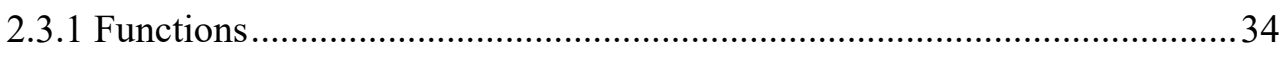

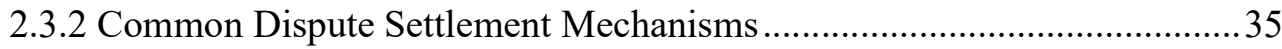

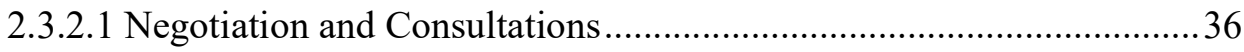

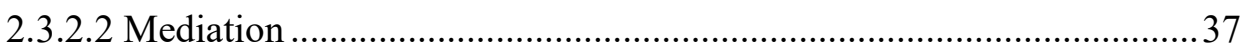

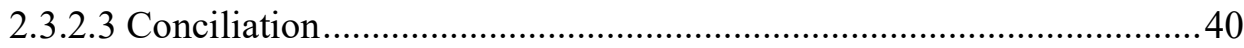

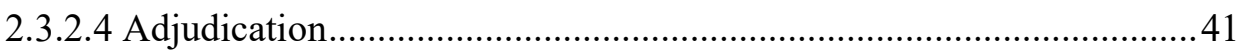

Part 2 Comparison between the Legal Culture in the Dispute Settlement of China

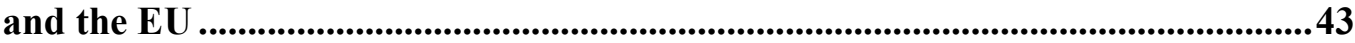

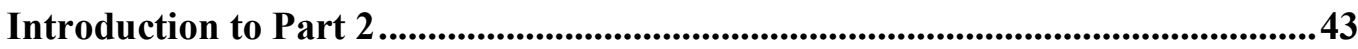

Chapter 3 Legal Cultural Characteristics of Dispute Settlement in China...........44

3.1 Dispute Settlement in Chinese Legal Culture .................................................44

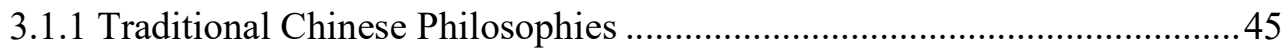

3.1.1.1 Confucianism and Other Influential Traditional Chinese Philosophies

3.1.1.2 Confucian Values and Teachings..................................................... 46

3.1.1.3 Confucian Guidelines on Dispute Settlement....................................48

3.1.2 Contemporary Chinese Ideology ...........................................................49

3.1.2.1 Inheriting the Pursuance of Harmony ...................................................49

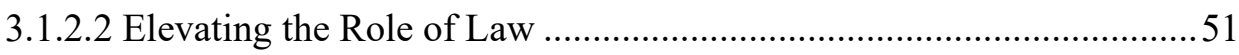

3.2 Dispute Settlement Mechanisms in China's Domestic Legal System...........53

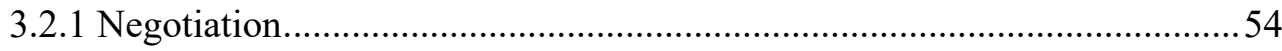

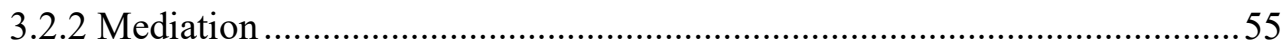

3.2.2.1 Mediation Conducted by Commercial Mediation and Arbitration

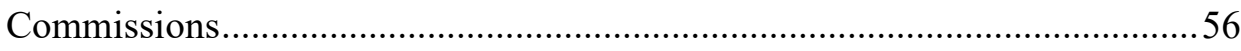

3.2.2.2 Mediation Conducted by Administrative Organs ................................57

3.2.2.3 Mediation in Administrative Reconsideration ....................................57

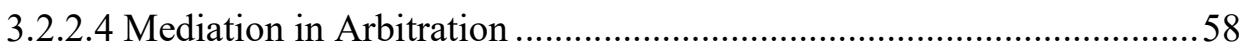

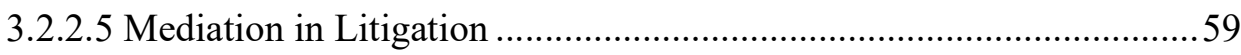

3.2.3 Complaints Coordination for Foreign Investment Related Disputes..........61

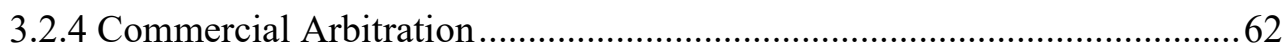

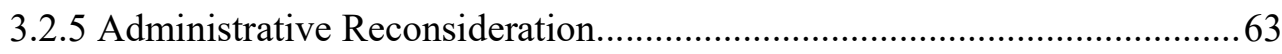

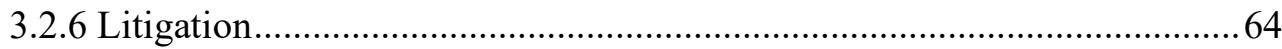


3.2.7 Dispute Settlement Mechanisms under the "One Belt One Road" Initiative

3.3 A Legal Cultural Interpretation of China's Domestic Dispute Settlement Mechanisms

3.3.1 Restoring Harmony through the Promotion of Amicable Dispute

Settlement Mechanisms 67

3.3.2 Satisfying Various Legal Cultural Needs through Extensive Use of Mediation 68

3.3.3 Combining the Construction of the Socialist Rule of Law and the Pursuit of Harmony .69

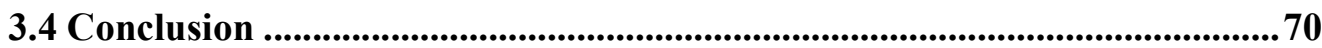

Chapter 4 Legal Cultural Characteristics of Dispute Settlement in the EU .........72

4.1 Dispute Settlement in the European Legal Culture..........................................73

4.1.1 Constants in the European Legal Tradition ........................................... 73

4.1.2 The European Legal Cultural Characteristics of Dispute Settlement......... 74

4.1.2.1 Perception of Law_Justice, Fairness and Legal Rights ....................75

4.1.2.2 The Rule of Law_Law's Supremacy and Benchmark Function........ 76

4.1.2.3 The Attitude towards Litigation-Seeking Rights and Procedural

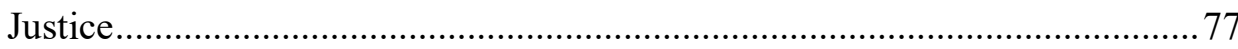

4.2 Dispute Settlement Mechanisms in the EU Member States.........................78

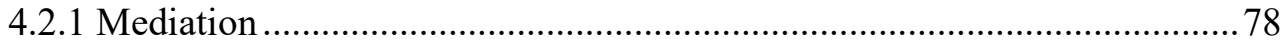

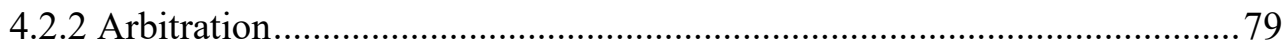

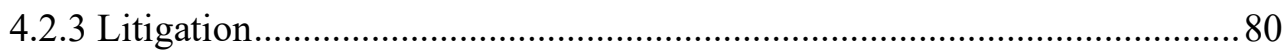

4.3 Rules on Dispute Settlement Mechanisms at the Union Level.....................81

4.3.1 The Legislative Measures of the Union in Dispute Settlement Mechanisms

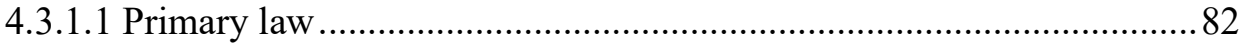

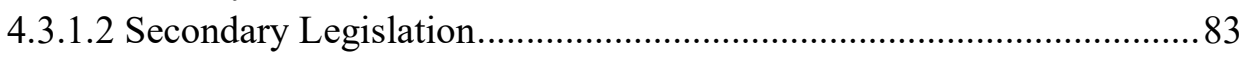

4.3.2 The Practice of the Court of Justice of the European Union on Procedural

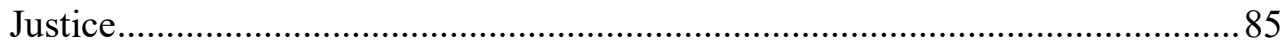

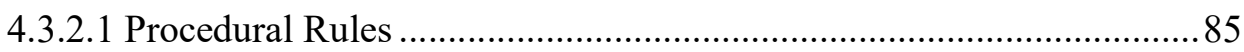

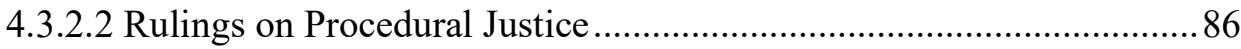

4.3.3 The Union's Other Efforts in Regulating Dispute Settlement Mechanisms

4.3.3.1 The Union's Accession to the European Convention on Human Rights

4.3.3.2 Supervision of EU Member States' National Procedural Justice

Systems . 89

4.3.3.3 The Joint ELI-UNIDROIT Project "From Transnational Principles to

European Rules of Civil Procedure" 90

4.4 An Interpretation of the Dispute Settlement Mechanisms in the EU Member States and the Union's Relevant Regulating Measures-From a Legal Cultural Perspective .90

4.4.1 Consistent Pursuance of the Rule of Law in Dispute Settlement . .91 
4.4.2 Common Use of Litigation for Realizing Justice .................................... 91

4.4.3 Increasing the Use of Mediation to Ensure Access to Justice ....................92

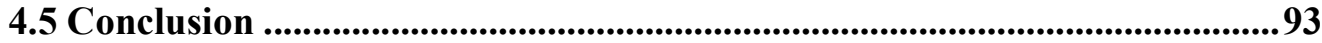

Chapter 5 Comparison of the Legal Culture on Dispute Settlement in China and

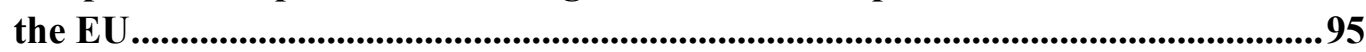

5.1 Legal Cultural Characteristics in Dispute Settlement.....................................95

5.1.1 The Key Aspects of Legal Culture .............................................................95

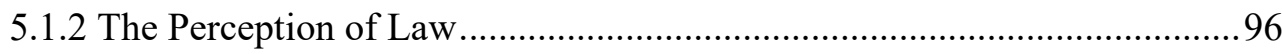

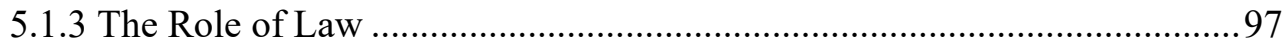

5.1.4 The Objective of Dispute Settlement .......................................................98

5.2 Internal Dispute Settlement Mechanisms............................................................99

5.2.1 The Focus of the Dispute Settlement Systems...........................................99

5.2.2 The Promotion of Mediation.................................................................. 100

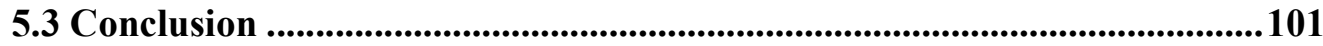

Part 3 Approaches to International Investment Dispute Settlement in China and

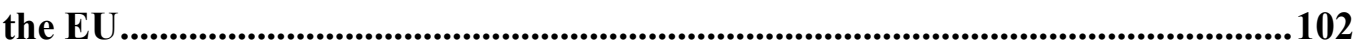

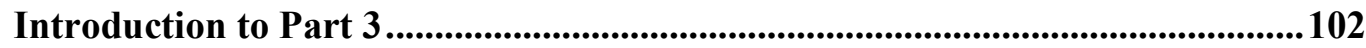

Chapter 6 China's Approach to International Investment and Trade Dispute

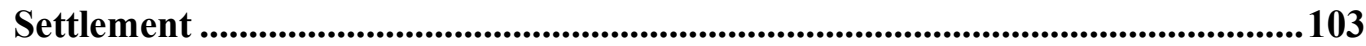

6.1 China's Traditional Attitude towards International Law and International Adjudication ............................................................................................................. 103

6.2 China's Engagement in International Investment Dispute Settlement ....106

6.2.1 Historical Development of China's International Investment Agreements

107

6.2.2 China's Practice of State-State Dispute Settlement Mechanisms ............. 108

6.2.2.1 The State-State Dispute Settlement Mechanisms in China's Model

Bilateral Investment Treaties ..................................................................... 108

6.2.2.2 The State-State Dispute Settlement Mechanisms in China's

International Investment Agreements ........................................................ 113

6.2.2.3 The State-State Dispute Settlement Mechanisms in China's Free Trade

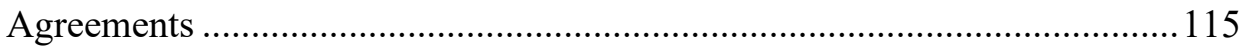

6.2.2.4 China's Practice in the WTO Dispute Settlement System................. 116

6.2.3 China's Practice of Investor-State Dispute Settlement Mechanisms........120

6.2.3.1 The Investor-State Dispute Settlement Mechanisms in China's Model

Bilateral Investment Treaties ............................................................... 120

(i) China's Model Bilateral Investment Treaties (1984 \& 1989)............... 120

(ii) China's Model Bilateral Investment Treaty (1997) ............................ 121

(iii) China's Model Bilateral Investment Treaty (2010) ........................... 121

6.2.3.2 The Investor-State Dispute Settlement Mechanisms in China's

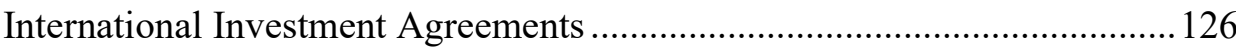

(i) Stage One: No or Limited Acceptance of Investor-State Arbitration

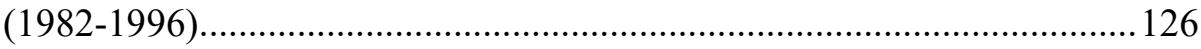


(ii) Stage Two: Overall Acceptance of Investor-State Arbitration (1997-

2009)

(iii) Stage Three: Revised Acceptance of Investor-State Arbitration (2010-)

6.2.3.3 Investment Cases under China's International Investment Agreements

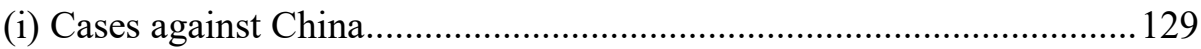

(ii) Cases brought by Chinese Investors ................................................ 130

(iii) Potential Investor-State Dispute Settlement Cases ............................. 132

(iv) An Analysis of China's Investment Cases ....................................... 134

6.2.3.4 China's Attitude towards Investor-State Dispute Settlement Reform

(i) Investor-State Dispute Settlement under the "One Belt One Road"

Initiative

(ii) Transparency in Investor-State Dispute Settlement in UNCITRAL

Working Group II

(iii) Investor-State Dispute Settlement Reform in UNCITRAL Working

Group III

6.3 Conclusion

Chapter 7 The EU's Approach to International Investment and Trade Dispute

7.1 Historical Development of the EU's International Investment Agreements

7.2 The EU's Practice of State-State Dispute Settlement Mechanisms............146

7.2.1 The State-State Dispute Settlement Mechanisms in the EU's Internatioanl

Investment Agreements 146

7.2.2 The State-State Dispute Settlement Mechanisms in the EU's Free Trade Agreements 148

7.2.2.1 Diplomatic State-State Dispute Settlement Mechanisms (with One Exception) 148

7.2.2.2 A Shift to a quasi-WTO dispute settlement Panel Proceedings Model

7.2.3 The EU's Practice in the WTO Dispute Settlement System 192

7.2.3.1 Consistently Frequent Use of the WTO Dispute Settlement System with a High Success Rate....

7.2.3.2 Supporting Attitude towards Amicable Dispute Settlement

Mechanisms

7.2.3.3 Mitigated Compliance and Vigorous Enforcement of Sanctions ...... 194

7.2.3.4 Seeking More Transparency and a Stronger Judiciary ..................... 196

7.3 The EU's Practice of Investor-State Dispute Settlement Mechanisms ..... 198

7.3.1 The Investor-State Dispute Settlement Mechanisms in the Pre-Lisbon Period

7.3.1.1 The Investor-State Dispute Settlement Mechanisms in the EU Member States' International Investment Agreements 198 
7.3.1.2 The Investor-State Dispute Settlement Mechanisms in the Energy

Charter Treaty

7.3.2 The Investor-State Dispute Settlement Mechanisms in the Post-Lisbon Period

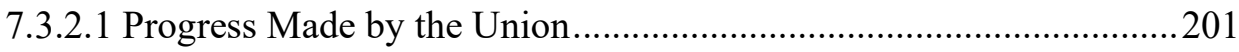

7.3.2.2 Progress Made by EU Member States ..............................................201

7.3.3 The EU's Up-to-date Approach to Investor-State Dispute Settlement - the

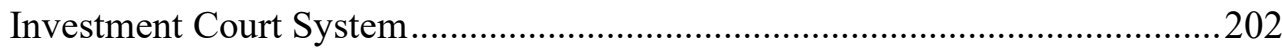

7.3.3.1 The Development History of the Investment Court System..............203

7.3.3.2 Procedural Features of the Investment Court System.......................206

(i) Amicable Settlement through Negotiation and Mediation...................206

(ii) Consultations as a Precondition for Adjudication................................207

(iii) A Two-tiered Court System .........................................................208

(iv) High Professional and Ethical Standards for Adjudicators................211

(v) Significant Roles of Joint Committees and Investors' Home States in Investor-State Dispute Settlement.......................................................212

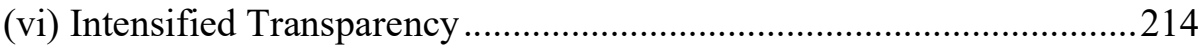

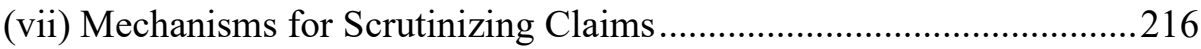

7.3.3.3 Analysis of the Investment Court System.........................................216

(i) Strengthening Amicable Dispute Settlement Mechanisms as an

Alternative Way to have Access to Justice ...

(ii) The Preference for a Permanent Two-tiered Court System to Enhance

the Soundness of Jurisprudence

(iii) Granting Treaty Parties a Significant Role to Stress the Public Law

Nature of International Investment Law ................................................220

7.3.3.4 Proposing the Investment Court System in Multilateral Fora ...........221

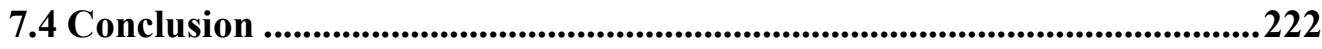

Chapter 8 Comparison between China and the EU on International Investment

Dispute Settlement .................................................................................................................224

8.1 Comparison between the Approaches of China and the EU to International Investment Dispute Settlement .......................................................................224

8.1.1 State-State Dispute Settlement: Similar Trust in a quasi-WTO dispute settlement Panel Proceedings Model ...........................................................224

8.1.2 Investor-State Dispute Settlement: Different Objectives and Focuses .....225

8.2 Comparison between China and the EU on the Reflection of Legal Culture in International Investment Dispute Settlement ..................................................226

8.2.1 Similarities: Consistency between Internal and International Practice and

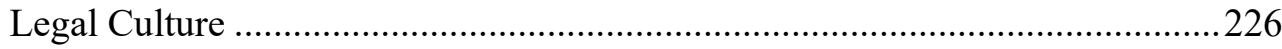

8.2.2 Differences: Compromise vs. Intensification ......................................226

8.3 Conclusion ..............................................................................................227

Part 4 Exploration of the Dispute Settlement System in the Prospective China-EU Bilateral Investment Treaty .........................................................................................228

Introduction to Part 4 ......................................................................................................228 
Chapter 9 The Legal Framework for China-EU Investment: Past and Present229

9.1 An Overview of the Development of the China-EU Investment Legal

Relationship ............................................................................................................229

9.1.1 Before the Lisbon Treaty: General Agreements on Economic Cooperation

and Bilateral Investment Treaties ...

229

9.1.2 After the Lisbon Treaty: Heading towards a China-EU Bilateral Investment Treaty

231

9.2 The Current International Legal Framework for the China-EU Investment

Relationship .................................................................................................................233

9.2.1 Bilateral Investment Treaties between China and EU Member States .....233

9.2.2 Other Applicable Multilateral International Agreements ........................2235

9.3 The Dispute Settlement Systems in the Bilateral Investment Treaties between China and EU Member States ........................................................2236

9.3.1 The State-State Dispute Settlement Mechanisms in the Bilateral Investment

Treaties between China and EU Member States ............................................2236

9.3.2 The Investor-State Dispute Settlement Mechanisms in the Bilateral

Investment Treaties between China and EU Member States..........................2252

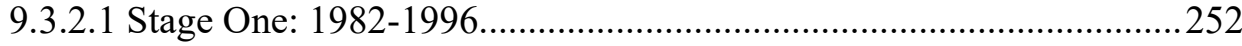

(i) Amicable Dispute Settlement Mechanisms .....................................252

(ii) Adjudicative Dispute Settlement Mechanisms .................................253

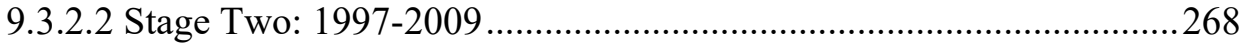

(i) Amicable Dispute Settlement Mechanisms .......................................268

(ii) Adjudicative Dispute Settlement Mechanisms ..................................268

9.3.3 Cases under the Bilateral Investment Treaties between China and EU

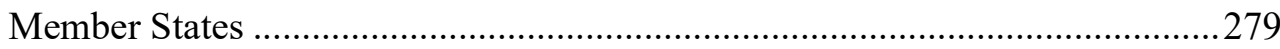

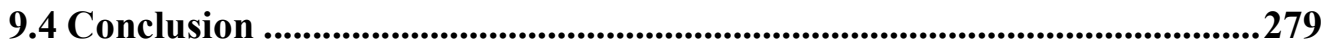

Chapter 10 The State-State Dispute Settlement System in the Prospective China-

EU Bilateral Investment Treaty .................................................................281

10.1 The Objective of the State-State Dispute Settlement System.....................281

10.2 The Jurisdiction of the State-State Dispute Settlement System................282

10.3 Procedural Designs of State-State Dispute Settlement Mechanisms.......283

10.3.1 Amicable Dispute Settlement Mechanisms .........................................283

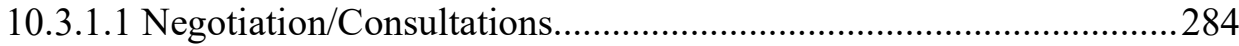

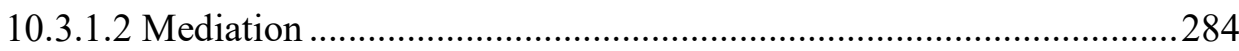

10.3.2 The Adjudicative Dispute Settlement Mechanism ...............................287

10.3.2.1 A quasi-WTO dispute settlement Panel Proceedings Mechanism...287

10.3.2.2 Transparency and Third-Party Participation..................................28

10.3.2.3 The Effect of State-State Adjudication Decisions ..........................289

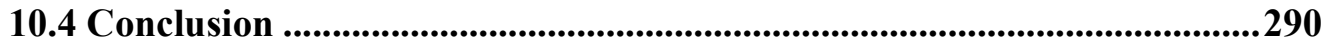

Chapter 11 The Investor-State Dispute Settlement System in the Prospective China-EU Bilateral Investment Treaty ........................................................292

11.1 The Objective of the Investor-State Dispute Settlement System .............293

11.2 The Jurisdiction of the Investor-State Dispute Settlement System .........294 
11.3 Amicable Dispute Settlement Mechanisms...........................................294

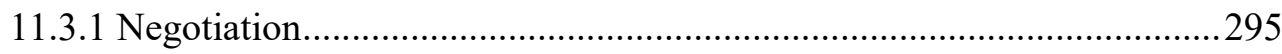

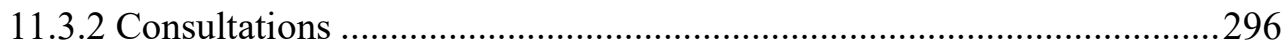

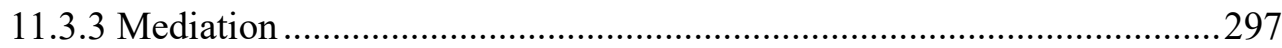

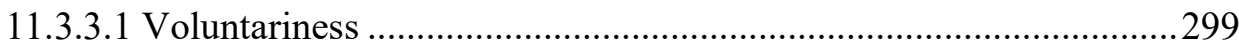

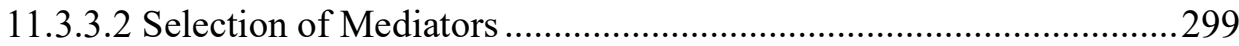

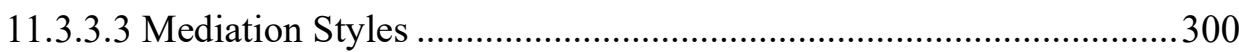

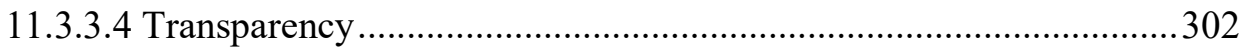

11.3.3.5 Enforcement of Settlement Agreements .........................................303

11.4 The International Adjudication Mechanism ........................................305

11.4.1 Adjudication Forum: Arbitration or an Investment Court? ...................305

11.4.2 Selection of Adjudicators: by Disputing Parties or by Treaty Parties? .. 308

11.4.3 The Role of the Joint Committee in Dispute Settlement: Influential or

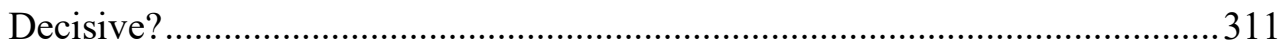

11.4.4 Procedural Transparency: Default or Exceptions? ................................. 314

11.4.5 An Appeal Mechanism: Necessary for Consistency and Correctness? ...316

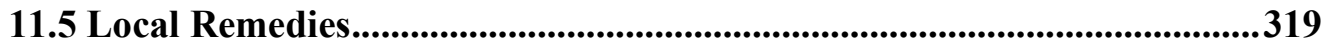

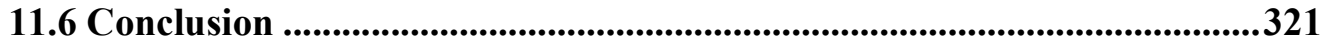

Chapter 12 The Relationship between the State-State Dispute Settlement System and the Investor-State Dispute Settlement System .....................................................323

12.1 The Separation and Connection between the State-State Dispute Settlement System and the Investor-State Dispute Settlement System............324

12.2 Combining the State-State Dispute Settlement System and the Investor-

State Dispute Settlement System .................................................................326

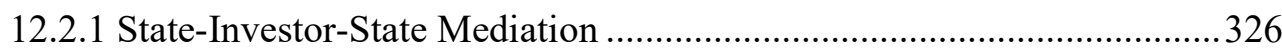

12.2.2 Combining the Rosters of Adjudicators for State-State and Investor-State

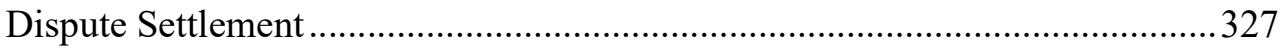

12.2.3 Granting Investors Procedural Rights in State-State Dispute Settlement

327

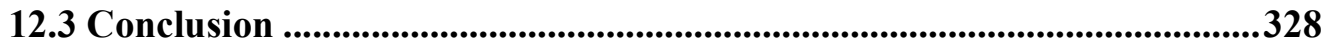

Part 5 Conclusion ................................................................................................329

Chapter 13 Summary of Conclusions .............................................................................3329

Bibliography ..........................................................................................................................340

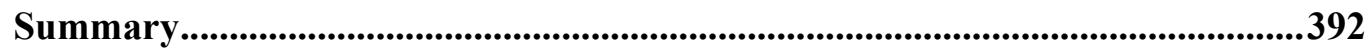

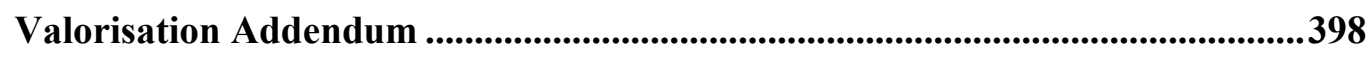

Curriculum Vitae .....................................................................................................................402 


\section{Part 1 Introduction}

\section{Chapter 1 Introduction}

\subsection{Purpose and Scope}

\subsubsection{Background Information: Respective Status of China and the EU in International Investment}

China $^{1}$ and the $\mathrm{EU}^{2}$ are two of the biggest players in international investment. In the past five years, the foreign direct investment inflows and outflows in China and the EU were among the top five in the world. ${ }^{3}$ China's position in international investment continues to improve, from being a purely destination for global foreign investment flows to being a state with both strong investment inflows and outflows. ${ }^{4}$ According to UNCTAD World Investment Report 2019, in 2018, China was the second largest recipient of foreign direct investment in the world, attracting \$139 billion inflows. It was in second place with regard to outflows, with an amount of $\$ 130$ billion. ${ }^{5}$ Since 2009, the Union began to handle foreign direct investment policies on behalf of its Member States. ${ }^{6}$ Now, the EU is the world's largest exporter and importer of foreign

\footnotetext{
${ }^{1}$ Since Hong Kong, China, Macao, China, and Chinese Taipei enjoy their own power in negotiating international investment agreements, and the prospective China-EU Bilateral Investment Treaty would be an agreement between mainland China and the EU, in the following discussion, "China" only refers to mainland China, unless otherwise specified.

2 For necessary differentiation, in the present thesis, unless specifically identified, "the EU" is used as a general reference to the European Union together its Member States. "The Union" is used when the reference is to the Union only. Regarding the situations where only EU Member States are referred to, the expression used is "EU Member States" or "its Member States".

${ }^{3}$ United Nations Conference on Trade and Development (UNCTAD), World Investment Report 2019: Special Economic Zones, 2019, available at: https://unctad.org/en/PublicationsLibrary/wir2019_en.pdf, last visited on 06.08.2020. United Nations Conference on Trade and Development (UNCTAD), World Investment Report 2018: Investment and New Industrial Policies, 2018, available at: https://unctad.org/en/PublicationsLibrary/wir2018_en.pdf, last visited on 06.08.2020. United Nations Conference on Trade and Development (UNCTAD), World Investment Report 2017: Investment and the Digital Economy, 2017, available at: http://unctad.org/en/PublicationsLibrary/wir2017_en.pdf, last visited on 06.08.2020. United Nations Conference on Trade and Development (UNCTAD), World Investment Report 2016: Investor Nationality: Policy Challenges, 2016, available at: https://unctad.org/en/PublicationsLibrary/wir2016_en.pdf, last visited on 06.08.2020. United Nations Conference on Trade and Development (UNCTAD), World Investment Report 2015: Reforming International Investment Governance, 2015, available at: http://unctad.org/en/PublicationsLibrary/wir2015_en.pdf, last visited on 06.08.2020.

${ }^{4}$ Norah Gallagher \& Wenhua Shan, Chinese Investment Treaties: Policies and Practice, Oxford University Press, 2009, pp. 7, 10. David Shambaugh, China Goes Global: The Partial Power, Oxford University Press, 2013. Unlike Chinese inbound investment, which became significant around 1990, Chinese outbound investment increased greatly only after 2000. In 2014, the inflow and outflow of foreign direct investment in China for the first time came close to being balanced. See: Ministry of Commerce of the People' s Republic of China \& National Bureau of Statistics of the People' s Republic of China \& State Administration of Foreign Exchange 中华人民共和国商务部\&中华 人民共和国国家统计局\&国家外汇管理局, 2014 Statistical Bullentin of China's Outward Foreign Direct Investment 2014 年度中国对外直接投资统计公报, China Statistics Press 中国统计出版社, 01.09.2015, p. 85.

${ }^{5}$ United Nations Conference on Trade and Development (UNCTAD), World Investment Report 2019: Special Economic Zones, 2019, available at: https://unctad.org/en/PublicationsLibrary/wir2019_en.pdf, pp. 4, 7, last visited on 06.08.2020. With the current progressively developed "One Belt One Road" Initiative, Chinese outward investment is expected to surpass the amount of inward investment flows into China soon.

${ }^{6}$ European Commission, Investment, available at: http://ec.europa.eu/trade/policy/accessing-markets/investment/, last visited on 31.07.2020.
} 
direct investment. ${ }^{7}$ During 2016-2017, the foreign direct investment inflows of the EU amounted to $\$ 304$ billion and the outflows were $\$ 435$ billion. $^{8}$

Since 1986, EU investment in China has increased more than 25-fold and, in 2000, the EU became the principal investor in China. ${ }^{9}$ Recent years also witnessed a rapid increase of Chinese investments in the EU. ${ }^{10}$ In fact, Chinese investments in Europe have been much more resilient than investments in other parts of the world. ${ }^{11}$

\subsubsection{Purpose}

With the proliferation of international investment agreements (hereinafter "IIAs") 12 throughout the world, China and the EU have also made concerted efforts to negotiate a China-EU Bilateral Investment Treaty (hereinafter "China-EU BIT"). Such negotiations were formally launched at the $16^{\text {th }}$ EU-China Summit of 21 November $2013{ }^{13}$ This prospective BIT will replace the 25 existing BITs between China and 27 EU Member States with one single comprehensive investment agreement. ${ }^{14}$ It aims to remove market access barriers to investment and provide a high level of protection to investors and investments in the EU and the Chinese markets by incorporating up-todate substantial and procedural regulations on investment. ${ }^{15}$ Once concluded, this investment agreement will undoubtedly be influential and further promote cooperation between China and the EU in the field of international investment. As of 30 April 2020, there have been 28 rounds of negotiations between the EU and China.

Although not much concrete information has been released concerning the ongoing negotiations, disagreements regarding what constitutes appropriate dispute settlement

\footnotetext{
7 European Commission, The Multilateral Investment Court Project, 07.06.2019, available at: http://trade.ec.europa.eu/doclib/press/index.cfm?id=1608, last visited on 31.07.2020.

${ }^{8}$ United Nations Conference on Trade and Development (UNCTAD), World Investment Report 2018: Investment and New Industrial Policies, 2018, available at: https://unctad.org/en/PublicationsLibrary/wir2018_en.pdf, p. 184, last visited on 06.08.2020.

9 Wenhua Shan, The Legal Framework of EU-China Investment Relations: A Critical Appraisal, Hart Publishing, 2005 , p. 1.

${ }^{10}$ The states of Eastern and Central Europe were identified as popular potential places for more Chinese investment. See: Armand de Mestral C.M., The Lisbon Treaty and the Expansion of EU Competence Over Foreign Direct Investment and the Implications for Investor-State Arbitration, at: Karl P. Sauvant (ed.), Yearbook on International Investment Law \& Policy 2010-2011, Oxford University Press, 2012, p. 366.

11 Rhodium Group LLC, EU-China FDI Monitorr-3Q 2017 Update: Public Version, 2017, available at: http://trade.ec.europa.eu/doclib/docs/2018/january/tradoc_156572.pdf, p. 8, last visited on 01.08.2020. This report identified three major reasons of such resilience: first, "investment in the EU were much more diversified and less driven by financial investors"; second, "investments in Europe can more easily ride on the 'Belt and Road' (B\&R) boom as investors can pitch European deals in infrastructure, transportation and finance as B\&R investments and thus easier access financing"; Third, "Europe's regulatory framework still does not pose a major problem for most investments".

${ }^{12}$ In this paper, the phrase "international investment agreement (IIA)" is used in a broad sense, which refers to an agreement on investment concluded by states, regardless whether it is in the form of an independent treaty or part of a comprehensive economic agreement in a bilateral or multilateral context.

13 European Commission, EU and China Begin Investment Talks, Press Release, 20.01.2014, available at $\mathrm{http}: / /$ europa.eu/rapid/press-release_IP-14-33_en.htm, last visited on 31.07.2020.

14 In June 2016, the United Kingdom held a referendum on membership of the EU, resulting in $51.89 \%$ of votes cast in favour of leaving. After that, on 29 March 2017, it formally initiated the withdrawal process. On 31 January 2020, the United Kingdom officially left the EU, making the total number of EU Member States reduce to 27. The only EU Member State that has not reached an IIA with China is Ireland.

15 European Commission, Countries and Regions-China, available at: http://ec.europa.eu/trade/policy/countriesand-regions/countries/china/, last visited on 31.07.2020.
} 
systems ${ }^{16}$ in the prospective China-EU BIT is expected to be one of the major stumbling blocks in the negotiations. ${ }^{17}$ This expectation is based on the fact that China and the EU have presented conflicting attitudes regarding various issues in investment dispute resolution. It is, therefore, important to consider what the appropriate arrangements would be for China, the EU and the investors from both territories to deal with potential investment disputes under a China-EU BIT.

This thesis aims to address this issue by exploring the procedural design of the dispute settlement systems proposed for the prospective China-EU BIT, including the systems for both state-state and investor-state disputes. It does not intend to present an allencompassing treaty text that to be incorporated into the prospective China-EU BIT. Instead, based on the expected possible proposals from China and the EU, it focuses on the potential thorny issues that could become the stumbling blocks in negotiations for this prospective investment agreement and recommends possible solutions in order to address those obstacles.

\subsubsection{Scope}

Various factors affect the proposals made in the negotiations of an investment agreement and the reactions to the proposals by each party, including proposals for the design of the dispute settlement system in such an agreement. This thesis does not aim to give a comprehensive analysis of all of these factors, but it will focus the examination on two essential factors: the negotiating parties' existing dispute settlement practice and the legal culture in each party with regard to dispute settlement.

First, the existing practice in the territory of each party in the field of investment dispute settlement can provide insights or direct evidence to predict a party's possible proposal regarding the design of the investment dispute settlement system in treaty negotiations for a new IIA. ${ }^{18}$ Thus, the practice of China and that of the EU in investment dispute settlement forms the foundation of the present work. This includes the concluded IIAs and the cases brought under those IIAs. In addition, state-state dispute settlement mechanisms (hereinafter "DSMs"), such as those in Free Trade Agreements (hereinafter "FTAs") ${ }^{19}$ and under the World Trade Organization (WTO) Dispute

\footnotetext{
${ }^{16}$ In the present thesis, a "dispute settlement system" is defined as a system composed of various dispute settlement mechanisms (DSMs). Under an IIA, for investment dispute settlement, two dispute settlement systems may be available: a state-state dispute settlement system and an investor-state dispute settlement system.

17 In the context of discussing dispute settlement, some scholars argued for the distinction between "dispute" "settlement" and "conflict" "resolution". See e.g. Raymond Shonholtz, A General Theory on Disputes and Conflicts, Journal of Dispute Resolution, Vol. 2003, 2003, pp. 403-415. However, considering "dispute" and "conflict" as well as "resolution" and "settlement" are more often used interchangeably, the present thesis follows the mainstream practice of using them as synonyms.

It should also be noted that dispute settlement and conflict resolution are different from conflict management, which often refers to the pre-dispute stage, where certain measures can play a role in preventing a conflict developing into a real dispute. See: Roberto Echandi, Complementing Investor-State Dispute Resolution: A Conceptual Framework for Investor-State Conflict Management, at: Roberto Echandi \& Pierre Sauvé (eds.), Prospects in International Investment Law and Policy: World Trade Forum, Cambridge University Press, 2013, pp. 270-305. Conflict management focuses more on gathering information, inspecting the situation and identifying issues, which thus goes beyond the scope of the present thesis.

18 Although the content of an IIA is a result of bargaining by the treaty parties and a compromise between their different preferences, the inspiration for each party's possible attitude towards certain issues can deduced, for example, by examining its practice under other IIAs concluded within the same period of time.

19 An FTA normally refers to a contractual arrangement that encompasses mutual preferential treatment between
} 
Settlement System are also relevant and are also fall within the scope of the present thesis. $^{20}$

In a fast-developing field such as international investment law, and especially investment dispute settlement, relying only on existing practice to predict a party's future approach is not enough. One reason is that the previously concluded treaties are likely not to cover all the issues that a treaty party would like to address in prospective treaties. Even when an issue was touched upon in past practice, a treaty party may still want to incorporate new changes to ensure that all up-to-date developments are included in a new treaty. Furthermore, compromise is normal when negotiating a new agreement and, therefore, predicting each party's reaction to the various proposals is indispensable. This makes it necessary to consider other elements that may affect a party's position. Such elements are admittedly broad and varied, and therefore it is difficult to provide a comprehensive analysis of all such elements. The focus here is on the elements that are relevant to dispute settlement, making a party's legal culture one of the elements that cannot be neglected, since a dispute settlement process is "in large part a reflection of the culture in which they are embedded". ${ }^{21}$ A legal cultural analysis can indicate some underlying reasons for certain approaches to dispute resolution and it can reveal the ideological preferences of the treaty parties. Moreover, it is reasonable to expect that certain procedural arrangements may be difficult to negotiate about if they are supported by the values and principles embedded in one's legal culture. Therefore, the present thesis also explores the legal cultural characteristics of China and those of the EU regarding dispute settlement by analysing the respective legal cultures and the internal practice in relation to dispute settlement. ${ }^{22}$

\subsection{Research Questions and Structure}

As mentioned in Section 1.1.2, supra, this thesis aims to explore the dispute settlement system in the prospective China-EU BIT by identifying the obstacles that may stand in the way of a successful conclusion of the agreement and to provide possible solutions. In order to achieve these aims, three main research questions are raised and will guide the discussion. Based on these three questions, the thesis is structured into five parts, including 13 chapters.

\footnotetext{
states, with regard to the trade in goods and/or services originating in such territories, by eliminating duties and other restrictions to commerce. Most contemporary agreements that are titled FTAs also often cover issues such as investment, government procurement, competition, etc. See: Stephen Woolcock, A Framework for Assessing Regional Trade Agreements: WTO-Plus, at: Gary P. Sampson \& Stephen Woolcock (eds.), Regionalism, Multilateralism and Economic Integration: the Recent Experience, United Nations University Press, 2003, pp.18-31. The phrase "Free Trade Agreement (FTA)" used in the present work refers to preferential trade arrangements reached among states, regardless of whether they are titled "free trade agreement", "preferential trade agreement", "cooperation agreement", or any other name.

${ }^{20}$ For a further explanation on the relevance of state-state DSMs in FTAs and the WTO Dispute Settlement System, see Section 1.5.2.1, infra.

${ }^{21}$ The author also pointed out that "in turn, the ways in which disputes are managed also play an important role in shaping the cultures in which they operate". See: Oscar G. Chase, Law, Culture, and Ritual-Disputing Systems in Cross-Cultural Context, New York University Press, 2005, p. 2.

${ }^{22}$ For a further illustration of the legal cultural analysis conducted in the thesis, see Section 1.5.1, infra.
} 


\subsubsection{Research Questions}

In order to guide the analysis, the three main research questions are divided into several sub-questions, as follows.

- Question 1: Whether, and if so to what extent, differences in legal culture determine China's and the EU's respective approaches to investment dispute settlement at the internal level?

- 1.1 Taking account of legal tradition, what are the legal cultural characteristics of China and those of the EU regarding dispute settlement? What are the similarities and differences between China and the EU in this respect?

- 1.2 Have the legal cultural characteristics in China and the EU been reflected in their internal dispute settlement systems and, if so, how? What are the similarities and differences between China and the EU in this respect?

- Question 2: Do differences in legal culture determine the respective approaches of China and the EU to investment dispute settlement at the international level and, if so, to what extent?

- 2.1 What have China and the EU done to date regarding international investment dispute settlement, including state-state and investor-state dispute resolution? What are the similarities and differences between China and the EU?

- 2.2 Have the legal cultural characteristics in China and the EU been reflected in their performances in international investment dispute settlement and, if so, how and to what extent?

- Question 3: What would/could the dispute settlement system in the prospective China-EU BIT look like?

- 3.1 How is the investment relationship between China and the EU, and what is the current legal framework that governs it? What progress has been made towards a China-EU BIT?

- 3.2 What would/could China and the EU propose for the dispute settlement system in a China-EU BIT? Anticipating proposals from both parties, what are the benefits and difficulties arising from the dispute settlement system? For the benefits, what could China and the EU do with them? For the potential thorny issues, what are the suggested solutions?

The above research questions are inter-related and require a progressive approach, which means that the latter questions depend upon the answers to the former questions. The answer to each question provides inspiration with its own value, and finally they all contribute to addressing the primary goal of the thesis: to explore the comprehensive dispute settlement system in the prospective China-EU BIT. 


\subsubsection{Structure}

Addressing the research questions in turn, this thesis is organized into five parts and 13 chapters. Part 1 contains two chapters dealing with preliminary issues, providing the necessary basis for the discussions in the following chapters and providing readers with useful background information. The present Chapter 1 offers an introduction to the whole thesis, including its purpose and scope, research questions and structure, methodology, literature review, and innovative characteristics. Chapter 2 addresses general topics that are relevant to the theme of the present thesis, including the legal framework of international investment and dispute settlement in this field. The latter specifically discusses the two systems under IIAs for state-state dispute settlement (hereinafter "SSDS") and investor-state dispute settlement (hereinafter "ISDS"), ${ }^{23}$ including the various DSMs often contained in such systems.

Part 2, which includes Chapters 3-5, compares the approach of China and that of the EU to dispute settlement from a legal cultural perspective. Chapter 3 analyses the legal cultural characteristics of dispute settlement in China from two points of view: dispute settlement under traditional Chinese philosophies and contemporary Chinese ideologies, and the DSMs in China's legal system. In particular, it provides an interpretation of China's domestic dispute settlement system from a legal cultural perspective, in order to examine whether and, if so, how China's legal cultural characteristics in relation to dispute settlement have been reflected in its current internal practice. Correspondingly, Chapter 4 identifies the legal cultural features of dispute settlement and internal DSMs within the EU. Compared to China, the situation of the EU is more complex because of its special nature as a Union comprised of 27 Member States. As a result, in order to provide a conclusion on the EU's legal culture of dispute settlement, both the Union's measures on regulating DSMs and the practice of the Member States deserves attention. Like the analysis conducted for China, a legal cultural interpretation of the DSMs in the domestic legal systems of EU Member States and the Union's relevant regulating measures is also provided. After that, Chapter 5 compares the research results presented in Chapters 3 and 4, in order to examine the similarities and differences between the legal culture of China and that of the EU on dispute settlement, and how their internal dispute settlement systems have respectively been affected by that legal culture.

Part 3 examines the existing practice of China and that of the EU in the field of international investment dispute settlement. Both concluded treaties and specific cases involving China or the EU or their investors are within the scope of analysis of Chapter 6 (focusing on China) and Chapter 7 (focusing on the EU). These two chapters also explore the relationship between the legal culture of dispute settlement and the approach to international investment dispute settlement in China and the EU. In the end,

\footnotetext{
${ }^{23}$ It is noted that "investor-state dispute settlement (ISDS)" often refers in particular to investor-state arbitration in the existing literature. At the same time, there are many ways to enable foreign investors to invoke ISDS, such as pursuant to the domestic legislation of the host state or through contracts between investors and governments. In the present thesis, ISDS is used in a broader sense by incorporating all types of DSMs for resolving disputes between investors and host states, and it only refers to disputes invoked by IIAs, namely, treaty-based claims.
} 
Chapter 8 offers a horizontal comparison between the two sides in a similar way as in Chapter 4.

Based on the analyses in previous chapters, Part 4 moves on to the crucial step of exploring the dispute settlement system in the prospective China-EU BIT. Chapter 9 first introduces the progress that has been made regarding the legal relationship between China and the EU with regard to investment, with a focus on the dispute settlement systems in the existing BITs concluded between China and EU Member States and the cases brought thereunder. The remainder of this part seeks to identify the possible design of state-state and investor-state dispute settlement systems, suggesting how they may be shaped to meet the special needs of the treaty parties. Specifically, Chapter 10 and Chapter 11 respectively discuss the systems for SSDS and ISDS, focusing on the objective, jurisdiction and the procedural features of the DSMs contained in each one. As a necessary further step, Chapter 12 analyses the relationship between these two dispute settlement systems by considering their separation, connection and possible combination. It aims at proposing innovative suggestions for this theoretically and practically difficult and problematic issue to ensure that the two aspects of the comprehensive dispute settlement system under a China-EU BIT can cooperate with each other, contributing to successful investment dispute settlement under this treaty.

In the end, Part 5 presents the summary of the conclusions reached in the present thesis.

\subsection{Methodology}

The methodology adopted in this thesis covers five methods: comparative analysis, normative analysis, case study, legal cultural analysis, and systemic analysis. How they are used in the analysis in the following chapters is introduced briefly below. Since the last two methods, legal cultural analysis and systemic analysis, are considered innovative characteristics in the present work, they are introduced separately in Section 1.5, infra.

\subsubsection{Comparative Analysis}

Comparative analysis is used as the primary method guiding the whole thesis, and it is undertaken in different ways. In this regard, the thesis first compares legal cultural characteristics of dispute settlement in China and the EU. Then the comparison addresses the practice of dispute settlement at internal and international levels in China and the EU. Such comparative analyses on the legal cultural characteristics of dispute settlement not only provide a necessary foundation for each territory to examine the proposals and also the reactions to the proposals in the negotiations for a China-EU BIT, but it also bridges different and contested interpretations by the parties, providing a way to improve communication between the parties. ${ }^{24}$

\footnotetext{
${ }^{24}$ As pointed out, without acknowledging the differences in legal cultural characteristics in relation to dispute settlement, "numerous misunderstandings can become a serious obstacle to the elaboration of international law". See: Jean Yves Heurtebise, Understanding Non-Trade Concerns Through Comparative Chinese and European Philosophy of Law, at: Paolo Davide Farah \& Elena Cima (eds.), China's Influence on Non-Trade Concerns in
} 


\subsubsection{Normative Analysis}

The second method used in this research is normative analysis. Rather than simply carrying out logical reasoning and theoretical analysis, this thesis tries to figure out the underlying reasons for various designs, particularly focussed on the values and principles that each side intends to preserve. These values and principles are taken as part of the standards for the analysis in Part 4 on the exploration of the possible procedural design of the dispute settlement system in a China-EU BIT, by considering whether certain features of each party's proposals can be related to such values and principles and thus would be difficult to change.

\subsubsection{Case Study}

The third method is undertaking a case study. As pointed out by Kurt Lewin, theory without practice is sterile, but practice without theory is blind. Real situations and practical examples thus are used to examine relevant issues. These include the treaties signed by China and by the EU in the past. At the same time, the disputes involving China, the EU or an investor from either side under their existing IIAs are also useful for interpreting the parties' performance in dispute settlement. However, since some aspects of dispute settlement procedures are confidential, especially those conducted under amicable DSMs, it may prove difficult to have a sufficient number of cases to represent a sound case study analysis.

\subsection{Literature Review}

To the author's knowledge, until now there is no comprehensive analysis of a possible dispute settlement system in the prospective China-EU BIT, in English or in Chinese. Only selected issues in ISDS under a China-EU BIT were touched upon in some papers. On the other hand, there is a wealth of literature providing a general discussion on the topics addressed in the present thesis, such as transparency in investor-state arbitration. This section presents two relevant topics where existing literature is abundant, the legal framework of the China-EU investment relationship and investment dispute settlement and summarizes the academic discussion from previously published works.

\subsubsection{Literature on the Legal Framework of the China-EU Investment Relationship}

A comprehensive analysis of the legal framework of the China-EU investment relationship was made in 2005. The book "The Legal Framework of EU-China Investment Relations - A Critical Appraisal" conducted a detailed examination of the legal framework that governed the China-EU investment relationship at that time and argued that the time was ripe to formulate a new international legal framework for both

sides. $^{25}$ After the negotiations on a China-EU BIT were officially initiated in 2013, an

International Economic Law, Routledge, 2016, pp. 290-291.

25 Wenhua Shan, The Legal Framework of EU-China Investment Relations: A Critical Appraisal, Hart Publishing, 2005 . 
increasing number of works were been produced. ${ }^{26}$ Many papers focused on predicting the development tendency of the China-EU investment relationship, the possible substantive and procedural issues covered by this prospective BIT, and how this treaty would contribute to sustainable investment development in the world. In particular, the EU's proposal of establishing an investment court system (hereinafter "ICS") created a wave of discussion among Chinese scholars. Some research considered the origin of this innovation in the $\mathrm{EU},{ }^{27}$ and many more paid particular attention to specific procedural issues, such as transparency, consistency and the selection of adjudicators. ${ }^{28}$

\subsubsection{Literature on Investment Dispute Settlement}

In the area of international economic law, literature on state-state DSMs in the area of international economic law mostly paid attention to DSMs in FTAs and the WTO Dispute Settlement System, instead of IIAs. Furthermore, since the end of the 1990s, virtually all relevant scholarship has attempted to analyse the DSMs in FTAs theoretically in terms of a single dimension of legislation - a DSM is "legal" or "political". ${ }^{29}$ Typical empirical research in this area appeared after 2000. ${ }^{30}$

In contrast, the situation of investor-state DSMs is quite different. This topic was one of the most debated topics among scholars and practitioners in the past decades, and

26 See e.g. Wenhua Shan \& Lu Wang, The China-EU BIT: The Emerging "Global BIT 2.0"?, ICSID Review, Vol. 30, 2015. Jun Xiao, How Can a Prospective China-EU BIT Contribute to Sustainable Investment: In Light of the UNCTAD Investment Policy Framework for Sustainable Development, Journal of World Energy Law and Business, Vol. 8, 2015. Ecorys Nederland \& Oxford Intelligence \& TNO \& Reichwein China Consult, Sustainability Impact Assessment (SIA) in Support of an Investment Agreement between the European Union and the People's Republic of China, 06.2016, available at: http://trade.ec.europa.eu/doclib/docs/2016/july/tradoc_154778.pdf, last visited on 05.08.2020.

27 See e.g. Shixi Huang 黄世席, The Origin of and the Response to the EU's Investment Court System 欧盟国际 投资仲裁法庭制度的缘起与因应, Studies in Law and Business 法商研究, Vol. 4, 2016.

${ }^{28}$ See e.g. Jun Xiao 肖军, The Investor-State Dispute Settlement Mechanism in a China-EU BIT: A Comparative Analysis Based on the China-Canada BIT and CETA 中欧BIT 的投资者-东道国争端解决机制一一基于中加BIT 与 CETA 的比较分析, Journal of Xidian University (Social Science Edition) 西安电子科技大学学报(社会科学 版), Vol. 25, 2015. Tingting Deng 邓婷婷, The Investor-State Dispute Settlement Mechanism in a China-EU Bilateral Investment Treaty: From the Perspective of the EU's Investment Court System 中欧双边投资条约中的 投资者一国家争端解决机制——以欧盟投资法庭制度为视角, Politics and Law 政治与法律, Vol. 4, 2017, pp. 99-111. Shaotang Wang 王少常, Legetimacy Crisis Resolved? Reconsideration of the EU's Reform of Investment Court System 正当性危机的解除? - 一欧盟投资争端解决机制改革再议, Studies in Law and Business 法商研 究, Vol. 2, 2018, pp. 159-170.

${ }^{29}$ See e.g. David Morgan, Dispute Settlement under PTAs: Political or Legal?, Melbourne Law School Legal Studies Research Paper No. 341, 2008, available at: http://ssrn.com/abstract=1203022, last visited on 31.07.2020. Victoria Donaldson \& Simon Lester, Dispute Settlement, at: Simon Lester \& Bryan Mercurio (eds.), Bilateral and Regional Trade Agreements: Commentary and Analysis, Cambridge University Press, 2009, pp. 367-414. Porges Amelia, Dispute Settlement, at: Jean-Pierre Chauffour \& Jean-Christophe (eds.), Preferential Trade Agreement Policies for Development: A Handbook, The World Bank, 2011, pp. 467-502.

${ }^{30}$ Smith seems to be the first to open up the black box of DSMs in FTAs by focusing on 62 regional trade pacts and differentiates among the levels of legalism ranging from diplomatic to legalistic types. See: James McCall Smith, The Politics of Dispute Settlement Design: Explaining Legalism in Regional Trade Pacts, International Organization, Vol. 54, 2000, pp.137-180. Following Smith's lead, Jo and Namgung carried out a more recent study. See: Hyeran Jo \& Hyun Namgung, Dispute Settlement Mechanisms in Preferential Trade Agreements: Democracy, Boilerplates, and the Multilateral Trade Regime, Journal of Conflict Resolution, Vol. 56, 2012, pp. 1041-1068. A more comprehensive empirical analysis published in the past five years is the the work conducted by Allee and Elsig, which was based on 589 FTAs concluded between 1947 and 2009. It considered how the dispute settlement components can be characterized by the degree to which they aid enforceability, entail greater delegation, specify flexibility, or promote the overall settlement of disputes. See: Todd Allee \& Manfred Elsig, Dispute Settlement Provisions in PTAs: New Data and New Concepts, at: Andreas Dür \& Manfred Elsig (eds.), Trade Cooperation: The Purpose, Design and Effects of Preferential Trade Agreements, Cambridge University Press, 2015, pp. 319-352. 
thus there is a wealth of literature in this area. ${ }^{31}$ Relevant discussions cover both substantive and procedural issues in investment dispute resolution. The former includes topics such as the definition of investment, the qualification of investors and fair and equitable treatment. In terms of the latter, the attention is on transparency, third-party funding, independence of adjudicators, consistency of decision making, costs, etc. ${ }^{32}$ Comparatively, there has been scattered research on other types of investor-state DSMs, such as investor-state mediation or conciliation. ${ }^{33}$

Until now, the relationship between a state-state dispute settlement system and an investor-state dispute settlement system has rarely been discussed. Most of the published works on this topic focus on theoretical analysis and some touched upon the limited existing cases. ${ }^{34}$ Literature on this issue in the context of a specific IIA is difficult to find. Although the existing literature on the different topics is diverse, all of the aforementioned valuable studies have pushed the scholarship on the legal framework of the China-EU investment relationship and investment dispute settlement in a useful direction.

\subsection{Innovative Character}

As introduced above, compared to the existing literature, the present thesis has two main innovative aims: to analyse dispute settlement practice from a legal cultural perspective, and to examine international economic dispute settlement and investment DSMs systemically. These two innovative points are argued to make the present thesis valuable before and after the conclusion of a China-EU BIT, by providing

\footnotetext{
${ }^{31}$ See e.g. United Nations Conference on Trade and Development (UNCTAD), Reform of the IIA Regime: Four Paths of Action and a Way Forward, 2014, available at: https://unctad.org/en/PublicationsLibrary/webdiaepcb2014d6_en.pdf, last visited on 06.08.2020. Transnational Dispute Management, TDM Special Issue on "Reform of Investor-State Dispute Settlement (ISDS): In Search of a Roadmap", 2014, available at: https:/www.transnational-dispute-management.com/journal-browse-issuestoc.asp?key $=52$, last visited on 30.07.2020. Stephan W. Schill, Reforming Investor-State Dispute Settlement (ISDS): Conceptual Framework and Options for the Way Forward, The E15Initiative (E15), 2015, available at: $\mathrm{http}: / / \mathrm{e} 15$ initiative.org/publications/reforming-investor-state-dispute-settlement-isds-conceptual-framework-andoptions-for-the-way-forward/, last visited on 05.08.2020.

32 See e.g. David Gaukrodger \& Kathryn Gordon, Investor-State Dispute Settlement: A Scoping Paper for the Investment Policy Community, 2012, available at: www.oecd.org/daf/investment/workingpapers, last visited on 02.08.2020. United Nations Conference on Trade and Development (UNCTAD), Investor-State Dispute Settlement: Review of Developments in 2016, 2017, available at: http://unctad.org/en/PublicationsLibrary/diaepcb2017d1 en.pdf, last visited on 06.08.2020. Frank J. Garcia \& Hyun Ju Cho \& Tara Santosuosso \& Randall Scarlett \& Rachel Denae Denae Thrasher, The Case Against Third-Party Funding in ISDS: Executive Summary, Boston College Law School Faculty Papers, Vol. 4-23, 2018.

${ }^{33}$ See e.g. Jack J. Coe, Toward a Complementary Use of Conciliation in Investor-State Disputes-A Preliminary Sketch, UC Davis Journal of International Law and Policy, Vol. 12, 2005, pp. 7-31. Ucheora O. Onwuamaegbu, The Role of ADR in Investor-State Dispute Settlement: The ICSID Experience, 2007, available at: https://www.transnational-dispute-management.com/, last visited on 09.06.2018. Chunlei Zhao, Investor-State Mediation in a China-EU Bilateral Investment Treaty: Talking About Being in the Right Place at the Right Time, Chinese Journal of International Law, Vol. 16, 2018, pp. 1-25.

${ }^{34}$ See e.g. Shu Xv 徐树, The Conflicts and Coordination between the Dule Tracks of the Enforcement Mechanisms of International Investment Agreements 国际投资条约 “双轨” 执行机制的冲突及协调, Studies in Law and Business 法商研究, Vol. 2, 2017, pp. 139-149. Jamal Seifi, Investor-State Arbitration v. State-State Arbitration in Bilateral Investment Treaties, Transnational Dispute Management (TDM), 2004, available at: $\mathrm{https}: / / w w w . t r a n s n a t i o n a l-d i s p u t e-m a n a g e m e n t . c o m / a r t i c l e . a s p ? k e y=112$, last visited on 05.08.2020. Anthea Roberts, State-to-State Investment Treaty Arbitration: A Hybrid Theory of Interdependent Rights and Shared Interpretive Authority, Harvard International Law Journal, Vol. 55, 2014, pp. 1-70.
} 
inspiration to governments, legal practitioners and academics not only from China and the EU, but also other states in the world.

\subsubsection{Legal Cultural Analysis}

As explained in Section 1.1.3, supra, to predict the form the dispute settlement system in a China-EU BIT would take, the existing practice of both parties can provide insights and direct evidence. However, this is not enough. Among the various elements having influence, legal culture is expected to play a vital role in dispute settlement. In general, to comprehend any particular procedural detail in a DSM, it is necessary to understand both the dispute settlement system in which it operates and how that system is culturally imbedded and socially constructed, sustaining and even amplifying the culture as a whole. Understanding and recognizing this inter-relationship between legal culture and a state's practice in dispute settlement will enrich our capacity to understand the underlying reasons for one party's particular choice, anticipate its attitude towards the practice of the other party and to evaluate recommendations for change. Thus, a legal cultural analysis of both parties' existing practice, which could indicate the values they intended to preserve, is argued to be important and necessary.

Legal cultural characteristics are often difficult to see and thus the identification of those characteristics should be the first step in the analysis. There are various definitions of legal culture and a rich discussion on related terms, such as legal mentalities, legal consciousness, legal tradition, etc ${ }^{35}$ Examples of the definitions of "legal culture" include "those parts of general culture - customs, opinions, ways of doing and thinking that bend social forces toward or away from the law", "a way of describing relatively stable patterns of legally oriented social behaviour and attitudes", ${ }^{37}$ and "the sum of non-enforceable prerequisites that a legal society within an autonomous legal system

\footnotetext{
35 Some academics argued that the terms "legal mentalities" or "legal families" were narrower than "legal culture" in that it primarily referred to legal traditions rather than the wider cultural setting within which law and legal institutions operate. See: Pierre Legrand, European Legal Systems Are Not Converging, International and Comparative Law Quarterly, Vol. 45, 1996, pp. 52-81. Holger Spamann, Contemporary Legal Transplants: Legal Families and the Diffusion of (Corporate) Law, Brigham Young University Law Review, Vol. 1813, 2009, pp. 18131877. The difference between "legal culture" and "legal consciousness" was described as "if research on legal culture focuses attention on the myriad of ways in which law exists within society generally, the study of legal consciousness traces the way in which law is experienced and interpreted by specific individuals as they engage, avoid, or resist the law and legal meanings". See: Neil J. Smelser \& Paul B. Baltes (eds.), International Encyclopaedia of the Social and Behavioural Sciences, Pergamon Press, 2001, p. 8626. Scott Barclay \& Susan S. Silbey, Understanding Regime Change: Public Opinion, Legitimacy, and Legal Consciousness, at: Gregory A. Caldeira \& R. Daniel Kelemen \& Keith E. Whittington (eds.), The Oxford Handbook of Law and Politics, Oxford University Press, 2008, pp. 663678. In terms of the meaning of "legal traditions", it was argued that "[a] formal legal tradition reflects the genesis and development of a legal system, its norms, doctrines, principles, standards and rules of law". See: Leon E. Trakman, "Legal Traditions" and international Commercial Arbitration, The American Review of International Arbitration, Vol. 17, 2007, p. 11. It was also pointed out that, similar to legal culture, the concept of legal tradition was not easy to define and "its boundaries are fuzzy". See: H. Patrick Glenn, Comparative Legal Families and Comparative Legal Traditions, at: Mathias Reimann \& Reinhard Zimmermann (eds.), The Oxford Handbook of Comparative Law, Oxford University Press, 2006, pp. 422-439.

For a further discussion on the concept of "legal culture", see e.g. Clifford Geertz, The Interpretation of Clutures: Selected Essays, Basic Books, 1973. Alan Watson, Legal Change: Sources of Law and Legal Culture, University of Pennsylvania Law Review, Vol. 131, 1983. Roger Cotterrell, The Concept of Legal Culture, at: David Nelken (ed.), Comparing Legal Cultures, Routledge, 1997, pp. 13-31.

${ }^{36}$ Tom Ginsburg, The Culture of Arbitration, Vanderbilt Journal of Transnational Law Vol. 36, 2003, p. 1336. (quoting Lawrence M. Friedman, The Legal System: A Social Science Perspective, Russell Sage Foundation, 1975, p. 15.)

37 David Nelken, Using the Concept of Legal Culture, Australian Journal of Legal Philosophy, Vol. 29, 2004, p. 1.
} 
has developed to make, find, interpret, and confirm law". ${ }^{38}$ To some scholars, legal culture even constitutes an inherent part of the wider political culture. ${ }^{39}$ In addition, it is noted that legal culture may manifest itself at different levels, including in the supranational legal culture, national legal culture and subnational legal culture. ${ }^{40}$ Despite the different opinions on its definition, it is generally recognized that legal culture is difficult to describe. ${ }^{41}$ Furthermore, it is clear that legal cultural characteristics are difficult to isolate from the legal system they exist in and are deeply rooted within their communities reflecting "the common history, traditions, outlook and approach of that system". ${ }^{42}$ The development of legal culture may follow religious, political, social patterns, or market forces that impact it differently over time, place and space. $^{43}$

This thesis does not intend to join the debate to support some opinions or bring up its own definition of legal culture. Considering legal cultural analysis is one of the methodologies adopted by the present thesis in addressing the final goal, instead of limiting its scope in a technical sense, a broad view of legal culture is appropriate. Along with the analysis of the general legal cultural situation in China and the EU, considering their significant roles in their respective legal cultures, traditional Chinese philosophies and the constants in the European legal tradition will be given particular attention.

Legal cultural analysis is used more often when one legal system is being examined. ${ }^{44}$ An innovative use of the legal cultural analysis in the area of international public law can be found in Colin B. Picker's work, in which he analysed the legal culture of different international organizations and compared it with the relevant states' own legal culture. ${ }^{45}$ The present thesis conducts a legal cultural analysis of practice on dispute settlement by China and the EU at both internal and international levels. Specifically, it first identifies both parties' legal cultural characteristics in dispute settlement and as influenced by their legal traditions. Second, it assesses the DSMs in the internal legal systems from a legal cultural perspective. As pointed out, "the legal culture present in an international investment law context will in broad terms reflect the legal culture of

\footnotetext{
38 Ari Afilalo \& Dennis Patterson \& Kai Purnhagen, Statecraft, the Market State and the Development of European Legal Culture, at: Geneviève Helleringer \& Kai Purnhagen (eds.), Towards a European Legal Culture, Hart Publishing, 2014, p. 278.

${ }^{39}$ See e.g. Åse B. Grødeland \& William L. Miller, European Legal Cultures in Transition, Cambridge University Press, 2015, p. 2.

$40 \mathrm{On}$ this point, any claim discussed in this thesis about legal culture does not assume uniformity within a system. It recognizes the existence of differences within China and the EU. However, considering the purpose of using legal cultural analysis in this thesis is to facilitate the exploration of the prospective China-EU BIT, the legal culture at the national level of China and at the internal or supranational level of the EU are focused on.

${ }^{41}$ Ari Afilalo \& Dennis Patterson \& Kai Purnhagen, Statecraft, the Market State and the Development of European Legal Culture, at: Towards a European Legal Culture, Hart Publishing, 2014, p. 299.

${ }^{42}$ Colin B. Picker, Comparative Legal Cultural Analyses of International Economic Law: A New Methodological Approach, The Chinese Journal of Comparative Law, Vol. 1, 2013, p. 34.

${ }^{43}$ Ehhard Blankenburg, Patterns of Legal Culture: The Netherlands Compared to Neighboring Germany, The American Journal of Comparative Law, Vol. 46, 1998, pp. 1-41.

44 See, e.g. Kun Fan, Arbitration in China: A Legal and Cultural Analysis, Hart Publishing, 2013.

${ }^{45}$ For example, he analysed the possible congruence and conflicts between the WTO and Chinese legal culture. See: Colin B. Picker, China, Global Governance \& Legal Culture: The Example of China \& the WTO, at: Junji Nakagaw (ed.), China and Global Economic Governance: Ideas and Concepts, The University of Tokyo-Institute of Social Science (ISS) Research Series No.45, 2011, pp. 69-88.
} 
the domestic legal systems involved". ${ }^{46}$ In this sense, internal dispute settlement systems can be taken as formally reflecting and confirming legal cultural characteristics. In other words, certain arrangements in DSMs reflect the deeply held normative values of the society that produced them and, at the same time, they help to maintain those ingredients of social life. ${ }^{47}$ Third, a legal cultural analysis is also conducted for the performance of both parties in international investment dispute settlement.

In brief, by focusing on the manner in which the legal culture of China and that of the EU has shaped their performance in resolving disputes, the legal cultural analysis in the present thesis can be instructive in terms of expecting how it would affect the current negotiations on a China-EU BIT. Furthermore, a comparative legal cultural analysis of the practice of both parties is arguably helpful for both to understand each other, making cultural conflicts more comprehensible and thus also facilitating the conclusion of the treaty.

\subsubsection{Systemic Analysis}

In the present thesis, a systemic analysis is adopted and applied in two ways: first, dispute resolution is positioned in the international economic law field as a system, combining the practice of a state towards dispute settlement in international trade and investment; second, various DSMs are viewed as a whole to constitute a comprehensive dispute settlement system for the disputes at issue.

\subsubsection{Systemic Examination of International Economic Dispute Settlement}

In order to understand a state's practice in the past and forecast its attitude to international investment dispute settlement in the future, a related area, international trade dispute resolution as a parallel constituent in the field of international economic law, is examined for inspiration, especially for the analysis of SSDS.

This approach is adopted mainly because international trade and investment are often discussed together with regard to procedural issues in dispute resolution. The DSMs for trade and those for investment share similarities and their development affects each other. In particular, recent years have witnessed a trend of concluding comprehensive economic agreements, which cover both trade and investment issues. Such agreements normally provide one set of rules for SSDS for disputes about provisions on trade and investment. Furthermore, even in separate IIAs, it seems to be clear that the design of state-state DSMs, even investor-state DSMs, is influenced by the relevant practice under FTAs and the WTO Dispute Settlement System. All of this provides a solid ground to put the approach of China and the EU to investment dispute settlement in the general context of their international economic dispute resolution practice and to garner inspiration from their relevant practice in trade.

\footnotetext{
${ }^{46}$ Colin B. Picker, International Investmnet Law: Some Legal Cultural Insights, at: Leon Trakman \& Nick Ranieri (eds.), International Trade and Investment Law: Developments and Directions, Oxford University Press, 2012, p. 148.

47 Oscar G. Chase, Law, Culture, and Ritual-Disputing Systems in Cross-Cultural Context, New York University Press, 2005, p. 46.
} 


\subsubsection{Systemic Examination of Investment Dispute Settlement Mechanisms}

Different DSMs, such as negotiation, mediation, consultations, and adjudication, are normally taken into account and examined separately. However, it is argued that taking a systemic view of a dispute settlement system, rather than only focusing separately on each DSM contained therein, is necessary. ${ }^{48}$ In other words, having recourse to multiple DSMs is essential, which arguably provides "the greatest opportunity in the future to seek out settlements in the venue that seems most appropriate to the parties at the time a particular dispute occurs", ${ }^{49}$ but this is not enough. A further essential step is to examine these mechanisms systemically, all with a view to formulating a coherent dispute settlement system composed of these mechanisms. Such a systemic approach can potentially improve the functioning of investment dispute settlement, but it has unfortunately been overlooked to a great extent in the literature and treaty practice.

In order to conduct a systemic examination in this thesis, first, it is considered which DSMs are appropriate and thus need to be incorporated into the systems for state-state and investor-state dispute settlement respectively. ${ }^{50}$ In addition to analysing various individual mechanisms for investment dispute settlement, the present thesis examines the interaction between these DSMs. Namely, instead of interpreting multiple DSMs as a collection of single method approaches, it pays attention to their interaction as well as their positions and functions in the dispute settlement system that is composed of those mechanisms. Each DSM has its own features, and they are expected to functionally cooperate with each other, thereby comprising a comprehensive dispute settlement system. Within the system, DSMs interwoven with each other, provide freedom to disputing parties to make full use of the characteristics of the different mechanisms. In addition, this thesis also explores the collaboration between the two systems, the state-state dispute settlement system and the investor-state dispute settlement system, in order to reach the final goal of facilitating dispute settlement through the overall system provided in the prospective China-EU BIT.

\footnotetext{
48 In this sense, it is noted that more discussions on the systematic design of DSMs in a domestic legal system are available in the existing literature. For example, Stephanie Smith and Jan Martinez raised six characteristics for the best dispute settlement systems for a domestic legal system: (1) multiple process options for parties, including rightsbased and interest-based processes; (2) ability for parties to "loop back" and "loop forward" among these options; (3) substantial stakeholder involvement in the system's design; (4) participation that is voluntary, confidential, and assisted by impartial third party neutrals; (5) system transparency and accountability; and (6) education and training of stakeholders on the use of the available process options. See: Stephanie Smith \& Jan Martinez, An Analytic Framework for Dispute Systems Design, Harvard Negotiation Law Review, Vol. 14, 2009, p. 128.

49 Todd Allee \& Manfred Elsig, Dispute Settlement Provisions in PTAs: New Data and New Concepts, at: Trade Cooperation: The Purpose, Design and Effects of Preferential Trade Agreements, Cambridge University Press, 2015, p. 345.

50 Different DSMs would fit the needs of different types of disputes in practice. For detailed analysis on the suitable DSMs for various types of investment disputes in practice, see: Wenhua Shan, Toward a Multilateral or Plurilateral Framework on Investment, The E15 Initiative, 11.2015, available at: http://e15initiative.org/publications/toward-amultilateral-or-plurilateral-framework-on-investment/, last visited on 05.08.2020.
} 


\section{Chapter 2 Background and Context: International Investment and Investment}

\section{Dispute Settlement Systems}

This chapter aims at defining the scope of and building the theoretical basis for the following discussion. In order to achieve this, it addresses general topics that are relevant to the present thesis, including the legal frameworks of international investment and international investment dispute settlement, dispute settlement systems under IIAs, and the mechanisms that are commonly provided for in investment dispute settlement.

It is noted that, under an IIA, in addition to the general system established for resolving disputes between treaty parties and between investors and host states, other DSMs are often provided for special types of disputes, such as financial services disputes. ${ }^{51}$ These specific types of disputes are outside the scope of the general dispute settlement system, because they are sensitive for treaty parties and/or have special features. Similarly, the DSMs therefore are designed to suit the particular characteristics and have very limited ranges of application, and they are therefore not covered by the present discussion.

\subsection{Legal Frameworks for International Investment and International Investment Dispute Settlement}

There is no single global multilateral legal framework for international investment comparable to the WTO. Current international investment law primarily relies upon a large number of IIAs. The development of the legal framework of international investment dispute settlement can be divided into two periods characterized by interstate based DSMs and investor-state arbitration respectively, which also both have different governing international legal regimes.

\subsubsection{The Legal Framework for International Investment}

There is no single global multilateral legal framework for investment comparable to the system established in 1995 by the WTO for international trade in goods, services and

\footnotetext{
51 An example of this was NAFTA, which enshrined no less than seven forms of dispute settlement. In specific, the different forms were as follows: (1) Chapter 11B, DSMs dealing with investment disputes under Chapter 11A; (2) Chapter 14, DSMs for financial services disputes, which adopts the same approach as Chapter 20 but provides for panels made up of financial experts; (3) Chapter 19, a recourse to challenge domestic decisions imposing antidumping and countervailing duties before a binational panel; (4) Chapter 20, the residual procedure based on the GATT panel model; (5) Art. 2002, recourse to the WTO Dispute Settlement System for the disputes that might fall under both NAFTA and the WTO agreements, and the possibility of recourse to arbitration and other alternative means of dispute resolution between the Parties; and (6) the "side agreements" on environmental and labour cooperation, complaints procedure for a private party before the respective Commissions, and a formal dispute settlement procedure available in limited circumstances to the three governments. For more analyses on these DSMs, see: Armand de Mestral, NAFTA Dispute Settlement: Creative Experiment or Confusion?, at: Lorand Bartels \& Federico Ortino (eds.), Regional Trade Agreements and the WTO Legal System, Oxford University Press, 2006, p. 361 .
} 
intellectual property. ${ }^{52}$ The proposal for an international legal investment regime envisaged in the 1948 Havana Charter did not materialize. A number of later initiatives also failed, such as the ill-fated attempt towards the end of the 1990s to establish a Multilateral Agreement on Investment within the Organization for Economic Cooperation and Development (OECD) framework. ${ }^{53}$ Current international investment law primarily relies upon a large number of IIAs, which include IIAs and comprehensive economic agreements covering both trade and investment, aiming at encouraging foreign investment and intensifying economic ties among treaty parties as well as protecting foreign investments. ${ }^{54}$

\subsubsection{The Legal Framework for International Investment Dispute Settlement}

The interpretations of the term "international investment disputes" can vary significantly. Such disputes can be based on an alleged violation of IIAs, investment contracts or the domestic investment law of the host states. ${ }^{55}$ IIA-based investment disputes can be divided into two categories, according to the dispute parties involved: disputes between treaty parties and disputes between investors and host states. Successful dispute settlement is important in international investment. By addressing disputes in a constructive manner, it provides opportunities for meaningful dialogue and the development of stronger relationships. Investors may be awarded damages for their alleged loss and thereby minimize concerns about continuing investment activities with the same state. Host states could develop a reputation for being an investmentfriendly place, increase investors' loyalty, and thus secure future investments. Furthermore, the effect of investment dispute settlement goes beyond specific disputes and the parties involved; it may provide predictability in international investment law as well. ${ }^{56}$

In broad brushstrokes, the development of the legal framework of investment dispute settlement can be divided into two periods: the first period is characterized by interstate-based mechanisms and the second refers to the rise of investor-state arbitration. ${ }^{57}$

During the first period, claims were made by home states on behalf of their investors by pursuing cases on a diplomatic basis or by using state-state adjudication, which is often based on customary international law and Friendship, Commerce, and Navigation treaties. In other words, in the IIAs drafted in this first period, state-state disputes were

\footnotetext{
52 The WTO agreements cover some aspects of investment, especially in the field of trade-related investment measures, but only in a rudimentary manner.

53 Peter Malanczuk, State-State and Investor-State Dispute Settlement in the OECD Draft Multilateral Investment Agreement, Journal of International Economic Law, Vol. 3, 2000, pp. 417-421.

54 Saluka Investments BV (Neth.) v. Czech Republic, UNCITRAL, Partial Award, 17.03.2006, para. 300. Despite the debate about the main goal of IIAs, the co-existence of various goals of an IIA is widely recognized.

55 Wenhua Shan, The Legal Framework of EU-China Investment Relations: A Critical Appraisal, Hart Publishing, 2005 , p. 205. Considering the topic of the present thesis, only the disputes concerning potential breaches of IIAs are taken into consideration in the following analysis.

${ }^{56}$ Yongjie Li, Factors to be Considered for China's Future Investment Treaties, at: Wenhua Shan \& Jinyuan Su (eds.), China and International Investment Law-Twenty Years of ICSID Membership, Brill | Nijhoff, 2015, p. 177.

${ }^{57}$ See e.g. Jason Webb Yackee, Conceptual Difficulties in the Empirical Study of Bilateral Investment Treaties, Brooklyn Journal of International Law, Vol. 33, 2008, pp. 405-462. Andrew Newcombe \& Lluís Paradell, Law and Practice of Investment Treaties: Standards of Treatment Kluwer Law International, 2009, pp. 41-46. Kenneth J. Vandevelde, Bilateral Investment Treaties: History, Policy, and Interpretation, Thomas Jefferson School of Law Research Paper, Vol. 3022249, 2010, pp. 49-59.
} 
often provided with two types of DSMs: diplomatic negotiation and international adjudication through ad hoc arbitration or litigation in the International Court of Justice (ICJ). Diplomatic negotiation was undertaken either by itself, in parallel with or as a precursor to international adjudication. IIAs normally only addressed the amicable settlement of disputes without providing detailed rules on the use of diplomatic negotiations. Unless specified in the IIA at issue, disputing parties decided the procedural rules for ad hoc arbitration. If the ICJ was chosen, then its procedural rules would apply. In general, during this period, investment dispute settlement was dominated by a public international law paradigm focused exclusively on treaty parties. ${ }^{58}$ The home states of investors had complete discretion over the commencement, prosecution and settlement of claims, as well as the any damages awarded.

In contrast, by incorporating investor-state arbitration in parallel with state-state arbitration, the second period of investment dispute settlement was dominated by an international commercial arbitration paradigm focused primarily on investor-state arbitration. ${ }^{59}$ The IIAs concluded in this period of time were largely drafted by capitalexporting states which were primarily concerned with protecting their investors abroad. ${ }^{60}$ The right to bring cases directly against host states through international arbitration greatly enhanced investors' power in dispute settlement. It is argued that the development of the legal framework for such arbitration started in 1965 with the adoption of the Convention on Settlement of Investment Disputes between States and Nationals of Other State (hereinafter "ICSID Convention") and the creation of the International Centre for the Settlement of Investment Disputes (ICSID). ${ }^{61}$ As of April 2020, over 160 states have signed the ICSID Convention. ${ }^{62}$ ICSID mainly aims at establishing an international forum to address disputes that arise between foreign investors and their host states, and thereby promotes any given state's investment climate and prospects for economic development. ${ }^{63}$ It does not engage in conciliation or arbitration by itself but facilities the conciliation commissions or arbitration tribunals constituted according to the ICSID Convention. ICSID jurisdiction is exclusive, ${ }^{64}$ and

\footnotetext{
58 Anthea Roberts, Clash of Paradigms: Actors and Analogies Shaping the Investment Treaty System, American Journal of International Law, Vol. 107, 2013, pp. 58-63.

59 Anthea Roberts, State-to-State Investment Treaty Arbitration: A Hybrid Theory of Interdependent Rights and Shared Interpretive Authority, Harvard International Law Journal, Vol. 55, 2014, pp. 2-3, 5.

${ }^{60}$ Anthea Roberts, Clash of Paradigms: Actors and Analogies Shaping the Investment Treaty System, American Journal of International Law, Vol. 107, 2013, pp. 75-76. As a result, the interest of home states was argued as being "largely ignored". See: Anthea Roberts, Power and Persuasion in Investment Treaty Interpretation: The Dual Role of States, American Journal of International Law, Vol. 104, 2010, pp. 179-84.

${ }^{61}$ Aaron Broches, The Convention on the Settlement of Disputes between States and Nationals of Other States, at: Collected Courses of the Hague Academy of International Law (Volume 136), Brill | Nijhoff, 1972, pp. 337-410. However, the first ISDS clause was not included in an IIA until 1969 with the Chad-Italy BIT. It was not until 1990 that a tribunal asserted its jurisdiction under such a clause. See: Asian Agricultural Products Limited v. Democratic Socialist Republic of Sri Lanka, ICSID Case No. ARB/87/3, Award, 27.06.1990.

${ }^{62}$ International Centre for Settlement of Investment Disputes (ICSID), Database of ICSID Member States, available at: https://icsid.worldbank.org/en/Pages/about/Database-of-Member-States.aspx, last visited on 03.08.2020.

${ }_{63}$ Frauke Nitschke, The IBA's Investor-State Mediation Rules and the ICSID Dispute Settlement Framework, ICSID Review, Vol. 29, 2014, p. 112.

${ }^{64}$ The ICSID Convention, Art. 26. However, a contracting state may require that local administrative and judicial remedies are exhausted as a precondition for its consent to ICSID arbitration. It may also provide for diplomatic protection or bring an international claim in respect of such a dispute when another contracting state has failed to abide by and comply with the award rendered therein. See: the ICSID Convention, Arts. 26, 27.
} 
ICSID awards are binding and final. ${ }^{65}$ In addition to ICSID, there are other sets of arbitration rules that were incorporated with reference into IIAs. ${ }^{66}$ In general, the procedural rules governing investor-state arbitration process are largely based on international commercial arbitration practice. ${ }^{67}$

In recent decades, the appearance of the cases brought against capital-exporting states seems to have changed these states' perception of "the ideal balance" reached in the second period dramatically. ${ }^{68}$ It was argued that a lack of gatekeeping by investors' home states increased opportunities for tribunals to "assert and establish new legal norms", going beyond what treaty parties intended or would have supported. ${ }^{69}$ As a result, a wave of new efforts were made to reform investment dispute settlement. This is reflected in newly concluded IIAs, the amendment of arbitration rules and the introduction of new rules particularly dealing with certain issues in investment dispute settlement, such as the UNCITRAL Rules on Transparency in Treaty-based InvestorState Arbitration (hereinafter "UNCITRAL Rules on Transparency"). ${ }^{70}$

In short, from the first stage when the focus was on states' procedural rights in dispute resolution and state-state arbitration to the second stage when the attention was changed to investors' procedural rights and investor-state arbitration, "the pendulum had swung from one extreme to the other". ${ }^{71}$ With the current reform process of investment dispute settlement, the pendulum seems to be dragged back to the middle ground.

\subsection{Dispute Settlement Systems under International Investment Agreements}

Nowadays, a state-state dispute settlement system and an investor-state dispute settlement system are normally provided in parallel to an IIA. ${ }^{72}$ The present section introduces these two systems respectively, focusing on the covered disputes, applicable claims and their relationship. Details of the DSMs often contained in these two systems are discussed separately in Section 2.3, infra.

\footnotetext{
${ }^{65}$ ICSID awards are not subject to appeal or to any other remedies except as provided for in the ICSID Convention. Every contracting state must recognize an ICSID award in its courts as if it were a final judgment of that state. See: the ICSID Convention, Art. 53.

${ }^{66}$ There are a limited set of rules in the field of investment arbitration. In addition to ICSID Arbitration Rules, the arbitration rules of the United Nations Commission for International Trade Law (UNCITRAL) and the International Arbitration Court of the International Chamber of Commerce (ICC) are often referred to in IIAs.

${ }^{67}$ Chiara Ragni, The Role of Amicus Curiae in Investment Disputes: Striking a Balance Between Confidentiality and Broader Policy Considerations, at: Tullio Treves \& Francesco Seatzu \& Seline Trevisanut (eds.), Foreign Investment, International Law and Common Concerns, Routledge, 2014, p. 86.

68 Anthea Roberts, Clash of Paradigms: Actors and Analogies Shaping the Investment Treaty System, American Journal of International Law, Vol. 107, 2013, p. 78.

${ }^{69}$ Gus Van Harten, Investment Treaty Arbitration and Public Law, Oxford University Press, 2008, pp. 96-99.

${ }^{70}$ Reforming investor-state arbitration has been one of the key topics in the past decades in the field of international investment law. For more discussions on investor-state arbitration crisis and reform, see: Section 2.2.2.3, infra.

${ }^{71}$ Anthea Roberts, State-to-State Investment Treaty Arbitration: A Hybrid Theory of Interdependent Rights and Shared Interpretive Authority, Harvard International Law Journal, Vol. 55, 2014, p. 26.

${ }^{72}$ Nathalie Bernasconi-Osterwalder, State-State Dispute Settlement in Investment Treaties, 10.2014, available at: https://www.iisd.org/sites/default/files/publications/best-practices-state-state-dispute-settlement-investmenttreaties.pdf, p. 1, last visited on 30.07.2020.
} 


\subsubsection{State-State Dispute Settlement Systems}

A state-state dispute settlement system under an IIA provides an important channel for treaty parties, namely the host state and the home state of investors, to re-engage with the investment treaty system through dispute settlement. As introduced above, at the initial development stage of international investment law, only state-state dispute settlement systems are available. In other words, these systems appeared long before the systems operating between investors and host states.

\subsubsection{Scope of Disputes}

Normally, the disputes covered by a state-state dispute settlement system are defined as "disputes" concerning the "interpretation" and/or "application" of treaty provisions. ${ }^{73}$ Two points in this definition deserve attention. First, different IIAs may use alternatives to "disputes", such as "differences", "divergences", "matters", and "questions", ${ }^{74}$ all of which indicate the existence of different opinions of treaty parties. Second, "interpretation" and "application" respectively refer to "the meaning of particular provisions of an agreement in concrete or proposed situations" and "the extent to which the actions or measures taken or proposed by the contracting parties comply with the terms of an agreement, its object and purpose". ${ }^{75}$ These two are closely related in the sense that their application is based on and in turn crystalizes the interpretation. The combination is arguably wide-ranging and any dispute arising from the investment covered by the underlying IIA to some extent relates to these two terms. $^{76}$

\subsubsection{Acceptable Claims}

For the disputes that are covered by a state-state dispute settlement system, claims that may be raised by a treaty party can be divided into three groups: diplomatic protection claims, interpretive claims and declaratory relief claims. ${ }^{77}$

First, in the context of investment dispute settlement, diplomatic protection deals with alleged injuries to the nationals of one treaty party that are foreign investors in another

\footnotetext{
73 Id, p. 7.

${ }^{74}$ United Nations Conference on Trade and Development (UNCTAD), Dispute Settlement: State-State (UNCTAD Series on Issues in International Investment Agreements), 2003, available at: http://unctad.org/en/docs/iteiit20031_en.pdf, p. 13, last visited on 06.08.2020. Regarding the definition of "dispute", it is noted that in the case concerning Mavrommatis Palestine Concessions, the Permanent Court of International Justice defined a dispute as "a disagreement on a point of law or fact, a conflict of legal views or of interests between two persons" (P.C.I.J., Series A, No. 2, p. 11). This definition has since been recognized, applied and clarified on a number of occasions.

75 Id, p. 14

${ }^{76}$ Nathalie Bernasconi-Osterwalder, State-State Dispute Settlement in Investment Treaties, 10.2014, available at: https://www.iisd.org/sites/default/files/publications/best-practices-state-state-dispute-settlement-investmenttreaties.pdf, p. 7, last visited on 30.07.2020. These two terms were argued to be derived from virtually identical provisions in Treaties of Friendship, Commerce and Navigation, where the SSDS clauses were understood as permitting "a broad range of direct claims for violations suffered by a state and diplomatic protection claims for violations suffered by a state's nationals". See: Anthea Roberts, State-to-State Investment Treaty Arbitration: A Hybrid Theory of Interdependent Rights and Shared Interpretive Authority, Harvard International Law Journal, Vol. 55,2014, p. 7 . In addition, it is noticeable that the broad availability of state-state DSMs may be limited by certain carve-outs. For example, the 2012 US Model BIT carves out the matters relating to state's obligations not to weaken its domestic environmental and labour laws to encourage investment. See: the US Model BIT (2012), Art. 37(5).

77 Anthea Roberts, State-to-State Investment Treaty Arbitration: A Hybrid Theory of Interdependent Rights and Shared Interpretive Authority, Harvard International Law Journal, Vol. 55, 2014, pp. 1-70.
} 
treaty party. Such protection is based on the recognition that an injury caused by the host state to the home state's national is seen as an injury to the home state itself and thus the home state enjoys the right to assert international claims against the host state. ${ }^{78}$ As Emmerich de Vattel said, "whoever ill-treats a citizen indirectly injures the State". ${ }^{79}$ In terms of its objective of securing the protection of and to obtain reparation for injured investors, these types of claims resemble ISDS. ${ }^{80}$ Such claims can be raised with or without the existence of an ISDS clause in the IIA at issue. ${ }^{81}$

Second, when there is a dispute about treaty interpretation that has raised particular concerns and no "authentic interpretation" can be reached based on the agreement of treaty parties, ${ }^{82}$ a treaty party can seek clarification through the dispute settlement process by bringing an interpretive claim. Interpretive claims focus on proper interpretation of provisions in the IIA at issue, which could serve "either a general rulemaking purpose or the clarification of a treaty provision that is relevant to a specific dispute". ${ }^{83}$ As evidenced by the Peru v. Chile case, such claims can be raised by investors' home states after the appearance of a relevant ISDS case. ${ }^{84}$

78 Robert Wisner \& Neil Campbell, Bringing the Home State Back in: the Case for Home State Control in InvestorState Dispute Settlement, International Bar Association, 14.02.2018, available at: https://www.ibanet.org/Article/NewDetail.aspx?ArticleUid=522de4cb-caa3-4656-8236-f1e13f261b86, last visited on 31.07.2020. In a general sense, the International Law Commission (ILC) Draft Articles on Diplomatic Protection defines "diplomatic protection" as the "procedure employed by the state of nationality of the injured persons to secure protection of that person and obtain reparation for the internationally wrongful act inflicted". See: The 2006 ILC Draft Articles on Diplomatic Protection with commentaries, Yearbook of the International Law Commission, 2006, Vol. II, Part Two, p. 24.

79 Emmerich de Vattel, The Law of Nations or the Principles of Natural Law Applied to the Conduct and to the Affairs of Nations and Sovereigns (1758) (Translated by Charles G. Fenwick), Carnegie Institution of Washington, 1916, p. 136.

${ }^{80}$ The 2006 ILC Draft Articles on Diplomatic Protection with commentaries, Yearbook of the International Law Commission, 2006, Vol. II, Part Two.

${ }^{81}$ As evidenced by the case US v. Cuba, where there is no ISDS clause in the Italy-the US Treaty of Friendship, Commerce and Navigation (1948), the ICJ upheld its jurisdiction over the US's diplomatic protection claim against Italy about the alleged injury to its investors based on the SSDS clause contained in the treaty at issue. See: Elettronica Sicula S.p.A. (ELSI) (United States of America v. Italy), ICJ, Judgment of 20 July 1989. In a more recent case, the ad hoc arbitral tribunal affirmed that, based on the SSDS clause contained in the Cuba-Italy BIT (1993), the investors' home state Italy could file a diplomatic protection claim against Cuba where investor-state arbitration would have been an alternative option under the disputed treaty. See: Italian Republic v. Republic of Cuba, Ad hoc state-state arbitration, Final Award (sentence finale), 15.01.2008.

${ }^{82}$ According to the International Court of Justice, endorsing the position of the International Law Commission, an authentic interpretation can be a subsequent agreement between treaty parties "which must be read into the treaty for purposes of its interpretation". See: Kasikili/Sedudu Island (Botswana. v. Namibia), [1999] ICJ Rep 1045, para. 49 (quoting Commentary of the International Law Commission (1966), 2 Yearbook of the International Law Commission 221, para. 14, U.N. Doc. A/CN.4/SER.A/1966/Add.1).

${ }^{83}$ Nathalie Bernasconi-Osterwalder, State-State Dispute Settlement in Investment Treaties, 10.2014, available at: https://www.iisd.org/sites/default/files/publications/best-practices-state-state-dispute-settlement-investmenttreaties.pdf, p. 10, last visited on 30.07.2020.

${ }^{84}$ Following a relevant ISDS proceeding, Empresas Lucchetti, S.A. and Lucchetti Peru, S.A. v. The Republic of Peru, after failing to reach an interpretive agreement on the point that was at the heart of the investor-state dispute with Chile, Peru launched a state-state claim under the UNCITRAL arbitration rules to clarify a provision. It is unknown whether the claim was pursued any further after the initiation of the state-state consultations. See: Luke Eric Peterson, ICSID Tribunal Declines to Halt Investor Arbitration in Deference to State-to-State Arbitration, International Institute for Sustainable Development (IISD), 19.12.2003, available at: http://www.iisd.org/pdf/2003/investment_investsd_dec19_2003.pdf, last visited on 05.08.2020. Nathalie Bernasconi-Osterwalder, State-State Dispute Settlement in Investment Treaties, 10.2014, available at: https://www.iisd.org/sites/default/files/publications/best-practices-state-state-dispute-settlement-investmenttreaties.pdf, p. 11, last visited on 30.07.2020. 
Third, declaratory relief claims aim at seeking a finding that certain measures taken by a treaty party have or have not violated the IIA at issue. Declaratory reliefs issued by tribunals could prevent or at least limit damages to treaty parties by resolving the problem before individual investors' interests are harmed, and they could facilitate treaty parties to deal with all the relevant claims at once with a single award in a consistent and streamlined way. ${ }^{85}$ In existing IIAs, this type of claim has been particularly provided to determine whether certain governmental measures violate treaty provisions, such as taxation and financial measures. ${ }^{86}$ It is worth noting that identifying specific injured investors was not considered a precondition for such claims by previous tribunals. ${ }^{87}$

Despite how rarely they are used in practice, given the numerous concerns associated with investor-state arbitration and the trend towards full-fledged investment chapters in FTAs and comprehensive economic agreements, where elaborate provisions are included to resolve a wide range of state-state disputes, ${ }^{88}$ state-state dispute settlement systems are gaining renewed attention. ${ }^{89}$ At the same time, it is noted that some IIAs do not include investor-state DSMs, opting instead for SSDS only. ${ }^{90}$

\subsubsection{Investor-State Dispute Settlement Systems}

Traditionally, an investor aggrieved by the conduct of the host state could have recourse to the domestic courts of that state; when such local remedies have been exhausted without any satisfactory result, the investor's only option is to apply to the home state for diplomatic protection. ${ }^{91}$ The investor-state dispute settlement systems in modern

\footnotetext{
85 Anthea Roberts, State-to-State Investment Treaty Arbitration: A Hybrid Theory of Interdependent Rights and Shared Interpretive Authority, Harvard International Law Journal, Vol. 55, 2014, pp. 67-68. Nathalie BernasconiOsterwalder, State-State Dispute Settlement in Investment Treaties, 10.2014, available at: https://www.iisd.org/sites/default/files/publications/best-practices-state-state-dispute-settlement-investmenttreaties.pdf, p. 14, last visited on 30.07.2020. Martins Paparinskis, Investment Arbitration and the Law of Countermeasures, British Yearbook of International Law 2008, Vol. 79, 2008, p. 300.

${ }^{86}$ For instance, the China-Canada BIT (2012) provides that state-state arbitration shall be referred to to determine whether a disputed measure constitutes a prudential financial measure and thereby qualifies as an exception under the treaty. The decision made by the state-state arbitral tribunal shall be binding on the investor-state tribunal. See: the China-Canada BIT (2012), Art. 20(2). For some academic discussion on this issue, see: Nathalie BernasconiOsterwalder, State-State Dispute Settlement in Investment Treaties, 10.2014, available at: https://www.iisd.org/sites/default/files/publications/best-practices-state-state-dispute-settlement-investmenttreaties.pdf, pp. 14-15, last visited on 30.07.2020.

87 For example, in the case Mexico v. US, Mexico brought a claim seeking a declaration that the US had breached its national treatment and most-favored-nation treatment obligations with respect to Mexico and potential Mexican investors. The tribunal upheld its jurisdiction over Mexico's claims and determined that the US's action was inconsistent with NAFTA provisions in the end. See: Mexico v. United States (in the Matter of Cross-Border Trucking Services), NAFTA Chapter 20 State-to-State arbitration, Final Report of the Panel, 06.02.2001, paras. 2, 15-24, 292.

${ }^{88}$ Nathalie Bernasconi-Osterwalder, State-State Dispute Settlement in Investment Treaties, 10.2014, available at: https://www.iisd.org/sites/default/files/publications/best-practices-state-state-dispute-settlement-investmenttreaties.pdf, p. 1, last visited on 30.07.2020.

${ }^{89}$ See e.g. Michele Potestá, Republic of Italy v. Republic of Cuba, American Journal of International Law, Vol. 106, 2012, pp. 341-347. Marcin Orecki, State-to-State Arbitration Pursuant to Bilateral Investment Treaties: the Ecuador-US Dispute, YoungICCA Blog, 2013, available at: http://www.youngicca-blog.com/state-to-statearbitration-pursuant-to-bilateral-investment-treaties-the-ecuador-us-dispute/, last visited on 05.08.2020. Clovis J. Trevino, State-to-State Investment Treaty Arbitration and the Interplay with Investor-State Arbitration Under the Same Treaty, Journal of International Dispute Settlement, Vol. 5, 2014, pp. 199-233.

90 See e.g. the Australia-US FTA (2004), the Japan-Philippines Economic Partnership Agreement (2006), and the Australia-Malaysia FTA (2012).

${ }_{91}$ Richard Happ, Why Investment Arbitration Contributes to the Rule of Law: Without Konwing Where We Came from We Cannot Know Where We are Heading, at: Loukas Mistelis \& Nikos Lavranos (eds.), European Investment Law and Arbitration Review, Brill | Nijhoff, 2016, p. 280.
} 
IIAs provide for an option for investors to have recourse to the international level for alleged wrongs by host states to be addressed directly, which was argued to be the "ultimate investor protection". ${ }^{92}$ At the same time, host states may also profit from such mechanisms by creating a more favorable investment climate which helps to attract more foreign investment and thus generate local jobs and economic growth. ${ }^{93}$ Such a system has been considered to be the most important accomplishment of the investment treaty regime by depoliticizing investment dispute settlement. ${ }^{94}$

Although an IIA usually incorporates a state-state dispute settlement system at the same time, state obligations are always also enforced through ISDS. ${ }^{95}$ In fact, compared to state-state dispute settlement systems, which are commonly used for problems that are serious enough to have a systemic impact, investor-state dispute settlement systems are more suitable for resolving the vast majority of routine investment disputes. ${ }^{96}$ Although state-state dispute settlement systems can also be used for disputes where specific investors' interests are at risk or have been injured, it would still be "the most responsive in the investment treaty context" to engage the investors in discussion and decision making directly. ${ }^{97}$ Furthermore, investor-state DSMs are in fact created to

92 Norah Gallagher \& Wenhua Shan, Chinese Investment Treaties: Policies and Practice, Oxford University Press, 2009, p. 299. See also: An Chen, CHEN's Papers on International Economic Law (two volumes) (Vol. 1), Peking University Press, 2005.

93 Wolfgang Koeth, Can the Investment Court System (ICS) Save TTIP and CETA?, European Institute of Public Administration Working Paper, Vol. 2016/W/01, 2016, p. 3.

94 "Politicization" in the context of international investment, in general, was defined as "wherein the dispute features on the bilateral diplomatic agenda and state power and apparatus are leveraged on behalf of the private investor's interest”. See: Geoffrey Gertz \& Srividya Jandhyala \& Lauge N. Skovgaard Poulsen, Legalization, Diplomacy, and Development: Do Investment Treaties De-politicize Investment Disputes?, World Development, Vol. 107, 2018, p. 240-241.

In terms of the effect of investor-state arbitration on depoliticizing investment disputes, Kenneth argued that investorstate dispute settlement systems led to the transformation from traditional international investment law to modern new liberalism international investment law. See: Kenneth J. Vandevelde, A Brief History of International Investment Agreements, U.C.-Davis Journal of International Law \& Policy, Vol. 12, 2005, pp. 174-175. Lowenfeld summarized that legal scholars had reached consensus on the essence of IIAs being "controversies between foreign investors and host states are insulated from political and diplomatic relations between states". See: Corn Products International, Inc. v. Mexico, ICSID AF Case no ARB/(AF)/04/1, Decision on Responsibility, 15.01.2008, Separate Opinion of Arbitrator Lowenfeld, para. 1. Similarly, Reisman argued that the "central achievement" of the investment treaty regime was the insulation of investor-state claims from "the caprice of sovereign-to-sovereign politics". See: Ecuador v. United States, Expert Opinion with Respect to Jurisdiction of Professor W. Michael Reisman, Permanent Court of Arbitration, 04.04.2012, pp. 20-21. For further academic discussion on this, see: Martins Paparinskis, The Limits of Depoliticisation in Contemporary Investor-State Arbitration, Select Proceedings of the European Society of International Law, Vol. 3, 2010, pp. 2-18. On the other hand, there are also arguments pointing out that the function of depoliticization of investor-state dispute settlement systems lacked empirical investigation. See e.g. Geoffrey Gertz \& Srividya Jandhyala \& Lauge N. Skovgaard Poulsen, Legalization, Diplomacy, and Development: Do Investment Treaties De-politicize Investment Disputes?, World Development, Vol. 107, 2018, p. 239.

In this regard, it was also pointed out that, given the goal of IIAs was not solely protecting foreign investment, depoliticizing investment disputes should likewise be understood as an important but not an absolute goal of ISDS. See: Martins Paparinskis, The Limits of Depoliticisation in Contemporary Investor-State Arbitration, Select Proceedings of the European Society of International Law, Vol. 3, 2010, pp. 271-282.

95 Yongjie Li, Factors to be Considered for China's Future Investment Treaties, at: China and International Investment Law-Twenty Years of ICSID Membership, Brill | Nijhoff, 2015, p. 177.

${ }^{96}$ Cecilia Malmström, Remarks at the European Parliament on Investment in TTIP and Beyond, Meeting of the International Trade Committee of the European Parliament, Brussels, 06.05.2015.

${ }^{97}$ Nancy A. Welsh \& Andrea K. Schneider, The Thoughtful Integration of Mediation into Bilateral Investment Treaty Arbitration, Harvard Negotiation Law Review, Vol. 18, 2013, p. 132. 
minimize home states' intervention in investment disputes, ${ }^{98}$ and there are good reasons that investors may actually wish to avoid diplomatic protection. ${ }^{99}$

Mechanisms are available at the internal and international levels to resolve disputes directly between investors and their host states. The mechanisms are based on the domestic legal system of the host states. Since the present thesis focuses on IIAs, which provide rules on international DSMs possibly with a simple reference to local remedies, only the mechanisms at the international level are being considered in the following discussion of the present chapter.

\subsubsection{Scope of Disputes}

The disputes covered by an investor-state dispute settlement system are usually defined as any dispute between a claimant of one treaty party and the other treaty party concerning treatment alleged to breach the provisions of investment protection provided by the IIA at issue and to cause loss or damage to the claimant or its locally established enterprise. ${ }^{100}$ The exact scope depends on agreement of the treaty parties on the substantive obligations of host states stipulated in IIAs, which often involve activities associated with the nationalization of a business without fair compensation, ${ }^{101}$ and, in recent decades, more subtle government conduct also became subject to dispute. ${ }^{102}$ Such disputes have quite distinctive features. For example, they are between a private party and a sovereign state governed by public international law in the form of treaties; the disputing parties are linked in a more or less permanent relationship and the amounts of money at stake in these disputes are often excessive. ${ }^{103}$

\subsubsection{Acceptable Claims}

Regarding the claims that can be brought by investors in investor-state dispute settlement systems, no specific categories have been established in the existing literature. However, it has become common practice that only monetary damages and returning the original property to investors can be decided by tribunals, which in turn shape the scope of possible claims raised by investors.

In this regard, two specialties of the acceptable claims in ISDS deserve particular attention. First, such claims may involve a host state's power to regulate, which are traditionally considered within constitutional or administrative law. In this sense, investor-state arbitration is comparable to a judicial review in international public

\footnotetext{
${ }_{98}$ Bernard Kishoiyian, The Utility of Bilateral Investment Treaties in the Formulation of Customary International Law, Northwestern Journal of International Law \& Business, Vol. 14, 1993, p. 330.

${ }^{99}$ United Nations Conference on Trade and Development (UNCTAD), Investor-State Disputes: Prevention and Alternatives to Arbitration, 2010, available at: http://unctad.org/en/docs/diaeia200911_en.pdf, pp. 6-7, last visited on 06.08.2020.

100 See e.g. the EU-Singapore IPA (2018), Art. 3.1.1.

101 See e.g. Elettronica Sicula, S.p.A (ELSI) (United States of America v. Italy), ICJ, Judgment of 20 July 1989.

102 For example, the implementation of an environmental regulation that has an adverse financial impact upon foreign investment (See e.g. Methanex Corporation v. United States of America, UNCITRAL, Final Award of the Tribunal, 03.08.2015), and a change in the interpretation of tax law that decreases an anticipated refund (See e.g. Occidental Exploration and Production Company v. The Republic of Ecuador, London Court of International Arbitration Administered Case No. UN 3467, 01.07.2014).

103 Jeswald W. Salacuse, Is There a Better Way? Alternative Methods of Treaty-Based, Investor-State Dispute Resolution, Fordham International Law Journal, Vol. 31, 2007, p. 140.
} 
law. ${ }^{104}$ Second, this type of claim is adjudicated under a procedural regime similar to international commercial arbitration, which is designed for equally-positioned private parties and thus reasonable concerns arise regarding its suitability to cases in which disputing parties are not in similar situations. ${ }^{105}$

\subsubsection{Recent Crisis}

The past decades have represented a tumultuous period for ISDS. The backlash against the investor-state dispute settlement system in general and investor-state arbitration in particular come from both academics and legal practitioners. More significantly, a number of states terminated their existing IIAs, withdrew from multilateral investment treaties, and abandoned the ratification process of the treaties that predecessor governments had negotiated. ${ }^{106}$

A wide range of criticism was raised regarding both substantive and procedural aspects. ${ }^{107}$ For substantive issues, a typical example is the striking number of compensation awarded to investors, which put huge financial pressure on host states 108 and exerted a "chilling effect" on regulation by governments. ${ }^{109}$ Procedurally, investor-state arbitration is considered to be more problematic for various issues. First, lacking necessary transparency is a typical example. ${ }^{110}$ Since investor-state arbitration

104 Qinglin Zhang 张庆麟, An Analysis of the EU's Reform of the Investor-State Dispute Settlement Mechanism 欧 盟投资者一国家争端解决机制改革实践评析, Studies in Law and Business 法商研究, Vol. 3, 2016. In other words, tribunals are called to review host states' measures acting in their public capacity and exercising their sovereign rights. See: Tomáš Fecák, International Investment Agreements and EU Law, Kluwer Law International, 2016, p. 134.

105 An alternative approach that emerged in recent years tends to take an opposite view, seeing investor-state arbitration as "a unique form of treaty-based public law adjudication". See: Santiago Montt, State Liability in Investment Treaty Arbitration-Global Constitutional and Administrative Law in the BIT Generation, Hart Publishing, 2009, p. 9. Gus Van Harten, Investment Treaty Arbitration and Public Law, Oxford University Press, 2008, pp. 4571.

106 Robert Wisner \& Neil Campbell, Bringing the Home State Back in: the Case for Home State Control in InvestorState Dispute Settlement, International Bar Association, 14.02.2018, available at: https://www.ibanet.org/Article/NewDetail.aspx?ArticleUid=522de4cb-caa3-4656-8236-f1e13f261b86, last visited on 31.07.2020.

107 Gloria Maria Alvarez et al., A Response to the Criticism Against ISDS by EFILA, Journal of International Arbitration, Vol. 33, 2016, pp. 4-42.

${ }^{108}$ For example, in a case against Ecuador, the tribunal ordered $\$ 1.77$ billion compensation for the investor, which equalled to $5 \%$ or $6.3 \%$ of Ecuador's yearly budget. See: Occidental Petroleum Corporation and Occidental Exploration and Production Company v. The Republic of Ecuador, ICSID Case No. ARB/06/11, Award, 05.10.2012. Another example is the Argentinean currency crisis of January 2002, which led 39 foreign investors to initiate claims under investment treaties for the economic harm they suffered from Argentina's devaluation of the peso. This resulted in millions of damages. See: United Nations Conference on Trade and Development (UNCTAD), Latest Developments in Investor-State Dispute Settlement, IIA MONITOR No. 4, 2006, available at: $\mathrm{http}: / /$ www.unctad.org/en/docs//webiteiit20052_en.pdf, pp. 1, 3, last visited on 06.08.2020. For an academic discussion on this, see e.g. Shaotang Wang 王少棠, Legetimacy Crisis Resolved? Reconsideration of the EU's Reform of Investment Court System 正当性危机的解除? 一一欧盟投资争端解决机制改革再议, Studies in Law and Business 法商研究, Vol. 2, 2018, p. 164.

109 The chilling effect coming from investor-state arbitration can be shown by, for example, the delayed issuance of plain packaging regulation in New Zealand, under the influence of the Phillip Morris v. Australia. See: Tariana Turia, Government Moves Forward with Plain Packaging of Tobacco Products, Beehive.govt.nz, 20.02.2013, available at: https://www.beehive.govt.nz/release/government-moves-forward-plain-packaging-tobacco-products, last visited on 06.08.2020. It is noted that arguments casting doubts on this effect also exist. For example, based on publicly available information on the existing investor-state arbitration cases, Wolfgang Koeth argued that it was not true that ISDS provisions tilted the balance of power away from governments. See: Wolfgang Koeth, Can the Investment Court System (ICS) Save TTIP and CETA?, European Institute of Public Administration Working Paper, Vol. 2016/W/01, 2016, pp. 4-5.

${ }^{110}$ It was pointed out that investment arbitration transparency includes external and internal transparency. The 
originally adopted the procedural regime of commercial arbitration, confidentiality is kept as a key feature. However, this has been criticized due to disputes being resolved "behind closed doors". 111 Second, the ISDS regime is causing a sense of frustration stemming from different decisions in similar situations. ${ }^{12}$ This can be partly ascribed to the use of diverse terms in IIAs, ${ }^{113}$ but, more significantly, concerns come from conflicting treaty interpretations and applications and varied decisions on apparently similar points of law or fact, as demonstrated by the infamous CME cases. ${ }^{114}$ Even in some cases, the same article in the same IIA was interpreted differently by different tribunals. ${ }^{115}$ Lacking consistency in decision making has coloured the whole system with unpredictability and unreliability. ${ }^{116}$ The public's confidence in the independence

former refers to procedural transparency, and the latter focuses on whether arbitral awards are intelligible for the public. See: Federico Ortino, Transparency of Investment Awards: External and Internal Dimensions, at: Junji Nakagawa (ed.), Transparency in International Trade and Investment Dispute Settlement, Routledge, 2013, pp. 136149. Extensive regulations on transparency normally involve six aspects, including the initiation of arbitration, publication of documents, public hearings, acceptance of amicus curiae, and exceptions. See: Nathalie BernasconiOsterwalder \& Lise Johnson, Transparency in the Dispute Settlement Process: Country Best Practices, Internatioanl Institute for Sustainable Development (IISD), 02.2011, available at: https://www.iisd.org/sites/default/files/publications/transparency_dispute_settlement_processes.pdf, last visited on 03.08.2020. Since the present thesis focuses on the procedural arrangements of the dispute settlement process, only the former will be covered.

It is noted that there are arguments about the difference between "transparency" and "openness", as well as "confidentiality" and "privacy". See e.g. Julian D.M. Lew, Expert Report of Dr. Julian D.M. Lew (in Esso/BHP v. Plowman), Arbitration International, Vol. 11, 1995, pp. 283-296. Gary B. Born, International Commercial Arbitration (2nd edition), Kluwer Law International, 2014, p. 2781. For a complete analysis of tribunals' discretion in transparency-related issues, the present work adopts a broad definition of "transparency", which includes disclosing arbitration information to parties outside the arbitration proceedings as well as opening the proceedings to hear from non-disputing parties.

111 Lise Johnson, The Mauritius Convention on Transparency: Comments on the Treaty and Its Role in Increasing Transparency of Investor-State Arbitration, Columbia Center on Sustainable Investment, 09.2014, available at: http://ccsi.columbia.edu/files/2013/08/Mauritius-Convention-Transparency-Paper-formatted-FINAL.pdf, last visited on 04.08.2020.

112 Luis González García, Making Impossible Investor-State Reform Possible, at: Jean E. Kalicki \& Anna JoubinBret (eds.), Reshaping the Investor-State Dispute Settlement System: Journeys for the 21 st Century, Brill | Nijhoff, 2015, pp. 424-436.

113 Joachim Pohl \& Kekeletso Mashigo \& \& Alexis Nohen, Dispute Settlement Provisions in International Investment Agreements-A Large Sample Survey, OECD Working Papers on International Investment, Vol. 2, 2012, p. 40.

${ }^{114}$ In these cases, the same facts led to two arbitrations by related investors (a company and its main shareholder) against the Czech Republic. One tribunal found no liability and thus awarded no damages, and the other found liability and awarded over $\$ 350$ million (equivalent to the Czech Republic's annual healthcare budget). See: Ronald S. Lauder v. Czech Republic, UNCITRAL, Final Award, 03.09.2001; CME Czech Republic B.V. (Neth.) v. Czech Republic, UNCITRAL, Final Award, 14.03.2003. Other typical examples include the different conclusions reached by the SGS tribunals about disputes concerning legal issues (as the meaning of umbrella clauses) and the different results obtained within the Argentina saga with regard to factual interpretations (as the assessment whether a state of necessity should prevail). See respectively: SGS Société Générale de Surveillance S.A. v. Islamic Republic of Pakistan, ICSID Case No. ARB/01/13, Decision on Jurisdiction of 6 August 2003; SGS Société Générale de Surveillance S.A. v. Republic of the Philippines, ICSID Case No. ARB/02/6, Decision on Jurisdiction of 29 January 2004. MS Gas Transmission Company v. The Argentine Republic, ICSID ARB/01/8, Award, 12.05.2005; Enron Corporation and Ponderosa Assets, LP v. Argentine Republic, ICSID Case No. ARB/02/3, Award, 22.05.2007; Sempra Energy International v. The Argentine Republic, ICSID Case No. ARB.02.16, Award, 28.09.2007; LG\&E Energy Corp. LG\&E Capital Corp and LG\&E International Inc v. Argentine Republic, ICSID Case No. ARB/02/1, Decision on Liability, 3.10.2006.

115 See e.g. Kıllı̧ İnşaat İthalat İhracat Sanayi ve Ticaret Anonim Şirketi v. Turkmenistan, ICSID Case No. ARB/10/1, Award, 02.07.2013; İçkale İnşaat Limited Şirketi v. Turkmenistan, ICSID Case No. ARB/10/24, Award, 08.03.2016.

116 The system's unpredictability and unreliability are essential for both states and investors, because they rely upon previous determinations to adjust the tone of their future specific actions and to negotiate better agreements. See: Eduardo Zuleta, The Challenge of Creating a Standing International Investment Court, at: Jean E. Kalicki \& Anna Joubin-Bret (eds.), Reshaping the Investor-State Dispute Settlement System: Journeys for the 21st Century, 2015, pp. 11-15. 
and impartiality of ISDS adjudicators has also been negatively affected by the "double hats" issue. ${ }^{117}$

The unprecedented level of scrutiny of investor-state arbitration makes its reform a highly charged issue, and this actually serves as the basis for the worldwide ongoing ISDS reform. ${ }^{118}$ In particular, recent decades have witnessed a public-minded revolution of investor-state arbitration to appease the legitimacy concerns. It was also argued that the recent changes in the practice of investor-state arbitration reveal the development trend towards the principal-agent relation theory, instead of the trust relation theory, by reserving more power for treaty parties than granting it to adjudicators. 119 Such a change has made investor-state arbitration more confrontational, more transparent and more akin to litigation and, as a result, aggressive positions are openly entrenched, and the final result can be unsatisfying even for a winning party. In brief, it is fair to say that we are "at a unique historical junction in the evolution of resolving investment-related conflict", and investor-state arbitration "will no doubt be an important part of the puzzle". ${ }^{120}$

\subsubsection{The Relationship between State-State Dispute Settlement Systems and Investor-State Dispute Settlement Systems}

The relationship between state-state dispute settlement systems and investor-state dispute settlement systems has been described as "extraordinarily complicated, yet little studied". ${ }^{121}$ The theoretical dilemma is mainly contributed to by the inter-related disputes involved in these two types of systems, the correlated interests of disputing parties, the co-existence of state-state and investor-state DSMs, and the shared interpretative authority of state-state and investor-state tribunals. In practice, the potential conflicts between these two systems have not been highlighted in the sense that treaty parties seemed to have tried to avoid state-state arbitration, which can be

117 The term "double hats" in ISDS refers to the situation where a person in one investment arbitration case serves as a counsel, and serves as an arbitrator in another that involves the same legal issue.

${ }^{118}$ In this regard, Anthea Roberts categorized the different attitudes towards investor-state arbitration reform into three camps, "loyalist", "reformist" and "revolutionaries". Specifically, the "loyalists" were states that "continue to actively champion investor-state arbitration as the primary form of dispute resolution". The two primary examples of loyalists were the US and Japan. "Reformists" believed that the system needed more fundamental, institutional reform, like the introduction of an international investment court and/or an appellate mechanism, in order to salvage its legitimacy. The most widely recognized reformists were Canada and the EU. "Revolutionaries" rejected the wisdom of permitting investors to bring direct claims before international tribunals, preferring instead to require investors to pursue domestic remedies and/or limiting international dispute resolution to state-state arbitration. Two examples of this approach were Brazil and South Africa. See: Anthea Roberts, The Shifting Landscape of InvestorState Arbitration: Loyalists, Reformists, Revolutionaries and Undecideds, EJIL: Talk!, 15.06.2017, available at: https://www.ejiltalk.org/the-shifting-landscape-of-investor-state-arbitration-loyalists-reformists-revolutionariesand-undecideds/, last visited on 05.08.2020.

119 Regarding the relationship between treaty parties and the treaty-based international dispute settlement institutions, there are two main types of international relations theories: the principal-agent relation theory and the trust relation theory. The former purports that the dispute settlement institutions should serve the function of dispute settlement based on treaty parties' intention since they are established mainly based on the treaty parties' consideration of efficiency. On the other hand, the trust relation theory focuses more on the accountability and independence of the institutions, which thus enjoy more autonomy and discretion. See: Anthea Roberts, Power and Persuasion in Investment Treaty Interpretation: The Dual Role of States, American Journal of International Law, Vol. 104, 2010, pp. 186-187.

${ }^{120}$ Susan D. Franck, Integrating Investment Treaty Conflict and Dispute Systems Design, Minnesota Law Review, Vol. 92, 2007, p. 229.

121 Jarrod Wong, The Subversion of State-to-State Investment Treaty Arbitration, Columbia Journal of Transnational Law, Vol. 53, 2014, p. 8. 
proven by the limited number of state-state investment arbitration cases and the relatively significant volume of investor-state arbitration. Despite this, relevant regulations in international treaties and the cases where SSDS and ISDS processes coexist with each other still exist, which reveals the status quo of this problematic issue.

\subsubsection{Theoretical Dilemma}

\section{(i) Inter-related Disputes and Correlated Interests}

As introduced in Sections 2.2.1.1 and 2.2.2.1, supra, the disputes covered by state-state dispute settlement systems and investor-state dispute settlement systems are different, but nevertheless they are inter-related. The overlap arises from the issue of treaty interpretation. Namely, in ISDS, before applying the IIA at issue and making a decision, the initial step is to interpret the relevant provisions contained therein, which is also within the scope of SSDS. At the same time, establishing the facts and applying the law as interpreted to the facts are related. It is also very possible that a SSDS case is actually inspired by an injured investor or an existing ISDS case.

In addition, in SSDS and ISDS, the three disputing parties involved, the investor, the investor's home state and host state, have independent but inter-related interests which are granted by the underlying IIA. In ISDS, disputing parties, the investor and its host state, argue for their specific interests. Although it is not a party to the present dispute, the investor's home state is reasonably willing to exert a certain influence, since its interests are also affected: on the one hand, it may have the intention to protect its national, ${ }^{122}$ while on the other hand, it may intend to safeguard a state's right to regulate under the IIA at issue and prevent its relationship with the host state from being negatively affected by the ongoing investor-state dispute. Such correlated interests also exist in SSDS cases, which occur between treaty parties without the investors' presence. However, the results would have the ultimate influence on specific investors.

\section{(ii) Co-existence of State-State Dispute Settlement Mechanisms and Investor-State Dispute Settlement Mechanisms}

State-state dispute settlement mechanisms and investor-state dispute settlement mechanisms are often both provided for under the same IIA. As pointed out, especially the co-existence of state-state arbitration and investor-state arbitration without setting out a clear priority results in a hybrid investment dispute settlement. ${ }^{123}$ Such a hybrid has both positive and negative effects. On the one hand, these two types of DSMs can functionally complement each other in reaching an appropriate resolution of investment disputes. ${ }^{124}$ SSDS may supplement ISDS in the sense that the scope of covered disputes and types of relief in SSDS are normally broader than the latter. ${ }^{125}$ At the same

\footnotetext{
${ }^{122}$ It is also possible that the investor and its home state have conflicting interests, and thus the home state may prefer a reaction that is not in the interest of its investor.

${ }_{123}$ Anthea Roberts, State-to-State Investment Treaty Arbitration: A Hybrid Theory of Interdependent Rights and Shared Interpretive Authority, Harvard International Law Journal, Vol. 55, 2014, p. 1.

${ }^{124} \mathrm{Shu} \mathrm{Xv}$ 徐树, The Conflicts and Coordination between the Dule Tracks of the Enforcement Mechanisms of International Investment Agreements 国际投资条约 “双轨” 执行机制的冲突及协调, Studies in Law and Business 法商研究, Vol. 2, 2017, pp. 144-146.

125 In state-state arbitration, one treaty party can ask the other to modify or repeal certain measures, which is not
} 
time, as Article 27 of the ICSID Convention indicates, if the host state did not implement the investor-state arbitration decision, the investor's home state may resort to diplomatic protection or bring an international state-state case. Furthermore, for the disputes that are covered by both state-state and investor-state DSMs, these two options give the parties involved the necessary flexibility to settle disputes in the way that suits their situation best. ${ }^{126}$ On the other hand, the state-state and investor-state arbitration proceedings triggered in parallel or in sequence may cause problems at different levels. Different tribunals may claim jurisdiction or supremacy over the matter, which leads to uncertainty and potential forum shopping. ${ }^{127}$ In addition, repetitive proceedings would not only be a waste of the time and energy of disputing parties and adjudicators, but it may result in conflicting decisions, double-compensation and difficulties and complexities in enforcement.

Because of the potential problems brought about by the co-existence of state-state dispute settlement systems and investor-state dispute settlement systems, the theoretical exploration of their relationship has been pursued since the very beginning of their coexistence. Since state-state arbitration and investor-state arbitration are the two that are more likely to end up with enforceable decisions, relevant analyses have focused on them, which can be categorized into three schools. One school prioritizes investor-state arbitration based on the argument that the purpose of creating investor-state arbitration protects investors and excludes political influence on investment dispute settlement. ${ }^{128}$ Another school argues for the claims to be brought by "either the investor or the home state, but not generally by both". ${ }^{129}$ The third one suggests leaving this issue to tribunals in individual cases based on the doctrine of lis alibi pendens, the principle of res judicata and the principle of good faith. ${ }^{130}$ Despite the existence of such various opinions, this issue has not been thoroughly explored in theory and in practice, which results in unpredictability and potential instability.

\footnotetext{
possible in investor-state arbitration where investors may only be awarded monetary compensation or the return of property.

126 It is possible that, under certain situations, only one of them is in fact practicable and suitable. For instance, when there is a big number of aggrieved small investors, the home state getting involved in through SSDS can be a more effective and efficient way of resolving disputes.

127 Kyung Kwak \& Gabrielle Marceau, Overlaps and Conflicts of Jurisdiction between the World Trade Organization and Regional Trade Agreements, at: Lorand Bartels \& Federico Ortino (eds.), Regional Trade Agreements and the WTO Legal System, Oxford University Press, 2007, p. 467. Although the authors here focused on the potential conflicting jurisdiction under WTO and FTAs, the theoretical analysis also applies to parallel statestate dispute settlement mechanisms and investor-state dispute settlement mechanisms.

${ }^{128}$ It was argued that the primary rationale of the investor-state system is that "investment disputes should not be turned into diplomatic or state-state disputes, but be left exclusively to the investor to resolve with the host state". See e.g. Nathalie Bernasconi-Osterwalder, Analysis of the European Commission's Draft Text on Investor-State Dispute Settlement for EU Agreements, 19.07.2012, available at: https:/www.iisd.org/itn/2012/07/19/analysis-ofthe-european-commissions-draft-text-on-investor-state-dispute-settlement-for-eu-agreements/, last visited on 30.07.2020.

129 See e.g. Anthea Roberts, State-to-State Investment Treaty Arbitration: A Hybrid Theory of Interdependent Rights and Shared Interpretive Authority, Harvard International Law Journal, Vol. 55, 2014, p. 29.

${ }_{130}$ See e.g. August Reinisch, The Use and Limits of Res Judicata and Lis Pendens as Procedural Tools to Avoid Conflicting Settlement Outcomes, The Law and Practice of International Courts and Tribunals, Vol. 3, 2004, p. 50.
} 
(iii) Shared Interpretive Authorities of State-State Tribunals and Investor-State Tribunals

In investment dispute settlement, the responsibility for treaty interpretation is shared among treaty parties, investor-state tribunals and state-state tribunals. ${ }^{131}$ In order to discuss the relationship between state-state dispute settlement and investor-state dispute settlement systems, the focus here is on the shared interpretive authorities of the latter two. The interaction between treaty parties and tribunals on treaty interpretation is addressed in Section 11.4.3, infra.

State-state tribunals' interpretive authority has been described as "an important way for treaty parties to establish binding interpretations of their treaties". ${ }^{132}$ While for tribunals in ISDS, discharging the function of resolving specific investment disputes between investors and host states inevitably involves interpreting and applying the treaty. Regarding the relationship between the interpretive authorities of investor-state tribunals and state-state tribunals, some scholars argued that the former had wide jurisdiction to interpret and apply the substantive provisions of investment treaties, while the latter had limited jurisdiction over residual issues, such as the failure of a state to pay an investor-state award. ${ }^{133}$ This was later criticized by other academics. ${ }^{134}$ In general, the possible co-existence or overlap of the two types of authority of the tribunals to interpret the same or related provisions has been rarely discussed, which leaves the issue of how the decision made by one tribunal should be treated by the another unclear and uncertain.

\subsubsection{Existing Rules and Cases}

The extensive use of investor-state arbitration did not eliminate or replace state-state arbitration. In fact, recent years have witnessed the re-emergence of SSDS, especially in some newly concluded IIAs and recent cases. This sub-section analyses typical examples of the existing rules on the relationship between SSDS and ISDS, and it examines how tribunals dealt with this issue in practice.

\section{(i) Rules in the ICSID Convention and International Investment Agreements}

Regarding rules regulating the relationship between SSDS and ISDS, the ICSID Convention Article 27 provides a starting point. This article gives priority to investorstate arbitration by restricting the possibility for investors' home states to give diplomatic protection or to bring an international claim if one of its nationals and another Contracting State have consented to submit or have submitted to arbitration

\footnotetext{
131 United Nations Conference on Trade and Development (UNCTAD), Interpretation of IIAs: What States Can Do?, 2011, available at: http://unctad.org/en/Docs/webdiaeia2011d10_en.pdf, p. 3, last visited on 06.08.2020.

132 For instance, Anthea Roberts presented a different opinion, arguing that "interpretative authority should be understood as being shared between the treaty parties, investor-state tribunals, and state-to-state tribunals", and thus bringing state-state arbitration back was necessary. See: Anthea Roberts, State-to-State Investment Treaty Arbitration: A Hybrid Theory of Interdependent Rights and Shared Interpretive Authority, Harvard International Law Journal, Vol. 55, 2014, p. 54.

${ }^{133}$ See e.g. Republic of Ecuador v. United States of America, PCA Case No. 2012-5, Expert Opinion with Respect to Jurisdiction in the Interstate Arbitration Initiated by Ecuador Against the United States (W. Michael Reisman), 24.04.2012, p. 4.

134 Anthea Roberts, State-to-State Investment Treaty Arbitration: A Hybrid Theory of Interdependent Rights and Shared Interpretive Authority, Harvard International Law Journal, Vol. 55, 2014, pp. 4-5, 10-20.
} 
under the Convention, unless the host state has failed to abide by and comply with the award. Such an arrangement has been described as a sequencing approach, which is "consistent with the object and purpose of increasing the efficacy of investment treaty obligations by increasing opportunities for enforcement by arbitration". ${ }^{135}$ However, it is worth noting that this simple rule leaves a host of situations untouched. For example, except for diplomatic protection claims, it is not clear whether interpretive claims and claims for declaratory relief are allowed. In addition, in cases under other arbitration venues, such as UNCITRAL, whether investor-state arbitration enjoys such a priority is still an open question.

Although not often, some IIAs also contain provisions on the relationship between SSDS and ISDS. Some incorporate a provision repeating Article 27 of the ICSID Convention and thus give priority to ISDS process. ${ }^{136}$ The OECD Draft Multilateral Agreement on Investment goes further in this direction by preventing diplomatic protection claims if the dispute has been referred to any investor-state arbitration. ${ }^{137}$ Some other IIAs take the opposite approach, stipulating that ISDS processes do not prejudice SSDS processes. ${ }^{138}$

\section{(ii) Cases}

Although the number is limited, there are some cases in which the relationship between SSDS and ISDS is addressed to a certain extent. Typical examples include Stephane Benhamou v. Uruguay, Italy v. Cuba, Lucchetti v. Peru and Peru v. Chile, Chevron v. Ecuador and Ecuador v. the US, as well as Mexico v. the US and CANACAR v. the US, which are introduced in turn in the following.

First, in the case Stephane Benhamou v. Uruguay, pursuant to the France-Uruguay BIT (1993), a French investor, Stephane Benhamou, lodged a claim against Uruguay regarding the privatization of a Uruguayan bank. The investor-state tribunal eventually ruled in favour of Uruguay. ${ }^{139}$ During the ISDS process, Uruguay proposed to France to reach an agreement on the definition of "company" in the BIT concerned, one of the key issues in the ongoing investor-state arbitration, by formally invoking state-state consultations according to Article 10.1 of the France-Uruguay BIT (1993). Uruguay further argued that the investor-state tribunal should suspend the arbitral proceedings until the finalization of the discussion between treaty parties via diplomatic channels. However, the investor-state tribunal declined to postpone its decision, considering that, by virtue of the competence-competence principle, it had the authority to reach its own conclusion as long as the treaty parties had not reached an agreement on a binding interpretation. According to publicly available information, the consultations between

\footnotetext{
135 Id, p. 47.

136 See e.g. the Barbados-Germany BIT (1994), Art. 10(6); the US-Turkey BIT (1985), Art. VII.

137 OECD Draft Multilateral Agreement on Investment (MAI), Negotiating Text as of 24 April 1998, Part V, C1b.

138 Nathalie Bernasconi-Osterwalder, State-State Dispute Settlement in Investment Treaties, 10.2014, available at: https://www.iisd.org/sites/default/files/publications/best-practices-state-state-dispute-settlement-investment-

treaties.pdf, p. 18, last visited on 30.07.2020. For a breakdown of this kind of treaty provision, see: Martins Paparinskis, Investment Arbitration and the Law of Countermeasures, British Yearbook of International Law 2008, Vol. 79, 2008, pp. 284-285.

139 Stephane Benhamou v. Uruguay, UNCITRAL, Award, 19.12.2002.
} 
Uruguay and France seemed to end without any concrete result. Although Article 10.2 of the France-Uruguay BIT (1993) permits a treaty party to have recourse to state-state arbitration if a dispute cannot be resolved within six months via diplomatic channels, it is not clear whether Uruguay ever invoked this provision and brought a state-state arbitration case against France.

Second, in the case Italy v. Cuba, Italy brought a claim against Cuba on behalf of itself and several Italian investors under Article 10 of the Cuba-Italy BIT (1993), where investor-state arbitration would have been an alternative. ${ }^{140}$ Although there was no parallel or subsequent ISDS proceeding, the co-existence of state-state and investorstate DSMs in the underlying BIT caused debates over a state's right to bring a diplomatic protection claim. Cuba argued that the existence of the investor-state arbitration clause in the treaty prevented Italy from bringing a state-state proceeding on behalf of its nationals, while Italy contended that it had "double standing" to bring a direct claim (to vindicate its own substantive rights) and a diplomatic protection claim (to vindicate the rights of Italian investors). ${ }^{141}$ In the absence of any provision dealing with the relationship between SSDS and ISDS in the Cuba-Italy BIT (1993), the statestate tribunal determined that, as long as no investor had brought an investor-state arbitration case, the home state could request diplomatic protection. ${ }^{142}$ In reaching its ruling, the tribunal referred to the view taken by the tribunal in CMS v. Argentina and drew an analogy with Article 27 of the ICSID Convention, holding that diplomatic protection is complementary to ISDS. ${ }^{143}$

Third, two parallel cases were brought by Peru and its investors concerning the same dispute, Empresas Lucchetti, S.A. and Lucchetti Peru, S.A. v. Republic of Peru and Peru v. Chile. The former investor-state arbitration was initiated by Chilean investors based on the Chile-Peru BIT (2000). ${ }^{144}$ Peru v. Chile was brought thereafter and continued in parallel with the former. In specific, after Chilean investors started the investor-state arbitration, Peru approached Chile to try to reach an interpretive agreement on the provision that was at the heart of the ISDS case. Failing that, Peru raised state-state arbitration, requesting the tribunal to deliver a clarification of the contested provision. ${ }^{145}$ At the same time, it sought a suspension of the ongoing ISDS case, arguing that the subject of the concurrent state-state arbitration between Peru and Chile

\footnotetext{
140 Italian Republic v. Republic of Cuba, Ad Hoc Arbitration, Interim Award, 15.03.2005; Italian Republic v. Republic of Cuba, Ad Hoc Arbitration, Final Award, 15.01.2008. See also: Michele Potestá, Republic of Italy v. Republic of Cuba, American Journal of International Law, Vol. 106, 2012, pp. 341-347.

${ }_{141}$ Italian Republic v. Republic of Cuba, Ad Hoc Arbitration, Interim Award, 15.03.2005, paras. 24-25.

142 Id, para. 65.

143 Id, para. 65. In the case CMS v. Argentina, the tribunal stated that "diplomatic protection is intervening as a residual mechanism to be resorted to in the absence of other arrangements recognizing the direct right of action by individuals". See: CMS Gas Transmission Co. v. Argentine Republic, ICSID No. ARB/01/8, Decision of the Tribunal on Objections to Jurisdiction, 17.07.2003, para. 45.

144 Empresas Lucchetti, S.A. and Lucchetti Peru, S.A. v. Republic of Peru, ICSID Case No. ARB/03/4, Award, 07.02.2005.

145 The documents in this case have not been published. Relevant information can be found in scholars' commentaries. See e.g. Luke Eric Peterson, ICSID Tribunal Declines to Halt Investor Arbitration in Deference to State-to-State Arbitration, International Institute for Sustainable Development (IISD), 19.12.2003, available at: http://www.iisd.org/pdf/2003/investment_investsd_dec19_2003.pdf, last visited on 05.08.2020.
} 
was the same and the tribunal in the latter had interpretive authority. ${ }^{146}$ The tribunal declined this request for the suspension of the case because "the conditions for a suspension of the proceedings were not met". ${ }^{147}$ Since the investor-state tribunal finally decided in favour of Peru's jurisdictional objection, Peru discontinued the statestate arbitration, which left the question unanswered regarding the jurisdiction of the state-state tribunal in the situation where investor-state arbitration had been raised regarding the same dispute.

Two more cases arose between a US investor, Ecuador and the US. Based on the Ecuador-US BIT (1993), Chevron, a US investor, initiated an investor-state arbitration case under the UNCITRAL Arbitration Rules (1976) against Ecuador. In order to resolve the dispute, the investor-state tribunal delivered its interpretation of "effective means" contained in the underlying BIT, based on which it decided in favour of the investor. ${ }^{148}$ Being unsatisfied with the investor-state tribunal's treaty interpretation, Ecuador first contacted the US diplomatically to try to reach a joint interpretation. Without receiving any concrete feedback from the US, it relied on the state-state arbitration provision in the same BIT, requiring a state-state tribunal to interpret the relevant provision. However, the US objected to the state-state tribunal's jurisdiction on the basis that there was no dispute between treaty parties. ${ }^{149}$ In particular, it asserted that the treaty did not grant the state-state tribunal an "advisory jurisdiction" or establish "an appellate mechanism". ${ }^{150}$ In the end, considering the US had not expressed any opinion on the treaty interpretation issue, the state-state tribunal denied its jurisdiction because of the absence of any "dispute". ${ }^{151}$ This decision again left a crucial question unresolved, which is whether the interpretation of substantive provisions in the BIT should be reserved for investor-state track once that process has been engaged.

Last, in the context of the North American Free Trade Agreement (NAFTA), after several unsuccessful attempts to resolve the dispute through meetings of the NAFTA Free Trade Commission and bilateral consultations with the US, Mexico brought a case to seek a declaration that the US had breached its national treatment and most-favourednation treatment obligations with respect to Mexico and potential Mexican investors. ${ }^{152}$

146 Empresas Lucchetti, S.A. and Lucchetti Peru, S.A. v. The Republic of Peru, ICSID Case No. ARB/03/4, Award, 07.02.2005, para. 7 .

$147 \mathrm{Id}$, para. 9.

148 Chevron Corporation and Texaco Petroleum Company v. Republic of Ecuador, PCA Case No. 34877, Partial Award on the Track II, 30.08.2018, paras. 242-244.

149 Republic of Ecuador v. United States of America, PCA Case No. 2012-5, Request for Arbitration, 28.06.2011, para. 1.

150 Republic of Ecuador v. United States of America, PCA Case No. 2012-5, Statement of Defense of Respondent United States of America, 29.03.2012, pp. 11-12. Regarding this, Ecuador argued that the purpose of the claim was to clarify the meaning of the provision for future cases rather than to appeal the tribunal's decision in the Chevron case. See: Luke Eric Peterson, United States Defeats Ecuador's State-to-State Arbitration, IAReporter, 02.09.2012, available at: https://www.iareporter.com/articles/united-states-defeats-ecuadors-state-to-state-arbitration-willoutcome-dissuade-argentine-copycat-case/, last visited on 05.08.2020.

151 The tribunal's award has not been publicly released, but it was reported that the majority declined its jurisdiction because there was no concrete dispute with practical consequences between Ecuador and the US, which was required in the state-state arbitration clause. See: Jarrod Hepburn \& Luke Eric Peterson, US-Ecuador Inter-State Investment Treaty Award Released to Parties, IAReporter, 30.10.2012, available at: https://www.iareporter.com/articles/usecuador-inter-state-investment-treaty-award-released-to-parties-tribunal-members-part-ways-on-key-issues/, last visited on 05.08.2020.

152 Mexico complained that the US failed to lift a moratorium on processing applications by Mexican-owned 
The US contended that Mexico could not make a claim on behalf of unidentified Mexican investors. ${ }^{153}$ In the end, the tribunal confirmed its jurisdiction and determined that the behaviour of the US was inconsistent with the NAFTA, "even if Mexico cannot identify a particular Mexican national or nationals". ${ }^{154}$ Since the US did not implement the decision of the state-state tribunal, in 2009, a Mexican association of trucking companies brought an UNCITRAL investor-state arbitration case under Chapter 11 of the NAFTA seeking damages for the violation by the US of national treatment, mostfavoured-nation treatment and minimum standard of treatment regarding the same subject matter decided in Mexico v. the US. ${ }^{155}$ It appears that this process was discontinued and a tribunal was never constituted. ${ }^{156}$ Relevant issues therefore remain open, such as whether the earlier state-state case precludes the later investor-state case and whether the investor-state tribunal would have been bound by the previous decision of the state-state tribunal.

In brief, a typical problematic situation regarding the relationship between SSDS and ISDS is where state-state arbitration and investor-state arbitration are resorted to concurrently or subsequently. Key issues are related to the jurisdiction of the tribunals and the effect of their decisions in these two types of cases. To summarize the lessons from the typical cases introduced above, first, when both types of proceedings exist at the same time, the tribunal in Stephane Benhanou v. France failed to wait for the result of diplomatic consultations under SSDS process. Similarly, the tribunal in Lucchettiv. Peru failed to suspend investor-state arbitration because of the co-existence of statestate arbitration. It can be inferred from the decision of the tribunal in Italy v. Cuba that, if the investor initiated investor-state arbitration on the same issue, its home state could not request diplomatic protection through a state-state process at a later stage. Second, no clear answer has been given regarding the effect of decisions in the situation where the interpretation of a substantive provision in an IIA is touched upon by an investorstate tribunal and a state-state tribunal in turn. The Ecuador v. the US tribunal did not touch upon this issue, since it declined its jurisdiction at the beginning, leaving the effect of the investor-state tribunal's decision unclear. The suspension of CANACAR $v$. the US left the question unanswered as to how the decision of the earlier state-state tribunal would have affected the decision of the later investor-state tribunal. Therefore, it is fair to say that the limited number of existing cases do not give much instruction on the potential problematic situations with regard to the relationship between SSDS and ISDS. Furthermore, it is uncertain how these cases would affect future tribunals considering the absence of a binding precedent until now. ${ }^{157}$

trucking firms. See: Mexico v. United States (in the Matter of Cross-Border Trucking Services), NAFTA Chapter 20 State-to-State Arbitration, Final Report of the Panel, 06.02.2001.

153 Id, paras. 147, 283.

${ }^{154}$ Id, para. 292.

155 CANACAR v. United States of America, Notice of Arbitration, 02.04.2009, para. 1.

156 US Department of State, CANACAR v. United States of America, 04.02.2009, available at: http://www.state.gov/s/1/c29831.htm, last visited on 21.05.2017.

157 Nathalie Bernasconi-Osterwalder, State-State Dispute Settlement in Investment Treaties, 10.2014, available at: https://www.iisd.org/sites/default/files/publications/best-practices-state-state-dispute-settlement-investmenttreaties.pdf, p. 17, last visited on 30.07.2020. 


\subsection{International Investment Dispute Settlement Mechanisms}

DSMs are indispensable for international treaties in general and IIAs in particular. For both SSDS and ISDS, both amicable and adjudicative DSMs can be identified in existing practice, among which negotiation, consultations, mediation, conciliation, and adjudication frequently appear in IIAs. ${ }^{158}$ This section first generally discusses the functions of DSMs for IIAs and then introduces the basic procedural arrangements and main characteristics of these often-used mechanisms.

\subsubsection{Functions}

In addition to dispute settlement, DSMs arguably have a variety of other functions. First, DSMs should a priori deter the parties from violating the agreement. ${ }^{159}$ Second, DSMs serve as a way of providing new information to treaty parties by clarifying their obligations. Furthermore, by clarifying the interpretation and scope of certain terms and conditions of an agreement, DSMs lead to "a more coherent implementation". ${ }^{160}$ Third, adjudicative DSMs can present how adjudicators deliberate and balance different legal principles, ${ }^{161}$ providing inspirations not only to disputing parties but also other stakeholders in international investment law. In addition, effective DSMs can channel the productive forces of conflicts, maximize the satisfaction of stakeholders, realize the international rule of law, and enhance the legitimacy of the dispute resolution process.

DSMs are related to each other. For example, mediation can be seen as a continuation of negotiation with the help of a third party. In this sense, arbitration and litigation in many cases may also be interpreted as a continuation of negotiation by other means to "a lesser but still important extent". ${ }^{162}$ In addition, multiple types of DSMs often coexist. ${ }^{163}$ Ideally, they complement and cooperate with each other to offer disputing parties a list of choices, in order to satisfy their needs under diverse specific situations by taking advantage of the different features of each mechanism. They come together

\footnotetext{
158 It is noted that ICSID also has a fact-finding facility as another DSM for ISDS, regulated by ICSID Fact-Finding (Additional Facility) Rules. According to these rules, provided both parties consent, a committee will be established to provide the parties with an impartial assessment of facts which, if accepted by them, resolve a conflict about specific factual issues. The Rules envisage that there will be oral proceedings, written submissions, evidence, witness testimony, and a report that "shall be limited to findings of fact [and] shall not contain any recommendations to the parties nor shall it have the character of an award," and the parties will be "entirely free as to the effect to be given to the Report." See: ICSID Fact-Finding (Additional Facility) Rules, Arts. 15, 16. However, this DSM has never been used since its inception in 1978. For more discussion on ICSID fact-finding facility, see: Ucheora O. Onwuamaegbu, The Role of ADR in Investor-State Dispute Settlement: The ICSID Experience, Transnational Dispute Management (TDM) in Mediation \& ADR, Vol. 1, 2007, p. 13.

159 Stefan Szepesi, Comparing EU Free Trade Agreements: Dispute Settlement, European Centre for Development Policy Management (ECDPM), 01.2004, available at: https://ecdpm.org/wp-content/uploads/2013/11/IB-6GComparing-EU-Free-Trade-Agreements-Dispute-Settlement-2004.pdf, last visited on 05.08.2020.

160 Id.

161 Joost Pauwelyn \& Manfred Elsig, The Politics of Treaty Interpretation: Variations and Explanations Across International Tribunals, at: Jeffrey Dunoff \& Mark Pollack (eds.), Interdisciplinary Perspectives on International Law and International Relations, Cambridge University Press, 2012, pp. 445-473.

162 Jeswald W. Salacuse, Is There a Better Way? Alternative Methods of Treaty-Based, Investor-State Dispute Resolution, Fordham International Law Journal, Vol. 31, 2007, p. 155.

163 Todd Allee \& Manfred Elsig, Dispute Settlement Provisions in PTAs: New Data and New Concepts, at: Trade Cooperation: The Purpose, Design and Effects of Preferential Trade Agreements, Cambridge University Press, 2015, p. 327.
} 
constituting a comprehensive dispute settlement system. A dispute settlement system that is palatable to treaty parties, attractive and practicable to potential users and functional to investment dispute resolution is essential to an IIA, without which the cost of resolving disputes would increase, investment risks will be amplified, investment disincentives would be generated, and even the success of an investment treaty regime could be undermined. ${ }^{164}$

\subsubsection{Common Dispute Settlement Mechanisms}

There are different ways of recognizing and differentiating between DSMs. ${ }^{165}$ Two common categories are amicable mechanisms and adjudicative mechanisms. These two groups of DSMs normally have a distinct focus and hence distinct moralities - the former focuses on "optimum settlement" while the latter focuses on "a decision according to the law of the contract". ${ }^{166}$ At the same time, it should also be noted that amicable and adjudicative DSMs are not mutually exclusive. Instead, they can be and often are used sequentially or in a customized combination. ${ }^{167}$

Specifically, amicable DSMs provide solutions based on the interests of the disputing parties, which may not necessarily reflect their exact legal standing. ${ }^{168}$ Compared to adjudication, amicable mechanisms are normally confidential instead of transparent, more economic, less time-consuming, and contribute to the parties' on-going cooperative relationship. Thus, both states and investors have incentives to at least first try to redress disputes through amicable DSMs. ${ }^{169}$ Such DSMs can be further grouped into bilateral mechanisms where only disputing parties are involved, such as negotiation

164 Susan D. Franck, Integrating Investment Treaty Conflict and Dispute Systems Design, Minnesota Law Review, Vol. 92, 2007, pp. 183-184. For a further discussion on the significance of DSMs to IIAs, see: Timothy A. Steinert, If the BIT Fits: The Proposed Bilateral Investment Treaty between the United States and the People's Republic of China, Columbia Journal of Asian Law, Vol. 2, 1988, p. 405. Barbara Koremenos, If Only Half of International Agreements Have Dispute Resolution Provisions, Which Half Needs Explaining?, The Journal of Legal Studies, Vol. 36, 2007, p. 209. Todd Allee \& Manfred Elsig, Dispute Settlement Provisions in PTAs: New Data and New Concepts, at: Trade Cooperation: The Purpose, Design and Effects of Preferential Trade Agreements, Cambridge University Press, 2015, p. 319.

165 For instance, one standard that was used for discussing the different DSMs in preferential trade agreements is the amount of delegation of dispute settlement authority states are willing to grant, namely, how much power or authority is delegated to a third party throughout the process. This can be reflected as ex ante control, such as the selection of panellists or court members, and on-the-spot control mechanisms, like interim reviews of the third party's decisions. See: Todd Allee \& Manfred Elsig, Dispute Settlement Provisions in PTAs: New Data and New Concepts, at: Trade Cooperation: The Purpose, Design and Effects of Preferential Trade Agreements, Cambridge University Press, 2015, pp. 341-342.

${ }^{166}$ Lon L. Fuller, Collective Bargaining and the Arbitrator, at: Mark L. Kahn (ed.), Collective Bargaining and the Arbitrator's Role: Proceedings of the Fifteenth Annual Meeting-National Academy of Arbitrators, Bureau of National Affairs Inc., 1962, pp. 29-30.

167 Id, at 7.

168 Michael Cohen, Alternative Dispute Resolution, EuroExpert Symposium, Estoril/Portugal, 2003. Jeswald W. Salacuse, Is There a Better Way? Alternative Methods of Treaty-Based, Investor-State Dispute Resolution, Fordham International Law Journal, Vol. 31, 2007, p. 176.

${ }^{169}$ For investors, such incentives can come from the intention to continue the investment project in its host state. In terms of states, they may have concerns about facing a decision of failing to honour its investment treaty obligations. See: Jeswald W. Salacuse, Is There a Better Way? Alternative Methods of Treaty-Based, Investor-State Dispute Resolution, Fordham International Law Journal, Vol. 31, 2007, p. 153. However, it is admitted that there is little empirical evidence that generally described settlement rates, let alone whether settlement was influenced by the use of any particular amicable DSMs. In particular, as pointed out, governments are likely to have a political disincentive to take responsibility for their conduct if it is preferable to hold a tribunal responsible for a particular result. See: Susan D. Franck, Integrating Investment Treaty Conflict and Dispute Systems Design, Minnesota Law Review, Vol. 92, 2007, p. 203. Todd Allee \& Paul K. Huth, Legitimizing Dispute Settlement: International Adjudication as Domestic Political Cover, American Political Science Review, Vol. 100, 2006, p. 219. 
and consultations, and trilateral mechanisms where disputes are referred to an external party to assist disputing parties in reaching a settlement, like mediation and conciliation. In a dispute settlement system, amicable mechanisms often exist as a complementary alternative which is available at any point during the whole dispute resolution process alongside adjudicative DSMs. Sometimes, they are set as a precondition to resorting to adjudication procedures with a requirement of minimum duration, which is referred to as the "cooling-off" period. ${ }^{170}$ Even if a complete settlement is not achieved, amicable DSMs may narrow issues for later adjudication or open lines of subsequent communication. Relevant treaty provisions may generally provide for amicable settlement without explicitly identifying specific DSMs.

Existing practice usually adopts the form of institutional or ad hoc arbitration for adjudicative DSMs. Compared to amicable mechanisms, the need for dispute settlement procedures being perceived as legitimate in adjudication is much stronger. ${ }^{171}$ In general, adjudicative DSMs enjoy the advantage of guaranteeing the resolution of disputes, contributing to the international rule of law and developing international jurisprudence. Their perceived weakness is reflected in high costs, long duration of time, potential frivolous and vexatious claims, etc. ${ }^{172}$ As mentioned in Section 2.2.2.3, supra, these shortcomings were particularly exaggerated in recent decades, which resulted in investor-state arbitration going through a "legitimate crises". ${ }^{173}$

\subsubsection{Negotiation and Consultations}

Negotiation and consultations are sometimes used interchangeably, both of which refer the communications between disputing parties regarding possible solutions to their dispute. These two DSMs provide channels that permit parties to address issues informally before ratcheting up the costs and formality related to conflict resolution. The process can be subject to the power asymmetry between disputing parties with the absence of any neutral third party participation. They are the least informal DSMs, and thus normally no procedural rules are provided. There is a slight difference between negotiation and consultations in the extent of formality: state-state negotiation becomes consultations when it is conducted in a more formal form, as shown by the practice in the WTO Dispute Settlement System.

In state-state disputes, negotiation and consultations address disputes through government-to-government communications and often result in a political settlement

\footnotetext{
170 Joachim Pohl \& Kekeletso Mashigo \& \& Alexis Nohen, Dispute Settlement Provisions in International Investment Agreements-A Large Sample Survey, OECD Working Papers on International Investment, Vol. 2, 2012.

${ }^{171}$ It was argued that such legitimacy had both internal and external dimensions, which meant that dispute settlement procedures should be generally accepted as fair and objective by users as well as the broader public. See: Ignacio Garcia Bercero \& Paolo Garzotti, DSU Reform: Why Have Negotiations to Improve WTO Dispute Settlement Failed so far and What Are the Underlying Issues?, The Journal of World Investment \& Trade, Vol. 6, 2005, p. 853. Although the author here focused on the WTO Dispute Settlement System, the theoretical arguments can be more generally applied in the area of international third-party adjudication.

${ }_{172}$ United Nations Conference on Trade and Development (UNCTAD), Investor-State Disputes: Prevention and Alternatives to Arbitration, 2010, available at: http://unctad.org/en/docs/diaeia200911_en.pdf, last visited on 06.08.2020.

173 Susan D. Franck, The Legitimacy Crisis in Investment Treaty Arbitration: Privatizing Public International Law Through Inconsistent Decisions, Fordham Law Review, Vol. 73, 2005, p. 1523.
} 
rather than a determination based on the merits of the case. ${ }^{174}$ Such a pure diplomatic process can happen on an ad hoc basis for a specific dispute, or it can be realized through periodic meetings of the joint committee under the disputed IIA. ${ }^{175}$ Similarly, investor-state negotiation and consultations are also amicable and non-structured DSMs with low procedural predictability. The different nature of disputing parties as private parties and governments results in the communication in this case to be more affected by their power asymmetries. It is safe to say that, in practice, virtually all investor-state disputes go through a period of negotiations before reaching settlement or turning to other DSMs. ${ }^{176}$

\subsubsection{Mediation}

Mediation is often defined as a confidential, informal, structured, and voluntary mechanism, where disputes are resolved in an amicable and cost-effective process with assistance from a third party. ${ }^{177}$ It encourages disputing parties to be forward-looking and normally extra-legal interests are included in the discussion to permit the development of "integrative solutions". ${ }^{178}$ In this way, mediation creates additional value by restructuring the parties' relationship to make it as profitable as possible. ${ }^{179}$ Compared to negotiation, the participation of a mediator to some extent increases the possibility of the disputes ending in settlement by providing assistance, addressing the influence of the power asymmetry, and letting parties "be realistic about their options" in a more organized process. ${ }^{180}$ The mediator's role can be described as an "honest broker", not a judge, but it is also noted that mediation can be interest-based pursuant to parties' needs as well as rule-based according to applicable laws. ${ }^{181}$ Through the intervention of a skilful and well-intentioned third party, mediation could overcome

174 Rachel Brewster, Rule-Based Dispute Resolution in International Trade Law, Virginia Law Review, Vol. 92 , 2006, pp. 254-256. State-state negotiation and consultations have been labelled by existing academic discussions as "political", the opposite of "legalization" in terms of dispute settlement design. See: Todd Allee \& Manfred Elsig, Dispute Settlement Provisions in PTAs: New Data and New Concepts, at: Trade Cooperation: The Purpose, Design and Effects of Preferential Trade Agreements, Cambridge University Press, 2015, p. 346.

175 Such a joint committee is normally composed of representatives from all treaty parties who are at a reasonably high political level. Despite lacking a systematic study of the overall efficacy, such meetings did succeed in resolving some disputes in the area of international economic law. See: William J. Davey, Dispute Settlement in the WTO and RTAs: A Comment, at: Lorand Bartels \& Federico Ortino (eds.), Regional Trade Agreements and the WTO Legal System, Oxford University Press, 2006, p. 353.

176 Jeswald W. Salacuse, Is There a Better Way? Alternative Methods of Treaty-Based, Investor-State Dispute Resolution, Fordham International Law Journal, Vol. 31, 2007, p. 166.

177 Anna Spain Bradley, Integration Matters: Rethinking the Architecture of International Dispute Resolution, University of Pennsylvania Journal of International Law, Vol. 32, 2010, p. 23. Robert B. Davidson, Initiating an International Mediation, at: Richard Chernick \& Daniel M. Kolkey \& Barbara Reeves Neal (eds.), Practitioner's Handbook on International Arbitration and Mediation (Third Edition), JurisNet, LLC, 2012, p. 479.

178 Carrie J. Menkel-Meadow \& Lela Porter Love \& Jean R. Sternlight \& Andrea Kupfer Schneider, Dispute Resolution: Beyond the Adversarial Model (Second Edition), Aspen Publishers, 2010, pp. 270-296.

179 Thomas Wälde, Efficient Management of Transnational Disputes: Mutual Gain by Mediation or Joint Loss in Litigation, Arbitration International, Vol. 22, 2006, p. 206.

180 Nancy A. Welsh \& Andrea K. Schneider, The Thoughtful Integration of Mediation into Bilateral Investment Treaty Arbitration, Harvard Negotiation Law Review, Vol. 18, 2013, pp. 82-83.

${ }^{181}$ Interest-based mediation and rule-based mediation are used to describe a mediator's function in the substantive aspect of dispute resolution - suggesting a resolution according to parties' interests or making an assessment of parties' positions based on the applicable law. See: Manon Schonewille \& Jeremy Lack, Mediation in the European Union and Abroad: 60 States Divided by a Common Word?, at: Manon Schonewille \& Fred Schonewille (eds.), The Variegated Landscape of Mediation: A Comparative Study of Mediation Regulation and Practices in Europe and the World, Eleven International Publishing, 2014, pp. 25-35. 
various barriers to a negotiated settlement. ${ }^{182}$ Furthermore, when properly done, mediation can effectively address fairness and justice. ${ }^{183}$ It is admitted that there is also an ongoing critique of mediation, such as that it lacks fair procedures in prioritizing settlement, hindering the development of jurisprudence in international investment law and reducing the inhibiting effect of arbitral awards on governments' illegal behaviours. ${ }^{184}$

Mediation can be scheduled to precede adjudication in the "cooling-off" process as an alternative or a compulsory step, and it is made available at any point during the process of other DSMs. ${ }^{185}$ Even if a complete settlement is not achieved, mediation may reduce the issues for later adjudication or open lines of communication for subsequent negotiation. As opposed to adjudication, the mediation process relies more on party autonomy. In addition to detailed procedural arrangements, particularly, entering into mediation depends on disputing parties' agreement and the ultimate solution is subject to their mutual decision to hammer out the outcome or to accept the suggestion from the mediator. ${ }^{186}$

Under IIAs, state-state mediation may not be explicitly mentioned, but there should be no doubt about its availability, since it can be covered by the general reference to making efforts to reach an amicable settlement. Nevertheless, state-state mediation is admittedly difficult to realize in practice. This can be contributed by a state's general reluctance to initiating dispute settlement proceedings with another state. Furthermore, it does not happen very often that complaints from a private investor motivates its home state to initiate a dispute settlement process with another state; even when the motivation is strong enough, it would still be "the most responsive in the investment treaty context" to engage the investors directly in discussion and decision making. ${ }^{187}$ At the same time, finding a proper mediator for state-state disputes is likely to be difficult.

For ISDS, mediation is arguably more practicable and valuable. In an on-going investment project, when there is a dispute between the investor and its host state, resolving the dispute is critical, but restoring the relationship and ensuring the continued operation of the investment project are also often of paramount importance. As was pointed out by the tribunal in Achmea BV . Slovakia, a black and white solution to a legal issue in which one side wins and the other side loses may not be the optimum

182 Jeswald W. Salacuse, Is There a Better Way? Alternative Methods of Treaty-Based, Investor-State Dispute Resolution, Fordham International Law Journal, Vol. 31, 2007, p. 169.

${ }^{183}$ Hualing Fu, Mediation and the Rule of Law: The Chinese Landscape, at: Joachim Zekoll \& Mortiz Bälz \& Iwo Amelung (eds.), Formalisation and Flexibilisation in Dispute Resolution, Brill | Nijhoff, 2014, p. 108.

184 Jeswald W. Salacuse, Is There a Better Way? Alternative Methods of Treaty-Based, Investor-State Dispute Resolution, Fordham International Law Journal, Vol. 31, 2007, p. 179.

${ }^{185}$ It was argued that offering mediation, conciliation and arbitration together may, in fact, be the most effective way to achieve sustainable investment dispute settlement and economic development. See: Frauke Nitschke, The IBA's Investor-State Mediation Rules and the ICSID Dispute Settlement Framework, ICSID Review, Vol. 29, 2014, p. 132.

186 Chang-fa Lo et. al., Concept Paper on the Creation of a Permanent "Asia-Pacific Regional Mediation Organization" for State-to-State (Economy-to-Economy) Disputes, Comtemporary Asia Arbitration Journal, Vol. 10, 2017, p. 328.

187 Nancy A. Welsh \& Andrea K. Schneider, The Thoughtful Integration of Mediation into Bilateral Investment Treaty Arbitration, Harvard Negotiation Law Review, Vol. 18, 2013, p. 132. 
outcome in every ISDS case. ${ }^{188}$ In this sense, by fostering the understanding of disputing parties, reconciling their interests, repairing the damaged relationship, contributing to further cooperation, mediation can add extra value to the dispute resolution process. ${ }^{189}$ Furthermore, with regard to addressing disputing parties various interests to reach a win-win solution, mediation increases the potential to offer a viable option than arbitration. ${ }^{190}$ Due to the level of confidentiality in mediation, published information on the existing investor-state mediation cases is very scarce and often limited to its occurrence without further details. ${ }^{191}$ Nevertheless, compared to investorstate arbitration, mediation was inferred to have had less real use. ${ }^{192}$ This can be due to the fact that government officials, investors and lawyers are not often deeply knowledgeable about mediation process. Furthermore, government officials may be reluctant to agree to a mediated settlement "for fear of being accused of weakness in defending national interests against foreigners, or worse, corruption". 193 Probably sparked by the rise in the number of investor-state disputes and the drawbacks of investor-state arbitration, interest in investor-state mediation has been growing in recent

${ }^{188}$ In this case, at the end of a hearing, the tribunal observed that the aims of both sides seemed to be approximately aligned, and a legal decision was not the optimum outcome. Thus, it recommended that the parties seek out somebody to act as a mediator to settle the dispute. See: Achmea BV v. Slovakia, PCA Case No 2008-13, Final Award, 07.12.2012, pp. 14-15.

189 Nancy A. Welsh \& Andrea K. Schneider, The Thoughtful Integration of Mediation into Bilateral Investment Treaty Arbitration, Harvard Negotiation Law Review, Vol. 18, 2013, pp. 116-117.

190 Shahla Ali, Prospects of Utilizing Investor-State Mediation and UNCITRAL Rules on Transparency for Polycentric Environmental Disaster-Related Disputes: The Case of Vattenfall v. Germany, at: Muruga Perumal Ramaswamy \& Jodo Ribeiro (eds.), Trade Development through Harmonization of Commercial Law, New Zealand Association of Comparative Law, 2015, p. 137. Shahla F. Ali \& Odysseas G. Repousis, Investor-State Mediation and the Rise of Transparency in International Investment Law: Opportunity or Threat?, Denver Journal of International Law and Policy, Vol. 45, 2016-2017, p. 235.

191 For instance, a recent disclosed investor-state mediation took place between a French company and the Philippines under the France-Philippines BIT (1994). This case was filed under the IBA Rules for Investor-State Mediation (2012), with the assistance of the ICC-ADR Centre. It was brought by Systra SA and its local subsidiary Systra Philippines Inc., arising out of allegedly long overdue invoices for services and work performed on metro and rail projects. Other information about this case has not been made public. See: Luke Eric Peterson, In an Apparent First, Investor and Host-State Agree to Try Mediation under IBA Rules to Resolve an Investment Treaty Dispute, IAReporter, 14.04.2016, available at: https://www.iareporter.com/articles/in-an-apparent-first-investor-and-hoststate-agree-to-try-mediation-under-iba-rules-to-resolve-an-investment-treaty-dispute/, last visited on 05.08.2020.

192 Nancy A. Welsh \& Andrea K. Schneider, The Thoughtful Integration of Mediation into Bilateral Investment Treaty Arbitration, Harvard Negotiation Law Review, Vol. 18, 2013, p. 144. Arguments supporting the possible frequent use of investor-state mediation also exist, which is mainly based on the fact that the number of cases ended with amicable settlement is around $28 \%$ of the total cases in the world. See: Shixi Huang 黄世席, The InvestorState Dispute Settlement Mechanisms in the EU's Investment Agreements: Together with the Discussion on Relevant Issues in a China-EU Bilateral Investment Treaty 欧盟投资协定中的投资者一国家争端解决机制——兼论中欧 双边投资协定中的相关问题, Global Law Review 环球法律评论, Vol. 5, 2015, p. 157. Furthermore, it was argued that third parties, other than formally designated "mediators" or "conciliators", other entities might have been involved to help disputing parties in reaching settlement amicably, and therefore the real use of mediation could be broader than what has been reported. See: Jeswald W. Salacuse, Is There a Better Way? Alternative Methods of Treaty-Based, Investor-State Dispute Resolution, Fordham International Law Journal, Vol. 31, 2007, p. 174.

193 Jeswald W. Salacuse, Is There a Better Way? Alternative Methods of Treaty-Based, Investor-State Dispute Resolution, Fordham International Law Journal, Vol. 31, 2007, p. 178. 
years, ${ }^{194}$ which demonstrates "the existence of an appetite for mediation as a new process choice". 195

\subsubsection{Conciliation}

Conciliation resembles mediation in the sense that it is an amicable process in which disputing parties try to negotiate a settlement with assistance from a third party. Regarding the differences between mediation and conciliation, traditionally, conciliation implies a rule-based process with a high level of institutionalization, while mediation implies a facilitative process with little institutional management. ${ }^{196}$ It was summarized that "mediators work on process, communications, and substance of disputes", while "conciliators focus almost exclusively on the substance of the dispute". 197

In particular, investor-state conciliation in practice is represented by ICSID conciliation proceedings, ${ }^{198}$ which is a lengthy and arbitration-like framework. ${ }^{199}$ Among the scant eight ICSID conciliation cases that have been concluded, at least two of them lasted for

194 This is evidenced by the clear reference to investor-state mediation in newly concluded IIAs and the efforts in promoting their real use by international institutions. In terms of the former, the integration of mediation into an investor-state dispute settlement system is more frequently reflected in IIAs. The incorporation is often quite simple, such as in the Comprehensive and Progressive Agreement for Trans-Pacific Partnership (CPTTP), while more detailed mediation rules can be found in certain recently concluded IIAs, such as the EU-Singapore IPA (2018). Regarding the latter, international institutions have made various efforts to promote the use of mediation for ISDS, which are represented by adopting tailored mediation rules, issuing guides and establishing centres for using investor-state mediation, and providing professional training for potential mediators. For instance, the International Bar Association (IBA) adopted its IBA Rules for Investor-State Mediation in 2012, providing detailed and practical guidelines for the conduct of investor-state mediation. More recently, on 19 July 2016, the Energy Charter Conference endorsed a Guide on Investment Mediation, recognizing investor-state mediation as "a helpful, voluntary instrument to facilitate the amicable resolution of investment disputes". ICSID also proposes a separate set of investor-state mediation rules in its ongoing rules amendment process.

195 Nancy A. Welsh \& Andrea K. Schneider, The Thoughtful Integration of Mediation into Bilateral Investment Treaty Arbitration, Harvard Negotiation Law Review, Vol. 18, 2013, p. 84.

196 Robert B. Davidson, Initiating an International Mediation, at: Practitioner's Handbook on International Arbitration and Mediation (Third Edition), JurisNet, LLC, 2012, p. 521. Esmé Shirlow, The Rising Interest in the Mediation of Investment Treaty Disputes, and Scope for Increasing Interaction between Mediation and Arbitration, Kluwer Arbitration Blog, 29.09.2016, available at: http://kluwerarbitrationblog.com/2016/09/29/the-rising-interestin-the-mediation-of-investment-treaty-disputes-and-scope-for-increasing-interaction-between-mediation-andarbitration/, last visited on 05.08.2020. For more discussions on the distinction between mediation and conciliation, see: Jeremy Lack, Appropriate Dispute Resolution (ADR): the Spectrum of Hybrid Techniques Available to the Parties, at: Arnold Ingen-Housz (ed.), ADR in Business: Practice and Issues Across Countries and Cultures-Volume II, Kluwer Law International, 2011, pp. 339-379. Jeremy Lack \& François Bogacz, The Neurophysiology of ADR and Process Design: A New Approach to Conflict Prevention and Resolution?, Cardozo Journal of Conflict Resolution, Vol. 4, 2012, pp. 33-80.

197 Jeswald W. Salacuse, Is There a Better Way? Alternative Methods of Treaty-Based, Investor-State Dispute Resolution, Fordham International Law Journal, Vol. 31, 2007, p. 173. In ISDS, conciliators make reports proposing appropriate settlement based on disputing parties' views, which may be accepted or rejected by parties, and, in this sense, conciliation was argued as "a kind of non-binding arbitration". See: Ucheora O. Onwuamaegbu, The Role of ADR in Investor-State Dispute Settlement: The ICSID Experience, Transnational Dispute Management (TDM) in Mediation \& ADR, Vol. 1, 2007.

198 Such proceedings took place under the auspices of the World Bank by applying ICSID Conciliation Rules or ICSID Conciliation (Additional Facility) Rules.

199 Frauke Nitschke, The IBA's Investor-State Mediation Rules and the ICSID Dispute Settlement Framework, ICSID Review, Vol. 29, 2014, pp. 113-114. Shahla F. Ali \& Odysseas G. Repousis, Investor-State Mediation and the Rise of Transparency in International Investment Law: Opportunity or Threat?, Denver Journal of International Law and Policy, Vol. 45, 2016-2017, p. 237. The ICSID conciliation procedures are similar to arbitration in many aspects, while admittedly having two key differences: first, conciliation procedures are more informal, less expensive and, potentially, less time-consuming; second, no binding award is rendered. See: Lester Nurick \& Stephen J. Schnably, The First ICSID Conciliation: Tesoro Petroleum Corporation v. Trinidad and Tobago, ICSID Review, Vol. 1, 1986, p. 342. 
about three years and appear to have taken the form of hard-fought trials. ${ }^{200}$ As stated by Lord Wilberforce as the conciliator in an ICSID conciliation case, the role of a conciliator was conceived as "to examine the contentions raised by the parties, to clarify the issues, and to endeavour to evaluate their respective merits and the likelihood of their being accepted, or rejected, in Arbitration or Court proceedings". ${ }^{201}$

\subsubsection{Adjudication}

International investment adjudication is realized through arbitration or litigation in international courts like the ICJ. In contrast to amicable DSMs, adjudication often comes with pre-established procedural rules. Decisions reached by qualified professionals through adjudication are rule-based and binding. ${ }^{202}$ This DSM is an important tool to ensure an authoritative interpretation of the rules and norms of an IIA. ${ }^{203}$ At the same time, through observing the basic standards of accountability and due process, the procedural design of adjudication contributes to procedural justice in international dispute resolution. ${ }^{204}$

State-state investment adjudication has been rarely used in reality, regardless of the form of arbitration or litigation. ${ }^{205}$ This may be contributed to by a reluctance by states to initiate such a contentious process against others. The possibility is likely to be further decreased by the availability and convenience of investor-state DSMs.

In contrast, investor-state adjudication has been one of the hottest topics in academic discussion and has been widely used in practice in the past decades. In fact, the important innovation that most commentators attribute to modern IIAs is possibility for investors to bring direct claims against host states in international arbitration. ${ }^{206}$ Since

${ }^{200}$ International Centre for Settlement of Investment Disputes (ICSID), The ICSID Caseload-Statistics (Issue 20171), 2017, available at: https://icsid.worldbank.org/en/Documents/resources/ICSID\%20Web\%20Stats\%2020171\%20(English)\%20Final.pdf, last visited on 03.08.2020.

201 Lester Nurick \& Stephen J. Schnably, The First ICSID Conciliation: Tesoro Petroleum Corporation v. Trinidad and Tobago, ICSID Review, Vol. 1, 1986, p. 348. It is worth mentioning that, in order to promote the use of ICSID conciliation, Counsel for ICSID notes that "the Centre has recently begun to remind parties of the existence of the [conciliation] mechanism." See: Ucheora O. Onwuamaegbu, The Role of ADR in Investor-State Dispute Settlement: The ICSID Experience, Transnational Dispute Management (TDM) in Mediation \& ADR, Vol. 1, 2007, p. 13.

202 As pointed out, there were two common elements in the adjudicative model of dispute settlement: first, the resolution is made on a legal basis by a third authority and, second, the decisions are binding. See: Edna Ramírez Robles, Political \& Quasi-Adjudicative Dispute Settlement Models in European Union Free Trade Agreements-Is the Quasi-adjudicative Model A Trend Or Is It Just Another Model?, World Trade Organization Economic Research and Statistics Division-Staff Working Paper ERSD-2006-09, 11.2006, available at: https://www.wto.org/english/res_e/reser_e/ersd200609_e.pdf, last visited on 05.08.2020.

203 Abram Chayes \& Antonia Handler Chayes, The New Sovereignty: Compliance with International Regulatory Agreements, Harvard University Press, 1998, p. 24.

204 Laurence R. Helfer \& Anne-Marie Slaughter, Why States Create International Tribunals: A Response to Professors Posner and Yoo, California Law Review, Vol. 93, 2005, pp. 904, 914.

205 In terms of adjudication through litigation, the number of cases being heard by the ICJ is limited. Based on the collection on Italaw, there have been five investment cases brought to the ICJ. For more information on these cases, see: italaw, Other Investment Cases, available at: https:/www.italaw.com/other-investment-cases, last visited on 03.08.2020. There are fewer existing cases of investment adjudication through state-state arbitration than investorstate arbitration cases. For a further discussion on typical examples of such cases, see: Section 2.2.3.2, supra, and Nathalie Bernasconi-Osterwalder, State-State Dispute Settlement in Investment Treaties, 10.2014, available at: https://www.iisd.org/sites/default/files/publications/best-practices-state-state-dispute-settlement-investment-

treaties.pdf, pp. 7-16, last visited on 30.07.2020. Anthea Roberts, State-to-State Investment Treaty Arbitration: A Hybrid Theory of Interdependent Rights and Shared Interpretive Authority, Harvard International Law Journal, Vol. 55, 2014, pp. 2-70.

206 José E. Alvarez \& Kenneth J. Vandevelde, The BIT Program: A Fifteen-Year Appraisal, Proceedings of the Annual Meeting (American Society of International Law), Vol. 86, 1992, p. 538. 
the late $1980 \mathrm{~s}$, the vast majority of IIAs coupled their substantive investment protection with recourse to investor-state arbitration. ${ }^{207}$ This DSM commercializes the administrative disputes between investors and host states, granting certain international status to individual investors so that they could enjoy procedural and substantive rights in international law. ${ }^{208}$ It provides foreign investors who think that any administrative, regulatory or judicial measures violate investment protection standards agreed upon in the relevant IIA with an effective means to bring their claims before an international tribunal to ensure the enforcement of international law without the backing from the governments of their home states. Investor-state arbitration makes it possible for private investors to challenge host states and, in this sense, it furthers the rule of law. ${ }^{209}$ This is particularly important for foreign investment in states "with a high level of corruption, systems of political patronage and weak institutions", since their local courts are taken as "an unreliable means to solve investment-related disputes". ${ }^{210}$ In practice, investorstate arbitration has been used very often as a mechanism to obtain redress for grievances in the area of international investment law. It has been developing since the 1960 s, and it is now contained in virtually all of the more than 3,000 IIAs in place. ${ }^{211}$ At the same time, the caseload of investor-state arbitration is continually increasing. ${ }^{212}$ It is fair to say that investor-state arbitration has progressively emerged as the one of the most common means for investment dispute settlement.

207 Geoffrey Gertz \& Srividya Jandhyala \& Lauge N. Skovgaard Poulsen, Legalization, Diplomacy, and Development: Do Investment Treaties De-politicize Investment Disputes?, World Development, Vol. 107, 2018, p. 241.

208 Xiantao Wen 温先涛, Discussion on "China Model Bilateral Investment Treaty (Draft)" 《中国投资保护协定 范本》 (草案) 论稿, Journal of International Economic Law 国际经济法学刊, Vol. 18 \& 19, 2011, p. 61.

209 Richard Happ, Why Investment Arbitration Contributes to the Rule of Law: Without Konwing Where We Came from We Cannot Know Where We are Heading, at: European Investment Law and Arbitration Review, Brill | Nijhoff, 2016, p. 287. The introduction of investor-state arbitration has been celebrated as "depoliticizing investment disputes and contributing to enhancing the rule of law in investor-state relations". See: Stephan W. Schill, Reforming InvestorState Dispute Settlement (ISDS): Conceptual Framework and Options for the Way Forward, The E15Initiative (E15), 2015, available at: http://e15initiative.org/publications/reforming-investor-state-dispute-settlement-isds-conceptualframework-and-options-for-the-way-forward/, last visited on 05.08.2020. It was even argued to be "a significant and successful substitute for the gunboat diplomacy of the past”. See: Stephen M. Schwebel, Introduction, at: Ulf Franke \& Annette Magnusson \& Joel Dahlquist (eds.), Arbitrating for Peace: How Arbitration Made a Difference, Kluwer Law International, 2016, pp. 1, 5.

210 Wolfgang Koeth, Can the Investment Court System (ICS) Save TTIP and CETA?, European Institute of Public Administration Working Paper, Vol. 2016/W/01, 2016, p. 3. Furthermore, it is often the case that international law is not enforceable in domestic legal systems. Therefore, an international investor cannot always be sure that the treatment which the state has accepted in the international investment treaty will in fact be provided. See: European Commission, Establishment of a Multilateral Investment Court for Investment Dispute Resolution, DG Trade - F2, 01.08.2016.

${ }^{211}$ In particular, EU Member States are parties to some 1,400 of these IIAs. See: European Commission, $A$ New System for Resolving Dispute between Foreign Investors and States in a Fair and Efficient Way, available at: http://trade.ec.europa.eu/doclib/docs/2017/september/tradoc_156042.pdf, last visited on 31.07.2020.

${ }^{212}$ This can be evidenced by the ICSID caseload statistics. See: Internatioanl Centre for Settlement of Investment Disputes (ICSID), The ICSID Caseload-Statistics, available at: https://icsid.worldbank.org/en/Pages/resources/ICSID-Caseload-Statistics.aspx, last visited on 03.08.2020. 


\section{Part 2 Comparison between the Legal Culture in the Dispute Settlement of}

\section{China and the EU}

\section{Introduction to Part 2}

Understanding the connection between legal culture and practice in dispute settlement can enrich our capacity to understand the underlying reasons for a party's particular choices. In other words, legal culture reveals the important values and principles that the practice in dispute settlement intends to preserve and develop. China and the EU each enjoy a distinctive legal culture, which has influenced various aspects of society and the legal system in each party, including their perspectives on dispute settlement. Part 2 of this thesis conducts a comparison of their approaches to dispute settlement from a legal cultural perspective.

This part includes three chapters, Chapters 3-5. Chapter 3 analyses the legal cultural characteristics of dispute settlement in China from two perspectives: dispute settlement under traditional Chinese philosophies and contemporary Chinese ideology and the DSMs in China's domestic legal system. Thereafter, it provides an interpretation of the procedural features of these DSMs from a legal cultural perspective, in order to examine whether and, if so, how China's legal cultural characteristics of dispute settlement are reflected in its current domestic practice. Chapter 4 puts the attention on the EU and identifies the characteristics of legal culture in dispute settlement and internal DSMs within the EU. Compared to China, the situation in the EU is more complex, because of its special nature as a Union comprised of 27 Member States. As a result, in order to draw a conclusion on the EU's legal culture in dispute settlement, both the Union's measures on regulating DSMs and its Member States' practices deserve attention and thus are included in the scope of analysis. Like the analysis conducted for China, a legal cultural interpretation of the DSMs in the EU Member States and the Union's relevant regulating measures is provided thereafter. Chapter 5 makes a comparison of the research results reached in Chapters 3 and 4, in order to examine the similarities and differences between the legal culture of China and that of the EU in dispute settlement and, how their internal dispute settlement systems have been affected by legal culture. 


\section{Chapter 3 Legal Cultural Characteristics of Dispute Settlement in China}

In Chinese history, traditional Chinese philosophies exerted great influence on Chinese society. In relation to dispute settlement, it can be said that it was those traditional philosophies, instead of the legal systems, that regulated the society. After thousands of years of turbulent developments, contemporary Chinese ideology replaced the role of traditional philosophies and continued to affect dispute settlement in Chinese society. Different from the previous situation, with the establishment of a new, but gradually maturing, legal system in China, the DSMs play an indispensable role in resolving conflicts in China.

This chapter aims at providing an overview of China's legal cultural characteristics of dispute settlement under traditional Chinese philosophies, contemporary Chinese ideology and China's current legal system, as well as the relationship between the two. In order to realize this, it first presents a picture of traditional Chinese philosophies, especially including influential Confucianism, to assess the legal traditions in dispute resolution in China under the influence of those philosophies. The focus then turns to contemporary Chinese ideology, introducing its contents and comparing it with traditional Chinese philosophies. To resolve disputes, including foreign investment disputes, the DSMs in China's current legal system play an indispensable role, which is addressed in detail in Section 3.2. After laying out the key features of dispute settlement in China, Section 3.3 provides an interpretation of China's domestic dispute settlement system from the perspective of Chinese legal culture, with a view to examining the similarities and differences between traditional Chinese philosophies, contemporary Chinese ideology and the mechanisms in China's current legal system for dispute settlment.

\subsection{Dispute Settlement in Chinese Legal Culture}

Traditional Chinese philosophies have played a significant role in regulating the behaviour of individuals as well as governing the whole state in Chinese history, which also arguably has spin off effects on contemporary society in China. This section starts with an introduction to those traditional Chinese philosophies. Due to the undebated dominant position of Confucianism, after briefly addressing the widely recognized

influential traditional Chinese philosophies, the analysis focuses on the core values and teachings of Confucianism and especially its guidelines on dispute settlement. Nowadays, contemporary Chinese ideologies have replaced the role of traditional philosophies, and therefore Section 3.1.2 analyses the features of contemporary Chinese ideologies, also with a focus on the issue of dispute settlement, examining what it has inherited from and/or how it deviates from traditional philosophies. 


\subsubsection{Traditional Chinese Philosophies}

In ancient China, traditional philosophies, in particular Confucianism, exerted great influence on the Chinese society. The core values, basic principles and mottos regulated diverse aspects of people's lives, including the issue of dispute settlement. In general, there are three widely recognized influential traditional Chinese philosophies: Confucianism, Legalism and Taoism. Among these three, Confucianism has had the most far-reaching effect and thus its core values and principles, as well as its approach to dispute settlement, will be given particular attention here.

\subsubsection{Confucianism and Other Influential Traditional Chinese Philosophies}

Traditional Chinese philosophies exerted great influence on society in Chinese history. Among these philosophies, Confucianism (Rújiā, 儒家), Taoism (Dàojiā, 道家) and Legalism (Făjiā, 法家) particularly played indispensable roles. ${ }^{213}$ In fact, their function in Chinese society went beyond the mere philosophical.

There is no doubt that Confucianism has played a significant role in the development of basic values in Chinese society. ${ }^{214}$ In view of the general influence over time, this traditional Chinese philosophy is arguably the one that has enjoyed a predominant position throughout Chinese history. Confucianism provides philosophical teachings regulating individuals' behaviour as well as the general social order based on the ethics and values that it promotes. There were even periods of time that, instead of law, Confucian teachings regulated individuals and governed the state. ${ }^{215}$ A typical feature of Confucianism is that maintaining harmony in the communities is prioritized over other goals. Confucian teachings can be briefly described as "regulations" based on virtue, benevolence, social rightness, and morality, with harmony at the centre. ${ }^{216}$ The core values and principles of Confucianism are discussed in more detail in Section 3.1.1.2.

Two other philosophies, Taoism and Legalism, have also contributed to the construction of the social order in Chinese history. Similar to Confucianism, Taoism advocates harmony as the ultimate goal, but it focuses more on a harmonious relationship between humans and nature. Taoism strongly opposes the use of force, in particular, and this position is argued as being at the root of mediation in China. ${ }^{217}$ Legalism, on the other hand, emphasizes the role of Fă in governing the society, which

\footnotetext{
213 It is admitted that, as evidenced by Theodore de Bary, traditional Chinese philosophies are not static sets of notions, but they enjoy dynamic processes that vary greatly over time. See: William Theodore de Bary, The Trouble with Confucianism, Harvard University Press, 1996, pp. 131-184. Considering the purpose of the present section being to provide a general picture of Confucianism, Taoism and Legalism, the discussion here is limited to the common grounds and the main characteristics during their development.

214 Tony Fang, Negotiation: the Chinese Style, Journal of Business \& Industrial Marketing, Vol. 21, 2006, p. 53.

215 Sébastien Billioud, Confucianism, "Cultural Tradition" and Official Discourses in China at the Start of the New Century, 2007, available at: http://journals.openedition.org/chinaperspectives/2033, pp. 1-3, last visited on 30.07.2020.

216 Albert H.Y. Chen, Toward a Legal Enlightenment: Discussions in Contemporary China on the Rule of Law, Pacific Basin Law Journal, Vol. 17, 1999, p. 130.

217 Low Sui Pheng, The Influence of Chinese Philosophies on Mediation and Conciliation in the Far East, Arbitration, Vol. 61, 1996, pp. 11-20.
} 
is similar to law but limited to criminal law and/or administrative law. ${ }^{218}$ In addition, Fă has been used as an instrument for dominance, which contrasts with the modern concept of law as a tool to protect individuals' rights. ${ }^{219}$

Compared to Taoism and Legalism, Confucianism takes a middle-ground position in various aspects. For example, Confucianism does not allow as much freedom as Taoism or provide as harsh punishments as Legalism does; at the same time, it proposes an active attitude, which is in contrast to the passive and radical approaches advocated by Taoism and Legalism respectively. Despite these differences, it is noticeable that these three traditional Chinese philosophies have some common views on promoted values and teachings. For instance, Taoism is in line with Confucianism with regard to the pursuit of harmony; Legalism and Confucianism share a proactive attitude towards national governance, although the tools used are different; Confucianism emphasizes humanism and courtesy for individuals, as well as hierarchy and harmony within the community, which are also recognized, to some extent, by the other two philosophies.

\subsubsection{Confucian Values and Teachings}

Rén (benevolence, 仁) and Ľ̌ (ritualism, 礼) are commonly taken as representatives of the values advocated by Confucianism. ${ }^{220}$ Rén requires everyone to be kind to others and to create conciliatory relationships, upon which the whole society should be constructed. ${ }^{221}$ Li stipulates the moral rules that function as regulations in the society, which oblige individuals to fulfil their social responsibilities and to respect the hierarchies in families, clans and the society. ${ }^{222}$ Although Lǐ does not have formal legal effects, it was taken as being effective as law by the public. In other words, it played a role similar to civil law in western legal systems, but it mostly stipulated obligations of individuals and not rights.

In addition to L $\breve{1}$, Confucianism also recognizes the regulatory role played by Fă as another element used to ensure social order. Different from Lĭ, Fă has a binding effect and punitive nature. Fă is limited to punishing criminal acts instead of protecting civil rights. ${ }^{223}$ Scholars even described Fă as an evil in ancient China. ${ }^{224}$ Compared to Ľ́,

\footnotetext{
${ }_{218}$ H. Patrick Glenn, Legal Traditions of the World: Sustainable Diversity in Law (Fifth Edition), Oxford University Press, 2014, p. 326.

219 Haiwen Zhou, Confucianism and the Legalism: A Model of the National Strategy of Governance in Ancient China, Munich Personal RePEc Archive (MPRA) Paper, Vol. 81944, 2017, pp. 7-9.

${ }^{220}$ Confucianism is characterized by the promotion of Five Constants (wǔ cháng, 五常), namely, Rén (benevolence, 仁), Yì (loyalty, 义), Lǐ (ritualism, 礼), Zhì (wisdom, 智), and Xìn (sincerity, 信). See: Anne Isabel Kraus, Chinese-European Dispute Resolution in China: Towards Culturally Matching Procedures, Centrum für angewandte Politikforschung (C.A.P), 09.2007, available at: https://css.ethz.ch/en/services/digitallibrary/publications/publication.html/39874, last visited on 03.08.2020. Junwu Pan, Chinese Philosophy and International Law, Asian Journal of International Law, Vol. 1, 2011, pp. 233-234. Low Sui Pheng, The Influence of Chinese Philosophies on Mediation and Conciliation in the Far East, Arbitration, Vol. 61, 1996, p. 2. Mark Juergensmeyer, Religion in Global Civil Society, Oxford University Press, 2005, p. 70.

221 Low Sui Pheng, The Influence of Chinese Philosophies on Mediation and Conciliation in the Far East, Arbitration, Vol. 61, 1996, p. 3.

${ }^{222}$ Edwin H. W. Chan, Amicable Dispute Resolution in the People's Republic of China and Its Implications for Foreign-related Construction Disputes, Construction Management and Economics, Vol. 15, 1997, p. 540.

223 Junwu Pan, Chinese Philosophy and International Law, Asian Journal of International Law, Vol. 1, 2011, p. 234. 224 Xingzhong Yu, Legal Pragmatism in the People's Republic of China, Cornell Law Faculty Publications, Vol. 993, 1989 , p. 32.
} 
Fă is relatively unimportant and it is meant to be used only for base persons but not for gentlemen (Fă bèi xiăo rén, bù fáng jūn ž̆, “法备小人, 不防君子”). ${ }^{225}$ Thus, the role of Fă was looked down upon and even unnecessary. Extensive pieces of legislation were considered unnecessary because the legislation was rarely used. ${ }^{226}$ In brief, Lĭ is "persuasive, preventive and enforced by social sanction", while Fă is "compulsive, punitive and enforced by legal sanction". ${ }^{227}$ It can be said that Lǐ and Fă constitute the two primary components of historic Chinese legal culture. ${ }^{228}$ Both of them contributed to regulating individuals' behaviour and maintaining social order, and the preference was obvious: Lǐ was much more preferable to Fă in Confucianism. ${ }^{229}$ It is even argued that "[1]aw was never perceived as a means of preserving rights, freedom, and justice, since these were completely alien concepts in ancient China". ${ }^{230}$ Bodde compares Lĭ and Fă to natural law and positive law in the Western legal history. ${ }^{231}$ However, it would go too far to consider Lǐ and Fă to be true equivalents to natural law and positive law. $^{232}$

In Confucianism, the permanent and ultimate goal of pursuing harmony supersedes all other values. ${ }^{233}$ The concept of harmony under the Confucian tradition was argued to be "the promotion of tolerance and conciliation among people with different thoughts and backgrounds, thereby creating a peacefully interpersonal relationship". ${ }^{234}$ The two main regulatory tools, Lǐ and Fă, serve the purpose of a harmonious relationship among individuals and constructs an overall harmonious society. Confucianism mainly relied on education to realize this goal and adopted the concept of Fair Education for All (Y̌u jiào wú lèi, “有教无类”). ${ }^{235}$ Bearing in mind the ultimate goal of social harmony,

225 Junwu Pan, Chinese Philosophy and International Law, Asian Journal of International Law, Vol. 1, 2011, p. 234. For more discussion on the meaning of "base persons" and "gentlemen" in Confucianism, see: Paul R. Goldin, Confucianism, Routledge, 2014. Roger T. Ames \& Henry Rosemont Jr. (Translators), The Analects of Confucius: A Philosophical Translation, Random House Publishing Group, 2010.

${ }^{226}$ It was argued that the Confucian concept of minimum order contributed to the disappearance of litigation in Chinese history. See: Frederick Tse-shyang Chen, The Confucian View of World Order, Indiana International \& Comparative Law Review, Vol. 1, 1991, p. 57-58.

227 Junwu Pan, Chinese Philosophy and International Law, Asian Journal of International Law, Vol. 1, 2011, p. 234.

228 Jianfu Chen, Chinese Law: Context and Transformations, Martinus Nijhoff Publishers, 2008, p. 19. Albert Hungyee Chen, An Introduction to the Legal System of the People's Republic of China (1st edition), Butterworths Asia, 1992, p. 11.

229 Various reasons may contribute to such a preference. First of all, compared to Fă, Lǐ is more positive and effective. In addition, Lǐ has the function of education and prevention. According to the Analects of Confucius, if people are governed legalistically and controlled by punishment, they will avoid crime, but without a personal sense of shame; if they are governed by virtue and controlled with propriety, they will have the fear of being shameful and thus behave properly. Furthermore, Lǐ is more beneficial to the construction of social harmony.

230 Zhiping Liang, Explicating "Law": A Comparative Perspective of Chinese and Western Legal Culture, Journal of Chinese Law, Vol. 3, 1989, p. 89.

231 Derk Bodde, Evidence for "Laws of Nature" in Chinese Thought, Harvard Journal of Asiatic Studies, Vol. 20, 1957, pp. 709-727.

${ }^{232}$ Some scholars argued that there are no equivalents for Lǐ and Fă in the Western legal system. See e.g. Junwu Pan, Chinese Philosophy and International Law, Asian Journal of International Law, Vol. 1, 2011, p. 234.

233 This can be shown by the Analects by Confucius, which are the core texts of Confucianism. For example, Confucius stated in the Analects that, in the application of the rites, harmony was to be prized (lĩ zhī yòng hé wéi guì, “礼之用和为贵”).

${ }^{234}$ Mo Zhang, The Socialist Legal System with Chinese Characteristics: China's Discourse for the Rule of Law and a Bitter Experience, Temple International \& Comparative Law Journal, Vol. 24, 2010, p. 45.

235 The main underlying reason for such a preference for education is that education has the function of prevention, while Fă can only deter wrongdoers from violating criminal codes (instead of promoting the good ones) and improve what has already happened. See: Zhiping L., The Past, the Present and the Future of Chinese Law: A Critical Retrospect of a Kind of Culture, Study of Comparative Law, Vol. 17, 1987, pp. 19-20. 
preventing undesired behaviour and conflicts had priority rather than dealing with undesired behaviour afterwards.

In brief, under Confucianism, the community has priority over individuals, social responsibility is more important than freedom, and morality plays the role of regulating the society. Most importantly, harmony is prioritized and takes the central position.

\subsubsection{Confucian Guidelines on Dispute Settlement}

Harmony of the community is promoted by Confucianism as the ultimate goal of a society and has priority over other things and which requires every effort from each member of society. ${ }^{236}$ While pursuing the overall goal of harmony, the main purpose of interaction is to establish conflict-free interpersonal relationships. As a result, conflicts are unpleasant disturbances, which detract from the ultimate goal and should be avoided. ${ }^{237}$ Furthermore, there is always a deep concern about being regarded as a "trouble-maker". Being involved in disputes is considered to result in "losing face" (miànzi, “面子”) and negatively affecting one’s self-esteem, while maintaining respect is considered essential. ${ }^{238}$ Therefore, for this reason more efforts are put into avoiding disputes at an earlier stage rather than dispute settlement after the fact.

The emphasis on harmony leads to an emphasis on maintaining amicable or at least conflict-free interpersonal and social relationships. ${ }^{239}$ This requires individuals to focus on personal development and to act as responsible contributors to the shared goal of a moral society. ${ }^{240}$ In other words, every member of the society should be wellbehaved and maintain perfectly functional relationships to avoid the occurrence of any dispute. The goal of maintaining harmonious relationships also applies to businesses, for example when entering into a contract. ${ }^{241}$ The ultimate goal of business negotiations is to build a reliable long-term relationship, rather than merely finalizing a once-off deal. A carefully built relationship is considered to be the way to ensure the implementation of contracts, as opposed to relying on the legal system, even when disputes arise.

When disputes are unavoidable, DSMs, where only disputing parties are involved, are preferred, and a settlement is expected to be reached in the form of mutual concessions. ${ }^{242}$ As a result, skipping negotiations and directly seeking help from a third

\footnotetext{
${ }_{236}$ Guiguo Wang, Chinese Mechanisms for Resolving Investor-State Disputes, Jindal Journal of International Affairs, Vol. 1, 2011, p. 222.

237 Guo-Ming Chen \& Jensen Chung, The Impact of Confucianism on Organizational Communication, The Annual Meeting of the Speech Communication Association (79th), Miami, 18-21.11.1993.

${ }^{238}$ Caifen Jiang 姜彩芬, The Origin and Social Function of Mianzi Culture 面子文化产生根源及社会功能, Guangxi Social Science 广西社会科学, Vol. 3, 2009, p. 117. See also: Zhongying Cheng 成中英, The Concept of "Face" and Its Confucian Origin 脸面观念及其儒学根源, Chinese Social Psychological Review 中国社会心理 学评论, Vol. 2, 2006, p. 43.

239 Low Sui Pheng, The Influence of Chinese Philosophies on Mediation and Conciliation in the Far East, Arbitration, Vol. 61, 1996, p. 3.

240 Id.

241 Jiachu K. \& Shifi Z. \& Li L., International Business Negotiations in the People's Republic of China, at: James R. Silkenat \& Jeffrey M. Aresty (eds.), The ABA Guide to International Business Negotiations-A Comparison of Cross-Cultural Issues and Successful Approaches (3rd Edition), ABA Publishing, 2000, p. 200.

${ }^{242}$ Under Confucianism, it is considered that "disputes should be dissolved rather than resolved". See: Xingzhong Yu, Legal Pragmatism in the People's Republic of China, Cornell Law Faculty Publications, Vol. 993, 1989, p. 29.
} 
party would probably be understood as a lack of goodwill and courtesy. In addition, during the process of reaching an amicable settlement, there is a greater appreciation for a harmonious relationship rather than the parties' rights and interests under contractual provisions. As was summarized, "balancing and harmonization were considered more important than determining who was right and who was wrong". ${ }^{243}$ Therefore, it is necessary to avoid adversarial posturing to ensure continued goodwill between parties. In accordance with this line of thinking, people are encouraged to compromise, instead of seeking justice.

If an intermediary for dispute resolution is unavoidable, win-win instead of win-lose oriented DSMs are recommended, since the former are more beneficial for repairing relationships. ${ }^{244}$ This is usually achieved through informal mechanisms, such as mediation, which ensure an amicable environment to restore the relationship. Using a formal mechanism to resolve disputes, such as litigation, means that there has been a relationship failure. As mentioned above, in ancient China, there was a general resentment towards litigation and courts, because they were connected to imposing severe punishment rather than seeking justice. ${ }^{245}$ Furthermore, a lawsuit was regarded as negative, since it prioritizes individuals' interests over the overall benefits to society. More importantly, a litigious society leads to an unpleasant, uncomfortable and even unacceptable situation, because it goes against the general goal of harmony. Therefore, resolving disputes through a lawsuit is considered to be a lose-lose scenario, and any form of litigious activity is "an indication of selfishness" and "a threat to universal cosmic harmony". ${ }^{246}$ In a nutshell, bringing a dispute to a formal DSM, or even just threatening legal action, is not considered a good choice; instead, taking extra-legal efforts to address problems has suited the Chinese environment better.

\subsubsection{Contemporary Chinese Ideology}

In contemporary Chinese ideology, Confucian morality has been replaced by socialist morality. Considering the domination of traditional philosophies in China over time, how traditional moralities have been inherited or changed by socialist morality undoubtedly deserves attention, especially with regard to the core values and its influence on dispute settlement.

\subsubsection{Inheriting the Pursuance of Harmony}

Mainly as a result of the implementation of the "Reform and Opening up" policy initiated in 1979, China's value system has been exposed to the influence of other states. ${ }^{247}$ The influence of traditional Chinese philosophies in particular has been affected by Western values. At the same time, the development of the political and

\footnotetext{
${ }^{243}$ Werner Menski, Comparative Law in a Global Context: The Legal Systems of Asia and Africa (2nd Edition), Cambridege University Press, 2009, p. 557.

244 Tony Fang, Negotiation: the Chinese Style, Journal of Business \& Industrial Marketing, Vol. 21, 2006, p. 55.

245 Junwu Pan, Chinese Philosophy and International Law, Asian Journal of International Law, Vol. 1, 2011, p. 237.

246 Werner Menski, Comparative Law in a Global Context: The Legal Systems of Asia and Africa (2nd Edition), Cambridege University Press, 2009, p. 547.

247 The "Reform and Opening up" Policy refers to the programme of economic reforms termed "Socialism with Chinese Characteristics", which was introduced in December 1978 by reformists within the Communist Party of China, led by Xiaoping Deng.
} 
economic environment has caused a further change to Chinese ideologies. Although traditional Chinese philosophies have influenced society for thousands of years, as was also the case in some other states, ${ }^{248}$ China may embrace other values from foreign societies rather than purely sticking to its own ones. In order to examine this, two questions are assessed in particular: (i) to what extent have socialist core values been affected by those in traditional Chinese philosophies and, in particular, does the goal of harmony continue to enjoy a predominant position in contemporary Chinese ideology; and (ii) in terms of dispute settlement, has the traditional preference for non-adjudicated solutions been inherited.

In modern Chinese society, socialist morality has replaced Confucian morality, and has resulted in a contemporary Chinese ideology. After years of turbulent developments, and particularly under the influence from the West, socialist morality arguably differs greatly from Confucian morality. However, it is noticeable that respecting traditional values is taken as part of the basis of designing the new socialist values in modern Chinese ideology and, in particular, the ultimate goal of this socialist construction is to create a "harmonious socialist society", which has clearly been inherited from the Confucian ideal of the pursuit of harmony. ${ }^{249}$ The idea of a harmonious society in essence is "the continuity of the national heritage bestowed by the Confucian tradition of promoting harmony". ${ }^{250}$ In particular, in 2004, the Chinese Communist Party, the founding and ruling political party of China, launched a campaign for the creation of a harmonious society ${ }^{251}$ and, two years later, it passed a resolution making the construction of a harmonious socialist society in China a goal that should be achieved by $2020 .{ }^{252}$ Furthermore, social harmony has become a strong ideological force that is being integrated into the development of the socialist rule of law and the Chinese legal system as a guiding principle. ${ }^{253}$ In turn, it is imperative that "the rule of law be geared toward creating and enhancing social harmony". ${ }^{254}$ As a result, similar to the situation

248 Taking Singapore as an example, it shares a similar legal cultural background with China, but it has accepted the Western legal ideologies to a large extent, especially with regard to dispute settlement. For a further discussion on this, see: P. Brooker \& A. Lavers, Perceptions of the Role of Alternative Dispute Resolution in the Settlement of Construction Disputes: Lessons from the UK and US Experience, at: P. In Fenn (ed.), Proceedings of CIB TG15 Meeting: Construction Conflict: Management and Resolution, E. \& F. N. Spon, 1994, pp. 49-69.

249 The Sixth Plenary Session of the Sixteenth Central Committee of the Communist Party of China 中国共产党 第十六届中央委员会第六次全体会议, Decision of the Central Committee of the Communist Party of China on Several Major Issues of Building a Harmonious Socialist Society 中共中央关于构建社会主义和谐社会若干重 大问题的决定，11.10.2006.

${ }^{250}$ Mo Zhang, The Socialist Legal System with Chinese Characteristics: China's Discourse for the Rule of Law and a Bitter Experience, Temple International \& Comparative Law Journal, Vol. 24, 2010, p. 44.

251 Joseph Fewsmith, Promoting the Scientific Development Concept The China Leadership Monitor, 2004, available at: http://media.hoover.org/sites/default/files/documents/clm11_jf.pdf, last visited on 01.08.2020.

252 Xin Hua News Agency, China Publishes Resolution on Building Harmonious Society, Press Release, 18.10.2006, available at https://chinadigitaltimes.net/2006/10/china-publishes-resolution-on-building-harmonious-societyxinhua/, last visited on 22.07.2018.

${ }^{253}$ Lin Li 李林, The Role of People's Congress System in the Building of the Harmonious Society 人民代表大会 制度在建设和谐社会中的作用, at: Lin Li (ed.) 李林（编）, Ruling Country According to Law and the Building of Harmonious Society 依法治国与和谐社会建设, China Legal Publishing House 中国法制出版社, 2007, pp. 157-159. Mo Zhang, The Socialist Legal System with Chinese Characteristics: China's Discourse for the Rule of Law and a Bitter Experience, Temple International \& Comparative Law Journal, Vol. 24, 2010, pp. 44-46.

${ }^{254}$ Mo Zhang, The Socialist Legal System with Chinese Characteristics: China's Discourse for the Rule of Law and a Bitter Experience, Temple International \& Comparative Law Journal, Vol. 24, 2010, pp. 45-46. 
under traditional Chinese philosophies, individuals are expected to self-police and forego their interests for a harmonious environment for the society. In other words, the interest of the community continues to enjoy priority. Based on this, in terms of dispute settlement, the avoidance of adversarial posturing still exists, including the use of litigation, although it is to a lesser extent that in former times. It is noticeable that, due to the establishment of the modern Chinese legal system and an enhanced legal consciousness of individuals, reference to adjudicative DSMs such as arbitration and litigation for dispute resolution is recognized more frequently and it is becoming more common. $^{255}$

In summary it can be argued that, although the values originate in ancient times and are subject to various counterweights, the core values of traditional Chinese philosophies have been arguably inherited by contemporary Chinese ideology. ${ }^{256}$ This is especially reflected in the goal of constructing a harmonious socialist society. Against this background, non-adjudicated resolutions to disputes through amicable mechanisms continue to be the preferred choice.

\subsubsection{Elevating the Role of Law}

As noted above, legal tradition remains "a vibrant and official part" of modern Chinese legal culture. At the same time, it is noted that the importation of Western legal elements constitutes another significant but very different component of contemporary Chinese ideologies. ${ }^{257}$ In general, Chinese legal culture today can be described as "a mix of many different and often contradictory modern and ancient strands that exist side-byside", ${ }^{258}$ and each of them exists "to different degrees in different legal fields and institutions". 259

Beginning with Yan Fu's translation of "The Meaning of Law" and continuing with Sun Yat-sen's "five-powers constitution", modern Western legal thought and legal systems have been introduced in China. ${ }^{260}$ As a result, a clear enhancement of the status of law under modern Chinese ideologies can be identified, which deviates from traditional Chinese philosophies. In addition, improving China's domestic legal system and strengthening the public's legal consciousness have been considered to be an indispensable part of the socialist construction. President Xi Jinping explained the interaction between law and virtue as "law governs the state, while virtue moistens

\footnotetext{
255 More discussion on the DSMs in China's legal system is provided in Section 3.2, infra.

256 James A. R. Nafziger \& Ruan Jiafang, Chinese Methods of Resolving International Trade, Investment and Maritime Disputes, Willamette Law Review, Vol. 23, 1987, p. 624.

257 Colin B. Picker, China, Global Governance \& Legal Culture: The Example of China \& the WTO, at: China and Global Economic Governance: Ideas and Concepts, The University of Tokyo-Institute of Social Science (ISS) Research Series No.45, 2011, p. 82.

258 These strands include Confucianism, Legalism, Marxism, Rationalism, and significant legal cultural characteristics imported from the Western world. See: Lisa C. Toohey, Rule of Law Discourse and the Accession of Transitional Economies to the World Trade Organization, to obtain the PhD Degree at The University of Queensland, 2008, p. 165.

${ }^{259}$ Colin B. Picker, China, Global Governance \& Legal Culture: The Example of China \& the WTO, at: China and Global Economic Governance: Ideas and Concepts, The University of Tokyo-Institute of Social Science (ISS) Research Series No.45, 2011, pp. 75-76.

260 The "five-powers constitution" was a government organization envisioned by Sun Yat-sen, composing five major branches: executive, legislative, judiciary, examination, and censoring (or control). See: James E. Sheridan, China in Disintegration: The Republican Era In Chinese History 1912-1949, The Free Press, 1975, pp. 145, 208.
} 
people's heart" and "law is the hard copy of virtue, while virtue is the law inside people’s heart” (“法安天下, 德润人心”, “法律是成文的道德, 道德是内心的法律”). Furthermore, the overall goal of constructing a socialist legal system with Chinese characteristics and the adherence to the combination of law and virtue to govern the state (依法治国和以德治国相结合) are emphasized. ${ }^{261}$ In order to realize this, it is important to insist on the Socialist Core Value System (社会主义核心价值体系), in which the Socialist Concept of Honor and Disgrace (社会主义荣辱观) is an indispensable part. $^{262}$

Socialist legality incorporates the rule of law, emphasizing the creation of social harmony and the legality of adjudication at the same time. ${ }^{263}$ Thus, the previous lack of a rule of law in China has been changed by implementing the socialist rule of law, which is also considered one of the basic principles of building a harmonious socialist society. ${ }^{264}$ Echoing former Chinese President Hu Jintao's remarks, many in China advocate for the idea that a harmonious society is a rule of law society, believing that law is the aggregate of rules of conduct necessary for social harmony. ${ }^{265}$ However, it deserves attention that the "socialist rule of law" is different from the notion of the "rule of law" that is generally recognized in Western legal systems. ${ }^{266}$ Evidence for this can be found in the striking contrast between the definition provided in the 2004 UN Secretary-General's report on the rule of law and transnational justice ${ }^{267}$ and the one proposed by the Chinese delegate in the General Assembly Sixth Committee's debate in 2007. ${ }^{268}$ It was argued that the Chinese interpretation of the rule of law omits the essence of the rule of law, such as accountability, and, furthermore, the Chinese

261 Jinping Xi 习近平, Sticking to the Combination of the Rule of Law and the Rule of Virtue 坚持依法治国和以 德治国相结合, www.xinhuanet.com 新华网, 10.12.2016, available at: http://www.xinhuanet.com//politics/201612/10/c_1120093133.htm, last visited on 07.08.2020.

262 Jinping Xi 习近平, Secure a Decisive Victory in Building a Moderately Prosperous Society in All Respects and Strive for the Great Success of Socialism with Chinese Characteristics for a New Era 决胜全面建成小康社会 夺 取新时代中国特色社会主义伟大胜利, www.xinhuanet.com 新华网，27.10.2017, available at: http://www.xinhuanet.com//politics/19cpcnc/2017-10/27/c 1121867529.htm, last visited on 07.08.2020.

${ }^{263} \mathrm{Fu}$ Hualing \& Richard Cullen, From Mediatory to Adjudicatory Justice: The Limits of Civil Justice Reform in China, at: Margaret Y. K. Woo \& Mary E. Gallagher (eds.), Chinese Justice: Civil Dispute Resolution in Contemporary China, Cambridge University Press, 2011, pp. 51-52.

264 The Sixth Plenary Session of the Sixteenth Central Committee of the Communist Party of China 中国共产党 第十六届中央委员会第六次全体会议, Decision of the Central Committee of the Communist Party of China on Several Major Issues of Building a Harmonious Socialist Society 中共中央关于构建社会主义和谐社会若干重 大问题的决定, 11.10.2006.

${ }^{265}$ Liming Wang 王利明, A Harmonious Society Should be a Rule of Law Society 和谐社会应当是法治社会, Legal Science 法学, Vol. 5, 2005, p. 211.

${ }^{266}$ Liming Wang 王利明, Discussion on Procedural Justic from the Perspective of Socrates 从苏格拉底之死谈 程序正义, aisixiang.com 爱思想, 08.07.2014, available at: http://www.aisixiang.com/data/76135.html, last visited on 07.08.2020.

267 The 2004 UN Secretary-General's report about the rule of law and transnational justice provides a contemporary definition of the rule of law: "[The rule of law] refers to a principle of governance in which all persons, institutions and entities, public and private, including the state itself, are accountable to laws that are publicly promulgated, equally enforced and independently adjudicated, and which are consistent with international human rights norms and standards." See: Report of the Secretary-General, The Rule of Law and Transitional Justice in Conflict and PostConflict Societies, UN Doc. S/2004/616, para. 6.

268 The definition of the rule of law proposed by the Chinese delegate in the General Assembly Sixth Committee's debate in 2007 goes as follows: "rule of law [is] a universal goal for all nations and the effective instrument for establishing and maintaining social order, promoting social justice and achieving social progress." See: UN Doc. A/C.6/62/SR.14 (2007), para. 35 . 
definition claims a top-down definition of law, which is "the very signature of the rule by law". ${ }^{269}$ In other words, the socialist rule of law has a clear pragmatic characteristic, ${ }^{270}$ which views law from an instrumentalist perspective: what the law can do for China's development and modernization. ${ }^{271}$ Law does not have independent values, instead, the emphasis on law serves the construction of a harmonious socialist society. ${ }^{272}$

In short, law has been considered by China to be an indispensable part of the socialist construction and much effort has been made to improve the state's legal system and to strengthen the public's legal consciousness. However, the enhancement of the status of law is secondary to the theme of socialist harmony and the socialist rule of law is viewed from an instrumentalist perspective.

\subsection{Dispute Settlement Mechanisms in China's Domestic Legal System}

Various DSMs have been established to resolve various types of disputes in China's domestic legal system. These DSMs provide important channels as local remedies for the resolution of disputes arising from foreign investment in China. This section provides an overview of the DSMs in China's legal system that are available for foreign investment disputes. First, as in many other states in the world, mediation, arbitration and litigation are made avaiable. At the same time, it is noticeable that amicable settlement through negotiation is explicitly required as a step in dispute settlement in many Chinese legal texts. With regard to the disputes between investors and administrative organs on certain administrative decisions, administrative reconsideration is available as an additional option or it is required to be used first in certain situations. Furthermore, a special DSM called complaints coordination for foreign investment has been created for foreign investors to settle their disputes in China. Thus, in total, there are six main DSMs that can be used to resolve foreign investment disputes: negotiation, mediation, arbitration, complaints coordination for foreign investment, administrative review, and litigation. Their key procedural features are introduced in the following.

\footnotetext{
269 Jean Yves Heurtebise, Understanding Non-Trade Concerns Through Comparative Chinese and European Philosophy of Law, at: China's Influence on Non-Trade Concerns in International Economic Law, Routledge, 2016, pp. 290-291.

270 The Decision of the CPC Central Committee on Major Issues Pertaining to Comprehensively Promoting the Rule of Law stresses that building a state under the rule of law should be based on China's actual conditions. See: The Third Plenary Session of the 18th Central Committee of the Communist Party of China 中国共产党第十八届 中央委员会第三次全体会议, Decision of the Central Committee of the Communist Party of China on Some Major Issues Concerning Comprehensively Deepening the Reform 中共中央关于全面深化改革若干重大问题的决定， 12.11.2013.

271 Jianfu Chen, Chinese Law: Context and Transformations, Martinus Nijhoff Publishers, 2008, p. 38. Pitman B. Potter, The Chinese Legal System-Globalization and Local Legal Culture, Routledge, 2001, pp. 2, 10.

${ }^{272}$ The State Council-The People's Republic of China, Communique of the Sixth Plenum of the 16th CPC Central Committee, 11.10.2006, available at: http://www.gov.cn/english/2006-10/11/content_410436.htm, last visited on 22.05.2020. See also: Mo Zhang, The Socialist Legal System with Chinese Characteristics: China's Discourse for the Rule of Law and a Bitter Experience, Temple International \& Comparative Law Journal, Vol. 24, 2010, p. 42.
} 
Before going into a detailed analysis, it is important to note that, with regard to procedural affairs, a divergence between the approach to domestic and foreign-related cases has been adopted in China's legal system. ${ }^{273}$ Under the same DSM, domestic and foreign-related cases are sometimes subject to different procedural rules. If a case is qualified as a foreign-related case, special regulations in various procedural laws can apply.

\subsubsection{Negotiation}

Negotiation refers to an informal process without defined procedures or rules, where disputing parties discuss the disputes in order to reach a mutually acceptable solution without any intervention from a third party. ${ }^{274}$ Negotiation is normally not regulated in the law, but this is not the case in China's legal system. The use of negotiation is mentioned specifically in Chinese legal texts in two ways. First, negotiation is required as a prerequisite before resorting to other DSMs. ${ }^{275}$ Second, Chinese procedural laws often explicitly stress the availability of negotiation during the process of formal DSMs. ${ }^{276}$ The clear provisions in the legal texts recommending and even requiring negotiation indicate to the negotiation-friendly attitude of China's legal system. Only a limited number of regulations are provided referring to negotiation procedures, ${ }^{277}$ which was argued as leaving considerable room for Chinese legal tradition to exert its influence on the negotiation process. ${ }^{278}$

\footnotetext{
273 According to Interpretation of the Supreme People's Court on the Application of the Civil Procedure Law of the People's Republic of China (2015), a foreign-related case is defined as a case where at least one of the following situations is satisfied: (1) either party or both parties are foreigners, stateless persons, foreign enterprises or organizations; (2) the habitual residence of either party or both parties is located outside the territory of China; (3) the subject matter is outside the territory China; (4) the legal fact that leads to the establishment, change or termination of civil relationship occurs outside the territory of China; (5) any other circumstances under which a case may be determined as a foreign-related civil case. See: Supreme People's Court of the People's Republic of China, Interpretation of the Supreme People's Court on the Application of the Civil Procedure Law of the People's Republic of China 最高人民法院关于适用《中华人民共和国民事诉讼法》的解释 (enforced on 04.02.2015), Art. 522. This unofficial translation is available at: http://en.pkulaw.cn/display.aspx?cgid=242703\&lib=law, last visited on 22.05.2020. Given that there are some inaccuracies in this translation, the author has made corrections wherever necessary. See also: Supreme People's Court of the People's Republic of China, Interpretations of the Supreme People's Court on Several Issues Concerning Application of the Law of the People's Republic of China on Choice of Law for Foreign-Related Civil Relationships (I) 最高人民法院关于适用《中华人民共和国涉外民事 关系法律适用法》若干问题的解释(一) (enforced on 07.01.2013), Art. 1.

${ }^{274}$ Robert Mnookin, Alternative Dispute Resolution, Harvard Law School John M. Olin Center for Law, Economics and Business Discussion Paper Series, Vol. 232, 1998, p. 5.

${ }^{275}$ For instance, the General Principles of the Civil Law of the People's Republic of China (2009) provides that, if there is any unclear provision in a contract, contracting parties are required to negotiate informally before bringing a case before a people's court. See: General Principles of the Civil Law of the People's Republic of China 中华人 民共和国民法通则 (enforced on 01.01.1987, as amended on 27.08.2009), Art. 88.

${ }^{276}$ For example, according to Civil Procedure Law of the People's Republic of China (2012), in litigation, parties can reach a settlement through negotiation at any time unless the enforcement is completed. See: Civil Procedure Law of the People's Republic of China 中国人民共和国民事诉讼法 (enforced on 09.04.1991, as amended on 31.08.2012), Arts. 50, 230.

277 Shuliang Wang, Introduction to International Trade Dispute Settlement in China, at: Pitman B. Potter \& Ljiljana Biuković, Globalization and Local Adaptation in International Trade Law, UBC Press, 2011, p. 228.

278 Ndapwilapo Shimutwikeni, The Impact of Culture in International Business Negotiations: Special Reference to China and United States of America, CEPMLP Annual Review, Vol. 14, 2009, p. 1. For example, during negotiations, Chinese parties usually focus on repairing the relationship, instead of arguing for their rights based on contractual provisions. For a further discussion on the characteristics of negotiation with Chinese parties from a cultural perspective, see: Anne Isabel Kraus, Chinese-European Dispute Resolution in China: Towards Culturally Matching Procedures, Centrum für angewandte Politikforschung (C.A.P), 09.2007, available at: https://css.ethz.ch/en/services/digital-library/publications/publication.html/39874, last visited on 03.08.2020.
} 
As analysed in Sections 3.1.1 and 3.1.2, supra, under traditional Chinese philosophies and contemporary Chinese ideologies, amicable DSMs are preferred. The promotion of negotiation in China's legal system, which is a typical example of an amicable and informal DSM, can be considered a reflection of how the preference for and the recognition of the importance of maintaining harmonious relationships has been inherited by the current system.

\subsubsection{Mediation}

Like negotiation, mediation is also a confidential, informal, and voluntary process, where disputes are resolved in an amicable environment, however with the assistance of a third neutral party. ${ }^{279}$ It combines the disputing parties' willingness to bargain and the mediator's coordinating skills, in order to foster understanding by the parties, reconcile their interests, repair the damaged relationships, and thus contribute to their further cooperation. ${ }^{280}$

The development of mediation in China went through some ups and downs. ${ }^{281}$ Now, mediation plays a significant role in China's legal system in resolving disputes, in the forms of independent mediation and in combination with other DSMs. ${ }^{282}$ There are four ways that mediation can take place. First, mediation can be hosted by commercial mediation and arbitration commissions. ${ }^{283}$ Second, administrative mediation is offered by the State Administration of Industry and Commerce, which uses its branches as mediators to resolve disputes between economic organizations. ${ }^{284}$ Third, mediation can be conducted during an arbitration process, which is known as the "Arb-Med" or

279 Anna Spain Bradley, Integration Matters: Rethinking the Architecture of International Dispute Resolution, University of Pennsylvania Journal of International Law, Vol. 32, 2010, p. 23. Robert B. Davidson, Initiating an International Mediation, at: Practitioner's Handbook on International Arbitration and Mediation (Third Edition), JurisNet, LLC, 2012, p. 479.

280 OLO De Witt Wijnen, ADR, the Civil Law Approach, Arbitration, Vol. 61, 1995, pp. 38-42.

${ }^{281}$ Mediation became a formalized method of civil dispute settlement since the 1950s in China's legislation. See: Stanley B. Lubman, Bird in a Cage-Legal Reform in China after Mao Standford University Press, 2000, p. 49. Randall Peerenboom, China's Long March Toward Rule of Law, Cambridge University Press, 2002, pp. 38-39. It was the predominant form of dispute resolution in China before the legal reform initiated in the late 1970s. As Chinese legal reform progressed throughout the 1980s and 1990s, the use of mediation dropped significantly in both judicial and extra-judicial processes. Another sudden change of direction happened in the early 2000s when the Communist Party aggressively began to promote the use the mediation to solve disputes in judicial and extra-judicial settings. See: Carl F. Minzner, China's Turn against Law, American Journal of Comparative Law, Vol. 59, 2011, p. 935. Hualing Fu, Mediation and the Rule of Law: The Chinese Landscape, at: Formalisation and Flexibilisation in Dispute Resolution, Brill | Nijhoff, 2014, p. 115.

282 Under Chinese laws, mediation and conciliation are often used interchangeably, although it is noted that some scholars differentiate between these two by arguing that mediation was referred to as "conciliation" when it was conducted in other legal proceedings, such as arbitration. See: Jingzhou Tao, Arbitration in China, at: Philip J. McConnaughay \& Thomas B. Ginsburg (eds.), International Commercial Arbitration in Asia (Second Edition), Juris Publishing, 2006, p. 54. Xuan Gu, The Combination of Arbitration and Mediation in China, to obtain the Master Degree at University of Geneva \& University of Lausanne, 2008, p. 1. The present Chapter 3 follows the normal practice, using mediation and conciliation interchangeably.

${ }^{283}$ In theory, this type of mediation can also be hosted by people's mediation commissions. However, in practice, people's mediation commissions are rarely used to resolve foreign investment disputes. Therefore, this chapter only focuses on mediation conducted by commercial mediation and arbitration commissions in China.

284 The phrase "economic organizations" are defined as legal person, individual partnership, individual industrial and commercial households, lease-holding farm household and other economic organizations. (“法人、个人合伙、

个体工商户、农村承包经营户以及其他经济组织”). See: Administration of Administrative Mediation of Contract Dispute by the State Administration for Industry and Commerce of the People's Republic of China 国家工 商行政管理总局合同争议行政调解办法 (enforced on 03.11.1997, repealed on 02.11.2017), Art. 6. 
"Oriental Experience". ${ }^{285}$ Finally, mediation can also be combined with litigation proceedings. All of these are introduced in the following sections.

\subsubsection{Mediation Conducted by Commercial Mediation and Arbitration Commissions}

Since 2009, the position of commercial mediation has been officially enhanced in China. ${ }^{286}$ Efforts on promoting the use of mediation have also been made by Chinese arbitration commissions. For example, many arbitration commissions began to accept mediation cases and created their own mediation rules. ${ }^{287}$ In addition, international cooperation was created aiming at providing services for mediating international business disputes. ${ }^{288}$ For example, the China Council for the Promotion of International Trade (CCPIT)/China Chamber of International Commerce (CCOIC) Conciliation Centre, which is the first and largest professional mediation organization in China, signed cooperation agreements with mediation centres from over ten countries, including some EU Member States, in order to create an international mediation network. ${ }^{289}$ All of these innovative measures emphasize China's firm belief that mediation is "the primary means to resolve transnational disputes while maintaining an ongoing business relationship". 290

Regarding the procedural regulations for this type of mediation, first, the principles of voluntariness and confidentiality are often required to be followed. ${ }^{291}$ If a settlement agreement is reached successfully, the mediator will deliver a mediation statement, which constitutes a new contract. ${ }^{292}$ Then disputing parties are given several options to ensure the implementation of the new contract, including applying to the competent people's court to confirm the settlement agreement, ${ }^{293}$ having such an agreement

\footnotetext{
${ }_{285}$ Edna Sussman, Developing an Effective Med-Arb/Arb-Med Process, New York Dispute Resolution Lawyer, Vol. 2, 2009, pp. 71-74.

286 This is realized particularly through the issuance of the "Several Opinions of the Supreme People's Court on Establishing a Sound Conflict and Dispute Resolution Mechanism that Connects Litigation and Non-litigation". In this document, commercial mediation is explicitly put on an equal footing with people's mediation, mediation by people's courts and administrative investigation and mediation. See: Several Opinions of the Supreme People's Court on Establishing a Sound Conflict and Dispute Resolution Mechanism that Connects Litigation and Non-litigation 最 高人民法院印发《关于建立健全诉讼与非诉讼相衔接的矛盾纠纷解决机制的若干意见》的通知 (issued on 24.07.2009, enforced on 24.07.2009).

287 An example is the Beijing Arbitration Commission, which issued its mediation rules in 2001. See: Beijing Arbitration Commission Mediation Center Mediation Rules (enforced on 28.09.2011).

288 James K. Lockett, Dispute Settlement in the People's Republic of China: The Developing Role of Arbitration in Foreign Trade and Maritime Disputes, George Washington Journal of International Law and Economics, Vol. 16, 1982, p. 262.

289 CCPIT/CCOIC Conciliation Center is dedicated to mediating international commercial disputes and promoting transnational cooperation; the cases dealt with here involve more than 50 countries and regions. See: China Council for the Promotion of International Trade (CCPIT)/China Chamber of International Commerce (CCOIC) Mediation Center 中国国际贸易促进委员会/中国国际商会调解中心, Introduction of the Center 中心简介, 05.03.2019, available at: https://adr.ccpit.org/articles/25, last visited on 07.08.2020.

290 Anne Judith Farina, "Talking Disputes into Harmony" China Approaches International Commercial Arbitration, American University International Law Review, Vol. 4, 1989, p. 157.

291 See e.g. CCPIT/CCOIC Mediation Rules (enforced on 01.05.2012), Art. 4.

${ }^{292}$ Several Opinions of the Supreme People's Court on Establishing a Sound Conflict and Dispute Resolution Mechanism that Connects Litigation and Non-litigation 最高人民法院印发《关于建立健全诉讼与非诉讼相衔接 的矛盾纠纷解决机制的若干意见》的通知 (issued on 24.07.2009, enforced on 24.07.2009).

${ }^{293}$ See e.g. CCPIT/CCOIC Mediation Rules (enforced on 01.05.2012), Art. 26. This is confirmed by Chinese Civil Procedure Law. See: Civil Procedure Law of the People's Republic of China (enforced on 09.04.1991, as amended on 31.08.2012), Art. 194.
} 
notarized, ${ }^{294}$ and transferring the case to an arbitration commission for an arbitral award in line with the content of the settlement agreement. ${ }^{295}$

\subsubsection{Mediation Conducted by Administrative Organs}

Disputing parties can choose administrative mediation for dispute resolution for contractual disputes between economic organizations that have not been brought before a people's court or an arbitration commission. ${ }^{296}$ Administrative organs, which are usually industry and commerce administrative authorities, mediate such disputes based on the consent of disputing parties, ${ }^{297}$ which can be terminated at any time upon the request of one party. ${ }^{298}$ The process is not open to the public. ${ }^{299}$ If the dispute is successfully resolved through administrative mediation, disputing parties shall sign a mediation agreement or a new contract. ${ }^{300}$ After that, like the mediation agreement reached in commercial mediation, parties can bring such agreements or contracts before the competent people's courts or notarial institutions to have it recognized or notarized. It is noted that, to facilitate disputing parties in confirming the result of administrative mediation, cooperation has been established among some branches of the State Administration of Industry and Commerce in order to connect administrative mediation with judicial confirmation from the people's courts. ${ }^{301}$

\subsubsection{Mediation in Administrative Reconsideration}

Mediation is also available during the process of administrative reconsideration when settling foreign investment disputes. ${ }^{302}$ Like other types of mediation, mediation in administrative reconsideration is also conducted based on the principle of voluntariness. ${ }^{303}$ Where disputing parties reach a settlement in the end, the administrative reconsideration organ shall make a written administrative reconsideration mediation agreement. ${ }^{304}$ Such an agreement begins to have legal effect

\footnotetext{
294 See e.g. CCPIT/CCOIC Mediation Rules (enforced on 01.05.2012), Art. 27. This is confirmed by Chinese Notaraization Law. See: Notaraization Law of the People's Republic of China (enforced on 01.03.2006, as amended on 24.04.2015), Art. 37.

295 See e.g. CCPIT/CCOIC Mediation Rules (enforced on 01.05.2012), Art. 28. In addition, if the settlement agreement only involves the payment of debts, parties can also apply to the competent people's court to issue an enforceable payment warrant. See e.g. CCPIT/CCOIC Mediation Rules (enforced on 01.05.2012), Art. 27.

${ }^{296}$ Administration of Administrative Mediation of Contract Dispute by the State Administration for Industry and Commerce of the People's Republic of China (enforced on 03.11.1997), Art. 8.

297 Id, Arts. 2, 3, 8.

298 Id, Art. 17.

299 Id, Art. 5.

300 Id, Art. 19.

301 See e.g. www.china.com.cn 中国网, Beijing Industry and Commerce Bureau Xicheng Branch: Connecting Administrative Mediation of Contract Disputes and Judicial Confirmation 北京市工商局西城分局合同纠纷行政 调解对接司法确认, 29.10.2012, available at: http://finance.china.cn/roll/20121029/1098465.shtml, last visited on 06.08.2020.

302 Administrative reconsideration applies to the situation where a citizen, legal person or any other organization considers that its lawful rights and interests have been infringed upon by a specific administrative act and applies to an administrative organ for administrative reconsideration. See: Administrative Reconsideration Law of the People's Republic of China 中华人民共和国行政复议法 (enforced on 01.10.1999, as amended on 27.08.2009), Art. 2. For further information of administrative reconsideration, see Section 3.2.5, infra.

${ }^{303}$ Regulations on the Implementation of the Administrative Reconsideration Law of the People's Republic of China 中华人民共和国行政复议法实施条例 (enforced on 01.08.2007), Art. 50.

304 Ibid.
} 
upon being signed by the disputing parties and can be further enforced by competent administrative organs or by the people's courts. ${ }^{305}$

\subsubsection{Mediation in Arbitration}

In China, the creation of mediation in arbitration, which is often referred to as "ArbMed", "Oriental Model" or "Oriental Experience", can be traced back to the 1950s. ${ }^{306}$ During the past decades, this practice has constantly developed in law and in practice. When China started to host foreign-related arbitration, "Arb-Med" was also implemented in that context.

"Arb-Med" combines two DSMs by conducting mediation during an arbitration process when there is the consent of the disputing parties. It is mainly regulated by the Chinese Arbitration Law (2009) and the arbitration rules chosen by the parties. According to the Chinese Arbitration Law (2009), a tribunal shall carry out mediation prior to delivering an arbitration award if both parties voluntarily refer to it. ${ }^{307}$ In practice, Chinese arbitrators often take the initiative to ask the disputing parties whether they would like the tribunal to assist them in achieving an amicable settlement. ${ }^{308}$ When mediation is consented to by the disputing parties and conducted during an arbitration process, there is no clear distinction between the proceedings under the two DSMs. ${ }^{309}$ If mediation successfully leads to a settlement agreement, the disputing parties may withdraw their claims or request the arbitral tribunal to render a written mediation statement or an arbitral award in accordance with the content of the settlement agreement. ${ }^{310}$ Such written mediation statements and arbitral awards have the same legal effect. ${ }^{311}$ It is noticeable that, where disputing parties wish to mediate but hesitate to have the same

\footnotetext{
305 Where an agreement is not reached after mediation or either party goes back on his words before the written administrative reconsideration mediation agreement takes effect, the administrative reconsideration organ shall issue a timely administrative reconsideration decision. See: Ibid.

306 China's practice of combining mediation with arbitration was originally developed by China International Economic and Trade Arbitration Commission (CIETAC) and China Maritime Arbitration Commission (CMAC) in the 1950s. Although there was no clear regulation on "Arb-Med" in Foreign Trade Arbitration Commission (FTAC, the predecessor of CIETAC) Provisional Rules (1956), the existence of such a practice was implied from Art. 31 of this set of rules. This could also be shown by the arbitration practice of this commission during that time. See: China International Economic and Trade Arbitration Commission 中国国际经济贸易仲裁委员会, Selected Works of China International Economic and Trade Arbitration Commission Awards (1963-1988) 中国国际经济贸易仲裁 裁决书选编（1963-1988）, China Renmin University Press 中国人民大学出版社, 1993, p. 1.

307 Arbitration Law of the People's Republic of China 中华人民共和国仲裁法 (enforced on 01.09.1995, as amended on 27.08.2009), Art. 51.

${ }^{308}$ Gabrielle Kaufmann-Kohler \& Fan Kun, Integrating Mediation into Arbitraiton: Why It Works in China, Journal of International Arbitration, Vol. 25, 2008, p. 487.

309 This is different from the practice in other mediation-friendly states. For example, in South Korea and Indonesia, an arbitrator only attempts to mediate at the outset of arbitration and an arbitrator will suspend the arbitration if the parties agree to mediation during the course of arbitral proceedings. See: M. Scott Donahey, Seeking Harmony: Is the Asian Concept of the Conciliator/Arbitrator Applicable in the West?, Dispute Resolution Journal, Vol. 50, 1995, p. 74 .

310 See e.g. CIETAC Arbitration Rules (2015), Art. 47.5.

311 Arbitration Law of the People's Republic of China 中华人民共和国仲裁法 (enforced on 01.09.1995, as amended on 27.08.2009), Art. 51. Like a normal arbitral award, the written mediation statement shall be signed by the arbitrators, sealed by the arbitration commission, and then served to both parties. The only difference between a mediation statement and an arbitral award based on a settlement agreement exists in the time when the document becomes effective. A written conciliation statement shall become legally effective after both parties have signed for receipt thereof, while arbitral awards shall be legally effective as of the date on which it is made. See: Arbitration Law of the People's Republic of China 中华人民共和国仲裁法 (enforced on 01.09.1995, as amended on 27.08.2009), Arts. 52, 57.
} 
tribunal acting as both arbitrators and mediators, it is possible for them to receive assistance from another independent mediator. ${ }^{312}$ If mediation is unsuccessful, the arbitration process continues and an arbitral award is made promptly. ${ }^{313}$ In such a situation, disputing parties cannot refer to the information used during the "Arb-Med" process and they must keep such information confidential. ${ }^{314}$

"Arb-Med" has been considered by Chinese parties to be very satisfactory and has drawn much attention from the rest of the world. ${ }^{315}$ According to the China International Commercial Arbitration Annual Report (2017), 58 per cent of the arbitration cases in China were finally settled through mediation. ${ }^{316}$ It is also noted that there has been some lingering doubts about the fairness and propriety of "Arb-Med". ${ }^{317}$ However, this was refuted by Lijun Cao in his research paper "CIETAC as A Forum for Resolving Business Disputes", where he proved the substantive fairness and procedural integrity of CIETAC arbitration by analysing the procedural features and the success rates by foreign parties. ${ }^{318}$

\subsubsection{Mediation in Litigation}

Mediation in litigation, or in-court mediation, which has been in place since the founding of the People's Republic of China, went through three stages of development: ${ }^{319}$ "Mediation as the Leading Method of Civil Litigation" (tiáojiě wéizhǔ, 调解为主), ${ }^{320}$ "Emphasizing Mediation, Voluntary Mediation and Legitimate Mediation”(zhuózhòng tiáojiě hé zìyuàn héfă tiáojiě，着重调解和自愿合法调解), ${ }^{321}$

312 See e.g. CIETAC Arbitration Rules (2015), Art. 47.8.

313 Arbitration Law of the People's Republic of China 中华人民共和国仲裁法 (enforced on 01.09.1995, as amended on 27.08.2009), Art. 51.

314 See e.g. CIETAC Arbitration Rules (2015), Art. 47.9.

315 Gabrielle Kaufmann-Kohler \& Fan Kun, Integrating Mediation into Arbitraiton: Why It Works in China, Journal of International Arbitration, Vol. 25, 2008, pp. 479-492. Edna Sussman, Developing an Effective Med-Arb/Arb-Med Process, New York Dispute Resolution Lawyer, Vol. 2, 2009, pp. 71-74. Thomas J. Stipanowich et al., East Meets West: An International Dialogue on Mediation and Med-Arb in the United States and China, Pepperdine Dispute Resolution Law Journal, Vol. 9, 2009, pp. 379-414. Shengchang Wang 王生长, The Theory and Practice of Combining Arbitration with Mediation 仲裁与调解相结合的理论与实务, Publishing House of Law 法律出版社, 2001, pp. 81-82. However, it is admitted that both the popularity and the effectiveness of the application of "ArbMed" in foreign-related arbitration cases were doubted. See: James V. Feinerman, The History and Development of China's Dispute Resolution System, at: Chris Hunter (ed.), Dispute Resolution in the PRC-A Practical Guide to Litigation and Arbitration in China, Asia Law \& Practice Ltd., 1995, pp. 5-21.

316 China International Economic and Trade Arbitration Commission 中国国际经济贸易仲裁委员会, China International Commercial Arbitration Annual Report 2016 中国国际商事仲裁年度报告 2016, 2017, available at: http://www.cietac.org/Uploads/201710/59df3824b2849.pdf, p. 13, last visited on 07.08.2020.

317 Weixia Gu, The Delicate Art of Med-Arb and its Future Institutionalisation in China, UCLA Pacific Basin Law Journal, Vol. 31, 2014. Matthew Gearing, The Dangers of Arb-Med, Allen \& Overy, 20.04.2011, available at: http://www.allenovery.com/publications/en-gb/Pages/The-dangers-of-arb-med-.aspx, last visited on 05.08.2020.

318 Lijun Cao, CIETAC as a Forum for Resolving Business Disputes, The Foundation for Law, Justice and Society, 24.01.2008, available at: http://www.fljs.org/sites/www.fljs.org/files/publications/FLJ\%2BS\%20Cao\%20pb_c.pdf, last visited on 03.08.2020.

319 Jianlong Yu 于健龙, Discussion on the Chinese Legal System of Commercial Mediation 论中国商事调解法律 制度, to obtain the Doctor Degree at University of International Business and Economics 对外经济贸易大学, 2013, p. 47.

${ }^{320}$ During this stage, disputing parties had no other choice but to follow the mediation process led by judges, so there was no real litigation in practice. See: Weiping Zhang 张卫平, Reflection on Returning Back to Xiwu Ma 回 归马锡五的思考, Modern Law Science 现代法学, Vol. 31, 2009, pp. 139-140.

${ }^{321}$ During the second stage, the voluntariness of reaching a mediation agreement was stressed, but the initiation of mediation was still mandatory. See: Civil Procedure Law of the People's Republic of China (For Trial Implementation) 中华人民共和国民事诉讼法(试行) (enforced on 01.10.1982, expired on 09.04.1991), Art. 97. In 
and "Giving Priority to Mediation, Combining Mediation with Judgment, Constructing the 'Triune' Big Mediation System of People's Mediation, Administrative Mediation and Judicial Mediation"( tiáojiě yōu xiān, tiáopàn jiéhé, zhuólì tuīdòng rénmín tiáojiě, xíngzhèng tiáojiě, sīfã tiáojiě “sānwèiyītî̀" de dàtiáojiě, 调解优先, 调判结合, 着力 推动人民调解、行政调解、司法调解 “三位一体”的大调解). ${ }^{322}$ In particular, the link between promoting mediation and realizing the goal of the socialist construction was pointed out: giving priority to mediation helps realize social harmony. ${ }^{323}$

People's courts are required to conduct mediation based on the principles of the free will of disputing parties and legality. ${ }^{324}$ During litigation, mediation can be referred to in three stages: before case registration, after case registration but before a hearing, and during or after a hearing but before the issuance of the final judgment. During the first stage, if parties reach an agreement, they could apply to the competent people's court for a mediation agreement to be issued, ${ }^{325}$ or they can go to a notarial office to have the agreement notarized. ${ }^{326}$ Without confirmation from a people's court or notarization, the settlement agreement has the same effect as a normal contract. If the consent statement is reached by disputing parties and issued by the people's court during the second stage, it would have the same effect as a judgment, which means that one party can directly apply for enforcement. ${ }^{327}$ If mediation fails, the court shall enter a judgment in a timely manner. ${ }^{328}$ Finally, before the final judgment is delivered, mediation could still be undertaken to reach a potential settlement. The settlement agreement reached during this stage has a similar effect to those in the second stage. ${ }^{329}$

Instead of justice, in China, serving the people constitutes the overarching principle pursued by the judiciary (sĩfãwèimín, 司法为民). ${ }^{330}$ In other words, adjudication is considered to be a service that is provided to disputing parties, with a view to meeting the disputing parties' needs to the greatest extent possible and resolving disputes effectively and efficiently. Thus, if there is any chance to resolve the dispute and bring

addition, mediation agreements were made according to "a clear distinction between right and wrong". See: Ibid, Art. 97. In 1991, the issuance of Chinese Civil Procedure Law brought full voluntariness to mediation, including both the initiation of mediation and the content of the mediation statement, and mediation was changed from a recommended choice to a voluntary choice.

322 Notice of the Supreme People's Court on Issuing Several Opinions on Further Implementing the Working Principle of "Giving Priority to Mediation and Combining Mediation with Judgment" 最高人民法院印发《关于 进一步贯彻 “调解优先、调判结合”工作原则的若干意见》的通知, 07.06.2010, Art. 1.1.2. This document contains a list laying out the types of cases where mediation should be given priority, where investment disputes may very likely fall under some of the categories and thus be promoted to be resolved through in-court mediation. See: ibid.

323 Ibid.

324 Civil Procedure Law of the People's Republic of China 中华人民共和国民事诉讼法(enforced on 09.04.1991, as amended on 31.08.2012), Art. 9.

325 Id, Arts. 194-195.

326 Notary Law of the People's Republic of China 中华人民共和国公证法 (enforced on 01.03.2006, as amended on 24.04.2015), Art. 37.

327 Civil Procedure Law of the People's Republic of China 中华人民共和国民事诉讼法 (enforced on 09.04.1991, as amended on 31.08.2012), Arts. 97, 236.

328 Id, Art. 9.

329 Id, Art. 142

330 Rong Liu 刘嵘, Establishing the Idea of the Judiciary Serves the People and Implementing the Theme of Justice and Efficiency: Note of the National Conference for Presidents of the Higher Courts 树立司法为民思想，践行公 正与效率主题一一记全国高级法院院长座谈会, People's Judicature 人民司法, Vol. 9, 2003, pp. 14-15. 
the dispute to an end through mediation, which is relatively faster, this will be tried. Furthermore, it was argued that mediation in litigation is not only a key component of this people-based or service-based doctrine, but it is closely linked to the creation of a harmonious society, ${ }^{331}$ since, in this way, disputes are settled without going through the formal and adversarial litigation process. Therefore, this practice can be seen as another reflection of China's traditional preference for the amicable settlement of disputes. At the same time, the wide use of mediation in litigation in China is a "reluctant response to political demands to maintain social stability", which means harmony in society; in fact, judges are required to always consider the law as well as keep the likely social impacts of their decisions in mind, even during litigation. ${ }^{332}$

\subsubsection{Complaints Coordination for Foreign Investment Related Disputes}

In 2006, the Ministry of Commerce of China created interim measures to deal with foreign investment disputes, which allows foreign-invested enterprises or foreign investors that deem their legitimate rights or interests as having been infringed by an administrative authority to file complaints with the complaint acceptance authority for coordination or settlement. ${ }^{333}$

This DSM is available for disputes that have not gone through judicial procedures, administrative reconsideration, or arbitral procedures, and they have not been accepted by the department of disciplinary inspection, supervision or credit investigation. ${ }^{334}$ After receiving the complaint, the relevant organ will try to settle the dispute through administrative coordination, by considering the real situation, setting forth suggestions, opinions or claims, or transferring the dispute to the local complaint acceptance organ or relevant department for handling, ${ }^{335}$ which is a process that can be described as a quasi-mediation process. ${ }^{336}$ In the recently issued Foreign Investment Law of China, Article 26 expressly made complaints coordination an available DSM for foreign investors to resolve their investment disputes within China. ${ }^{337}$

\footnotetext{
331 Weiping Zhang 张卫平, Court Mediation: Analysis and Reflection of the Current Situation 诉玄调解: 时下 态势的分析与思考, Law Science 法学, Vol. 5, 2007, pp. 18-27. Fu Hualing \& Richard Cullen, From Mediatory to Adjudicatory Justice: The Limits of Civil Justice Reform in China, at: Chinese Justice: Civil Dispute Resolution in Contemporary China, Cambridge University Press, 2011, p. 50.

${ }^{332} \mathrm{Fu}$ Hualing \& Richard Cullen, From Mediatory to Adjudicatory Justice: The Limits of Civil Justice Reform in China, at: Chinese Justice: Civil Dispute Resolution in Contemporary China, Cambridge University Press, 2011, p. 51. The preference for mediation is also argued as a result of the claimed failure of adjudicatory justice and the perceived effectiveness of mediatory justice, and judges have been relegated to settling private disputes, instead of serving a more public and general role of norm finding and application. See: id, p. 49.

333 Interim Measures of the Ministry of Commerce for the Work Relating to the Complaints of Foreign-funded Enterprises 商务部外商投资企业投诉工作暂行办法 (enforced on 01.10.2006), Art. 2.

334 Id, Art. 9.

${ }^{335}$ Id, Arts. 2, 11.

336 Guiguo Wang, Chinese Mechanisms for Resolving Investor-State Disputes, Jindal Journal of International Affairs, Vol. 1, 2011, p. 211. Compared to administrative litigation and administrative reconsideration, complaints coordination is more amicable and efficient. For more information on administrative litigation and administrative reconsideration, see Sections 3.2.5 and 3.2.6, infra.

337 Foreign Investment Law of the People's Republic of China (issued on 15.03.2019, coming into effect on 01.01.2020), Art. 26.
} 


\subsubsection{Commercial Arbitration}

In China, arbitration shall be carried out independently, free from interference from administrative organs, social organizations or individuals. ${ }^{338}$ The precondition for referring a dispute to arbitration is having a valid arbitration agreement, ${ }^{339}$ and challenges to the arbitration agreement can be submitted to the arbitration commission or to the competent people's court. If one party make a request to the arbitration commission and the other party applies to the competent people's court to decide whether an arbitration agreement is valid or not, the people's court shall deliver the ruling. ${ }^{340}$ This can be taken as the evidence that China does not completely recognize the doctrine of "competence-competence". ${ }^{411}$ In principle, arbitration is held in camera, and disputing parties are free to make other agreements unless state secrets are involved. ${ }^{342}$ Parties are free to choose foreign arbitrators and foreign lawyers in foreign-related arbitration cases. ${ }^{343}$ It should be noted that ad hoc arbitration is not allowed in China. ${ }^{344}$ The underlying reason for such a prohibition is argued the be the fear of recourse to ad hoc arbitration becoming out of control and that the Chinese legal system would suffer from its flexibility. ${ }^{345}$ This corresponds with the high level of institutional management in Chinese arbitration institutions. ${ }^{346}$ Furthermore both reflect the traditional value that the collective is more recognized than individuals.

Notably, regarding the enforcement of international arbitral awards, an internal reporting system has been established in response to the concerns about possible local protectionism and the limited experience of judges in foreign-related cases in local

\footnotetext{
338 Arbitration Law of the People's Republic of China 中华人民共和国外商投资法 (enforced on 01.09.1995, as amended on 27.08.2009), Arts. 8, 14.

339 A valid arbitration agreement shall: "(1) be in written form; (2) contain an expression of intention to apply for arbitration, matters for arbitration, and a designated arbitration commission; (3) be within the range of arbitrable matters as specified by law”. See: Arbitration Law of the People's Republic of China 中华人民共和国仲裁法 (enforced on 01.09.1995, as amended on 27.08.2009), Arts. 3, 16, 17.

340 Id, Art. 20.

341 The term "competence-competence" refers to the power/competence of an arbitral tribunal to decide upon its own jurisdiction/competence, which has been accepted as a basic doctrine in international arbitration. See: Nigel Blackaby \& Constantine Partasides \& Alan Redfern \& Martin Hunter (eds.), Redfern and Hunter on International Arbitration (Sixth Edition), Oxford University Press, 2015, para. 5.105.

342 Arbitration Law of the People's Republic of China 中华人民共和国仲裁法 (enforced on 01.09.1995, as amended on 27.08.2009), Art. 40 .

${ }^{343}$ Id, Art. 67. Compared to Chinese lawyers, foreign lawyers are only prohibited from giving opinions on the application of Chinese laws. See: Regulations on Administration of Representative Offices of Foreign Law Firms in China 外国律师事务所驻华代表机构管理条例 (issued on 22.12.2001, enforced on 01.01.2002), Art. 15.

${ }^{344}$ Chinese law does not give any definition of ad hoc arbitration. This type of arbitration usually refers to the situation where "there is no formal administration by any established arbitral agency; instead the parties have opted to create their own procedures for a given arbitration". See: Gerald Aksen, Ad Hoc Versus Institutional Arbitration, the ICC International Court of Arbitration Bulletin, Vol. 10, 1991, p. 8.

Although ad hoc arbitration is not allowed to be conducted in China, the arbitral awards of ad hoc arbitration made outside of China are considered in the same way as awards of foreign institutional arbitration with regard to recognition and enforcement in China. See: Interpretation of the Supreme People's Court on the Application of the Civil Procedure Law of the People's Republic of China (enforced on 04.02.2015), Art. 545.

${ }^{345}$ Lijun Cao, CIETAC as a Forum for Resolving Business Disputes, The Foundation for Law, Justice and Society, 24.01.2008, available at: http://www.fljs.org/sites/www.fljs.org/files/publications/FLJ\%2BS\%20Cao\%20pb_c.pdf, last visited on 03.08.2020.

346 This is evidenced by the significant role in arbitration case management played by CIETAC compared to other main international arbitration institutions in the world. A typical reflection is the large scope of arbitration work that CIETAC arbitration secretaries are involved in. As a result, there are concerns about CIETAC secretariat's ultra vires. See: id, p. 5.
} 
people's courts. ${ }^{347}$ Specifically, lower courts are required to report to the higher courts, including ultimately the Supreme People's Court, whenever they deny the recognition of the enforcement of a foreign award. ${ }^{348}$ This internal reporting system is evidence typical of China's increasing acceptance of international arbitration as a means to resolve international commercial disputes. ${ }^{349}$

Compared to litigation, arbitration is less aggressive and keeps more procedural factors within the parties' hands. In this vein, considering the consistent preference for amicable DSMs and the general understanding of DSMs as a service to disputing parties, arbitration is arguably more favoured in China than litigation.

\subsubsection{Administrative Reconsideration}

Administrative reconsideration is another way of resolving disputes between investors and administrative authorities. It applies to the situation in which a citizen, legal person or any other organization considers that its lawful rights and interests have been infringed upon by a specific administrative act and applies for administrative reconsideration to an administrative organ. ${ }^{350}$ In general, administrative reconsideration organs enjoy power similar to courts and the process of administrative reconsideration is similar to litigation. The process starts with the applicant's application to the competent administrative organs, ${ }^{351}$ after which the respondent replies and provides relevant documents to prove the basis for the specific administrative act that has been undertaken. ${ }^{352}$ In principle, administrative reconsideration refers to an examination based on written submissions, but, if there is a need, the administrative reconsideration organ may investigate facts among the organizations and citizens concerned and listen to the views of the applicant, respondent and third parties. ${ }^{353}$ In the end, the administrative reconsideration organ makes a decision, which can be enforced directly. ${ }^{354}$ Party autonomy does not play as big a role

\footnotetext{
347 This system was created and completed gradually through three documents. See: China Academy of Arbitration Law 中国仲裁法学研究会, China International Commercial Arbitration Annual Report (2014) 中国国际商事仲 裁年度报告 (2014)，2015, available at: http://www.cietac.org/Uploads/201602/56cbb883901f0.pdf, pp. 22, 49, last visited on 07.08.2020. The three documents are: Notice on People's Courts' Dealing with Foreign-related Arbitration and Foreign Arbitration 关于人民法院处理与涉外仲裁及外国仲裁事项有关问题的通知 (issued on 28.08.1995); Notice on People's Courts Setting Aside Foreign-related Arbitral Awards 关于人民法院撤销涉外仲 裁裁决有关事项的通知 (issued on 23.04.1998); and Regulations on Charges and Review Period of Recognition and Enforcement of Foreign Arbitral Awards 关于承认和执行外国仲裁裁决收费及审查期限问题的规定（issued on 21.10.1998).

348 Jingzhou Tao, Arbitration in China, at: International Commercial Arbitration in Asia (Second Edition), Juris Publishing, 2006, pp. 18-19. The implementation of this system has led to a great decrease in the number of cases where foreign arbitral awards were set aside or rejected in relation to recognition and enforcement. See: China Academy of Arbitration Law 中国仲裁法学研究会, China International Commercial Arbitration Annual Report (2014) 中国国际商事仲裁年度报告（2014），2015, available at: http://www.cietac.org/Uploads/201602/56cbb883901f0.pdf, p. 49, last visited on 07.08.2020.

349 Won Kidane, China-Africa Dispute Settlement: The Law, Economics and Culture of Arbitration, Seattle University School of Law Legal Research Paper Series, Vol. 12-16, 2011, pp. 72-73, 165-188.

350 Administrative Reconsideration Law of the People's Republic of China 中华人民共和国行政复议法 (enforced on 01.10.1999, as amended on 27.08.2009), Art. 2.

${ }^{351}$ Id, Arts. 11-15.

352 Id, Art. 23.

353 Id, Art. 22. See also: Regulations on the Implementation of the Administrative Reconsideration Law of the People's Republic of China 中华人民共和国行政复议法实施条例 (enforced on 01.08.2007), Arts. 33-34.

354 Administrative organs can use administrative power to force private parties to follow the decision or use the
} 
in administrative reconsideration as it does in other DSMs. For example, although negotiation and mediation are available to disputing parties during administrative reconsideration, it is the administrative organ that decides whether a case can be withdrawn if any settlement agreement has been reached. ${ }^{355}$

\subsubsection{Litigation}

Foreign investment disputes can also be resolved through litigation in China, which includes civil litigation and administrative litigation. ${ }^{356}$ The following issues concerning process deserve particular attention for the present analysis. First, as a special feature of foreign-related litigation cases in China, the principle of "countertreatment" is adopted regarding the procedural rights and obligations of foreign disputing parties. Specifically, as a principle, foreign parties enjoy national treatment in people's courts; where the courts of a foreign state impose any restriction on the civil procedural rights of Chinese parties, the people's courts shall apply the principle of reciprocity to the civil procedural rights of parties of that foreign state. ${ }^{357}$ Second, if a foreign party needs to be represented by a lawyer as its agent ad litem in a people's court, a Chinese lawyer is required. ${ }^{358}$ Third, the publication of a litigation process is considered as a basic requirement and exceptions are provided for situations in which state secrets, individual privacy, business secrets, and other elements otherwise prescribed by laws are involved. ${ }^{359}$ Fourth, even during the period of enforcement of a judgment, parties still have the opportunity to reach a settlement. ${ }^{360}$ In other words, in addition to undertaking mediation during litigation, this is another attempt at a possible amicable settlement of disputes at the very last stage. Last but not least, although it is neither explicitly stated in legal texts nor evidenced by other official documents, it was argued that, in practice, the satisfaction of parties was the major criterion in measuring

effect of internal hierarchy to allow the involved administrative organ to alter the disputed actions. See: Administrative Reconsideration Law of the People's Republic of China 中华人民共和国行政复议法 (enforced on 01.10.1999, as amended on 27.08.2009), Arts. 31-33.

355 Id, Art. 25. See also: Regulations on the Implementation of the Administrative Reconsideration Law of the People's Republic of China 中华人民共和国行政复议法实施条例 (enforced on 01.08.2007), Art. 38.

356 When the dispute has a contractual nature, the process will be commercial litigation and Chinese Civil Procedure Law will apply. Where the dispute happens between foreign investors and local administrative authorities on issues like license authorization and expropriation, the process will be administrative litigation governed by Chinese Administrative Procedure Law. The general procedure of administrative litigation is similar to that of foreign-related commercial litigation, with subtle differences to suit the specific nature of administrative disputes. For easy reference, the following analysis is mainly based on Chinese Civil Procedure Law.

357 Civil Procedure Law of the People's Republic of China 中国民事诉讼法 (enforced on 09.04.1991, as amended on 31.08.2012), Art. 5.

${ }^{358}$ For litigation in people's courts, foreign lawyers need to cooperate with Chinese lawyers and cannot provide opinions on interpretation of Chinese legal documents. See: id, Art. 263.

${ }^{359}$ Id, Art. 134.

360 Where this happens, the enforcement personnel shall record the provisions of the settlement agreement in the enforcement transcripts, to which both sides shall affix their signatures or seals. Such a settlement agreement means an end to the process of enforcement. If, later, one party acts against their settlement agreement reached during enforcement, the people's court will resume execution based on an application. See: id, Art. 230. Civil Procedure Law of the People's Republic of China 中国民事诉讼法 (enforced on 09.04.1991, as amended on 31.08.2012), Art. 230. Interpretation of the Supreme People's Court on the Application of the Civil Procedure Law of the People's Republic of China 最高人民法院关于适用《中华人民共和国民事诉讼法》的解释 (enforced on 04.02.2015), Art. 467. 
the outcome of the trial, ${ }^{361}$ which seems to be in clear contrast to the goal generally recognized in Western legal systems that adjudication aims to realize justice.

\subsubsection{Dispute Settlement Mechanisms under the "One Belt One Road" Initiative}

Against the background of China's current investment development strategy, the "One Belt One Road" (OBOR) Initiative no doubt deserves special attention. ${ }^{362}$ This Initiative was first launched by President Jinping Xi during his visit to central and southeast Asian states in 2013. In 2015, "Vision and Actions on Jointly Building Silk Road Economic Belt and 21 ${ }^{\text {st }}$-Century Maritime Silk Road" was jointly issued by the National Development and Reform Commission, the Ministry of Foreign Affairs and the Ministry of Commerce of the People's Republic of China, with the State Council's authorization, which created the blueprint for further development. The OBOR Initiative envisages an investment of more than $\$ 1$ trillion "so as to promote international policy coordination, infrastructure facilities connectivity, unimpeded trade, financial integration as well as human 'people-to-people bonds' among more than 65 countries". ${ }^{363}$

Even though the design of the OBOR Initiative seems to have evolved pragmatically, its legal coherence and legitimacy require proper DSMs. ${ }^{364}$ Many scholars have been working on this and many constructive suggestions have been made. Some scholars recommended that the dispute settlement system under the OBOR Initiative should be built upon existing DSMs by using the WTO Dispute Settlement System and ICSID as the basis to be further facilitated with certain flexible diplomatic mechanisms and other arrangements under FTAs and IIAs. ${ }^{365}$ Others argued for establishing a new comprehensive multi-fold dispute settlement centre providing consultation, mediation, arbitration, and litigation. ${ }^{366}$ In particular, building a comprehensive system for effective dispute settlement under the OBOR Initiative also appeared in various policy documents issued by different entities, in which the promotion of alternative dispute resolution was stressed in particular. ${ }^{367}$ The promotion of alternative dispute resolution

361 Lei Zhao 赵蕾, The Biggest Controversy over Judicial Reform: the Revival of Xiwu Ma 司法改革最热争议 马锡五复活, infzm.com 南方周末网, 10.06.2009, available at: http://www.infzm.com/content/29885, last visited on 07.08.2020.

362 The OBOR Initiative is composed of a "Silk Road Economic Belt" and a "21st Century Maritime Silk Road".

${ }^{363}$ Ernst-Ulrich Petersmann, Trade and Investment Adjudication Involving 'Silk Road Projects': Legal Methodology Challenges, European University Institute Working Papers, Vol. 2, 2018, p. 1. Uniview (UNV), The Belt and Road Initiative, 29.09.2018, available at: http://en.uniview.com/News/News/201809/804999_169683_0.htm, last visited on 06.08.2020.

364 Ernst-Ulrich Petersmann, Trade and Investment Adjudication Involving 'Silk Road Projects': Legal Methodology Challenges, European University Institute Working Papers, Vol. 2, 2018, p. 1.

365 See e.g. Li Liao 廖丽, Innovative Study on the Dispute Settlement Mechanism under the 'One Belt One Road' Initiative: From International Law and Comparative Law Perspectives “一带一路” 争端解决机制创新研究一 一国际法与比较法的视角, Law Review 法学评论, Vol. 2, 2018, p. 166.

366 See e.g. Heqisheng Research Group 何其生课题组, Discussion on the Construction of China International Commercial Court 论中国国际商事法庭的构建, Wuhan University International Law Review 武大国际法评论, Vol. 3, 2018. Shaotang Wang 王少棠, Legetimacy Crisis Resolved? Reconsideration of the EU's Reform of Investment Court System 正当性危机的解除? - - 欧盟投资争端解决机制改革再议, Studies in Law and Business 法商研究, Vol. 2, 2018, p. 170.

367 See e.g. Several Opinions of the Supreme People's Court on Providing Judicial Services and Safeguards for the Construction of the “Belt and Road” by People's Courts 最高人民法院关于人民法院为“一带一路”建设提供司 法服务和保障的若干意见 (issued on 16.06.2015, entered into force on 16.06.2015); Instrumentalities of the State 
can be understood as encouraging the use of non-governmental actors as judicial promoters of justice, the rule of law and other public goods. ${ }^{368}$ Although such "legal innovations" of China's OBOR Initiative raise questions of justice and legal methodology, it is also suggested that " $[\mathrm{t}]$ he Chinese traditions favouring alternative dispute resolution methods (like mediation and conciliation procedures) should be institutionalized at national and regional levels of OBOR cooperation". ${ }^{369}$ Until now, many efforts have been made and the development of the construction of the dispute settlement system under the OBOR Initiative can be seen. One such piece of evidence is the establishment of the Xi' an and Shenzhen international commercial courts. ${ }^{370} \mathrm{In}$ addition, for investment arbitration, CIETAC issued its Investment Arbitration Rules in 2017, in which the practice of combining mediation with arbitration continues. As argued, future practice in relation to the construction of DSMs in the implementation of the OBOR Initiative "will help to discover comparative advantages and 'best practices' of alternative judicial, mediation and conciliation procedures and multilevel institutions for dispute settlement". 371

\subsection{A Legal Cultural Interpretation of China's Domestic Dispute Settlement Mechanisms}

As revealed in the above analysis, each DSM has its own features and, at the same time, they come together to constitute the whole picture of China's legal system for the resolution of foreign investment disputes. There are various elements that affect the procedural design of these DSMs and the way they cooperate with each other, but it seems that they are branded with characteristics originating from contemporary Chinese ideology, which can be further traced back to influential traditional Chinese philosophies.

This section explores the potential connection between traditional Chinese philosophies and contemporary Chinese ideology analysed in Section 3.1, supra, on the one hand, and the procedural features of the DSMs discussed in Section 3.2, supra, on the other. It aims to interpret China's domestic dispute settlement system from a legal cultural perspective, which would provide a better understanding of the underlying values and principles that the DSMs intend to protect and preserve.

\footnotetext{
Council, General Office of the State Council, Opinions on the Construction of the "One Belt One Road" Initiative International Commercial Dispute Settlement Mechanisms and Organizations 中共中央办公厅、国务院办公厅 印发《关于建立“一带一路”国际商事争端解决机制和机构的意见》 (issued on 06.01.2018, entered into force on 06.01.2018).

368 Ernst-Ulrich Petersmann, Trade and Investment Adjudication Involving 'Silk Road Projects': Legal Methodology Challenges, European University Institute Working Papers, Vol. 2, 2018, p. 16.

369 Id, pp. 1, 16.

370 These courts are a part of the Supreme People's Court. For more information on these courts, see: China International Commercial Court, A Brief Introduction of China International Commercial Court, 28.06.2018, available at: http://cicc.court.gov.cn/html/1/219/193/195/index.html, last visited on 31.07.2020.

371 Ernst-Ulrich Petersmann, Trade and Investment Adjudication Involving 'Silk Road Projects': Legal Methodology Challenges, European University Institute Working Papers, Vol. 2, 2018, p. 15.
} 


\subsubsection{Restoring Harmony through the Promotion of Amicable Dispute Settlement Mechanisms}

China's dispute settlement system presents a clear and explicit welcoming attitude towards amicable and informal DSMs, from negotiation, mediation to complaints coordination, all of which constitute a wide net for possible settlements. First of all, the explicit reference to negotiation in legal texts and the great freedom given to disputing parties to resort to this mechanism in other DSMs shows how the use of this DSM is encouraged. Second, the availability of different types of independent mediation and the creative combination of mediation and other formal DSMs increase the possibility that they are used. Third, for foreign investment disputes, a special type of DSM, complaints coordination, which is procedurally similar to mediation, has been established. This further enhances the possibility of disputes raised by foreign investors being resolved amicably. Fourth, the design of China's whole dispute resolution system shows an intended reluctance to use formal or adversarial mechanisms. Different modes of alternative DSMs limit the use of litigation, and, even when litigation is referred to, it is still very likely to be "disturbed" by in-court mediation. As has been pointed out, "Chinese societies and legal arrangements over disputes point towards social patterns of dispute resolution rather than state-sponsored official fora". ${ }^{372}$ Facing various amicable options in China's legal system, the willingness of disputing parties to settle disputes through non-judicial mechanisms can be promoted in turn. In this sense, the combination of mediation with arbitration and litigation may be especially effective, since adjudicators' suggestions are expected to have a great influence or even put pressure on disputing parties. It can be summarized that the ultimate goal of building a "harmonious socialist society" has been clearly reflected in the procedural design of China's dispute settlement system.

Informal DSMs are beneficial to the re-establishment of a harmonious relationship between disputing parties and the pursuit of social harmony, which is at the centre of the value system of traditional and contemporary Chinese ideologies. Amicable and informal mechanisms are considered to be more honourable than confrontational mechanisms. This is because disputes are regarded as abnormal and constitute a factor of instability which needs to be eliminated, instead of being exaggerated in adversarial DSMs. It is admitted that there are other elements that contribute to the preference for non-adjudicative methods in China, ${ }^{373}$ but the incentives that originate in Chinese ideologies are clear. Although the drawbacks of these DSMs also exist in the case of China, such as not contributing to the jurisprudence, ${ }^{374}$ they seem to be light when

\footnotetext{
372 Werner Menski, Comparative Law in a Global Context: The Legal Systems of Asia and Africa (2nd Edition), Cambridege University Press, 2009, p. 517.

${ }^{373}$ For a further discussion on other elements, such as political ones, see: Guiguo Wang, Chinese Mechanisms for Resolving Investor-State Disputes, Jindal Journal of International Affairs, Vol. 1, 2011, p. 224. Hualing Fu, Mediation and the Rule of Law: The Chinese Landscape, at: Formalisation and Flexibilisation in Dispute Resolution, Brill | Nijhoff, 2014, pp. 117-118.

374 There is extensive discussion on the pros and cons of alternative dispute resolution. See e.g. Owen M. Fiss, Against Settlement, Yale Law School Legal Scholarship Repository, Vol. 1, 1984, p. 1088.
} 
weighed against the theme of resolving disputes effectively and efficiently and reinstating interpersonal and community harmony and stability.

In short, the existing legal apparatus in China's dispute settlement system has been greatly influenced by the long-standing harmony-centred tradition and the preference for the amicable settlement of disputes. ${ }^{375}$ Such an effect is expected to continue to exist. The DSMs in China's legal system reflect the harmonious society rhetoric and, in turn, contribute to the preference for a non-adversarial means of settling disputes. In other words, the design of China's dispute settlement system is both reflective of and beneficial for the Chinese legal culture.

\subsubsection{Satisfying Various Legal Cultural Needs through Extensive Use of Mediation}

As presented in Section 3.2.2, supra, mediation plays a significant role in China's dispute resolution system by existing as an independent DSM as well as being combined with other DSMs. In particular, when it comes to foreign investment disputes, the creation of complaints coordination demonstrates China's firm belief that mediation represents "the primary means to resolve transnational disputes while maintaining an ongoing business relationship". ${ }^{376}$ As mentioned in Section 3.2.2.5, supra, the preference for mediation was explicitly pointed out by a Notice of "Giving Priority to Mediation, Combining Mediation with Judgment, Constructing the 'Triune' Big Mediation System of People's Mediation, Administrative Mediation and Judicial Mediation" issued by the Supreme People's Court in $2010 .{ }^{377}$ It can be said that "Mediation First" has been established as a basic principle of dispute resolution in China's legal system, which reinforces the general preference for amicable DSMs. Although there are some doubts particularly regarding the appropriateness of conducting mediation in other DSMs, the success of this "oriental experience" in China has proven its value and, at the same time, has drawn much attention from around the world. ${ }^{378}$

Chinese mediation has deep cultural roots. In Chinese legal culture, the encouragement for using amicable means of dispute resolution, the consistent pursuit of harmony,

\footnotetext{
375 Stanley B. Lubman \& Gregory C. Wajnowski, International Commercial Dispute Resolution in China: A Practical Assessment, The American Review of International Arbitration, Vol. 4, 1993, pp. 107, 115.

376 John Farina, The Study of Spirituality: Some Problems and Opportunities, US Catholic Historian, Vol. 8, 1989, p. 157.

377 Notice of the Supreme People's Court on Issuing Several Opinions on Further Implementing the Working Principle of “Giving Priority to Mediation and Combining Mediation with Judgment” 最高人民法院印发《关于 进一步贯彻“调解优先、调判结合”工作原则的若干意见》的通知 (issued on 07.06.2010), Art. 1.1.2.

378 For example, from 2011 to 2017, Shanghai Commercial Mediation Center accepted 493 cases entrusted by people's courts, and 262 cases of them were successfully resolved through mediation (the success rate was $68 \%$ ); in 2019, 18.27\% arbitration cases administered by the Beijing International Arbitration Center ended in mediation. See: www.legaldaily.com.cn 法制网, The Blossom of the Oriental Flower: The Current Status, Problems and Solutions Regarding Mediation in China 东方之花的绽放——调解在中国的发展现状、问题及对策, 21.11.2018, available at: http://www.legaldaily.com.cn/Arbitration/content/2018-11/21/content_7690176.htm, last visited on 07.08.2020. Beijing Arbitration Commission \& Beijing International Arbitration Center 北京仲裁委员会 \& 北京 国际仲裁中心, The Conference on BIAC 2019 Report Was Successfully Held 北仲 “2019 年工作报告会” 成功 举办, 20.01.2020, available at: http://www.bjac.org.cn/news/view?id=3653, last visited on 31.07.2020. There is also an academic discussion on this topic, see e.g. Thomas J. Stipanowich et al., East Meets West: An International Dialogue on Mediation and Med-Arb in the United States and China, Pepperdine Dispute Resolution Law Journal, Vol. 9, 2009, pp. 379-414.
} 
individuals' negative sentiment towards litigation, ${ }^{379}$ and their concerns about losing face because of being known as being involved in conflicts can all be satisfied by mediation. Furthermore, mediation is a means to make society less individualist and more relational, ${ }^{380}$ which again resonates with the emphasis on community in Chinese legal culture. It was argued that Chinese mediation "draws on a collectivist view of the world", which means that the dispute is not just an issue for the disputing parties, but it is relevant for the community, and thus mediation contributes to "the restoration of harmony in the sense of social stability and status quo to the community affected by the conflict". ${ }^{381}$ Although extensive use of mediation reasonably raises the question of "loss of law", including the loss of precedents and the absence of norm-setting functions, ${ }^{382}$ this does not seem to be a big issue in Chinese society, probably because of the positive consideration of mediation in Chinese legal culture and the possibility for its development. In brief, the basic principles and features of Chinese mediation are in line with traditional values, and those beliefs and teachings in legal culture have guided the Chinese community towards mediation.

\subsubsection{Combining the Construction of the Socialist Rule of Law and the Pursuit of Harmony}

With the construction of the modern Chinese legal system, the rule of law is also being established. In terms of dispute settlement, this leads to the increased legal awareness of individuals and relatively common recourse to litigation where procedural justice should be respected and the decision is expected to be reached by a neutral judicial organ based on the applicable law. ${ }^{383}$

However, as introduced in Section 3.1.2, supra, the socialist rule of law has been promoted, which is arguably different from the rule of law perceived by Western legal systems. Because of the combination of the pursuit of harmony and the construction of the socialist rule of law, the overall objective of dispute settlement in China is more about resolving conflicts and restoring the relationship between disputing parties, rather than seeking justice by reaching decisions regarding which party is right or wrong under the law. In this regard, it is necessary to differentiate social justice from personal justice in dispute settlement under China's legal system. Specifically, social justice stresses

\footnotetext{
379 A Chinese saying that is referred to often is that "it is better to be vexed to death than to bring a law suit". For more discussion on this, see: Urs Martin Lauchli, Cross-cultural Negotiations, With a Special Focus on ADR with the Chinese, William Mitchell Law Review, Vol. 26, 2000, p. 1062. Carlos de Vera, Arbitrating Harmony: "MedArb" and the Confluence of Culture and Rule of Law in the Resolution of International Commercial Disputes in China, Columbia Journal of Asian Law, Vol. 18, 2004, p. 149.

380 Robert A. Baruch Bush \& Joseph P. Folger, The Promise of Mediation: Responding to Conflict through Empowerment and Recognition, Jossey-Bass, 1994, pp. 255, 259. Oscar G. Chase, Law, Culture, and RitualDisputing Systems in Cross-Cultural Context, New York University Press, 2005, pp. 135-136.

381 Nadja Alexander, The Mediation Meta Model: Understanding Practice Around the World, Conflict Resolution Quarterly, Vol. 26, 2008, p. 99. Here, the author is introducing the categorization given by Bush and Folger in: Robert A. Baruch Bush \& Joseph P. Folger, The Promise of Mediation: Responding to Conflict through Empowerment and Recognition, Jossey-Bass, 1994, pp. 236-248.

${ }^{382}$ Sundaresh Menon, Mediation and the Rule of Law, The Law Society Mediation Forum, Singapore, 10.03.2017.

383 However, as pointed out, litigation is still an undesired DSM. Chinese parties will not resort to litigation unless all other avenues have been exhausted, since lawsuits can signify a complete severance of relations between disputing parties. See: Liyu Han \& Henry Gao, China's Experience in Utilizing the WTO Dispute Settlement Mechanism, at: Gregory C. Shaffer \& Ricardo Meléndez-Ortiz (eds.), Dispute Settlement at the WTO: The Developing Country Experience, Cambridge University Press, 2010, pp. 165-166.
} 
amicable settlement so as to maintain the harmonious conditions in society, while personal justice focuses on the realization of legal rights and obligations. Considering the established central theme of maintaining harmony, it is arguable that social justice has played a relatively greater role in dispute settlement, which has influenced the various DSMs in China's legal system. As pointed out, "law is but one means, far from the most important means, of resolving disputes and obtaining justice". ${ }^{384}$

\subsection{Conclusion}

Traditional philosophies, especially Confucianism, created the ideological foundation of Chinese legal culture. Instead of law, the advocated values and teachings played a significant role in regulating the ancient Chinese society. Under Confucianism, community came before individuals, social responsibility was more important than freedom and, most importantly, harmony was prioritized and took a central position. Dispute settlement focused on restoring harmonious relationships through amicable informal DSMs. Bringing a dispute to a formal DSM like litigation was not desired and was even resented.

Concerning contemporary Chinese legal culture, a mix of modern and ancient elements that exist side-by-side can be identified. ${ }^{385}$ On the one hand, although coming from ancient times, it can be argued that the core values of traditional Chinese philosophies have been inherited by contemporary Chinese ideologies, and this is especially reflected in the goal of constructing a harmonious socialist society. Against this background, non-adjudicated solutions to disputes through amicable mechanisms is consistently the preferred solution. On the other hand, law has been taken by China as an indispensable part of socialist construction, and the socialist rule of law is established. However, this is subject to the overall theme of socialist harmony.

For the resolution of disputes arising from foreign investment, six DSMs act as the main mechanisms in the Chinese legal system: negotiation, mediation, arbitration, complaints coordination for foreign investment, administrative review, and litigation. In general, the whole system has a clear preference for amicable DSMs, especially mediation. However, a different development from the situation in the past is that now adjudication is increasingly recognized.

While influenced by the practice in Western legal systems, the DSMs in China's legal system are arguably tainted with elements from Chinese ideologies, which can be taken as the ideological foundation of China's dispute resolution system. Such elements affect the procedural design of each DSM and the general structure of China's dispute

\footnotetext{
384 Ethan Michelson, Popular Attitudes Towards Dispute Processing in Urban and Rural China, The Foundation for Law, Justice and Society, 24.01.2008, available at: http://www.fljs.org/content/popular-attitudes-towardsdispute-processing-urban-and-rural-china, last visited on 04.08.2020.

385 Albert Hung-yee Chen, An Introduction to the Legal System of the People's Republic of China (1st edition), Butterworths Asia, 1992, p. 2. It is pointed out that many of such modern components "remain in a state of flux, struggling to thrive in rather adverse conditions”. See: Colin B. Picker, China, Global Governance \& Legal Culture: The Example of China \& the WTO, at: China and Global Economic Governance: Ideas and Concepts, The University of Tokyo-Institute of Social Science (ISS) Research Series No.45, 2011, p. 75.
} 
settlement system that is made up of those mechanisms. The promotion of amicable DSMs aims at restoring harmony between disputing parties as well as in society; the extensive use of mediation resonates with the requirement of various legal cultural elements; even the construction of the socialist rule of law is combined with the pursuit of harmony. As a result, social justice is considered of greater weight than personal justice, which means that the harmonious and stable condition of the society is more important than legal rights and obligations of the disputing parties.

In summary, from traditional Chinese philosophies to contemporary Chinese ideology, the core values have been insisted upon and, in particular, the amicable settlement of disputes has been consistently preferred. Such an inheritance from the legal tradition is further formally expressed by the institutional construction of China's domestic dispute settlement system. The design of each DSM in China's legal system for foreign investment disputes and the features of the whole dispute settlement system resonate with the virtues present in contemporary Chinese ideology under the influence of traditional philosophies. All of the mechanisms nudge the disputing parties in the same direction, to aim at retaining a harmonious socialist society. 


\section{Chapter 4 Legal Cultural Characteristics of Dispute Settlement in the EU}

This chapter aims at conducting a parallel analysis of the EU regarding its legal cultural characteristics of dispute settlement. Therefore, the three main perspectives that have been taken into consideration in Chapter 3 are analysed: dispute settlement according to the legal tradition, the DSMs in the internal legal system, and interpreting the DSMs in the internal legal system from a legal cultural perspective. This chapter also serves as the basis of the examination of the EU's approach to investment dispute settlement at the international level in Chapter 7, infra.

However, various differences between China and the EU lead to it being impossible to formulate an exact parallel analysis. In particular, since the EU is a Union comprising 27 states, ${ }^{386}$ rules on DSMs can be categorized into two levels: one from EU Member States and the other from the Union. Although the relationship between the rules at these two levels is complicated, ${ }^{387}$ it is clear that the former constitutes part of the foundation of the latter and the latter influences the former. In addition, when the Union represents its Member States in the negotiations of investment dispute settlement systems in prospective IIAs, including the one with China, the situation in the Member States and the requirements of EU Member States are borne in mind by the Union. This confirms that it is also necessary to consider the situations of EU Member States. Furthermore, according to Opinion 2/15 issued by the Court of Justice of the European Union (CJEU), the Union only has "shared competence" with EU Member States in relation to a dispute settlement system in an investment treaty. ${ }^{388}$ Namely, agreement from EU Member States is necessary for any treaty on investment. This shows that, for the present analysis, it is necessary to take both levels into account.

Specifically, the discussion in this chapter is divided into five sections. Section 4.1 explores the characteristics of dispute settlement in European legal culture, including the designated constants and other notable European legal cultural characteristics related to dispute settlement. Moving on to the design of current DSMs, considering that it is not feasibe to provide a complete description of all DSMs in each EU Member State in the present thesis, Section 4.2 offers a general description of the main DSMs that can be often referred to to resolve foreign investment disputes in EU Member States. These include mediation, arbitration and litigation. Section 4.3 assesses the efforts made to regulate DSMs that operate at the Union level. ${ }^{389}$ After that, in Section 4.4, an assessment of the DSMs in the EU Member States and the Union's relevant regulating

\footnotetext{
386 In June 2016, the United Kingdom held a referendum on its membership of the EU, resulting in $51.89 \%$ of votes cast in favour of leaving. After that, on 29 March 2017, it formally initiated the withdrawal process. On 31 January 2020, the United Kingdom officially left the EU, making the total number of EU Member States now 27.

387 For more information on the interaction between EU law and national laws of EU Member States, see e.g. Paul Craig \& Gráinne de Búrca, EU Law-Text, Cases, and Materials (Sixth Edition), Oxford University Press, 2015, pp. 266-315.

388 The Court of Justice of the European Union, Opinion 2/15 of the Court (Full Court), 16.05.2017.

389 Considering the subject of this thesis, similar to the discussion on China, only the DSMs that are relevant to investment related dispute settlement are taken into consideration, which applies to both Section 4.2 and Section 4.3.
} 
measures is conducted from a legal cultural perspective. The final Section 4.5 summarizes and concludes.

\subsection{Dispute Settlement in the European Legal Culture}

This section explores the features of dispute settlement in the European legal culture. It first discusses three identified constants in the European legal tradition. This builds the necessary basis and offers important inspiration for the next section, which focuses on the European legal cultural characteristics of dispute settlement, especially those that are in contrast with the legal cultural characteristics of dispute settlement in Chinese legal culture.

In brief, there are five different epochs of European legal history: the Middle Ages (C.E. 500-1000), the late Middle Ages (C.E. 1000-1453), the early Modern Age (1453-1648), the Modern Age (1648-1914), and the post-Modern Age (1914-2004). ${ }^{390}$ Although the whole development process is complicated, what needs to be summarized here, in the interest of the following analysis, is that, in European legal history, the focus on individuals, which was mainly inspired by liberalism, appeared together with the emphasis on law, and the development of both aspects was intertwined. ${ }^{391}$ Despite the ups and downs in this development, law was mainly designed to protect individuals' rights and ensured the proper use of power by the government or parliament. ${ }^{392}$

\subsubsection{Constants in the European Legal Tradition}

In the development of European legal history, according to Franz Wieacker and Edgar Boenheimer, three elements can be depicted as constants in the European legal tradition: personalism, legalism and intellectualism. These three elements were generally recognized as the common characteristics among EU Member States that continuously existed throughout the historical development, and thus they constitute the essential constants in European legal culture. ${ }^{393}$

Personalism is the first identified constant. Compared to the communitarian spirit, which can be described as "with one another", the nature of human relationships in Europe should be described as having a "vis-à-vis" character. ${ }^{394}$ In other words, instead

\footnotetext{
390 See e.g. Randall Lesaffer, European Legal History: A Cultural and Political Perspective, Cambridge University Press, 2009. Franz Wieacker \& Edgar Boenheimer, Foundations of European Legal Culture, The American Journal of Comparative Law, Vol. 38, 1990, pp. 11-19. Bart Wauters \& Marco de Benito, The History of Law in Europe: An Introduction, Edward Elgar Publishing, 2017. It is noted that different years were used by different scholars to divide the stages, but there is no substantial divergence. Here, the author follows the approach used by Randall Lesaffer in "European Legal History: A Cultural and Political Perspective", since the perspective used for analysis there is relevant for the present work.

391 For more discussion on this, see e.g. Randall Lesaffer, European Legal History: A Cultural and Political Perspective, Cambridge University Press, 2009, pp. 348, 354-357, 447-448, 464, 476. Charles de Secondat baron de Montesquieu-The Spirit of Law (Volume I), Thomas Ruddingman, 1793, p. 154. Heather M. Campbell (ed.), The Britannica Guide to Political and Social Movements That Changed the Modern World, Britannica Educational Publishing, 2010, p. 59.

${ }^{392}$ For a further discussion on this, see e.g. Randall Lesaffer, European Legal History: A Cultural and Political Perspective, Cambridge University Press, 2009, pp. 484-485, 498.

393 Id.

394 Franz Wieacker \& Edgar Boenheimer, Foundations of European Legal Culture, The American Journal of Comparative Law, Vol. 38, 1990, pp. 11-19.
} 
of placing importance on the fusion of "I" into "we", European legal culture focuses on the individualism of each member of the society. The root of this tradition can be traced back to the appearance of humanism in the early Modern Age. Inspired by classical philosophy, such as Platonism, Stoicism and Scepticism, humanism shifted the focus from "the static and the collective to the dynamic and the individual", and it opened the door to the individualization and mutability of society. ${ }^{395}$ As a result, freedom of decision and responsibility, and liberum arbitrium, complemented each other. ${ }^{396}$ It can be noted that, unlike in other jurisdictions, the effect of the combination of individuals and the ultimate goal of the whole society together is not clear when coming from this individualist approach.

The second element is legalism, which is represented by the separation between law and extrinsic social values. ${ }^{397}$ In fact, legalism is taken as the feature that "most distinguishes European civilization from that of other cultures, in which law emanates from an accepted social ethic as it did in classical China". ${ }^{398}$ Specifically, positive legal norms enjoy independence from other relevant elements and guarantee that the benchmark for decisions is the law. ${ }^{399}$ Legalism determines the role of law as the primary basis of judicial decisions in dispute settlement, assuring legal certainty against the potential arbitrariness of decision makers.

Intellectualism is the third identified constant. It is regarded as "a figure of formal thinking", the peculiar way in which law is understood and it is "closely connected with the specific structures and traditions of the European thinking". ${ }^{400}$ Intellectualism provides European jurists with the creation of concepts and a general systematization of legal phenomena in a general idea of justice. ${ }^{401}$

In brief, these three constants confirm the emphasis on individuals instead of the community, reveal the separation between law and social values and recognize the role of law and justice in dispute settlement in the European legal tradition.

\subsubsection{The European Legal Cultural Characteristics of Dispute Settlement}

Although the EU is a "supranational entity which has a state-like character", 402 the interactions between national and European patterns of legal culture lead to an overall

\footnotetext{
395 Bart Wauters \& Marco de Benito, The History of Law in Europe: An Introduction, Edward Elgar Publishing, 2017.

396 Randall Lesaffer, European Legal History: A Cultural and Political Perspective, Cambridge University Press, 2009 , p. 186.

397 Such a separation came from the growth of a specific professional administration of justice in ancient Rome. It was re-established and intensified by the separation of morality and law at the end of the $17^{\text {th }}$ century and ultimately led to the jurisprudential formalism and the statutory positivism of the modern constitutional state. See: id, p. 169.

398 Franz Wieacker \& Edgar Boenheimer, Foundations of European Legal Culture, The American Journal of Comparative Law, Vol. 38, 1990, pp. 11-12.

${ }^{399}$ Based on this, legalism has been argued as a pillar of European legal culture. However, it is noticeable that the separation between law and moral virtues does not mean excluding constructing statutes in the light of social objectives. See: id, pp. 237, 283.

400 Harold J. Berman, Law and Revolution: The Formation of the Western Legal Tradition, Harvard University Press, 1983 , p. 38 .

401 Franz Wieacker \& Edgar Boenheimer, Foundations of European Legal Culture, The American Journal of Comparative Law, Vol. 38, 1990, pp. 265, 270-271.

402 Harold J. Berman, Law and Revolution: The Formation of the Western Legal Tradition, Harvard University Press, 1983, p. 38.
} 
complex system, which is characterized by self-sufficiency, hybridization, conflict, and resistance, as well as convergence. ${ }^{403}$ Bearing this in mind, this section does not aim at providing a complete overview of the legal culture in the European dimension. Instead, it tries to provide a general picture of the widely recognized common features of the EU legal culture in relation to dispute settlement based on the common heritage of values and aims, especially those that differ greatly from those of Chinese legal culture.

\subsubsection{Perception of Law-Justice, Fairness and Legal Rights}

As revealed by the constants in the European legal tradition addressed above, the law plays an indispensable role in dispute settlement. There are different perceptions of the law among various legal theories, where natural law and legal positivism are the most important. ${ }^{404}$ Natural law is a reflection of rationalism in legal scholarship. ${ }^{405}$ The term "law" is understood in an anthropological way: social order should emerge from the informal institutionalization of ethical behaviours. ${ }^{406}$ Thus, law consists of a number of moral-legal principles that are considered to be natural and reasonable by a reasonable person, ${ }^{407}$ and the concept of individual "natural rights" is advocated. ${ }^{408}$ Similarly, natural justice is argued as existing beyond the laws implemented by states and should apply to all human beings. In contrast with natural law, legal positivism focuses on the investigation of valid law and is not so concerned with morally correct law. ${ }^{409}$ There is no need to test law for its justness or social utility, since "the formal laws of a parliamentary democracy ensure that the law is automatically in accordance with justice and general welfare". ${ }^{410}$ In addition, it is noticeable that the overarching

\footnotetext{
${ }^{403}$ Randall Lesaffer, European Legal History: A Cultural and Political Perspective, Cambridge University Press, 2009 , p. 348

404 The debate between natural law and legal positivism was argued as echoing the debate between Chinese Confucianism and Legalism. See e.g. Id, p. 354. id, pp. 354-357. There are also scholars who criticized such a comparison. See e.g. Id, p. 447.

405 The tradition of natural law goes back to ancient Greece and Rome, where Socrates and his followers Plato and Aristotle argued for the existence of natural justice. See: id, p. 464. For more discussions regarding natural law, see e.g. Charles de Secondat baron de Montesquieu-The Spirit of Law (Volume I), Thomas Ruddingman, 1793, p. 154. Randall Lesaffer, European Legal History: A Cultural and Political Perspective, Cambridge University Press, 2009, p. 476. id, p. 448. Heather M. Campbell (ed.), The Britannica Guide to Political and Social Movements That Changed the Modern World, Britannica Educational Publishing, 2010, p. 59. Randall Lesaffer, European Legal History: A Cultural and Political Perspective, Cambridge University Press, 2009, pp. 484-485.

406 Randall Lesaffer, European Legal History: A Cultural and Political Perspective, Cambridge University Press, 2009 , p. 498.

408 "Natural rights" have since become one of the basic principles in Western legislation. For instance, the Code of Frederick the Great of Prussia, the 1804 French Civil Code, the 1896 German Civil Code, and the 1907 Swiss Civil Code all included the idea of protecting individual rights and individual freedom, equality and security. See: Franz Wieacker \& Edgar Boenheimer, Foundations of European Legal Culture, The American Journal of Comparative Law, Vol. 38, 1990, p. 20. id.

409 The origin of legal positivism can be traced back to the Greek sophists. It was continuously developed by a series of leading thinkers who generally developed three versions of legal positivism: the command theory of law (by Jeremy Bentham and John Austin), the norm theory of law (by Hans Kelsen), and the rule theory of law (by Herbert Lionel Adolphus Hart). Despite the differences among these three versions, the investigation of valid law is shared among them. See: Randall Lesaffer, European Legal History: A Cultural and Political Perspective, Cambridge University Press, 2009, pp. 348-349. For a further discussion on legal positivism, see e.g. Franz Wieacker \& Edgar Boenheimer, Foundations of European Legal Culture, The American Journal of Comparative Law, Vol. 38, 1990, p. 21. id, pp. 23-24. id, p. 24.

410 Franz Wieacker \& Edgar Boenheimer, Foundations of European Legal Culture, The American Journal of Comparative Law, Vol. 38, 1990, p. 23.
} 
position of law does not keep law away from society; on the contrary, law is portrayed as accessible and not unduly hierarchical. ${ }^{411}$ In brief, according to natural law, social order should emerge from the informal institutionalization of ethical behaviours, ${ }^{412}$ while legal positivism views positive law as the sole legitimate authority. ${ }^{413}$

At the same time, it is important to note that natural law and legal positivism do not completely contradict each other. Law is at the same time taken as the guarantor of rights and the extent of freedom by both natural law and legal positivism. As a result of the development of Western civilization based on "social compromise between pluralistic groups", law in fact has the role of balancing the power of the ruler. ${ }^{414}$ This has been carried down into the legal systems in modern Europe. According to the empirical research done by Åse B. Grødeland \& William L. Miller, attitudes towards the understanding of law in societies in Europe are similar: law is equated with justice, fairness and legal rights. ${ }^{415}$

\subsubsection{The Rule of Law_Law's Supremacy and Benchmark Function}

In addition to arriving at a common understanding of law, agreement is also reached on the concept of the rule of law between natural law and legal positivism, ${ }^{416}$ which constitutes an important element of the European legal tradition. Despite the existence of different schools of thought relating to the rule of law, ${ }^{417}$ it is fair to say that this notion presupposes the supremacy of law. ${ }^{418}$ In other words, the rule of law signifies the "imperium legume", i.e. "the empire of laws and not of men", ${ }^{419}$ and it requires that private and public power should be regulated by the law. ${ }^{420}$ Furthermore, everybody is equal before law and the law acts as the guarantor of individuals' civil rights. ${ }^{421}$ Under this notion, the law governs each individual and the entire society, and it brings all

\footnotetext{
411 Id, pp. 25-26.

412 Id, p. 26.

413 Hans W. Micklitz, The (Un)-Systematics of (Private) Law as an Element of European Culture, at: Geneviève Helleringer \& Kai Purnhagen (eds.), Towards a European Legal Culture, Hart Publishing, 2014, p. 85. id.

414 Id, p. 82.

415 Paolo Davide Farah, L'influenza Della Concezione Confuciana Sulla Costruzione del Sistema Giuridico e Politico Cinese (The Influence of Confucianism on the Construction of the Chinese Political and Juridical System), at: Giovanni Bombelli \& Bruno Montanari (eds.), Identità Europea e Politiche Migratorie, Vita e Pensiero, 2008, pp. 193-226. Åse B. Grødeland \& William L. Miller's research revealed that the attitudes of citizens in Eastern and Western Europe towards law and what law was all about were remarkably similar, whereas perceptions of "law in practice" differed by state and often correlated with GDP per capita and country ranking in rule of law indices.

416 Jean Yves Heurtebise, Understanding Non-Trade Concerns Through Comparative Chinese and European Philosophy of Law, at: China's Influence on Non-Trade Concerns in International Economic Law, Routledge, 2016, p. 289. The author also pointed out that such a synthesis did not exist between Confucianism and Legalism or in China' legal tradition.

417 There were three major schools of the rule of law existing in European historical development, which constituted the root of the rule of law in Europe: British, French and German schools of the rule of law. For a further discussion on these three schools, see: Kenneth Winston, The Internal Morality of Chinese Legalism, Singapore Journal of Legal Studies, Vol. 12, 2005, pp. 313-347.

418 Mehmet Ruhi Demiray, Natural Law Theory, Legal Positivism, and the Normativity of Law, The European Legacy, Vol. 20, 2015, p. 808.

419 Jacques Martain (translated by Doris C. Anson), The Rights of Man and Natural Law, Gordian Press, 1971. During its historical development in Europe, this notion was continuously developed by various scholars, like John Locke, Cesare Beccaria and Walter Hallstein. For more information on the arguments of these scholars, see: John Finnis, Natural Law and Natural Right, Clarendon Press, 1980.

${ }^{420}$ Heinrich A. Rommen (translated by Thomas R. Hanley \& Russell Hittinger), The Natural Law: A Study in Legal and Social History and Philosophy, Liberty Fund Inc, 1998.

${ }^{421}$ Mark C. Murphy, Natural Law in Jurisprudence and Politics, Cambridge University Press, 2006.
} 
social life within an impersonalized framework. ${ }^{422}$ The main elements that are recognized as composing the rule of law can be summarized as "legality, or supremacy of the law", "legal certainty", "prohibition of arbitrariness", "access to justice before independent and impartial courts", "respects for human rights", and "nondiscrimination and equality before the law". 423

In addition to identifying the role of law, in terms of dispute settlement in particular, the rule of law requires law to be taken as the benchmark in making evaluations and judgments. It also presents the basic requirements of a judicial system, such as the existence of an accessible and independent body to resolve disputes according to the law $^{424}$ and compliance with substantial and procedural justice.

\subsubsection{The Attitude towards Litigation-Seeking Rights and Procedural Justice}

The development of litigation in Europe is argued to be a result of an amalgam of law and culture, tradition, and ritual; particularly, access to litigation stemmed historically from a commitment to democratic governance. ${ }^{425}$ In general, litigation ensures the protection and realization of individuals' rights. Rule makers approach the evolution of civil litigation to equip litigants better and to encourage them as rights seekers. ${ }^{426}$

Procedural justice is considered indispensable in the litigation process. As the oftenquoted saying goes, justice must satisfy the appearance of justice. ${ }^{427}$ Procedural justice in Europe has its origin in natural justice and is linked to protecting human rights. ${ }^{428}$ Among the well-recognized components of procedural justice, transparency, in particular, exists as part of the European legal tradition. ${ }^{429}$ Based on the principle of transparency, the public is educated, judges, litigants and lawyers are supervised, and

422 Tony Burns, Aristotle and Natural Law, History of Political Thought, Vol. 19, 1998.

423 These elements were based on the observation of two definitions by Maravall and by Tom Bingham, as well as the Rechtsstaat concept of the rule of law. See: Lon L. Fuller, The Morality of Law, Yale University Press, 1969, p. 23. For more literature on the definition of the rule of law, see: Randall Lesaffer, European Legal History: A Cultural and Political Perspective, Cambridge University Press, 2009, p. 449. Edger Bodenheimer, Jurisprudence-The Philosophy and Method of the Law, Harvard University Press, 1974, pp. 58-59. Kun Fan, Arbitration in China: A Legal and Cultural Analysis, Hart Publishing, 2013, p. 192. Mehmet Ruhi Demiray, Natural Law Theory, Legal Positivism, and the Normativity of Law, The European Legacy, Vol. 20, 2015, p. 813. W. J. Waluchow, Inclusive Legal Positivism, Clarendon Press, 1994. Michael D.A. Freeman, Legal Theory at the End of the Millennium, Oxford University Press, 1998.

424 The need for a judicial system can also be explained from the perspective of individualism: individualists promoted the establishment of legal institutions as private guardians. See: Robert P. George, The Autonomy of Law: Essays on Legal Positivism, Oxford University Press, 1999.

${ }^{425}$ In Europe, the development of democracy affected the need for, the access to, and the mode of adjudication; in return, the "triumphant expansion of adjudication" was "a touchstone of thriving democracy". See: Randall Lesaffer, European Legal History: A Cultural and Political Perspective, Cambridge University Press, 2009, p. 463. Judith Resnik, Whither and Whether Adjudication, Boston University Law Review, Vol. 86, 2006, p. 1126.

${ }^{426}$ It is not denied that there was also a promotion of using amicable DSMs in European legal history at certain stages. For example, according to the Roman historian Tacitus (Publius Cornelius Tacitus, c.AD 55-120), traditionally, the Germans brought and resolved their disputes before the assembly. The tribal leaders would generally seek to persuade the parties to resolve the dispute rather than to impose a judgment. However, this promotion was more of an incident instead of anything consistent. See: Lon L. Fuller, The Morality of Law, Yale University Press, 1969, p. 23.

427 This is also stated as not only must justice be done; it must also be seen to be done.

428 Randall P. Peerenboom, Law and Morality in Ancient China: The Silk Manuscripts of Huang-Lao, State University of New York Press, 1993.

429 This came together with the insisted opposition to secretive adjudication processes. See: Yang Shang (translated and noted by J.J.L. Duyvendak), The Book of Lord Shang: A Classic of the Chinese School of Law, The Lawbook Exchange, Ltd., 1963, p. 170. 
knowledge of legal requirements is disseminated. ${ }^{430}$ In addition, in litigation, judges are expected to deliver judgments according to the applicable law, instead of merely helping disputing parties to settle disputes. Courts throughout Europe aim at "protecting fundamental rights of citizens and transnational rule of law based on coherent 'principles of justice' respecting the legitimacy of 'constitutional pluralism' and of legal diversity". ${ }^{431}$

\subsection{Dispute Settlement Mechanisms in the EU Member States}

Considering the unfeasibility of conducting a complete analysis of the DSMs in each EU Member State, within the scope of this thesis, this section instead offers a general description of the main DSMs used by EU Member States for foreign investment disputes, which include mediaiton, arbitration, and litigation, with a view to presenting the main common procedural features of these DSMs under the laws at level of the EU Member States.

\subsubsection{Mediation}

The historical development of mediation in Europe can be traced back to Ancient Rome, ${ }^{432}$ after which the Middle Ages brought about the development of the modern concept and methodology of mediation procedures. As society moved into the Industrial Age, the increasing number of cases and the complexity of the disputes made states realize the necessity of promoting mediation and encouraging disputing parties to reach a settlement. ${ }^{433}$ Subsequently, in the post-industrial society, there was a trend of using mediation as an important mechanism by dispute resolution institutions, including judicial bodies. ${ }^{434}$ However, the "institutionalization of mediation" was argued to have taken place only a few decades ago, and even just a few years ago in some EU Member States. ${ }^{435}$

The development of mediation and its status quo in the EU Member States is diverse. Some states, such as the Netherlands, embraced mediation earlier than others, and they consider this DSM an essential part of their dispute settlement systems, ${ }^{436}$ some other states, such as Germany, have a relatively short history of mediation legislation, but rule-making is carried out based on extensive comparative research; there are also EU

\footnotetext{
${ }^{430}$ Kun Fan, Arbitration in China: A Legal and Cultural Analysis, Hart Publishing, 2013, p. 193.

431 It was also pointed out that the legal and judicial traditions in many Asian states were different and could legitimately prioritize alternative dispute resolution methodologies. See: Åse B. Grødeland \& William L. Miller, European Legal Cultures in Transition, Cambridge University Press, 2015, p. 123.

432 Jean Yves Heurtebise, Understanding Non-Trade Concerns Through Comparative Chinese and European Philosophy of Law, at: China's Influence on Non-Trade Concerns in International Economic Law, Routledge, 2016, pp. 289-290.

433 For example, the first French Constitution prescribed compulsory mediation and conciliation as prerequisites for disputes being heard by courts.

${ }^{434}$ Alessia Azzini \& Alban Heron, The Meaning of the Rule of Law, Seminar Towards European Constitutionalism, 23-24.05.2016.

435 Åse B. Grødeland \& William L. Miller, European Legal Cultures in Transition, Cambridge University Press, 2015 , p. 83.

436 The 2011 study of the Netherlands Mediation Institute (NMI) "De stand van Mediation in Nederland" estimated that a total of 51,690 mediation cases had been conducted by persons affiliated with the NMI in the year 2011.
} 
Member States, such as Bulgaria, where mediation is still in its infancy. ${ }^{437}$ In addition, the regulatory approach towards mediation also differs among EU Member States: some opt for extensive regulatory measures; some prefer very little legislation to ensure flexibility and creativity; while others trying to solve the tension between voluntariness and the possible abuse of freedom through selected regulations. ${ }^{438}$ Such differences among EU Member States are partly due to their diverse legal environments. ${ }^{439}$ For example, if the duration of litigation before the first instance courts is long, and/or the courts' caseloads are excessive, legislation may push disputing parties to use out-ofcourt resolution procedures. In recent years, as a reaction to the EU's Directive on Mediation adopted in 2008, many EU Member States now promote a comprehensive reform of mediation law and have moved towards more extensive and more intensive regulations. ${ }^{440}$

\subsubsection{Arbitration}

Arbitration in Europe was initially developed as a reaction to the need to resolve disputes about transactions at merchant fairs. ${ }^{441}$ During the Post-Classical period, arbitration became increasingly popular because of its expediency and the intrinsic commercial expertise, as well as the deficiencies of national courts at that time, which were characterized as "unreliable, cumbersome and costly, and faced particular difficulties in international and other cross-border matters". ${ }^{442}$ However, there was also opposition to arbitration, for example from France. ${ }^{443}$

A study was carried out in 2015, upon the request of the European Parliament, regarding the current law and practice of arbitration across the EU. ${ }^{444}$ In this study, various issues of arbitration were examined based on the factual situations in the EU Member States. Those that are relevant to the present analysis are summarized as follows: 1. Distinction between domestic and international arbitration. The majority of jurisdictions do not

\footnotetext{
437 In Bulgaria, mediation is still in its infancy stage with several 100 mediations per year. See: Mortimer Sellers, What Is the Rule of Law and Why Is It So Important?, at: Flora A.N.J. Goudappel \& Ernst M.H. Hirsch Ballin (eds.), Democracy and Rule of Law in the European Union-Essays in Honour of Jaap W. de Zwaan, T.M.C. Asser Press, 2016, p. 4.

438 Alessia Azzini \& Alban Heron, The Meaning of the Rule of Law, Seminar Towards European Constitutionalism, 23-24.05.2016.

439 Mortimer Sellers, What Is the Rule of Law and Why Is It So Important?, at: Democracy and Rule of Law in the European Union-Essays in Honour of Jaap W. de Zwaan, T.M.C. Asser Press, 2016, p. 6.

440 Åse B. Grødeland \& William L. Miller, European Legal Cultures in Transition, Cambridge University Press, 2015, p. 83. The EU's Directive on Mediation is further discussed in the following Section 4.3.1.2.

${ }^{441}$ Zhiping Liang, Explicating "Law": A Comparative Perspective of Chinese and Western Legal Culture, Journal of Chinese Law, Vol. 3, 1989, p. 154.

442 Alessia Azzini \& Alban Heron, The Meaning of the Rule of Law, Seminar Towards European Constitutionalism, 23-24.05.2016. The author did not give any definition of the period referred to as the "Post-Classical period" in this book. The Post-Classical period often runs from about $500 \mathrm{CE}$ to $1450 \mathrm{CE}$, characterized by the expansion of civilizations in different areas and the development of trade networks between them. See e.g. Gottfried Dietze, Two Concepts of the Rule of Law, Liberty Fund, 1973.

${ }^{443}$ During the French Revolution, the revolutionaries presented great hostility towards arbitration by opposing its use, essentially because they believed "parties should be protected against the advance and abstract waiver of access to judicial protection and guarantees". As Born pointed out, "[t]he Edict of 1560 and merchant practice led to widespread use of arbitration for resolving commercial disputes in the 16th, 17th and 18th centuries [but] the French Revolution changed this like much else". See: Ronald Dworkin, Law's Empire, Belknap Press of Harvard University Press, 1986.

${ }^{444}$ Franz Leopold Neumann, The Rule of Law: Political Theory and the Legal System in Modern Society, Berg Publishers Ltd., 1986.
} 
make a difference between domestic and international arbitration, but this co-exists with the fact that some leading arbitral states like France have adopted such a split approach; 2. Competence-competence doctrine. All EU Member States allow arbitrators to decide their own jurisdiction, but some also grant national courts the power to decide on the jurisdiction of arbitral tribunals; 3. Arbitrators' qualification. Almost all EU Member States do not require arbitrators to possess a certain qualification. However, being independent and impartial is explicitly prescribed; 4. Ad hoc vs. institutional arbitration. Disputing parties are free to choose ad hoc or institutional arbitration, although some EU Member States restrict the establishment of arbitral institutions, while some others make ad hoc arbitration less attractive through legislation; 5. Appeal and setting aside. Arbitral awards generally cannot be appealed, but they can be set aside. EU Member States overwhelmingly adopted the approach that a very limited number of situations relating to procedural unfairness and public policy constitute the basis of setting aside. ${ }^{445}$ In general, substantial harmonization has been reached regarding the current situations of arbitration in EU Member States, including legislation and legal practice, ${ }^{446}$ which at the same time is in line with international arbitration practice. ${ }^{447}$

\subsubsection{Litigation}

Most domestic legislation of EU Member States on DSMs focuses on litigation. ${ }^{448}$ This DSM forms part of the EU Member States' and the EU's legal tradition, reflecting their conviction about the "proper organization of the courts' judicial system in delivering timely and fair judgments". ${ }^{449}$ Detailed regulations on litigation, which are normally contained in the EU Member States' civil procedural regimes, differ greatly, which makes it difficult to provide a general description. ${ }^{450}$

Aside from such differences, common fundamental procedural principles are reflected in most EU Member States' judicial systems, which can be confirmed by the Joint ELIUNIDROIT Project recently initiated by the European Commission, "From Transnational Principles to European Rules of Civil Procedure". This project aims at establishing European rules of civil procedure based on the recognized minimum principles of civil procedure common to EU Member States. Since this project is part

\footnotetext{
445 Buyun Li 李步云, Discussion on The Rule of Law 论法治, Social Sciences Academic Press 社会科学文献出 版社, 2008.

446 Leonardo Morlino \& Gianluigi Palombella (eds.), Rule of Law and Democracy: Inquiries into Internal and External Issues, Brill, 2010, p. 47.

447 This resonates with the argument that contemporary international arbitration has its roots in the dominant Western legal tradition. See: European Commission for Democracy Through Law (Venice Commission), Rule of Law Checklist, Adopted by the Venice Commission at its 106th Plenary Session, Venice, 11-12.03.2016.

448 Kun Fan, Arbitration in China: A Legal and Cultural Analysis, Hart Publishing, 2013, pp. 185-186.

449 Judith Resnik, Whither and Whether Adjudication, Boston University Law Review, Vol. 86, 2006, pp. 1108, 1154. See also: Judith Resnik, For Owen M. Fiss: Some Reflections on the Triumph and the Death of Adjudication, University of Miami Law Review, Vol. 10, 2003.

${ }^{450}$ Randall Lesaffer, European Legal History: A Cultural and Political Perspective, Cambridge University Press, 2009, pp. 164-165. See also: Franz Wieacker \& Edgar Boenheimer, Foundations of European Legal Culture, The American Journal of Comparative Law, Vol. 38, 1990, p. 29. Judith Resnik, Whither and Whether Adjudication, Boston University Law Review, Vol. 86, 2006, p. 1114. For more detailed information on litigation in EU Member States' civil procedural laws, see: Judith Resnik, Due Process: A Public Dimension, The University of Florida Law Review, Vol. 39, 1987, pp. 405-426.
} 
of the efforts made at the Union level on regulating DSMs, more information is provided in the following Section 4.3.3.3.

\subsection{Rules on Dispute Settlement Mechanisms at the Union Level}

This section presents the characteristics of the rules on DSMs at the Union level, especially those that are in line with the EU's legal culture on dispute settlement identified in Section 4.1.2, supra. Specifically, it first investigates relevant legislative measures taken by the Union. Following that, as the judicial body of the EU and the highest judicial decision maker regarding EU law, the CJEU's practice, including its procedural rules, rulings on procedural justice and other relevant practice, deserves attention and thus is also assessed. Then Section 4.3.3 explores the Union's other efforts that have had some regulative effect on DSMs in the EU, which include the Union's accession to the European Convention on Human Rights, its supervision of the EU Member States' national legal systems and the Joint ELI-UNIDROIT Project. ${ }^{451}$

As a supranational body, the Union only has authority where this has been granted by its Member States. The Treaty on the European Union (TEU) and the Treaty on the Functioning of the European Union (TFEU) stipulate the authority of and general guidance for the Union to regulate civil procedure in its Member States, which includes DSMs. According to the explicit provisions in these two treaties, the main purpose of relevant rules has been defined as ensuring effective access to justice and creating an area of freedom, security and justice. ${ }^{452}$ Following this general guidance, with the EU's transformation from the original common market project to a diverse constitutional entity, both economic and non-economic elements play a role in further justifying the Union's efforts in regulating DSMs within the EU. ${ }^{453}$ As an example of the effect of economic elements, reinforcing market integration promoted the Union's legislative measures on cross-border litigation. ${ }^{454}$ In terms of the effects of non-economic elements, European citizenship, which encompasses a right to knowledge of the law and procedure and participating in legal processes in available and accessible

\footnotetext{
${ }^{451}$ In order to limit the discussion to a manageable scope, the creation of the EU by the Treaty of Maastricht (signed on 07.02.1992, came into force on 01.11.1993) is taken as the starting point for setting the scope of relevant measures that are taken into consideration by the present analysis.

${ }^{452}$ The Treaty on the European Union (TEU), Art. 3.2; the Functioning of the European Union (TFEU), Arts. 67, 81.2 .

${ }^{453}$ Four elements were discerned as widely acknowledged justifications: market integration, efficiency, European citizenship, and fundamental human rights. More detailed analyses of these four elements can be found in the literature, which also pointed out other possible elements of justification. See e.g. Ernst-Ulrich Petersmann, Trade and Investment Adjudication Involving 'Silk Road Projects': Legal Methodology Challenges, European University Institute Working Papers, Vol. 2, 2018, p. 9. Here, the author selects those that are widely recognized and relevant for the subject of the present thesis.

454 Accordingly, efficiency, a requirement emanating from the market, acted as a guiding principle. See: Randall Lesaffer, European Legal History: A Cultural and Political Perspective, Cambridge University Press, 2009, pp. 164165. This related to various aspects of the rules on civil procedure, such as the duration of proceedings, clearance rate and the number of pending cases. See: Davydenko Dmitry Leonidovich, Amicable Dispute Resolution in the European Legal Tradition, Infotropic Media Publishing House, 2013.
} 
institutions, ${ }^{455}$ as well as the promotion of fundamental rights in the EU, ${ }^{456}$ are taken an indispensable part of building the area of freedom, security, and justice, and especially in ensuring access to justice. ${ }^{457}$ Thus, they also justify the Union's efforts making regulations in the field of civil procedure.

\subsubsection{The Legislative Measures of the Union in Dispute Settlement Mechanisms}

The sources of EU law are generally divided into three levels: primary law, secondary law and supplementary law. ${ }^{458}$ Regarding the legislative measures on DSMs, the relevant primary law is identified as the Charter of Fundamental Rights of the European Union (CFREU); secondary legislation includes the Directive on Mediation and two Regulations on specific kinds of disputes; and for the analysis of supplementary law, the focus is put on the practice of the CJEU, which is discussed separately in Section 4.3.2, infra.

\subsubsection{Primary law}

In primary law, the Union regulates civil procedure mainly from the perspective of ensuring that European citizens have access to proper civil procedure to resolve potential disputes and to protect their fundamental rights. This should be in line with personalism, legalism, and a consistent pursuit of individual's rights especially with reference to adjudication in dispute settlement in the EU's legal tradition.

A key legal instrument in this respect is the Charter of Fundamental Rights of the European Union (CFREU). ${ }^{459}$ Article 47 of the CFREU establishes the minimum procedural standards of the dispute settlement process under the right to "a fair trial" enshrined in the concept of "effective access to justice". These standards include the right to an effective remedy before a tribunal, the right to a fair and public hearing within a reasonable time by an independent and impartial tribunal previously established by law, the right to be advised, defended and represented, and the right to legal aid for those who lack sufficient resources in so far as such aid is necessary to ensure effective access to justice. ${ }^{460}$ This Article clearly echoes Article 6 of the ECHR, as both of them resonate with each other on protecting procedural justice in civil

\footnotetext{
455 Some legislative measures, such as the Legal Aid Directive, the Small Claims Regulation, have illustrated the wish to support lay litigants and contribute to citizen participation in the legal process. See: Felix Steffek, Mediation in the European Union: An Introduction, Europa.eu, 06.2012, available at: https://ejustice.europa.eu/fileDownload.do?id=b3e6a432-440d-4105-b9d5-29a8be95408f, last visited on 05.08.2020.

${ }^{456} \mathrm{Id}$, pp. 13-14. This is in particular evidenced by the Charter of Fundamental Rights of the European Union (CFREU)

457 This is enshrined in Art. 9 of the TEU and Art. 20 of the TFEU. The formal introduction of EU citizenship was preceded by several prior attempts, such as the direct elections to the European Parliament. See: id, p. 14.

458 Primary law is the supreme source of EU law and consists mainly of the Treaties of the EU; secondary law, which includes legal instruments based on the Treaties; supplementary sources that designate the unwritten sources of EU law as opposed to the primary and secondary sources. See: id.

459 The advent of the Charter of Fundamental Rights of the European Union (CFREU), proclaimed in Nice in December 2000, brought the fundamental rights protected in the EU together in a single document. See: id, p. 13. It became legally binding on the EU institutions and EU Member States with the entry into force of the Treaty of Lisbon in 2009. See: Francis M. Burdick, What Is the Law Merchant?, Columbia Law Review, Vol. 2, 1902, pp. 472-475. In particular, Article 6 of the TEU confers the same legal force on the CFREU as that of the Treaty itself. This means that the CFREU is at the top of the EU legal hierarchy and applies to the situation where EU law is implemented. See: Gary B. Born, International Commercial Arbitration (2nd edition), Kluwer Law International, 2014, pp. 29, 31.

460 Charter of Fundamental Rights of the European Union, OJ C 326 (entered into force on 18.12.2000), Art. 47.
} 
procedure. ${ }^{461}$ As pointed out, the fundamental right to a fair trial encapsulated in the CFREU stems from a shared value of EU Member States' legal histories, which constitutes part of the European legal foundation and provides the basis for further legislation on dispute settlement procedures. ${ }^{462}$

\subsubsection{Secondary Legislation}

Recent years witnessed the emergence of an increasing number of harmonized legal rules adopted by the Union in the area of civil procedure, which address dispute settlement processes. ${ }^{463}$ The necessity of such rules at the Union level arises mainly from the fact that the differences among the EU Member States' procedural rules create problems in cross-border cases, and effective access to justice in certain EU Member States is not guaranteed. ${ }^{464}$ As was pointed out, "[m]aintaining national civil procedural rules that impede litigants from having access to effective remedies and fair adjudication of their rights is unacceptable in the EU remit". ${ }^{465}$ As a result, it is considered necessary that the Union lays down a number of minimum procedural standards in these legislative measures. ${ }^{466}$ Such secondary legislative measures particularly include the EU Directive on Mediation and two other regulations on specific types of disputes. ${ }^{467}$ Since the focus of these two Regulations is on protecting certain groups through simplifying procedures to ensure the efficiency of dispute settlement process, these legal instruments are not very helpful for exploring the general procedural features of dispute settlement promoted by the Union and therefore are not discussed in detail in the present work.

\footnotetext{
${ }^{461}$ In fact, Art. 52.3 of the CFREU explicitly states that Charter rights corresponding to the ECHR rights should generally have the same meaning and scope.

${ }^{662}$ Peter N. Stearns, Periodization in World History: Challenges and Opportunities, at: Weller R. Charles (ed.), 21st-Century Narratives of World History: Global and Multidisciplinary Perspectives, Palgrave Macmillan, 2017, pp. 83-110.

463 The harmonization of civil procedure traces back to the Storme's report presenting the result of a study on the approximation of EU Member States' rules of civil procedure. See: Gary B. Born, International Commercial Arbitration (2nd edition), Kluwer Law International, 2014, pp. 35-41. For a more complete analysis of the EU Regulations and Directives on civil procedure (as of 31 December 2011), see: European Parliament-Directorate General for Internal Policies-Policy Department C: Citizens' Rights and Constitutional Affairs, Legal Instruments and Practice of Arbitration in the EU, 2014, available at: http://www.europarl.europa.eu/RegData/etudes/STUD/2015/509988/IPOL_STU(2015)509988_EN.pdf, last visited on 01.08 .2020 .

464 This may be due to the long duration, high cost and other drawbacks of domestic judicial systems. For example, a long duration of civil proceedings is typical seen in Italy, where the average length of first instance proceedings is 3.3 years, whereas the appeal process can stretch the final decision by several more years. In terms of legal fees, taking lawyers' fees as an example, it can be very expensive in some states, such as France, Spain, and Switzerland. See: European Parliament-Directorate General for Internal Policies-Policy Department C: Citizens' Rights and Constitutional Affairs, Legal Instruments and Practice of Arbitration in the EU, 2014, available at: http://www.europarl.europa.eu/RegData/etudes/STUD/2015/509988/IPOL_STU(2015)509988_EN.pdf, last visited on 01.08 .2020 .

465 Id.

466 Won L. Kidane, The Culture of International Arbitration, Oxford University Press, 2017, pp. 286-287.

467 They are the European Regulation on Small Claims Procedure, and the Legal Framework for Consumer Alternative and Online Dispute Resolution. See: Regulation (EC) No 861/2007 of the European Parliament and of the Council of 11 July 2007 establishing a European Small Claims Procedure, OJ L 199, 31.7.2007; European Commission, Directive 2013/11/EU of the European Parliament and of the Council of 21 May 2013 on alternative dispute resolution for consumer disputes and amending Regulation, (EC) No 2006/2004 and Directive 2009/22/EC, OJ L 165, 18.06.2013; European Commission, Regulation (EU) No 524/2013 of The European Parliament and of the Council of 21 May 2013 on online dispute resolution for consumer disputes and amending Regulation, (EC) No 2006/2004 and Directive 2009/22/EC, OJ L 165, 18.06.2013.
} 
The EU Directive on Mediation aims at facilitating access to alternative dispute resolution and promoting the amicable settlement of disputes "by encouraging the use of mediation and by ensuring a balanced relationship between mediation and judicial proceedings". ${ }^{468}$ Guided by the principles of flexibility and predictability, ${ }^{469}$ the Union adopted "Directive 2008/52/EC of the European Parliament and of the Council of 21 May 2008 on certain aspects of mediation in civil and commercial matters". ${ }^{470}$ This Directive applies to intra-EU mediation, ${ }^{471}$ which includes mediation conducted by a judge who is not responsible for any judicial proceedings concerning the dispute in question. ${ }^{472}$ According to this Directive, mediation is a structured process, whereby two or more parties to a dispute attempt to reach an agreement, by themselves, on a voluntary basis, on the settlement of their dispute with the assistance of a mediator. ${ }^{473}$ Mediators are required to conduct mediation in an effective, impartial and competent way, ${ }^{474}$ and it is considered important for them to follow the European Code of Conduct for Mediators. ${ }^{475}$ Mediation is supposed to be confidential. Article 7.2 of the EU Directive on Mediation expressly entitles EU Member States to enact stricter measures to protect the confidentiality of mediation. ${ }^{476}$ At the same time, this Directive also covers the enforcement of the agreed solution from mediation, requiring EU Member States to guarantee the possibility of the enforcement of settlement agreements with the explicit consent of the disputing parties. ${ }^{477}$ Although EU Member States are obliged to achieve the objectives set out in the Directive, since it is a Directive and not a Regulation, they have discretion as to how to achieve those objectives. ${ }^{478}$ Thus, EU

\footnotetext{
468 European Parliament, Directive 2008/52/EC of the European Parliament and of the Council of 21 May 2008 on Certain Aspects of Mediation in Civil and Commercial Matters, Directive 2008/52/EC, 24.05.2008, Art. 1.

469 European Parliament resolution of 13 September 2011 on the implementation of the directive on mediation in the Member States, its impact on mediation and its take-up by the courts [2011/2026[INI]].

470 This Directive came into force on 13 June 2008. It requires EU Member States (except Denmark) to bring into force the laws, regulations and administrative provisions necessary to comply with this Directive before 21 May 2011. See: European Parliament, Directive 2008/52/EC of the European Parliament and of the Council of 21 May 2008 on Certain Aspects of Mediation in Civil and Commercial Matters, Directive 2008/52/EC, 24.05.2008, Art. 12. 471 Id, Arts. 1, 2.

472 Id, Art. 3(a). This excludes attempts made by the court or the judge to settle a dispute in the course of judicial proceedings concerning the dispute in question.

473 Id, Art. 3(a).

474 Id, Art. 3(b).

475 Id, Art. 4.1. This Code of Conduct sets out a number of principles, covering main areas of mediation, including competence, advertising, impartiality, and fees, to which individual mediators can voluntarily decide to commit. It is intended to be applicable to all kinds of mediation in civil and commercial matters. For more information on this, see: Felix Steffek, Mediation in the European Union: An Introduction, Europa.eu, 06.2012, available at: https://ejustice.europa.eu/fileDownload.do?id=b3e6a432-440d-4105-b9d5-29a8be95408f, last visited on 05.08.2020.

476 European Parliament, Directive 2008/52/EC of the European Parliament and of the Council of 21 May 2008 on Certain Aspects of Mediation in Civil and Commercial Matters, Directive 2008/52/EC, 24.05.2008, Art. 7.2.

477 Id, Art. 6.1.

${ }^{478}$ A "directive" is a legislative act that sets out a goal that all EU Member States must achieve. However, it is up to the individual EU Member States to devise their own laws on how to reach these goals. See: Konstantinos D. Kerameus, Procedural Harmonization in Europe, American Journal of Comparative Law, Vol. 43, 1995, pp. 404405. Furthermore, it deserves attention that the provisions in this Directive do not have the same binding force. Some articles set concrete rules for EU Member States to transpose them into their national laws, such as Art. 6, while others are designed in a soft way and only express a desire, such as Art. 4. There are also issues that were left untouched, for example, the liability of mediators and the regulation of professional mediator associations. This can be read as a reflection of the divergence among EU Member States regarding the different approaches to regulating mediation and the fact that mediation is still in the process of development within the EU area. See: Hugh Collins, European Private Law and the Cultural Diversity, European Review of Private Law, Vol. 3, 1995, p. 364.
} 
Member States are "left free to develop a culturally-shaped and nationally-biased view of what the word 'mediation' means". 479

The Union's efforts in promoting mediation by providing relevant rules is based on the increased awareness of the function of alternative dispute resolution in improving access to justice. ${ }^{480}$ As pointed out by EU legislators, "the concept of access to justice does not only refer to courts, but should also include all proceedings that are suitable for resolving disputes". ${ }^{481}$ At the same time, such alternatives can lessen the increasing workload of courts, reduce the legal costs of disputing parties and help them reach amicable settlements.

The adoption of the EU Directive on Mediation undoubtedly increased the awareness of and incentivized the use of mediation to a certain extent. Regarding the practical influence of this Directive, empirical research revealed that "[d]espite its proven and multiple benefits, mediation in civil and commercial matters is still used in less than $1 \%$ of the cases in the EU". ${ }^{482}$ This is probably due to many factors, including hesitation from disputing parties to refer to mediation because of its low effectiveness in ending disputes, general anti-mediation culture and ineffective implementation by some EU Member States. ${ }^{483}$ Another report issued in 2010 confirmed how little mediation is used and further argued that mediation in Europe can be described as a high quality product that was rarely used. ${ }^{484}$

\subsubsection{The Practice of the Court of Justice of the European Union on Procedural Justice}

The Court of Justice of the European Union (CJEU) is the judicial body of the EU and where disputes concerning EU law are finally decided. The discussion in this section aims at exploring procedural justice from the prism of the practice of the CJEU, mainly based on its applicable procedural rules and its rulings on procedural justice.

\subsubsection{Procedural Rules}

The procedural rules of the CJEU come from the Statute of the CJEU and the procedural rules of each of the EU courts. ${ }^{485}$ Based on the requirements provided in these rules,

479 Stephen Goldstein, On Comparing and Unifying Civil Procedural Systems, at: Roger Cotterrell (ed.), Butterworth Lectures 1994: Process and Substance, Butterworths, 1995, pp. 3-28.

${ }^{480}$ Pierre Legrand, On the Unbearable Localness of the Law: Academic Fallacies and Unseasonable Observations, European Review of Private Law, Vol. 1, 2002, p. 61.

481 Alan Uzelac, Reforming Mediterranean Civil Procedure: Is There a Need for Shock Therapy?, at: C. H. van Rhee \& Alan Uzelac (eds.), Civil Justice between Efficiency and Quality: From Ius Commune to the CEPEJ, Intersentia, 2008, p. 71.

482 europa.eu, The European Judicial Network in Civil and Commercial mMatters, available at: http://ec.europa.eu/civiljustice/index_en.htm, last visited on 06.08.2020.

${ }_{483}$ Based on an analysis of the situations of mediation in all EU Member States, it was summarized that " $[\mathrm{t}] \mathrm{he}$ Directive's intended purpose to stimulate cross-border mediation has been impeded by the way it has been conceived, implemented and regulated”. See: Eva Storskrubb, Civil Procedure and EU Law: A policy Area Uncovered, Oxford University Press, 2008, pp. 78, 278-283.

484 This conclusion is based on a paradox comprised of two numbers: based on the ratio of the number of mediations/the number of litigated cases in Europe, an average use of mediation was $0.5 \%$, but the average settlement rate in mediation was 75\%. See: Fernández Arroyo DP, Exorbitant and Exclusive Grounds of Jurisdiction in European Private International Law: Will They Ever Survive?, at: Heinz P Mansel et al. (eds.), Festschrift für Erik Jayme, Sellier, 2004, p. 182.

${ }^{485}$ The CJEU is composed of the Court of Justice (ECJ), the General Court, and the specialized courts. The present 
several features deserve attention. First, according to Article 18 of the Statute of the CJEU, judges are allowed to adjudicate cases involving their home states. ${ }^{486}$ This is in line with the assumption that judges are completely independent and they do not represent any particular state. ${ }^{487}$ Second, a public hearing is a basic principle. The Statute of the CJEU Article 31 explicitly provides for a public hearing, ${ }^{488}$ and an exception applies only when "serious reasons" appear. ${ }^{489}$ This is "designed to prevent a secret justice and to enhance public confidence in the European judicial system". 490 Third, although most EU Member States share a civil law tradition, after 1973, when common-law judges joined the CJEU, the Court started to cite its previous judgments more frequently. ${ }^{491}$ It was argued that the use of precedents employed by the CJEU is where common and civil law traditions meet. ${ }^{492}$ Fourth, regarding the particular issue of the relationship between out-of-court mediation and court proceedings, the CJEU holds that EU directives and general principles do not prevent national law from providing for mandatory out-of-court mediation procedures as a condition of admissibility to court proceedings. ${ }^{493}$

\subsubsection{Rulings on Procedural Justice}

The rulings from the CJEU on procedural justice are significant in supplementing the application of relevant legislation. It is even argued that the most important standards

discussion takes the Rules of Procedure of the Court of Justice as the example for the examination. See: European Commission, Communication from the Commission to the European Parliament, the Council, the European Central Bank, the European Economic and Social Committee and the Committee of the Regions-The 2017 EU Justice Scoreboard, COM(2017) 167 final, 2017, p. 7.

486 The Statute of the Court of Justice of the European Union, Art. 18.

${ }^{487}$ However, in practice, since the CJEU in most cases sits in a chamber of three judges, party judges are not very common.

488 The Statute of the Court of Justice of the European Union, Art. 31. As Advocate General Maduro noted in his Opinion in Sweden and Others v. API and Commission, the practice of various international tribunals suggests that there should be no reason to fear a disclosure of documents relating to judicial process and that all submissions should be public unless there are exceptional reasons to keep them confidential. See: Robin White, Lawyers and the Courts, at: Robert Blackburn (ed.), Rights of Citizenship, Mansell Publishing, 1993, p. 236.

489 Such "serious reasons" include the protection of the private life of parties that is at issue and the protection of individual interests when they prevails over the principle of a transparent judiciary. See: Court of Justice of the European Union-the Court of Justice, Rules of Procedure of the Court of Justice, 29.09.2012, Art. 79. It was argued that "[e]xcluding the public from the oral hearing is an exceptional measure and must thus be interpreted narrowly". See: European Parliament, European Parliament Recommendation to the Council and to the European Council on the Future of the Area of Freedom, Security and Justice as well as on the Measures Required to Enhance the Legitimacy and Effectiveness Thereof (2004/2175(INI)), P6_TA(2004)0022, 07.07.2005, p. 24.

490 Derek Heater, A Brief History of Citizenship, Edinburgh University Press, 2004, p. 103.

491 EUR-Lex, Sources of European Union Law, available at: https://eur-lex.europa.eu/legalcontent/EN/TXT/?uri=LEGISSUM\%3A114534, last visited on 01.08.2020. Prior to 1973, the Court basically just repeated its decisions without indicating that it had ruled on the issue before. See: Charter of Fundamental Rights of the European Union, OJ C 326 (entered into force on 18.12.2000), p. 1.

492 The Common Law prevailed in only two EU Member States, the United Kingdom and Ireland. See: European Commission, Justice-Building a European Area of Justice, Rule of Law, available at: http://ec.europa.eu/justice/effective-justice/rule-of-law/index_en.htm, last visited on 30.05.2020. Currently, as stated above, with the United Kingdom leaving the EU, Ireland is the only EU Member State now that has a common law background.

493 Specifically, the CJEU found that, mandatory out-of-court mediation before court proceedings did not hurt the principle of effective judicial protection, as long as four requirements were satisfied. Namely, the procedure: 1 . does not result in a decision that is binding on the parties; 2. does not cause a substantial delay in bringing legal proceedings; 3 . suspends the period for the time-barring of claims; and 4. does not give rise to more than minimal costs for the parties. See: European Parliament \& Council of the European Union \& European Commission, Explanations Relating to the Charter of Fundamental Rights of the European Union, 2007/C 303/02, 12.12.2007. 
are not found in EU instruments, but have mainly been developed by the case law of the CJEU. ${ }^{494}$ In addition, the basic values and the fundamental rights codified in the EU legislative instruments are guaranteed through the complete system of legal procedures that permit the CJEU to review the legality of measures adopted by the Union and by EU Member States. ${ }^{495}$

According to the CJEU's rulings on procedural justice, the following three points are of interest in the present analysis. First, the notion of access to justice is confirmed as a fundamental requirement. ${ }^{496}$ As stated by Advocate General Ruiz-Jarabo Colomer, access to justice is taken as one of the constitutive elements of the EU based on the rule of law, which "entails not only the commencement of legal proceedings but also the requirement that the competent court must be seized of those proceedings". ${ }^{497}$ Second, the CJEU expressly recognizes the value of procedural fairness as a common value shared by EU Member States. In particular, in the Krombach judgment, the CJEU transformed "public policy, traditionally a vector of inward-looking national values even in a European context", to "the very cornerstone of the edification of common European values", which is particularly with respect to the fundamental right to procedural fairness. ${ }^{498}$ Such guarantees with regard to a fair trial in courts has been further expanded to be relevant for arbitration bodies. ${ }^{499}$ Third, general principles of procedural law are taken as making up an indispensable part of the primary law of the

\footnotetext{
${ }^{494}$ Franz Wieacker \& Edgar Boenheimer, Foundations of European Legal Culture, The American Journal of Comparative Law, Vol. 38, 1990, p. 29. Marcel L. Storme (ed.), Rapprochement du droit judiciaire de l'Union Européenne/Approximation of Judiciary Law in the European Union, Kluwer Law International, 1994.

$495 \mathrm{M}^{\mathrm{a}}$ Pía Calderón Cuadrado \& José Luis Iglesias Buhigues, Mediation as an 'Alternative' to Jurisdiction: Directive 2008/52, at: European Civil Procedure, Thomoson Reuters, 2011, pp. 249-264.

496 Rule of law was first mentioned by the CJEU in the Case Les Verts in 1986 before its appearance in the official legislative documents of the EU, by stating that the "European Economic Community was a community based on the rule of law". See: Adrian A. S. Zuckerman (ed.), Justice in Crisis: Comparative Dimensions of Civil Procedure, Oxford University Press, 1999, pp. 9-10.

497 Anthony Ogus, Competition between National Legal Systems: A Contribution of Economic Analysis to Comparative Law, The International and Comparative Law Quarterly, Vol. 48, 1999, p. 408.

498 Viviane Reding, Strengthening Mutual Trust: Towards a True European Area of Civil Justice, 25.03.2014, available at: https://www.mpi.lu/fileadmin/mpi/medien/news/2014/4/Speech_VP_Reding.pdf, last visited on 05.08.2020. It was argued that "the Court also took a substantive methodological step, a 'merger of values', combining the economic interests of the Community with the human rights values of the Council of Europe". See: Center for Effective Dispute Resolution, EU Launches Code of Conduct for Mediators, 21.07.2004, available at: https://www.cedr.com/news/?item=EU-launches-Code-of-Conduct-for-Mediators, last visited on 05.08.2020.

${ }_{499}$ europa.eu, Regulations, Directives and Other Acts, available at: https://europa.eu/european-union/eu-law/legalacts_en, last visited on 01.08.2020. Namely, in this regard, arbitration bodies are "equally obliged to deliberate under the same conditions as a court". See: Felix Steffek, Mediation in the European Union: An Introduction, Europa.eu, 06.2012, available at: https://e-justice.europa.eu/fileDownload.do?id=b3e6a432-440d-4105-b9d5-29a8be95408f, last visited on 05.08.2020.
} 
$\mathrm{EU},{ }^{500}$ which include access to a fair legal process, ${ }^{501}$ the right of defence, ${ }^{502}$ equal treatment, ${ }^{503}$ etc. These rights are considered similar to constitutional rights common to the EU Member States, ${ }^{504}$ and they apply even if there is no specific legislative provision to that effect. ${ }^{505}$

\subsubsection{The Union's Other Efforts in Regulating Dispute Settlement Mechanisms}

In addition to the legislative instruments discussed above, the Union's intention to regulate DSMs is also mirrored by other efforts. Typical examples include the EU's accession to the European Convention on Human Rights, its supervision of the national justice systems of the EU Member States, and the Joint ELI-UNIDROIT Project "From Transnational Principles to European Rules of Civil Procedure".

\subsubsection{The Union's Accession to the European Convention on Human Rights}

Required under the Treaty of Lisbon, the EU's accession to the European Convention on Human Rights (ECHR) was intended to be "a landmark in European legal history". ${ }^{506}$ However, the accession entered into a deadlock because of the negative opinion of the CJEU, as it was concerned that the accession would give an external body the power to review the application of EU law. ${ }^{507}$ Although the Union has not joined the ECHR, the adoption of this Convention by all EU Member States arguably reflects the "important commonalities in the underlying historical, political, and

${ }^{500}$ Manon Schonewille \& Jeremy Lack, Mediation in the European Union and Abroad: 60 States Divided by a Common Word?, at: The Variegated Landscape of Mediation: A Comparative Study of Mediation Regulation and Practices in Europe and the World, Eleven International Publishing, 2014, pp. 20-21.

501 See e.g. Commission of the European Communities, Green Paper on Alternative Dispute Resolution in Civil and Commercial Law (presented by the Commission), COM(2002) 196 final, 19.04.2002, pp. 5, 9-10. M Máa Calderón Cuadrado \& José Luis Iglesias Buhigues, Mediation as an 'Alternative' to Jurisdiction: Directive 2008/52, at: European Civil Procedure, Thomoson Reuters, 2011, pp. 249-250. European Parliament-Directorate-General for Internal Policies-Policy Department C: Citizens' Rights and Constitutional Affairs, 'Rebooting' the Mediation Directive: Assessing the Limited Impact of Its Implementation and Proposing Measures to Increase the Number of Mediations in the EU, 2014, available at: http://www.europarl.europa.eu/RegData/etudes/etudes/join/2014/493042/IPOL-JURI_ET(2014)493042_EN.pdf, last visited on 31.07.2020.

502 See e.g. Manon Schonewille \& Jeremy Lack, Mediation in the European Union and Abroad: 60 States Divided by a Common Word?, at: The Variegated Landscape of Mediation: A Comparative Study of Mediation Regulation and Practices in Europe and the World, Eleven International Publishing, 2014, p. 20. ADR Center for Development, The Costs of Non ADR-Surveying and Showing the Actual Costs of intra-Community Commercial Litigation, Project Timeline: 12.2008-04.2010, available at: https://www.adrcenterfordevelopment.com/2018/06/08/eu-member-statesthe-costs-of-non-adr-surveying-and-showing-the-actual-costs-of-intra-community-commercial-litigation/, last visited on 31.07.2020.

${ }^{503}$ See e.g. Court of Justice of the European Union-the Court of Justice, Rules of Procedure of the Court of Justice, 29.09.2012; Opinion of Advocate General Poiares Maduro in Joined Cases C-514/07 P, C-528/07 P and C-532/07 $P$, Kingdom of Sweden v. Association de la presse internationale ASBL (API), Association de la presse internationale ASBL (API) v. Commission of the European Communities, Commission of the European Communities v. Association de la presse internationale ASBL (API), 01.09.2009, available at: http://curia.europa.eu/juris/document/document_print.jsf?doclang $=E N \&$ text $=\&$ pageIndex $=0 \&$ part $=1 \&$ mode $=1$ st \& docid $=72663 \&$ occ $=$ first \&dir $=\&$ cid $=1210687$, para. 26 , last visited on 30.07.2020.

${ }^{504}$ See e.g. Bertrand Wägenbaur, Court of Justice of the European Union: Commentary on Statue and Rules of Procedure, C.H. Beck·Hart·Nomos, 2013, p. 96.

505 Id, p. 31.

506 This is mainly because such an accession would make it possible for individuals and undertakings to apply to the European Court of Human Rights for a review of the acts of EU institutions. See: Henry G. Schermers \& Denis Waelbroeck, Judicial Protection in the European Communities (Fourth Edition), Kluwer Law and Taxation Publishers, 1987, p. 86.

${ }^{507}$ Lisa J. Conant, Justice Contained: Law and Politics in the European Union, Cornell University Press, 2002, pp. 64-65. 
cultural substratum of European legal traditions". 508 The adoption of the CFREU, which was discussed in Section 4.3.1.1, supra, confirms this point. It is noted that in the ECHR, Article 6 "Right to a fair trial" demands that an adjudicatory system can conduct "a fair and public hearing within a reasonable time by an independent and impartial tribunal established by law". 509 This was argued as reinforcing "what is already deeply rooted in the popular understanding of civil justice" in the EU. ${ }^{510}$

\subsubsection{Supervision of EU Member States' National Procedural Justice Systems}

In addition to ensuring compliance with EU law through the CJEU, the Union has also taken other measures to supervise its Member States' national justice systems. First, a Commissioner for Justice and Fundamental Rights was appointed within the European Commission, which shows that the European Commission understands its mission as including improving the efficiency and independence of national court systems. ${ }^{511}$ Second, the European Commission adopted a Rule of Law Framework in 2013. This Framework set out a structured process for the European Commission to react to indications of any systemic threat to the rule of law, ${ }^{512}$ which could further guarantee access to justice and fundamental procedural rights. Moreover, the EU Justice Scoreboard has been published annually since 2013. ${ }^{513}$ This Scoreboard provides an annual comparative overview of the independence, quality and efficiency of EU Member States' national justice systems. ${ }^{514}$

\footnotetext{
${ }^{508}$ Manon Schonewille \& Jeremy Lack, Mediation in the European Union and Abroad: 60 States Divided by a Common Word?, at: The Variegated Landscape of Mediation: A Comparative Study of Mediation Regulation and Practices in Europe and the World, Eleven International Publishing, 2014, p. 20. This fundamental right also has its constitutional equivalent in the EU Member States, such as Art. 111 of the Italian Constitution on 'diritto al giusto processo' and Art. 24 on 'diritto di azione'.

509 The European Court of Human Rights (ECtHR), the judicial body of the ECHR, has explained this Article in reports as well as in decisions in specific cases. For a more explanation of this Article, see e.g. Judgment of the Court (Fourth Chamber), Rosalba Alassini v. Telecom Italia SpA (C-317/08), Filomena Califano v. Wind SpA (C-318/08), Lucia Anna Giorgia Iacono v. Telecom Italia SpA (C-319/08) and Multiservice Srl v Telecom Italia SpA (C-320/08), Joined cases C-317/08, C-318/08, C-319/08 and C-320/08, 18.03.2010.

510 Adrian A. S. Zuckerman, Court Adjudication of Civil Disputes: A Public Service to be Delivered with Proportionate Resources, within a Reasonable Time and at Reasonable Cost, at: C.H. van Rhee \& D. Heirbaut \& M. Storme (eds.), The French Code of Civil Procedure (1806) after 200 Years: the Civil Procedure Tradition in France and Abroad, Kluwer, 2008, p. 438.

511 Directorate General for Internal Policies-Policy Department C: Citizens' Rights and Constitutional Affairs, The European Law Institute/UNIDROIT Civil Procedure Projects as a Soft Law Tool to Resolve Conflicts of Law, 2016, available at: http://www.europarl.europa.eu/RegData/etudes/IDAN/2017/556972/IPOL_IDA(2017)556972_EN.pdf, p. 6, last visited on 30.07.2020.

512 Francesco Pesce, International and EU Perspective on Mediation: Mediation and Fundamental Right of Access to Justice, at: Francesco Pesce \& Dana Rone, Mediation to Foster European Wide Settlement of Disputes, Aracne, 2016, pp. 165-166.

513 Judgment of the Court, Parti écologiste "Les Verts" v. European Parliament Case 294/83, 23.04.1986, para. 2.23. 514 Opinion of Mr Advocate General Ruiz-Jarabo Colomer, Judicial Cooperation in Civil Matters - Preliminary References - Jurisdiction of the Court - Definition of 'Dispute' - Regulation (EC) No 1348/2000 - Service of extrajudicial documents in the absence of legal proceedings - Notarial act, 05.03.2009, para.29. It is worth pointing out that this EU Justice Scoreboard shows that there are big differences in the national legal systems of the EU Member States, especially when it comes to access to justice for foreign investors and timeframes for delivering and implementing justice. See: Dieter Krombach v. André Bamberski, Case C-7/98, 28.03.2000. Horatia Muir Watt, Evidence of an Emergent European Legal Culture: Public Policy Requirements of Procedural Fairness under the Brussels and Lugano Conventions, Texas International Law Journal, Vol. 36, 2001, pp. 539, 549, 554.
} 


\subsubsection{The Joint ELI-UNIDROIT Project "From Transnational Principles to European Rules of Civil Procedure"}

In 2013, UNIDROIT and the European Law Institute (ELI) started to cooperate to produce a model of European rules of civil procedure, ${ }^{515}$ which would include a set of uniform procedural rules regarding dispute settlement. The common legal tradition in EU Member States, together with the CFREU and other relevant texts, principles, and soft law, formed the starting point of this project. ${ }^{516}$

On 21 December 2015, the Committee on Legal Affairs of the European Parliament proposed that, in line with the European Commission's past initiatives and the preliminary result of the joint projects of the ELI and UNIDROIT, the time was ripe for a legislative proposal setting out common minimum standards. ${ }^{517}$ During the past ELI-UNIDROIT joint meetings, eight procedural issues were discussed, such as court settlements and third-party funding. ${ }^{518}$ In addition, this project was showcased at a conference held in November 2018, where various aspects of the draft of the legislative proposal provided by the Project Working Groups were discussed under the theme of "Structure of civil proceedings - towards a coherent model law". As of 30 May 2020, this project is still in progress. Although there has not been any concrete result from this project until now, its initiation and the progress made thereunder confirm the existence of common elements shared within the EU regarding the legal tradition of civil justice.

\subsection{An Interpretation of the Dispute Settlement Mechanisms in the EU Member States and the Union's Relevant Regulating Measures-From a Legal Cultural Perspective}

Various elements can be expected to have affected the procedural design of the DSMs within the EU, especially considering its nature as a Union comprised of 27 Member States and the corresponding two-tiered regulation structure. This section takes a legal culture perspective and explores the potential connection between the European legal cultural characteristics on dispute settlement discussed in Section 3.1, supra, on the one hand, and the features of the DSMs in the EU Member States and the EU's relevant rules introduced in Sections 3.2 and 3.3, supra, on the other.

\footnotetext{
515 Judgment of the Court (Fifth Chamber), Samuel Sidney Evans v. The Secretary of State for the Environment, Transport and the Regions and The Motor Insurers' Bureau, Case C-63/01, 04.12.2003.

516 The EU Network of Independent Experts on Fundamental Rights, Commentary of the Charter of Fundamental Rights of the European Union, 2006, available at: http://ec.europa.eu/justice/fundamentalrights/files/networkcommentaryfinal_en.pdf, p. 367, last visited on 05.08.2020.

517 Bertrand Wägenbaur, Court of Justice of the European Union: Commentary on Statue and Rules of Procedure, C.H. Beck·Hart·Nomos, 2013, pp. 4-5. See also: Judgment of the Court (First Chamber), Salzgitter Mannesmann GmbH v. Commission of the European Communities, Case C-411/04 P, 25.01.2007, paras 40-41.

${ }^{518}$ International Institute for the Unification of Private Law (UNIDROIT), Study LXXVIA - Transnational Civil Procedure - Formulation of Regional Rules: ELI - UNIDROIT Transnational Rules of Civil Procedure, available at: $\mathrm{https}$ ://www.unidroit.org/work-in-progress-eli-unidroit-european-rules, last visited on 06.08.2020.
} 


\subsubsection{Consistent Pursuance of the Rule of Law in Dispute Settlement}

The most notable feature of the dispute settlement practice of the EU is arguably the respect for the rule of law, which in fact constitutes the basis of other characteristics. This is evidenced by EU Member States' practice on dispute settlement as well as the Union's measures on regulating civil procedure in its Member States, which at the same time echoes the important role of the rule of law in European legal culture in general.

Guided by the rule of law, law has its own value and enjoys priority, ${ }^{519}$ instead of being simply a tool for or only used in combination with realizing other political or social objectives. In other words, the separation between law and extrinsic social values is clear. In addition, individuals' rights are emphasized and protected by law, instead of being sacrificed for the community's interests. In dispute settlement, the rule of law requires the law to be taken as the benchmark, so as to guarantee the realization of substantive and procedural justice. Regarding the former, law is intended to protecting individuals' rights from being infringed by others and it ensures procedural justice and due process, etc. This resonates with the EU's legal tradition of requiring the law to protect individuals' rights and to ensure the proper use of power by the government or parliament, as well as its traditional emphasis on individuals instead of the community.

It is fair to say that, as reflected concretely in the practice of dispute settlement in the EU Member States and the Union, the rule of law, which originates from European legal history, has been firmly applied, developed and has become an indispensable and important element of European legal culture.

\subsubsection{Common Use of Litigation for Realizing Justice}

Litigation is a commonly used DSM in the EU, if not the one that is resorted to most frequently. In addition, most domestic legislation of EU Member States on DSMs focuses on litigation. Furthermore, common fundamental procedural principles have been reached and reflected in most EU Member States' judicial systems. In fact, resorting to litigation for dispute settlement is argued to form part of the EU Member States' and the Union's legal tradition, mirroring their convictions about the "proper organization of the courts' judicial system in delivering timely and fair judgments". ${ }^{520}$ In particular, procedural justice is required to be realized and has its independent significance. Namely, not only the result of dispute resolution, but also the process are indispensable elements of the fundamental notion of justice. ${ }^{521}$

It deserves attention that, in addition to resolving disputes, more importantly, litigation is taken as a way to protect individuals' fundamental procedural and substantive rights.

\footnotetext{
${ }^{519}$ It is also noted that arguments claiming that the function of law to realize other objectives also exists. For example, it was pointed out that access to justice "is bound to the European integration process", where social values, if any, are realized in a pick-a-pack procedure tied to market integration. However, this should not affect the fact that "[s]ocial justice, in the sense of distributive justice, plays limited role only". See: Judgment of the Court, Regina $v$. Kent Kirk, Case 63/83, 10.07.1984, para. 22.

520 Judgment of the General Court (Second Chamber), Siemens v. European Commission, Case T-110/07, 03.03.2011, paras. 189, 199. See also: Jean-E. Humblet v. Belgian State, Case C-6/60, 16.12.1960, para. 1.

${ }^{521}$ Judgment of the Court (First Chamber), Nuova Agricast Srl and Cofra Srl v. European Commission, Case C67/09 P, 14.10.2010, para. 65 .
} 
This resonates with the EU's consistent reliance on the rule of law. As revealed by the 2011 Report on the Rule of Law of the Venice Commission of the Council of Europe, access to justice before independent and impartial courts and the independence and impartiality of the judiciary are necessary elements of the rule of law. ${ }^{522}$ The rule of law requires access to justice, procedural justice and due process, which can all be properly realized in litigation. In particular, the practice of the CJEU gives a concentrated expression of the detailed requirements of procedural justice in litigation, such as a public hearing. It also explicitly confirmed the notion of access to justice as a fundamental requirement, as well as general principles of procedural law as being an indispensable part of the primary law of the EU. In litigation, adjudicators are expected to fulfil the role of delivering judgments according to the law. In brief, adjudication in courts is taken as a normal and common way of settling disputes throughout Europe, aiming at ensuring the fundamental rights of citizens and the transnational rule of law.

\subsubsection{Increasing the Use of Mediation to Ensure Access to Justice}

Recent years witnessed increasing efforts of some EU Member States as well as the Union in promoting mediation and other alternative DSMs other than litigation. ${ }^{523}$ From a practical perspective, this appeared as a response to the increasing number of cases in domestic courts, the lengthy duration of litigation, and ever-more complicated disputes. Ideologically, the promotion of mediation is supported by the idea that this DSM provides another way to have access to justice. In fact, the justification of any regulatory measure on alternative DSMs goes back the fundamental rule of law, in particular access to justice. This is typically evidenced by the CJEU's decision that mandatory out-of-court mediation before court proceedings is allowed and is based on the fact that this does not negatively affect the principle of effective judicial protection.

This may constitute a kind of deviation from the traditional preference for adjudication in pursuing justice. It is advocated by the European Commission that alternative dispute resolution can play an integral part in improving access to justice and can complement the traditional judicial procedures, thereby "helping the parties enter into a dialogue and constituting a means of achieving social harmony". ${ }^{524}$ Similarly, but more pragmatically, the European Parliament emphasized that the complexity and technical nature of the issues facing the potential litigant can be mitigated by recourse to quicker and less stressful alternative dispute resolution routes. ${ }^{525}$ Therefore, on the one hand, the promotion of the use of alternative dispute resolution by the EU is a reaction to the practical difficulties related to using adjudication and it is still guided by the general traditional aim of ensuring access to justice; on the other hand, some other elements,

\footnotetext{
${ }^{522}$ In its search for the content of the rule of law, the Venice Commission based its analysis on the case law of the European Court of Human Rights, the developments with respect to the UN Universal Declaration of Human Rights, as well as in the context of the OSCE, the OECD and the EU. See: Judgment of the Court (Fifth Chamber), Paula Gomez-Rivero v. Bundesanstalt für Arbeit, Case C-211/97, 03.06.1999, para. 1.

523 Judgment of the Court of First Instance (Third Chamber), Jungbunzlauer AG v. Commission of the European Communities, Case T-43/02, 27.09.2006.

${ }^{524}$ Bertrand Wägenbaur, Court of Justice of the European Union: Commentary on Statue and Rules of Procedure, C.H. Beck·Hart $\cdot$ Nomos, 2013, pp. 4-5.

525 European Parliament, Report on the Green Paper on alternative dispute resolution in civil and commercial matters, T5 841/2003, Report published as legislative resolution, OJ C-61 E, 10.03.2004, 20.02.2003, p. 6.
} 
such as social effects, procedural economy and the significance of mutual recognition, play an increasingly important role.

\subsection{Conclusion}

Regarding the traditional values that have been preserved throughout European legal history, three constants can be identified: personalism, legalism and intellectualism. These constants, in particular, formed the basis of the European legal culture in dispute settlement. Against this background, the law is considered as the guarantor of justice, fairness and legal rights; the insistence on the rule of law ensures the supremacy of law and the law's function as the benchmark in resolving disputes. As a usual way of resolving disputes, litigation focuses on preserving substantive rights and procedural justice and, therefore, judges must make decisions according to the law and must follow due process. As summarized, after hundreds of years of changes in European legal history, some elements of the traditional legal culture are still clearly discernible. ${ }^{526}$

The commonly available DSMs for investment disputes in EU Member States are identified as mediation, arbitration and litigation. As a result of the various legal traditions in EU Member States, the current legislative situations in each Member State are quite different in terms of the general attitude towards mediation and the detailed procedural rules. Legislation on arbitration is less diversified and consensus has been reached generally on basic principles and key points, such as the principle of competence-competence, arbitrators' qualification and conditions for appealing and setting aside arbitral awards. With regard to litigation, although procedural rules are different in their details, basic values are shared and consensus on fundamental principles on procedural issues has been reached in relation to the minimum standards, such as due process and equal treatment, which have their roots in the European legal tradition and are a reflection of European legal culture. ${ }^{527}$

Alongside the relevant rules in the EU Member States, the Union has also taken legislative measures as well as other efforts to regulate civil procedure, which include rules on DSMs. From primary law, secondary legislation, the CJEU's practice on procedural justice, to the Union's other efforts, a common underlying motivation that is visible in all of them is to preserve the individual's right to access to justice, effective remedy and fair trial, and establishing the European area of justice, ${ }^{528}$ which can be

\footnotetext{
526 European Court of Human Rights, Accession of the European Union, available at: http://www.echr.coe.int/Pages/home.aspx?p=basictexts/accessionEU\&c=, last visited on 05.08.2020.

527 It was pointed out that "the rule of law" and "due process" are at the core of the substantive protection of individuals and, as such, form an ancient achievement of law. See: Opinion 2/13 of the Court (Full Court), Opinion pursuant to Article 218(11) TFEU - Draft International Agreement - Accession of the European Union to the European Convention for the Protection of Human Rights and Fundamental Freedoms - Compatibility of the Draft Agreement with the EU and FEU Treaties, 18.12.2014, paras. 181, 185, 210. In addition, as was argued by the British former Member of the European Parliament, Glyn Ford, "genuine partnership (in Europe) can only develop on the basis of shared common values - in particular, democracy, the rule of law and respect for human and civil rights". See: Mary Ann Glendon \& Paolo G. Carozza \& Colin B. Picker, Comparative Legal Traditions in a Nutshell (4th Edition), West Academic Publishing, 2016, p. 60.

528 European Court of Human Rights, Guide on Article 6 of the European Convention on Human Rights, 30.04.2013, available at: http://www.echr.coe.int/Documents/Guide_Art_6_ENG.pdf, last visited on 23.08.2016.
} 
traced back to the principle of the rule of law and the protection of human rights. In other words, the value-oriented identity of the EU has acted as an impetus in the Union to implement measures that are expressly built upon common values and principles arising from the constitutional tradition shared by EU Member States.

By analysing the DSMs in the EU Member States and the Union's relevant regulating measures from a legal cultural perspective, three points deserve attention. First, a consistent pursuit of the rule of law can be identified in dispute settlement. Second, litigation has been commonly used, which focuses on realizing substantive and procedural justice. Third, recently increased attention on mediation is based on the recognition of its function in ensuring access to justice. In brief, the relevant practice of the EU Member States and the Union to a large extent reflects the EU legal cultural characteristics in dispute settlement, which, in turn, arguably reinforce the corresponding underlying values and principles. 


\section{Chapter 5 Comparison of the Legal Culture on Dispute Settlement in China and}

\section{the EU}

Based on the discussion in Chapters 3 and 4 on the legal culture of and internal DSMs for foreign investment disputes in China and the EU, this chapter compares the features of both. While there are commonalities evident in the two systems, ${ }^{529}$ considering the main goal of the present analysis, the focus here will be on their differences. As such, the comparison in this chapter is presented from two perspectives. Section 5.1 analyses the legal cultural characteristics of dispute settlement, including the key elements of legal culture, the perception of law, the role of law, and the objective of dispute settlement. Section 5.2 identifies two issues regarding the DSMs in the internal legal systems, the focuses of dispute settlement systems and the promotion of mediation in China and the EU.

\subsection{Legal Cultural Characteristics in Dispute Settlement}

China and the EU each have a different legal culture. Focusing on dispute settlement, this section addresses four relevant issues in which the situation in China and that of the EU present noticeable differences to a certain extent. These include the key aspects of legal culture, the perception of law, the role of law, and the objective of dispute settlement, all of which are analysed in turn in the following.

\subsubsection{The Key Aspects of Legal Culture}

Traditional Chinese philosophies played the role of regulating the society in ancient China and such traditional philosophies still have a great effect on modern Chinese ideologies. Under their influence, a clear importance of collectivism can be identified. The community is viewed as a whole, and individuals are expected to follow the overall goal of the society to preserve harmony and the interests of the individual are secondary to those of the community. Traditional Chinese philosophies neglect individual rights and have a vision of the society where "individual lives were led within hierarchies and social distinctions and proper behavior derived from an individual's status in those hierarchies". ${ }^{530}$ Furthermore, the notion of subordinating individuals' rights and duties to collective interests "continues to inform many Chinese and Marxist conceptions of individual rights in modern China". 531

\footnotetext{
529 Despite the difference in legal traditions, there are efforts made by scholars in looking for a correspondence and compatibility of ancient Chinese and Confucian thought with ancient European and Christian thought. See e.g. Janne Nijman, A Universal Rule of Law for a Pluralist World Order: Leibniz's Universal Jurisprudence and his Praise of the Chinese Ruler, Amsterdam Center for International Law (ACIL) Research Paper, Vol. 16, 2016, pp. 24-28.

${ }_{530}$ Stanley B. Lubman, Bird in a Cage-Legal Reform in China after Mao Standford University Press, 2000, pp. 15$16,19$.

${ }^{531}$ Ernst-Ulrich Petersmann, Trade and Investment Adjudication Involving 'Silk Road Projects': Legal Methodology Challenges, European University Institute Working Papers, Vol. 2, 2018, p. 3. (citing: Joseph Chan, Confucian Perfectionism: A Political Philosophy for Modern Times, Princeton University Press, 2014.)
} 
In contrast, individualism can be considered the cornerstone of the relevant situation in the EU, where the focus has been on individuals instead of the community. This means that, instead of being subject to or submerged in the pursuit of the society's goals, individuals' rights are greatly respected. Such rights are based on "the fundamental dignity and equality of every human being", 532 being protected as "constituent powers" and "democratic principles". 533

Therefore, comparing to the legal culture in Western society, Chinese legal culture is described as follows: community is more important than individuals, morality is more important than law, responsibility is more important than freedom, obligations are more important than rights, people's livelihood is more important than democracy, order is more important than liberty, and harmony is more important than disputes. ${ }^{534}$

\subsubsection{The Perception of Law}

The perception of law constitutes part of the basis of a legal system, the recognition of which provides more context to understand the features of the DSMs made available in that legal system. On this issue, the difference between China and the EU regarding how the law is perceived in the legal culture deserves attention.

For a long time in Chinese history, traditional Chinese philosophies acted as the source of regulations, which resulted in the inclusion of morality in those regulations. ${ }^{535}$ For most civil matters, it was not law, but the teachings from traditional Chinese philosophies that provided the basis for rules. Law meant punishment and was used as a tool of suppression and control by the ruler, which led to the society's rejection of the law in general. The nature of the law has changed in modern times, having moved away from being only of a punitive nature and having become a source of regulations on people's daily life. The perception of law has changed in contemporary Chinese ideologies to a certain extent, but the negative connotations deriving from the traditional understanding of law as a tool of punishment can still be traced. Although contemporary Chinese ideologies incorporate and recognize the importance of the law in protecting individuals' legal rights, it is noticeable that the law at the same time is used as a tool to realize extrinsic social values. It can be said that the law can be seen as having an instrumental purpose, existing with its own values and at the same time serving the overall goal of pursuing harmony.

This was not the case in European legal culture. Historically, the law was also once focused on punishment and power or tied with morality and religious beliefs, but the influence of this aspect is relatively limited. Law enjoys its own value and fundamental importance and is fundamentally separated from social ideologies. Furthermore, the

\footnotetext{
532 Stanley B. Lubman, Bird in a Cage-Legal Reform in China after Mao Standford University Press, 2000, pp. 15$16,19$.

${ }^{533}$ Ernst-Ulrich Petersmann, Trade and Investment Adjudication Involving 'Silk Road Projects': Legal Methodology Challenges, European University Institute Working Papers, Vol. 2, 2018, pp. 2-3.

${ }^{534}$ Lai Chen 陈来, The Core Values of Chinese Civilization 中华文明的核心价值, Joint Publishing (H.K.) 三联 书店（香港），2016, pp. 1, 4. See also: Dainian Zhang \& Yishan Cheng 张岱年 \& 程宜山, Cultural Spirits of China 中国文化精神, Joint Publishing (Hong Kong) 三联书店（香港）, 2016, pp. 55-134.

535 Franz Wieacker \& Edgar Boenheimer, Foundations of European Legal Culture, The American Journal of Comparative Law, Vol. 38, 1990, p. 4.
} 
general systematization of legal phenomena founded in a general idea of justice can be traced far back in the EU's legal history. Law restricts the power of the ruler, rather than functioning as the ruler's tool of realizing its controlling powers. Equally important, the law is viewed as a protector of individuals' rights and, in turn, it supports social life within "an impersonalized framework". ${ }^{536}$ In this regard, in contrast to the situation in China, with the legal culture in the EU there has been a significant gap between law and morality. ${ }^{537}$

\subsubsection{The Role of Law}

Regarding the role of law in a legal system, a clear difference exists between "rule by law" and "rule of law". In general, the "rule by law" means "the control by the government over the governed", while the "rule of law" refers to "the control over the governance of the government". ${ }^{538}$ In other words, the former means that the law should stand above political power as a value to be respected, while the latter, in contrast, connotes the instrumental use of law as a tool of political power. In addition, rule by law and rule of law relate to another two norms operating in a legal system: authoritarian and democratic governance. Rule by law is a typical feature of authoritarian or totalitarian regime, while democratic societies are characterized by a reliance on the rule of law. ${ }^{539}$

Any concept of the rule of law should be assessed with due regard for the socio-political and historical context from which it emerged. This inspires the exploration of the meaning of the same term in the context of China or the EU, beyond the terminology. In the Chinese legal tradition, the rule by law was the approach adopted the majority of the time. The ancient Chinese political system was argued as "rule of man" or "rule by law", where the law served as the extended arm of the ruler. ${ }^{540}$ This model of governing corresponds with the formula "man $\rightarrow$ law $\rightarrow$ man". ${ }^{541}$ Although this situation has changed to a great extent in modern China, some remnants can still be traced in the concept of "socialist rule of law". Under contemporary Chinese ideologies, it is the "socialist rule of law" with Chinese characteristics that determine the role of the law. ${ }^{542}$ It was argued that China faces difficulties "when it comes to formulating a concept of the rule of law entailing a clear distinction from the rule by law". ${ }^{433}$ This is typically

\footnotetext{
536 Zhiping Liang, Explicating "Law": A Comparative Perspective of Chinese and Western Legal Culture, Journal of Chinese Law, Vol. 3, 1989, p. 88.

${ }^{537}$ It was argued that law determined "what is necessary and therefore required to prevent domination and promote the public good", while morality reflected "what is useful in advancing the good of society as a whole, but may not be required". See: Mortimer Sellers, What Is the Rule of Law and Why Is It So Important?, at: Democracy and Rule of Law in the European Union-Essays in Honour of Jaap W. de Zwaan, T.M.C. Asser Press, 2016, p. 6.

538 Jean Yves Heurtebise, Understanding Non-Trade Concerns Through Comparative Chinese and European Philosophy of Law, at: China's Influence on Non-Trade Concerns in International Economic Law, Routledge, 2016, p. 288.

539 Id.

540 Zhiping Liang, Explicating “Law”: A Comparative Perspective of Chinese and Western Legal Culture, Journal of Chinese Law, Vol. 3, 1989, p. 89.

${ }^{541}$ Jean Yves Heurtebise, Understanding Non-Trade Concerns Through Comparative Chinese and European Philosophy of Law, at: China's Influence on Non-Trade Concerns in International Economic Law, Routledge, 2016, p. 288.

542 Jinping Xi 习近平, Accelerating the Establishment of Socialist Rule of Law in China 加快建设社会主义法治 国家, Qiu Shi 求是, Vol. 1, 2015. The original paper is in Chinese and the translation was carried out by the author. 543 Jean Yves Heurtebise, Understanding Non-Trade Concerns Through Comparative Chinese and European
} 
evidenced by the combination of law and the goal of constructing a harmonious socialist society promoted by the Chinese Communist Party as a key aspect of contemporary Chinese ideology.

On the side of the EU, the rule of law arguably constitutes "part of Europe's DNA", 544 and thus the supremacy of law is an indispensable part of the European legal tradition. As a result, individuals and authorities should be bound by and entitled to the benefits of laws "publicly made, prospectively promulgated and publicly administered in the courts". ${ }^{545}$ The formula of legality is "law $\rightarrow$ man $\rightarrow$ law". ${ }^{546}$ This approach has come from the EU's legal history and constitutes a significant feature of the EU's current legal culture. Its significance is evidenced by legislation at both the EU Member States and the Union levels. ${ }^{547}$ Furthermore, it was argued that European integration transformed the rule of law from a widely recognized philosophy into "a structural part of the EU legal system" and "a fundamental value". 548

\subsubsection{The Objective of Dispute Settlement}

The key aspects and characteristics of legal culture establish the context of the practice of dispute settlement and especially the overall objective of dispute settlement.

In Chinese legal culture, as a consequence of the pursuit of harmony, DSMs function as a tool to resolve disputes and, more importantly, to restore the relationship between disputing parties and to keep harmony within the society. The focus is on the ultimate effect of dispute settlement and not on the process. As a result, at times, the evaluation of substantive decisions and procedural matters are based on the final social effect according to criteria outside the scope of positive law. In this sense, it can be said that social justice plays a role in dispute settlement, in parallel with individual justice, while it can be said that social justice can overrule the latter. Thus, unless resorting to litigation is unavoidable, it is preferable to settle through amicable mechanisms.

As a result, resorting to litigation is normal practice, where substantial and procedural justice is guaranteed by the rule of law. At the same time, this also contributes to the

Philosophy of Law, at: China's Influence on Non-Trade Concerns in International Economic Law, Routledge, 2016, p. 290.

${ }^{544}$ European Commission, The European Union and the Rule of Law, Keynote speech at Conference on the Rule of Law, Tilburg University, 31.08.2015.

545 Thomas Bingham, "The Sixth Sir David Williams Lecture: The Rule of Law" (16.11.2006), Cambridge University: Centre for Public Law, p. 5; Kun Fan, Arbitration in China: A Legal and Cultural Analysis, Hart Publishing, 2013, pp. 185-186.

546 Jean Yves Heurtebise, Understanding Non-Trade Concerns Through Comparative Chinese and European Philosophy of Law, at: China's Influence on Non-Trade Concerns in International Economic Law, Routledge, 2016, p. 288.

${ }_{547}$ A typical evidence of this is the preamble of the TFEU, which speaks of EU Member States "drawing inspiration from the cultural, religious and humanist inheritance of Europe, from which have developed the universal values of the inviolable and inalienable rights of the human person, freedom, democracy, equality and the rule of law [emphasis added]".

548 European Commission, The European Union and the Rule of Law, Keynote speech at Conference on the Rule of Law, Tilburg University, 31.08.2015. As has been pointed out by the ex-president of the European Commission, José Manuel Durão Barroso, “...the rule of law is not just an inspiration; it is also an aspiration - a principle that guides both our internal and external actions; it is what we are and what we want to be”. See: José Manuel Durão Barroso, The Rule of Law as Inspiration and Aspiration, Press Release, European Commission, 28.05.2013, available at https://ec.europa.eu/commission/presscorner/detail/en/SPEECH_13_469, last visited on 30.07.2020. 
development of jurisprudence, which is another significant element within the notion of the rule of law.

\subsection{Internal Dispute Settlement Mechanisms}

As presented in Sections 3.2, 4.2 and 4.3, supra, both China and the EU have established internal dispute settlement systems that are composed of various DSMs. The features of the general structure of these two systems and detailed procedural designs of each mechanism contained therein are different, where their legal cultural characteristics play a role together with other contributing elements. The discussion in this section generally compares the different focus of the internal dispute settlement systems in China and the EU and addresses specific points regarding the various reasons underlying the similar promotion of mediation in both jurisdictions.

\subsubsection{The Focus of the Dispute Settlement Systems}

Various DSMs are available for dispute resolution in the current Chinese legal system for foreign investment related disputes, , including negotiation, mediation, arbitration, complaints coordination for foreign investment, administrative reconsideration, and litigation. As particularly evidenced by the practice of combining mediation with other DSMs, the whole dispute settlement system shows a strong preference for pursuing amicable settlements through social channels rather than through state-sponsored official fora. The core objective of these DSMs is to resolve disputes, restore relationships, and maintain social harmony. This clearly resonates with China's legal culture. It can be said that the harmony-centred tradition has greatly affected, if not dominated, the use of DSMs in China's legal system.

In the EU, rules on DSMs, both at the level of EU Member States and the Union, need to be taken into consideration. At the level of the EU Member States, although detailed rules on the three main DSMs, mediation, arbitration and litigation, are diverse, consensus has been reached on fundamental values and principles, such as due process. Regarding relevant measures at the Union level, both legislative and other efforts have been taken, including primary law and secondary legislation, the CJEU's practice of procedural justice, as well as other relevant efforts, such as supervising its Member States' dispute settlement systems on procedural arrangements. In general, the focus has been on the use of litigation, especially in upholding the rule of law. Under the theme of ensuring the rule of law, litigation is preferable than other DSMs for realizing substantive and procedural justice, preserving individuals' fundamental rights and developing jurisprudence.

Another difference presented by China and the EU's dispute settlement systems that deserves to be mentioned here is China' service-based doctrine and the EU's justicebased doctrine of dispute settlement. In general, the DSMs in China's legal system have the aim of providing a service to disputing parties to resolve their disputes, while in the EU DSMs are used as a method to ensure the disputing parties' access to justice, including substantive and procedural justice. Such a difference in doctrine can provide 
an explanation for and is confirmed by the various detailed arrangements in some DSMs, such as mediation, which is illustrated in the following section.

\subsubsection{The Promotion of Mediation}

The promotion of mediation as a mechanism of alternative dispute resolution can be found in the current legal system of China and also in the EU. Typical examples include the combination of mediation with other DSMs in China and the adoption of the EU Directive on Mediation in the EU. However, despite such a similarity in this promotion of mediation, a different motivation can be identified in each jurisdiction. ${ }^{549}$

The promotion of mediation in China's legal system is consistent with its traditional pursuit of harmony. Compared to litigation and arbitration, mediation provides a more desirable environment for dispute resolution through reaching a satisfactory settlement amicably and informally. In turn, mediation helps to realize the supreme goal of building a harmonious socialist society. Against this motivation, the procedure used in mediation is not important and it is rarely regulated in legislation. In contrast, the promotion of mediation in the EU is based on the perception that mediation is an alternative means to adjudication to ensure access to justice. ${ }^{550}$ Relevant efforts made by the Union and its Member States are a rational response to the factual situations that hinder the realization of this pursued goal, such as the increasing caseload of national courts. This results in the fact that the basic requirements coming from procedural justice are also reflected in mediation. ${ }^{551}$

The difference between the underlying reasons for the promotion of mediation is likely to also come from China's service-based doctrine and the EU's justice-based doctrine of dispute resolution. The different practice of selecting of mediators can be taken as an example to show this. Chinese parties prefer to choose "insider mediators known to both parties who do not necessarily have formal mediation qualifications", which could assist disputing parties resolve their disputes and restore the previous harmonious relationship; while, on the side of the EU, outsider mediators possessing "formal mediation qualifications and a high level of knowledge and skill in relation to managing conflict" are the normal choice, which are expected to facilitate the access to justice in a professional manner. ${ }^{552}$

\footnotetext{
549 It is noted that the rise of alternative dispute resolution can be a product of various factors, such as institutional demands, political manoeuvring and cultural movement. Here, the analysis focuses on the contribution of the legal culture in dispute settlement, which is one of the key elements in the promotion of mediation in the case of China and that of the EU.

${ }_{550}$ As argued by scholars, access to justice should be understood as a common element tying European legal culture together. See e.g. Hans W. Micklitz, The (Un)-Systematics of (Private) Law as an Element of European Culture, at: Towards a European Legal Culture, Hart Publishing, 2014, p. 82.

${ }^{551}$ This can be evidenced by the procedural requirements of mediation and the quality of mediators stipulated in rules issued by the EU Member States and the Union.

${ }_{552}$ Nadja Alexander, The Mediation Meta Model: Understanding Practice Around the World, Conflict Resolution Quarterly, Vol. 26, 2008, p. 100. Here the author is introducing: Cris Currie, Mediating off the Grid, Dispute Resolution Journal, Vol. 59, 2004, pp. 11-14.
} 


\subsection{Conclusion}

China and the EU enjoy diverse legal cultural characteristics in dispute resolution, which range from the key aspects of legal culture, the perception of law, the role of law, to the objective of dispute settlement. In general, in contrast to the role of collectivism presented in Chinese legal culture, where individuals are required to act in line with the overall goal of the society to preserve harmony and where individual interests are secondary to the collective goals, the legal culture of the EU shows clear signs of individualism, where individuals' rights are respected and protected as constituent rights and democratic principles. Regarding the perception of law, contemporary Chinese ideologies recognize the importance of law in setting rules and protecting individuals' legal rights, but there is a negative connotation coming from the traditional understanding of law as a tool for punishment that can still be identified. Furthermore, the "socialist rule of law" combines law with and even takes law as a tool of realizing extrinsic social values, with a view to constructing a harmonious socialist society. On the side of the EU, the law protects individuals' rights and balances the power of the ruler. It enjoys its own value and fundamental importance, which is also separated from morality. The rule of law constitutes "part of the Europe's DNA", and thus the supremacy of law is an indispensable part of the European legal tradition. In Chinese legal culture, under the overall pursuit of harmony, the objective of dispute settlement

can be described as resolving disputes, restoring the relationship between disputing parties and preserving social harmony. However, the practice of dispute settlement in the EU has its focus on realizing individual procedural and substantive justice and developing jurisprudence.

The legal cultural characteristics in dispute settlement in China and those in the EU have respectively affected the focus of their dispute resolution systems in general and, in particular, their approaches to mediation. In terms of the former, China's dispute settlement system shows a strong preference for amicable DSMs, while in the EU the focus has been on the use of litigation, especially its conformity with the rule of law. In addition, China arguably adopts a service-based doctrine of dispute settlement, using DSMs to provide a service to disputing parties. This seems to be different from the approach of the EU, which takes a justice-based approach, using DSMs to realize justice. With regard to the latter, both China and the EU have made efforts to enhance the use of mediation in dispute settlement, but the underlying motivations are different: the EU takes mediation as an alternative way of realizing access to justice, instead of being based on the pursuit of personal and social harmony, which is the case of China.

While the existence or non-existence of certain characteristics is not always clear-cut, the differences between China and the EU regarding the legal cultural characteristics in dispute settlement and the design of internal DSMs are certainly clearly identifiable, and these differences may lead to difficulties when the two parties try to reach an agreement on relevant issues in negotiating an IIA. 


\section{Part 3 Approaches to International Investment Dispute Settlement in China and}

\section{the EU}

\section{Introduction to Part 3}

There should be no doubt that not all investment disputes can be resolved in domestic legal systems. For state-state disputes, domestic DSMs cannot play a role at all. The role of domestic remedies in investor-state dispute settlement is also often limited, particularly because of the doubts investors have surrounding the integrity of a foreign legal system and potential intention of the adjudicators in domestic DSMs to protect the local interests involved in investment disputes. Even when such issues do not exist, DSMs at the international level could be preferable for other reasons, such as efficiency. Thus, it is necessary to have both domestic and international DSMs for investment dispute settlement. In fact, this has become the general practice of many states, including China and the EU. Part 2 discussed the internal DSMs in China and the EU, and Part 3 will now focus on the approaches of both parties to investment dispute settlement at the international level.

For investor-state dispute settlement, the basis for the exploration of the practice in China and in the EU is relatively simple and straightforward, and it includes the IIAs China and the EU have concluded and the cases brought thereunder. While for statestate dispute settlement, in addition to IIAs, similar DSMs can also be found in FTAs and the WTO system in the area of international trade law, which is another key element in international economic law. In particular, recent years have witnessed the trend of combining trade and investment in one comprehensive economic agreement, where the same set of state-state DSMs is provided, covering disputes in both areas. Furthermore, the design of state-state DSMs, including investor-state DSMs, in separate IIAs seems to gain inspiration from the relevant practice under FTAs and the WTO Dispute Settlement System. As a result, the state-state DSMs in a state's IIAs are likely to be affected by its performance in the area of international trade dispute resolution. Such an influence can be identified particularly in practice in China and the EU. Therefore, for a better understanding of the practice in state-state investment dispute settlement, the analysis in this part covers the state-state DSMs in China's and the EU's IIAs and FTAs, as well as their performance in the WTO Dispute Settlement System. 


\section{Chapter 6 China's Approach to International Investment and Trade Dispute}

\section{Settlement}

In terms of dispute settlement at the international level, it is noticeable that China used to have a quite resistant attitude towards international adjudication. This has affected its behaviour on the international plane in various aspects, including in investment dispute settlement. Therefore, this chapter starts with an introduction of China's traditional attitude to international law and international adjudication, in order to provide the background for the following analysis. Regarding China's engagement in international investment dispute settlement, Section 6.2.1 first looks at the historical development of China's IIAs, providing background information on China's investment development strategy at various stages. Then Section 6.2.2 and Section 6.2.3 focus on China's practice of SSDS and ISDS respectively, analysing relevant provisions in its concluded treaties and existing cases thereunder. In addition, considering the ongoing worldwide process of ISDS reform, the opinions expressed by China in various international fora are also examined. In the end, Section 6.3 summarizes and provides the conclusion.

\subsection{China's Traditional Attitude towards International Law and International Adjudication}

Looking into Chinese history, the "century of humiliation", between the first Opium War starting from 1840 and the establishment of the People's Republic of China in 1949, left China with various "unequal treaties", ${ }^{553}$ which resulted in China's dramatic negative perception of international law and a traditional resistance to international adjudication. ${ }^{554}$ Following the "Reform and Opening up" policy, ${ }^{555}$ China began to open its doors to the world in 1978, but the effect brought about by such a change to its perception of international law and international adjudication seems to be limited. From

\footnotetext{
553 In general, "unequal treaties" refers to "a historical category of bilateral treaties concluded in the late $19^{\text {th }}$ and early $20^{\text {th }}$ century between European states, the United States of America (USA) or Latin American countries (states that fulfilled the standards of 'civilization'), and Asian or African states (perceived as 'uncivilized'). Most of these treaties were signed after military defeat or as a consequence of such a threat and often provoked dissatisfaction, as they were establishing a system of benefits for the "civilized' powers, while restricting the sovereignty of the 'uncivilized' and subordinate states". See: Elena Conde Pérez \& Zhaklin Valerieva Yaneva, Unequal Treaties in International Law, Oxford Bibliographies, 25.03.2020, available at: https://www.oxfordbibliographies.com/view/document/obo-9780199796953/obo-9780199796953-0131.xml, last visited on 06.08.2020.

554 As Hanqin Xue, the Chinese judge at the International Court of Justice (ICJ), pointed out, the victimization period under the strong-armed foreign powers left a lasting impact on China's view of international law. See: Hanqin Xue, Chinese Contemporary Perspectives on International Law: History, Culture and International Law, The Pocket Books of the Hague Academy of International, Vol. 15, 2012, p. 14-15.

555 The "Reform and Opening up" Policy refers to the programme of economic reforms termed "Socialism with Chinese characteristics" in China, which was introduced in December 1978 by reformists within the Communist Party of China, led by Xiaoping Deng.
} 
its foundation in 1949 until 2001, the jurisdiction of only two international dispute settlement systems has been accepted by China.

First, in 1993, China signed the Convention on the Settlement of Investment Disputes between States and Nationals of Other States (ICSID Convention). ${ }^{556}$ Under this Convention, China agreed to submit disputes to the International Centre for Settlement of Investment Disputes (ICSID). However, it should be noted that signing this Convention is not equal to accepting the jurisdiction unconditionally: written consent to the ICSID's jurisdiction is still required in each case. ${ }^{557}$ In fact, after signing the ICSID Convention, China did not subject all of its newly negotiated IIAs to the jurisdiction of the ICSID, leaving some treaties signed without any reference to it at all. Moreover, when China ratified the ICSID Convention, it entered a notification pursuant to Article 25(4) of the ICSID Convention, stating that China would only consider submitting to the jurisdiction of ICSID "disputes over compensation resulting from expropriation and nationalization". 558

Second, in 1996, China gave its consent to another international dispute settlement system by ratifying the United Nations Convention on the Law of the Sea (UNCLOS). Article 287 of this Convention stated the possible mechanisms for the settlement of disputes concerning the interpretation or application of this Convention, among which a state shall be free to choose. ${ }^{559}$ Although often described as compulsory, the argument that this dispute settlement system is consent-based is also strong. ${ }^{560}$ Even a UNCLOS tribunal once suggested that "UNCLOS falls significantly short of establishing a truly comprehensive regime of compulsory jurisdiction entailing binding decisions". ${ }^{561}$ At the same time, China excluded certain disputes from this dispute settlement system through a declaration in $2006 .{ }^{562}$

Based on the only two cases before 2001 where an international dispute settlement system was accepted by China, the intention to avoid international adjudication was

556 The ICSID Convention entered into force for China on 6 February 1993. For more information, see: International Center for Settlement of Investment Disputes (ICSID), ICSID Membership-Designations and Notifications_China, available at: https://icsid.worldbank.org/en/Pages/about/MembershipStateDetails.aspx?state=ST30, last visited on 31.07.2020.

${ }^{557}$ ICSID Convention, Art. 25(1). This can be realized by incorporating such acceptance into IIAs or contracts.

558 On 7 January 1993, China submitted its Notifications Concerning a Class or Classes of Disputes Which the Contracting State Would or Would Not Consider Submitting to the Jurisdiction of the Centre (Article 25(4)). See: International Center for Settlement of Investment Disputes (ICSID), ICSID Membership-Designations and Notifications_China, available

https://icsid.worldbank.org/en/Pages/about/MembershipStateDetails.aspx?state=ST30, last visited on 31.07.2020.

559 United Nations Convention on the Law of the Sea, Art. 287. The options are: "(a) the International Tribunal for the Law of the Sea established in accordance with Annex VI; (b) the International Court of Justice; (c) an arbitral tribunal constituted in accordance with Annex VII; (d) a special arbitral tribunal constituted in accordance with Annex VIII for one or more of the categories of disputes specified therein".

560 See e.g. Natalie Klein, Dispute Settlement in the UN Convention on the Law of the Sea, Cambridge University Press, 2005, p. 3.

561 The Arbitration Tribunal Constituted under Annex VII of UNCLOS, Southern Bluefin Tuna (New Zealand $v$. Japan, Australia v. Japan), 39 ILM 1359, Award on Jurisdiction and Admissibility, 04.08.2000. This is cited in: Natalie Klein, Dispute Settlement in the UN Convention on the Law of the Sea, Cambridge University Press, 2005, p. 3 .

562 Oceans \& Law of the Sea-United Nations, United Nations Convention on the Law of the Sea: Declarations Made Upon Signature, Ratification, Accession or Succession or Anytime Thereafter, 13.02.2020, available at: http://www.un.org/depts/los/convention_agreements/convention_declarations.htm\#China after ratification, last visited on 04.08.2020. 
quite clear. China's historical experience contributes to its stance as an enthusiastic champion of the principle of sovereignty. ${ }^{563} \mathrm{In}$ fact, the protection of national sovereignty has long been China's top foreign policy goal. ${ }^{564}$ However, this policy can come under threat in international adjudication. This was argued as being a primary concern of China when interpreting its rejection of international adjudication, because it considered that a decision from an international tribunal regarding the appropriateness of a state's actions would be seen as an intrusion into its domestic affairs. $^{565}$

Another possible legacy of China's historical experience is the concern about the independence and impartiality of international bodies. Until the beginning of the People's Republic China, China had come to consider international courts as "biased courts dominated by the West" $" 566$ and the decisions of international courts or arbitral organs as being subject to the manipulation of "big capitalist powers". ${ }^{567}$ After the foundation of the People's Republic China, China has continuously remained outside the international legal system for the most part. As a result, its unfamiliarity with the content of international legal texts and their application, taken together, which further causes China to distrust and avoid international law and international adjudication wherever possible.

In addition to the contribution from historical events, China's reticence is also possibly influenced by its philosophical tradition. As noted in Chapter 2, supra, traditional philosophies, especially Confucianism, have greatly affected the aversion to litigation in Chinese society. Under Confucian doctrines, litigation is an unpleasant process, because it is harmful to the existing relations and is against the pursued condition of harmony. What is worse, such procedures are unhelpful and may even have an adverse effect on resolving disputes. Thus, the Western style of adjudication, which dominates

\footnotetext{
563 Hanqin Xue, Chinese Perspectives on International Law: History, Culture and International Law, Martinus Nijhoff Publishers, 2012, p. 95.

${ }^{564}$ The desire to protect sovereignty is clearly enshrined in the preamble of China's Constitution, which states that "China consistently carries out an independent foreign policy and adheres to the five principles of mutual respect for sovereignty and territorial integrity, mutual non-aggression, non-interference in each other's internal affairs, equality and mutual benefit, and peaceful coexistence in developing diplomatic relations and economic and cultural exchanges with other countries". For a further discussion on this, see: Allen Carlson, More Than Just Saying No: China's Evolving Approach to Sovereignty and Intervention Since Tiananmen, at: Alastair Iain Johnston \& Robert S. Ross (eds.), New Directions in the Study of China's Foreign Policy, Stanford University Press, 2006, pp. 217-241. Marcia Don Harpaz, Sense and Sensibilities of China and WTO Dispute Settlement, Journal of World Trade, Vol. 44, 2010, p. 19.

565 See e.g. Marcia Don Harpaz, China and International Tribunals: Onward from the WTO, at: Lisa Toohey \& Colin B. Picker \& Jonathan Greenacre (eds), China in the International Economic Order: New Directions and Changing Paradigms, Cambridge University Press, 2015, p. 47. Liyong Jiang, WTO Dispute Settlement Mechanism and China's Participation, at: Henry Gao \& Donald Lewis (eds.), China's Participation in the WTO, Cameron May, 2005, p. 304. Julian Ku, China and the Future of International Adjudication, Maryland Journal of International Law, Vol. 27, 2012, pp. 157, 171-172.

566 Pasha L. Hsieh, China's Development of International Economic Law and WTO Legal Capacity Building, Journal of International Economic Law, Vol. 13, 2010, p. 1001.

567 Ying Tao, Recognize the True Face of Bourgeois International Law from a Few Basic Concepts, at: Jerome Alan Cohen \& Hungdah Chiu (eds.), People's China And International Law: A Documentary Study, Princeton University Press, 1974, pp. 70-71. Julian Ku, Enforcement of ICSID Awards in the People's Republic of China, Contemporary Asia Arbitration Journal, Vol. 6, 2013, pp. 33-34.
} 
the process of dispute resolution in international courts and arbitral organs, is by comparison overly confrontational and litigious in China's view. ${ }^{568}$

All these factors have caused China to avoid resolving disputes using those "dubious" international bodies which operate under unfamiliar and litigious rules. However, the need for economic development in recent decades required greater international cooperation with other states, deeper involvement in the world's economic system, and recognizing more international dispute settlement systems in order to boost confidence from its trade and investment partners as well as to complete China's own legal system. In 2001, China's accession to the WTO resulted in its acceptance of the compulsory dispute settlement system of the WTO, which is a milestone on the way to becoming a player in international dispute settlement. ${ }^{569}$

In brief, under the strong influence of its historical experience and traditional philosophies, China was doubtful of international law and treated international adjudication with caution or even hostility for a long period of time, jealously guarding its sovereignty against other states and international tribunals. Although China began to participate in a few binding international dispute settlement systems in recent decades, it has generally been careful to limit the scope of its obligations and the jurisdiction of such international bodies. ${ }^{570}$ To the extent China made a commitment to such an international dispute settlement system, it has done so only when the treaty itself made that mandatory. Past decades witnessed relevant changes in China's performance, but its unique historical experience and traditional attitude to international law and international adjudication still should not and cannot be neglected when analysing its performance at the international level, particularly its performance in international dispute settlement.

\subsection{China's Engagement in International Investment Dispute Settlement}

Based on the understanding of China's traditional attitude towards international law and international adjudication, this section focuses on China's engagement in international investment dispute settlement. It first introduces the historical development of China's IIAs to provide the necessary background to analyse the

\footnotetext{
568 Justice Robert F. Utter, Dispute Resolution in China, Washington Law Review, Vol. 62, 1987, p. 392.

569 Joining ICSID Convention and ratifying the United Nations Convention on the Law of the Sea (UNCLOS) are arguably not comparable to accepting the jurisdiction of the WTO's Dispute Settlement System. This is because, under the former two, a disputing state party maintains a certain control over the constitution of the tribunal, which is not the case under the latter. See: Julian Ku, China and the Future of International Adjudication, Maryland Journal of International Law, Vol. 27, 2012, p.167. In specific, the composition of WTO panels depends on the consent of the parties, while the composition of the Appellate Body division in a specific case is completely outside the influence of disputing parties. This is in contrast with international arbitration, where a disputing party can often choose its own arbitrator.

${ }^{570}$ In addition to the two examples analysed in this section, it is also noticeable that when China ratified the Vienna Convention on the Law of Treaties in 1997, it made a reservation regarding Art. 66 on submitting disputes to the International Court of Justice (ICJ). See: United Nations, Treaties and International Agreements Registered or Filed and Recorded with the Secretariat of the United Nations, I. Nos. 34026-34034, 1997, Volume 1989, I. Nos. 3402634034, p. 540. After that, China continued to enter reservations regarding the dispute settlement provisions in most of its other international agreements. See: Liyong Jiang, WTO Dispute Settlement Mechanism and China's Participation, at: China's Participation in the WTO, Cameron May, 2005, p. 303.
} 
approach China adopted to resolve the disputes under the IIAs. The two types of DSMs that are often regulated under IIAs, state-state DSMs for resolving disputes about the interpretation and application of treaty provisions and investor-state DSMs for investors to bring cases against their host states regarding alleged damages to their investment, are discussed in turn in Section 6.2.2 and Section 6.2.3. After analysing the procedural designs of these DSMs, considering the ongoing ISDS reform in the world, Section 6.2.4 looks at China's positions in various fora. The last section provides a summary and concludes.

\subsubsection{Historical Development of China's International Investment Agreements}

Since the first BIT was signed with Sweden in 1982, China has built a dense network of IIAs. As of 7 June 2019, it has entered into 146 BITs and 23 other IIAs, among which 26 are concluded with EU Member States. ${ }^{571}$

From an overview of these IIAs, their development can be generally divided into three generations. ${ }^{572}$ The first generation was between 1982-1989, during which China's position was predominantly as an investment recipient. It focused on promoting inward rather than outward investment, and correspondingly more efforts were made in protecting China as a host state instead of addressing Chinese investors that went abroad. China's first and second Model BITs were drafted in 1984 and 1989 respectively. China's IIAs entered into the second generation during 1990-1997. Compared to the previously concluded IIAs, two changes can be particularly identified in the IIAs signed in this period of time: first, national treatment was required to be provided by host states and, second, reference to the ICSID for resolving investor-state disputes became available. Such changes reflect "the increasing role of outward investment in China's economic development and the corresponding interest in effective investor protection rules and procedures for Chinese investments abroad". ${ }^{573}$ China's third Model BIT was released during this stage. Since 1998, China's IIAs have entered into the third generation. In this period of time, China gradually changed from mainly importing investment to also substantially exporting capital. In order to protect

\footnotetext{
${ }^{571}$ For a list of IIAs concluded by China, see: UNCTAD, International Investment Agreements Navigator_China, available at: https://investmentpolicy.unctad.org/international-investment-agreements/countries/42/china, last visited on 26.05.2020. In terms of the number of IIAs that are in force, China is second only to Germany, although the gap "has been closing in recent years and China looks set to overtake Germany for the top place soon". See: Norah Gallagher, China's BIT's and Arbitration Practice: Progress and Problems, at: Wenhua Shan \& Jinyuan Su (eds.), China and International Investment Law: Twenty Years of ICSID Membership, Brill | Nijhoff, 2014, p. 182. 572 The three generations of China's IIAs are widely recognized in the literature, but differences exist in the specific starting and ending years of each generation. Based on the similarity in the perspective of the analysis, here the author adopts the opinion stated in: Norah Gallagher \& Wenhua Shan, Chinese Investment Treaties: Policies and Practice, Oxford University Press, 2009, 35-43. For a further discussion on these three generations, see: Cai Congyan, China-US BIT Negotiations and the Future of Investment Treaty Regime: A Grand Bilateral Bargain with Multilateral Implications, Journal of International Economic Law, Vol. 12, 2009. Axel Berger, Investment Rules in Chinese Preferenctial Trade and Investment Agreements: Is China Following the Global Trend Towards Comprehensive Agreements, German Development Institute Discussion Paper, Vol. 7, 2013, pp. 6-12. Wenhua Shan \& Sheng Zhang, The Potential EU-China BIT: Issues and Implications, at: Marc Bungenberg \& August Reinisch \& Christian Tietje (eds.), EU and Investment Agreements: Open Questions and Remaining Challenges, Hart Publishing, 2013, p. 1. Marc Bungenberg \& Catharine Titi, The Evolution of EU Investment Law and the Future of EU-China Investment Relations, at: Wenhua Shan \& Jinyuan Su (eds.), China and International Investment Law: Twenty Years of ICSID Membership, Brill | Nijhoff, 2015, pp. 348-351.

573 Peter Malanczuk, China and the Emerging Standard of Transparency in Investor-State Dispute Settlement (ISDS), New Zealand Association for Comparative Law, Vol. 19, 2015, p. 85.
} 
its investors' interests abroad and further induce inward investment, China accepts some high-standard protection of international investment in its IIAs, such as a minimum standard of treatment. ${ }^{574}$ In 2010, China's fourth Model BIT was drafted, but it has not been officially published yet. ${ }^{575}$

It is noticeable that the IIAs concluded by China in the last decade seem to indicate a new trend. These Agreements contain more state-friendly provisions, providing host states with more room to regulate. ${ }^{576}$ Under the currently prosperous "One Belt One Road" Initiative, more IIAs are expected to be concluded with advanced substantive and procedural rules based on China's experience and the recent development in the area of international investment law. Therefore, the fourth generation of China's IIAs is arguably coming or even has already started.

\subsubsection{China's Practice of State-State Dispute Settlement Mechanisms}

State-state DSMs are designed to resolve disputes between treaty parties on the interpretation and application of certain provisions in the underlying IIAs. This section first addresses the rules on such mechanisms in China's Model BITs, followed by an examination of China's concluded treaties, including IIAs and FTAs. Since there is no publicly available information of any case under these Agreements, the analysis is only based on relevant treaty provisions. As explained in the Introduction to Part 3, supra, considering the existing practice of adopting the WTO DSU as the model for drafting provisions on state-state DSMs in IIAs and FTAs, China's practice in the WTO Dispute Settlement System is also relevant in the context of the present analysis and thus is examined accordingly.

\subsubsection{The State-State Dispute Settlement Mechanisms in China's Model Bilateral Investment Treaties}

Each of China's Model BITs incorporates mechanisms for SSDS. TABLE 6.2.2.1 provides an overview of the procedural designs of these DSMs. Based on the comparison shown in this TABLE, it is clear that barely any substantive change took place from China's first Model BIT to the fourth one. Only the China Model BIT (1997) refines the language of some of the provisions, making them more concise and clearer.

All China's Model BITs provide a two-step system to resolve disputes between contracting states concerning the interpretation and application of certain provisions: first, any dispute "shall, as far as possible, be settled with consultation through diplomatic channel". ${ }^{777}$ If it cannot be settled within six months, then, as the second step, any disputing party may resort to an ad hoc arbitral tribunal. Such a tribunal should

\footnotetext{
574 It was argued that China's third generation IIAs are the equivalent of the global new generation of IIAs, which was launched with the US and Canadian Model BITs. See: Catharine Titi, The Arbitrator as a Lawmaker: Jurisgenerative Processes in Investment Arbitration, Journal of World Investment \& Trade, Vol. 14, 2013, p. 15.

${ }^{575}$ China Model BIT (2010) has not been officially published, but the content can be found in an academic article. The discussion on this Model BIT in the present thesis is based on the information disclosed in this article. See: Xiantao Wen 温先涛, Discussion on "China Model Bilateral Investment Treaty (Draft)" 《中国投资保护协定范 本》(草案) 论稿, Journal of International Economic Law 国际经济法学刊, Vol. 18 \& 19, 2011.

576 José E. Alvarez, The Return of the State, Minnesota Journal of International Law, Vol. 20, 2011, pp. 237-238.

577 China Model BIT (1997), Art. 8.1.
} 
be composed of three arbitrators: each party chooses one and the chairman is appointed by an agreement by the parties or by the President of the ICJ. Tribunals enjoy the power and discretion to establish detailed procedural arrangements during the dispute resolution process. The awards shall be reached in accordance with the involved IIA and generally recognized international law by a majority of votes, and they shall be final and binding on disputing parties. Each disputing party bears the cost of its appointed arbitrator and representation, and other costs are to be borne by them equally. There is no provision that addresses the implementation of awards made by the tribunals. 

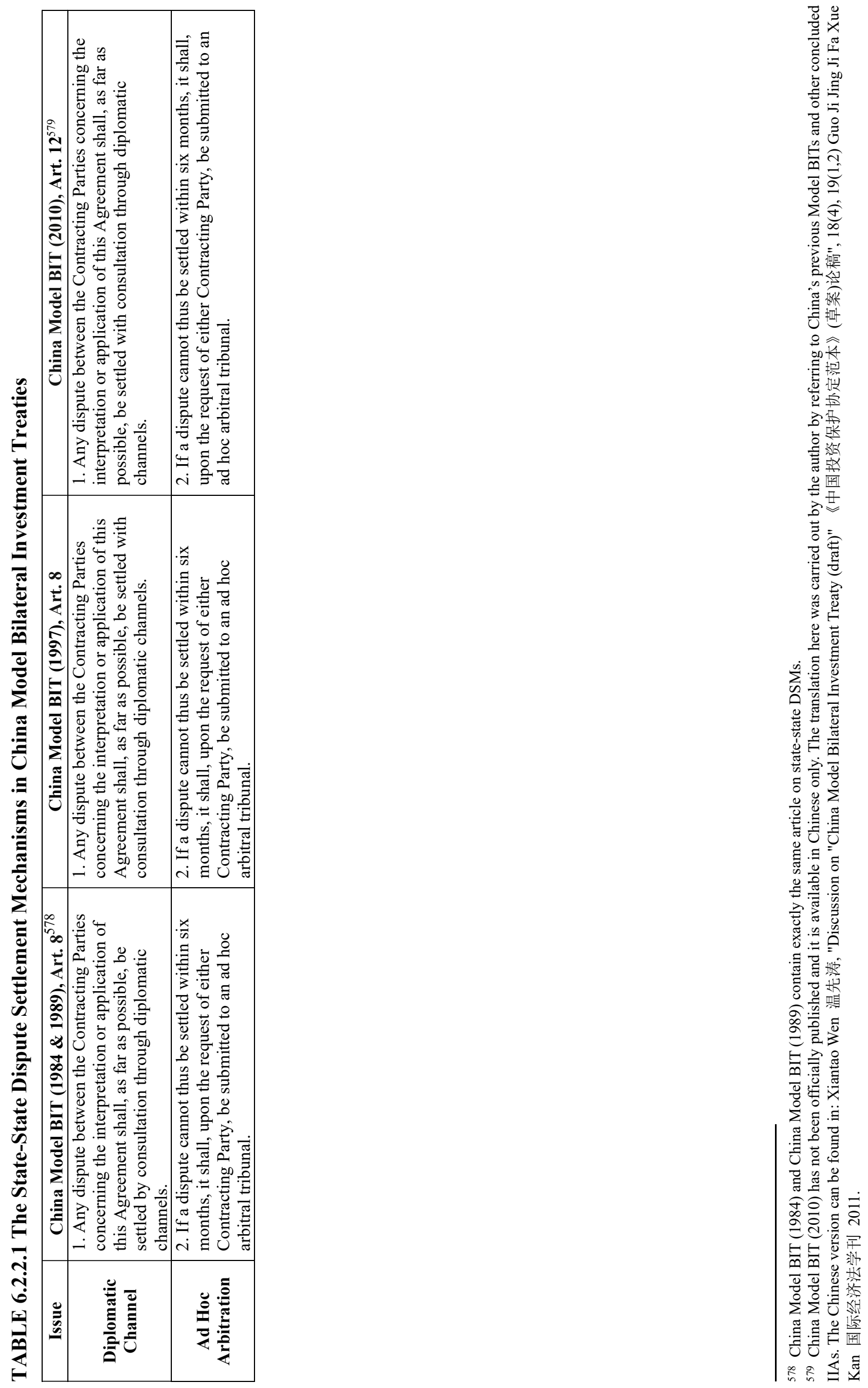


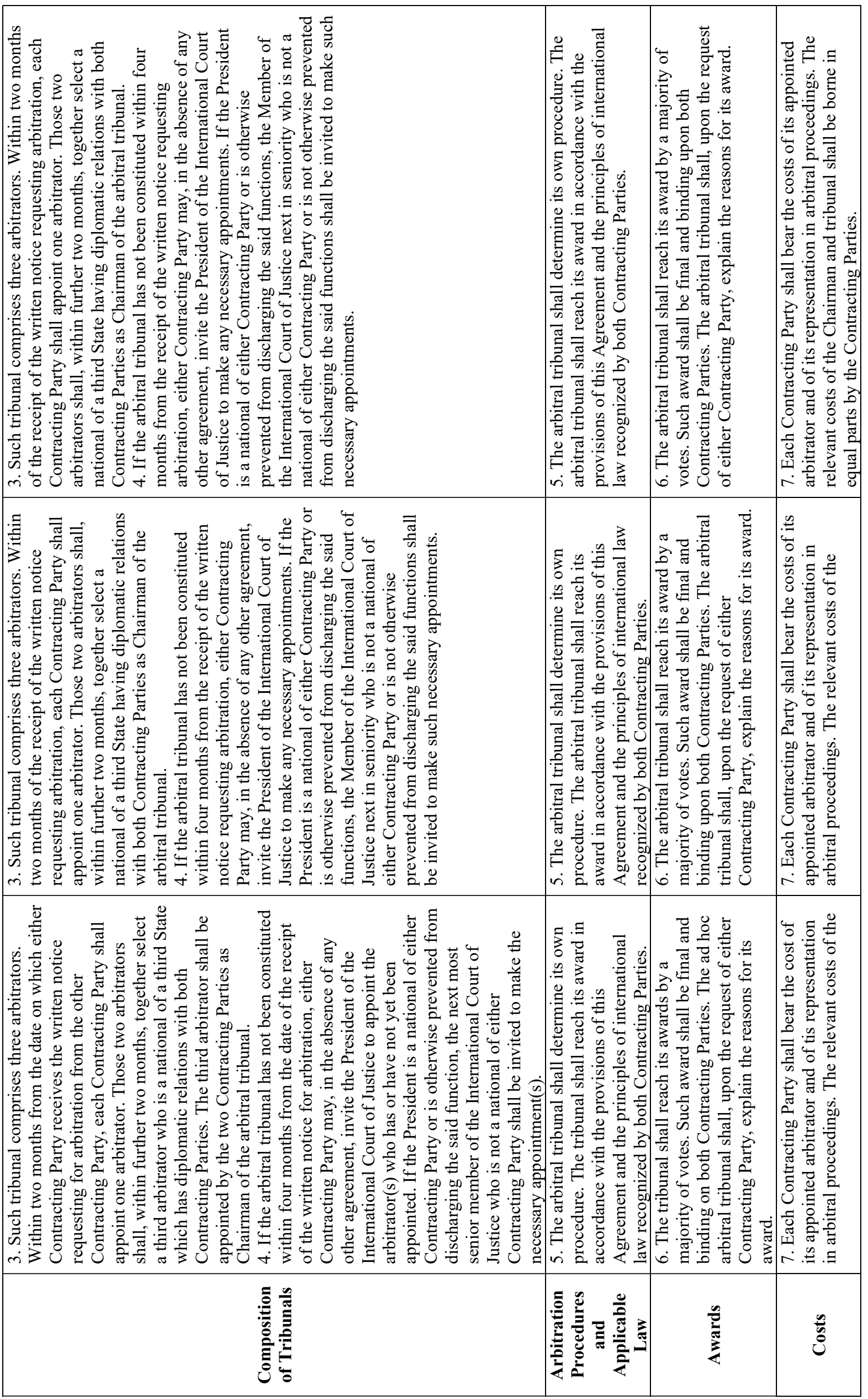




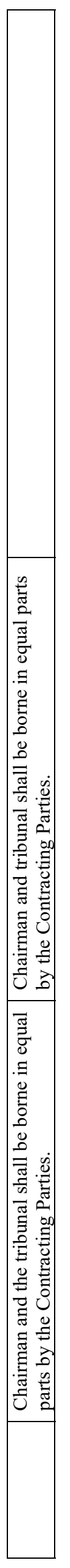

112 


\subsubsection{The State-State Dispute Settlement Mechanisms in China's International Investment Agreements}

From an overview of the state-state DSMs in China's concluded IIAs, few differences can be identified among the provisions of most of China's IIAs signed before 2015 . They actually resemble the provisions in China's Model BITs. According to the legal texts, in general, the scope of this type of DSM is defined as disputes "concerning the interpretation and application" of the treaty; consultation through the diplomatic channels shall be resorted to first, which is possibly followed by ad hoc arbitration; the tribunal is to be made up of three arbitrators with each disputing party selecting its own and the chair is chosen jointly by the two arbitrators; the tribunal enjoys the power to determine the arbitration procedures in each case, and no further guidance is provided for arbitrators in this sense. In addition, these IIAs are silent as to whether the arbitration process shall require any degree of publicity.

Despite the similarities, from a chronological perspective, some differences can also be identified. For example, newly concluded treaties often include more detailed procedural rules than those signed in the past, which can be as a result of China's accumulated experience in treaty drafting. Another noteworthy change is the disappearance of certain diplomatic elements. For example, when no agreement can be reached between disputing parties, the designated authority to appoint the chairman of a tribunal changed from the Secretary-General of the United Nations, which is a position of a diplomatic nature, to persons in international adjudication institutions with a judicial nature, such as the President of the ICJ. ${ }^{580}$ In addition, the requirement in many early IIAs that the chairman of the tribunal should be selected with the approval of the two treaty parties has disappeared in some newly concluded IIAs. ${ }^{581}$ The disappearance of these diplomatic elements can be interpreted as China's increasing confidence in international adjudication. It is noted that the conclusion of the ChinaCanada BIT (2012) brought more innovations in China's IIAs. For instance, when treaty parties fail to reach a decision on the manner in which they resolve their disputes within 60 days of the decision of an arbitral tribunal, the party bringing the dispute "shall be entitled to receive compensation of equivalent value to the arbitral tribunal's award". ${ }^{882}$ This gives tribunals the power to award financial damages, as opposed to merely answering abstract questions of treaty interpretation and application. This development can also constitute a further step in China's increasing trust in international adjudication.

The practice of using the two-step system composed of amicable negotiation and ad hoc arbitration continued until China concluded the comprehensive economic

\footnotetext{
${ }^{580}$ It is also noted that, in one recently concluded BIT, the China-France BIT (2007), the relevant choice goes back to the Secretary-General of the United Nations. See: the China-France BIT (2007), Art. 10.4.

581 See e.g. the China-Netherlands BIT (2001), Art. 9.3.

582 The China-Canada BIT (2012), Art. 15.8. This article may pertain to the arbitration of diplomatic protection claims, and/or disputes about a state's non-compliance with an earlier investor-state decision. See: Luke Eric Peterson, Analysis: A Closer Look at the Dispute Settlement Provisions of the China-Canada Investment Treaty, Including Its State-to-State Mechanism, 26.09.2012, available at: https://www.iareporter.com/articles/analysis-acloser-look-at-the-dispute-settlement-provisions-of-the-china-canada-investment-treaty-including-its-state-to-statemechanism/, last visited on 05.08.2020.
} 
agreement covering both trade and investment with Australia in 2015. Under this treaty, a system which echoes the WTO Dispute Settlement System was established for SSDS. Specifically, in addition to a general reference to amicable settlement, ${ }^{583}$ consultations are required as the precondition for resorting to adjudication. ${ }^{584}$ Each disputing party is supposed to select its own arbitrator and the two arbitrators should jointly select a third one as the chair; if any member of the tribunal is not appointed on time, either party may request the Director-General of the WTO to designate an arbitrator. ${ }^{585}$ Each stage of the proceedings must take pace withing a certain time limit. ${ }^{586}$ After hearing the case, the tribunal issues an initial report for the disputing parties to review and comment upon, which is followed by issuing a final report. ${ }^{587}$ Guidance on the implementation and the review of compliance with the tribunals' reports is also provided. ${ }^{588}$ At the same time, optional amicable mechanisms, like good offices, mediation and conciliation, are available for disputing parties. ${ }^{589}$

Using a quasi-WTO dispute settlement Dispute Settlement System for SSDS in the China-Australia FTA (2015) is likely affected by the comprehensive nature of this treaty. Thus relevant practice that can be found in FTAs is used to resolve both trade and investment SSDS here. At the same time, it also indicates to the confidence of both parties in the functioning of the WTO Dispute Settlement System in resolving disputes between states.

The state-state DSMs in the IIAs between China and EU Member States are of great relevance and deserve detailed discussion. An analysis of these DSMs is conducted in the following Chapter 8 on the China-EU investment relationship.

There has been no case under the state-state DSMs in China's IIAs. This is not an unusual situation and, in fact, under other IIAs in the world, such DSMs have also been rarely used. This is understandable, considering that the disputes concerning specific investors are not often considered worthwhile for a state to initiate an inter-state process. In addition, the existence of investor-state DSMs, which are considered more convenient and effective in resolving disputes between investors and host states, seem to be sufficiently functional. ${ }^{590}$ A particular reason for China can be that China's trade and investment treaties were concluded on the basis of inter-state political relationships, and thus diplomatic negotiation is expected to be referred to normally when disputes arise instead of adjudication. ${ }^{591}$

\footnotetext{
583 The China-Australia FTA (2015), Art. 15.1.

584 Id, Art. 15.5.

585 Id, Art. 15.7.

586 For example, the arbitral tribunal "shall present the Parties with its initial report within 90 days of appointment of the final arbitrator". See: id, Art. 15.12.

587 Id.

${ }^{588}$ Id, Arts., 15.13-15.17.

589 Id, Art. 15.6.

590 Xiantao Wen 温先涛, Discussion on "China Model Bilateral Investment Treaty (Draft)" 《中国投资保护协定 范本》(草案) 论稿, Journal of International Economic Law 国际经济法学刊, Vol. 18 \& 19, 2011, pp. 58-59.

591 Wenhua Shan, The Legal Framework of EU-China Investment Relations: A Critical Appraisal, Hart Publishing, 2005 .
} 


\subsubsection{The State-State Dispute Settlement Mechanisms in China's Free Trade Agreements}

China started to work on its FTAs since the beginning of the $19^{\text {th }}$ century. ${ }^{592}$ From the Framework Agreement of China-ASEAN FTA in 2002, as of 20 April 2020, China has signed and implemented 16 FTAs and another 24 FTAs are under construction, which include pure trade deals as well as comprehensive economic agreements covering both trade and investment with developing and developed states. ${ }^{593}$

All of China's concluded FTAs incorporate intergovernmental systems for resolving potential disputes between treaty parties regarding interpretation and application of treaty provisions. Based on their nature, these dispute settlement systems can be divided into two categories: diplomatic systems, which exist in the Special Arrangements with Hong Kong, Macau and Taipei, ${ }^{594}$ and those that combine diplomatic negotiation and ad-hoc arbitration, which appear in China's FTAs with other states. Considering the administrative relationship between mainland China and Hong Kong, Macau and Taipei, the value of these dispute settlement systems for the present thesis is limited and thus will not be further analyzed.

Despite being concluded with different states with various economic and legal backgrounds over diverse periods of time, there is a remarkable resemblance among dispute settlement systems that combine diplomatic negotiation and ad-hoc arbitration: they are built upon the structure of the WTO Dispute Settlement System with necessary amendments. ${ }^{595}$ Similar to what can be seen under the China-Australia FTA (2015), the dispute resolution process starts with consultations, followed by an ad hoc panel process, which ends with a report delivered by the panel regarding the resolution of the

\footnotetext{
592 For a further discussion on the development of China's FTAs in the past 20 years, see: Lin Zhang 张琳, The New Developments in China's FTAs 中国区域自由贸易协定的新发展, 10.02.2015, available at: http://fta.mofcom.gov.cn/article/ftazixun/201502/20454_1.html, last visited on 07.08.2020. Shuchao Henry Gao, China's Strategy for Free Trade Agreements: Political Battle in the Name of Trade, Asian Regional Workshop on Free Trade Agreements: Towards Inclusive Trade Policies in Post-crisis Asia, Bangkok, 08-09.12.2009. Jun Zhao \& Timothy Webster, Taking Stock: China's First Decade of Free Trade, University of Pennsylvania Journal of International Law, Vol. 33, 2011, pp. 65-119. Qingjiang Kong, China's Uncharted FTA Strategy, Journal of World Trade, Vol. 46, 2012. Tyler Cohen \& David Schneiderman, The Political Economy of Chinese Bilateral Investment Treaty Policy, The Chinese Journal of Comparative Law, Vol. 5, 2017.

${ }^{593}$ More information on these treaties can be found at: Ministry of Commerce of the People's Republic of China, China FTA Network, available at: http://fta.mofcom.gov.cn/english/index.shtml, last visited on 31.07.2020.

${ }_{594}$ Mainland and Hong Kong Closer Economic Partnership Arrangement (signed on 29.06.2003, entered into force on 29.06.2003), Art. 19.3; Mainland and Macau Closer Economic Partnership Arrangement (signed on 29.10.2004, entered into force on 29.10.2004), Art. 19.5; Cross-Straits Economic Framework Agreement (signed on 29.06.2010, entered into force on 12.09.2010), Arts. 10, 11.

${ }^{595}$ Marcia Don Harpaz, China and International Tribunals: Onward from the WTO, at: China in the International Economic Order: New Directions and Changing Paradigms, Cambridge University Press, 2015, p. 54. Francis Snyder, The Creation of New Sites of Governance: China, Regional Trade Agreements and WTO Law, at: The EU, the WTO and China: Legal Pluralism and International Trade Regulation, Hart Publishing, 2010, p. 365. Compared to the WTO Dispute Settlement System, the ones in China's FTAs are less formal in terms of the lack of an institutional dispute settlement body and a permanent appellate body, and they are much less detailed than the WTO equivalent. See: Weidong Zhu, The Dispute Settlement Mechanism of ASEAN Free Trade Area (AFTA) and Its Implications for $S A D C$, The first International Conference on Regional Integration and SADC Law, Maputo, 2325.04.2008. Francis Snyder, The Creation of New Sites of Governance: China, Regional Trade Agreements and WTO Law, at: The EU, the WTO and China: Legal Pluralism and International Trade Regulation, Hart Publishing, 2010, p. 387-388. It is also suggested that a possible alternative template of the DSMs in China's FTAs could be the one under the North American Free Trade Agreement (NAFTA). See: id, p. 370.
} 
dispute. ${ }^{596}$ If the content of the report is not implemented within a reasonable period of time, compensation and the suspension of concessions and obligations will be allowed. ${ }^{597}$ The panels' final reports shall be made public. ${ }^{598}$ It is noticeable that, in addition to encouraging the amicable settlement of disputes through consultation or mediation, as is available in the DSU, ${ }^{599}$ a provision stressing the use of amicable DSMs is always provided at the beginning of the dispute settlement chapter. ${ }^{600}$ This is described as the "Chinese Model" 601 and it is considered as giving priority to stronger and deeper economic cooperation and high level contact. ${ }^{602}$ No case has been brought under China's FTAs or at least no information has been reported on such complaints. Thus, it is hard to judge the function of these DSMs from a practical perspective.

The adoption of a WTO panel proceedings model for SSDS under FTAs can be seen as evidence of China's confidence and trust in that system. ${ }^{603}$ In fact, joining the WTO, especially accepting its compulsory dispute settlement system, is argued as being the turning point in China's approach to international economic dispute settlement. ${ }^{604}$

\subsubsection{China's Practice in the WTO Dispute Settlement System}

The WTO is not only a forum for promulgating and upholding international trade law, but it also provides an outstanding mechanism for resolving international trade disputes between its Member States, which is widely regarded as "the jewel in the crown". 605 Since China was admitted into the WTO in $2001,{ }^{606}$ as of 9 June 2019, it became an active participant in the WTO Dispute Settlement System, participating as a disputing party in 63 cases and reserving its third party rights in another 172 cases. ${ }^{607}$ For the purpose of the present analysis, certain features of China's participation in the WTO Dispute Settlement System deserve attention.

\footnotetext{
596 See e.g. Agreement on Dispute Settlement Mechanism of the Framework Agreement on Comprehensive Economic Co-operation between the Association of Southeast Asian Nations and the People's Republic of China (signed on 04.11.2002, entered into force on 01.07.2003), Arts. 4, 6-9.

597 See e.g. id, Arts. 12-13.

598 See e.g. id, Art. 9.9.

599 See e.g. id, Arts. 5, 8. The relevant provision in the DSU is Art. 5.

${ }^{600}$ See e.g. the China-Pakistan FTA (2009), Arts. 53.1, 54.1; the China-Iceland FTA (2013), Art. 105.

${ }^{601}$ Guiguo Wang, China's FTA Practices and Prospects, Asian WTO Research Network Seoul Meeting 2010, Seoul, 22.05.2010.

${ }^{602}$ Rajesh Sharma, China-India FTA: Is the Future Imperfect?, Journal of World Trade, Vol. 48, 2014, p. 941.

${ }^{603}$ Kuik Cheng-Chwee, Multilateralism in China's ASEAN Policy: Its Evolution, Characteristics, and Aspiration, Contemporary Southeast Aisa, Vol. 27, 2005.

${ }^{604}$ Marcia Don Harpaz, China and International Tribunals: Onward from the WTO, at: China in the International Economic Order: New Directions and Changing Paradigms, Cambridge University Press, 2015, p. 53.

605 World Trade Organization, WTO Disputes Reach 400 Mark, Press Release, 06.11.2009, available at https://www.wto.org/english/news_e/pres09_e/pr578_e.htm, last visited on 05.08.2020.

${ }^{606}$ Although China had been seeking to resume its status as a Contracting Party to the General Agreement on Tariffs and Trade (GATT) (1947) since 1986, the repeated rejection of its application by certain states meant that it only managed to do so in 1994. For more information on China's accession negotiation, see: Henry Gao, China's Participation in the WTO: A Lawyer's Perspective, Singapore Year Book of International Law, Vol. 11, 2007, pp. 18.

607 China was in the position of a complainant in 20 cases and a respondent in 43 cases. See: World Trade Organization, Disputes by Member, available at: https://www.wto.org/english/tratop_e/dispu_e/dispu_by_country_e.htm, last visited on 05.08.2020.
} 
First, China has always preferred to resort to amicable mechanisms in the WTO Dispute Settlement System, including negotiation and consultations. ${ }^{608}$ A good example of the efforts made to resolve disputes through negotiation is the case about certain measures affecting renewable energy generation between China and the EU, where China's Premier at that time, Keqiang $\mathrm{Li}$, played a decisive role in pushing forward the negotiation process and resolving the dispute eventually through amicable settlement. ${ }^{609}$ If negotiation did not work, China would continue to make full use of consultations. As stated by the MOFCOM spokesman, China was very serious about consultations. ${ }^{610}$ Although in some cases going through adjudication was unavoidable, this only happened after the Chinese government had exhausted all possible amicable avenues to eliminate differences, regardless whether China was a complainant or a respondent. ${ }^{611}$ In addition to the effectiveness and efficiency of negotiation and consultations in resolving disputes, a special impetus may have played a role in the case of China ${ }^{612}$ Considering that the WTO Dispute Settlement System is arguably the first international adjudication system with compulsory jurisdiction that China has accepted, China's traditional distrust of international adjudication may nevertheless have had an impact on its reluctance to refer disputes to the WTO Dispute Settlement System. ${ }^{613}$ China's avoidance of adjudication must also have been affected by its legal culture of pursuing harmony, and as a result, resorting to adjudication means a shameful failure of and will further cause irreparable harm to relationships. ${ }^{614}$ As argued, such a tradition should have exerted a "psychological burden" on the Chinese government when it decided to initiate a new case. ${ }^{615}$

Second, in the past 20 years, China transformed from an outsider to a main player in the WTO Dispute Settlement System. The growth of China's experience seemed to bring about a change in its perception of this system: at the beginning, China was more comfortable with the diplomatic DSMs, namely, negotiation and consultations.

\footnotetext{
${ }^{608}$ In the context of the WTO Dispute Settlement System, "negotiation" often refers to the communication between disputing parties, usually in the form of political dialogue, which may happen at any time, even before the request for consultations is raised; while the term "consultations" refers to the mandatory first stage before an adjudication process.

${ }^{609}$ Just before the EU Commission released its preliminary decision on an anti-dumping investigation with regard to Chinese relevant products, China's Premier at that time, Keqiang Li, phoned the European Commission President, José Manuel Barroso, showing his concern about the economic interests involved and expressing the hope to resolve the trade frictions through dialogue in lieu of a trade war and, in the end, peaceful settlement was reached. See: cn.chinadaily.com.cn 中国日报网, Foreign Media: Keqiang Li Promoted China-EU Negotiations on Solar to Achieve Success 外媒: 李克强促使中欧光伏谈判取得成功, 05.08.2013, available at: http://caijing.chinadaily.com.cn/2013-08/05/content_16870071.htm, last visited on 07.08.2020.

610 www.chinanews.com 中国新闻网, The Ministry of Commerce (MOFCOM) Researches on the Request for Consultations from the US and the Dispute Regarding Subsidy May Take Two Years 商务部研究美方群商请求 补 贴争端可能耗时两年, 06.02.2007, available at: http://www.chinanews.com/cj/gncj/news/2007/0206/868895.shtml, last visited on 07.08.2020.

611 Yenkong Ngangjog Hudu Qi Zhang, The Political Economy of WTO Implementation and China's Approach to Litigation in the WTO, Edward Elgar Publishing, 2016, p. 132.

612 It is admitted that the impetus to use negotiation and consultations must have been balanced by practical concerns, such as the importance of China's affected interests. See: id, p. 131. Wenhua Ji \& Cui Huang, China's Path to the Center Stage of WTO Dispute Settlement: Challenges and Responses, Global Trade and Customs Journal, Vol. 5, 2010 , p. 373.

613 X. Jiang \& S. Tan, Non-litigation Tradition in China, Legal System and Society, Vol. 4, 2008, p. 239.

${ }^{614}$ Id.

${ }^{615}$ Liyu Han \& Henry Gao, China's Experience in Utilizing the WTO Dispute Settlement Mechanism, at: Dispute Settlement at the WTO: The Developing Country Experience, Cambridge University Press, 2010, p. 166.
} 
Gradually, the adjudication by panels and the Appellate Body became more acceptable to China. In other words, the WTO Dispute Settlement System began to be considered by China as a normal tool to adjust unhealthy trade relations instead of "a means of political assault". ${ }^{616}$ China's acceptance of and participation in the WTO Dispute Settlement System was further deemed to be a "distinct departure from its past policy of avoiding international adjudication". ${ }^{617}$ Through taking part in the WTO Dispute Settlement System, China learned how to bear its international obligations and, more importantly, how to make full use of international adjudication to protect its legitimate rights. ${ }^{618}$ China's integration in the WTO also explains its growing legal assertiveness. ${ }^{619}$ Its successful experience in the WTO Dispute Settlement System is likely to affect its approaches in other areas of international economic law.

Third, China's compliance with the rulings adopted by panels and the Appellate Body has been laudable, which deserves attention particularly because of its traditional reticence to accepting international adjudication and former refusal to implement international obligations. ${ }^{620}$ In the WTO Dispute Settlement System, China has a good record of compliance with no authorized retaliation or compensation. ${ }^{621}$ This can be explained by the theory of reputation costs ${ }^{622}$ which is particularly relevant when seen

${ }^{616}$ Id, p. 168. Deming Chen 陈德铭, An In-depth Implementation of the Seventeenth Party Congress' s Spirits and a Comprehensive Inauguration of the Commercial Cause: Report by the Minister of Commerce Deming Chen at the 2008 National Business Working Conference (Exerpt) 深入贯彻党的十七大精神 全面开创商务工作新局面 一一商务部部长陈德铭在 2008 年全国商务工作会议上的报告（摘要）, Ministry of Commerce of the People's Republic of China 中华人 民 共 和 国 商 务 部 ， 21.01.2008, available at: http://www.mofcom.gov.cn/aarticle/ae/ai/200801/20080105344851.html, last visited on 07.08.2020.

${ }_{617}$ Marcia Don Harpaz, China and International Tribunals: Onward from the WTO, at: China in the International Economic Order: New Directions and Changing Paradigms, Cambridge University Press, 2015, p. 46.

${ }^{618}$ Guohua Yang \& Xiaoli Shi (eds.) 杨国华、史晓丽 编, We Are Practicing in the WTO: Collection of Essaies on Participation in the WTO Hearings 我们在WTO 打官司一一参加WTO 听证会随笔集, Intellectual Property Publishing House 知识产权出版社, 2014.

${ }^{619}$ Marcia Don Harpaz, Sense and Sensibilities of China and WTO Dispute Settlement, Journal of World Trade, Vol. 44, 2010, pp. 1155-1186.

${ }^{620}$ Regarding the assessment of a WTO Member's implementation performance, scholars have raised two issues: timeliness and quality. See: William J. Davey, Compliance Problems in WTO Dispute Settlement, Cornell International Law Journal, Vol. 42, 2009, p. 119. The present judgment of China's implementation performance is based on these two factors. Although it should be positively recognized, China's performance is not flawless. It was argued that, after 2009, the quality of China's implementation deteriorated. See: Timothy Webster, China's Implementation of WTO Decisions, at: Lisa Toohey \& Colin B. Picker \& Jonathan Greenacre (eds.), China in the International Economic Order: New Directions and Changing Paradigms, Cambridge University Press, 2015, p. 101. William J. Davey, Compliance Problems in WTO Dispute Settlement, Cornell International Law Journal, Vol. 42, 2009, pp. 103-109.

${ }^{621}$ Other major trading WTO Members, such as the EU, the US and Japan, have been challenged in compliance proceedings for the WTO consistency of their measures to implement rulings. See e.g. European CommunitiesMeasures Concerning Meat and Meat Products (Hormones), WT/DS 26; US-Measures Relating to Zeroing and Sunset Reviews, WT/DS 322; Japan-Measures Affecting the Importation of Apples, WT/DS 245. It was argued that, compared to its international obligations in other areas, China had taken the compliance with WTO rulings as the "standard conduct to follow", which can be described as outstanding. See: Marcia Don Harpaz, China and International Tribunals: Onward from the WTO, at: China in the International Economic Order: New Directions and Changing Paradigms, Cambridge University Press, 2015, p. 60. Marcia Don Harpaz, China and International Tribunals: Onward from the WTO, at: Lisa Toohey \& Colin Picker \& Jonathan Greenacre (eds.), China in the International Economic Order - New Directions and Changing Paradigms, Cambridge University Press, 2015, p. 60. Timothy Webster, China's Implementation of WTO Decisions, at: China in the International Economic Order: New Directions and Changing Paradigms, Cambridge University Press, 2015, p. 110.

${ }^{622}$ It was pointed out that reliability is communicated through action and reputation is constructed based on consistent reliable behaviour, which works especially well in the context of multilateral treaties. See: Joel Sobel, $A$ Theory of Credibility, Review of Economic Studies, Vol. 52, 1985, pp. 557-573. In terms of the easy flow of information and public discussion nowadays, the reputation costs of violating international obligations are arguably 
in the context of Confucianism to explain China's performance. ${ }^{623}$ Under the influence of Confucianism, China has a tradition of "saving face", which is closely related to reputation. International reputation is a significant element that the Chinese government cares about, thus a bad reputation coming from non-compliance would cause the Chinese government to feel humiliated and "lose face".

At the same time, China's legal culture on dispute settlement may also explain three other phenomena: China's frequent appearance as a third party, the passive participation of Chinese private entities in WTO-related affairs, ${ }^{624}$ and China's attitude towards transparency in the WTO Dispute Settlement System. First, China has been actively participating in the WTO Dispute Settlement System as a third party. In addition to the need to learn at the beginning, ${ }^{625}$ China's appearance in almost all relevant cases may also be attributed to its traditional preference for avoiding confrontational ways of resolving disputes. ${ }^{626}$ Second, the passive participation of Chinese industries could be explained by the consistent pursuit of harmony, the traditional reluctance to be "trouble-makers", and their view of participating in WTO dispute settlement as being the job of the Chinese government and outside the remit of private parties' business. ${ }^{627}$ This can also be supported by the fact that the Chinese government seldom released information on its own legal arguments in WTO cases, citing confidentiality concerns. ${ }^{628}$ In this vein, the Chinese government's rejection of greater transparency in the WTO Dispute Settlement System should also be understandable: ${ }^{629}$ the Dispute Settlement System is an inter-governmental system and

increasing. See: John H. Jackson, The World Trading System: Law and Policy of International Economic Relations (2nd Edition), The MIT Press, 1997, p. 170.

${ }^{623}$ Yenkong Ngangjog Hudu Qi Zhang, The Political Economy of WTO Implementation and China's Approach to Litigation in the WTO, Edward Elgar Publishing, 2016, pp. 81-88.

${ }^{624}$ This can be evidenced by how rare it is for Chinese private entities to resort to the trade barrier investigation (TBI) mechanism established by the Chinese government. China's TBI mechanism was initially created in 2002 by learning from the experience of other WTO Members, especially the EU and the US. Through participating in the procedures of gathering, processing and prioritizing information, domestic industries could collaborate with the government to challenge foreign trade barriers through this mechanism. Until now, China's TBI mechanism was only resorted to once, in 2004.

${ }^{625}$ According to the DSU, third parties undertake no potential responsibility or compulsory work, thus frequent participation as a third party was a great opportunity for China to gain knowledge of the substantive and procedural laws in the WTO.

${ }^{626}$ Acting as a third party gives China the chance to express its relevant concerns without directly being up against other WTO Members.

627 Wenhua Ji \& Cui Huang, China's Path to the Center Stage of WTO Dispute Settlement: Challenges and Responses, Global Trade and Customs Journal, Vol. 5, 2010, p. 376. It is noticed that, in recent years, there seems to be an increase of the indirect participation of Chinese companies or industry associations in WTO cases, which resonates with the increasing legal awareness of Chinese society, although how such a change would operate in concrete WTO cases remains to be seen.

${ }^{628}$ Liyu Han \& Henry Gao, China's Experience in Utilizing the WTO Dispute Settlement Mechanism, at: Dispute Settlement at the WTO: The Developing Country Experience, Cambridge University Press, 2010, p. 165.

${ }^{629}$ According to the DSU, dispute settlement proceedings are confidential for the disputing parties and third parties to a dispute. See: Understanding on rules and procedures governing the settlement of disputes, Arts. 17.10, 18. Transparency in the WTO Dispute Settlement System means opening up the dispute resolution proceedings either to the public or to other WTO Members. See: World Trade Organization, Hong Kong Briefing Notes-Briefing Notes on the Ministerial and the Main Issues, 2005, available at: https://www.wto.org/english/thewto_e/minist_e/min05_e/brief_e/brief00_e.htm, last visited on 05.08.2020. During the Sixth WTO Ministerial Conference in Hong Kong in 2005, the issue of transparency in the WTO Dispute Settlement System was listed in the draft legal text circulated by the chairman of the negotiations and was actively negotiated by WTO Members. However, China found the proposal of increasing transparency unacceptable. See: Bryan Mercurio, Improving Dispute Settlement in the World Trade Organization: The Dispute Settlement Understanding Review-Making it Work?, Journal of World Trade, Vol. 38, 2004, p. 847. 
thus it should not be open to the public in any regard. ${ }^{630}$ Such an objection to enhancing transparency in the WTO Dispute Settlement System may also relate to China's practice of "saving face" through reducing the exposure of existing disputes to the public.

\subsubsection{China's Practice of Investor-State Dispute Settlement Mechanisms}

In addition to state-state DSMs, IIAs may also provide investors with mechanisms to resolve investment disputes with their host states directly. Both China's Model BITs and its concluded IIAs follow this practice. In addition, different from the situation of state-state DSMs, cases under China's IIAs are also introduced and illustrated in the this section. Last but not least, against the background of the ongoing worldwide ISDS reform, China's attitude towards the various issues that have been presented also deserves attention in this analysis.

\subsubsection{The Investor-State Dispute Settlement Mechanisms in China's Model Bilateral Investment Treaties}

All China's four Model BITs incorporate mechanisms for ISDS. Different from the similarity among the state-state DSMs, a clear divergence can be identified in China's Model BITs regarding investor-state DSMs. The transformation of investor-state DSMs in China's Model BITs mirrors the generational changes that are consistent with China's evolving foreign investment aspirations. ${ }^{631}$ TABLE 6.2.3.1 provides details of the relevant provisions and presents a comparison of them. The key features of each of these Model BITs are analysed in the following.

\section{(i) China's Model Bilateral Investment Treaties (1984 \& 1989)}

China's first and second Model BITs were adopted in 1984 and 1989 respectively. Regarding the provisions on ISDS, these two versions include exactly the same Article 9. According to this Article, settlement through negotiation is stressed as the compulsory first step in resolving any investment dispute between an investor and its host state, which shows a desire for an amicable settlement. If the dispute cannot be settled through negotiation, after six months, either party is entitled to submit the dispute to the competent court of the host state. Investor-state arbitration is only available for disputes in relation to amounts of compensation for expropriation which have not already been brought before the competent domestic court. As a result, the door to international arbitration is only open for a very limited group of disputes, while other issues are left to the jurisdiction of domestic courts. This approach shows that China had quite a cautious attitude towards investor-state arbitration at that time. The underlying reasons for this may include China's perception of arbitral awards relating to expropriation as "an infraction on its sovereignty". ${ }^{632}$ Furthermore, since China was not a member of the ICSID Convention when its first and second model BITs were

\footnotetext{
${ }^{630}$ Bryan Mercurio, Improving Dispute Settlement in the World Trade Organization: The Dispute Settlement Understanding Review-Making it Work?, Journal of World Trade, Vol. 38, 2004 , p. 847.

${ }^{631}$ Leon E. Trakman, Geopolitics, China, and Investor-State Arbitration, at: Lisa Toohey \& Colin Picker \& Jonathan Greenacre (eds.), China in the International Economic Order: New Directions and Changing Paradigms, Cambridge University Press, 2015, p. 271.

632 Id, p. 272.
} 
drafted, only ad hoc arbitration was mentioned. Article 9 also provides basic procedural rules on certain aspects of investor-state arbitration proceedings, such as composition of tribunals, applicable law, decision making, and allocation of costs.

\section{(ii) China's Model Bilateral Investment Treaty (1997)}

In 1997, China published its third Model BIT. This Model BIT basically inherits the structure of the provision on ISDS in China's first two Model BITs, providing negotiation, domestic remedies and international arbitration as possible options. Specifically, first, the importance of amicable settlement through negotiation is recognized and it is considered a compulsory stage. Second, for the disputes which cannot be settled through bilateral mechanisms within six months, the right to choose from the competent court of the host state and ICSID is granted to the aggrieved investors through a fork-in-the-road clause, ${ }^{63}$ subject to possible domestic administrative review procedures specified by the laws and regulations of any treaty party as a precondition to initiating arbitration. It is noticeable that the limit on the subject matter for international arbitration is eliminated. In other words, this Model BIT accepts investor-state arbitration for all legal disputes, instead of limiting the scope to disputes related to the amount of compensation for expropriation. This represents a new era of the practice of ISDS in China, reflecting its enhanced readiness to endorse international mechanisms for liberalizing investment. One possible reason for this change is that China's outflow investment had increased quickly and substantially. As a result, the focus of ISDS is not only on protecting China as a host state, but it is also on providing Chinese investors with sufficient protection for their investments abroad. The rules on applicable law and the binding effect of awards are the same as those stated in China's first two Model BITs. Other procedural issues are not particularly regulated, probably because they are already covered by ICSID Arbitration Rules. Thus, Articles 9.4-9.8 from China's Model BITs (1984 \& 1989) are not available in China's Model BIT (1997).

\section{(iii) China's Model Bilateral Investment Treaty (2010)}

In the China's Model BIT (2010), Article 13 establishes rules on ISDS. Compared to China's previous Model BITs, this 2010 version is more detailed. ${ }^{634}$ First, the compulsory six-month period for amicable settlement as the initial step in dispute settlement is still provided. It is noticeable that this 2010 Model BIT expressly pointed out the possibility of realizing settlement through mediation, which was not available in the previous versions. For any dispute that cannot be settled in six months, the investor can resort to the competent court of the host state, ICSID arbitration, ad hoc arbitration under the UNCITRAL Arbitration Rules, or other arbitration or ad hoc

\footnotetext{
${ }^{633}$ A "fork-in-the-road" clause in IIAs refers to the regulation providing that investors must make a choice between pursuing their claims either through international arbitration, local courts or other venues provided for in the relevant agreement. See: Norton Rose Fulbright, Fork-in-the-Road Clauses-Divergent Paths in Recent Decisions, 10.2015, available at: https://www.nortonrosefulbright.com/en/knowledge/publications/0bd10ad8/fork-in-the-road-clauses, last visited on 01.08.2020. Rudolf Dolzer \& Christoph Schreuer, Principles of International Investment Law (Second Edition), 2nd edition, Oxford University Press, 2012, pp. 267-268.

${ }^{634}$ Xiantao Wen 温先涛, Discussion on "China Model Bilateral Investment Treaty (Draft)" 《中国投资保护协 定范本》(草案) 论稿, Journal of International Economic Law 国际经济法学刊, Vol. 18 \& 19, 2011, p. 58.
} 
tribunals based on agreement by the parties. ${ }^{635}$ Such a choice shall be final. This Model BIT continues the practice of China's Model BIT (1997) by opening international arbitration to all legal disputes. However, at the same time, a time limit of three years "since the investor first knew or should have known the event that the dispute arose from" is introduced as a precondition for submitting a dispute to international arbitration. One noticeable change in the applicable law is that party autonomy is recognized, which means tribunals shall first look at the law chosen by the disputing parties. In the absence of such an agreement, "the law of the Contracting Party to the dispute accepting the investment including its rules on the conflict of laws, as well as the applicable international law, especially this Agreement" will come into play. In the case where any conflict exists between the disputed IIA and applicable arbitration rules, the regulation in the IIA shall prevail. If any violation of the IIA is found, tribunals may only award monetary damages with suitable interest and/or require the original property to be returned to investors. This excludes the possibility of requiring host states to change the disputed regulating measures. The award shall be final and binding upon both disputing parties and treaty parties shall commit to the enforcement of awards. Regarding allocation of costs, the practice of equal allocation used in China's previous Model BITs is kept as the default rule, with some additional discretion granted to tribunals, especially when it finds that the claims or objections raised by one disputing party are reckless.

${ }^{635}$ Some scholars described this as "a traditional European model". See: Jun Xiao, How Can a Prospective ChinaEU BIT Contribute to Sustainable Investment: In Light of the UNCTAD Investment Policy Framework for Sustainable Development, Journal of World Energy Law and Business, Vol. 8, 2015, p. 526. 


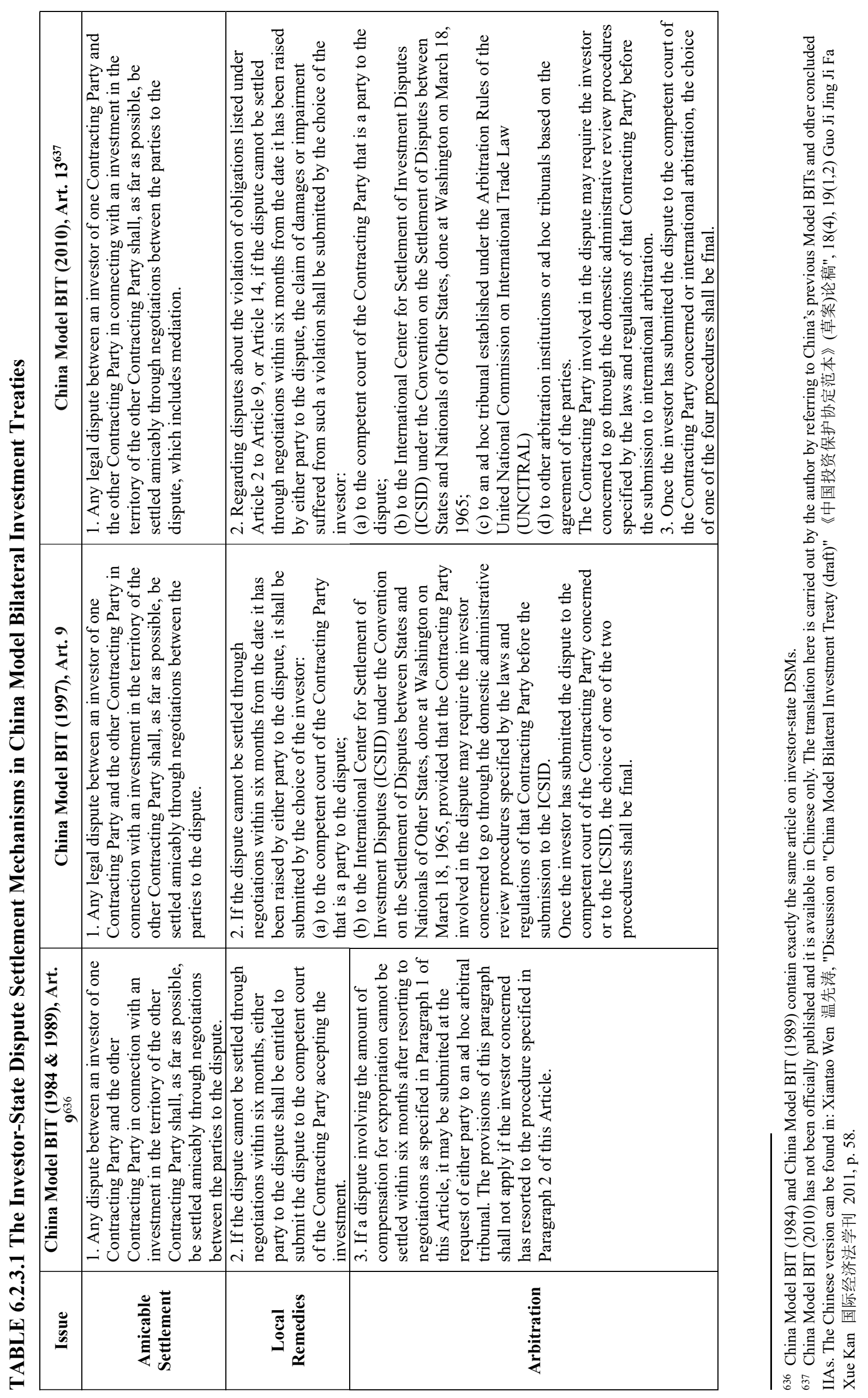




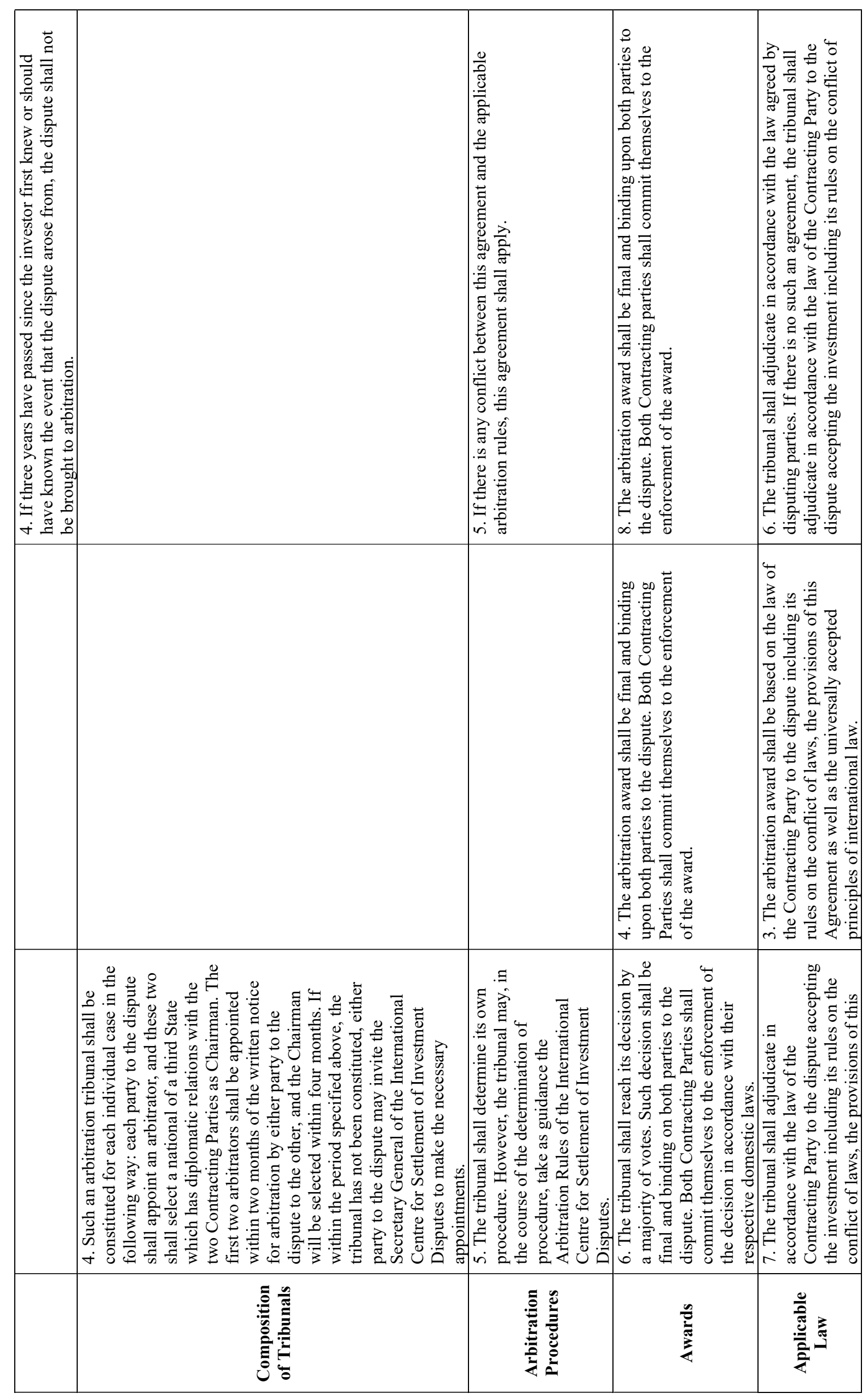




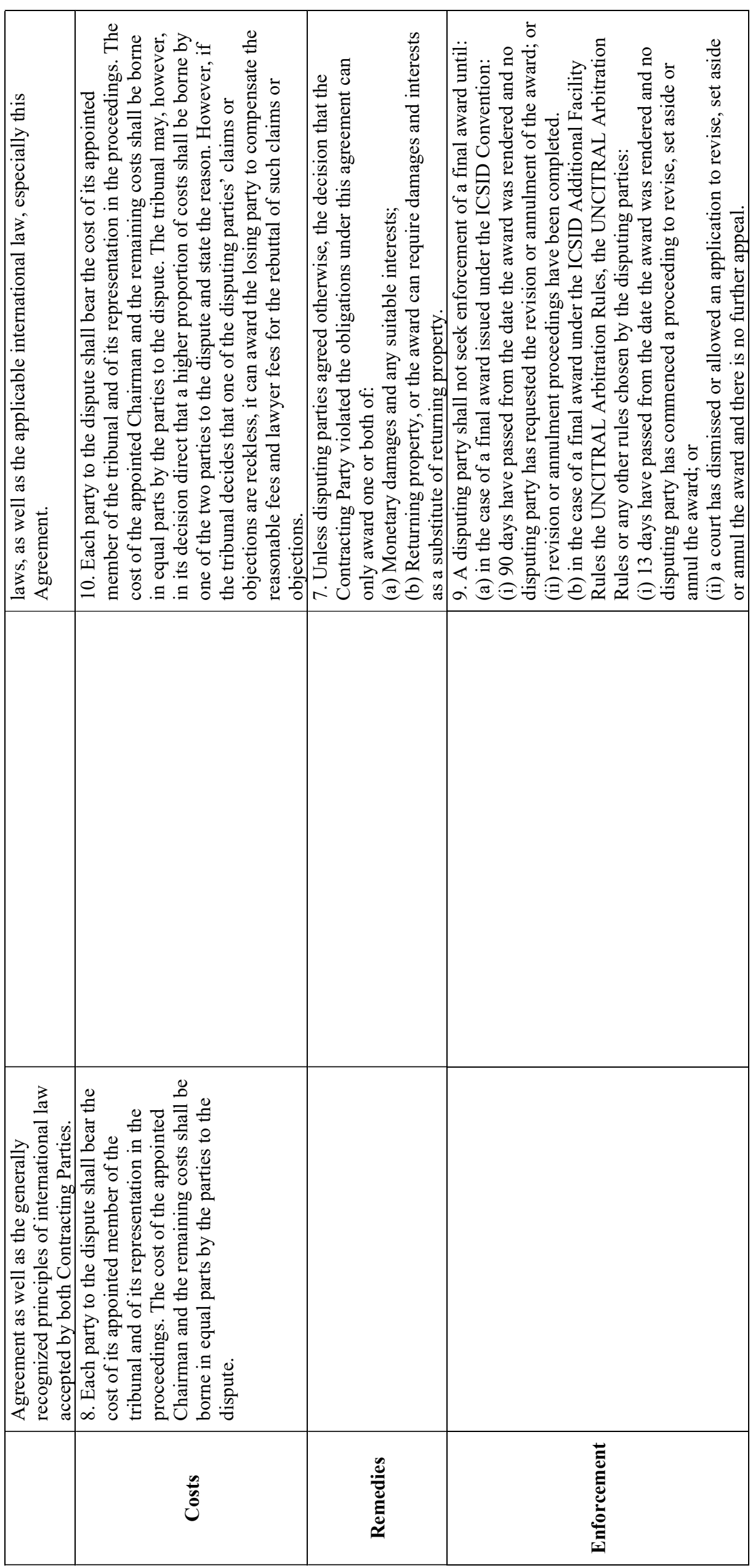




\subsubsection{The Investor-State Dispute Settlement Mechanisms in China's International Investment Agreements}

In general, the differences among the investor-state DSMs in China's various IIAs respond to the transformation in China's Model BITs, symbolically reflected in the change of China's attitude towards investor-state arbitration. ${ }^{638}$ According to China's different attitudes to international arbitration for ISDS, the development process of the investor-state DSMs in China's IIAs can be divided into three stages: before 1996, 1997-2009 and after 2010.

This section aims at providing an overview of the key features of the IIAs concluded by China at the three development stages. As state-state DSMs, the IIAs between China and EU Member States are more relevant to the subject of the present thesis and thus deserve a separate analysis, which can be found in Section 9.3.2, infra.

(i) Stage One: No or Limited Acceptance of Investor-State Arbitration (1982-1996)

The primary goal of investor-state DSMs as protecting China as a host state are reflected not only in China's first and second Model BITs but also in the IIAs concluded during its first development stage from 1982 to 1996. Regarding the provisions on ISDS in the IIAs concluded by China at this stage, a clear similarity to China's Model BITs (1984 \&1989) can be identified. This is typically evidenced by the fact that investorstate arbitration is only available for disputes about the amount of compensation for expropriation, while other disputes should be resolved locally. Foreign investors' limited rights in this regard indicate China's lack of sufficient impetus for making efforts in protecting investors, as well as its cautious attitude towards international adjudication.

Regarding other issues in ISDS, the regulations on the applicable law in these early BITs deserve attention. Some of them are silent on this issue. Some provide that the disputes should be governed by the domestic law of the host state, provisions of the BIT at issue and generally accepted principles of international law adopted by both parties. It was argued that the qualifying phrase of "adopted by both parties" shows that "traditional' rules of international law, in which China had not participated, would not be applied". ${ }^{639}$ Some later BITs signed at this stage made improvements on this issue by simply stipulating "principles of international law" without the qualifying phrase used before. ${ }^{640}$ Such a development was argued as being of great significance, "as it shows that China has become more confident in and more willing to accept general international law". ${ }^{641}$

\footnotetext{
${ }^{638}$ The change of China's attitude towards investor-state arbitration was argued to be the watershed, or at least an important landmark in China's IIA development. See: Jun Xiao 肖军, The Investor-State Dispute Settlement Mechanism in a China-EU BIT: A Comparative Analysis Based on the China-Canada BIT and CETA 中欧 BIT 的 投资者-东道国争端解决机制一一基于中加 BIT 与 CETA 的比较分析, Journal of Xidian University (Social Science Edition) 西安电子科技大学学报(社会科学版), Vol. 25, 2015, p. 77.

${ }^{639}$ Wenhua Shan, The Legal Framework of EU-China Investment Relations: A Critical Appraisal, Hart Publishing, 2005, p. 216.

${ }^{640}$ See e.g. the China-Morocco BIT (1995), Art. 9.6.

641 Wenhua Shan, The Legal Framework of EU-China Investment Relations: A Critical Appraisal, Hart Publishing,
} 


\section{(ii) Stage Two: Overall Acceptance of Investor-State Arbitration (1997-2009)}

China's new membership of the ICSID Convention since 1993 and the overall acceptance of international arbitration without limiting the subject matter of the disputes brought about changes to corresponding provisions in China's IIAs. The first IIA in which international arbitration was expanded to all investment disputes is the China-Barbados BIT (1998), after which adopting international arbitration for ISDS, particularly ICSID arbitration, seems to have become China's mainstream practice. In particular, the 11 IIAs concluded between China and EU Member States at this stage reflect China's approach to investor-state arbitration without exception. The elimination of restrictions on the subject matter and the overall adoption of ICSID started a new era of ISDS under China's IIAs.

\section{(iii) Stage Three: Revised Acceptance of Investor-State Arbitration (2010-)}

In general, compared to China's practice in the past, most of the IIAs that belong to this third stage provide more detailed regulations. ${ }^{642}$ The features of the investor-state DSMs in China's Model BIT (2010) are reflected in some of its IIAs signed after 2010, such as the China-Uzbekistan BIT (2011). However, different from the situation in the past, more differences among the IIAs can be identified at this stage. More noticeably, some IIAs concluded between China and certain developed countries present great differences with the China Model BIT drafted in this period of time. For example, in 2012, China concluded a comprehensive and progressive BIT with Canada, ${ }^{643}$ which was described by MOFCOM as "different from the other existing investment treaties between China and other parties, reflecting the trend of international investment agreement". ${ }^{644}$ The provisions on ISDS in this treaty have many similarities with the Canadian Model Foreign Investment Promotion and Protection Agreement (hereinafter "Canadian Model FIPA"), ${ }^{645}$ which thus presents China's general open and flexible attitude towards accepting its treaty partners' preferred practice. ${ }^{646}$

\footnotetext{
2005, p. 216.

642 For instance, they often contain specific provisions on tribunal constitution, consolidation, costs, and transparency. See: Elodie Dulac, The Emerging Third Generation of Chinese Investment Treaties, Transnational Dispute Management, 2010, available at: https://www.transnational-disputemanagement.com/article.asp?key=1636, last visited on 01.08.2020.

${ }^{643}$ For a further discussion on selected substantive and procedural provisions in the China-Canada BIT (2012), see: Luke Eric Peterson, China-Canada Bilateral Investment Treaty Unveiled: A First Look at the Provisions of Longdelayed Pact, 26.09.2012, available at: https://www.iareporter.com/articles/china-canada-bilateral-investmenttreaty-unveiled-a-first-look-at-the-provisions-of-long-delayed-pact/, last visited on 05.08.2020.

${ }^{644}$ Ministry of Commerce of the People's Republic of China, Interpretation of China-Canada Bilateral Investment Protection Agreement by An Official from the Department of Treaty and Law of MOFCOM, 13.09.2012, available at: http://English.mofcom.gov.cn/article/policyrelease/Cocoon/201209/20120908359187.shtml, last visited on 31.07.2020.

${ }^{645}$ For example, certain tax measures, environmental measures and cultural industries are carved out of the investorstate dispute settlement system. For more discussion on this, see: Norah Gallagher, China's BIT's and Arbitration Practice: Progress and Problems, at: China and International Investment Law: Twenty Years of ICSID Membership, Brill | Nijhoff, 2014, p. 185.

${ }^{646}$ This can also be evidenced by the different rules on the same issue in China's other IIAs. For example, whether investors are allowed to submit disputes to international arbitration after they resort to domestic courts but withdraw such a reference before a binding decision is issued is regulated differently in the China-New Zealand FTA (2008) and the China-Japan-Korea Investment Agreement (2012), and the relevant provisions seem to follow the preferred approaches of New Zealand, and Japan and Korea.
} 
More recently, the conclusion of the China-Australia FTA (2015) further introduces some new practices into China's IIAs. First, the jurisdiction of the investor-state DSMs under this treaty is relatively limited. ${ }^{647}$ This is understandable considering the fact that this Agreement was negotiated at a time of strong resistance in Australia to the inclusion of an ISDS clause in FTAs or IIAs. ${ }^{648}$ At the same time, China's acceptance of such an approach may be caused by other elements, such as the inexperience of Chinese investors in investment arbitration. ${ }^{649}$ Second, this Agreement provides for a compulsory consultation process for ISDS, if necessary, to be followed by an arbitration under ICSID, the ICSID Additional Facility Rules, UNCITRAL arbitration rules, or any other rules agreed upon by parties. ${ }^{650}$ In addition, the treaty specifies that, except for certain exceptions, arbitral proceedings shall be conducted in public, and third parties may make amicus curiae submissions. ${ }^{651}$ There is also a provision for claims to be subject to preliminary objections and disposed of promptly. ${ }^{652}$ Furthermore, this treaty envisions the establishment of an appellate mechanism, which constitutes a further step regarding the recognition of international adjudication in practice in China. ${ }^{653}$

\subsubsection{Investment Cases under China's International Investment Agreements}

China's fast progress in negotiating and concluding IIAs did not equally bring about its active participation in investor-state arbitration, even with the overall acceptance of this DSM in its IIAs in the late 1990s. Although the caseload of investor-state arbitration worldwide exploded since $2000,{ }^{654}$ as of 30 April 2020, there are only eight publicly available treaty-based investor-state arbitration cases involving China or Chinese investors (including the cases in which investors come from mainland China, Hong Kong, Macau, and Taiwan). ${ }^{655}$ Among these eight cases, two cases were discontinued; one case is pending, and the other five cases have been concluded with awards. TABLE

\footnotetext{
${ }^{647}$ Under the China-Australia FTA (2015), investor-state DSMs are limited to breaches of national treatment which result in alleged loss or damage. Measures that are non-discriminatory and for the legitimate public welfare objectives are not eligible to be brought to international arbitration. Under such circumstances, the respondent may serve a "public welfare notice" to the complaining party so as to trigger a state-state consultation process and exclude the application of ISDS. See: the China-Australia FTA (2015), Arts. 9.11, 9.18. Regarding more discussion on this, see: Ashurst Australia, Bull in a China Shop? The Investor-State Dispute Settlement Provisions of the ChinaAustralia Free Trade Agreement, 23.06.2015, available at: https://www.ashurst.com/en/news-and-insights/legalupdates/bull-in-a-china-shop/, last visited on 30.07.2020.

${ }^{648}$ For a further discussion on Australia's policy changes on ISDS, see e.g. Jürgen Kurtz, Australia's Rejection of Investor-State Arbitration: Causation, Omission and Implication, ICSID Review, Vol. 27, 2012, p. 65. Leon E. Trakman, Investor-State Arbitration: Evaluating Australia's Evolving Position, The Journal of World Investment \& Trade, Vol. 15, 2014, p. 152.

${ }^{649}$ For a further discussion on the reasons of China's reluctance to resort to investor-state arbitration, see: Karl P. Sauvant \& Michael D. Nolan, China's Outward Foreign Direct Investment and International Investment Law, Journal of International Economic Law, Vol. 18, 2015, pp. 931-933.

${ }^{650}$ The China-Australia FTA (2015), Arts. 9.11, 9.12.

${ }^{651}$ Id., Arts. 9.16.3, 9.17.

${ }^{652}$ Id., Art. 9.16.5.

${ }^{653}$ Id., Art. 23.

${ }^{654}$ International Centre for Settlement of Investment Disputes (ICSID), The ICSID Caseload-Statistics (Issue 20161), 2016, available at: https://icsid.worldbank.org/en/Documents/resources/ICSID\%20Web\%20Stats\%2020161\%20(English)\%20final.pdf, last visited on 03.08.2020.

655 The statistics here are based on the information published by the ICSID's and Italaw's websites, which may not count in all the existing investment arbitration cases involving China or Chinese investors, since information on ad hoc arbitration is not always public.
} 
6.2.3.3 provides the basic information of these cases, and a detailed discussion is provided in the following.

\section{(i) Cases against China}

\section{Ekran Berhad v. People's Republic of China}

The first ICSID case ever brought against China was the Ekran case, filed in May 2011. ${ }^{656}$ Ekran, a Malaysian construction and development company, claimed a breach of the China-Malaysia BIT (1988) because of a revocation by a local government of its construction license, which was argued amounted to expropriation. However, just two months after filing the claim, the case was suspended by mutual agreement even before a tribunal was nominated, and two years later the dispute was finally settled privately. ${ }^{657}$ The terms of the settlement are not known to the public. ${ }^{658}$ Given the absence of a public statement concerning the reasons for the settlement of the case and the withdrawal of the claim, it is difficult to draw a definitive conclusion. However, it was argued that one clear inference here is that "inbound investors may perceive that China would be a tenacious adversary, that China could protract and raise the costs of investor claims, and that it could invoke its regulatory authority to terminate a claimant's investment in China". 659

\section{Ansung Housing Co. Ltd. v. People's Republic of China}

The second case against China was brought on 4 November 2014 by Ansung Housing Co. Ltd., a South Korean property developer. ${ }^{660}$ Ansung had invested in the development of a golf and country club and condominiums in various Chinese cities. It alleged that the provincial government frustrated its investment plan and illegally deprived it of its investment and thus breached the China-Korea BIT (2007). On the other side, China referred to ICSID Arbitration Rule 41(5) arguing for an early dismissal of the claims since they were "manifestly without legal merit" and asked the tribunal to render an award under ICSID Arbitration Rule 41(6). On 9 March 2017, the tribunal decided that Ansung's claims were time-barred and thus the case was dismissed. ${ }^{661}$

\section{Hela Schwarz GmbH v. People's Republic of China}

\footnotetext{
${ }^{656}$ Ekran Berhad v. People's Republic of China, ICSID Case No. ARB/11/15. For an academic discussion on this case, see e.g. Tong Qi, How Exactly Does China Consent to Investor-State Arbitration: On the First ICSID Case against China, Contemporary Asia Arbitration Journal, Vol. 5, 2012, pp. 265-291.

${ }^{657}$ On 16 May 2013, the Secretary-General of ICSID issued a procedural order taking note of the discontinuance of the proceeding pursuant to ICSID Arbitration Rule 43(1).

${ }^{658} \mathrm{Had}$ the arbitration claim proceeded, the tribunal would need to determine issues including whether it had jurisdiction to decide the compensation claim arising from an expropriation.

${ }^{659}$ Leon E. Trakman, Geopolitics, China, and Investor-State Arbitration, at: China in the International Economic Order: New Directions and Changing Paradigms, Cambridge University Press, 2015, p. 279.

${ }^{660}$ Ansung Housing Co. Ltd. v People's Republic of China, ICSID Case No. ARB/14/25. For some academic discussions on this case, see: Alison Ross \& Lacey Yong, China Faces Second ICSID Claim, Global Arbitration Review (GAR), 07.11.2014, available at: https://globalarbitrationreview.com/article/1033850/china-faces-secondicsid-claim, last visited on 05.08.2020.

${ }_{661}$ Ansung Housing Co, Ltd v People's Republic of China, ICSID Case No. ARB/14/25, Award, 9 March 2017.
} 
On 21 June 2017, a German spice products company, Hela Schwarz GmbH, registered a case under ICSID Convention and Arbitration Rules against China. ${ }^{662}$ Hela had been operating in the city of Jinan since 1996 as a joint-venture with a local meat processing company, which was transferred to German ownership in 1999. This case is currently pending. The recent update of this case is the tribunal's Procedural Order No. 4 concerning Hela's request to amend the request for arbitration. No information about the content of the claims has been released to the public.

\section{(ii) Cases brought by Chinese Investors}

\section{Tza Yap Shum v. Republic of Peru}

The first instance involving a Chinese investor is Tza Yap Shum v. Peru based on an alleged breach of the China-Peru BIT (1994). ${ }^{663}$ Tza Yap Shum is a Hong Kong resident with Chinese nationality, ${ }^{664}$ investing and doing business as a fish flour manufacturer and exporter in Peru. In this case, Tza Yap Shum alleged that a number of measures taken by the tax authority of Peru constituted an indirect expropriation of his investment. Interesting jurisdictional issues were raised before the process proceeded to substantive disputes, including whether a Hong Kong resident was qualified to rely on investor protection under the China-Peru BIT (1994), whether the prescribed waiting period of six months for an amicable settlement had taken place, and whether the claimant was required to exhaust local remedies before proceeding to investor-state arbitration under the applicable treaty. The tribunal affirmed its jurisdiction in 2009 and ultimately rendered a final award on merits in 2011. It adopted an activist stance in ruling that the provision in Article 8(3) of the China-Peru BIT (1994) "involving the amount of compensation for expropriation" included a determination of whether the property was actually expropriated and awarded Tza Yap Shum a fraction in damages and interest of the amount claimed. ${ }^{665}$ The annulment request initiated by Peru was dismissed on 12 February 2015, which brought the case to an end. ${ }^{666}$

\footnotetext{
${ }^{662}$ Hela Schwarz GmbH v. People's Republic of China, ICSID Case No. ARB/17/19.

${ }^{663}$ Tza Yap Shum v. Republic of Peru, ICSID Case No. ARB/07/6.

${ }^{664}$ Although Hong Kong's autonomy in economic affairs includes the competence to conclude BITs internationally, in this case there was no Hong Kong BIT with Peru on which the investor could have sought to rely. For more information about Hong Kong's autonomy in economic affairs, see: Peter Malanczuk, Hong Kong, at: Rüdiger Wolfrum (ed.), The Max Planck Encyclopedia of Public International Law, Oxford University Press, 2012, Vol. IV, pp. 958-980.

${ }^{665}$ Mr. Tza Yap Shum v. Republic of Peru, ICSID Case No. ARB/07/6, Decision on Jurisdiction and Competence, 19.06.2009; Award on Merits, 07.07.2011. For some academic discussion on this award, see: Guiguo Wang, Consent in Investor-State Arbitration: A Critical Analysis, Chinese Journal of International Law, Vol. 13, 2014, pp. 349-352. Such a decision plainly digresses from earlier investment jurisprudence having interpreted similar provisions. See e.g. Berschader v. Russia, SCC Case No. 080/2004, Award, 21.04.2006, para. 153; Austrian Airlines v. Slovak Republic, UNCITRAL, Final Award, 20.10.2009. Therefore, this is likely to have significant ramifications for investors covered under China's BITs that contain similarly restrictive investment arbitration provisions.

${ }^{666}$ Mr. Tza Yap Shum v. Republic of Peru, ICSID Case No. ARB/07/6, Decision on Annulment, 12.02.2015. For some academic discussions on this award, see: Kyriaki Karadelis, Peru Fails to Annul Chinese Treaty Award, Global Arbitration Review (GAR), 04.03.2015, available at: https://globalarbitrationreview.com/article/1034270/peru-failsto-annul-chinese-treaty-award, last visited on 03.08.2020.
} 
2. China Heilongjiang International Economic \& Technical Cooperative Corp., Beijing Shougang Mining Investment Company Ltd., and Qinhuangdaoshi Qinlong International Industrial Co. Ltd. v. Mongolia

In this case, three Chinese investors turned to arbitration in 2010 following the cancellation of a key license in 2009. ${ }^{667}$ The tribunal declined jurisdiction over the claim. Although the award is not public, it appears from a public statement that the tribunal's rejection was based on a "narrow" reading of the jurisdictional clause in the China-Mongolia BIT (1991), allowing for arbitration only in relation to the amount of compensation due for an established expropriation. ${ }^{668}$ If this is the case, such a decision would constitute a deviation from the decision made by the earlier Tza Yap Shum tribunal regarding the interpretation of similar provisions on the jurisdiction clause in China's oldest BITs.

\section{Sanum Investments Limited (Macau) v. Lao}

The Macau-incorporated company Sanum made investments in the gaming and hospitality industry in Laos in 2007. As a result of allegedly unfair and discriminatory taxes imposed by the Lao government, Sanum commenced arbitration proceedings under the China-Laos BIT (1993) in 2012. ${ }^{669}$ On 13 December 2013, the arbitral tribunal rendered a preliminary award upholding its jurisdiction, finding that the ChinaLaos BIT (1993) applied to a legal entity incorporated in Macau and the subject matter of the claim which related to the propriety of state taxation measures fell within the scope of the disputed BIT that only permitted arbitration in "a dispute involving the amount of compensation for expropriation". ${ }^{670}$ The Lao government then challenged the decision in proceedings before the High Court in Singapore, which granted the Lao government's application to vacate the award. However, this was later reversed by the Singapore Court of Appeal, which decided that the China-Laos BIT (1993) applied to Macau and accepted a broad interpretation of the jurisdiction clause, based on the specific context of the disputed BIT. ${ }^{671}$

\section{Ping An Life Insurance Company of China, Limited and Ping An Insurance (Group) Company of China, Limited v. Kingdom of Belgium}

This is the first case in which an investor from mainland China resorted to ICSID to resolve an investment dispute, ${ }^{672}$ which represented "a turning point in the readiness

667 China Heilongjiang International Economic and Technical Cooperative Corp. et al. v. Mongolia, PCA Case No 2010-20.

${ }^{668}$ Luke Eric Peterson, Mongolia Prevails in Long-Running Chinese BIT Arbitration, as Arbitrators Distinguish Their Reading of Constricted Jurisdiction Clause From More Generous Readings in Prior Cases, IAReporter, 07.07.2017, available at: https://www.iareporter.com/articles/mongolia-prevails-in-long-running-chinese-bitarbitration-as-arbitrators-distinguish-their-reading-of-constricted-jurisdiction-clause-from-more-generous-

readings-in-prior-cases/, last visited on 05.08.2020. For some academic discussions on this case, see: Leon E. Trakman, Geopolitics, China, and Investor-State Arbitration, at: China in the International Economic Order: New Directions and Changing Paradigms, Cambridge University Press, 2015, p. 284.

669 Sanum Investments Limited v. Lao People's Democratic Republic, UNCITRAL, PCA Case No. 2013-13.

670 The China-Laos BIT (1993), Art. 8(3).

${ }^{671}$ This included issues like whether it expressly demarcated the determination of the legitimacy of the expropriation from the amount of compensation and whether there was a "fork-in-the-road" provision.

${ }^{672}$ Ping An Life Insurance Company of China, Limited and Ping An Insurance (Group) Company of China, Limited v. Kingdom of Belgium, ICSID Case No. ARB/12/29. For more background information about this case, see: 
of large Chinese companies to bring substantial claims against China's BITs partners". ${ }^{673}$ After losing approximately $\$ 3$ billion from nationalizing and subsequently selling the failed Belgian-Dutch bank Fortis during the 2008 financial crisis, Ping An, China's second largest insurer, brought the claim under the ChinaBelgium \& Luxembourg BIT (1984). The key issue in this case was whether a dispute that arose under the substantive provisions of this 1984 BIT before the China-Belgium \& Luxembourg BIT (2005) entered into force would be covered by the dispute settlement provisions of the latter treaty. In the award issued on 30 April 2015, the tribunal held that this was not the case and dismissed the claim for lack of jurisdiction.

\section{Beijing Urban Construction Group Co. Ltd. v. Republic of Yemen}

Another ICSID case brought by a Chinese entity, Beijing Urban Construction Group Co. Ltd. v. Yemen, was filed on 3 December $2014{ }^{674}$ Relying on the China-Yemen BIT (1998), the claim concerned a $\$ 114$ million international airport project in Sana'a. The tribunal first issued its jurisdictional decision in May 2017, upholding its jurisdiction to rule on an alleged expropriation despite the presence of a narrow dispute resolution clause in the disputed BIT, which granted jurisdiction only in claims "relating to the amount of compensation for expropriation". ${ }^{675}$ After initial filings on the merits had been exchanged, in January 2018, the disputing parties suspended the proceedings and in May 2018 discontinuance of the proceedings was formally requested. This was finally confirmed by the tribunal in June 2018. In a brief statement, the parties said that "BUCG and the Republic of Yemen are pleased to announce that they have settled their differences in relation to the Sana'a airport project and they look forward to future cooperation". Further details on the terms of the parties' settlement are not publicly available yet. ${ }^{676}$

\section{(iii) Potential Investor-State Dispute Settlement Cases}

In addition to the cases mentioned above, based on reports in the media, there are some potential disputes in which China or Chinese investors are involved, which may lead to ISDS cases in the near future.

\footnotetext{
Financial Times, Ping An in Arbitration Claim over Fortis, 24.09.2012, available at: www.ft.com/intl/cms/s/0/87437290-0620-11e2-bd29-00144feabdc0.html\#axzz3bPhlPP5e, last visited on 06.08.2020. For some academic discussions on this case, see: Alison Ross, Belgium Prevails Against Chinese Investor, Global Arbitration Review (GAR), 05.05.2015, available at: https:/globalarbitrationreview.com/article/1034431/belgium-prevails-against-chinese-investor, last visited on 05.08.2020.

${ }^{673}$ Leon E. Trakman, Geopolitics, China, and Investor-State Arbitration, at: China in the International Economic Order: New Directions and Changing Paradigms, Cambridge University Press, 2015, p. 285.

${ }^{674}$ Beijing Urban Construction Group Co. Ltd. v. Republic of Yemen, ICSID Case No. ARB/14/30. For some academic discussions on this case, see: Global Arbitration Review (GAR), Chinese Investor Takes on Yemen at ICSID, 09.12.2014, available at: https://globalarbitrationreview.com/article/1033938/chinese-investor-takes-onyemen-at-icsid, last visited on 31.07.2020.

675 The China-Yemen BIT (1998), Art. 10.

676 Jarrod Hepburn, Chinese State-Owned Investor Settles Treaty Claim After 2017 Jurisdictional Ruling That Took Generous View of Treaty's Scope for Arbitration of Claims, IAReporter, 12.06.2018, available at: https://www.iareporter.com/articles/chinese-state-owned-investor-settles-treaty-claim-after-2017-jurisdictionalruling-that-took-generous-view-of-treatys-scope-for-arbitration-of-claims-recent-ruling-in-libya-case-adopteddiffering-a/, last visited on 01.08.2020.
} 
First, at the end of 2017, the investment dispute between a duo of state-owned Chinese investors, China Railway Construction Corporation and China Railway Construction Corporation International, and the Mexican government appeared in the media. ${ }^{677}$ The dispute concerns the Mexican government's refusal to approve the tender won by the Chinese investors to build a new train-line. The investors reportedly asked for $\$ 600$ million for the alleged expropriation of their investment, claiming that the Mexican authorities' measures lacked good faith, transparency and due process and thus violated the China-Mexico BIT (2008). This BIT provides investors with the right to choose among ICSID, ICSID (AF) and UNCITRAL arbitration, as long as they have gone through the process in the host state's administrative courts for at least four months before submitting a claim. Other information is currently not available to the public.

Second, in March 2018, a Singapore-registered phosphate mining company, Asiaphos Ltd., threatened to file for arbitration against China, because the application to renew its mining rights in the central province of Sichuan was rejected. Asiaphos noted that local authorities had desired an amicable settlement of the situation, and that parties were in talks in relation to settlement. Asiaphos also made clear that it had a potential case under the China-Singapore BIT (1985) or ASEAN Comprehensive Investment Agreement (2009). ${ }^{678}$

Third, in September 2018, it was reported that a Chinese mining company, Minerals and Metals Group, initiated negotiations with the Democratic Republic of Congo pursuant to the China-Congo BIT (2011). The negotiations related to Congo's mining code, which was overhauled in January 2018 to impose a variety of new conditions on miners and to increase the state's take from mining activity. ${ }^{679}$

In addition, Jinlong Dongli Minera Internacional S.A., the Mexican subsidiary of a Chinese investor, sent a Notice of Intent on 7 September 2018, invoking the expropriation provision in the China-Mexico BIT (2008) against Mexico. According to the investor's report, certain materials it had imported to invest in Mexico's mineral sector had been unfairly embargoed and the investor's bank accounts had been frozen under orders from Mexican courts and tax authorities. The investor claimed that Mexico's actions stifled its development in Mexico and thus amounted to an expropriation of its investment. It is unclear how much is at stake. ${ }^{680}$

Last but not least, on 10 June 2019, a new report revealed that Greece had been served a notice of arbitration by two Chinese investors, Wuxi T. Hertz Technologies Co. Ltd.

\footnotetext{
677 Damien Charlotin \& Luke Eric Peterson, BIT Dispute Involving Chinese State-owned Investors Leads Government to Hire Lawyers, IAReporter, 04.12.2017, available at: https://www.iareporter.com/articles/bit-disputeinvolving-chinese-state-owned-investors-leads-government-to-hire-lawyers/, last visited on 05.08.2020.

678 IAReporter, China Warned of Possible Investment Treaty Arbitration 06.03.2018, available at: https://www.iareporter.com/articles/china-warned-of-possible-investment-treaty-arbitration/, last visited on 26.05 .2020

${ }^{679}$ Zoe Williams, Chinese Mining Giant Puts State on Notice of BIT Claim, IAReporter, 10.09.2018, available at: https:/www.iareporter.com/articles/chinese-mining-giant-puts-state-on-notice-of-bit-claim/, last visited on 06.08.2020.

680 Damien Charlotin, Chinese Miner Files BIT Notice Complaining of Judicially-Embargoed Material and Frozen Accounts, 05.10.2018, available at: https://www.iareporter.com/articles/chinese-miner-files-bit-notice-complainingof-judicially-embargoed-material-and-frozen-accounts/, last visited on 03.08.2020.
} 
and Jetion Solar Co. Ltd., regarding their difficulties in developing a photovoltaic project in Northern Greece. This notice invoked the China-Greece BIT (1992), which provides for UNCITRAL arbitration in cases concerning the amount of compensation for expropriation. ${ }^{681}$ Other information has not been released to the public.

\section{(iv) An Analysis of China's Investment Cases}

As presented above, until now, only three ISDS cases have been initiated against China and four cases initiated by investors from mainland China. Such low numbers contrast with the thousands of ISDS cases raised annually around the world, the more than 140 BITs concluded by China until now, as well as the much larger number of cases that involved China in one way or another in the WTO Dispute Settlement System.

Regarding the underlying reasons for such a small number of investment arbitration cases commenced by Chinese investors or filed against the Chinese government, despite the limited factual record, a few observations may be ventured. ${ }^{62}$ In this regard, some scholars identified three general factors of influence: China's evolution from a state focused primarily on attracting foreign investment to one with increasing amounts of outward direct investment, the relatively recent practice of China entering into BITs $^{683}$ and the absence of an international arbitration option in China's early BITs. ${ }^{684}$ Regarding the last factor, it also deserves attention that, even when international arbitration is provided for, under the first generation of China's BITs, foreign investors could claim compensation, but they could not ordinarily challenge China on the grounds that an expropriation had occurred. ${ }^{685}$

In terms of the scarcity of claims filed against China in particular, there has been some speculation about the contributions from the Chinese government and foreign investors. On the side of the Chinese government, its willingness to reach a compromise in dispute settlement is arguably an important contribution. ${ }^{686}$ This is in line with China's traditional preference for alternative dispute resolution that avoids recourse to international or domestic courts. ${ }^{687}$ At the same time, through limiting its involvement in arbitration cases, China may want to protect its political image that it is both "friendly" and "fair" to foreign investors. ${ }^{68}$ In relation to foreign investors, first, China has a

681 Damien Charlotin, Chinese Investors Launch Bilateral Investment Treaty Arbitration against Greece, IAReporter, 10.06.2019, available at: https://www.iareporter.com/articles/chinese-investors-launch-bilateral-investment-treatyarbitration-against-greece/, last visited on 31.07.2020.

${ }^{682}$ A concrete analysis of this issue requires more empirical research, which is unfortunately difficult to identify in the existing literature.

${ }^{683}$ Here Norah Gallagher pointed out that China had no history of entering into Friendship Commerce \& Navigation Treaties like other states in the $19^{\text {th }}$ and early $20^{\text {th }}$ centuries given its experience with unequal treaties after the Opium Wars. See: Norah Gallagher \& Wenhua Shan, China, at: Chester Brown (ed.), Commentaries on Selected Model Investment Treaties, Oxford University Press, 2013, p. 141.

${ }^{684}$ Norah Gallagher, China's BIT's and Arbitration Practice: Progress and Problems, at: China and International Investment Law: Twenty Years of ICSID Membership, Brill | Nijhoff, 2014, p. 182.

685 Although diverse interpretations of this requirement can be found in various decisions made by different tribunals, such an expression in treaty provisions should at least have exerted a certain discouraging effect on investors when they considered whether to initiate international arbitration.

${ }^{686}$ Norah Gallagher, China's BIT's and Arbitration Practice: Progress and Problems, at: China and International Investment Law: Twenty Years of ICSID Membership, Brill | Nijhoff, 2014, p. 183.

${ }^{687}$ Ernst-Ulrich Petersmann, Trade and Investment Adjudication Involving 'Silk Road Projects': Legal Methodology Challenges, European University Institute Working Papers, Vol. 2, 2018, p. 1.

688 Leon E. Trakman, Geopolitics, China, and Investor-State Arbitration, at: China in the International Economic 
large and lucrative market with great allure, where foreign investors probably do not want to jeopardize their future dealings. Second, a report by the European Commission states that initiating arbitration against China is likely to be a "last resort, due to fear of retaliation". ${ }^{689}$ Furthermore, foreign investors conceivably benefit more from reaching a negotiated settlement with the Chinese government than they would with adjudication. ${ }^{690}$ In this sense, it was pointed out that investors preferred to avoid investor-state arbitration on the grounds that China often accorded foreign investors better than "national treatment". ${ }^{691}$ Third, investors may also perceive that China is well-resourced to engage in costly, dilatory and fractious arbitration proceedings. ${ }^{692}$ Last but not least, concerns can relate to the law governing the enforcement of an investment award. ${ }^{693}$

For the few cases that were initiated by Chinese investors, some scholars indicate a desire on the part of Chinese investors to preserve reputation and future business opportunities in host states as an important contribution. ${ }^{694}$ It was also argued that such limited litigation activity is in accoordance with the general scarceness of investor-state arbitration brought by Asian investors. ${ }^{695}$ Both of these may relate to China's legal cultural characteristics of preserving and respecting "miànzi" and preferring amicable settlements. ${ }^{696}$ Another point that is worth pointing out here is one disputed issue that repeatedly appeared in existing cases, the understanding of the jurisdictional limit of international arbitration to disputes about the amount of compensation regarding expropriation, which is a typical feature of China's BITs concluded at an early stage.

Order: New Directions and Changing Paradigms, Cambridge University Press, 2015, p. 281. In turn, foreign investors "(usually) receive handsome returns on their investments". Leon E. Trakman, China and Foreign Direct Investment: Does Distance Lend Enchantment to the View?, The Chinese Journal of Comparative Law, Vol. 2, 2014, p. 5 .

It is noted here that preserving the image should be differentiated from preserving China's own "miànzi". Namely, given China's extensive treaty regime, it does not seem "realistic" for China to preserve its reputation on the international stage as never having a case filed against it in ISDS. See: Norah Gallagher \& Wenhua Shan, China, at: Commentaries on Selected Model Investment Treaties, Oxford University Press, 2013, pp. 131-181.

689 European Commission-Director-General for Trade, Summary of Contributions to the European Commission's Public Consultation on "The Future Investment Relationship Between the EU and China", 2011, available at: http://trade.ec.europa.eu/doclib/docs/2011/december/tradoc_148394.pdf, last visited on 29.05.2020.

${ }^{690}$ Leopoldo Rubinacci, EU-China Investment Relationship-Update on State of Play, DG TRADE Civil Society Dialogue, 07.03.2012.

${ }^{691}$ Luke Nottage \& Romesh Weeramantry, Investment Arbitration in Asia: Five Perspectives on Law and Practice, at: Vivienne Bath \& Luke Nottage (eds.), Foreign Investment and Dispute Resolution Law and Practice in Asia, Routledge, 2011, p. 25. Wenhua Shan \& Norah Gallagher \& Sheng Zhang, National Treatment for Foreign Investment in China: A Changing Landscape, ICSID Review, Vol. 27, 2012, p. 120.

${ }^{692}$ Leon E. Trakman, Geopolitics, China, and Investor-State Arbitration, at: China in the International Economic Order: New Directions and Changing Paradigms, Cambridge University Press, 2015, pp. 280-281.

${ }^{693}$ There is uncertainty as to whether it is an international treaty or Chinese domestic law that would govern the enforcement of investment awards. See: Norah Gallagher \& Wenhua Shan, China, at: Commentaries on Selected Model Investment Treaties, Oxford University Press, 2013, pp. 131-181. Leon E. Trakman, Enter the Dragon IV: China's Proliferating Investment Treaty Program, UNSW Centre for Law, Markets and Regulation, 2011, available at: https://clmr.unsw.edu.au/article//enter-the-dragon-iv\%3A--china\%27s-proliferating-investment-treaty-program, last visited on 06.08.2020.

694 Valentina Vadi, Converging Divergences: The Rise of Chinese Outward Foreign Investment and its Implications for International (Investment) Law, at: Karl P. Sauvant (ed.), Yearbook on International Investment Law \& Policy 2011-2012, Oxford University Press, 2013, pp. 715, 717.

${ }^{695} \mathrm{Id}, \mathrm{p} .714$.

${ }^{696}$ For more discussion on "miànzi", see Section 3.1.1.3, supra. 
China and Chinese investors have different and even opposite decisions on the interpretation of such clauses from various tribunals. 


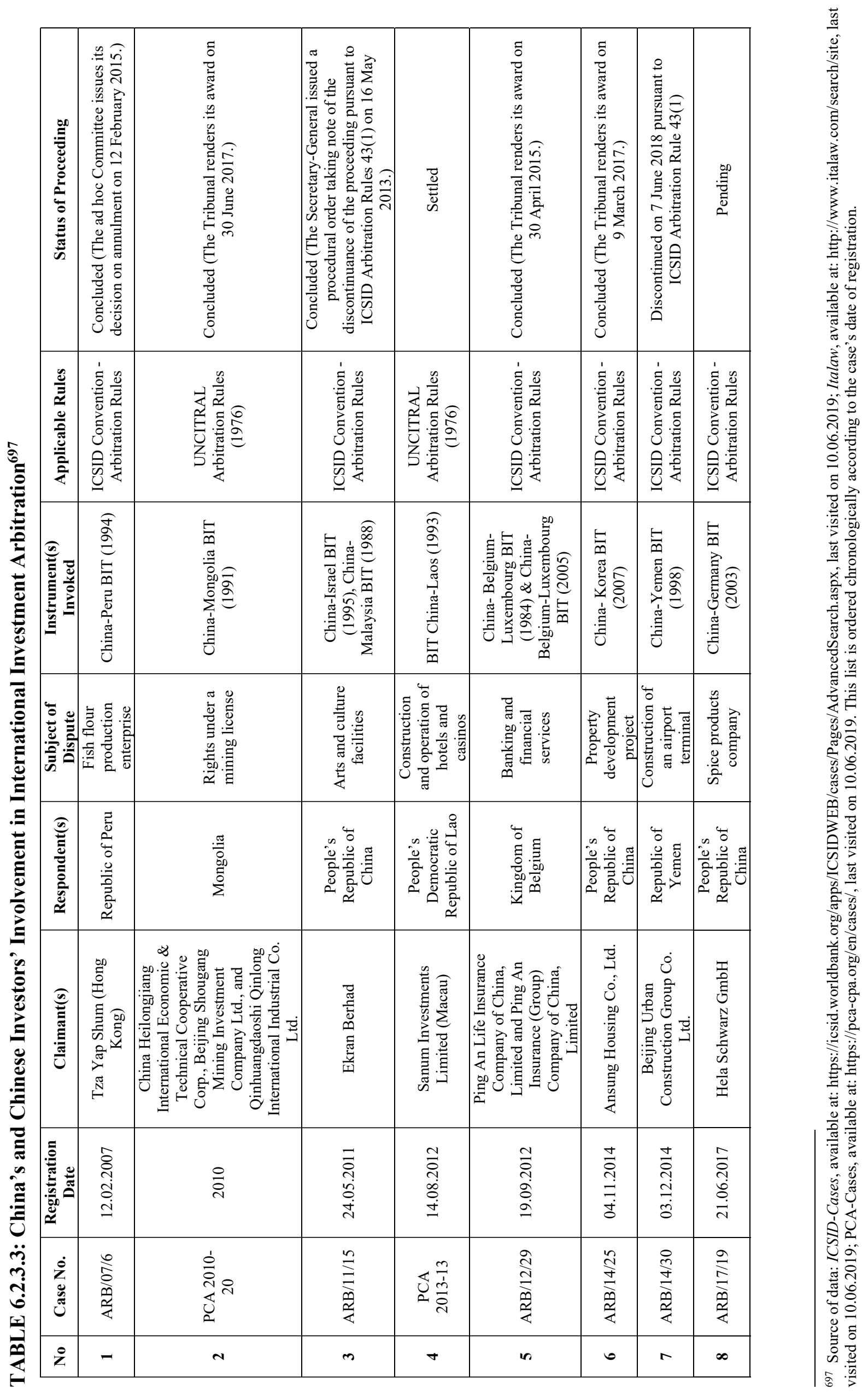




\subsubsection{China's Attitude towards Investor-State Dispute Settlement Reform}

In the past decades, "fragmentation" was frequently used to describe the area of international investment law. This is being exacerbated by various efforts worldwide on the reform of ISDS. ${ }^{698}$ As a main player in international investment, China also participates and contributes to this ongoing reform process.

In general, China's attitude towards ISDS reform seems to lie in the middle of a spectrum of various approaches, on the one side of which is loyalty to arbitration, while on the other side is substituting it with a court system. Considering the differences among China's IIAs and its interests as a capital importer and exporter, it was observed that "China may be happy to develop its approach on an incremental, case-by-case basis instead of seeking to forge a multilateral or regional one-size-fits-all solution". ${ }^{69}$ At the same time, it was argued that most likely, China would take a gradual approach towards ISDS reform following Deng Xiaoping's phrase "crossing the river by feeling for stones" (mōzhe shítóu guòhé, 摸着石头过河). ${ }^{700}$

Based on publicly available information, the discussion in this section focuses on the opinions expressed by China in various international fora, together with its relevant treaty practice if there is any, which include China's "One Belt One Road" Initiative, transparency in ISDS in UNCITRAL Working Group II and overall ISDS reform in UNCITRAL Working Group III.

\section{(i) Investor-State Dispute Settlement under the "One Belt One Road" Initiative}

As introduced in Section 3.2.7, supra, China is constructing its "One Belt One Road" Initiative to further its economic ties with other states. Under this Initiative, China suggests to establish a comprehensive system for investment dispute settlement where the use of amicable DSMs is particularly stressed. A concrete reflection of this general guidance is visible in the 2017 CIETAC Investment Arbitration Rules, which adopt the unique practice of combining mediation with arbitration. More recently, in February 2019, the Beijing Arbitration Commission/Beijing International Arbitration Center launched its draft International Investment Arbitration Rules, where "Arb-Med" is also provided for. More concrete efforts in this direction have been made by the Chinese government in the field of commercial arbitration, ${ }^{701}$ which may have a spill over

\footnotetext{
698 This is represented by rejecting investment arbitration and proposing a court system to substitute, adjusting current investment arbitration practice, as well as keeping a vague attitude towards arbitration but emphasizing alternative dispute resolution mechanisms instead.

699 Anthea Roberts, The Shifting Landscape of Investor-State Arbitration: Loyalists, Reformists, Revolutionaries and Undecideds, EJIL: Talk!, 15.06.2017, available at: https://www.ejiltalk.org/the-shifting-landscape-of-investorstate-arbitration-loyalists-reformists-revolutionaries-and-undecideds/, last visited on 05.08.2020.

${ }^{700}$ Peter Malanczuk, China and the Emerging Standard of Transparency in Investor-State Dispute Settlement (ISDS), New Zealand Association for Comparative Law, Vol. 19, 2015, p. 109.

701 For example, at the beginning of 2018, Qianhai "One Belt One Road" docking center for international commercial litigation and mediation was established. See: Ling Zhang 张玲, Qianhai “One Belt One Road" Docking Center for International Commercial Litigation and Mediation Inaugurated on January 7 前海” 一带一 路”国际商事诉调对接中心 1 月 7 日揭牌, Qianhai News 前海新闻, 08.01.2018, available at: http://iqianhai.sznews.com/content/2018-01/08/content_18209556.htm, last visited on 07.08.2020. Furthermore, the newly established China International Commercial Court (CICC) particularly promotes the connectivity of litigation, mediation, and arbitration, in order to "form a convenient, expeditious, low-cost 'one stop' dispute resolution platform". See: China International Commercial Court, A Brief Introduction of China International Commercial
} 
effect and thus influence China's measures in investment dispute resolution in the near future.

\section{(ii) Transparency in Investor-State Dispute Settlement in UNCITRAL Working Group II}

The discussion in UNCITRAL Working Group II witnessed a change of China's attitude to the issue of transparency in ISDS. At the beginning of the debate in UNCITRAL Working Group II in 2010, states expressed quite different views on the need for transparency in ISDS. Supporters of more transparency included states like Canada and the US, while opposition to transparency came from Russia, Germany, etc. ${ }^{702}$ China belonged to the latter, clearly expressing its perception of ISDS transparency as superfluous. ${ }^{703}$ At that time, China had not entered into any IIA including provisions on transparency or third-party intervention and there had been no such case where China or a Chinese investor was involved. China stressed that, given the confidentiality of arbitration, it was not appropriate to impose provisions on publicity and transparency in ISDS. ${ }^{704}$

China's rejection of transparency changed in 2013. This was evidenced for the first time during the UN General Assembly discussion on the work of UNCITRAL and its Rules on Transparency in October 2013, when the Chinese Delegation expressed its appreciation of and support for the adoption of the UNCITRAL Rules on Transparency to enhance the transparency of international investment arbitration procedures. ${ }^{705}$ It was argued that such a change was "induced particularly by the changing role of China from a major recipient of global foreign direct investment to a rising outward investor". 706

The change in China's attitude towards transparency in ISDS is also reflected in its IIAs. In this regard, China took quite a cautious approach at the initial stage. For example, in 2008, it concluded a BIT with Mexico, which only provides that the award "will be publicly accessible, unless the disputing parties agree otherwise". ${ }^{707}$ In the same year, China concluded the China-New Zealand FTA (2008), in which discretion is granted to the host state regarding the publication of tribunal documents, subject to

Court, 28.06.2018, available at: http://cicc.court.gov.cn/html/1/219/193/195/index.html, last visited on 31.07.2020.

${ }_{702}$ Mark Kantor, The Transparency Agenda for UNCITRAL Investment Arbitrations: Looking in all the Wrong Places, New York University Investment Law Forum, New York, 07.02.2011.

${ }_{703}$ Peter Malanczuk, China and the Emerging Standard of Transparency in Investor-State Dispute Settlement (ISDS), New Zealand Association for Comparative Law, Vol. 19, 2015, p. 91.

704 United Nations Commission on International Trade Law Working Group II (Arbitration and Conciliation), Settlement of Commercial Disputes-Transparency in Treaty-based Investor-State Arbitration-Compilation of Comments by Governments-Note by the Secretariat-Addendum, A/CN.9/WG.II/WP.159/Add.1, 04.08.2010, p. 12.

705 The Chinese Delegation further expressed that it believed that this set of rules would help dispel the apprehension that investment arbitration would sacrifice public interest for the protection of investors, reinforce social monitoring of the host state's measures and thus contribute to the establishment of the trust in investment arbitration mechanisms. See: Statement by Mr Shang Zhen, Chinese Delegate at the 68th Session of the UN General Assembly on Agenda Item 79 Report of UNCITRAL on the Work of Its 46th Session, 14.10.2013, available at: http://www.chinaun.org/eng/chinaandun/legalaffairs/sixthcommittee1/t1091525.htm, last visited on 13.02.2017.

${ }^{706}$ Peter Malanczuk, China and the Emerging Standard of Transparency in Investor-State Dispute Settlement (ISDS), New Zealand Association for Comparative Law, Vol. 19, 2015, p. 105.

707 The China-Mexico BIT (2008), Art. 20.4. 
the disputing parties identifying confidential information. ${ }^{708}$ In 2012, the conclusion of the China-Canada BIT (2012) constituted "a landmark in the history of the development of China's BIT practice on ISDS transparency". ${ }^{709}$ This treaty contains extensive regulations on various transparency-related issues. First, the non-disputing treaty party is explicitly given the right to participate in ISDS proceedings by receiving arbitration documents, attending hearings and making submissions on questions of treaty interpretation. ${ }^{710}$ At the same time, public access to hearings and arbitration documents is also realized to a certain extent: subject to the redaction of confidential information, at least the awards shall be publicly available. ${ }^{711}$ Third, submissions by non-disputing parties may be accepted and relevant procedural guidance is also provided. ${ }^{712}$ In fact, the provisions in the China-Canada BIT (2012) on transparency-related issues correspond to the wording of pertinent provisions in the Canadian Model FIPA (2004), which indicates that incorporating these provisions may be introduced by Canada. ${ }^{713}$ At the same time, the discrepancies between the China-Canada BIT (2012) and the Canadian Model FIPA (2004) point to China's resistant attitude to some issues, such as automatic public hearings. ${ }^{714}$ It is noteworthy that many other IIAs concluded by China after 2009 do not contain ISDS transparency provisions. ${ }^{715}$ Until 2015, the ChinaAustralia FTA (2015) reintroduced transparency requirements into China's IIA practice, which was further continued by the China-Turkey BIT (2015). ${ }^{716}$

In brief, although China has explicitly addressed its support of transparency in ISDS in the context of UNICTRAL Transparency Rules, none of its existing IIAs directly refer to this set of rules. Instead, China's IIAs reveal its cautious attitude towards this issue, which has been affected by the preferences of its treaty partners. ${ }^{717}$

\footnotetext{
708 The China-New Zealand FTA (2008), Art. 157.

709 Peter Malanczuk, China and the Emerging Standard of Transparency in Investor-State Dispute Settlement (ISDS), New Zealand Association for Comparative Law, Vol. 19, 2015, p. 95. Frank J. Garcia, Evaluating International Economic Law Dispute Resolution Mechanisms, South Texas Law Review, Vol. 42, 2001, p. 310.

710 The China-Canada BIT (2012), Art. 27.2.

711 The China-Canada BIT (2012), Art. 28.

712 The China-Canada BIT (2012), Art. 29.

713 Luke Eric Peterson, Canada Announces Conclusion of Investment Treaty with China, but There's an Asterisk, IAReporter, 16.02.2012, available at: https://www.iareporter.com/articles/canada-announces-conclusion-ofinvestment-treaty-with-china-but-theres-an-asterisk/, last visited on 05.08.2020.

${ }^{714}$ Under the Canadian Model FIPA (2004), public hearings in ISDS cases is the default rule. See: the Canadian Model FIPA (2004), Art. 38. It was argued that, in light of the China-Canada BIT (2012), publishing an arbitral award seemed to be the maximum negotiation position China could give in to, and it probably took some time before China agreed to the publication of arbitral proceedings and documents. See: Frank J. Garcia, Evaluating International Economic Law Dispute Resolution Mechanisms, South Texas Law Review, Vol. 42, 2001, p. 311.

715 Completely silence and equally uninformative on ISDS transparency is evidenced in the China-Malta BIT (2009), the China-Uzbekistan BIT (2011), the China-Japan-South Korea IIA (2012), the China-Tanzania BIT (2013), and the China-South Korea BIT (2015).

716 The China-Turkey BIT (2015) incorporates provisions modelled on the UNCITRAL Rules on Transparency. See: the China-Turkey BIT (2015), Art. 9.2(c).

717 In this regard, Chinese scholars warned the Chinese government that, without a sound domestic system of information disclosure and secrecy, accepting a high level of transparency would not contribute to protecting public interests; what was worse, was the risk of entangling in mire. See: Jun Zhao \& Yun Liu 赵骏、刘芸, The Reform of Transparency in International Investment Arbitration and China's Response 国际投资仲裁透明度改革及我国 的应对, Journal of Zhejiang University (Humanities and Social Science) 浙江大学学报（人文社会科学版）, Vol. 44, 2014, p. 159.
} 


\section{(iii) Investor-State Dispute Settlement Reform in UNCITRAL Working Group III}

The UNCITRAL Working Group III, which comprises states, intergovernmental and non-governmental organizations, began its work on ISDS reform in November 2017. It is entrusted with a broad mandate and carries out its work according to the following three steps: first, by identifying concerns regarding ISDS; second, considering whether reform is desirable in the light of any identified concerns; and third, if the Working Group were to conclude that reform is desirable, developing any relevant solutions to be recommended. ${ }^{718}$ For this, the Working Group III meets twice every year, and its latest session, the $39^{\text {th }}$ session in New York, was devoted to addressing the possible reform of ISDS on various issues, including shareholder claims and reflective loss, dispute prevention and mitigation, interpretation of investment treaties by treaty parties, security for costs and frivolous claims, multiple proceedings and counterclaims, and multilateral instrument on ISDS reform. ${ }^{719}$

As a member state of the UN, China participated in this ISDS reform discussion and expressed its opinions on various issues. First, China pointed out that, in the current ISDS system, inconsistency and incorrectness of investment arbitration decisions were problems and the existing annulment and judicial review were inadequate, but there was not necessarily a problem with the mechanism of disputing parties appointing arbitrators itself. ${ }^{720}$ Second, regarding the appointment of arbitrators, China expressed that, compared to commercial arbitration, investment arbitration was special in nature because of the involvement of governments, and thus arbitrators should be persons having a background in public international law or legal knowledge of investment treaties. ${ }^{721}$ At the same time, China mentioned other requirements for arbitrators in ISDS, including independence and impartiality, and protecting the legitimate rights and interests of investors in strict compliance with the underlying IIAs, the assurance of which required an integrated approach. ${ }^{722}$ Third, China argued that many developing countries, including China, faced difficulties in translating its documents in ISDS, since the meaning of certain terms related to the legal culture, and this process could also cause extra delays and costs in the proceedings. ${ }^{723}$

\footnotetext{
718 United Nations, Report of the United Nations Commission on International Trade Law, Fiftieth session (321.07.2017), A/72/17, para. 264.

719 United Nations Commission on International Trade Law (UNCITRAL), Working Group III: Investor-State Dispute Settlement Reform, available at: https://uncitral.un.org/en/working_groups/3/investor-state, last visited on 06.08.2020.

720 Anthea Roberts, UNCITRAL and ISDS Reforms: Moving to Reform Options...the Politics, EJIL: Talk!, 08.11.2018, available at: https://www.ejiltalk.org/uncitral-and-isds-reforms-moving-to-reform-options-the-process/, last visited on 05.08.2020.

721 Anthea Roberts \& Zeineb Bouraoui, UNCITRAL and ISDS Reforms: Concerns about Arbitral Appointments, Incentives and Legitimacy, EJIL: Talk!, 06.06.2018, available at: https://www.ejiltalk.org/uncitral-and-isds-reformsconcerns-about-arbitral-appointments-incentives-and-legitimacy/, last visited on 05.08.2020.

722 Id.

723 Anthea Roberts \& Zeineb Bouraoui, UNCITRAL and ISDS Reforms: Concerns about Costs, Transparency, Third Party Funding and Counterclaims, 06.06.2018, available at: https:/www.ejiltalk.org/uncitral-and-isds-reformsconcerns-about-costs-transparency-third-party-funding-and-counterclaims/, last visited on 06.08.2020.
} 


\subsection{Conclusion}

The historical experience and traditional philosophies have led to China's doubts about international law and its cautious attitude to international adjudication, which still affects its performance on the international plane.

Two types of mechanisms need to be analysed in relation to China's engagement in investment dispute settlement in particular: state-state mechanisms for resolving disputes about treaty interpretation and application and investor-state DSMs for investors to bring cases against host states regarding complaints related to specific investments. With regard to the former, a hybrid approach combining diplomatic consultations and ad hoc arbitration was adopted consistently in China's Model BITs, as well as most of its concluded IIAs and FTAs. In other words, the state-state DSMs in China's IIAs are quite similar to each other, and they resonate with those in the China Model BITs. At the same time, by examining the DSMs in China's IIAs chronologically, the treaties that were concluded at a later stage often contain more detailed procedural rules. In addition, certain diplomatic elements in early treaties disappeared in the treaties concluded at a later stage, which can be taken as evidence of China's increasing confidence in international adjudication. China's most recent practice has adjusted such DSMs to a model replicating quasi-WTO dispute settlement panel proceedings. This has been the practice of state-state DSMs under its FTAs. In general, China's FTAs emphasized amicable DSMs and mutually satisfactory solutions, and this practice is expected to be continued. ${ }^{724}$ At the same time, the adoption of a system similar to the WTO panel proceedings can indicates a new level of confidence and the intention of learning from relevant experience in international trade dispute settlement. In relation to the WTO, generally speaking, China has transformed from being reluctant or even afraid to use the Dispute Settlement System to being confident and now making use of the system frequently. China's performance in this system raised a combination of practical concerns related to the influence from its legal culture on dispute settlement. More importantly, joining the WTO and the great involvement in its Dispute Settlement System arguably have had a great impact on China's understanding of "the utility, effectiveness and legitimacy of a system ruled by law". ${ }^{725}$ The lessons China learned from its experience in the WTO Dispute Settlement System play a role in its position on SSDS in the field of international economic law.

Regarding ISDS, both China Model BITs and its concluded IIAs reflect the changes of China's approach in the three stages. These changes are particularly evidenced by the attitude towards investor-state arbitration, which has transformed from limiting international arbitration to disputes about the amount of compensation for expropriation to an overall acceptance of investment arbitration. In addition, since signing the ICSID

\footnotetext{
724 This can be evidenced by China's President Xi Jinping's speeches at the G20 Summit and APEC Leader's Meeting in 2015. See: www.cpcnews.cn 中国共产党新闻网, Jinping Xi: Deepen Partnership and Promote Prosperity in Asia-Pacific 习近平: 深化伙伴关系 共促亚太繁荣, 20.11.2015, available at: http://cpc.people.com.cn/n/2015/1120/c64094-27835631.html, last visited on 04.08.2020.

725 Jan Wouters \& Matthieu Burnay, China and the European Union in the World Trade Organization: Living Apart Together?, at: Jan Wouters \& Tanguy de Wilde \& Pierre Defraigne \& Jean-Christophe Defraigne, China, the European Union and the Restructuring of Global Governance, Edward Elgar, 2012, p. 87.
} 
Convention in 1993, it has become China's normal practice to incorporate ICSID arbitration for ISDS into its IIAs. This reflects "the increasing role of outward investment in China's economic development and the corresponding interest in effective investor protection rules and procedures for Chinese investments abroad". ${ }^{726}$ This is also evidence of China's changing attitude to international adjudication. ${ }^{727}$ Detailed procedural designs of the DSMs in China's IIAs vary among each other, which represents China's flexibility and open attitude. Until now, there have been eight cases under the IIAs concluded by China. Compared to the large amount of IIAs and increasing investment flows, this number of cases is relatively small. Possible underlying reasons for this include the Chinese government's preference for the amicable settlement of investment disputes to preserve harmony and its political image as a friendly host state, foreign investors' worries of the Chinese government's retaliation, and how lucrativeness the Chinese market is. In addition, China has joined the worldwide ongoing reform of ISDS, presenting its approach at different international fora and adopting new practices in its IIAs.

China's practices in both SSDS and ISDS reflect some of its legal cultural characteristics on dispute settlement, such as the preference for amicable settlement and confidentiality in the dispute settlement process, as already presented in relation to its domestic level dispute settlement process. However, at the same time, from accepting the jurisdiction of an international adjudication body to actively participating in relevant reform discussions in various international fora, it is also clear that China has increasingly recognized the function of international adjudication in state-state and investor-state dispute settlement.

\footnotetext{
${ }^{726}$ Peter Malanczuk, China and the Emerging Standard of Transparency in Investor-State Dispute Settlement (ISDS), New Zealand Association for Comparative Law, Vol. 19, 2015, p. 85.

${ }^{727}$ It was argued that joining the ICSID had profound implications because of the obligation to enforce any relevant arbitration award, and this could be read as a confirmation of "China's preparedness and determination to engage as an equal partner in international economic exchanges". See: Guiguo Wang, Chinese Mechanisms for Resolving Investor-State Disputes, Jindal Journal of International Affairs, Vol. 1, 2011, p. 228.
} 


\section{Chapter 7 The EU's Approach to International Investment and Trade Dispute}

\section{Settlement}

The EU's approach to investment dispute settlement at the international level can be divided into state-state dispute settlement and investor-state dispute settlement.

As explained in the Introduction to Part 3, in addition to appearing in IIAs, state-state DSMs can also be found in another relevant treaties, such as FTAs. In particular, recent years have witnessed the combination of trade and investment in one comprehensive economic agreement, where the same set of mechanisms is provided for dispute resolution between treaty parties. Therefore, the state-state DSMs in IIAs can be affected by those in FTAs, as well as by the WTO DSU. This is actually evident from the EU's practice in recent years. Therefore, by following the same method of examination adopted in Chapter 6, supra, the analysis in the present chapter covers the state-state DSMs in the EU's IIAs and FTAs, as well as its performance in the WTO Dispute Settlement System.

With regard to ISDS, relevant practice is visible from the IIAs and the cases arising from them. However, because of the shift of the competence to conclude IIAs from the EU Member States to the Union in 2009, there are investor-state DSMs at both the Union and the Member State level in practice. Due to the fact that the Union conducts treaty negotiations with China and will be the contracting party to the prospective China-EU BIT, the practice at the Union level will provide more direct and useful evidence. Furthermore, as explained below, the Union's practice of ISDS largely deviates from the practice of its Member States and there has been no concrete evidence showing any EU Member State objection to the Union's proposal. Thus, the analysis in this thesis will focus on the Union's practice, unless it appears to be necessary to address the situation at the EU Member State level.

For both state-state and investor-state DSMs, relevant treaty provisions and specific cases are examined, aiming at identifying the features of the EU's approach to international investment dispute settlement from a procedural perspective. At the same time, by bearing in mind the analysis of the EU's legal cultural characteristics of dispute settlement in Chapter 3, supra, the discussion in this chapter will consider in particular whether and, if so how, these legal cultural characteristics have been reflected in the EU's approach to state-state and investor-state investment dispute settlement at the international level.

\subsection{Historical Development of the EU's International Investment Agreements}

Due to the shift in the competence to conclude IIAs from the EU Member States to the Union, the analysis of the EU's IIA network is not straightforward. Before the Lisbon Treaty entered into force, the competence for international investment issues was 
shared by the Union and its Member States. Specifically, the establishment of new foreign investments formed part of the Union's exclusive competence in relation to market access, ${ }^{728}$ and therefore the IIAs signed by the Union only covered the preestablishment phase of foreign investment but did not cover post-establishment investment protection. ${ }^{729}$ EU Member States enjoyed exclusive competence in relation to the post-establishment treatment of investments, ${ }^{730}$ and thus, by and large, the EU Member States' IIAs covered investments that had already been established in host states. ${ }^{731}$ As a result, the majority of the IIAs that are currently in place were concluded by EU Member States, while others involve the Union only or both the Union and its Member States. In particualr, rules on investment dispute settlement was in the hands of the EU Member States and are mainly found in their IIAs. While the European Commission was busy elaborating "a liberalization agenda focused on market access for direct investment", EU Member States focused on the protection and promotion of investment. ${ }^{732}$

In 2009, the Union's power in invesmtent policymaking was increased by the Lisbon Treaty, which transferred the exclusive power in relation to investment protection from the EU Member States to the Union. ${ }^{733}$ In such a new situation, only the Union "may legislate and adopt legally binding acts" in the field of foreign direct investment, while its Member States may only do so if they are empowered by the Union or for the implementation of acts of the Union. ${ }^{734}$ This shift of competence provides a legal basis for the Union's external action in bilateral and multilateral investment negotiations. ${ }^{735}$

728 Marc Bungenberg \& Stephan Hobe, The Relationship of International Investment Law and European Union Law, at: Marc Bungenberg \& Jörn Griebel \& Stephan Hobe \& August Reinisch (eds.), International Investment Law: A Handbook, C.H.Beck-Hart-Nomos, 2015, p. 1608.

729 Lorenza Mola, Which Role for the EU in the Development of International Investment Law?, Society of International Economic Law (SIEL) Inaugural Conference 2008, Geneva, 15-17.07.2008.

${ }^{730}$ It should be noted that, even when agreements fall outside the Union's exclusive competence, EU Member States' treaty-making power is constrained by their duty of loyalty and sincere cooperation with the Union, as well as their duty to support the Union's external policy. See: the Treaty on European Union (entered into force on 1 December 2009), Arts. 4.3, 24.3; Commission of European Communities v. Denmark, Case C-487/98, 2002 E.C.R. 1-9619, pp. $122-139$.

731 Anna Joubin-Bret, Admission and Establishment in the Context of Investment Protection, at: August Reinisch (ed.), Standards of Investment Protection, Oxford University Press, 2008, pp. 10-11. There are exceptions. For instance, Finnish BITs cover, in principle, the pre-establishment stage. However, the relevant question of competence with respect to such exceptions does not appear to have been evoked in any setting or to have resulted in any controversy. See: Marc Bungenberg \& Catharine Titi, The Evolution of EU Investment Law and the Future of EUChina Investment Relations, at: China and International Investment Law: Twenty Years of ICSID Membership, Brill | Nijhoff, 2015, p. 301.

732 European Commission, Communication from the Commission to the Council, the European Parliament, the European Economic and Social Committee and the Committee of the Regions: Towards a Comprehensive European International Investment Policy, COM(2010)343 final, 07.07.2010, p. 11.

733 By amending the Treaty on European Union and the Treaty Establishing the European Community, the Treaty of Lisbon subjected the European international investment law landscape to "a drastic change", which inserted the Union's exclusive competence for foreign direct investment by establishing a link between the Common Commercial Policy and foreign direct investment. See: Treaty on the Functioning of the European Union (TFEU), Art. 207. Marc Bungenberg \& Catharine Titi, The Evolution of EU Investment Law and the Future of EU-China Investment Relations, at: China and International Investment Law: Twenty Years of ICSID Membership, Brill | Nijhoff, 2015, p. 300. Armand de Mestral C.M., The Lisbon Treaty and the Expansion of EU Competence Over Foreign Direct Investment and the Implications for Investor-State Arbitration, at: Yearbook on International Investment Law \& Policy 2010-2011, Oxford University Press, 2012, pp. 367-368.

734 TFEU, Art. 2(1).

735 Marc Bungenberg, The Division of Competences Between the EU and Its Member States in the Area of Investment Politics, at: Marc Bungenberg et al. (eds.), International Investment Law and EU Law, Springer, 2011, p. 36. See 
It has also reshaped the EU-China investment relations, as well as the negotiations and conclusion of a China-EU BIT.

Except for the general reference to foreign direct investment, the Lisbon Treaty does not give a precise delineation of the shift of competence. Based on a request from the European Commission, this ambiguity was subsequently clarified by the Court of Justice of the European Union (CJEU) in its Opinion 2/15. According to this Opinion, the Union does not have the necessary exclusive competence in relation to non-direct foreign investment and ISDS, and the conclusion of relevant treaty provisions falls under the shared competence between the Union and its Member States. ${ }^{736}$ The CJEU also clarified that a regime for settling disputes between states instead falls under the exclusive competence of the Union. ${ }^{737}$ As such, the fate of state-state DSMs is different from that of investor-state DSMs in the agreements on investment concluded by the Union, where the former falls within the scope of the Union's exclusive competence but the latter belongs to the area of shared competence between the Union and its Member States.

\subsection{The EU's Practice of State-State Dispute Settlement Mechanisms}

State-state DSMs are provided for in the Union's concluded treaties for disputes about issues regarding the interpretation and application of treaty provisions. Different from the practice in China, the Union has not adopted any Model BIT, and therefore the analysis in this section directly addresses the Union's IIAs and FTAs. Based on publicly available information, no case has been brought under these treaties, and therefore no examination can be conducted in this sense. Furthermore, considering the trend of following the WTO panel proceedings as the model for the provisions on state-state DSMs in the Union's treaties for international trade and investment, the practice in the WTO Dispute Settlement System is also analysed.

\subsubsection{The State-State Dispute Settlement Mechanisms in the EU's Internatioanl Investment Agreements}

Before the Lisbon Treaty, the Union did not have the competence to sign IIAs with third states on investment protection. Despite this, it was authorized to negotiate a number of trade agreements with investment provisions, including the WTO

\footnotetext{
also: Marc Bungenberg \& Catharine Titi, The Evolution of EU Investment Law and the Future of EU-China Investment Relations, at: China and International Investment Law: Twenty Years of ICSID Membership, Brill | Nijhoff, 2015, p. 305.

${ }^{736}$ CJEU Opinion 2/15 of the Court (Full Court), 16.05.2017, paras. 285-293. Before Opinion 2/15, there had already been various arguments raised by scholars and practitioners supporting signing any new IIA as mixed, especially considering the stipulated way of determining the respondent in a specific case. See e.g. Tomáš Fecák, International Investment Agreements and EU Law, Kluwer Law International, 2016, p. 309. In addition, after the issuance of Opinion 2/15, the underlying reasons and the corresponding effect of the CJEU's decision have been discussed in a heated way. For example, it was commented that the CJEU had never been a big fan of other international courts meddling in the interpretation of EU Law or a supporter of arbitration. See: Despite Our Differences-A Blog about EU Law and Other Creatures by Daniel Sarmiento, The Singapore Silver Bullet, 17.05.2017, available at: https://despiteourdifferencesblog.wordpress.com/2017/05/17/the-singapore-silver-bullet/, last visited on 30.07.2020.

${ }^{737}$ CJEU Opinion 2/15 of the Court (Full Court), 16.05.2017, paras. 294-304.
} 
Agreement, the Energy Charter Treaty (ECT) and various association and economic cooperation agreements. ${ }^{738}$ In terms of dispute settlement under such a treaty, the same state-state dispute settlement system was provided for disputes regarding the interpretation and application of provisions on trade and investment, which are analysed in the following Section 7.2.2, infra. ${ }^{739}$ After the Lisbon Treaty, the Union's current practice of the state-state DSMs is visible in the three recently concluded treaties, EUCanada Comprehensive Economic and Trade Agreement (2016) ${ }^{740}$ (hereinafter "CETA"), the EU-Singapore Investment Protection Agreement (2018) ${ }^{741}$ (hereinafter "EU-Singapore IPA (2018)"), and the EU-Vietnam Investment Protection Agreement (2018) ${ }^{742}$ (hereinafter "EU-Vietnam IPA (2018)"). CETA is a comprehensive economic agreement covering both trade and investment, where the same set of statestate DSMs is used in disputes about provisions on trade and investment. As standalone investment treaties, the EU-Singapore IPA and the EU-Vietnam IPA each have their own state-state dispute settlement systems.

In general, these three state-state dispute settlement systems are quite similar to each other. The two treaties concluded at a later stage, the EU-Singapore IPA and the EUVietnam IPA, provide rules covering more procedural issues, such as the replacement of arbitrators, information and technical advice, decision making by tribunals, the review of measures taken to comply with the final report, time limits, etc. Furthermore, from amicable settlement through to consultations and mediation, the initiation of an arbitration procedure, the establishment of the arbitration panel, the interim panel report, the issuance of and compliance with arbitration panel ruling, to temporary remedies in the case of non-compliance, together many more procedural details, the relevant provisions rely heavily on the WTO panel proceedings, copying the procedures and even the language contained in the corresponding part of the WTO DSU. At the same time, some adjustments that deviate from the WTO Dispute Settlement System can be found. A typical example is the selection of adjudicators in a specific case. In the WTO Dispute Settlement System, disputing parties do not have control over the composition of the panel unless they reach an agreement, while in the EU's practice party autonomy is more respected by granting disputing parties the possibility to select their own arbitrators from the pre-established lists of arbitrators. ${ }^{743}$

The state-state DSMs contained in the EU Member States' IIAs concluded with different third states in different periods of time vary to a large extent. For the purpose

\footnotetext{
738 These agreements include limited, but sometimes extensive, investment provisions together with provisions on goods, services, etc. It was even argued that, before the Lisbon Treaty, the Union had already started to "aspire to establish its own investment policy". See: Marc Bungenberg \& Catharine Titi, The Evolution of EU Investment Law and the Future of EU-China Investment Relations, at: China and International Investment Law: Twenty Years of ICSID Membership, Brill | Nijhoff, 2015, p. 301.

739 There is no separate state-state DSM for investment in these treaties or provisions on ISDS. See: Armand de Mestral C.M., The Lisbon Treaty and the Expansion of EU Competence Over Foreign Direct Investment and the Implications for Investor-State Arbitration, at: Yearbook on International Investment Law \& Policy 2010-2011, Oxford University Press, 2012, pp. 372-373.

${ }^{740}$ EU-Canada Comprehensive Economic and Trade Agreement (finalized on 02.2016, provisionally entered into force on 09.2017).

741 The EU-Singapore Investment Protection Agreement (authentic texts as of 04.2018).

742 The EU-Vietnam Investment Protection Agreement (authentic texts as of 08.2018).

743 See e.g. the EU-Singapore IPA, Art. 3.29.
} 
of the present thesis, the 26 IIAs concluded between China and the EU Member States before Lisbon Treaty are of more relevance and provide more direct inspiration. Section 9.3.1, infra, gives a detailed analysis of the state-state DSMs in these IIAs. After 2009, because of the ongoing negotiations for a China-EU BIT, no EU Member States are in contact with China in relation to updating the existing agreements or negotiating new investment agreements. Nevertheless, they are still active in the area of investment treaty making, including negotiating with other third states based on the Union's authorization and updating their own Model BITs. ${ }^{744}$

\subsubsection{The State-State Dispute Settlement Mechanisms in the EU's Free Trade Agreements}

The EU can be described as a "veteran" in concluding FTAs, ${ }^{745}$ being one of the most active players in the world in this area. As of 30 April 2020, among the 294 FTAs notified to the WTO, ${ }^{746}$ about 40 were concluded by the EU (or formerly the EC). ${ }^{747}$ The dispute settlement systems in these FTAs have undergone a transformation over time from a diplomatic approach to following a quasi-WTO dispute settlement panel proceedings model. ${ }^{748}$ These two stages are discussed in turn below. Since there has not been a single dispute under these FTAs, the analysis is based purely on treaty texts.

\subsubsection{Diplomatic State-State Dispute Settlement Mechanisms (with One Exception)}

Most of the FTAs concluded between the EC and third states aiming at preparing them as accession candidates to the EC included diplomatic state-state DSMs. ${ }^{749}$ This approach relies solely on a political channel for potential disputes. ${ }^{750}$ The dispute

\footnotetext{
744 For example, in 2018, the Netherlands updated its Model BIT, where some innovations on the design of statestate arbitration can be identified. An example is that, in state-state arbitration, the Netherlands Model BIT (2018) explicitly allows tribunals to propose to disputing states at any stage of the proceedings to settle the dispute amicably, which can be realized through the settlement of the dispute ex aequo et bono if disputing states thus agree. See: The Netherlands Model BIT (2018), Art. 25.5.

745 Szilárd Gáspár-Szilágyi, A Follow-up to the EU Commission's Decision to 'Split' Trade and Investment Protection, International Economic Law and Policy Blog, 14.09.2017, available at: http://worldtradelaw.typepad.com/ielpblog/2017/09/guest-post-a-follow-up-to-the-eu-commissions-decision-tosplit-trade-and-investment-protection.html, last visited on 01.08.2020.

746 World Trade Organization, Regional Trade Agreements, available at: https://www.wto.org/english/tratop_e/region_e/region_e.htm, last visited on 05.08.2020.

747 World Trade Organization, Regional Trade Agreements Database, available at: http://rtais.wto.org/UI/PublicMaintainRTAHome.aspx, last visited on 26.05.2020. European Commission, Negotiations and Agreements, available at: http://ec.europa.eu/trade/policy/countries-and-regions/negotiations-andagreements/\#_in-place, last visited on 31.07.2020.

${ }^{748}$ Ignacio Garcia Bercero, Dispute Settlement in European Union Free Trade Agreements: Lessons Learned?, at: Lorand Bartels \& Federico Ortino (eds.), Regional Trade Agreements and the WTO System, Oxford University Press, 2006, p. 383. In addition to the political and adjudicative model, some scholars identified another model, the hybrid model of DSMs, in the EU's FTAs, where arbitration includes both political and adjudicative elements. See: Edna Ramírez Robles, Political \& Quasi-Adjudicative Dispute Settlement Models in European Union Free Trade Agreements-Is the Quasi-adjudicative Model A Trend Or Is It Just Another Model?, World Trade Organization Economic Research and Statistics Division-Staff Working Paper ERSD-2006-09, 11.2006, available at: https://www.wto.org/english/res_e/reser_e/ersd200609_e.pdf, last visited on 05.08.2020.

${ }^{749}$ Ignacio Garcia Bercero, Dispute Settlement in European Union Free Trade Agreements: Lessons Learned?, at: Regional Trade Agreements and the WTO System, Oxford University Press, 2006, p. 389. An exception is the EuroMediterranean Agreements (EUROMED), which also adopts a diplomatic DSM, but the political sensitivity coming from a membership seems to be absent.

${ }^{750}$ For example, in the EC-Croatia FTA, in order to settle disputes about the application or interpretation of treaty provisions, recourse to the Association Council, which may settle the dispute by means of a binding decision, is the only way. See: Council and Commission Decision concerning the conclusion of the Stabilisation and Association
} 
settlement process is barely regulated, and very often only one article addresses this in the FTA. These diplomatic DSMs in the EU's FTAs are similar to the political DSMs in international public law, particularly the one provided for under the GATT $1947 .{ }^{751}$ The unavoidable weaknesses of such DSMs have been pointed out: first, resolutions are made on a political basis; second, there is no pre-established legal state or only a barely detailed legal stage; third, the respondent can easily block the dispute settlement proceedings; fourth, parties are allowed to take unilateral decisions, such as retaliation. ${ }^{752}$ Regarding the underlying reasons for such a choice for the EU's FTAs, contributing factors include, in addition to political sensitivity in terms of membership, partnership and geopolitics, the EU's institutional conservativism and tendency to follow models used previously. ${ }^{753}$ In addition, the GATT 1947 model of dispute settlement, which included negotiation, conciliation and a consensus-based decisionmaking process, operated as an example for state-state DSMs in the area of international economic law and tended to be followed.

At a later point of this development stage, timid steps towards a judicial model were taken by adding the possibility of referring disputes to arbitration, such as the EuroMediterranean Agreement. ${ }^{754}$ However, under these DSMs, a respondent still has opportunities to block the process at various points, such as the selection of its own arbitrator and the appointment of the chair. Moreover, there is no compliance procedure provided, and therefore the implementation of arbitral awards essentially relies on the "best efforts" of disputing parties. ${ }^{755}$

One exceptional treaty concluded by the EC in the 1990s is the Energy Charter Treaty (ECT). Like in the WTO, the EC became a member to the ECT along with its Member States. ${ }^{756}$ In fact, the EC played a major role as a coordinator and driving force behind the negotiations leading to the ECT. ${ }^{757}$ To resolve disputes concerning the

Agreement between the European Communities and their Member States, of the one part, and the Republic of Croatia, of the other part (entered into force on 01.03.2002), OJ L 026, 2005, Art. 113. With Croatia's accession to the EU on 1 July 2003, this FTA was denounced.

${ }^{751}$ Edna Ramírez Robles, Political \& Quasi-Adjudicative Dispute Settlement Models in European Union Free Trade Agreements-Is the Quasi-adjudicative Model A Trend Or Is It Just Another Model?, World Trade Organization Economic Research and Statistics Division-Staff Working Paper ERSD-2006-09, 11.2006, available at: https://www.wto.org/english/res_e/reser_e/ersd200609_e.pdf, last visited on 05.08.2020.

${ }_{752}$ Id, pp. 19-22.

753 Ignacio Garcia Bercero, Dispute Settlement in European Union Free Trade Agreements: Lessons Learned?, at: Regional Trade Agreements and the WTO System, Oxford University Press, 2006, p. 390. Edna Ramírez Robles, Political \& Quasi-Adjudicative Dispute Settlement Models in European Union Free Trade Agreements-Is the Quasiadjudicative Model A Trend Or Is It Just Another Model?, World Trade Organization Economic Research and Statistics Division-Staff Working Paper ERSD-2006-09, 11.2006, available at: https://www.wto.org/english/res_e/reser_e/ersd200609_e.pdf, last visited on 05.08.2020.

${ }_{754}$ The Euro-Mediterranean Agreement establishing an association between the European Communities and their Member States, of the one part, and the State of Israel, of the other part (signed on 20.11.1995, entered into force on 01.06.2000), Art. 75.

${ }_{755}$ Edna Ramírez Robles, Political \& Quasi-Adjudicative Dispute Settlement Models in European Union Free Trade Agreements-Is the Quasi-adjudicative Model A Trend Or Is It Just Another Model?, World Trade Organization Economic Research and Statistics Division-Staff Working Paper ERSD-2006-09, 11.2006, available at: https://www.wto.org/english/res_e/reser_e/ersd200609_e.pdf, last visited on 05.08.2020.

756 Council of the European Union \& Commission of the European Communities, Council and Commission Decision of 23 September 1997 on the Conclusion, by the European Communities, of the Energy Charter Treaty and the Energy Charter Protocol on Energy Efficiency and Related Environmental Aspects, 98/181/EC, ECSC, Euratom, 23.09.1997.

757 European Commission, Press Release Database, available at: http://europa.eu/rapid/press-release_MEMO-94- 
interpretation and application of this treaty, a two-tiered system was designed and incorporated. Initially, disputing parties shall endeavour to settle disputes through diplomatic channels. ${ }^{758}$ According to the ECT's official website, such "diplomatic channels" include good offices, which can be made available to disputing parties at any time, with the facilitation from the Energy Charter Secretariat as a trusted third party. ${ }^{759}$ If no settlement can be reached, ad hoc arbitration would become available for matters on most aspects of the ECT. ${ }^{760}$ Procedural issues, such as the composition of tribunals, applicable arbitration rules and applicable laws are prescribed. ${ }^{761}$ The arbitral awards reached at the end of the process shall be final and binding. ${ }^{762}$ Thus, compared to other treaties concluded during the same phase, the EC's unconditional commitment to ad hoc arbitration in the ECT was quite unusual. Considering its leading role in the negotiations of the ECT, the EC's support for this DSM was more likely to be the case instead of passive acceptance. This confirms, to a certain extent, that the practice of adopting diplomatic DSMs in its FTAs was largely due to the fact that the treaty parties were potentially acceding members or had a partnership with the EC.

\subsubsection{A Shift to a quasi-WTO dispute settlement Panel Proceedings Model}

Marked by the conclusion of the EU-Mexico Global Agreement, the state-state dispute settlement systems in the EU's FTAs shifted to a model that is similar to the WTO Dispute Settlement System. ${ }^{763}$ Under this Agreement, for dispute settlement, treaty parties are required to initially "make every attempt through cooperation and consultations to arrive to a mutually satisfactory resolution", possibly with the assistance from the Joint Committee. ${ }^{764}$ If the dispute is not resolved through the Joint Committee within the given time, either disputing party may request the establishment

75_en.htm?locale $=$ EN, last visited on 26.05.2020. The ECT was even described as a child of the EU. See: Jan Kleinheisterkamp, The Next 10 Year ECT Investment Arbitration: A Vision for the Future-From a European Law Perspective, London School of Economics Legal Studies Working Paper, Vol. 7, 2011.

758 The Energy Charter Treaty, Art. 27(1).

759 International Energy Charter, Dispute Settlement, available at: https://energycharter.org/what-we-do/disputesettlement/overview/, last visited on 31.07.2020.

${ }^{760}$ Exceptions to the application of ad hoc arbitration include: (i) competition disputes, for which a bilateral nonbinding consultation mechanism is offered in Art. 6 of the ECT; (ii) environmental disputes, for which the ECT Art. 19 provides for disputes to be reviewed by the Charter Conference if no other international fora are appropriate for the consideration of such disputes; (iii) transit disputes, where a specialised conciliation mechanism was presented by Art. 7.7, allowing for a faster and less formal procedure. Additionally, Art. 29 and Annex D established a mechanism which is largely similar to the WTO Dispute Settlement System for Energy Charter member countries to resolve trade disputes, provided that at least one of them is not a WTO member.

761 The Energy Charter Treaty, Art. 27 (2)\&(3).

762 The Energy Charter Treaty, Art. 27 (3)(h).

763 Economic Partnership, Political Coordination and Cooperation Agreement between the European Community and its Member States, of the one part, and the United Mexican States, of the other part (signed on 08.12.1997, entered into force on 01.20.2000). The initial agreement postponed the establishment of dispute settlement provisions to a later decision by the Joint Council, which was taken in March 2000. See: The EC/Mexico Joint Council, Decision 2/2000 of the EC-Mexico Joint Council of 23 March 2000 (Covering Trade in Goods, Government Procurement, Cooperation for Competition, Consultation on Intellectual Property Rights, Dispute Settlement), CEMX 3854/00, 23.03.2000.

Currently, the EU and Mexico have reached an "agreement in principle" on the main trade parts of a new EU-Mexico association agreement. This new agreement replaces the previous deal in effect from 2000. See: European Commission, New EU-Mexico Agreement: The Agreement in Principle and its Texts, available at: $\mathrm{http} / / /$ ec.europa.eu/trade/policy/in-focus/eu-mexico-trade-agreement/, last visited on 30.07.2020.

${ }^{764}$ The EC/Mexico Joint Council, Decision 2/2000 of the EC-Mexico Joint Council of 23 March 2000 (Covering Trade in Goods, Government Procurement, Cooperation for Competition, Consultation on Intellectual Property Rights, Dispute Settlement), CE-MX 3854/00, 23.03.2000, Art. 42 (1)\&(2). 
of an arbitration panel, where each party may choose its own arbitrator and the chair is in principle to be decided by consensus. ${ }^{765}$ Failure to appoint arbitrators will lead to a selection by lot from the candidates proposed. ${ }^{766}$ After hearing the case, the panel should issue an initial report followed by comments submitted by the parties and a final report in the end. ${ }^{767}$ The time frames for the various stages are clearly stated for both normal and urgent situations. ${ }^{768}$ It is also noted that the EU-Mexico Global Agreement (1997) goes beyond panels' final rulings and regulates the implementation of panel reports. ${ }^{769}$ In brief, the procedural design of the whole dispute settlement system is very similar to the WTO panel proceedings. ${ }^{770}$

One year later, the EU concluded the EU-Chile Association Agreement (2002), ${ }^{771}$ in which the state-state dispute settlement system constitutes another typical example of the quasi-WTO dispute settlement panel proceedings model. Compared to the EUMexico Global Agreement (1997), in addition to the more detailed procedural arrangements added to the treaty text, two issues deserve particular attention. ${ }^{772}$ First, the EU-Chile Association Agreement (2002) adds provisions on the submission of amicus curiae briefs and cooperation by parties on increasing transparency. ${ }^{773}$ Second, under the EU-Chile Association Agreement (2002), the composition of the panel for a specific case is determined by lot from a pre-established roster of 15 panellists. ${ }^{774}$ These two can be read as a sign of the EU's intention and treaty parties' agreement to add judicial features and to increase the institutionalization of such dispute settlement systems.

After the Lisbon Treaty, as of 31 April 2020, the EU has concluded two trade deals that include state-state DSMs. In addition to CETA (2016), a more recent example is the EU-Japan Economic Partnership Agreement. ${ }^{775}$ The state-state dispute settlement system in this newly negotiated agreement follows the practice of quasi-WTO dispute

765 Id, Art. 44 (1)\&(2).

${ }^{766}$ Id, Art. 44 (4). Thus, on this point, the respondent does not have the chance to block the dispute settlement process.

767 Id, Art. 45 (1)\&(2).

${ }^{768}$ Id, Arts. 43-46.

769 The EC/Mexico Joint Council, Decision 2/2000 of the EC-Mexico Joint Council of 23 March 2000 (Covering Trade in Goods, Government Procurement, Cooperation for Competition, Consultation on Intellectual Property Rights, Dispute Settlement), CE-MX 3854/00, 23.03.2000, Art. 46.

${ }^{770}$ In addition, also similar to the practice under the WTO Dispute Settlement System, a separate Code of Conduct for arbitrators is attached to the EU-Mexico Global Agreement (1997) to add to the panels' credibility. See: id, Appendix I of Annex XVI.

${ }^{771}$ Agreement establishing an association between the European Community and its Member States, of the one part, and the Republic of Chile, of the other part (signed on 18.11.2002, entered into force on 01.03.2005).

${ }^{772}$ For a comprehensive analysis of the differences between the EU-Mexico Global Agreement (1997) and the EUChile Association Agreement (2002), see: Edna Ramírez Robles, Political \& Quasi-Adjudicative Dispute Settlement Models in European Union Free Trade Agreements-Is the Quasi-adjudicative Model A Trend Or Is It Just Another Model?, World Trade Organization Economic Research and Statistics Division-Staff Working Paper ERSD-200609, 11.2006, available at: https://www.wto.org/english/res_e/reser_e/ersd200609_e.pdf, last visited on 05.08.2020.

773 The EU-Chile Association Agreement (2002), Annex XV paras. 35-37.

774 Id, Art. 185(2)(3).

775 The negotiations between the EU and Japan on the Economic Partnership Agreement have been finalized and the legal revision of the texts has been completed. The texts will be binding upon the EU and Japan under international law after the completion by each treaty party of its internal legal procedures necessary for the entry into force of the Agreement. For more information on this, see: European Commission, EU-Japan Economic Partnership Agreement: Texts of the Agreement, 18.04.2018, available at: $\mathrm{http} / /$ trade.ec.europa.eu/doclib/press/index.cfm?id=1684, last visited on 31.07.2020. 
settlement panel proceedings model. Specifically, first of all, amicable and confidential consultations are compulsory. ${ }^{776}$ Mediation is provided as an additional optional amicable option, which is available at any time based on the consent of the disputing parties. ${ }^{777}$ If disputes fail to be resolved through consultation, the panel procedure can be initiated by one party. ${ }^{778}$ The composition of the panel in a specific case should be based on an agreement between the disputing parties as the first choice; if no agreement can be reached, the panel is selected from a pre-established list. ${ }^{779}$ This follows the practice under the EU-Chile FTA (2002), but is differs from arbitration practice where each disputing party normally enjoys the right to choose its own adjudicator. ${ }^{780}$ The constituted panel is expected to issue an interim panel report first, to be followed by the process of seeking comments from disputing parties and then a final report. ${ }^{781}$ Rules on compliance proceedings are also listed, regulating issues such as the reasonable period of time for compliance, temporary remedies in the case of non-compliance, the review of measures taken to comply after the suspension of obligations. ${ }^{782}$

In brief, despite the differences in the details, ${ }^{783}$ the common features in the EU's FTAs concluded within this phase show the transformation from a diplomatic to a quasi-WTO dispute settlement panel proceedings model. ${ }^{784}$ Compared to the diplomatic DSMs adopted by the EU at the earlier stage, the quasi-WTO dispute settlement panel proceedings model is apparently more demanding in terms of human resources and institutional requirements, ${ }^{785}$ but the EU has insisted on using it in all of its FTAs concluded with third states after the transformation. At the same time, the EU seems to have tried hard to realize its proposals raised in the DSU reform negotiations at the WTO in its FTAs, such as greater transparency. The possible underlying reasons for such a shift in practice may include the EU's dissatisfaction with the diplomatic approach where one party can easily block the dispute settlement process, its inclination towards having procedures that ensure a rapid resolution and the satisfaction with its experience in the WTO Dispute Settlement System. ${ }^{786}$

\footnotetext{
776 The EU-Japan Economic Partnership Agreement, Art. 21.5.

777 Id, Art. 21.6.

778 Id, Art. 21.7.

779 Id, Art. 21.8.

780 This can be found in many other FTAs in the world. See e.g. Free Trade Agreement between the Government of the People's Republic of China and the Government of the Republic of Singapore (signed on 23.10.2008, entered into force on 01.01.2009), Art. 9.

781 The EU-Japan Economic Partnership Agreement, Arts. 21.18, 21.19.

782 Id, Arts. 21.20-21.23.

783 A comparison of the detailed differences between the FTAs concluded by the EU before 2004 can be found in: Stefan Szepesi, Comparing EU Free Trade Agreements: Dispute Settlement, European Centre for Development Policy Management (ECDPM), 01.2004, available at: https://ecdpm.org/wp-content/uploads/2013/11/IB-6GComparing-EU-Free-Trade-Agreements-Dispute-Settlement-2004.pdf, last visited on 05.08.2020.

${ }^{784}$ As confirmed by the clear expression of the European Commission, the EU "has included dispute settlement mechanism based on the WTO dispute settlement mechanism in all of its Free Trade Agreements since 2000". See: European Commission, Dispute Settlement, available at: http://ec.europa.eu/trade/policy/accessing-markets/disputesettlement/, last visited on 31.07.2020.

785 Stefan Szepesi, Comparing EU Free Trade Agreements: Dispute Settlement, European Centre for Development Policy Management (ECDPM), 01.2004, available at: https://ecdpm.org/wp-content/uploads/2013/11/IB-6GComparing-EU-Free-Trade-Agreements-Dispute-Settlement-2004.pdf, last visited on 05.08.2020.

786 Ignacio Garcia Bercero, Dispute Settlement in European Union Free Trade Agreements: Lessons Learned?, at: Regional Trade Agreements and the WTO System, Oxford University Press, 2006, p. 391.
} 
Since CETA, the EU-Singapore IPA, the EU-Vietnam IPA, and the EU-Japan Economic Partnership Agreement were concluded after the Lisbon Treaty and thus represent the EU's most up-to-date practice, TABLE 7.2.1-2 lists the details regarding the design of and the comparison of their state-state dispute settlement systems. 


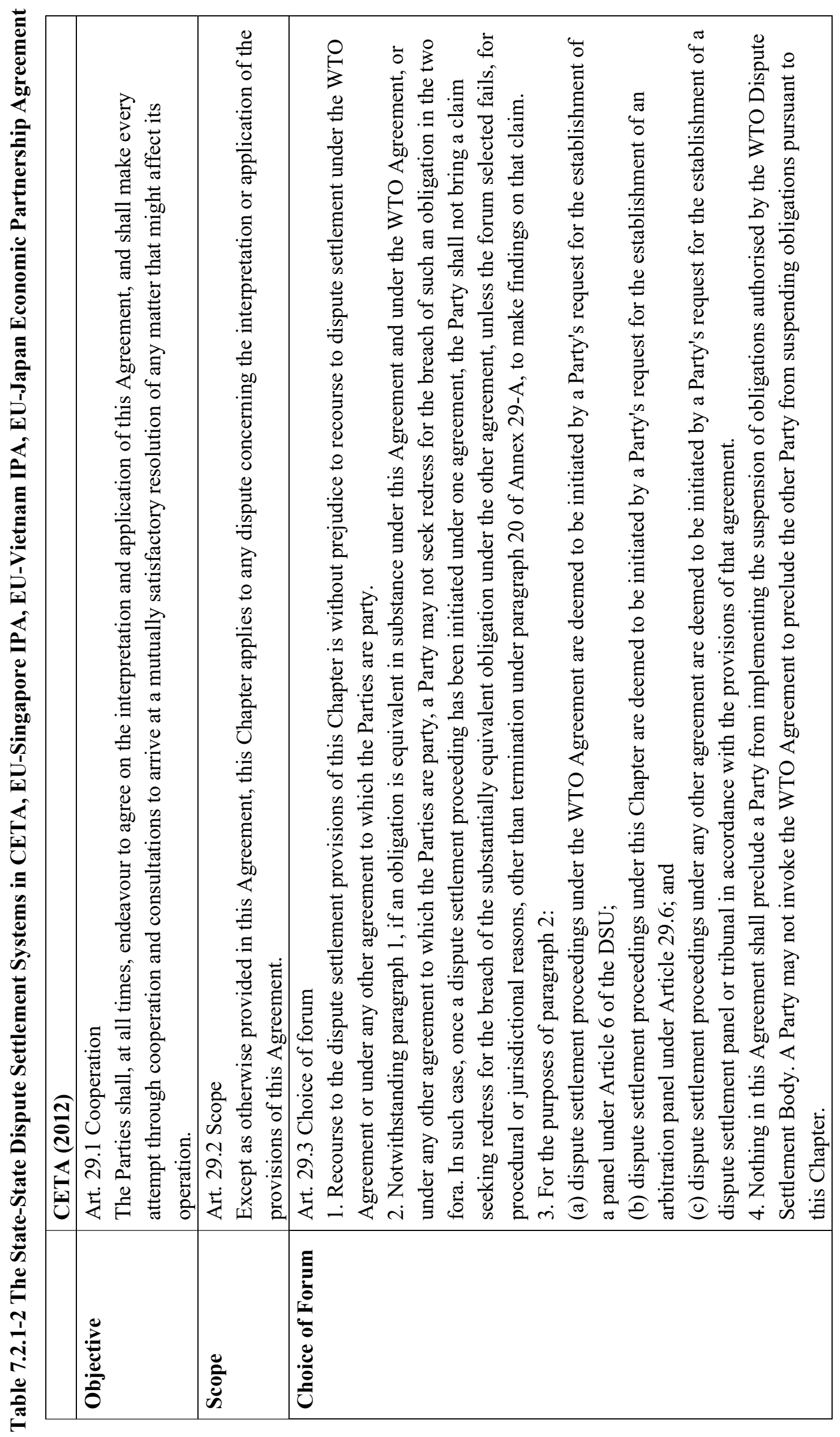




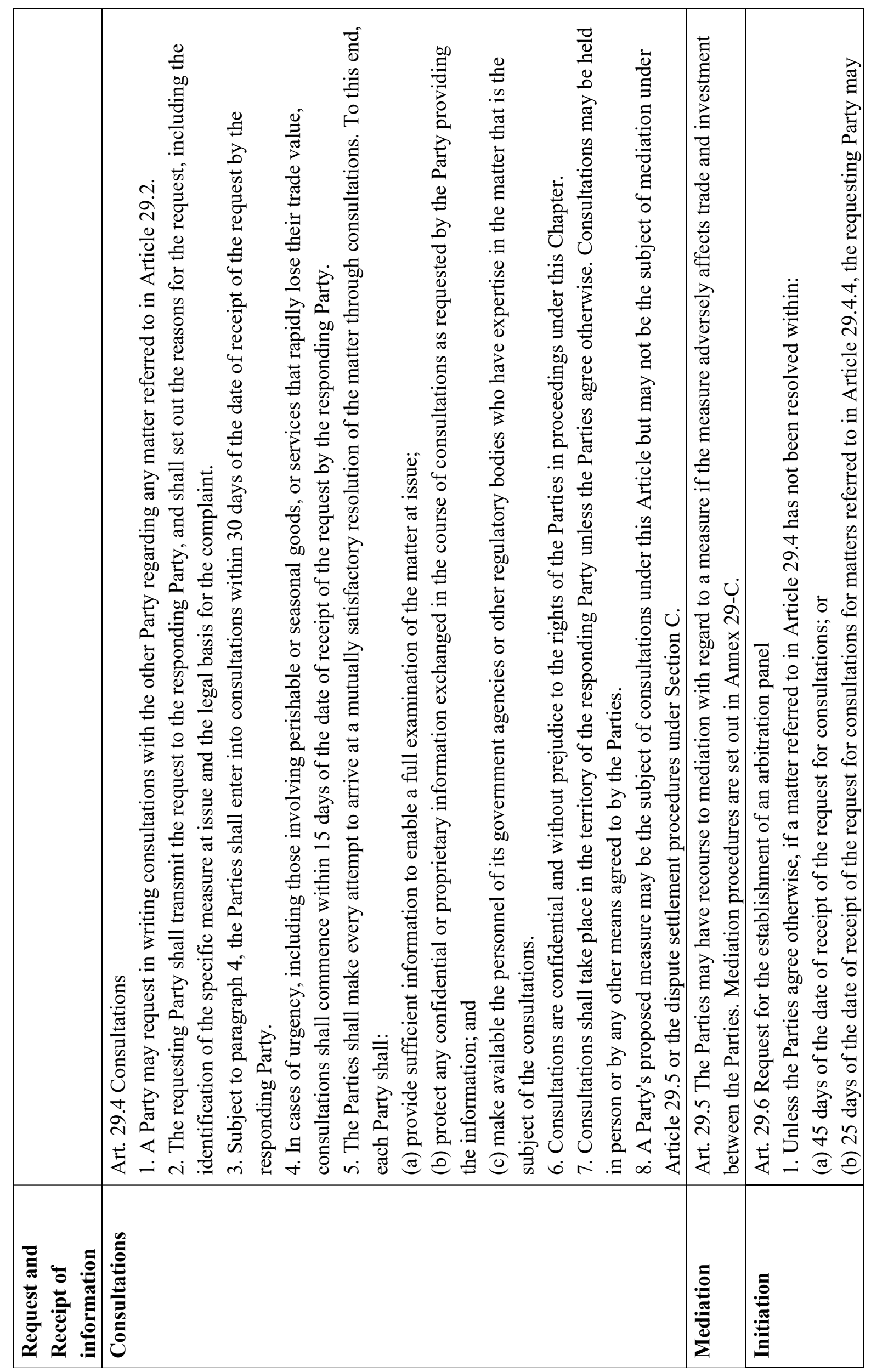




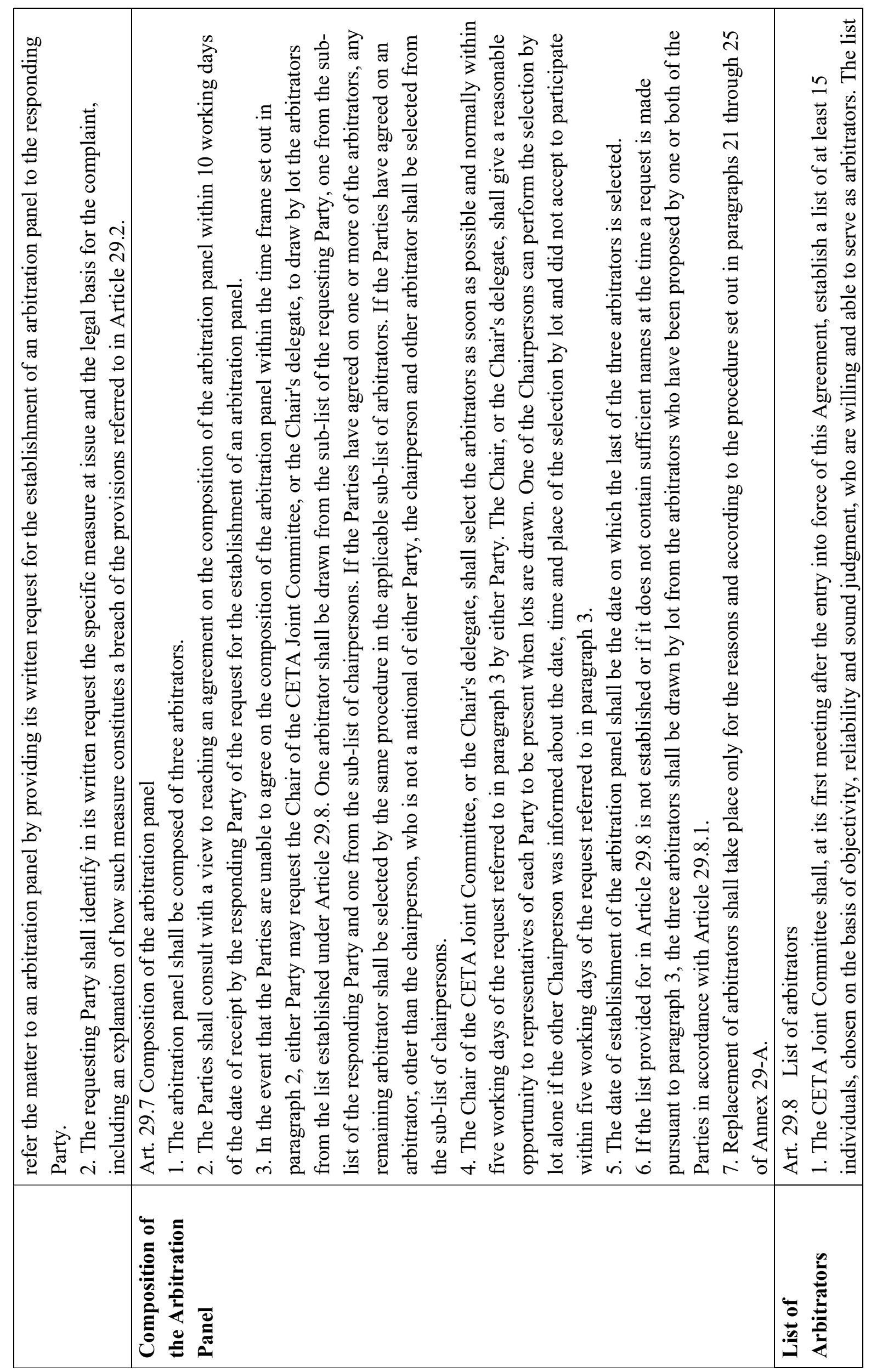




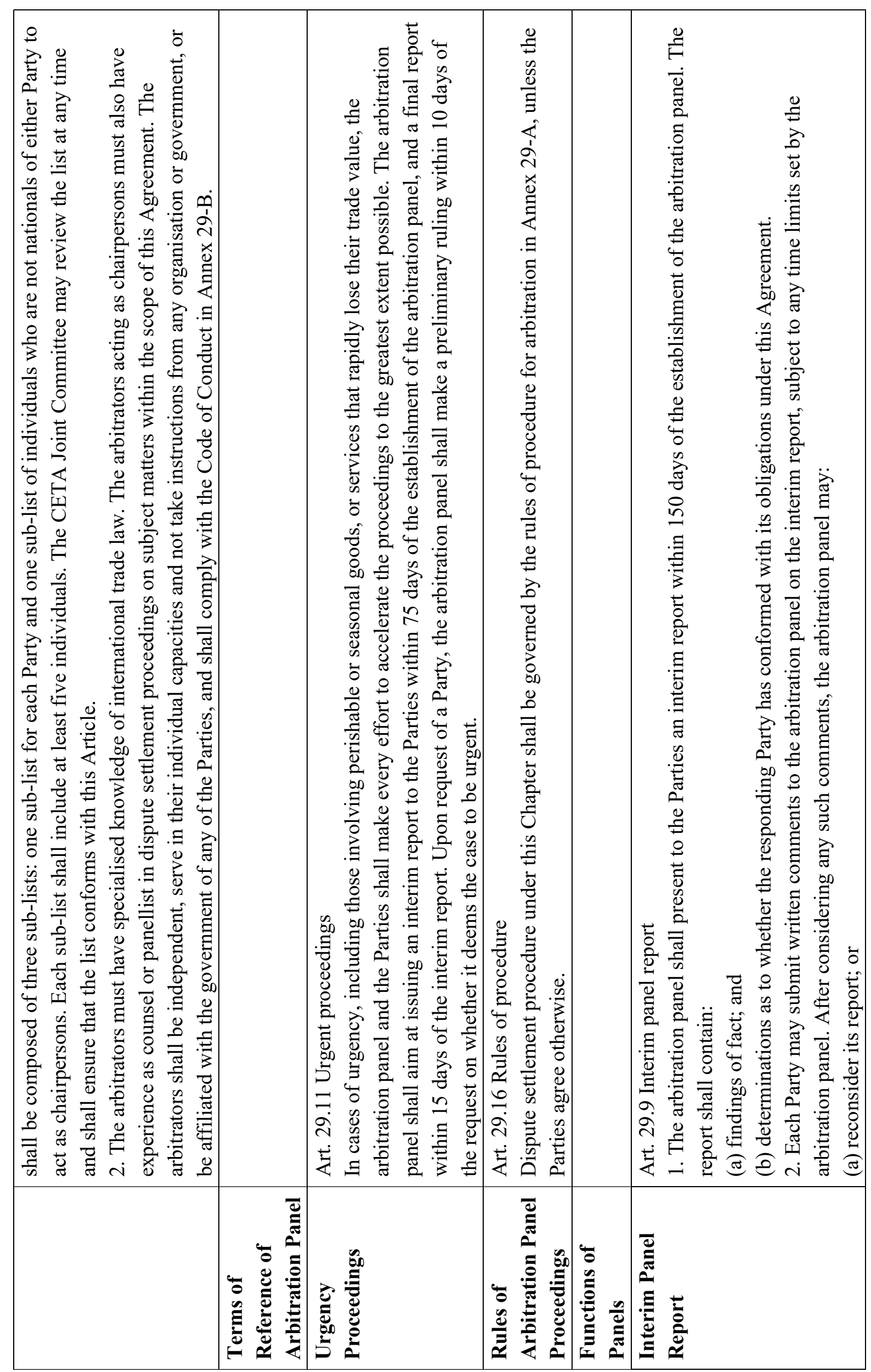




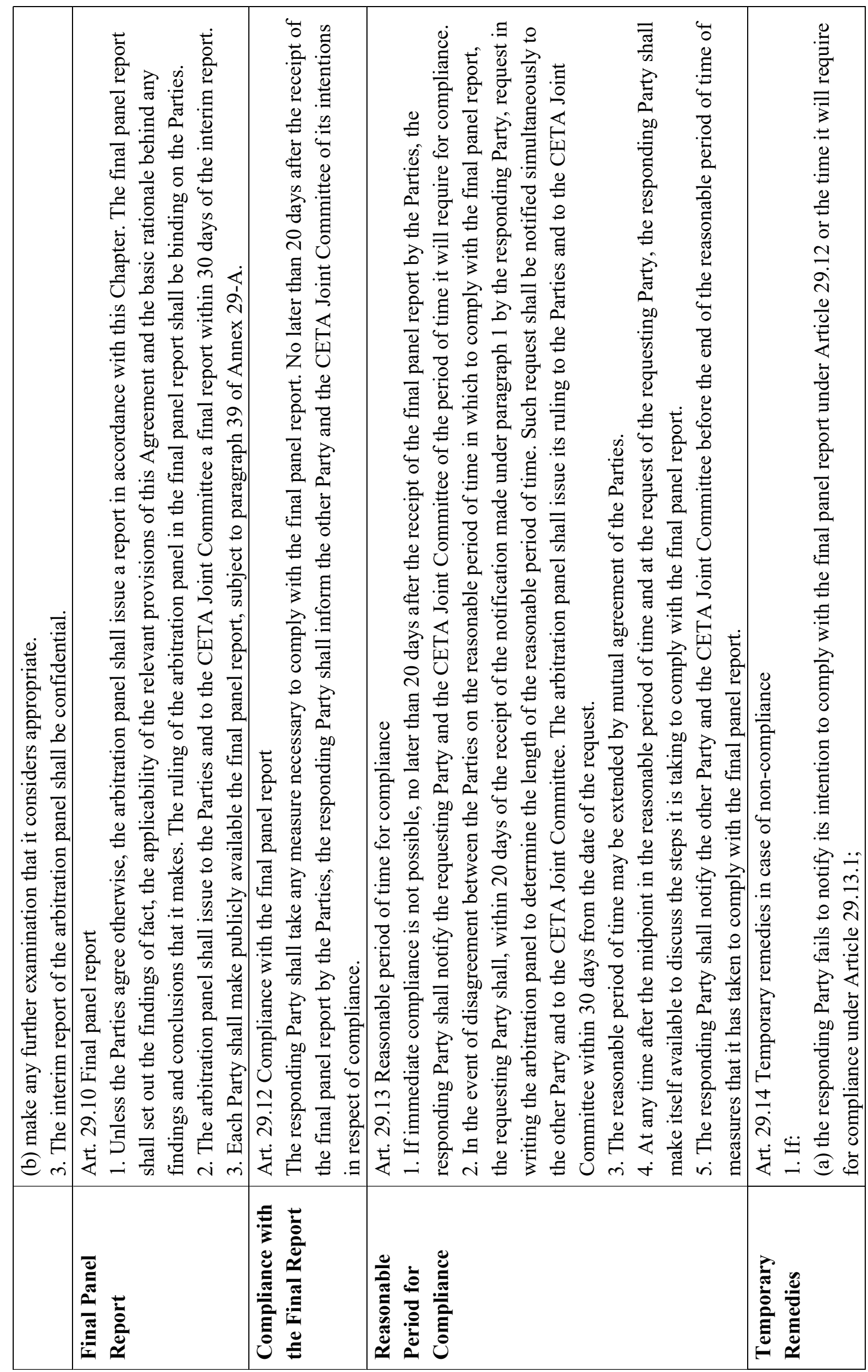




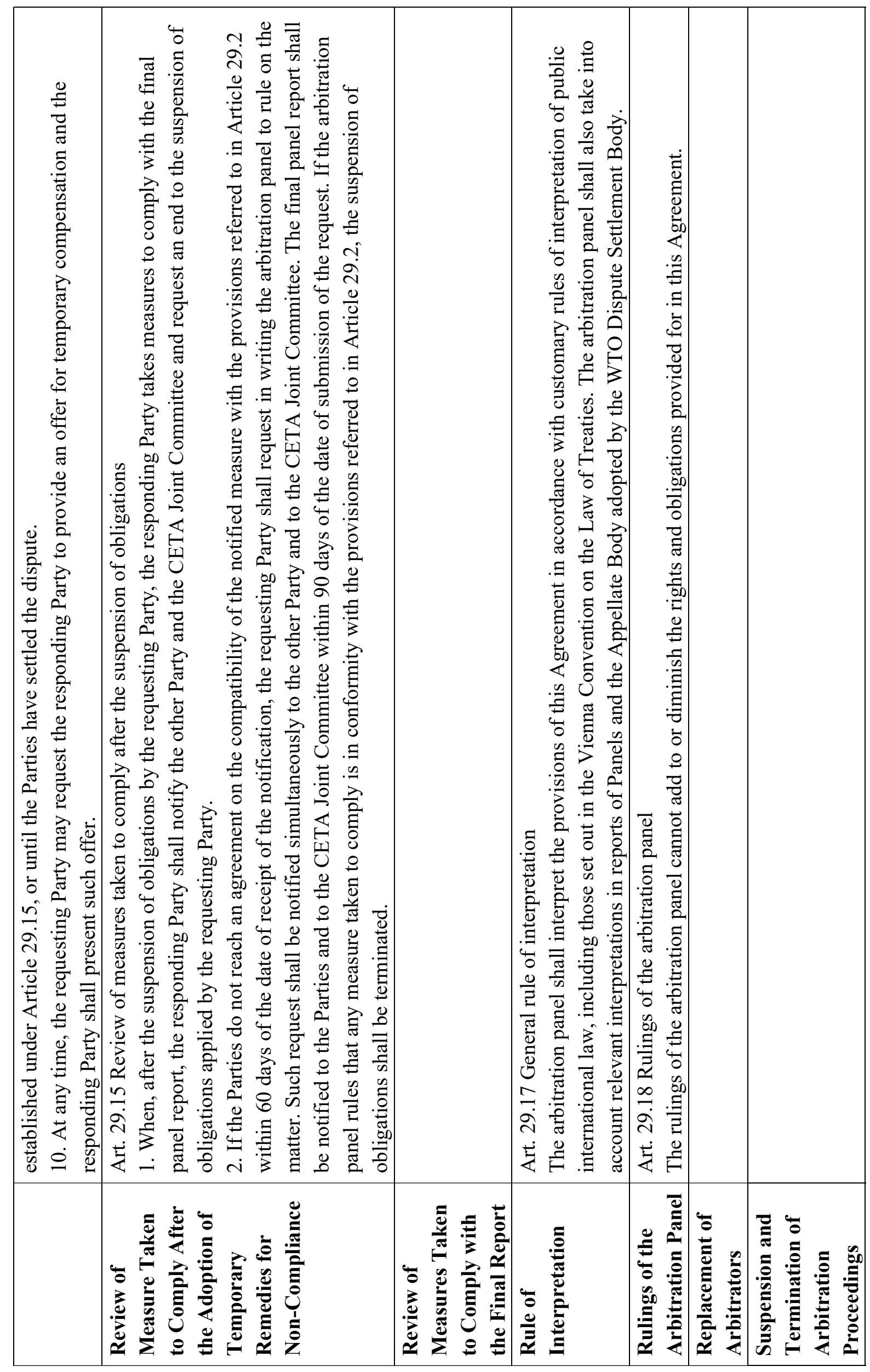




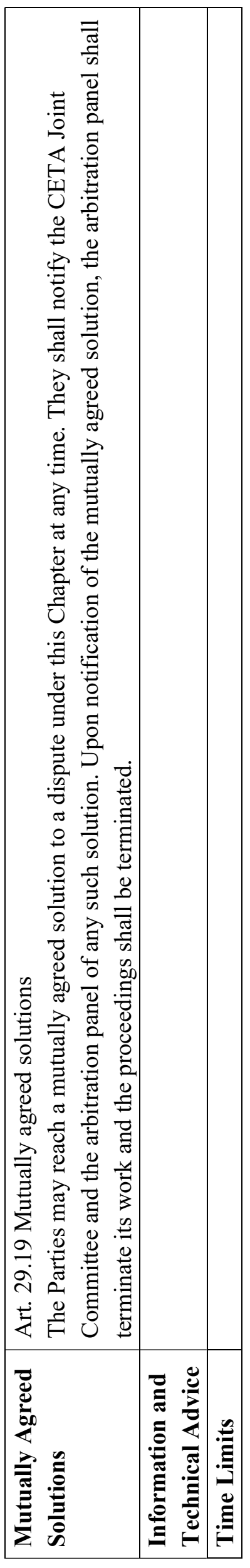




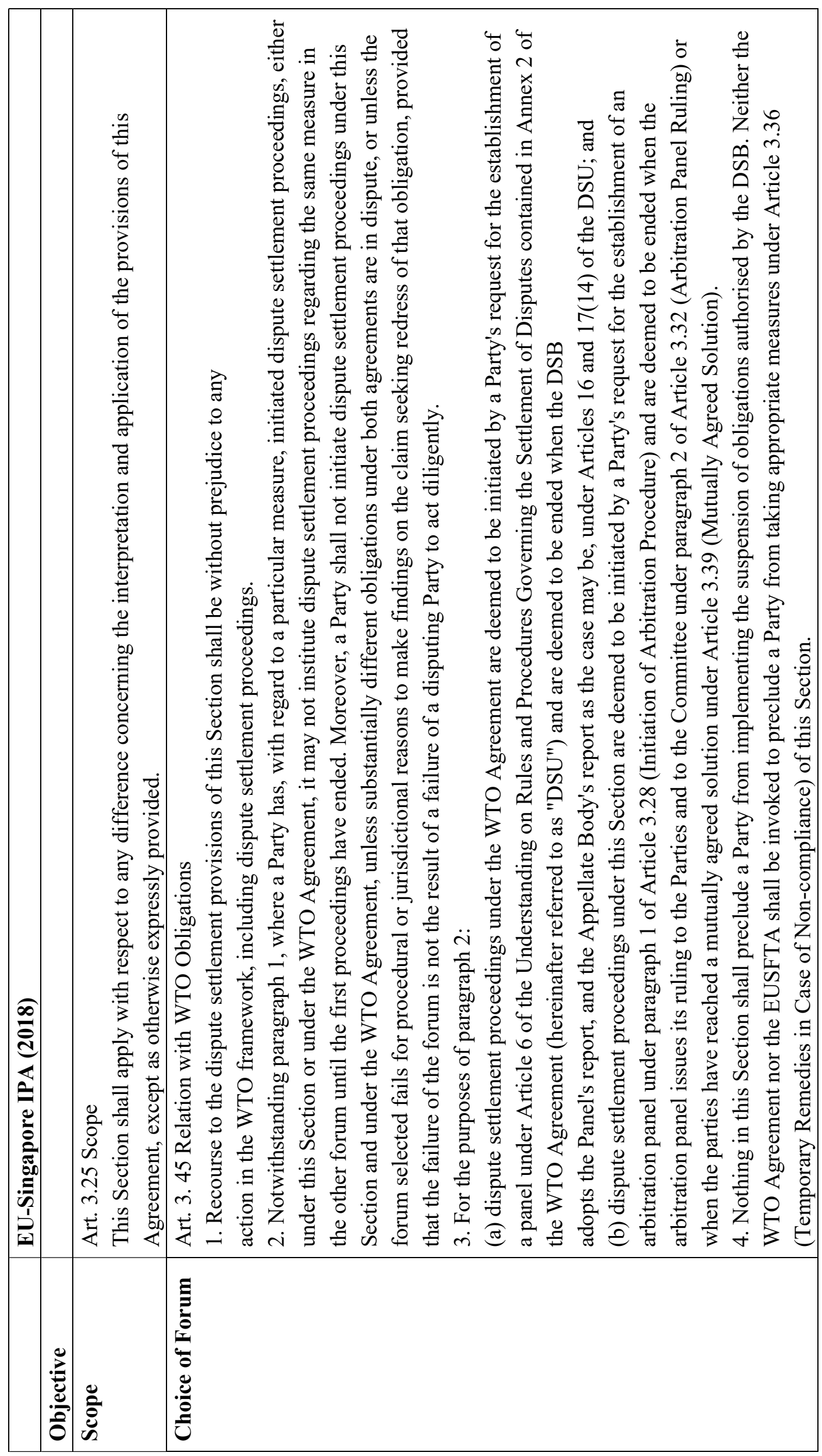




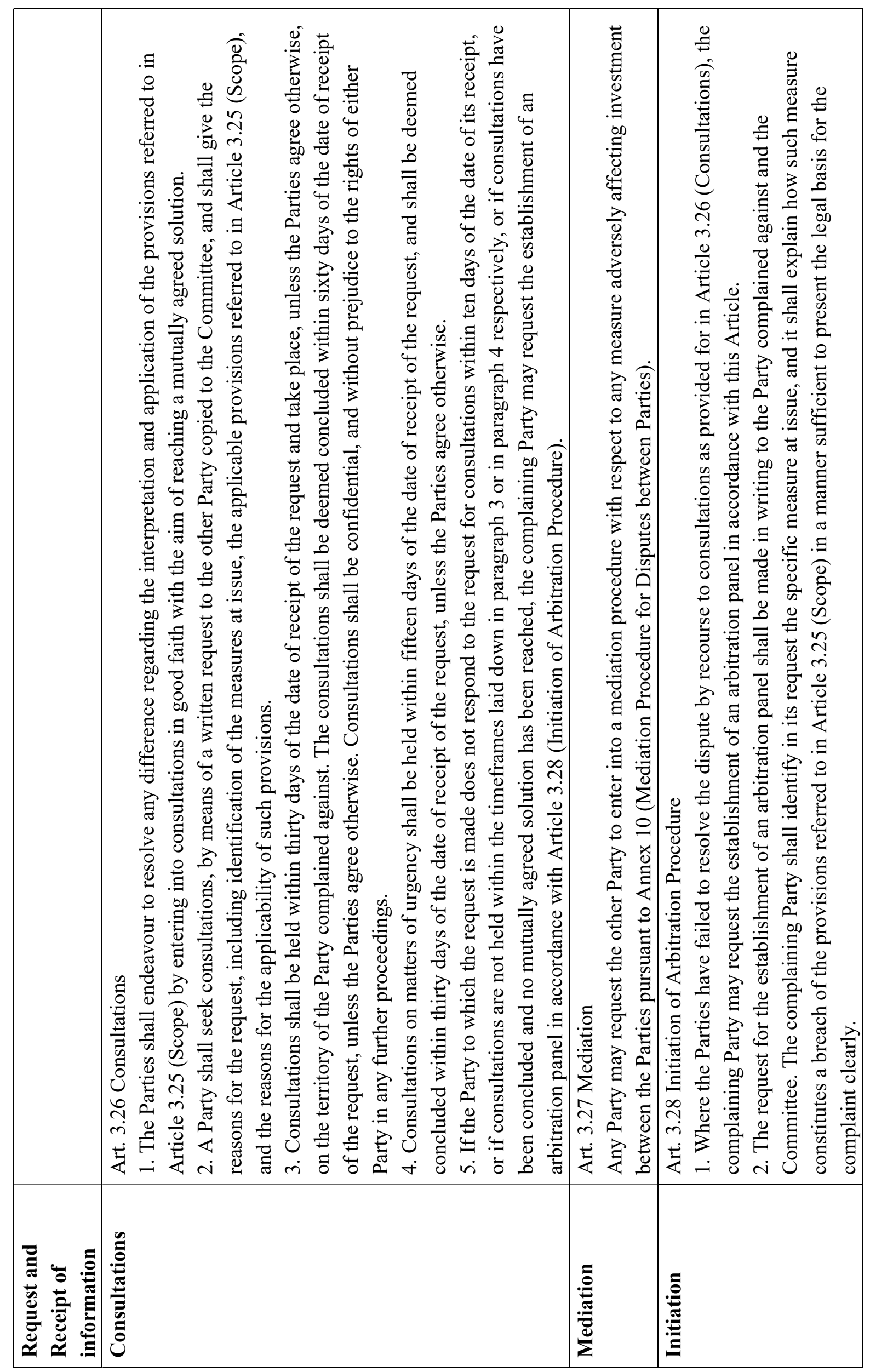




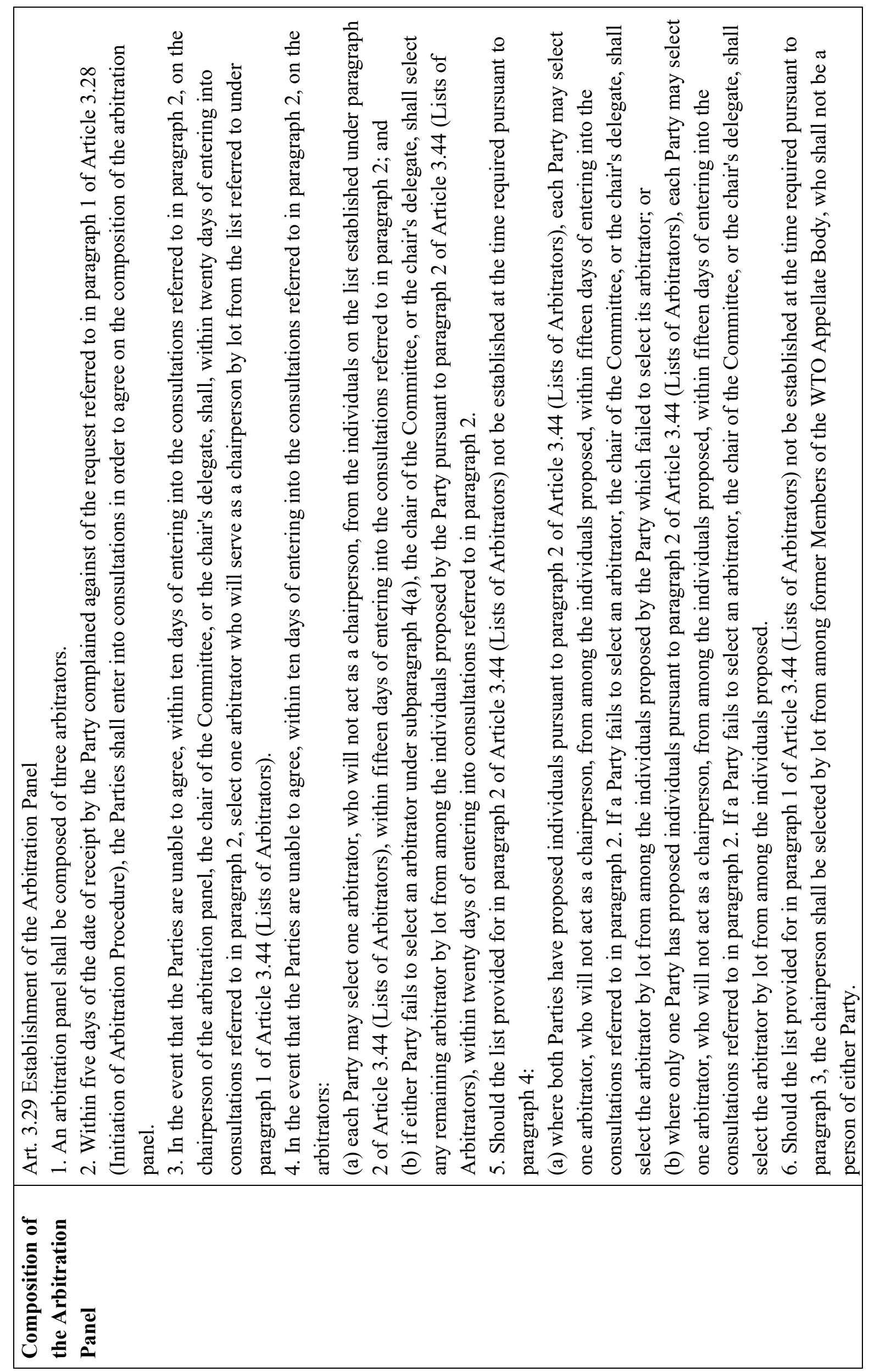




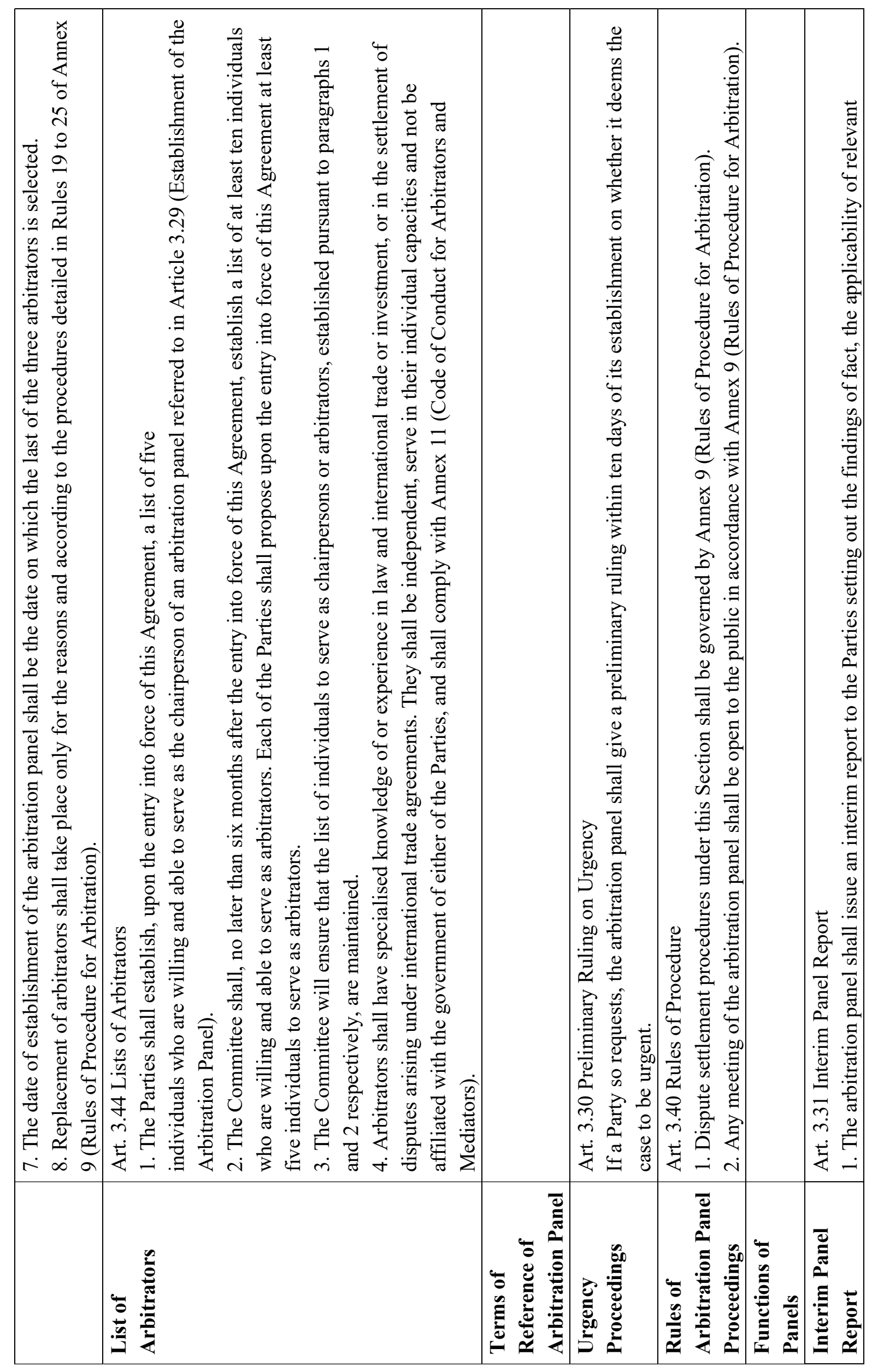




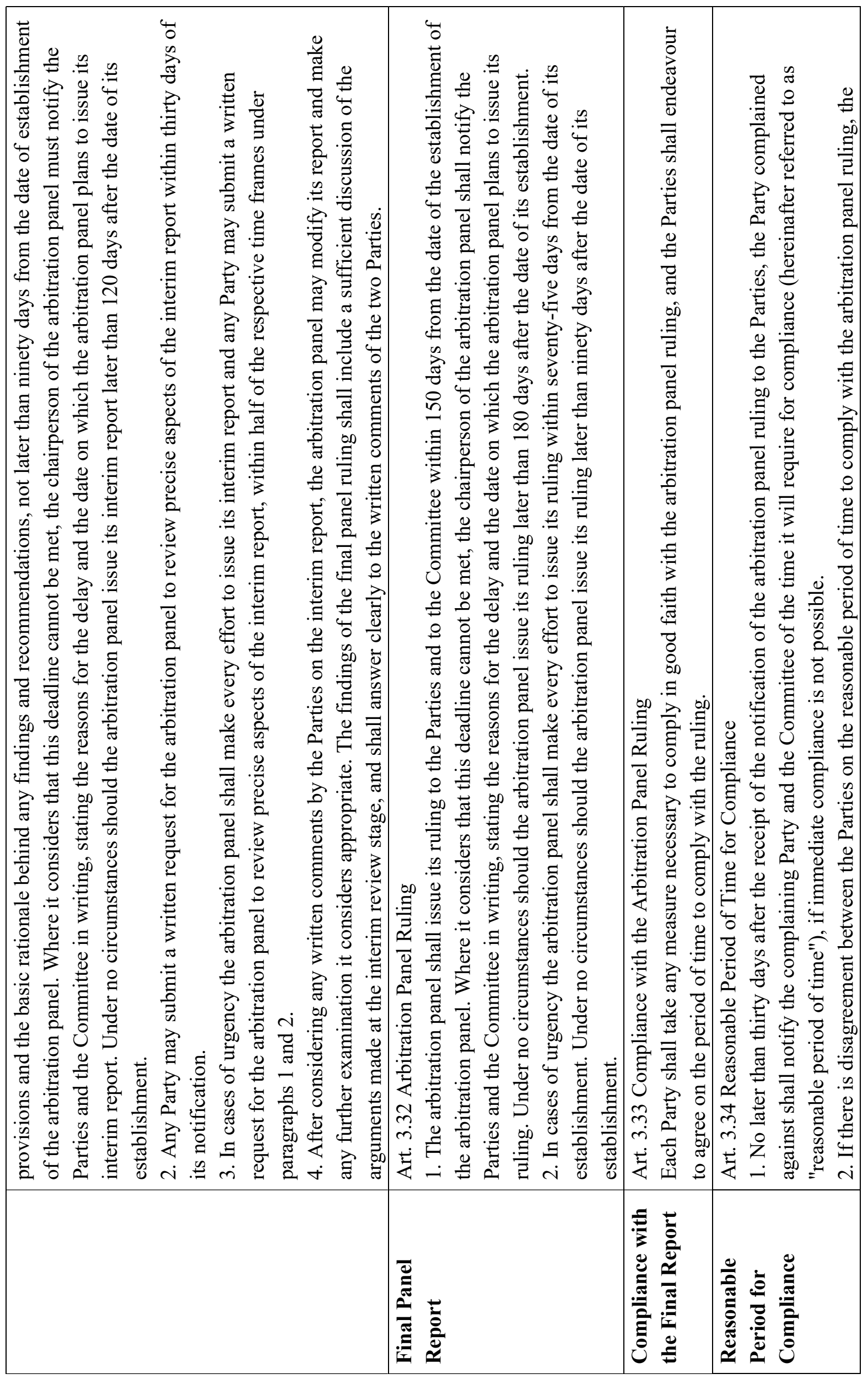




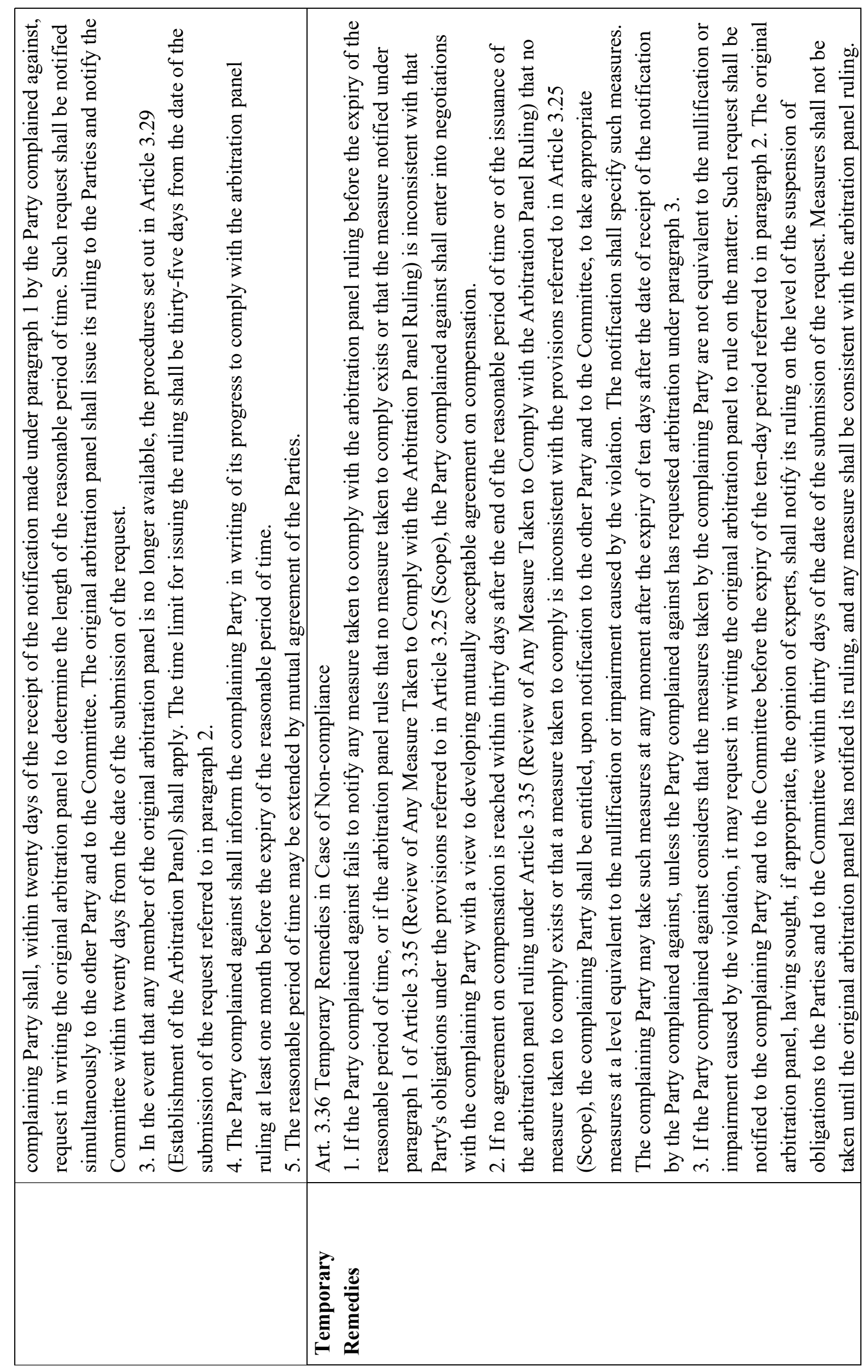




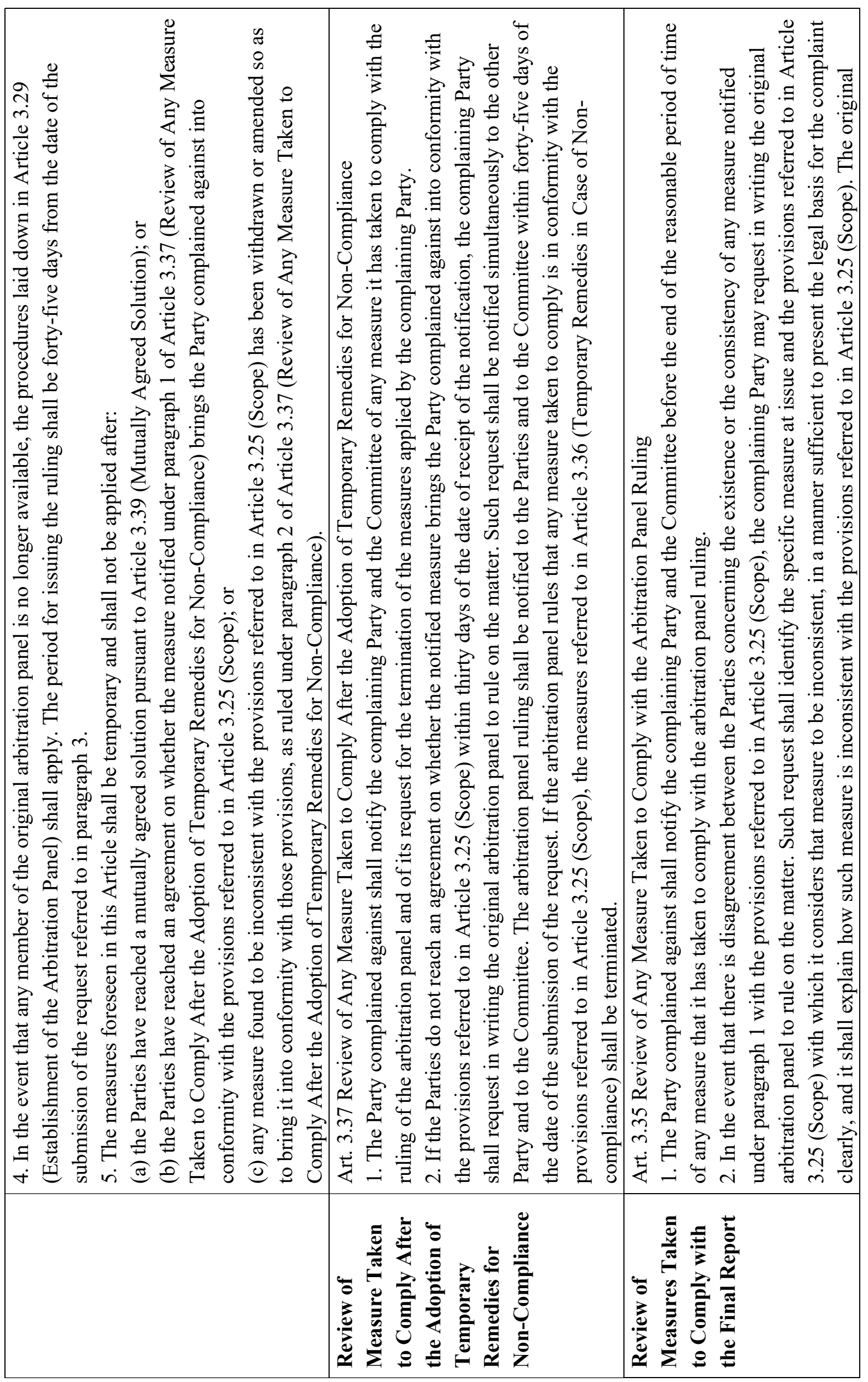




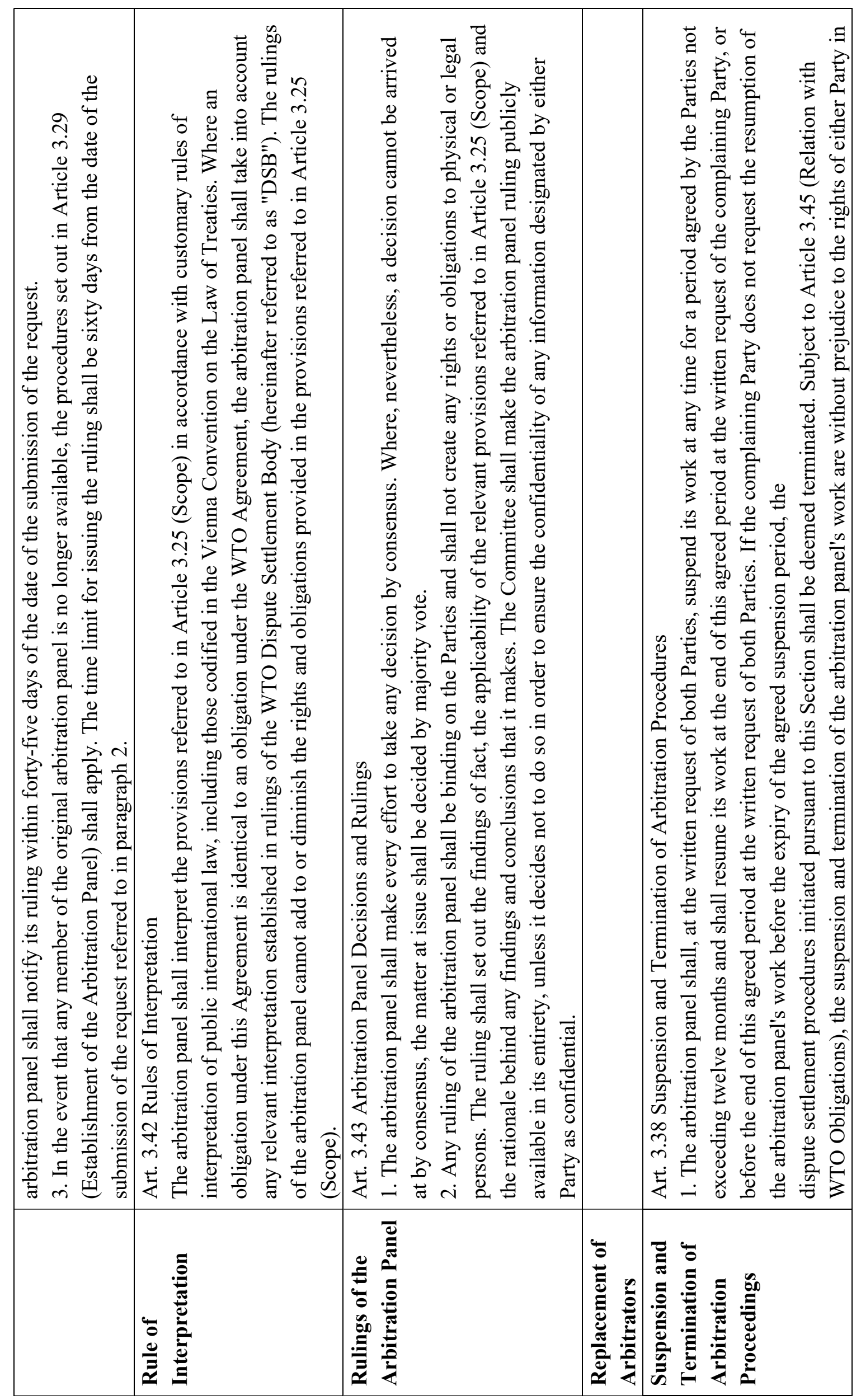




\begin{tabular}{|c|c|c|c|}
\hline 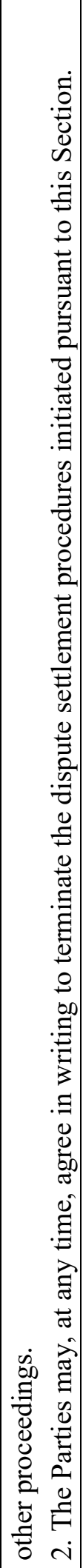 & 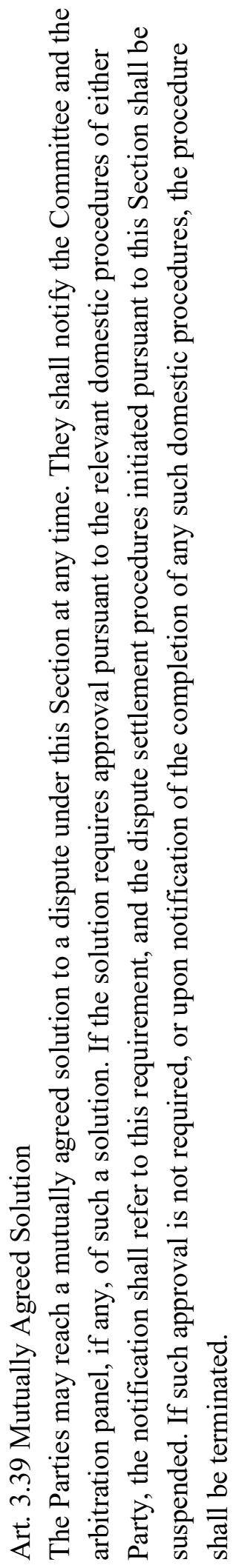 & 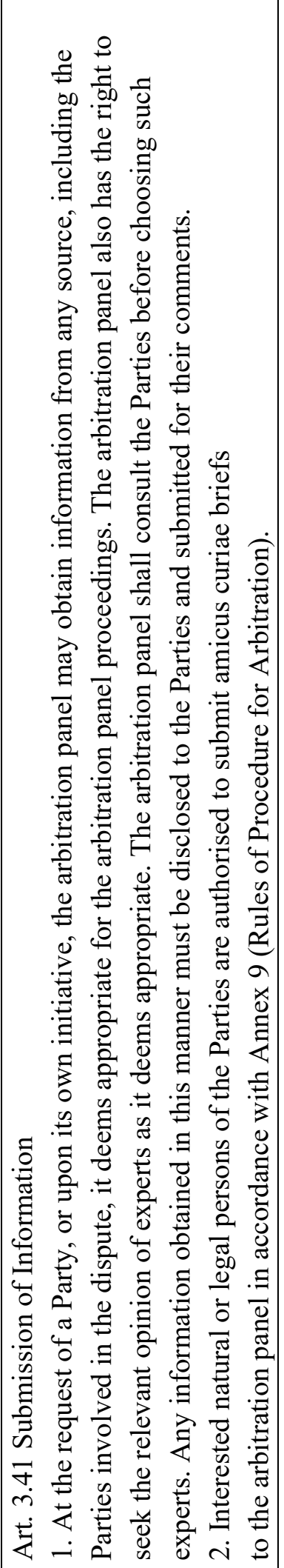 & 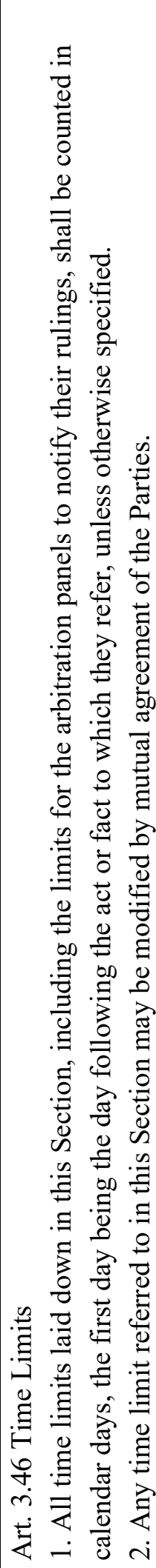 \\
\hline & 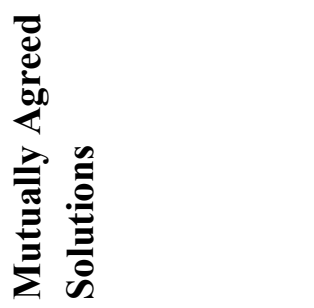 & 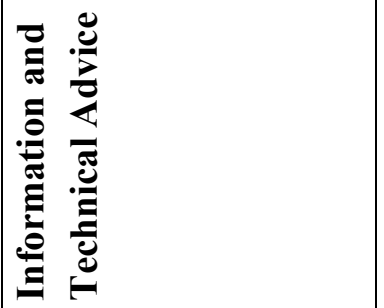 & 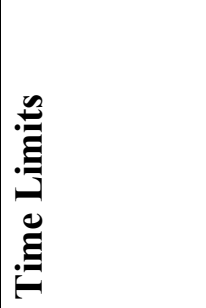 \\
\hline
\end{tabular}




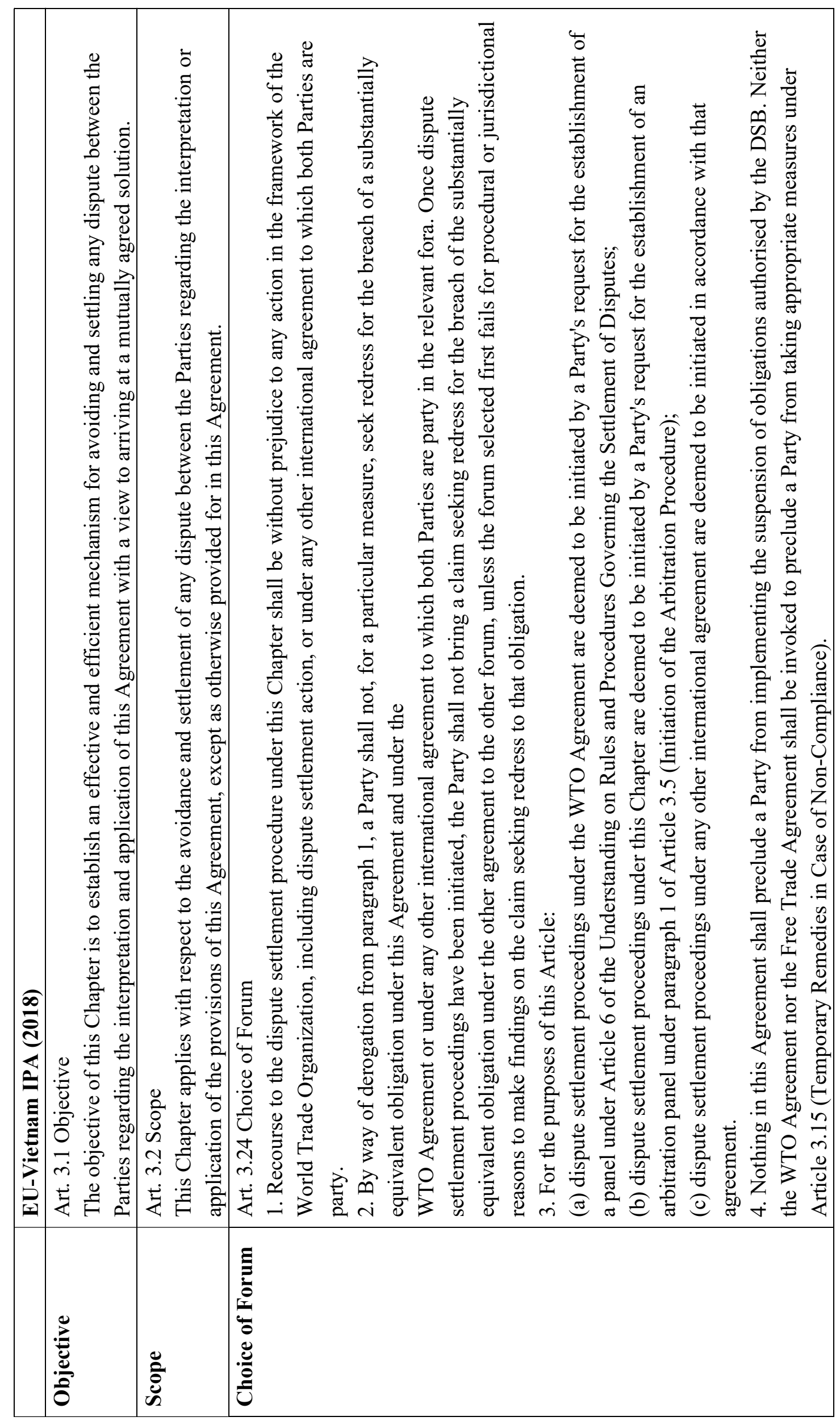




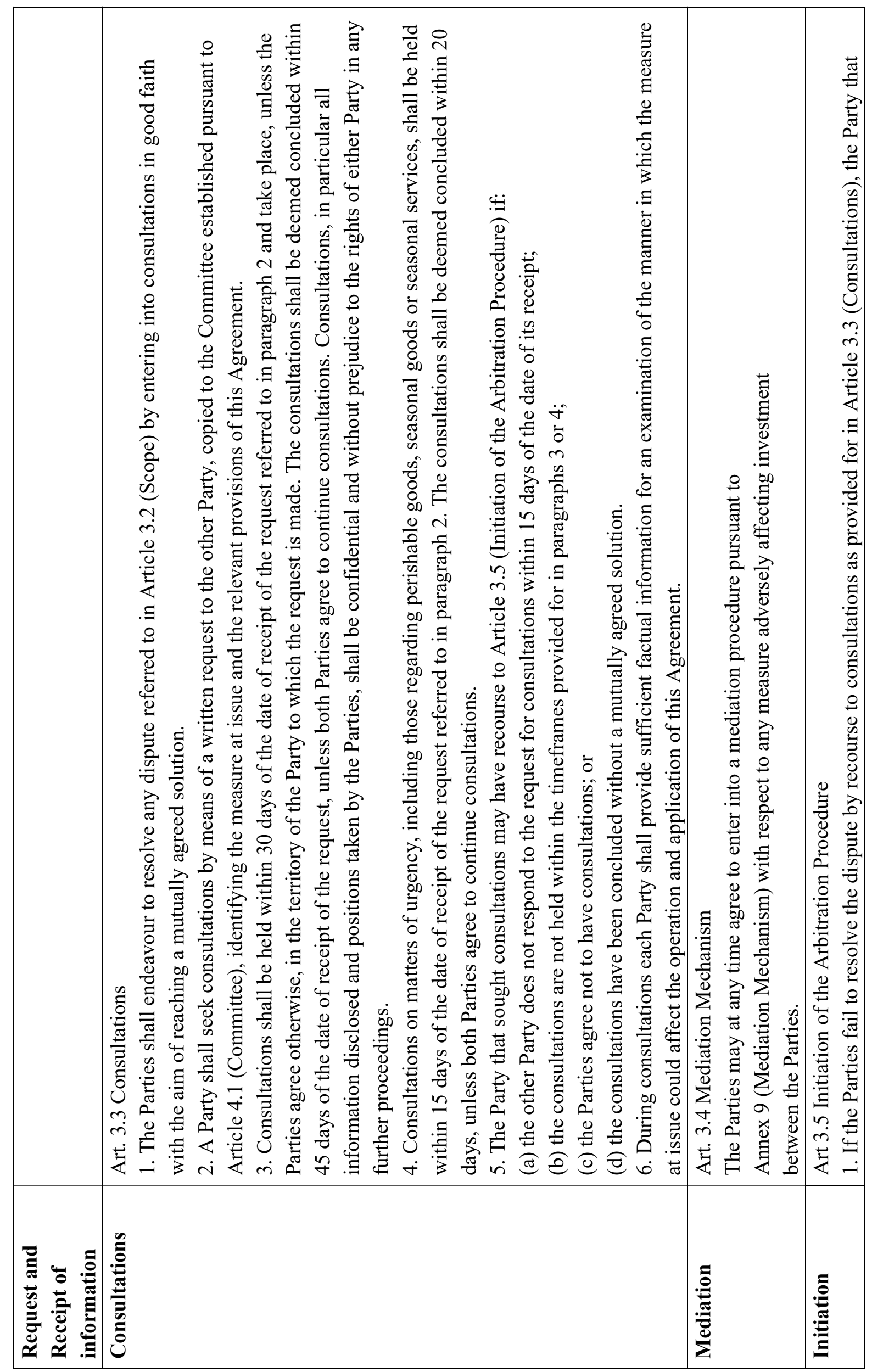




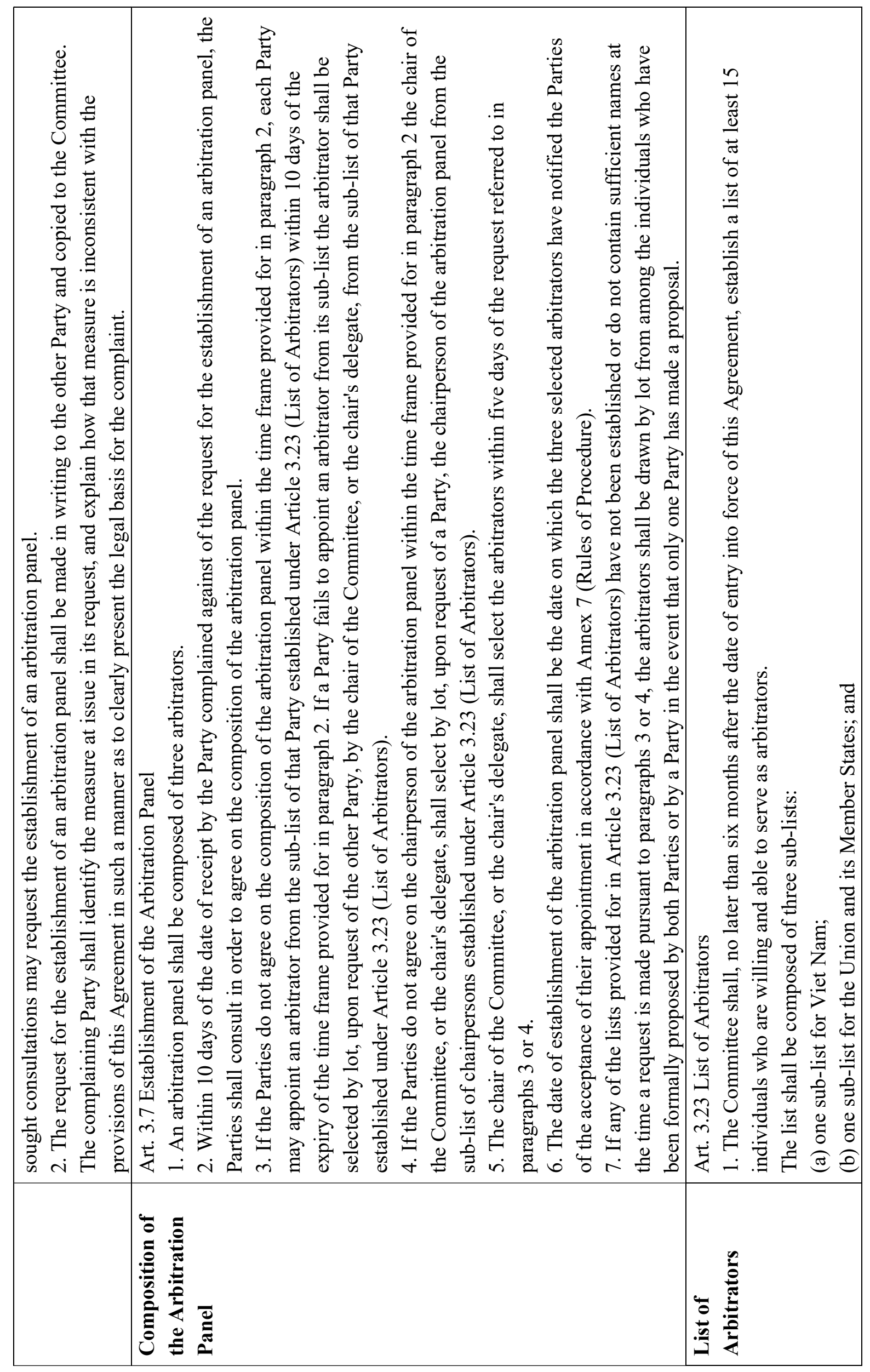




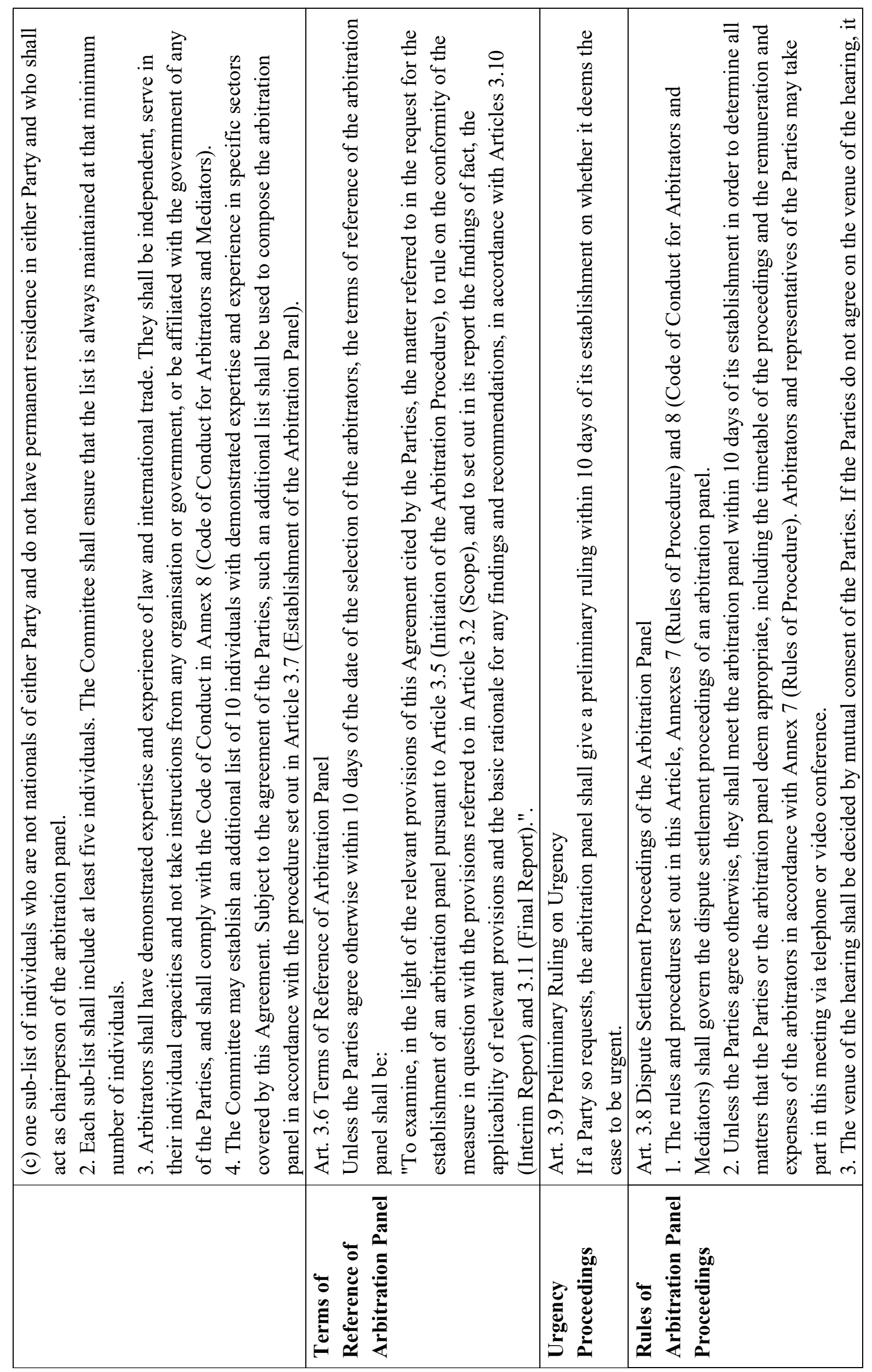




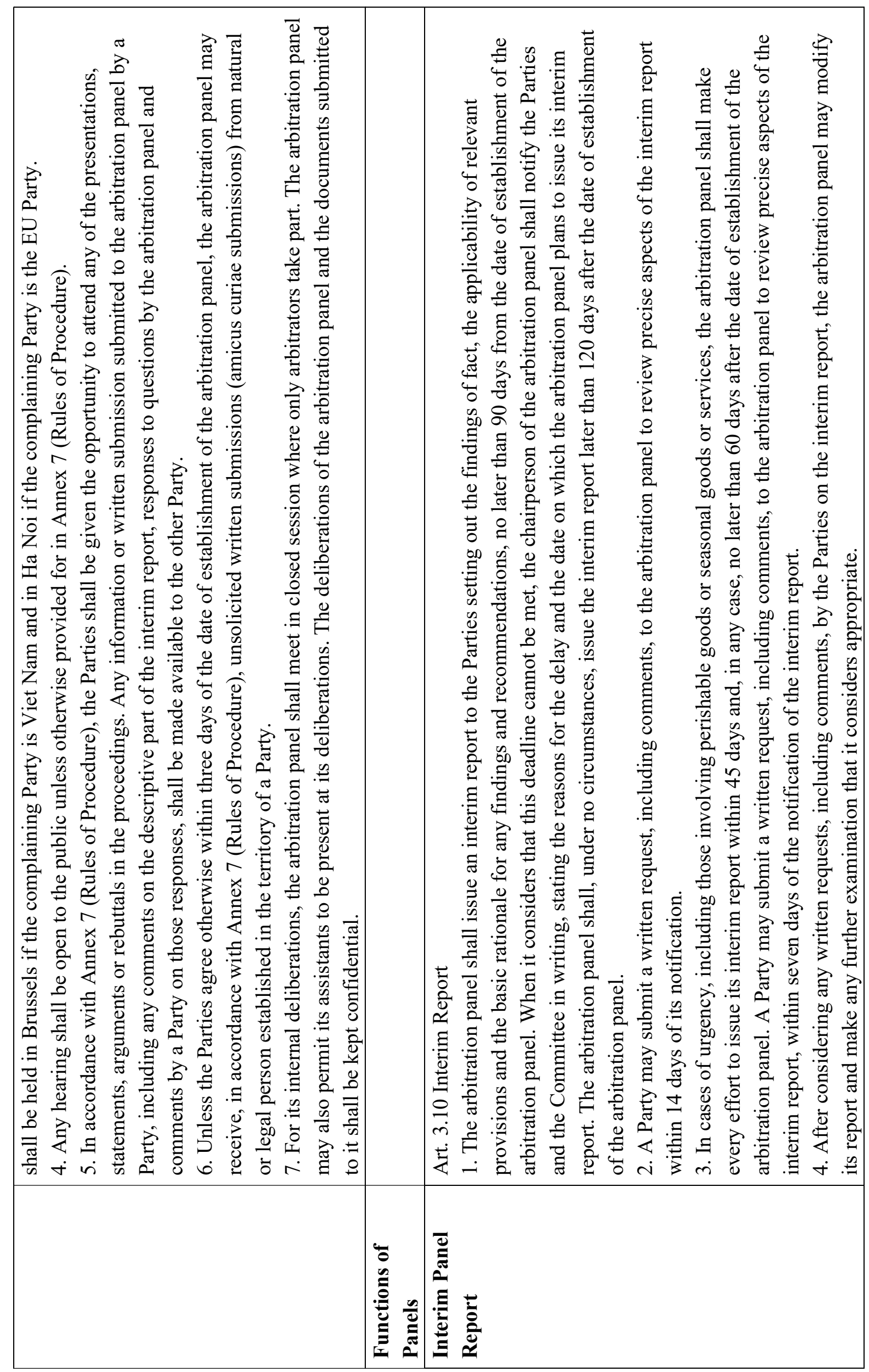




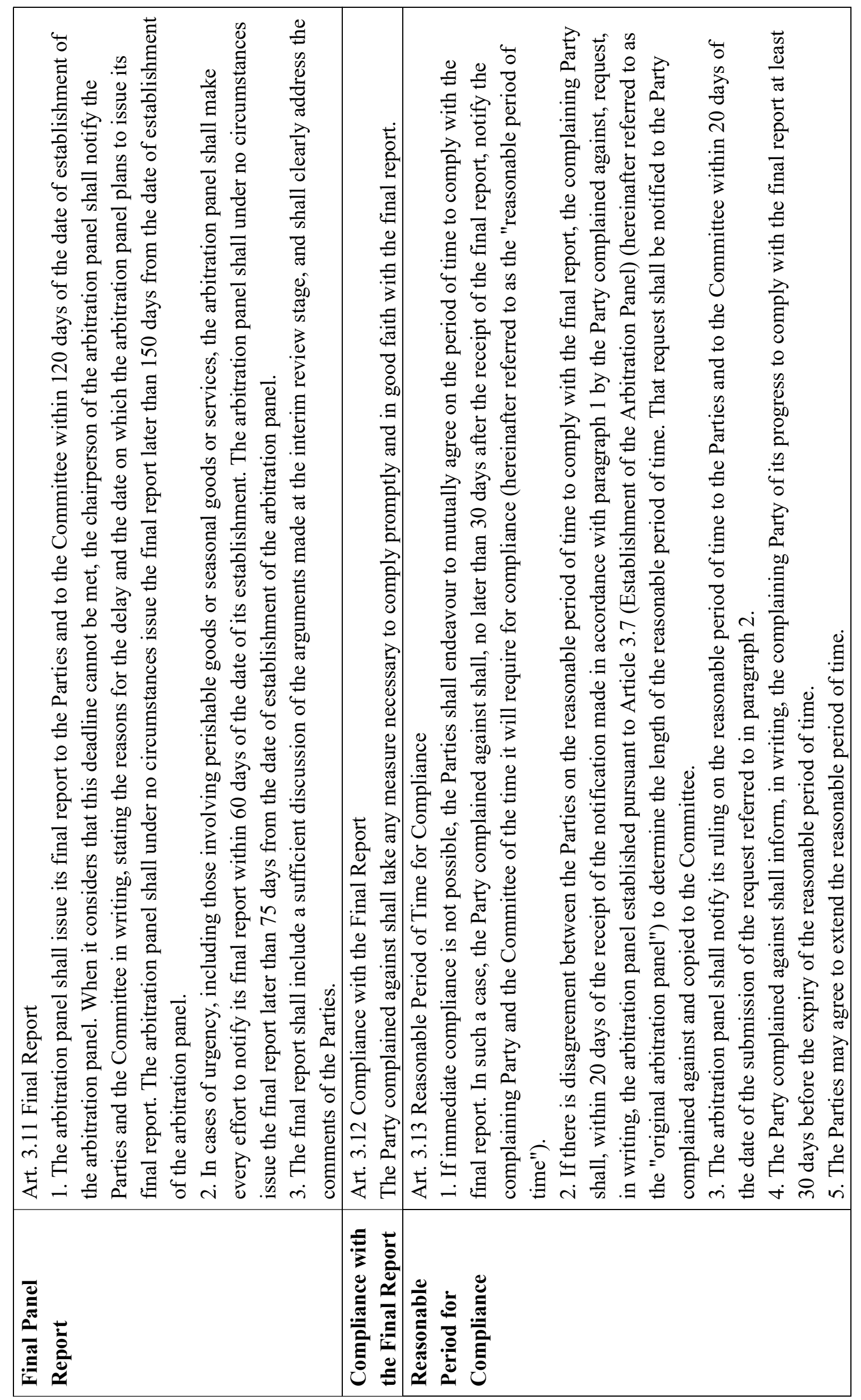




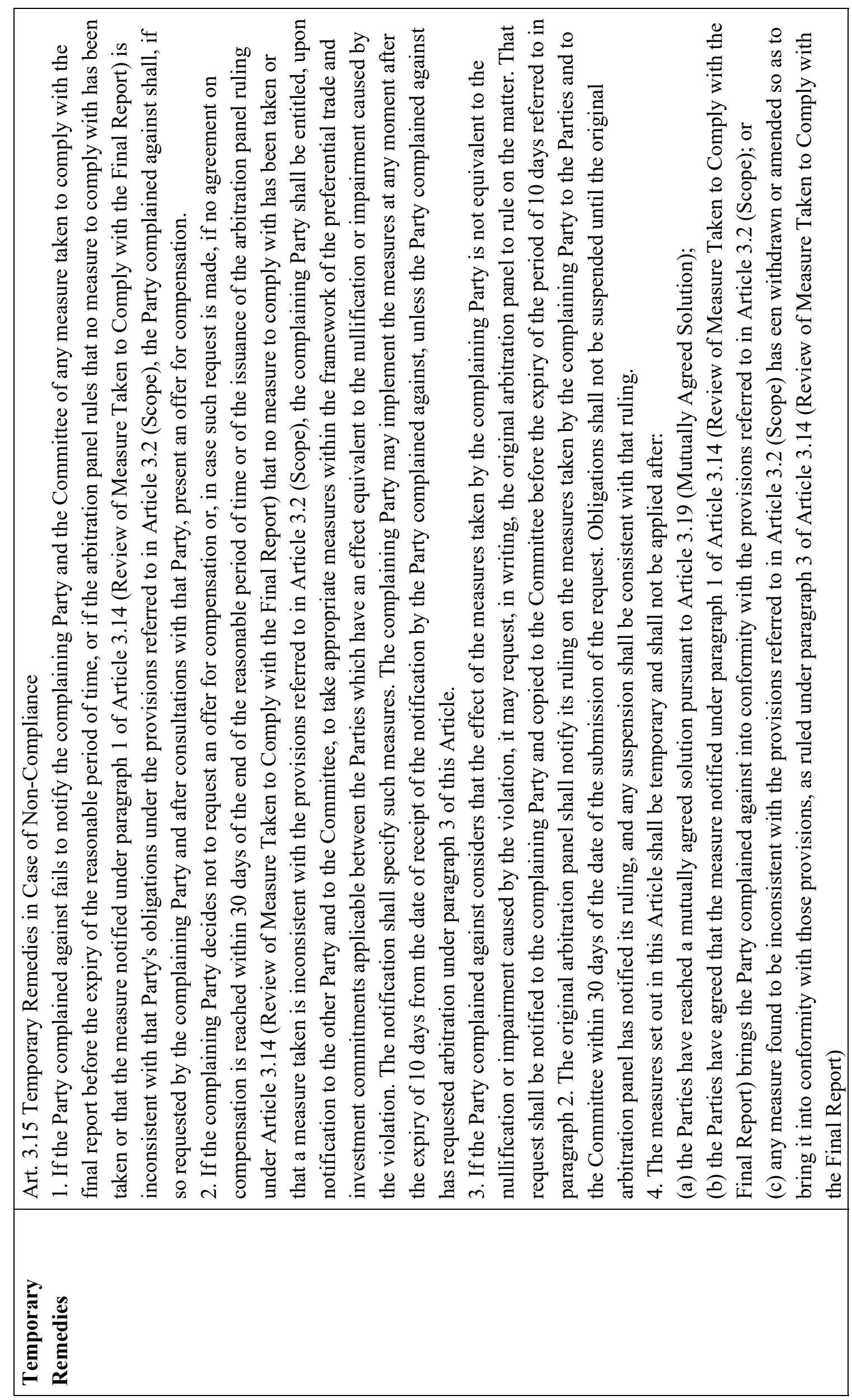




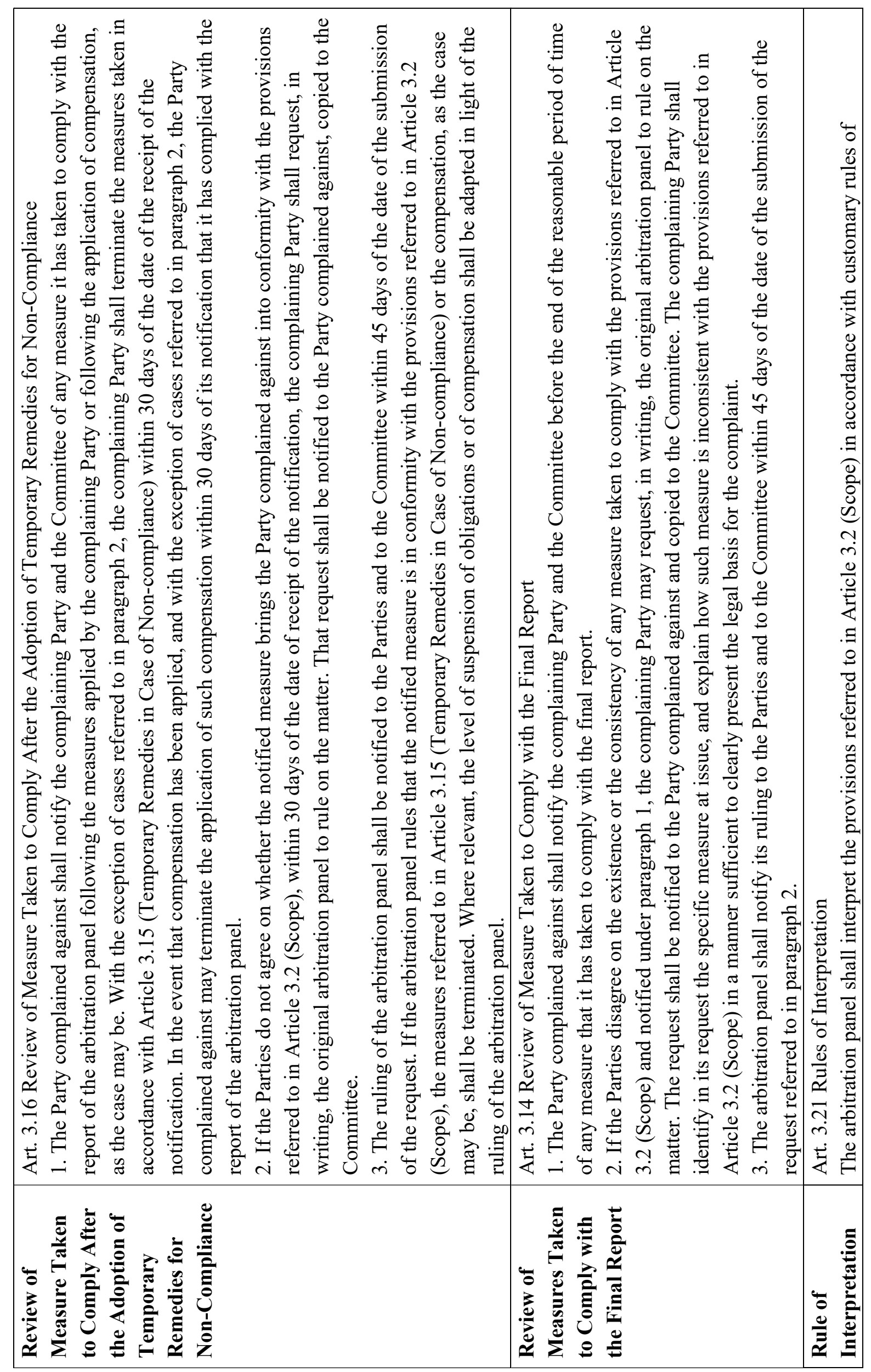




\begin{tabular}{|c|c|c|c|}
\hline 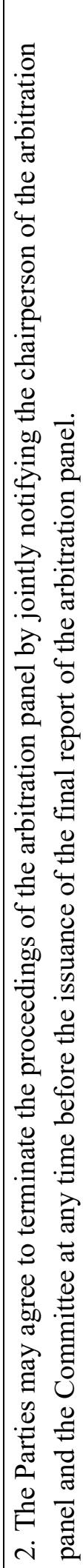 & 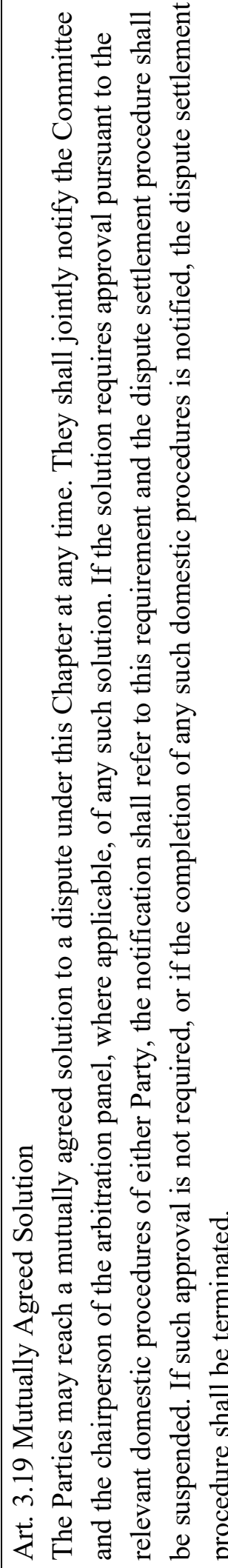 & 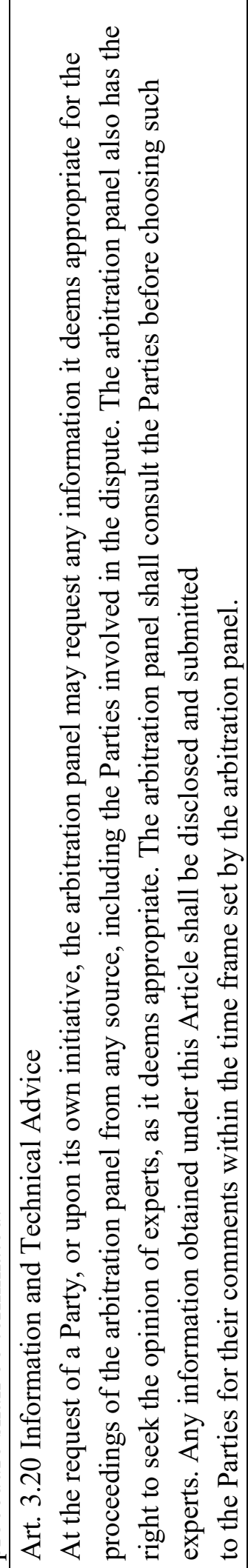 & 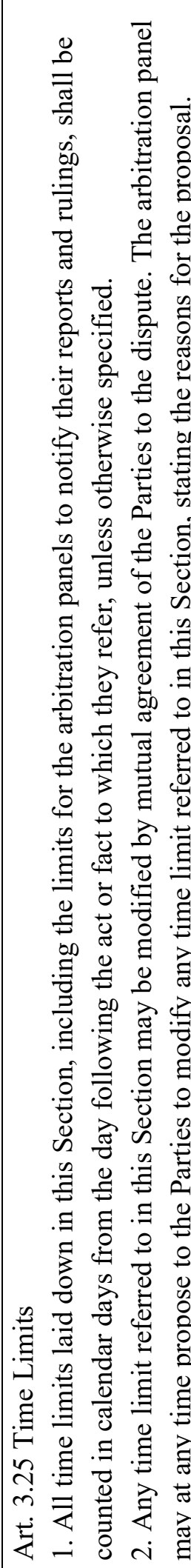 \\
\hline & 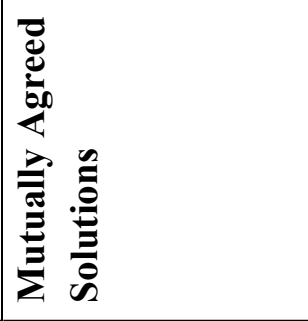 & 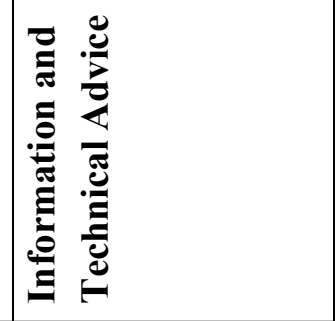 & 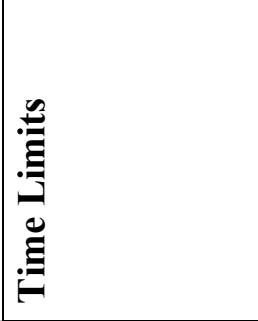 \\
\hline
\end{tabular}




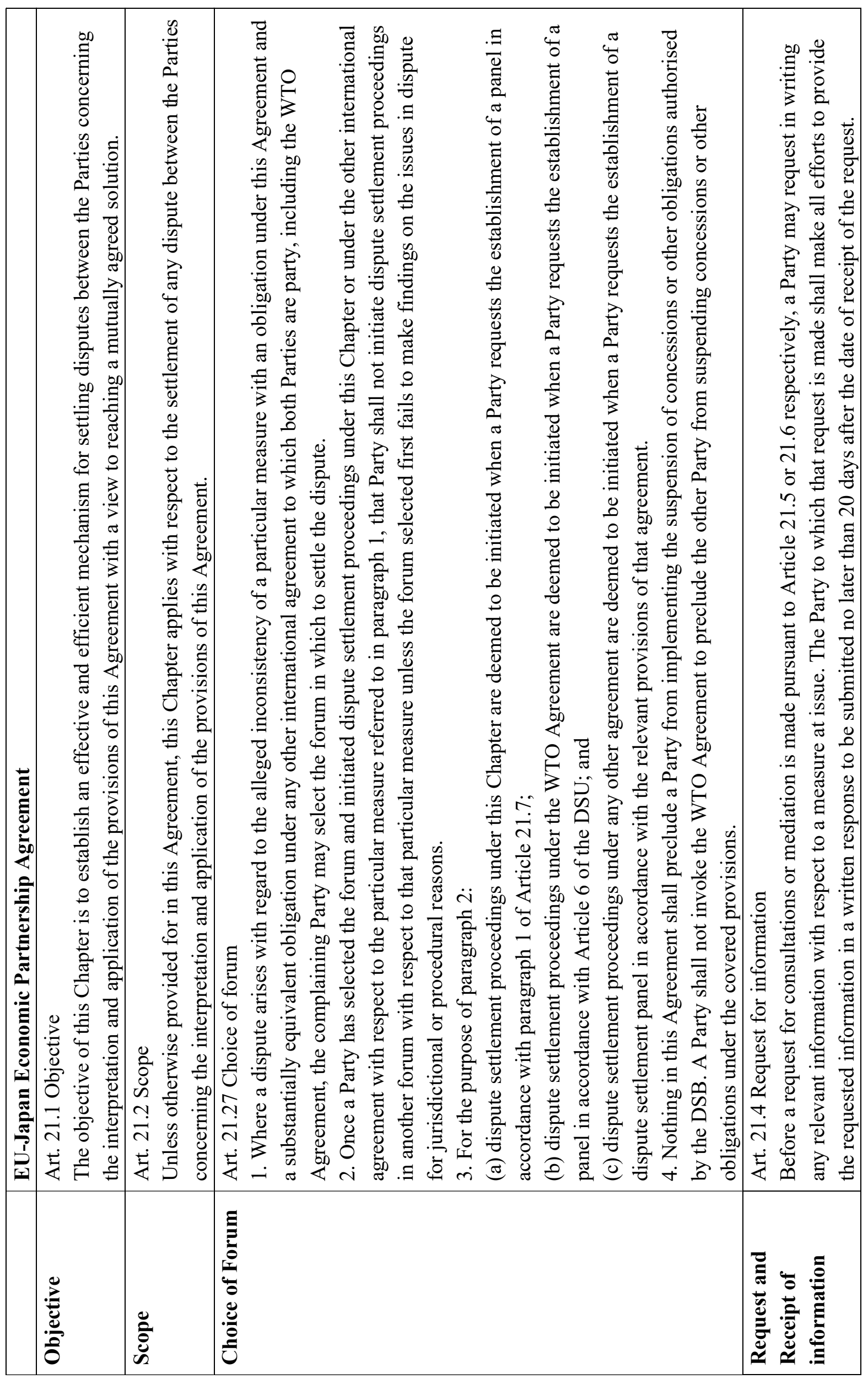




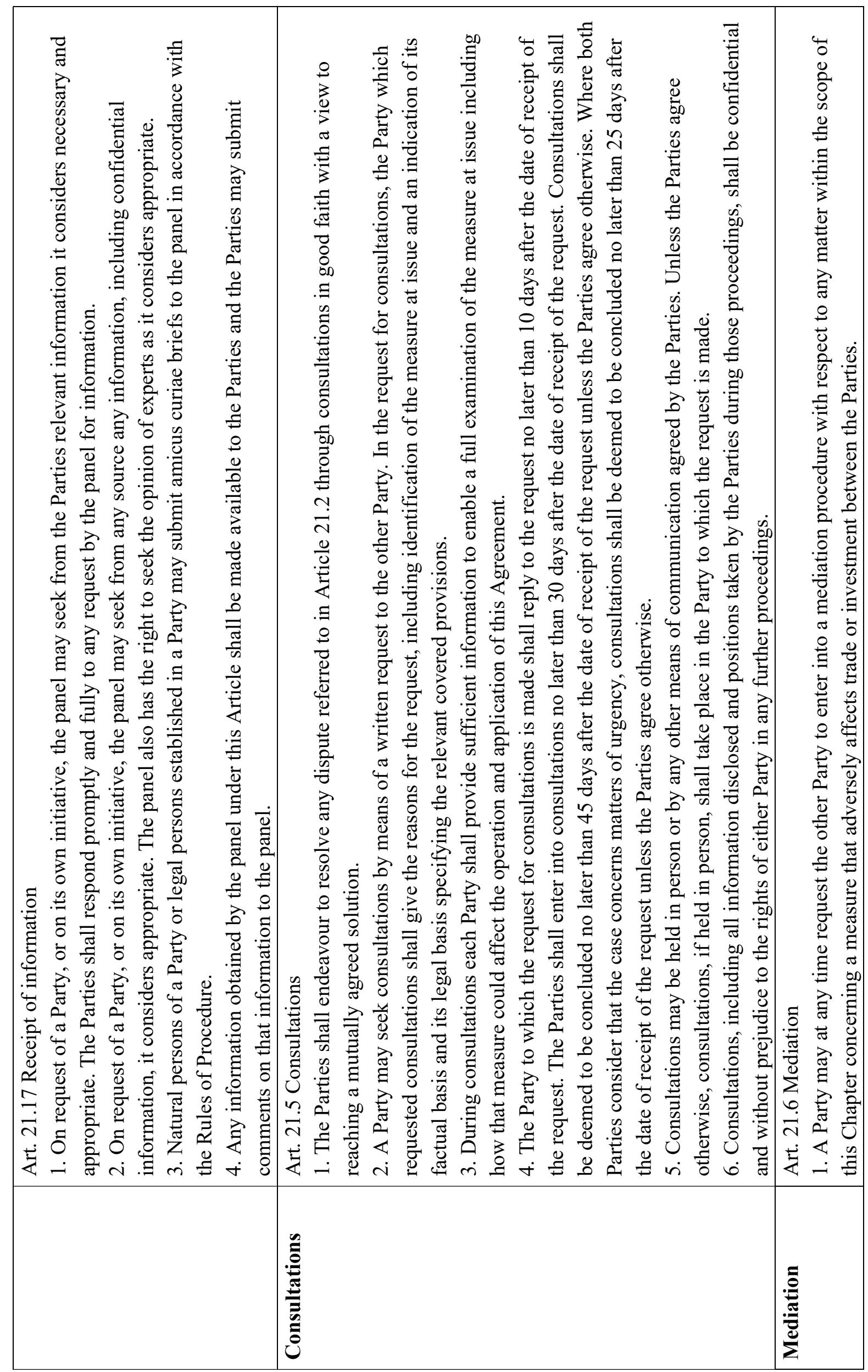




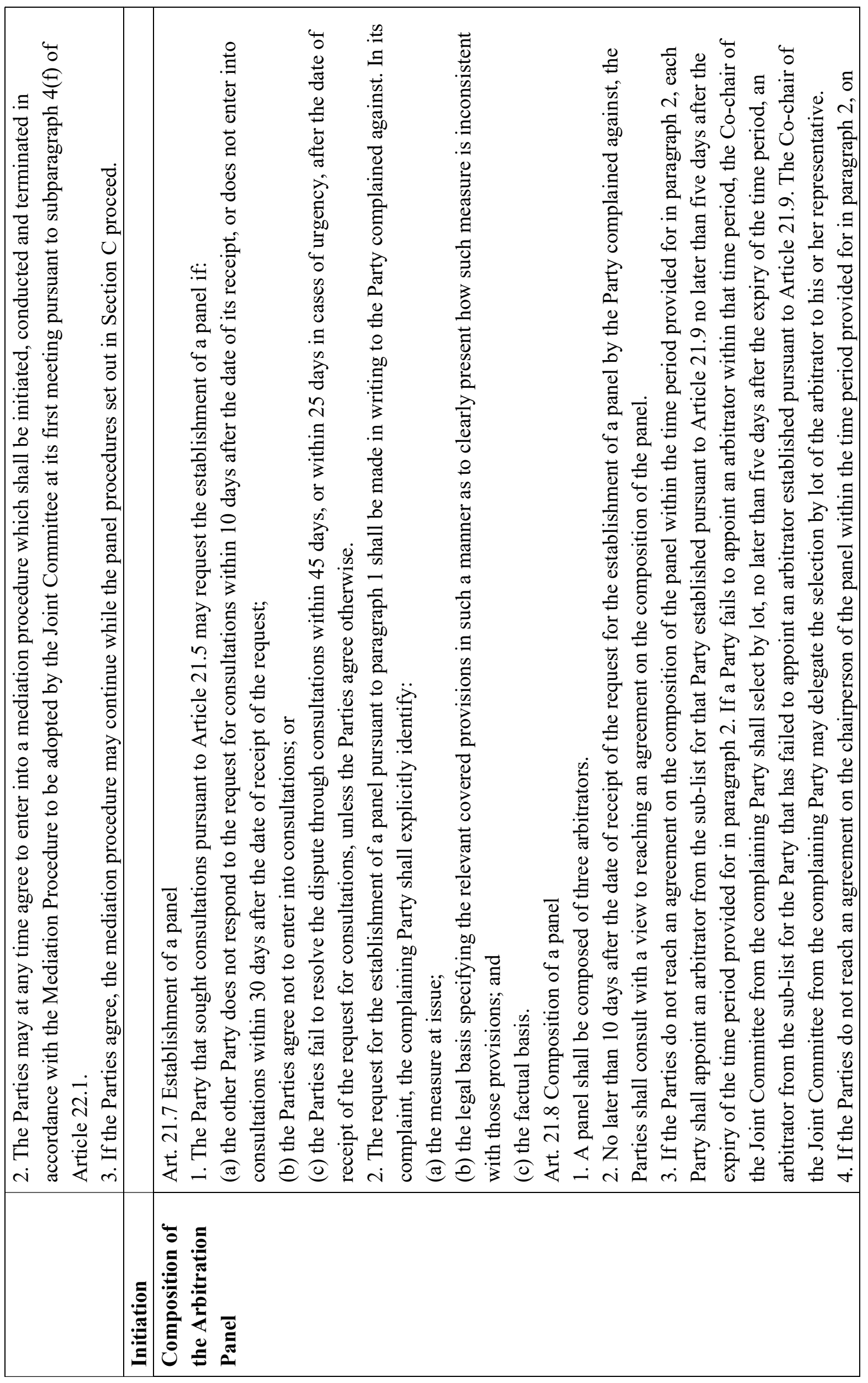




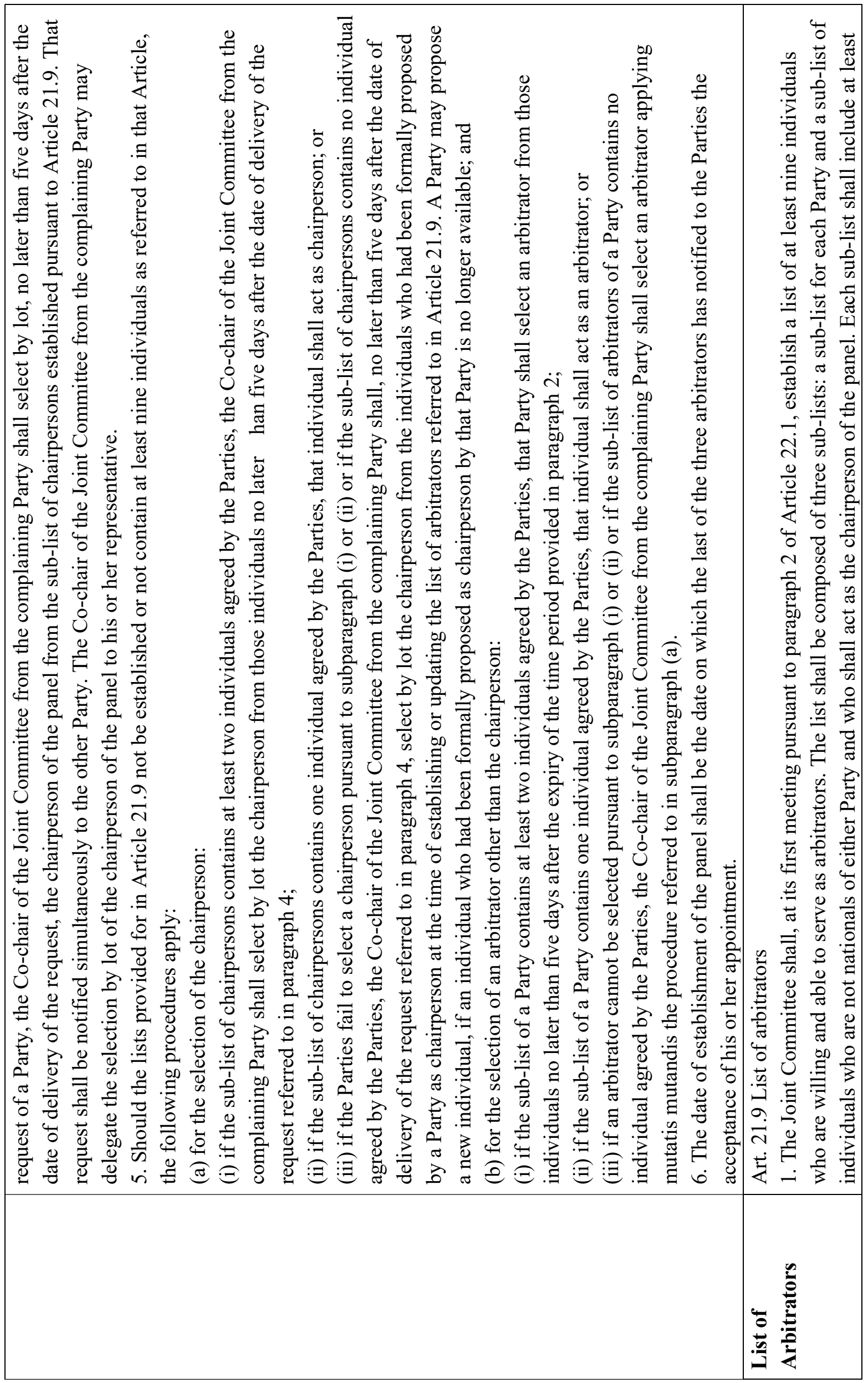




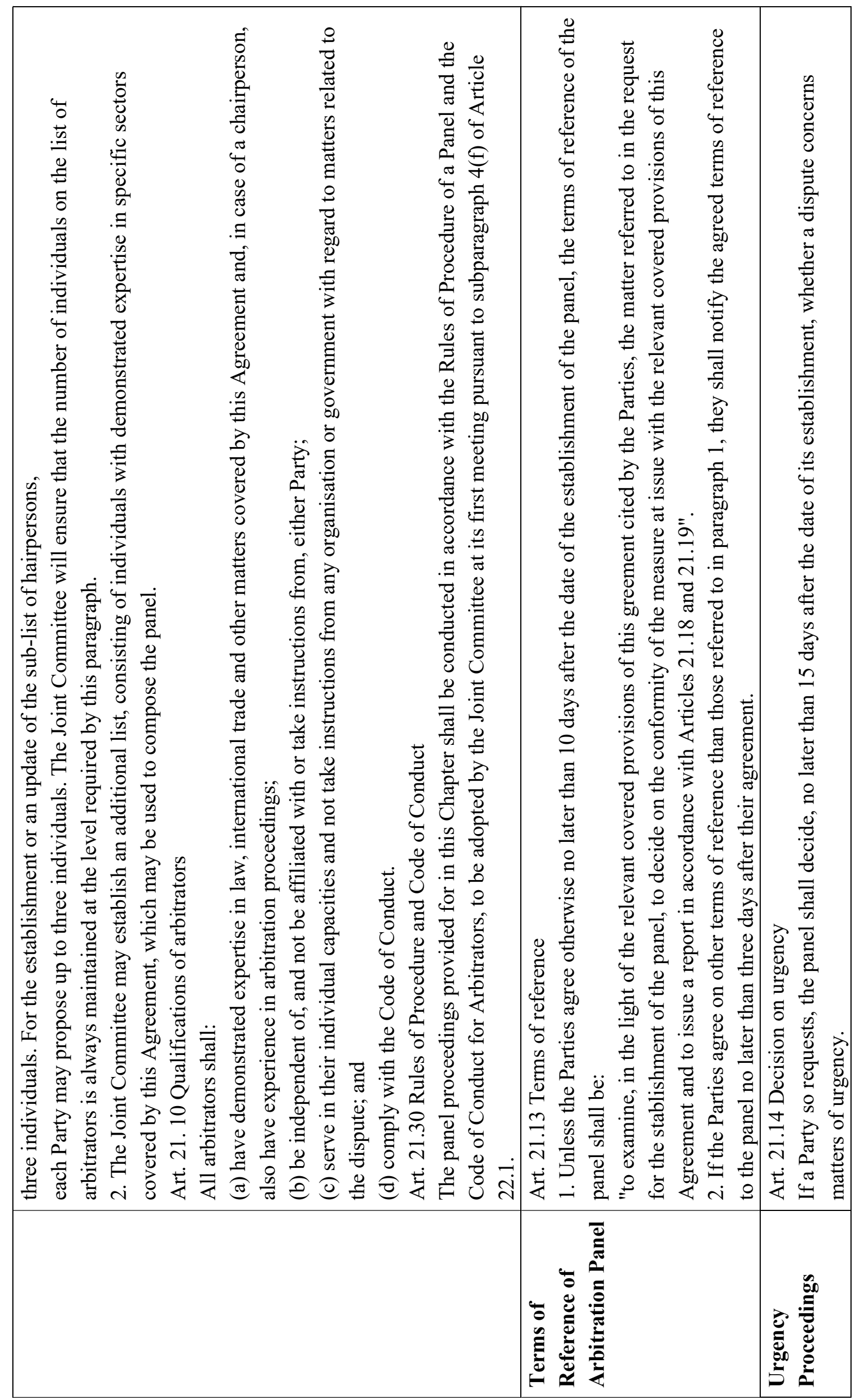




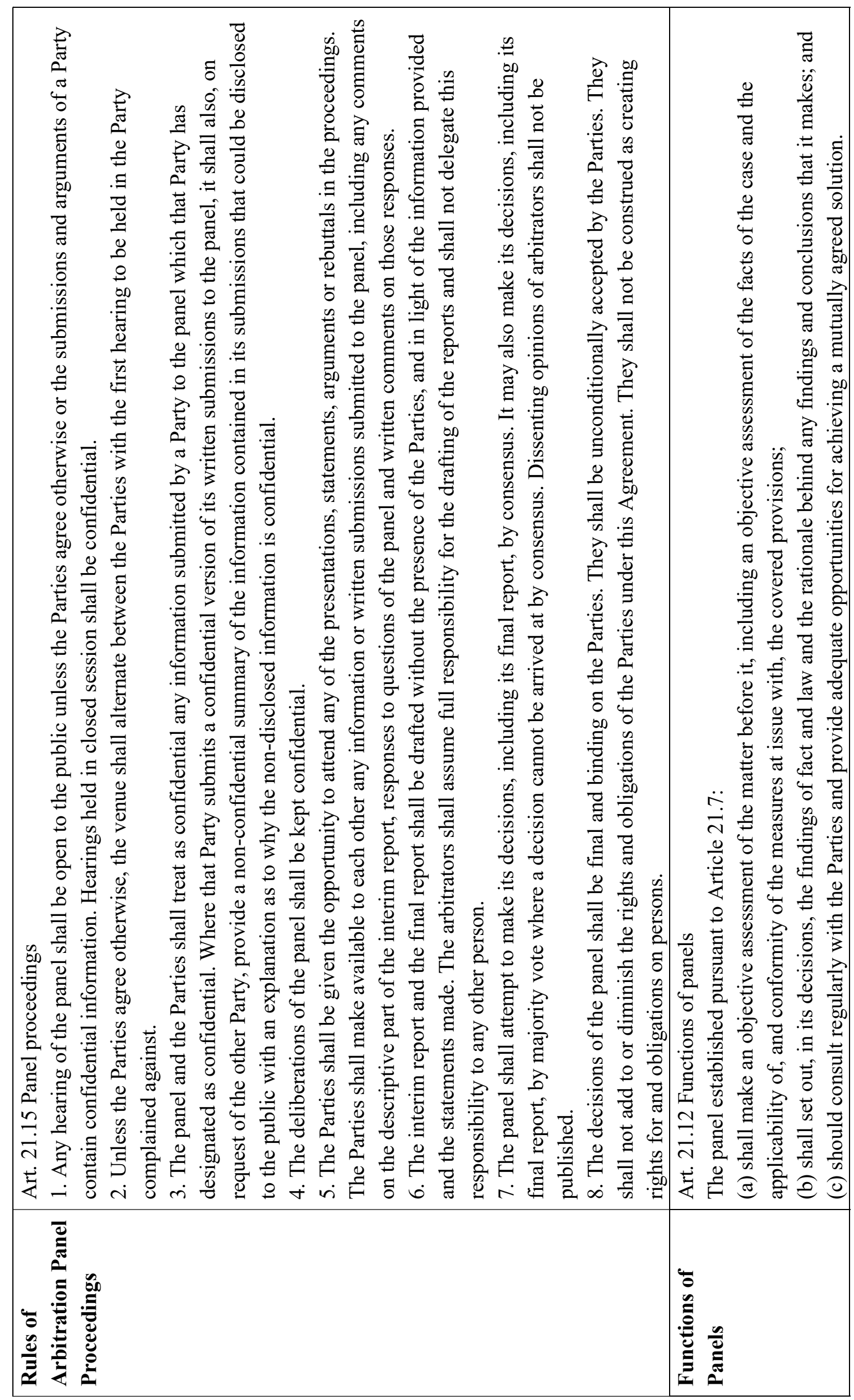




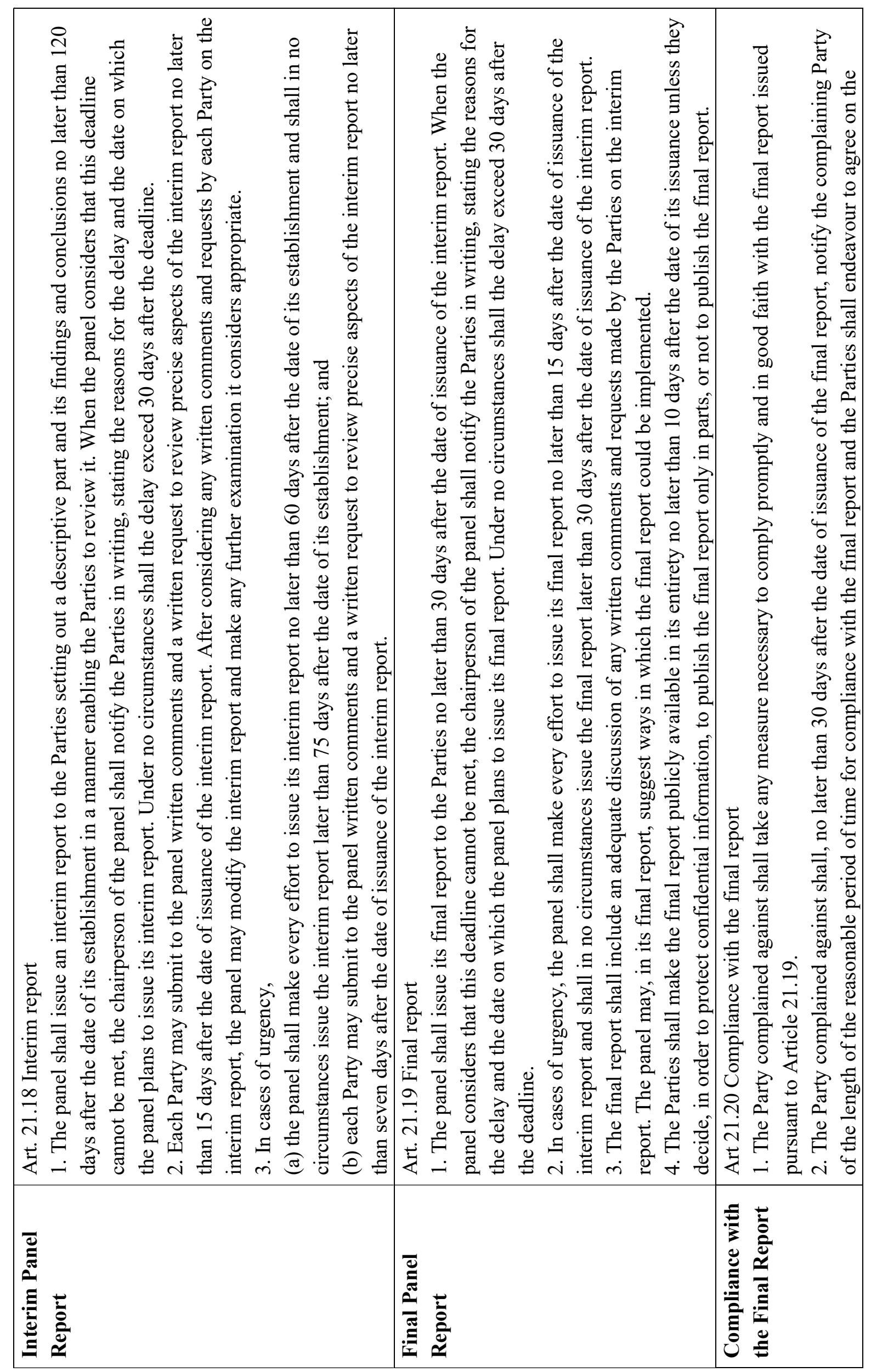




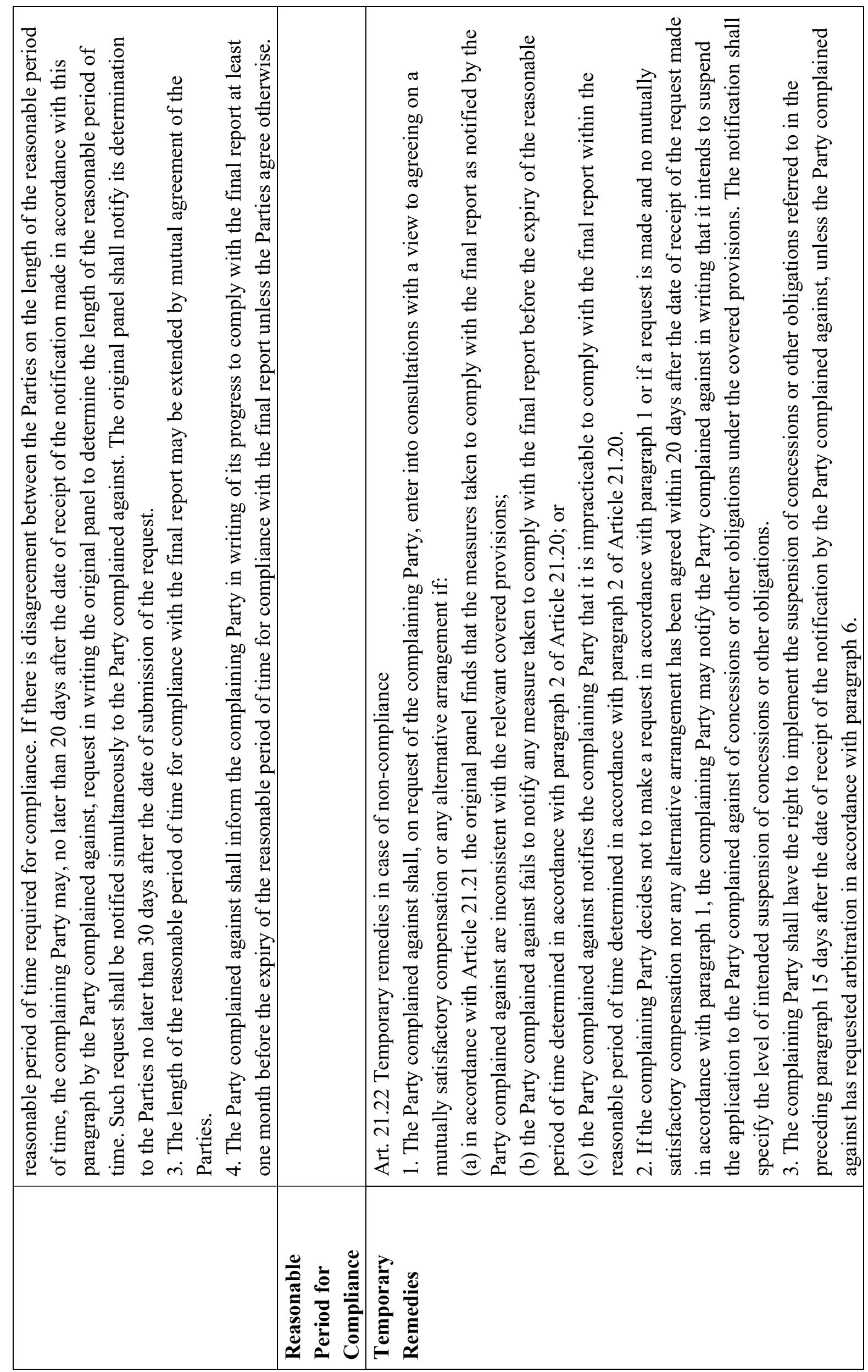




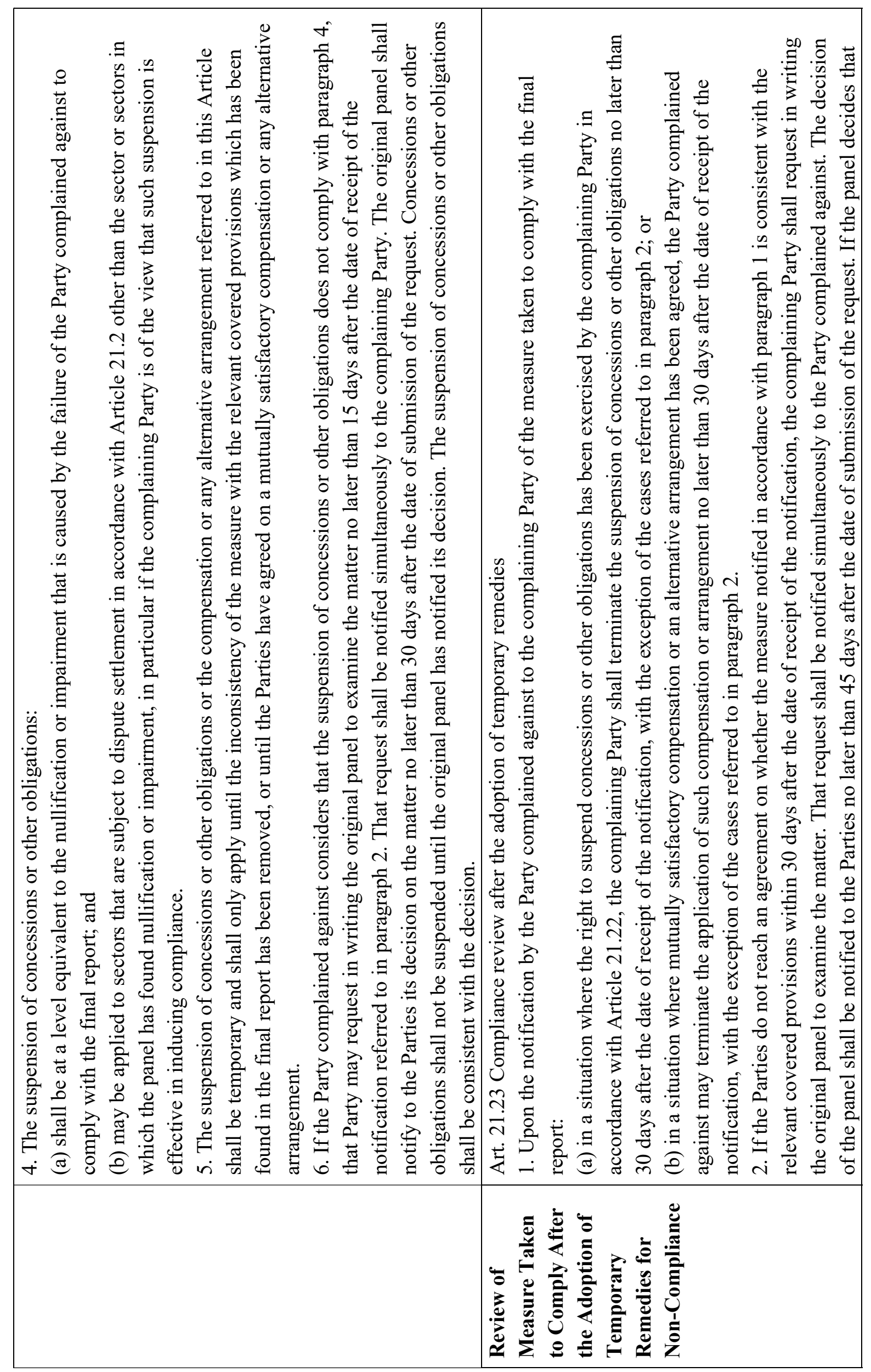




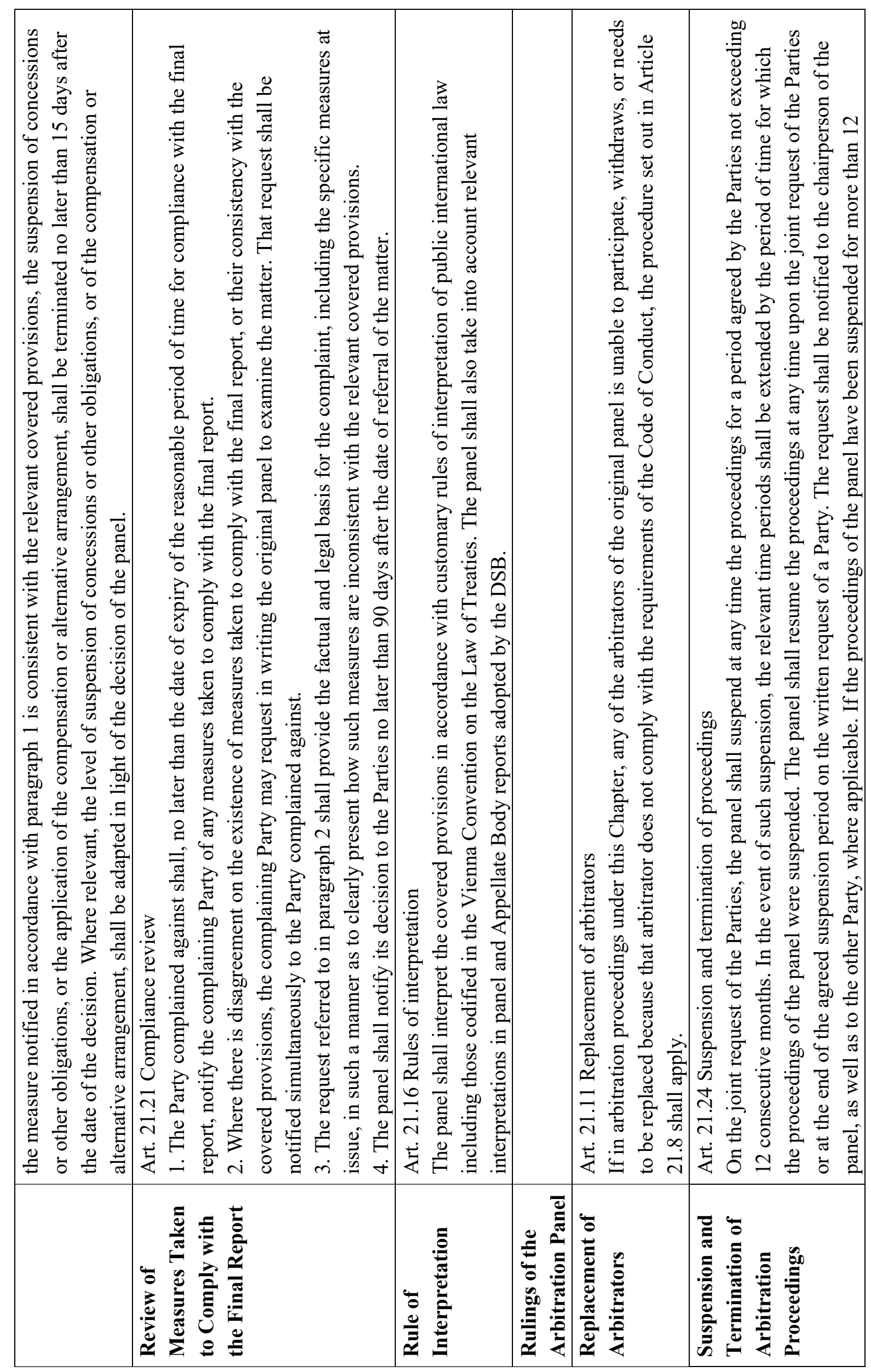




\begin{tabular}{|c|c|c|c|c|}
\hline & \multirow{2}{*}{\multicolumn{2}{|c|}{ 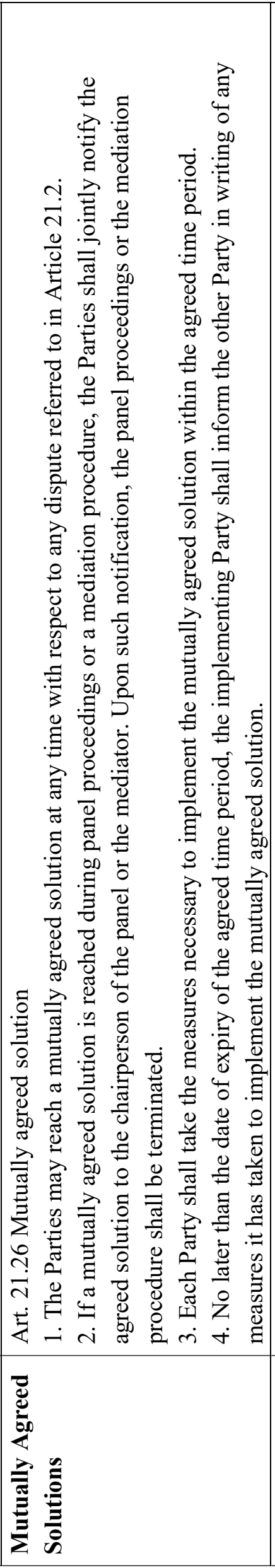 }} & 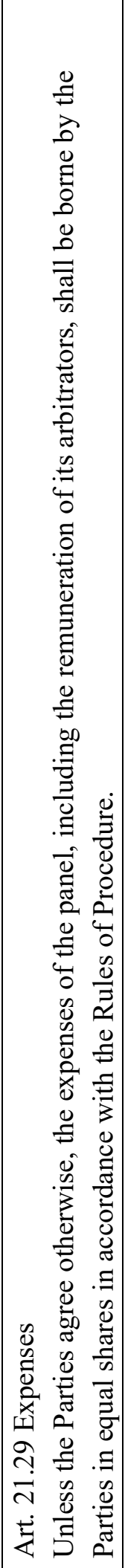 & 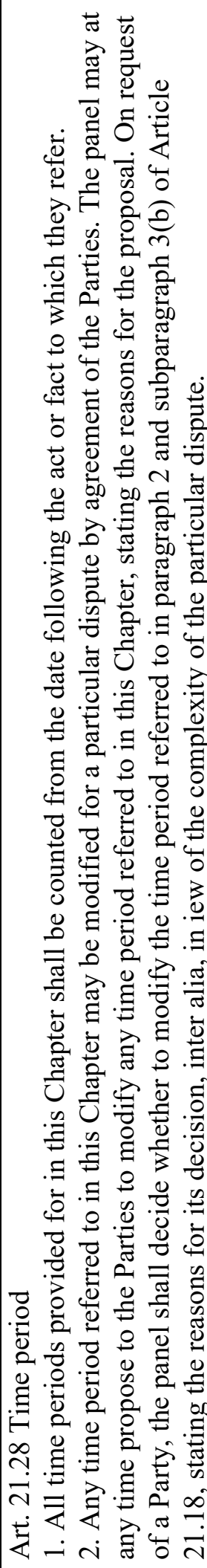 \\
\hline & & & 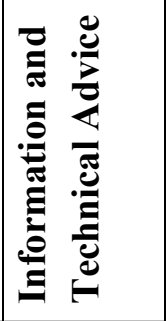 & 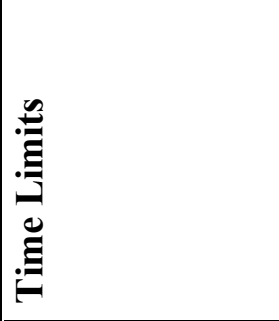 \\
\hline
\end{tabular}




\subsubsection{The EU's Practice in the WTO Dispute Settlement System}

In 1995, the WTO agreements entered into force for the European Communities (EC) ${ }^{787}$ and its Member States, giving them access to equal rights and obligations as the WTO Members. ${ }^{788}$ However, in practice, since the very beginning, the EU has exercised the bundled rights of its Member States for WTO-related affairs. ${ }^{789}$ As a result, the European Commission alone represents the Union and its Members States in almost all WTO affairs, ${ }^{790}$ including dispute settlement in the WTO. ${ }^{791}$

From an overview of the EU's practice in the WTO Dispute Settlement System in the past 15 years, from a procedural perspective, four features can be identified that are relevant to the discussion in the present thesis and thus are examined in turn.

\subsubsection{Consistently Frequent Use of the WTO Dispute Settlement System with a High Success Rate}

Different from China's experience in the WTO Dispute Settlement System, where the participation at different stages varied, the EU's performance has been relatively stable. The EU has consistently made use of the WTO Dispute Settlement System to resolve state-state trade-related disputes, claiming its legal rights and addressing other WTO Members' behaviour. ${ }^{792}$ As of 26 May 2020, the EU had initiated 104 cases, being the

\footnotetext{
787 "European Communities (the EC)" was the official name in WTO before 1 December 2009, which then changed into "European Union (the EU)". However, "European Communities" continues to appear in old materials. This thesis will use the term "European Union (the EU)" in general, unless it is clear that the subject was titled "European Communities (the EC)" when the relevant events took place.

788 According to Art. XI (1) of the Marrakesh Agreement, the contracting parties to the GATT 1947 and the European Communities shall become original Members of the WTO. See: Marrakesh Agreement Establishing the World Trade Organization (signed on 15.04.1994, entered into force on 01.01.1995), Art. XI (1). See also: Frank Hoffmeister, The European Union in the World Trade Organization-A Model for the EU's Status in International Organisations?, at: Christine Kaddous (ed.), The European Union in International Organisations and Global Governance, Hart Publishing, 2015, p. 125. János Volkai, The European Union and its Member States' Participation in the World Trade Organization: A WTO Perspective, at: Christine Kaddous (ed.), The European Union in International Organisations and Global Governance, Hart Publishing, 2015, p. 116.

789 Detlev Brauns \& Tomas Baert, The European Union in the World Trade Organization Post-Lisbon: No Single Change to the Single Voice?, at: Christine Kaddous (ed.), The European Union in International Organisations and Global Governance, Hart Publishing, 2017, pp. 110-112. For this reason, WTO materials only refer to the "EU" (or the "EC") in most situations. Sometimes references are made to specific EU Member States. This is the case in some disputes where an EU Member State's law or measure is cited. It also happens when individual EU Member States speak in committee meetings, particularly in the Budget, Finance and Administration Committee. See: World Trade Organization, The European Union and the WTO, available at: https://www.wto.org/english/thewto_e/countries_e/european_communities_e.htm, last visited on 05.08.2020.

${ }^{790}$ In most meetings, representatives of EU Member States and the Union participate alongside each other, but only the Union's representatives speak. When meetings are small and informal, even sometimes for consultations in trade negotiations, it may involve the Union's representatives only. See: World Trade Organization, The European Union and the WTO, available at: https://www.wto.org/english/thewto_e/countries_e/european_communities_e.htm, last visited on 05.08.2020.

791 There have been cases: (i) against the EU Member State concerned, such as Belgium-Administration of Measures Establishing Customs Duties for Rice (DS210); (ii) against the Union and EU Member States concerned, such as EC and certain member States-Large Civil Aircraft (DS 316); (iii) against the Union alone, such as European Communities-Measures Affecting Asbestos and Products Containing Asbestos (DS 135).

792 Although there are 27 EU Member States and their interests may not always be consistent with each other, the high degree of delegation has enabled the EU to initiate complaints effectively. See: Alasdair Young, The European Union's Use of the World Trade Organization's Dispute Resolution Process, 2004, available at: https://www.gla.ac.uk/media/media_36176_en.pdf, last visited on 07.08.2020.
} 
second most prolific initiator of WTO complaints, ${ }^{793}$ among which nine cases were against China. ${ }^{794}$

Frequently initiating disputes does not mean that the EU is litigious. Among the 102 complaints initiated by the EU, only 49 cases entered into the adjudication process and eight cases were settled in the end through mutually agreed solutions during or after the adjudication process. ${ }^{795}$ Furthermore, the EU did not take action hastily when initiating disputes. In the cases where the EU resorted to adjudication for its claims, the success rate is significantly higher than the average of the top ten most frequent complainants. ${ }^{796}$ This points to the EU's prudent attitude towards the WTO Dispute Settlement System.

\subsubsection{Supporting Attitude towards Amicable Dispute Settlement Mechanisms}

In addition to adjudicative proceedings, Article 5 of the DSU provides for other amicable DSMs, including good offices, conciliation and mediation. However, these mechanisms have only been resorted to once and it was in a case involving the EC. ${ }^{797}$ This case concerned Thailand and the Philippines as the complainants, on the one hand, and the EC as the respondent, on the other, and concerned tuna exports. The complainants had wanted to pursue adjudication, but, because of the EC's insistence on avoiding adversarial procedures, mediation was chosen under Article 5 of the DSU. This was another attempt at an amicable settlement after the consultation failed. The WTO Deputy Director-General Rufus Yerxa was appointed as the mediator upon the request of the disputing parties. ${ }^{798}$ During mediation, both parties sent written

793 The EU comes only after the US which has brought complaints in 124 cases. In addition, the EU has acted as the respondent in 87 cases and requested third party status in 205 other cases. See: World Trade Organization, Disputes by Member, available at: https:/www.wto.org/english/tratop_e/dispu_e/dispu_by_country_e.htm, last visited on 05.08.2020. See also: János Volkai, The European Union and its Member State's Participation in the World Trade Organization: A WTO Perspective, at: Christine Kaddous (ed.), The European Union in International Organisations and Global Governance: Recent Developments, 2015, p. 118.

$794 \quad$ World Trade Organization, Disputes by Member, available at: https://www.wto.org/english/tratop_e/dispu_e/dispu_by_country_e.htm, last visited on 05.08.2020. These eight cases are China-Measures Affecting Imports of Automobile Parts, DS339; China-Measures Affecting Financial Information Services and Foreign Financial Information Suppliers, DS372; China-Measures Related to the Exportation of Various Raw Materials, DS395; China-Provisional Anti-Dumping Duties on Certain Iron and Steel Fasteners from the European Union, DS407; China-Definitive Anti-Dumping Duties on X-Ray Security Inspection Equipment from the European Union, DS425; China-Measures Related to the Exportation of Rare Earths, Tungsten and Molybdenum, DS432; China-Measures Imposing Anti-Dumping Duties on High-Performance Stainless Steel Seamless Tubes ("HP-SSST") from the European Union, DS460; China-Duties and other Measures concerning the Exportation of Certain Raw Materials, DS509; China-Certain Measures on the Transfer of Technology, DS549.

795 Id. These eight cases are Korea-Laws, Regulations and Practices in the Telecommunications Procurement Sector, DS40; Japan-Measures concerning Sound Recordings, DS42; Japan-Procurement of a Navigation Satellite, DS73; United States-Measures Affecting Textiles and Apparel Products, DS85; India-Quantitative Restrictions on Imports of Agricultural, Textile and Industrial Products, DS96; United States-Measures Affecting Textiles and Apparel Products (II), DS151; Australia-Quarantine Regime for Imports, DS 287; Canada-Tax Exemptions and Reductions for Wine and Beer, DS354.

796 Alasdair Young, The European Union's Use of the World Trade Organization's Dispute Resolution Process, 2004, available at: https://www.gla.ac.uk/media/media_36176_en.pdf, last visited on 07.08.2020.

${ }^{797}$ World Trade Organization, Dispute Settlement Without Recourse to Panels and the Appellate Body, available at: https://www.wto.org/english/tratop_e/dispu_e/disp_settlement_cbt_e/c8s1p1_e.htm, last visited on 05.08.2020. The majority of amicable settlements in the WTO are realized through consultations. See: Alasdair Young, The European Union's Use of the World Trade Organization's Dispute Resolution Process, 2004, available at: https://www.gla.ac.uk/media/media_36176_en.pdf, p. 4, last visited on 07.08.2020.

798 Communication from the Director-General, Request for Mediation by the Philippines, Thailand and the European Communities, WT/GC/66, 16.10.2002. As the mediator, Rufus was requested to examine the extent to which a preferential tariff treatment granted by the EU to other WTO Members unduly impaired the two requesting 
submissions to the mediator to explain the dispute, their positions and arguments, as well as attended meetings to deliver oral statements and to answer mediator's questions. ${ }^{799}$ At a later stage, the mediator delivered an advisory opinion as to how the matter should be resolved. The dispute was settled in the end and did not proceed to panel proceedings. ${ }^{800}$

This case provides a valuable example that demonstrates the possibility of successful mediation of state-state disputes in the WTO Dispute Settlement System. It also shows, to a certain extent, the EU's supporting attitude towards state-state mediation. ${ }^{801}$ In order to promote the real use of amicable mechanisms in the WTO Dispute Settlement System, the EC also made contributions during the DSU reform negotiations. For example, it suggested that the compliance with mutually agreed solutions reached through these mechanisms should be examined via the procedures of DSU Article 21.5 (or proposed 21bis) and 22, to the extent that they had been notified to the Dispute Settlement Body in full. ${ }^{802}$ The EU's supporting attitude towards amicable DSMs resonates with its expression in the context of the WTO - "the purpose of a dispute settlement procedure is the amicable-and-quick-resolution of a dispute...any improvements of the DSU should contribute towards this overall goal of facilitating the earliest possible resolution of disputes". ${ }^{803}$

\subsubsection{Mitigated Compliance and Vigorous Enforcement of Sanctions}

In the WTO Dispute Settlement System, compliance normally takes place within deadlines, without any party requesting authorization to retaliate. ${ }^{804}$ The EU also generally has a good record of complying with the rulings from panels and the Appellate Body. In addition to the potential negative effect of retaliation full compliance is argued as a matter of "abiding by the international rule of law" and "helping a worldwide system to command respect throughout the entire membership". ${ }^{805}$ A good record of compliance also improves the EU's reputation in the WTO and helps when the EU is enforcing rulings against other WTO Members.

\footnotetext{
Members' legitimate export interests.

799 Anna Spain Bradley, Integration Matters: Rethinking the Architecture of International Dispute Resolution, University of Pennsylvania Journal of International Law, Vol. 32, 2010, pp. 31-32.

${ }^{800}$ The mediator called for the EC to establish a quota and tariff rates. On 5 June 2003, the EC adopted the mediator's recommendation in Council Regulation (EC) No. 975/2003. See: Nilaratna Xuto, Thailand: Conciliating a Dispute on Tuna Exports to the EC, at: Peter Gallagher \& Patrick Low \& Andrew L. Stoler (eds.), Managing the Challenges of WTO Participation: 45 Case Studies, Cambridge University Press, 2005, p. 562. Communication from the Director-General, Request for Mediation by the Philippines, Thailand and the European Communities, Addendum, WT/GC/66/Add.1, 23.12.2002.

${ }^{801}$ In fact, prior to the Uruguay Round, the EC was regarded as being opposed to legalistic dispute settlement, but favoured amicable negotiated solutions. See: John Howard Jackson, The European Community and World Trade: The Commercial Policy Dimension, at: William James Adams (ed.), Singular Europe: Economy and Polity of the European Community After 1992, University of Michigan Press, 1993, p. 333.

802 World Trade Organization-Dispute Settlement Body-Special Session, Contribution of the European Communities and its Member States to the Improvement of the WTO Dispute Settlement Understanding, TN/DS/W/1, 13.03.2002, p. 8 .

${ }^{803}$ Id, p. 1.

${ }^{804}$ Ignacio Garcia Bercero \& Paolo Garzotti, DSU Reform: Why Have Negotiations to Improve WTO Dispute Settlement Failed so far and What Are the Underlying Issues?, The Journal of World Investment \& Trade, Vol. 6, 2005, p. 860.

${ }^{805}$ Pieter Jan Kuijper \& Frank Hoffmeister, WTO Influence on EU Law: Too Close for Comfort?, at: Ramses A.
} 
However, at the same time, the EU is unfortunately on the record as having delayed and incomplete compliance in several sensitive cases, such as Bananas, Hormones and $G M O{ }^{806}$ Various reasons were pointed to as contributing to its imperfect compliance, such as the static state of WTO law and the vague notions contained therein, ${ }^{807}$ the lack of effective legislation ensuring implementation in defensive cases, ${ }^{808}$ and the priority of the EU's fundamental societal choices involved in the disputes. ${ }^{809}$ Nonetheless, considering how few problematic cases there, non-compliance by the EU is rare. ${ }^{810}$

The EU has been vigorous in seeking enforcement when the ruling was in favour of its position. Despite the difficulties in enforcing WTO decisions through the imposition of sanctions, the EU has been successful in overcoming these obstacles and realizing its legal rights through enforcement, especially when the stakes were sufficiently high. ${ }^{811}$

Wessel \& Steven Blockmans (eds.), Between Autonomy and Dependence: The EU Legal Order under the Influence of International Organisations, T.M.C. Asser Press, 2013, pp. 156-157.

806 European Communities-Regime for the Importation, Sale and Distribution of Bananas, DS27; European Communities-Measures Affecting the Approval and Marketing of Biotech Products, DS291; United StatesContinued Suspension of Obligations in the EC-Hormones Dispute, DS320. Although the EU adopted certain policy changes in every instance, they were not sufficient to placate the complainants.

807 This leaves room for the judicial branch to exercise discretion and results in the hesitation of compliance when the exercise is not "right" in the eyes of the EU. See: Pieter Jan Kuijper \& Frank Hoffmeister, WTO Influence on EU Law: Too Close for Comfort?, at: Between Autonomy and Dependence: The EU Legal Order under the Influence of International Organisations, T.M.C. Asser Press, 2013, pp. 156-157.

808 There is only a partial legal basis in the EU's Regulation 1515/2001, where the European Commission can quickly amend or repeal the disputed Union measure in accordance with the examination procedure after losing a case before the WTO. See: Council Regulation no 1515/2001 of 23 July 2001 on the measures that may be taken by the Community following a report adopted by the WTO Dispute Settlement Body concerning anti-dumping and antisubsidy matters, OJ L201, 26.07.2001, codified by Regulation (EU) 2015/476 of the European Parliament and the Council, OJ L 83, 27.03.2015. If an EU Member State does not comply with the WTO decision, the only leverage that the European Commission has is the infringement procedure, which is in itself "cumbersome and not prone to prevent retaliation against the EU quickly". See: Frank Hoffmeister, The European Union in the World Trade Organization-A Model for the EU's Status in International Organisations?, at: The European Union in International Organisations and Global Governance, Hart Publishing, 2015, p. 132. Thus, the European Commission in fact faced great pressure emanating from other Members in the WTO on the one hand and from its Member States on the other. See: Bart Kerremans, The European Commission in the WTO's DDA Negotiations-A Tale of an Agent, a Single Undertaking and Twenty-seven Nervous Principals, at: Spyros Blavoukos \& Dimitris Bourantonis (eds.), The EU Presence in International Organizations, Routledge Taylor \& Francis Group, 2011, pp. 135-136, 138.

Delays in the adoption of a negotiated settlement in the Banana case, or the compliance in Hormones case and GMO case, can be understood from the perspective of the high political costs in each of them. For analyses on the Banana case, see: Karen J. Alter \& Sophie Meunier, Nested and Overlapping Regimes in the Transatlantic Banana Dispute, Journal of European Public Policy, Vol. 13, 2007. Tim Josling \& Tim Taylor, Conclusion, at: Timothy Josling \& Timothy Taylor (eds.), Banana Wars: The Anatomy of a Trade Dispute, CABI Publishing, 2003, pp. 195-196. For analyses on Hormones Case, see: Chad Damro \& Alberta M. Sbragia, The New Framework of Transatlantic Economic Governance: Strategic Trade Management and Regulatory Conflict in Multilateral Global Economy, at: Miriam L. Campanella \& Sylvester C.W. Eijffinger (eds.), EU Economic Governance and Globalization, Edward Elgar, 2003, pp. 105-141. Sebastiaan Princen, EC Compliance with WTO Law: The Interplay of Law and Politics, European Journal of International Law, Vol. 15, 2004, p. 570. For analyses on GMOs Case, see: Thomas Bernauer, Genes, Trade and Regulation: The Seeds of Conflict in Food Biotechnology, Princeton University Press, 2003. Mark A. Pollack \& Gregory C. Shaffer, When Cooperation Fails: The International Law and Politics of Genetically Modified Foods, Oxford University Press, 2009.

${ }^{809}$ Pieter Jan Kuijper \& Frank Hoffmeister, WTO Influence on EU Law: Too Close for Comfort?, at: Between Autonomy and Dependence: The EU Legal Order under the Influence of International Organisations, T.M.C. Asser Press, 2013, pp. 131-158, 148-153, 156-157. Alasdair R. Young, Effective Multilateralism on Trial: EU Compliance with WTO Law, at: Spyros Blavoukos \& Dimitris Bourantonis (eds.), The EU Presence in International Organizations, Routledge, 2011, pp. 123-124.

810 Alasdair R. Young, Effective Multilateralism on Trial: EU Compliance with WTO Law, at: The EU Presence in International Organizations, Routledge, 2011, pp. 119, 124.

811 Alasdair Young, The European Union's Use of the World Trade Organization's Dispute Resolution Process, 2004, available at: https://www.gla.ac.uk/media/media_36176_en.pdf, last visited on 07.08.2020. The one occasion where it imposed sanctions, the Foreign Sales Corporations complaint, the potential value contained therein has been the highest sanctions authorized thus far. See: United States - Tax Treatment for "Foreign Sales Corporations", DS108. 
To date the EU has sought, threatened or imposed sanctions on five occasions, which is more than any other WTO Member. ${ }^{812}$

\subsubsection{Seeking More Transparency and a Stronger Judiciary}

Although the text of the DSU has not been changed since it entered into force in 1995, some developments can be identified in practice. One example is that more transparency has been gradually realized in the dispute settlement proceedings, represented by opening hearings and accepting amicus curiae. This is largely due to the efforts made by several WTO Members, including the EU.

The WTO had always held hearings behind closed doors, which was criticized as departing from generally accepted judicial standards and, in particular, its reputation of "international standards of fairness, impartiality and due-process". ${ }^{813}$ Encouraged by the willingness of the EU and several other WTO Members, there was an increase of transparency in hearings on an ad hoc basis since 2005. The first time that the WTO made hearings open for public observation was in the case brought by the EU against the US and Canada regarding the continued suspension of obligations in connection with the Hormones dispute. ${ }^{814}$

Another issue related to transparency is amicus curiae. The acceptance of amicus briefs rests on the premise that providing a maximum amount of information to decisionmakers would contribute to more objective adjudication. ${ }^{815}$ Similar to opening hearings, accepting amicus curiae in the WTO Dispute Settlement System also received support from the EU. In fact, the EU expressly presented its intention during the Doha round negotiations for the improvement of the WTO DSU. The EU pointed out that the DSU should provide sufficient flexibility for disputing parties to decide on the openness of their hearings, in order to show that trade dispute settlement was conducted in a fair, unbiased and professional manner. ${ }^{816}$ In particular, it was necessary to define the

812 The five cases are: United States-Tax Treatment for "Foreign Sales Corporations", DS108; United StatesDefinitive Safeguard Measures on Imports of Certain Steel Products, DS 248; United States-Anti-Dumping Act of 1916, DS136; United States—Continued Dumping and Subsidy Offset Act of 2000, DS217; United States—Measures Affecting Trade in Large Civil Aircraft-Second Complaint, DS 353. For more information on the EU's enforcement of sanctions, see: Alasdair R. Young \& John Peterson, Parochial Global Europe: 21 st Century Trade Politics, Oxford University Press, 2014, pp. 111-113.

${ }^{813}$ Ignacio Garcia Bercero \& Paolo Garzotti, DSU Reform: Why Have Negotiations to Improve WTO Dispute Settlement Failed so far and What Are the Underlying Issues?, The Journal of World Investment \& Trade, Vol. 6, 2005 , p. 854. The DSMs established under public international law normally provide for public access during the proceedings, which is the case of, for example, the International Court of Justice (ICJ), the International Tribunal for the Law of the Sea (ITLOS) and the European Court of Human Rights (ECtHR).

${ }^{814}$ In this case, following the joint request by the EU, the US and Canada, the panel decided to open up hearings in 2005 and 2006. The proceedings were broadcasted through closed-circuit. See: World Trade Organization, DS320: United States-Continued Suspension of Obligations in the EC-Hormones Dispute, available at: https://www.wto.org/english/tratop_e/dispu e/cases_e/ds320 e.htm, last visited on 05.08.2020. At a later stage of this case, the Appellate Body made a similar decision to open hearings in 2008. See: European Commission, $E U$ welcomes first opening of WTO Appellate Body hearing to the public, Press Release, 11.07.2008, available at http://trade.ec.europa.eu/doclib/docs/2008/july/tradoc_139603.pdf, last visited on 27.09.2019.

${ }_{815}$ Ignacio Garcia Bercero \& Paolo Garzotti, DSU Reform: Why Have Negotiations to Improve WTO Dispute Settlement Failed so far and What Are the Underlying Issues?, The Journal of World Investment \& Trade, Vol. 6, 2005, p. 854

816 World Trade Organization-Dispute Settlement Body-Special Session, Contribution of the European Communities and its Member States to the Improvement of the WTO Dispute Settlement Understanding, TN/DS/W/1, 13.03.2002, pp. 6-7. 
framework for allowing amicus curiae briefs better, in order to facilitate such submissions and avoid delays in the proceedings or additional burdens for the developing WTO Members. ${ }^{817}$ Decisions on whether to accept and consider amicus curiae briefs are now taken on a case-by-case basis in the WTO Dispute Settlement System. ${ }^{818}$

In addition, although the WTO Dispute Settlement System already has a quasi-judicial nature, the EU is active in further enhancing the judicial features of this system. Typical evidence includes its proposal for establishing a permanent Panel Body. The EU suggested that such a body would be composed of 15 to 24 panellists, appointed through a process similar to that used for Appellate Body members or a less "political" selection procedure including a review of candidates by an ad hoc group of experts on WTO dispute settlement. ${ }^{819}$ Such a permanent Panel Body was argued as being able to expediate dispute settlement proceedings, issue consistent rulings, strengthen the WTO Dispute Settlement System's judicial nature, and increase the involvement of developing countries in the panel process. ${ }^{820}$

Most recently, on 5 July 2018, the EU submitted its proposals on WTO modernization, including a part on dispute settlement, which aims at "strengthening of the independence of the Appellate Body and its members" by introducing an additional mechanism for the interaction between them. ${ }^{821}$ For example, regarding the 90 -day rule in Artice 17.5 of the DSU, the EU suggested a consultation obligation for the Appellate Body. ${ }^{822}$ In addition, it is suggested that there should be regular exchanges between the Appellate Body and WTO Members. The EU's proposals were submitted in response to concerns raised by the US in the context of the crisis of the continuing the Appellate Body's function which was caused by the US blocking the selection of new Appellate Body members. It is fair to say that such suggestions increase the influence of the WTO Members on the dispute settlement process, while, at the same time, they do not negatively affect the judicial function of the Appellate Body. ${ }^{823}$

\footnotetext{
817 Id, p. 7.

818 Appellate Body Report, United States-Import Prohibition of Certain Shrimp and Shrimp Products, WT/DS58/AB/R, adopted on 06.11.1998, paras. 105-108.

819 World Trade Organization-Dispute Settlement Body-Special Session, Contribution of the European Communities and its Member States to the Improvement of the WTO Dispute Settlement Understanding, TN/DS/W/1, 13.03.2002, pp. 3-4. Before this, there had been discussion papers submitted by the EU on 21 October 1998 and 23 July 1999, and the text co-sponsored by the EC and its Member State before the Third Ministerial Conference, circulated as document WT-MIN(99)/8 of 22 November 1999.

${ }^{820}$ Id, pp. 2-3. See also: Marc L. Busch \& Krzysztof J. Pelc, Does the WTO Need a Permanent Body of Panelists?, Journal of International Economic Law, Vol. 12, 2009, pp. 583-584.

821 Council of the European Union-General Secretariat, WTO-EU's proposals on WTO Modernisation, WK 8329/2018 INIT, 05.07.2018.

822 The Appellate Body would need to consult with the parties early in appellate proceedings (or even before the appeal is filed) if it estimates that the report will be circulated after 90 days. If there is no agreement of the parties on exceeding this timeframe, there could be a mechanism pursuant to which the procedure or working arrangements for the particular appeal could be adapted to ensure the meeting of the 90-day timeframe. For example, the Appellate Body could propose that the parties voluntarily focus the scope of the appeal, set an indicative page limit on the parties' submissions or could take appropriate measures to reduce the length of its report.

${ }^{823}$ Communication from the European Union, China, Canada, India, Norway, New Zealand, Switzerland, Australia, Republic of Korea, Iceland, Singapore and Mexico and Montenegro to the General Council, WT/GC/W/752/Rev. 2, 11.12.2018, available

at: https://docs.wto.org/dol2fe/Pages/FE_Search/FE_S_S006.aspx?Language=ENGLISH\&SourcePage=FE_B_009\&
} 


\subsection{The EU's Practice of Investor-State Dispute Settlement Mechanisms}

Following the main approach to investment dispute settlement practice, in addition to state-state DSMs, the IIAs concluded by the EU also provide investor-state DSMs, granting foreign investors the right to resolve investment disputes directly with host states at the international level.

Due to the change brought by the Lisbon Treaty, the EU's investor-state DSMs can be divided into two groups: those concluded in the pre-Lisbon period and those from the post-Lisbon period. In particular, considering the importance of the EU's current approach in this thesis, which set out to analyse the possible design of the dispute settlement system in the prospective China-EU BIT, ${ }^{824}$ the investment court system (hereinafter "ICS") undoubtedly deserves particular attention and thus is explored separately in the following Section 7.3.3, infra.

\subsubsection{The Investor-State Dispute Settlement Mechanisms in the Pre-Lisbon Period}

As introduced in Section 7.1, supra, the Lisbon Treaty transferred the competence for foreign direct investment from EU Member States to the Union. As a result, in the preLisbon period, the treaties on investment protection, including investment dispute settlement, were concluded mainly by EU Member States, only with the exception of the ECT where the Union and its Member States joined together.

\subsubsection{The Investor-State Dispute Settlement Mechanisms in the EU Member States' International Investment Agreements}

During the pre-Lisbon period, EU Member States were very active in negotiating and concluding investment treaties with third states, evidenced by their more than 1,356 extra-EU IIAs. ${ }^{825}$ Despite the occasional reluctance of Ireland, ${ }^{826}$ all other EU Member States were relatively prolific in this field. In particular, Germany concluded about 130 IIAs, being the most productive state worldwide in this respect. Most of these IIAs include ISDS mechanisms, and nearly 1,200 of them contain provisions on investor-state arbitration. ${ }^{827}$ As the European Commission stated, ISDS is "an

Context $=$ Script $\&$ DataSource $=$ Cat $\& Q u e r y=\% 40$ Symbol $\% 3 \mathrm{dWT} \% 2 \mathrm{fGC} \% 2 \mathrm{fW} \% 2 \mathrm{f} * \&$ DisplayContext $=$ popup $\&$ lan guageUIChanged=true, last visited on 25.05.2020; Communication from the European Union, China, India and Montenegro to the General Council, WT/GC/W/753, 26.11.2018 and WT/GC/W/753/Rev., 11.12.2018, available at: https://docs.wto.org/dol2fe/Pages/FE_Search/FE_S S006.aspx?Language=ENGLISH\&SourcePage=FE B 009\& Context $=$ Script\&DataSource $=$ Cat\&Query $=\% 40$ Symbol $\% 3 \mathrm{dWT} \% 2 \mathrm{fGC} \% 2 \mathrm{fW} \% 2 \mathrm{f} *$ DisplayContext=popup \&lan guageUIChanged=true, last visited on 25.05.2020.

${ }^{824}$ It is apparent, at least until now, that the European Commission will probably push through its ICS in IIAs to be concluded in the near future.

${ }^{825}$ For an official list of EU Member States' IIAs documented by the Union, see: List of the Bilateral Investment Agreements Referred to in Article 4(1) of Regulation (EU) No 1219/2012 of the European Parliament and of the Council of 12 December 2012 Establishing Transitional Arrangements for Bilateral Investment Agreements between Member States and Third Countries, 2016/C 149/01, 27.04.2016. Among these IIAs, 1,160 are currently in force. See: United Nations Conference on Trade and Development (UNCTAD), Investor-State Dispute Settlement: An Informationa Note on the United States and the European Union, 06.2014, available at: http://unctad.org/en/PublicationsLibrary/webdiaepcb2014d4_en.pdf, p. 3, last visited on 06.08.2020.

${ }^{826}$ Ireland currently has no BIT with a third state in force. See: United Nations Conference on Trade and Development (UNCTAD) Investment Policy Hub, IIAs by Economy_Ireland, available at: http://investmentpolicyhub.unctad.org/IIA/CountryBits/100\#iiaInnerMenu, last visited on 06.08.2020.

827 European Parliament, Prospects for a Multilateral Investment Court, 06.2017, available at: 
established feature of investment agreements" and forms "a key part of the inheritance that the Union receives from Member State BITs". 828

Many ISDS cases have been initiated under EU Member States' IIAs. Studies conducted by the United Nations Conference on Trade and Development $(\mathrm{UNCTAD})^{829}$ and by the International Centre for Settlement of Investment Disputes (ICSID $)^{830}$ identified some features of the ISDS cases, where EU Member States or their investors are involved. First, investors from EU Member States are the greatest users of investor-state arbitration. As of 12 March 2015, the number of cases brought by EU investors in total was 327 , accounting for more than $50 \%$ of ISDS cases initiated at the global level. ${ }^{831}$ Investors from almost all EU Member States had brought ISDS cases, and particularly investors from the Netherlands, the UK, Germany, France, Spain, and Italy had launched a total of 236 cases. ${ }^{832}$ Second, EU Member States have rarely been challenged by investors from outside the EU. Out of the 117 known cases in which EU Member States were respondents, ${ }^{833}$ only 29 cases were between an investor from a third state and an EU Member State. ${ }^{834}$ Furthermore, among this limited number of cases, EU Member States were more successful than other states in having claims dismissed. ${ }^{835}$

Considering the purpose of this thesis exploring explore the possible design of the dispute settlement system in the prospective China-EU BIT, the focus will be limited to the 26 IIAs concluded between China and the EU Member States and the cases that arose from these IIAs. These IIAs and the cases illustrate the current ISDS system between China and EU Member States, which also provides a better understanding of the EU's current practice. The analysis is provided in Section 9.2, infra.

http://www.europarl.europa.eu/RegData/etudes/ATAG/2017/607252/EPRS_ATA(2017)607252_EN.pdf, p. 1, last visited on 05.08.2020.

${ }^{828}$ European Commission, Communication from the Commission to the Council, the European Parliament, the European Economic and Social Committee and the Committee of the Regions: Towards a Comprehensive European International Investment Policy, $\operatorname{COM(2010)343~final,~07.07.2010,~pp.~9-10.~}$

${ }^{829}$ United Nations Conference on Trade and Development (UNCTAD), Recent Trends in IIAs and ISDS, 2015, available at: http://unctad.org/en/PublicationsLibrary/webdiaepcb2015d1_en.pdf, last visited on 06.08.2020.

830 As of April 30, 2017, ICSID had registered 608 cases under the ICSID Convention and Additional Facility Rules. 105 of these cases (17\%) involved a State Party from the EU. No conciliation case had been registered by ICSID involving a State Party from the EU. See: International Centre for Settlement of Investment Disputes (ICSID), The ICSID Caseload-Statistics-Special Focus-European Union, 04.2017, available at: https://icsid.worldbank.org/en/Documents/resources/ICSID\%20Web\%20Stats\%20EU(English)April\%202017.pdf, pp. $6 \& 8$, last visited on 03.08.2020.

831 European Commission, Investor-to-State Dispute Settlement (ISDS)-Some Facts and Figures, 12.03.2015, available at: http://trade.ec.europa.eu/doclib/docs/2015/january/tradoc_153046.pdf, p. 5, last visited on 27.07.2020. ${ }^{832}$ Id.

${ }^{833}$ Among these cases, almost a quarter were faced by one state, the Czech Republic. Several EU Member States, such as Austria, Denmark or Finland, have not faced any known ISDS claim to date. See: United Nations Conference on Trade and Development (UNCTAD), Investor-State Dispute Settlement: An Informationa Note on the United States and the European Union, 06.2014, available at: http://unctad.org/en/PublicationsLibrary/webdiaepcb2014d4_en.pdf, p. 1, last visited on 06.08.2020.

834 European Commission, Investor-to-State Dispute Settlement (ISDS)-Some Facts and Figures, 12.03.2015, available at: http://trade.ec.europa.eu/doclib/docs/2015/january/tradoc_153046.pdf, p. 5, last visited on 27.07.2020. ${ }^{835}$ The data from ICSID shows the following figures for disputes against EU Member States: in $44 \%$ of the cases, all claims were dismissed or jurisdiction was declined; in $36 \%$ of the cases, the disputes were settled or otherwise discontinued; in $20 \%$ of the cases, the disputes led to an award upholding claims in part or in full. See: id. 


\subsubsection{The Investor-State Dispute Settlement Mechanisms in the Energy Charter Treaty}

Like in the WTO, the EC became a member to the ECT along with its Member States, ${ }^{836}$ for the first time assuming specific commitments in the field of investment. ${ }^{837}$ In addition to state-state DSMs, which were introduced in Section 7.2.2.1, supra, the ECT provides DSMs to resolve disputes between an investor and a treaty party over alleged breaches of the treaty.

Similar to state-state dispute settlement, the starting point of ISDS under the ECT is the desirability of an amicable settlement between the disputing parties, which can be realized through the good offices of the Energy Charter Secretariat. In the event that a dispute cannot be settled amicably within three months, the investor is allowed to submit the dispute to the courts or administrative tribunals of the treaty party, in accordance with any applicable previously agreed dispute settlement procedure, or to international conciliation or arbitration. With regard to investor-state arbitration in particular, both ad hoc and institutional arbitration are available. The content of the relevant provision in the ECT is summarized in TABLE 7.3.1.2. Considering the ECT is taken as "a child of the European Union", ${ }^{838}$ the design of the investor-state DSMs represent the EU's attitude towards ISDS at that stage.

TABLE 7.3.1.2 Investor-State Arbitration under the ECT

\begin{tabular}{|c|c|c|c|c|c|}
\hline \multirow{3}{*}{$\begin{array}{l}\text { ECT } \\
\text { Art. } \\
26\end{array}$} & \multirow[t]{2}{*}{$\begin{array}{l}\text { Ad Hoc } \\
\text { Arbitration }\end{array}$} & \multicolumn{2}{|c|}{$\begin{array}{l}\text { Institutional } \\
\text { Arbitration }\end{array}$} & \multirow[t]{2}{*}{$\begin{array}{l}\text { Applica } \\
\text { ble Law }\end{array}$} & \multirow[t]{2}{*}{ Result } \\
\hline & & $\begin{array}{l}\text { ICSID } \\
\text { Arbitrati } \\
\text { on }\end{array}$ & $\begin{array}{l}\text { Other } \\
\text { Institutio } \\
\text { ns }\end{array}$ & & \\
\hline & $\begin{array}{l}\text { A sole } \\
\text { arbitrator or } \\
\text { ad hoc } \\
\text { arbitration } \\
\text { tribunal } \\
\text { established } \\
\text { under the } \\
\text { UNCITRA } \\
\text { L }\end{array}$ & $\begin{array}{l}\text { ICSID } \\
\text { arbitratio } \\
n\end{array}$ & $\begin{array}{l}\text { The } \\
\text { Arbitrati } \\
\text { on } \\
\text { Institute } \\
\text { of the } \\
\text { Stockhol } \\
\mathrm{m} \\
\text { Chamber } \\
\text { of }\end{array}$ & $\begin{array}{l}\text { The ECT } \\
\text { and } \\
\text { applicabl } \\
\text { e rules } \\
\text { and } \\
\text { principle } \\
\text { s of } \\
\text { internati } \\
\text { onal law }\end{array}$ & $\begin{array}{l}\text { Arbitration awards are } \\
\text { final and binding upon } \\
\text { the parties to the } \\
\text { dispute. Each } \\
\text { Contracting Party shall } \\
\text { carry out without delay } \\
\text { any such award and } \\
\text { shall make provision } \\
\text { for the effective }\end{array}$ \\
\hline
\end{tabular}

${ }^{836}$ Council of the European Union \& Commission of the European Communities, Council and Commission Decision of 23 September 1997 on the Conclusion, by the European Communities, of the Energy Charter Treaty and the Energy Charter Protocol on Energy Efficiency and Related Environmental Aspects, 98/181/EC, ECSC, Euratom, 23.09.1997.

${ }^{837}$ Frank Hoffmeister \& Güneş Ünüvar, From BITS and Pieces Towards European Investment Agreements, at: Marc Bungenberg \& August Reinisch \& Christian Tietje (eds.), EU and Investment Agreements: Open Questions and Remaining Challenges, Nomos/Hart Publishing, 2013, p. 59.

${ }^{838}$ Jan Kleinheisterkamp, The Next 10 Year ECT Investment Arbitration: A Vision for the Future-From a European Law Perspective, London School of Economics Legal Studies Working Paper, Vol. 7, 2011, p. 1. For the following historic account, see: EUR-Lex, Final Act of the Energy Charter Conference, 31.12.1994, available at: https://eurlex.europa.eu/legal-content/EN/TXT/PDF/?uri=CELEX:21994A1231(51)\&from=EN, last visited on 30.07.2020. 


\begin{tabular}{|l|l|l|l|}
\hline $\begin{array}{l}\text { Arbitration } \\
\text { Rules }\end{array}$ & $\begin{array}{l}\text { Commer } \\
\text { ce }\end{array}$ & $\begin{array}{l}\text { enforcement in its area } \\
\text { of such awards. }\end{array}$ \\
\hline
\end{tabular}

While the first few ECT cases involving EU Member States were brought predominantly against eastern European states, the number of cases against western European states has been increasing in recent years. ${ }^{839}$ The Union has not been in the position of respondent in any ISDS case under the ECT, ${ }^{840}$ but it acted as amicus curiae in at least one case involving an EU Member State under the ICSID arbitration rules. ${ }^{841}$ In the cases brought by EU investors, only ICSID arbitration has been resorted to, while arbitration cases under the UNCITRAL Arbitration Rules or before the Arbitration Institution of the Stockholm Chamber of Commerce may arise in the future. ${ }^{842}$

\subsubsection{The Investor-State Dispute Settlement Mechanisms in the Post-Lisbon Period}

Although the Lisbon Treaty resulted in Union's exclusive competence in foreign direct investment, the progress in negotiating IIAs has been made both by the Union and by its Member States, which are introduced respectively in the following.

\subsubsection{Progress Made by the Union}

After the Lisbon Treaty, the Union joined the impetus of reforming investor-state arbitration. This is evidenced by its concluded IIAs, its proposals for potential IIAs, as well as other relevant internal and external measures. As of 30 April 2020, three IIAs have been concluded, CETA (2012), the EU-Vietnam IPA (2018) and the EUSingapore IPA (2018). The relevant provisions in these Agreements have many similarities and, thus, it is fair to say that they represent the EU's most up-to-date practice, which is expected will be insisted upon for prospective IIAs. All of these three IIAs set up both amicable and adjudicative mechanisms for ISDS. Negotiation, mediation and consultations are explicitly stressed as amicable DSMs. A court system has been created for adjudication. For a detailed analysis of the ICS, see Section 7.3.3, infra.

\subsubsection{Progress Made by EU Member States}

As a necessary arrangement following the shift in competence, a transitional regime for the existing IIAs concluded by EU Member States with third states was established, which is composed of a replacement mechanism and an authorization mechanism. ${ }^{843}$

839 Deborah Ruff \& Julia Belcher \& Charles Golsong, Energy Charter Treaty Coming up for 20 years, 2014, available at: http://www.nortonrosefulbright.com/files/energy-charter-treaty-115911.pdf, p. 4, last visited on 27.05.2020.

${ }^{840}$ Frank Hoffmeister \& Güneş Ünüvar, From BITS and Pieces Towards European Investment Agreements, at: EU and Investment Agreements: Open Questions and Remaining Challenges, Nomos/Hart Publishing, 2013, p. 59.

${ }^{841}$ This case is: AES Summit Generation Limited and AES-Tisza Erömü Kft v. The Republic of Hungary, ICSID Case No. ARB/07/22. For some academic discussions on this, see: Frank Hoffmeister \& Güneş Ünüvar, From BITS and Pieces Towards European Investment Agreements, at: EU and Investment Agreements: Open Questions and Remaining Challenges, Nomos/Hart Publishing, 2013, p. 60.

${ }^{842}$ Danae Azaria, The European Union's Contribution to the Law on Standing and Jurisdiction in International Dispute Settlement, at: Marise Cremona \& Anne Thies \& Ramses A Wessel (eds.), The European Union and International Dispute Settlement, Hart Publishing, 2017, p. 79.

${ }^{843}$ Regulation 1219/2012 of the European Parliament and of the Council of 12 December 2012 establishing 
Under this regime, EU Member States' existing IIAs are maintained in force until new agreements that are concluded between the Union and the same third states and come into effect. ${ }^{844}$ At the same time, EU Member States are allowed to amend existing IIAs and conclude new ones with third states, provided that they obtain authorization from the European Commission. Therefore, a successful implementation of the Union's international investment policy will subsequently result in the gradual replacement of at least some of its Member States' IIAs.

Relying on EU Regulation 1219/2012, by mid-2016, the European Commission had granted 93 authorizations to its Member States to open new negotiations, 41 authorizations to open re-negotiations, 16 authorizations to conclude new treaties, and 21 authorizations to conclude protocols for existing BITs with third states. ${ }^{845}$ Thus, after the entry into force of the Lisbon Treaty, EU Member States still remain active in negotiating IIAs. In addition to stressing the preference for amicable settlement, arbitration held by the ICSID or ad hoc arbitration established under the UNCITRAL arbitration rules are often provided as investor-state DSMs contained in those newly concluded IIAs by EU Member States. ${ }^{846}$ It deserves attention that that some of these IIAs reflect features of the current investment arbitration reform. For instance, the UNCITRAL Rules on Transparency in Treaty-based Investor-State Arbitration (2014) are explicitly required to be applied to investor-state arbitration. ${ }^{847}$ In the recently adopted Netherlands Model BIT, ${ }^{848}$ more reforms of traditional arbitration were introduced, especially including some practices adopted in the EU's ICS, such as the importance of using amicable DSMs, temporal conditions for bringing claims, rules on third-party-funding, cost-shifting, etc.

\subsubsection{The EU's Up-to-date Approach to Investor-State Dispute Settlement- the Investment Court System}

Since 2015, the European Commission has been working on the establishment of an investment court project, with a view to setting up a permanent body for ISDS. ${ }^{849}$

\footnotetext{
transitional arrangements for bilateral investment agreements between Member States and third countries (adopted on 12.12.2012, entered into force on 09.01.2013), (2012) OJ L351/40. See also: Philip Strik, Shaping the Single European Market in the Field of Foreign Direct Investment, Hart Publishing, 2016.

${ }^{844}$ On 8 May 2013, the Official Journal of the European Union for the first time published the List of the bilateral investment agreements between EU Member States and third states. See: List of the Bilateral Investment Agreements Referred to in Article 4(1) of Regulation (EU) No 1219/2012 of the European Parliament and of the Council Establishing Transitional Arrangements for Bilateral Investment Agreements between Member States and Third Countries, 2013/C 131/02, 08.05.2013. This list includes the IIAs that, after the issuance of Regulation No. 1219/2012, EU Member States wish to maintain or to permit to enter into force with third states that were signed before 1 December 2009. This list was recently updated in 2016. See: List of the Bilateral Investment Agreements Referred to in Article 4(1) of Regulation (EU) No 1219/2012 of the European Parliament and of the Council of 12 December 2012 Establishing Transitional Arrangements for Bilateral Investment Agreements between Member States and Third Countries, 2016/C 149/01, 27.04.2016.

${ }^{845}$ Stefanie Schacherer, Can EU Member States Still Negotiate BITs with Third Countries?, International Institute for Sustainable Development (IISD), 10.08.2016, available at: https://www.iisd.org/itn/2016/08/10/can-eu-memberstates-still-negotiate-bits-with-third-countries-stefanie-schacherer/\#_edn11, last visited on 03.08.2020.

${ }^{846}$ See e.g. Agreement between the Government of the Hellenic Republic and the Government of the United Arab Emirates on the Promotion and Reciprocal Protection of Investments (signed on 06.05.2014, entered into force on 06.03.2016), Arts. 10.1-10.3.

847 See e.g. id, Art. 10.4.

848 The finalized text was adopted and released on 19 October 2018.

849 European Commission, Dispute Settlement, available at: http://ec.europa.eu/trade/policy/accessing-
} 
Remarkably different from classic arbitration, the three investment agreements concluded by the EU after the Lisbon Treaty-CETA (2012), the EU-Vietnam IPA (2018) and the EU-Singapore IPA (2018) — establish a bilateral two-tiered ICS for ISDS separately. ${ }^{850}$ This ICS can be taken as a radical reaction, or a sea change, to the widely used investor-state arbitration: it proposed a complete renovation, which, by nature, is a permanent court system with a high level of transparency and independence. Such a practice constitutes the EU's most up-to-date approach on the issue of ISDS.

There is much literature on whether the EU's proposal of replacing traditional investment arbitration with an ICS is a workable and viable way forward to improve the current situation of ISDS. ${ }^{851}$ While considering the subject of this thesis, in this section, the focus is put on analysing the procedural features of the proposed ICS and the values the EU tries to pursue and promote. In order to do this, it first summarizes the development history of the ICS. Then attention is paid to the procedural features of this court system, followed by an exploration of the reasons and values behind them. CETA (2012), the EU-Vietnam IPA (2018) and the EU-Singapore IPA (2018), together with relevant internal documents issued by the Union, act as the basis of the following analysis.

\subsubsection{The Development History of the Investment Court System}

As the starting point, on 7 July 2010, the European Commission issued a policy document, "Towards a comprehensive European international investment policy", which identified certain characteristics of the ISDS system that presented challenges and should be addressed in the Union's international investment policy, such as transparency, consistency, predictability, and the possibility to appeal. ${ }^{852}$ After the mandate to negotiate a comprehensive trade and investment agreement with the US for the Transatlantic Trade and Investment Partnership was given to the European Commission in July 2013, the negotiations, particularly on the inclusion of ISDS in this prospective treaty, faced fierce opposition from various sides. ${ }^{853}$ In response, internal

\footnotetext{
markets/dispute-settlement/, last visited on 31.07.2020.

${ }^{850}$ It is noted that there are other DSMs created for special types of disputes like disputes on financial issues, which are not included in the following discussion.

${ }^{851}$ For comments challenging the EU's ICS on a number of grounds, see: Maria Beatrice Deli \& Maria Laura Marceddu, Is the European Commission Issuing a Dismissal Letter to Arbitrators?, Kluwer Arbitration Blog, 19.10.2015, available at: http://arbitrationblog.kluwerarbitration.com/2015/10/19/the-investment-court-system-forttip-is-the-european-commission-issuing-a-death-certificate-for-arbitrators/, last visited on 04.08.2020. In addition, different arguments have been raised on various procedural features of this ICS. For example, regarding the feasibility and application of the independence and impartiality prerequisites listed in the Code of Conduct for adjudicators in the ICS, see e.g. Sophie Nappert, Escaping from Freedom? The Dilemma of an Improved ISDS Mechanism, at: Loukas Mistelis \& Nikos Lavranos (eds.), European Investment Law and Arbitration Review (Volume 1), Brill | Nijhoff, 2016, pp. 178-179. Qinglin Zhang 张庆麟, An Analysis of the EU's Reform of the Investor-State Dispute Settlement Mechanism 欧盟投资者-国家争端解决机制改革实践评析, Studies in Law and Business 法商研究, Vol. 3, 2016, pp. 148-150. Elisabeth Talbourdet, The EU's Investment Court System-A Possible Solution to Conflicts of Interest in Investment Arbitration, EU Law Blog-King's Student Law Review (KSLR) Blog on European Law, 10.04.2017, available at: https://blogs.kcl.ac.uk/kslreuropeanlawblog/?p=1121\#.Wr9dZJNuZE4, last visited on 05.08.2020.

${ }^{852}$ European Commission, Communication from the Commission to the Council, the European Parliament, the European Economic and Social Committee and the Committee of the Regions: Towards a Comprehensive European International Investment Policy, $\operatorname{COM}(2010) 343$ final, 07.07.2010.

${ }^{853}$ For example, in 2014, the German Minister for Economic Affairs told the German Federal Assembly that he would block the planned ISDS clauses, which would allow foreign companies to bypass the national courts and
} 
public consultations were opened, and the final report of the consultations showed the necessity of substantial and far-reaching reforms of the ISDS system. ${ }^{854}$ As a further step, on 5 May 2015, the European Commission released a Concept Paper, in which it addressed four major controversial issues by suggesting: (i) rectifying the investment tribunals' imbalanced interpretation of IIAs by reiterating governments' rights to regulate to achieve legitimate public policy objectives; (ii) establishing a roster of arbitrators to deal with arbitrators' potential conflicts of interests; (iii) differentiating between the role of domestic courts and international tribunals: the former being competent to rule on investment disputes by applying domestic laws, while the latter would interpret the international agreement and would examine EU law as a matter of fact; (iv) proposing a bilateral appellate mechanism modelled on the institutional set up for the WTO Appellate Body, to ensure correctness and consistency in interpretation, and thus legitimacy, independence, impartiality, and predictability could be enhanced. ${ }^{855}$ In addition, it was pointed out that these innovative proposals were intended to be the stepping stones towards the establishment of a multilateral ICS. ${ }^{856}$

In September 2015, the European Commission released the proposed negotiating text for investment provisions within the Transatlantic Trade and Investment Partnership. ${ }^{857}$ In this proposal, the European Commission clearly sought to transform investment arbitration into a court-like system, moving towards the final goal of fully replacing the old ISDS mechanism with "a modern, efficient, transparent and impartial system". 858 On 14 October 2015, the European Commission further proposed a new trade and investment strategy, which particularly stressed the objective of developing "a coherent,

\footnotetext{
instead appeal directly to international arbitration. He explained that there should be no double standards, which meant only the international investors had the rights before international arbitration tribunals, but not the national enterprises. See: Financial Times, Germany Expresses Concerns about US and Canada Trade Deals, 25.09.2015, available at: https://www.ft.com/content/671841da-44c1-11e4-bce8-00144feabdc0, last visited on 06.08.2020.

${ }^{854}$ European Commission, Commission Staff Working Papter-Report: Online Public Consultation on Investment Protection and Investor-to-State Dispute Settlement (ISDS) in the Transatlantic Trade and Investment Partnership Agreement (TTIP), SWD(2015) 3 final, 13.01.2015. In this Report, the European Commission particularly identified four major areas which, among others, required a further analysis: (i) the protection of the right to regulate; (ii) the establishment and functioning of arbitral tribunals; (iii) the relationship between domestic judicial systems and the ISDS; and (iv) the review of ISDS decisions for legal correctness through an appellate mechanism. Relevant academic discussions on this can be found in: Tomáš Fecák, International Investment Agreements and EU Law, Kluwer Law International, 2016, pp. 282-283.

${ }^{855}$ In particular, it was stressed that the bilateral appellate mechanism and the fixed list of arbitrators would be a standard feature in all EU IIAs. See: European Commission, Concept Paper-Investment in TTIP and Beyond-the Path for Reform: Enhancing the Right to Regulate and Moving from Current Ad Hoc Arbitration towards an Investment Court, 05.05.2015, available at: http://trade.ec.europa.eu/doclib/docs/2015/may/tradoc_153408.PDF, p. 11, last visited on 29.07.2020.

${ }^{856}$ The next step would be establishing an actual fully-fledged permanent investment court with tenured judges on the basis of an opt-in system. The final objective is to multi-lateralize the court, either as a self-standing international body or by embedding it into an existing multilateral organization. This idea was put forward by a number of stakeholders, including EU Member States, the European Parliament and civil society groups in the public consultation conducted in 2014. See: id, p. 4.

${ }^{857}$ This was released together with a Reading Guide. See: European Commission, Reading Guide-Draft Text on Investment Protection and Investment Court System in the Transatlantic Trade and Investment Partnership, 16.09.2015, available at: http://europa.eu/rapid/press-release_MEMO-15-5652_en.htm, last visited on 29.07.2020. The proposal was formally presented to the US in November 2015 after informal consultations with EU Member States and the European Parliament.

858 European Commission, EU Finalises Proposal for Investment Protection and Court System for TTIP, 12.11.2015, available at: http://europa.eu/rapid/press-release_IP-15-6059_en.htm, last visited on 29.07.2019.
} 
unified and effective policy on investment dispute resolution". ${ }^{859}$ In December 2015, the EU and Vietnam finalized negotiations on their treaty where an ICS was incorporated and, in September 2016, such a court system was also added to CETA for ISDS. ${ }^{860}$ In April 2018, the arbitration mechanism in the former version of the EUSingapore FTA (authentic text as of May 2015) was updated, in which both parties agreed to use the ICS to substitute investment arbitration.

While adding the ICS to treaty negotiations, the European Commission also seeks to expand the effect of this system to a multilateral level. In 2016, it made a proposal for a Council Decision authorizing the Commission to negotiate a Convention to establish a multilateral court on investment. ${ }^{861}$ Recently, the May 2017 Commission Reflection Paper on Harnessing Globalisation reiterated that the proposed multilateral investment court would create a fair and transparent mechanism for international investment disputes. ${ }^{862}$ At this point, it can be said that the EU's proposal of the ICS basically came into force and concrete steps are being taken to move towards establishing a multilateral court system for ISDS.

In response to Belgium's request, ${ }^{863}$ the CJEU issued Opinion 1/17 on 1 May 2019, confirming the compatibility of the ICS with EU law in the context of CETA. ${ }^{864}$ It is fair to say that the importance of this Opinion goes beyond CETA's ICS. Given the similarities between the ICS in CETA (2012) and those in the EU-Singapore IPA (2018) and the EU-Vietnam IPA (2018), Opinion 1/17 should also clarify the concerns about the legitimacy of the relevant provisions in the latter two IPAs. Furthermore, as underscored by Advocate General Bot in his opinion, "what is at issue here is the definition of a model which is consistent with the structural principles of the EU legal

\footnotetext{
859 European Commission, Communication from the Commission to the European Parliament, the Council, the European Economic and Social Committee and the Committee of the Regions: Trade for All-Towards a More Responsible Trade and Investment Policy, COM(2015) 497 final, 14.10.2015.

860 The 2014 version of the CETA relied on traditional investment arbitration with arbitrators appointed by disputing parties. In late 2015, the European Commission reopened negotiations with Canada, and the treaty parties agreed on incorporating the mechanism analogous to the Investment Court System in CETA. See: European Commission, CETA: EU and Canada Agree on New Approach on Investment in Trade Agreement, Press Release, 29.02.2016, available at http://europa.eu/rapid/press-release_IP-16-399_en.htm, last visited on 31.07.2020. European Commission, European Commission Welcomes Parliament's Support of Trade Deal with Canada, 15.02.2017, available at: http://europa.eu/rapid/press-release_IP-17-270_en.htm, last visited on 31.07.2020. It is noticeable that Canada concluded a BIT with more conventional investment arbitration for ISDS just before the update of CETA, the Canada-Hong Kong BIT (signed in 2016), which could indicate the EU's affirmative attitude to the ICS.

${ }^{861}$ European Commission, Establishment of a Multilateral Investment Court for Investment Dispute Resolution, DG Trade - F2, 01.08.2016. After that, between 21 December 2016 and 15 March 2017, an online public consultation was carried out, which showed overall broad support for a multilateral reform of investment dispute settlement. See: European Commission, Recommendation for a Council Decision: Authorising the Opening of Negotiations for a Convention Establishing a Multilateral Court for the Settlement of Investment Disputes, COM(2017) 493 final, 13.09.2017, p. 5.

862 European Commission, Reflection Paper on Harnessing Globalisation, COM(2017) 240, 10.05.2017, p. 15.

863 On 7 September 2017, in the context of CETA negotiations, Belgium requested the CJEU to render an opinion on the ICS's compatibility with EU law, in particular with (i) the exclusive competence of the CJEU to provide the definitive interpretation of EU law, (ii) the general principle of equality, (iii) the requirement that EU law is effective, and (iv) the right to an independent and impartial judiciary. See: Request for an opinion submitted by the Kingdom of Belgium pursuant to Article 218(11) TFEU (Opinion 1/17), 30.10.2017, C 369/2.

${ }^{864}$ Opinion 1/17 of the Court (Full Court), 30.04.2019.
} 
order" ${ }^{865}$ therefore it is reasonable to say that this Opinion also envisages the ultimate goal of replacing the bilateral ICS in each IIA with a single multilateral ICS.

\subsubsection{Procedural Features of the Investment Court System}

Based on relevant provisions in CETA (2012), the EU-Vietnam IPA (2018) and the EUSingapore IPA (2018), this section discusses some key procedural features of the ICS, covering both the amicable and adjudicative DSMs contained therein.

\section{(i) Amicable Settlement through Negotiation and Mediation}

Reaching amicable settlement through negotiation and mediation for investor-state disputes is recommended in treaty texts. Both the EU-Vietnam IPA (2018) and the EUSingapore IPA (2018) set out separate provisions on "amicable resolution", generally emphasizing the availability of negotiation and mediation at any time, even during adjudication, and the significance in resolving disputes amicably. ${ }^{866}$

In particular, mediation is further regulated in a separate provision, where rules on some key procedural issues are provided, such as the appointment of mediators. At the same time, in the two more recently concluded IIAs, the EU-Vietnam IPA (2018) and the EU-Singapore IPA (2018), a Mediation Mechanism for Disputes between Investors and Parties is attached as an annex to each of them, which contains a comprehensive set of investor-state mediation rules. ${ }^{867}$ These two sets of rules are nearly identical, covering issues of the objective and scope of mediation, initiation of the procedure, selection of the mediator, rules for the mediation procedure, implementation of a mutually agreed solution, time limits, costs, etc. ${ }^{868}$ Among these rules, several procedural arrangements deserve particular attention. First, mediation is established as a voluntary and structured process, with much room left for party autonomy and mediators with regard to the detailed procedural arrangements. Recourse to mediation can happen at any time and is without prejudice to the disputing parties' legal positions or rights. ${ }^{869}$ Second, mediators are supposed to be selected upon the agreement of the disputing parties and, if no such an agreement can be reached, either disputing party may request the President of the Tribunal to draw by lot and appoint a mediator from the members of the Tribunal. ${ }^{870}$ Third, mediators are explicitly prevented from giving advice or comments on the consistency of the measure at issue with the applicable IIA. ${ }^{871}$ This means that

\footnotetext{
865 Opinion of Advocate General Bot (delivered on 29.01.2019), paras. 86, 108. For more discussions on the CJEU's Opinion 1/17, see: Guillaume Croisant, Opinion 1/17-The CJEU Confirms that CETA's Investment Court System is Compatible with EU Law, Kluwer Arbitration Blog, 30.04.2019, available at: http://arbitrationblog.kluwerarbitration.com/2019/04/30/opinion-117-the-cjeu-confirms-that-cetas-investmentcourt-system-is-compatible-with-eu-law/, last visited on 31.07.2020.

${ }^{866}$ The EU-Singapore IPA (2018), Art. 3.2; the EU-Vietnam IPA (2018), Art. 3.29.

867 The EU-Singapore IPA (2018), Annex 6; the EU-Vietnam IPA (2018), Annex 10. CETA (2012) postpones the adoption of mediation rules to a later action of the Committee on Services and Investment. See: CETA (2012), Art. 8.20.2.

${ }^{868}$ These two sets of investor-state mediation rules are also basically the same as state-state mediation rules in the EU's IIAs, with slight differences. See: the EU-Singapore IPA (2018), Annex 10; the EU-Vietnam IPA (2018), Annex 9.

869 The EU-Singapore IPA (2018), Annex 6, Art. 6.2; the EU-Vietnam IPA (2018), Annex 10, Art. 6.2.

870 The EU-Singapore IPA (2018), Annex 6, Art. 3; the EU-Vietnam IPA (2018), Annex 10, Art. 3. This is different from the rule under CETA (2012), where disputing parties may request the Secretary General of ICSID to appoint the mediator if no agreement can be reached.

871 The EU-Singapore IPA (2018), Annex 6, Art. 4.3; the EU-Vietnam IPA (2018), Annex 10, Art. 4.3.
} 
only interest-based mediation, instead of rules-based mediation, is allowed. ${ }^{872}$ Fourth, the process of mediation should be confidential, but the final result must be available to the public. ${ }^{873}$ Last but not least, the issue of the implementation of settlement agreements reached through mediation is not regulated. It also noticeable that a Code of Conduct for Mediators is attached to ensure the quality and the behaviour of mediators. $^{874}$

Compared to a simple reference to mediation that is often found in other IIAs in the world, ${ }^{875}$ the EU's IIAs provide more concrete guidance on practical issues, which enhances procedural certainties and predictability in mediation proceedings and thus is expected to promote the use of mediation. ${ }^{876}$

\section{(ii) Consultations as a Precondition for Adjudication}

Although consultations are also an amicable and informal DSM, different from the autonomous nature of negotiation and mediation, consultations are set as mandatory in the ICS with a minimum period of time prior to the adjudication procedure. Furthermore, in order to initiate consultations, an investor shall submit a request to the other disputing party, setting out, in addition to other information, the provisions that are alleged to have been breached, the legal and the factual basis for the claim, and the relief sought and the estimated amount of damages claimed. ${ }^{877}$ This points to the corresponding requirement of consultations in the DSU, where it is stated that any request for consultations shall be submitted in writing and shall give the reasons for the request, including identification of the measures at issue and an indication of the legal basis for the complaint. ${ }^{878}$

${ }^{872}$ Interest-based mediation and rule-based mediation are used to describe the mediators' function in the substantive aspect of dispute resolution - suggesting a resolution according to parties' interests or making an assessment of parties' positions based on the applicable law. See: Manon Schonewille \& Jeremy Lack, Mediation in the European Union and Abroad: 60 States Divided by a Common Word?, at: The Variegated Landscape of Mediation: A Comparative Study of Mediation Regulation and Practices in Europe and the World, Eleven International Publishing, 2014, pp. 25-35.

${ }^{873}$ For example, in the EU-Singapore IPA (2018), it is provided that "[m]utually agreed solutions shall be made publicly available. However, the version disclosed to the public may not contain any information that a disputing party has designated as confidential [...] All steps of the procedure, including any advice or proposed solution, shall be confidential. However, any disputing party may disclose to the public that mediation is taking place". See: the EU-Singapore IPA (2018), Annex 6, Art. 4.6. Similar provisions also exist in the EU-Vietnam IPA (2018). See: the EU-Vietnam IPA (2018), Annex 10, Art. 4.6.

${ }^{874}$ CETA (2012), Annex 29-B; the EU-Singapore IPA (2018), Annex 11; the EU-Vietnam IPA (2018), Annex 11. 875 See e.g. Art. 9.18 of the Comprehensive and Progressive Agreement for Trans-Pacific Partnership (CPTPP) provides that "[i]n the event of an investment dispute, the claimant and the respondent should initially seek to resolve the dispute through consultation and negotiation, which may include the use of non-binding, third party procedures, such as good offices, conciliation or mediation". Here, only the possibility of resorting to mediation is mentioned and no further guidance is provided.

${ }^{876}$ Since investor-state mediation does not involve the issue of depriving jurisdictions of EU Member States in relation to investment cases, it should be less problematic in terms of the CJEU's Opinion 2/15. See: CJEU Opinion 2/15 of the Court (Full Court), 16 May 2017. In this Opinion, upon the request of the European Commission regarding the EU's competence in entering into comprehensive economic agreements in the context of the EUSingapore FTA, the CJEU found that the EU did not have exclusive competence over ISDS provisions, since a choice between bringing a dispute before a court of an EU Member State and submitting it to international arbitration had the effect of removing the case from the jurisdiction of an EU Member State.

877 CETA (2012), Art. 8.19.4. Similar provisions can be found in the EU-Singapore IPA (2018), Art. 3.3.2; the EUVietnam IPA (2018), Art. 3.30.1.

878 The DSU, Art. 4.4. 
It is noticeable that the requirement of the request for consultations is clearly distinguishable from the required information for initiating mediation. For initiating investor-state mediation, CETA (2012) prescribes that the request should identify the specific measure at issue, provide a statement of the alleged adverse effects of the measure complained of, and explain how those effects are linked to the measure. ${ }^{879}$ In comparison, it seems that the purpose of consultations is to let the disputing parties examine their cases from a legal perspective, such as examining the advantages and disadvantages of the respective positions as a preparation for the case going to adjudication, while negotiation and mediation are designed for disputing parties to try to resolve the disputes by considering the interests of both. In other words, consultations appear to be more of a process for parties to have a clear understanding of their legal positions and reconsider the value of their cases, rather than settling the disputes based on their overall interests. This understanding is based on the fact that an investor cannot identify a measure in its claim during adjudication if it was not identified in its request for consultations. ${ }^{880}$ Therefore, it is fair to say that consultations are a preliminary step, or a stepping-stone, to adjudication in the ICS, which should be differentiated from negotiation and mediation, at least from the perspective of their differing objectives.

\section{(iii) A Two-tiered Court System}

As mentioned above, the key innovation of the ICS is the creation of a two-tiered court system for ISDS, which is intended to be a permanent institution composed of a Tribunal and an Appeal Tribunal with standing adjudicators. ${ }^{881}$ Thus, instead of having ad hoc arbitral tribunals, the ICS increases the level of institutionalization by including rules on the constitution of the adjudication body.

Members of Tribunals are to be appointed jointly by the EU and the other treaty party to the relevant IIA, completely changing the arrangement in traditional investment arbitration in which investors have a say in the selection of arbitrators. ${ }^{882}$ CETA Tribunal is composed of 15 members: five of the members shall be nationals of the EU Member States, five shall be nationals of Canada and five shall be nationals of third states. ${ }^{883}$ These numbers are different from those of the EU-Vietnam IPA Tribunal, where nine members are provided for: three coming from the EU, three nationals of Vietnam and the remaining three being nationals of third states. ${ }^{884}$ Under the EUSingapore IPA (2018), the total number is reduced further to six, two nominated by the

\footnotetext{
879 The EU-Vietnam IPA, Annex 10, Art. 2.4. The EU-Singapore IPA does not contain any provision on the requirement of the request for mediation.

${ }^{880}$ CETA (2012), Art. 8.22.1. The EU-Singapore IPA and the EU-Vietnam IPA do not contain provisions on such requirements.

${ }^{881}$ Although it is widely referred to as a "court" system, CETA (2012), the EU-Singapore IPA (2018) and the EUVietnam IPA (2018) do not use the term "court" or "judge", instead, only "Tribunal" and "Members of the Tribunal" are adopted. The title "judge" was only adopted to indicate the members of the First Instance under the EU's TTIP proposal. It is possible that the EU readjusted the tone to reduce any risk of "re-politicization". See: Jan Paulsson, Avoiding Unintended Consequences, at: Karl P. Sauvant \& Michael Chiswick-Patterson (eds.), Appeals Mechanism in International Investment Disputes, Oxford University Press, 2008, p. 258.

${ }^{882}$ Gus Van Harten, Comments on the European Commission's Approach to Investor-State Arbitration in TTIP and CETA, Osgoode Legal Studies Research Paper No. 59/2014, Vol. 10, 2014, p. 21.

883 CETA (2012), Art. 8.27.

${ }^{884}$ EU-Vietnam IPA (2018), Art. 3.38.2.
} 
EU, two by Singapore and two from third states. ${ }^{885}$ Joint committees are in charge of corresponding appointments. ${ }^{886}$ The appointment length of members of Tribunals also varies. ${ }^{887}$ For a specific case, the division shall be composed of one or three members. ${ }^{888}$

Failing to settle disputes through consultations, an investor may submit a claim to the Tribunal on its own behalf or on behalf of a locally established enterprise under one of the provided rules: the ICSID Convention and Rules of Procedure for Arbitration Proceedings, the ICSID Additional Facility Rules, the UNCITRAL Arbitration Rules, or any other rules upon agreement of the disputing parties. ${ }^{889}$ After adjudication, the Tribunal issues a provisional award, which can be appealed before an Appeal Tribunal.

Under the EU-Vietnam IPA (2018) and the EU-Singapore IPA (2018), Appeal Tribunals are established in a permanent manner. ${ }^{890}$ An Appeal Tribunal shall be composed of six pre-ordained members, two of whom shall be nationals of a Member State of the EU, two shall be nationals of the other treaty state and two shall be nationals of third states. ${ }^{891}$ These members are appointed for a four-year or eight-year term. ${ }^{892}$ Such explicit and clear guidance is absent under CETA (2012), where the composition and other administrative and organizational matters regarding the Appeal Tribunal are left for future decisions of the CETA joint committee. ${ }^{893}$ Similar to the arrangement for the Tribunal, the Appeal Tribunal shall hear an appeal in a division consisting of three members. ${ }^{894}$ For a specific case, the appeal is supposed to be made on prescribed grounds, including the Tribunal's errors in the interpretation or application of the applicable law, manifest errors in the appreciation of the facts, including the

\footnotetext{
${ }^{885}$ EU-Singapore IPA (2018), Art. 3.9.2.

${ }^{886}$ CETA (2012), Art. 8.27.2; the EU-Singapore IPA (2018), Art. 3.9.2; the EU-Vietnam IPA (2018), Art. 3.38.2.

887 In CETA (2012), members of the Tribunal are expected to serve for a five-year term, renewable once. The terms of seven of the fifteen persons appointed immediately after the entry into force of the Agreement shall be extended to six years. See: CETA (2012), Art. 8.27.5. In the EU-Singapore IPA (2018), members shall be appointed for an eight-year term, and the inaugural terms of three of the six persons appointed immediately after the entry into force, which are to be determined by lot, shall extend to twelve years. A member's term of appointment may be renewed by the decision of the joint committee. See: the EU-Singapore IPA (2018), Art. 3.9.5. In the EU-Vietnam IPA (2018), members of the Tribunal are in charge for four years, to be extended to six for those pulled out. See: the EU-Vietnam IPA (2018), Art. 3.38.5.

${ }_{888}$ CETA (2012), Arts. 8.23.5, 8.27.9; the EU-Singapore IPA (2018), Arts. 3.9.7, 3.9.9; the EU-Vietnam IPA (2018), Arts. 3.38.6, 3.38.9. The composition of a division is "random and unpredictable, while giving equal opportunity to all Members of the Tribunals to serve". See: CETA (2012), Art. 8.27; the EU-Singapore IPA (2018), Art. 3.9.8; the EU-Vietnam IPA (2018), Art. 3.38.7. This is similar to the corresponding requirement of a selection of the WTO Appellate Body division for a specific case.

${ }_{889}$ CETA (2012), Art. 8.23.1; the EU-Singapore IPA (2018), Art. 3.6; the EU-Vietnam IPA (2018), Art. 3.33.

890 The EU-Singapore IPA (2018), Art. 3.10.1; the EU-Vietnam IPA (2018), Art. 3.39.1.

891 The EU-Vietnam IPA (2018), Art. 3.39.2. The EU-Singapore IPA is slightly different on this point, since the nationality requirement is eliminated. See: the EU-Singapore IPA (2018), Art. 3.10.2.

${ }^{892}$ The EU-Singapore IPA (2018), Art. 3.10.5; the EU-Vietnam IPA (2018), Art. 3.39.5.

${ }^{893}$ CETA, Arts. 8.28.3, 8.28.7. On this issue, it is noted that the European Commission made a proposal as regards the adoption of a decision setting out the administrative and organizational matters regarding the functioning of the Appellate Tribunal. See: Proposal for a Council Decision on the position to be taken on behalf of the European Union in the CETA Joint Committee established under the Comprehensive Economic and Trade Agreement (CETA) between Canada, of the one part, and the European Union and its Member States, of the other part as regards the adoption of a decision setting out the administrative and organizational matters regarding the functioning of the Appellate Tribunal, $\operatorname{COM}(2019) \quad 457$ final, 11.10.2019, available at: https://eurlex.europa.eu/resource.html?uri=cellar:d4636933-ec0f-11e9-9c4e-01aa75ed71a1.0001.02/DOC_1\&format=PDF, last visited on 25.05.2020.

${ }^{894}$ CETA (2012), Art. 8.28.5; the EU-Singapore IPA (2018), Art. 3.10.7; the EU-Vietnam IPA (2018), Art. 3.39.8.
} 
interpretation of relevant domestic law, and the conditions provided in Article 52 of the ICSID Convention. ${ }^{895}$ As a result, the appeal mechanism in the ICS not only aims at resolving a the procedural irregularity in a Tribunal's award but also correcting its substantive errors. This clearly expands the scope of current relevant practice, arguably granting the Appeal Tribunal the power to give a case a de novo review. ${ }^{896}$ In the end, the Appeal Tribunal can maintain, modify or reverse the legal findings and conclusions in the provisional award in whole or part. ${ }^{897}$ This also goes beyond existing practice, such as the ICSID annulment proceeding, where the result is limited to "annul"voiding a decision in whole or in part. ${ }^{898} \mathrm{~A}$ final award issued by the Tribunal or the Appeal Tribunal shall be binding for the disputing parties and shall not be subject to other remedies, such as review, set aside and annulment. ${ }^{899}$

The appeal system aims at increasing the quality of adjudication and realizing justified consistency and coherence, because appeal decisions are expected to have a persuasive effect on future disputes, indirectly resulting in the development of precedent. It is expected to resolve the problem of diverging decisions from different ad hoc tribunals, ${ }^{900}$ making the ICS more predictable in delivering consistent case law in an efficient and cost-effective way and reaching "acceptable levels of quality in jurisprudential outcomes". ${ }^{901}$ The idea of having an appeal mechanism in ISDS is not new, ${ }^{902}$ but the EU's ICS is the first to develop procedural designs in treaties, which is a much more concrete step than simply envisaging the possibility.

Despite the fact that some features of the ICS are still ad hoc, it undoubtedly signals an evolution towards an "institutionalized" process. In addition, although, until now, the ICS has been built on a case-by-case basis, separately in the EU's IIAs, as was foreseen

${ }^{895}$ CETA (2012), Art. 8.28.9(a); the EU-Singapore IPA (2018), Art. 3.19; the EU-Vietnam IPA (2018), Art. 3.54.1.

${ }^{896}$ Kristina Anđeli, Why ICSID Doesn't Need an Appellate Procedure, and What to Do Instead, at: Jean E. Kalicki \& Anna Joubin-Bret (eds.), Reshaping the Investor-State Dispute Settlement System, Brill, 2015, p. 502.

897 CETA (2012), Art. 6.10.2; the EU-Singapore IPA (2018), Art. 3.19; the EU-Vietnam IPA (2018), Art. 3.54.3.

898 Thomas Johnson, ICSID Annulment: Factual Review, The Second Conference of the British Institute of International and Comparative Law's Investment Treaty Forum-Appeals and Challenges to Investment Treaty Awards: Is it Time for an International Appellate System, London, 07.05.2004.

${ }^{899}$ CETA (2012), Art. 8.41; the EU-Singapore IPA (2018), Art. 3.22.1; the EU-Vietnam IPA (2018), Art. 3.57.1.

900 Audley Sheppard \& Hugo Warner, Appeals and Challenges to Investment Treaty Awards: Is It Time for an International Appellate System?-Editorial Note, Transnational Dispute Management (TDM), 04.2005, available at: https://www.transnational-dispute-management.com/article.asp?key=399, last visited on 06.08.2020.

901 Jürgen Kurtz, Building Legitimacy Through Interpretation in Investor-State Arbitration: On Consistency, Coherence, and the Identification of Applicable Law, at: Zachary Douglas \& Joost Pauwelyn \& Jorge Vinuales (eds.), The Foundations of International Investment Law: Bridging Theory Into Practice, Oxford University Press, 2014, p. 281.

902 For example, the 2012 US Model BIT already introduced a provision envisaging the establishment of an appeal mechanism. See: the US Model BIT (2012), Art. 28.10. In 2014, the ICSID secretariats also discussed a potential appeal system. See: ICSID Secretariat, Possible Improvements of the Framework for ICSID Arbitration, International Centre for Settlement of Investment Disputes (ICSID), 26.10.2014, available at: $\mathrm{http}$ ://icsid.worldbank.org/news-and-events/news-releases/possible-improvements-framework-icsid-arbitration, last visited on 05.08.2020. Similarly, UNCTAD's World investment Report 2015 suggested an appeal mechanism for international investment. See: United Nations Conference on Trade and Development (UNCTAD), World Investment Report 2015: Reforming International Investment Governance, 2015, available at: http://unctad.org/en/PublicationsLibrary/wir2015_en.pdf, p. 150, last visited on 06.08.2020. At the same time, paying lip-service to the future development of an appeal mechanism has been fashionable in the IIAs concluded in recent years, which can be found in various IIAs of different states. See e.g. the China-Australia FTA (2015), Art. 9.23 . 
and referred to in each of these agreements, the final goal is to set up a multilateral twotiered ICS. ${ }^{903}$

\section{(iv) High Professional and Ethical Standards for Adjudicators}

The ICS sets clear and stringent requirements for the professional qualifications of competent professionals to serve as members of Tribunals and Appeal Tribunals respectively. In order to be a member of the Tribunal, having the qualifications required in the national state for the appointment to a judicial office or to be a jurist of recognized competence, as well as demonstrating expertise in public international law, are compulsory conditions. ${ }^{904}$ For members serving on the Appeal Tribunal, a higher requirement is set as possessing "the qualifications required in their respective countries for appointment to the highest judicial offices, or be jurists of recognized competence". 905

Furthermore, in order to avoid any unnecessary influence, members of the Tribunal and the Appeal Tribunal shall be independent, not affiliated with any government, and they are prohibited from taking on work as a legal counsel in any investment disputes. ${ }^{906}$ Finally, members of a division can be removed when their behaviour appears to be inconsistent and incompatible with continued membership. ${ }^{907}$ Such strict ethical standards are further strengthened by the fact that the ICS created its own codes of conduct for adjudicators. ${ }^{908}$ By comparing the other international standards that can be applied to investment dispute adjudicators, such as the IBA Guidelines on Conflicts of Interest in International Arbitration ${ }^{909}$ and the Chartered Institute of Arbitrators Code of Professional and Ethical Conduct for Members, ${ }^{910}$ the substantive criteria contained in the ICS codes of conduct only reaffirm the normal requirements of fairness, diligence and impartiality which can also be found elsewhere. The real innovation, or the true safeguard, lies in the binding nature of the obligations under the ICS, transforming them from soft law to enforceable norms. ${ }^{911}$ Furthermore, compared to the procedure available to challenge a suspected biased arbitrator in the domestic law of the seat of

\footnotetext{
903 CETA (2012), Art. 8.29; the EU-Singapore IPA (2018), Art. 3.12; the EU-Vietnam IPA (2018), Art. 3.41. In order to achieve this goal, the Union has identified two steps: the first one is the inclusion of the ICS in the EU's future trade and investment agreements; then, as the second step, the EU is to work towards the establishment of a multilateral investment court by replacing all the bilateral ICSs. See: European Commission, Recommendation for a Council Decision: Authorising the Opening of Negotiations for a Convention Establishing a Multilateral Court for the Settlement of Investment Disputes, COM(2017) 493 final, 13.09.2017, pp. 2-3.

904 CETA (2012), Art. 8.27(4); the EU-Singapore IPA (2018), Art. 3.9.4; the EU-Vietnam IPA (2018), Art. 3.39.7.

905 The EU-Singapore IPA (2018), Art. 3.10.4; the EU-Vietnam IPA (2018), Art. 3.39.7.

906 CETA (2012), Art. 8.30.1; the EU-Singapore IPA (2018), Art. 3.11.1; the EU-Vietnam IPA (2018), Art. 3.40.1.

907 CETA (2012), Art. 8.30 (4); the EU-Singapore IPA (2018), Art. 3.11.5; the EU-Vietnam IPA (2018), Art. 3.40.5.

908 CETA (2012), Annex 29-B; the EU-Singapore IPA (2018), Annex 11; the EU-Vietnam IPA (2018), Annex 8. In addition, CETA also requires the application of IBA Guidelines on Conflict of Interest in International Arbitration. See: CETA (2012), Art. 8.30.1.

909 International Bar Association, IBA Guidelines on Conflict of Interest in International Arbitration (adopted on 23.10.2014).

910 The Chartered Institute of Arbitrators, the Chartered Institute of Arbitrators Code of Professional and Ethical Conduct for Members (2009).

911 Before the EU's proposal, the arbitral community had attempted to solve the issue of arbitrators' independence through the adoption of a number of procedural measures, but they are not legally binding and do not provide any enforcement mechanism. In other words, they can only be applied as "soft law" and thus lack efficacy. See: Matthieu de Boisséson, La Soft Law dans l'arbitrage, Les Cahiers de l'Arbitrage, Vol. 3, 2014, p. 520.
} 
arbitration, these standards help prevent a bias developing. ${ }^{912}$ It deserves attention that the ICS in CETA (2012) passes on the important task of deciding challenges to adjudicators to a more unrelated body, the President of the ICJ. However, in the EUSingapore IPA (2018) and the EU-Vietnam IPA (2018), this was changed to be dealt with in-house. The President of the Tribunal is tasked with hearing challenges to members of the Appeal Tribunal, and the head of the Appeals Tribunal likewise hears challenges to members of the First Instance Tribunal. ${ }^{913}$

The high professional and ethical standards of adjudicators provided for in the ICS is a response to increasing doubts about the independence and impartiality of arbitrators in investment arbitration, especially the severely criticized "double-hat issue". ${ }^{114}$ In the CJEU's Opinion 1/17, independence in Tribunals is particularly addressed by confirming that CETA (2012) offers sufficient procedural guarantees to ensure this independence. ${ }^{915}$ The European Commission explained that these standards were considered to be comparable to those required for the members of permanent international courts, such as the International Court of Justice and the WTO Appellate Body. ${ }^{916}$

\section{(v) Significant Roles of Joint Committees and Investors' Home States in Investor- State Dispute Settlement}

The ICS establishes a joint committee and sets out its organization and functions in treaty texts. ${ }^{917}$ Such a joint committee is composed of representatives from each treaty party and its function relies on negotiations and cooperation between the parties. A joint committee is entitled to establish operative committees to implement a wide range of matters, ${ }^{918}$ which can extend the subject matter of the respective IIA considerably. ${ }^{919}$

During ISDS, a joint committee is competent to rule upon issues of treaty interpretation by making recommendations, which shall be binding on a Tribunal and even the starting date of such binding effect can be determined by the joint committee. ${ }^{920}$ Such an

\footnotetext{
912 Gloria Maria Alvarez et al., A Response to the Criticism Against ISDS by EFILA, Journal of International Arbitration, Vol. 33, 2016, pp. 15-17. Maria Beatrice Deli \& Maria Laura Marceddu, Is the European Commission Issuing a Dismissal Letter to Arbitrators?, Kluwer Arbitration Blog, 19.10.2015, available at: http://arbitrationblog.kluwerarbitration.com/2015/10/19/the-investment-court-system-for-ttip-is-the-europeancommission-issuing-a-death-certificate-for-arbitrators/, last visited on 04.08.2020.

913 The EU-Singapore IPA (2018), Art. 3.11.2; the EU-Vietnam IPA (2018), Art. 3.40.2.

914 This expression is used to describe the conflicts arising when a person in one investment arbitration case serves as a counsel, while serves as an arbitrator in another case that involves the same legal issue. See: Stephan W. Schill, Ordering Paradigms in international Investment Law: Bilateralism-Multilateralism-Multilateralization, at: Zachary Douglas \& Joost Pauwelyn \& Jorge E. Viñuales (eds.), The Foundations of international Investment Law: Bringing Theory into Practice, Oxford Univresity Press, 2014, p. 134.

915 Opinion 1/17 of the Court (Full Court), 30.04.2019, paras. 195-204.

916 European Commission, Reading Guide-Draft Text on Investment Protection and Investment Court System in the Transatlantic Trade and Investment Partnership, 16.09.2015, available at: http://europa.eu/rapid/pressrelease_MEMO-15-5652_en.htm, last visited on 29.07.2020.

917 CETA (2012), Chapter 26; the EU-Singapore IPA (2018), Art. 4.1; the EU-Vietnam IPA (2018), Art. 4.1.

918 For example, under CETA, nine types of committees focusing on more specific and technical issues are set forth, whose authorities are to be granted by the CETA joint committee. See: CETA (2012), Art. 26.2.

919 Andreas Fischer-Lescano (Translation into English by Elisabeth Schmalen), The Limits of EU and Constitutional Law for the Comprehensive Economic and Trade Agreement between the EU and Canada (CETA)-Legal Opinion on Behalf of attac/Munich, 10.2014, available at: https://blog.campact.de/wpcontent/uploads/2014/12/Gutachten_CETA_engl_final_27112014.pdf, last visited on 05.08.2020.

${ }^{920}$ CETA (2012), Art. 8.31.2; the EU-Singapore IPA (2018), Art. 3.13.3; the EU-Vietnam IPA (2018), Art. 3.42.5.
} 
arrangement is considered to reduce the risk of an unforeseen interpretation from adjudicators. ${ }^{921}$ It may also contribute to resolving the fragmentation of the decisions in dispute resolution, especially before the establishment of a multilateral investment court, at least for the disputes under the EU's own IIAs. ${ }^{922}$ As has been pointed out, such novelties put forward by the EU appears to be crucial to overcome the "conglomerate of global fragmented and diverging bilateral rules". ${ }^{923}$ In addition, under the EU-Singapore IPA (2018) and the EU-Vietnam IPA (2018), joint committees will meet once a year to examine difficulties in ISDS and consider possible improvements. ${ }^{924}$ Based on its assigned function, a joint committee was described as "a parallel permanent interpretive body for the interpretation in a coherent, authoritative, evolutive fashion that would be mindful of the intentions to the State parties", which "would thereby dissociate the settlement of the discrete factual dispute from the interpretive, jurisprudential function". 925

In addition to exerting an influence on ISDS through joint committees, the independent power of investors' home states has also been enhanced by directly being involved in treaty and domestic law interpretation in ISDS. Regarding the former, in a particular case, the home state can make submissions or be invited by the Tribunal to attend relevant hearings and to give submissions on the interpretation of the IIA at issue. ${ }^{926}$ As has been pointed out, a non-disputing state party has "a legitimate interest in the interpretation of the treaty to which they are a party". ${ }^{927}$ In terms of the latter, domestic law is required to be treated as "a matter of fact" and the Tribunal shall follow the prevailing interpretation given to the domestic law by the courts or authorities of that treaty party. ${ }^{928}$ Such an arrangement aims at safeguarding the autonomy of EU law, and preventing the emergence of competing jurisdictions between Tribunals in the ICS and the CJEU, as well as any risk of incompatibility stemming from contrasting interpretations by international tribunals and the EU court. ${ }^{929}$

The increased power of joint committees and investors' home states in the ICS decreases the level of delegation, showing the EU's intention for treaty parties to have

\footnotetext{
${ }^{921}$ European Commission, Concept Paper-Investment in TTIP and Beyond-the Path for Reform: Enhancing the Right to Regulate and Moving from Current Ad Hoc Arbitration towards an Investment Court, 05.05.2015, available at: http://trade.ec.europa.eu/doclib/docs/2015/may/tradoc_153408.PDF, last visited on 29.07.2020.

922 Different joint committees under various IIAs include representatives from the EU. When the EU negotiates with one of its treaty partners through a joint committee on treaty interpretation, it would bear in mind its other concluded treaties where similar provisions are contained therein.

923 Stephan W. Schill, Ordering Paradigms in international Investment Law: Bilateralism-MultilateralismMultilateralization, at: The Foundations of international Investment Law: Bringing Theory into Practice, Oxford Univresity Press, 2014, p. 141.

924 The EU-Singapore IPA (2018), Art. 4.1.3; the EU-Vietnam IPA (2018), Art. 4.1.3. The relevant provision in the CETA (2012) only states that the joint committee shall provide a forum for the treaty parties to consult on issues related to difficulties which may arise in implementation and possible improvements. See: CETA (2012), Art. 8.44.1. 925 Sophie Nappert, Escaping from Freedom? The Dilemma of an Improved ISDS Mechanism, at: European Investment Law and Arbitration Review (Volume 1), Brill | Nijhoff, 2016, p. 188.

926 CETA (2012), Art. 8.38.2; the EU-Singapore IPA (2018), Art. 3.17.1; the EU-Vietnam IPA (2018), Art. 3.51 .2

927 Anthea Roberts, Power and Persuasion in Investment Treaty Interpretation: The Dual Role of States, American Journal of International Law, Vol. 104, 2010, p. 182.

${ }_{928}$ CETA (2012), Art. 8.31(2); the EU-Singapore IPA (2018), Art. 3.13.2; the EU-Vietnam IPA (2018), Art. 3.42.3.

929 European Commission, Concept Paper-Investment in TTIP and Beyond-the Path for Reform: Enhancing the Right to Regulate and Moving from Current Ad Hoc Arbitration towards an Investment Court, 05.05.2015, available at: http://trade.ec.europa.eu/doclib/docs/2015/may/tradoc_153408.PDF, last visited on 29.07.2020.
} 
more control over ISDS. ${ }^{930}$ As a result, it appears that the Tribunal and the Appellate Tribunal, together with the joint committee, result in a triadic architecture for ISDS. Although the judicial nature of the ICS has been repeatedly stressed, after a second reading, it is clear that the diplomatically functioning joint committees play a role in decision making. This could raise concerns about letting diplomatic elements take over the judicial function of the ICS, going against the original purpose of creating an ISDS mechanism, which is to depoliticize the process.

\section{(vi) Intensified Transparency}

Another typical feature of the EU's ICS is the high level of transparency. To make proceedings more open and transparent, the ICS adopted the UNCITRAL Rules on Transparency (2014) or similar provisions, ${ }^{931}$ and even takes further steps to increase transparency to a higher level.

In the ICS, procedural transparency is mainly reflected in two ways: through the publication of documents and open hearings. ${ }^{932}$ Regarding the former, it is provided that "the request for consultations, the notice requesting a determination of the respondent, the notice of determination of the respondent, the agreement to mediate, the notice of intent to challenge a Member of the Tribunal, the decision on challenge to a Member of the Tribunal and the request for consolidation shall be included in the list of documents to be made available to the public". ${ }^{933}$ As a result, almost all documents are public. In particular, exhibits, which are excluded from the UNCITRAL Rules on Transparency, are also made public in the ICS. ${ }^{934}$ A relevant issue here is third-party funding, which refers to "any funding provided by a natural or legal person who is not a party to the dispute but who enters into an agreement with a disputing party in order to finance part or all of the cost of the proceedings either through a donation or grant,

\footnotetext{
930 Two issues, who selects adjudicators and whether there is any standing body composed of treaty parties, were argued to present the amount of delegation. See: Todd Allee \& Manfred Elsig, Dispute Settlement Provisions in PTAs: New Data and New Concepts, at: Trade Cooperation: The Purpose, Design and Effects of Preferential Trade Agreements, Cambridge University Press, 2015, pp. 341-342. The roles of the joint committee and treaty parties in the ICS were argued as possibly being inspired by the practice of the joint committee under the NAFTA. See: Shaotang Wang 王少棠, Legetimacy Crisis Resolved? Reconsideration of the EU's Reform of Investment Court System 正当性危机的解除? - 一欧盟投资争端解决机制改革再议, Studies in Law and Business 法商研究, Vol. 2, 2018, p. 165.

931 The UNCITRAL Rules on Transparency, as modified by IIAs, shall apply in connection with proceedings under the EU's ICS. See: CETA (2012), Art. 8.36.1; the EU-Vietnam IPA (2018), Art. 3.46.1. Differently, the EU-Singapore IPA did not mention the application of the UNCITRAL Transparency Rules, but drafted its own Rules on Public Access to Documents, Hearings and the Possibility of Third Persons to Make Submissions. This set of Rules provides for levels of transparency that match those of the UNCITRAL Transparency Rules, with provisions and language that are sometimes directly copied from the latter. Moreover, the UNCITRAL Secretariat is designated as a repository for the documents and information covered by the annex, playing the role it already plays under the UNCITRAL Rules on Transparency. See: the EU-Singapore IPA (2018), Annex 8. This can be the EU's concession to Singapore's lesser enthusiasm for those UNCITRAL transparency rules.

${ }^{932}$ Christian Tietje \& Freya Baetens, The Impact of Investor-State-Dispute Settlement (ISDS) in the Transatlantic Trade and Investment Partnership (Study prepared for: Minister for Foreign Trade and Development Cooperation, Ministry of Foreign Affairs, The Netherlands), 2014, available at: http://media.leidenuniv.nl/legacy/the-impact-ofinvestor-state-dispute-settlement-isds-in-the-ttip.pdf, pp. 105-109, last visited on 30.07.2020.

${ }^{933}$ CETA (2012), Art. 8.36.2. Similar provisions are also available at the EU-Singapore IPA (2018), Annex 8, Art. 1.1 and the EU-Vietnam IPA (2018), Art. 3.46.2.

${ }^{934}$ CETA (2012), Art. 8.36.3. A similar provision is also available at the EU-Vietnam IPA (2018), Art. 3.46.3. The EU-Singapore IPA (2018) does not contain such a provision.
} 
or in return for remuneration dependent on the outcome of the dispute". 935 The disputing party benefiting from third party funding shall give a notification of at least the name and address of the third party funder. ${ }^{936}$ Hearings are public, in principle, except for situations in which the Tribunal determines that there is a need to protect confidential or protected information. ${ }^{937}$ Along with enhancing transparency related to documents and hearings, the ICS also works on opening the ISDS process for the participation of third parties. Third parties are explicitly permitted to submit amicus curiae briefs, provided that the status of the entity making the submission and the nature of its interest in the proceeding are presented. ${ }^{938}$

Intensified transparency is a response to criticism against traditional investment arbitration where investor-state arbitration took place behind closed doors excluding the public and thus can be considered undemocratic. ${ }^{939}$ In fact, the European Commission had been strongly advocating for ISDS transparency since $2010 .{ }^{940}$ The approach to transparency adopted in the ICS represents the EU's assertive stance of seeking more transparent dispute settlement proceedings. This practice has shifted significantly from the prevailing practice adopted in EU Member States' BITs, and it even goes beyond what has been considered common in the procedural laws in European Member States, where similarly a state is the respondent and therefore public interest is naturally involved. ${ }^{941}$ This is also a radical step in light of the positions expressed by EU Member States during the discussions on the formulation of the UNCITRAL Rules on Transparency. ${ }^{942}$ It was explained by the European Commission that "[i]n line with the EU's approach in the WTO, the EU should ensure that investorstate dispute settlement is conducted in a transparent manner (including requests for arbitration, submissions, open hearings, amicus curiae briefs and publication of awards)". ${ }^{943}$ Therefore, it seems that, for dispute resolution in the area of international

935 CETA (2012), Art. 8.1. Similar definitions are available at the EU-Singapore IPA (2018), Art. 3.1.1 and the EUVietnam IPA (2018), Art. 3.28.

936 CETA (2012), Art. 8.26.1; the EU-Singapore IPA (2018), Art. 3.8.1. The EU-Vietnam IPA (2018) further requires the disclosure of the existence and nature of the funding arrangement, and any failure to disclose third-party funding may affect the tribunal's eventual costs order. See: the EU-Vietnam IPA (2018), Arts. 3.37.1, 3.37.3.

937 UNCITRAL Rules on Transparency (2014), Art. 6; the EU-Singapore IPA (2018), Annex 8, Art. 2.

938 UNCITRAL Rules on Transparency (2014), Art. 4; the EU-Singapore IPA (2018), Annex 9, paras. 42-44.

939 Pia Eberhardt \& Cecilia Olivet with contributions from Tyler Amos \& Nick Buxton, Profiting from Injustice: How Law Firms, Arbitrators and Financiers are Fueling an Investment Arbitration Boom, Corporate Europe Observatory and the Transnational Institute, 2012. Stephan W. Schill, International Investment Law and the Rule of Law, at: Jeffrey Lowell \& J. Christopher Thomas \& Jan van Zyl Smit (eds.), Rule of Law Symposium 2014: The Importance of the Rule of Law in Promoting Development, Singapore: Academy Publishing, 2015, pp. 81, 84.

940 Jansen N. Calamita, Dispute Settlement Transparency in Europe's Evolving Investment Treaty Policy, The Journal of World Investment \& Trade, Vol. 15, 2014, pp. 672-675.

${ }^{941}$ In this sense, in contrast, the practice of some arbitration institutions that are involved in investment arbitration, such as ICSID and the Secretariat of the ECT which normally only publishes the registration and subject of cases, was argued to be "much in tradition of European procedural laws". See: Mathias Wolkewitz, Transparency and Independence of Arbitrators in Investment Arbitration: Rule of Law Implications, European Investment Law and Arbitration Review, Vol. 1, 2016, pp. 295-296.

${ }_{942}$ It was pointed out that the formal positions submitted by EU Member States to UNCITRAL in 2010 showed that "not a single EU Member State came out in general favour of transparency" and considerable scepticism about the necessity of transparency in ISDS without consent from the disputing parties in specific cases was raised. See: Jansen N. Calamita, Dispute Settlement Transparency in Europe's Evolving Investment Treaty Policy, The Journal of World Investment \& Trade, Vol. 15, 2014, p. 672.

943 European Commission, Communication from the Commission to the Council, the European Parliament, the European Economic and Social Committee and the Committee of the Regions: Towards a Comprehensive European International Investment Policy, $\operatorname{COM}(2010) 343$ final, 07.07.2010, p. 10. 
trade and investment law, the EU intends to maintain a consistent approach towards procedural transparency; at the same time, compared to internal standards, a higher standard of transparency is preferred in international adjudication proceedings.

\section{(vii) Mechanisms for Scrutinizing Claims}

The ICS includes filters to restrict investors' access and to prevent possible abuse, including the time limits for filing a claim, a prohibition against parallel proceedings, a fast-track system for rejecting unfounded or frivolous claims, and a loser pays rule.

First, investors can only bring a claim within a limited period of time, namely three years or 30 months after the knowledge of the treatment alleged to be inconsistent with the relevant IIA and knowledge of the loss or damage alleged to have been incurred is first attained or should have been first acquired. ${ }^{944}$ Second, parallel proceedings are prohibited, in order to avoid double compensation and diverging verdicts. With respect to a measure alleged to constitute a breach of the underlying IIA, withdrawing or discontinuing any existing proceeding before a tribunal or a court under domestic or international law is provided as a precondition to bringing a claim to the ICS. ${ }^{945}$ Third, an innovative fast track system for rejecting unfounded or frivolous claims is established, through which claims manifestly without legal merit or unfounded as a matter of law can be thrown out promptly. ${ }^{946}$ Fourth, under the ICS, the losing party is supposed to pay the costs. ${ }^{947}$ The clear expression of the loser pays rule changes the current situation that a government in an investor-state arbitration case probably needs to bear at least all of its own costs, even if it is successful. ${ }^{948}$

These mechanisms for scrutinizing claims can prevent investors from abusing their rights and have a certain deterrent effect on investors causing them be more cautious about bringing a claim to the Tribunal. Furthermore, an article on security for costs can be found in the EU-Vietnam IPA (2018), ${ }^{949}$ which can also lead a potential claimant to reconsider its case and thus indirectly filter some claims.

\subsubsection{Analysis of the Investment Court System}

The innovations in the ICS have caused heated discussions on many technical and practical issues. ${ }^{950}$ Instead of summarizing the existing discussion or giving the author's own analysis of the advantages and disadvantages of various procedural arrangements, in line with the analysis in previous chapters, this section aims at

${ }_{944}$ CETA (2012), Art. 8.19.6; the EU-Singapore IPA (2018), Art. 3.3.3; the EU-Vietnam IPA (2018), Art. 3.30.2.

945 CETA (2012), Art. 8.22 (1); the EU-Singapore IPA (2018), Art. 3.7.1; the EU-Vietnam IPA (2018), Art. 3.34.1.

946 CETA (2012), Arts. 8.32, 8.33; the EU-Singapore IPA (2018), Arts. 3.14, 3.15; the EU-Vietnam IPA (2018), Arts. $3.44,3.45$.

947 CETA (2012), Art. 8.39.5; the EU-Singapore IPA (2018), Art. 3.21.1; the EU-Vietnam IPA (2018), Art. 3.53.4.

${ }^{948}$ European Commission, Investment Provisions in the EU-Canada Free Trade Agreement (CETA), 25.09.2014, available at: http://data.parliament.uk/DepositedPapers/Files/DEP20150877/Lord_Livingston_to_Sir_William_Cash_MP_05.03.15_Annex_B.PDF, p. 6, last visited on 31.07.2020.

949 The EU -Vietnam IPA (2018), Art. 3.48. Considering the fact that Vietnam's experience of struggling to collect on a trio of costs orders against unsuccessful BIT claimants and the absence of similar provisions in CETA (2012) and the EU-Singapore IPA (2018), this article may be inserted based on Vietnam's request.

950 See, e.g. Maria Beatrice Deli \& Maria Laura Marceddu, Is the European Commission Issuing a Dismissal Letter to Arbitrators?, Kluwer Arbitration Blog, 19.10.2015, available at: http://arbitrationblog.kluwerarbitration.com/2015/10/19/the-investment-court-system-for-ttip-is-the-europeancommission-issuing-a-death-certificate-for-arbitrators/, last visited on 04.08.2020. 
exploring the underlying reasons for the features identified in Section 7.3.3.2, supra, with a view to revealing the values underpinning the EU's choices.

(i) Strengthening Amicable Dispute Settlement Mechanisms as an Alternative Way to have Access to Justice

In the ICS, various treaty provisions provided for amicable DSMs, aiming at incorporating and strengthening the use of DSMs for ISDS in practice, especially mediation.

This recalls the EU's internal encouragement for using mediation in recent years. As discussed in Sections 4.3 and 4.4, supra, many internal measures have been taken by the Union, which evidenced the trend of promoting the use of amicable DSMs. The underpinnings for these measures are complex, but taking non-adjudication DSMs as an alternative way to have access to justice, which is an indispensable element of the rule of law, arguably also partly explains the EU's support of amicable mechanisms for ISDS at the international level, especially considering the fact that pursuing the rule of law is also a guiding principle in the EU's external action. ${ }^{951}$ In particular, the advantages of amicable DSMs as more cost-effective ways than resorting to international adjudication ensures that disputing parties have access to justice, and this is especially important for small and medium-sized enterprises. In conclusion, amicable DSMs complement adjudication procedures in the ICS in realizing access to justice and the international rule of law.

(ii) The Preference for a Permanent Two-tiered Court System to Enhance the Soundness of Jurisprudence

Inspired by the dissatisfaction with traditional investment arbitration, the EU's complete abandonment of arbitration and its proposal of the ICS is rather radical and innovative compared to the measures taken by other actors in this are around the world. ${ }^{952}$ Justifications for such an approach should thus go beyond simply responding to the drawbacks of arbitration.

First of all, to the EU, the reform of investment arbitration is probably not due to doubts about investors' rights to bring actions against states, since granting individuals such a right is not exceptional under EU law. On the contrary, EU law provides very similar standards under the fundamental freedoms. In particular, the CJEU did not object to the possibility of an individual bringing a complaint to the European Court of Human Rights (ECtHR) when it considered accession to the European Convention on Human Rights. ${ }^{953}$ It is important to note, however, that the procedural setting of international arbitration for resolving disputes between an investor and its host state is not typical. The CJEU is a typical judicial organ with a permanent two-tiered institution. This is

951 Laurent Pech, Rule of Law as a Guiding Principle of the European Union's External Action, Centre for the Law of EU External Relations (CLEER) Working Papers, Vol. 3, 2012.

952 Shaotang Wang 王少棠, Legetimacy Crisis Resolved? Reconsideration of the EU's Reform of Investment Court System 正当性危机的解除? - 一欧盟投资争端解决机制改革再议, Studies in Law and Business 法商研究, Vol. 2, 2018, p. 159.

953 Juliane Kokott \& Christoph Sobotta, Investment Arbitration and EU Law, Cambridge Yearbook of European Legal Studies, Vol. 18, 2016, pp. 4, 17-18. 
also the case for the ECtHR. However, investment arbitration is often carried out ad hoc with no possibility of appeal. Second, in arbitration, arbitrators are often selected by the disputing parties, and thus their independence, impartiality and professionality may not be fully guaranteed. In particular, the arbitrators that are currently active in investment cases often come from the area of commercial arbitration and thus may not pay enough attention to the special nature of the cases in which a state is involved. At the same time, they may adjudicate issues from a private law perspective, which is not suitable for international investment law. More importantly, the justification of democracy is missing when an adjudicator is selected by a private entity in ISDS. Third, under EU law, investor protection primarily relies on the judiciary of the EU Member States and the CJEU, which are linked because of the preliminary ruling procedure and enables the CJEU to give a binding interpretation of EU law. ${ }^{954}$ However, the same does not apply to international arbitration. Therefore, it is fair to say that the problem that the EU probably wanted to resolve is the entire structure of arbitration, not just certain elements of the current practice of investor-state arbitration.

As a result, it is not be completely unexpected that the EU proposed a court system for ISDS, which, as a temporary arrangement, is bilateral and intended to be multilateral as the final goal. In fact, the establishment of a permanent multilateral structure for international investment dispute settlement has been proposed by the EU for a relatively long time. As early as 1995, negotiations on a Multilateral Agreement on Investment started at the Organisation for Economic Co-operation and Development (OECD), where the EC requested the OECD "as a contribution to strengthening the multilateral system, to pursue its work aimed at elaborating a multilateral investment agreement". ${ }^{955}$ However, the negotiations were discontinued in $1998 .{ }^{956}$ Later, at the WTO Ministerial Conference in Cancun in 2003, the EC tried to put investment on the agenda, which failed again however. ${ }^{957}$ After realizing that the existing platforms were not capable of providing solutions, or at least the prospect of this was quite gloomy, the EU proposed the ICS when the time came to propose a new generation of ISDS mechanisms for its own IIAs. In addition, it should be noted that, from the perspective of its institutional

\footnotetext{
954 Id, p. 4.

955 Commission of the European Communities, A Level Playing Field for Direct Investment World-Wide, COM(95) 42 final, 01.03.1995, p. 13. Negotiations on a proposed Multilateral Agreement on Investment were launched by governments at the Annual Meeting of the OECD Council at Ministerial level in May 1995. The objective was to provide a broad multilateral framework for international investment with high standards for the liberalization of investment regimes and investment protection and with effective dispute settlement procedures. See: The Organisation for Economic Cooperation and Development (OECD), Multilateral Agreement on Investment, available https://www.oecd.org/investment/internationalinvestmentagreements/multilateralagreementoninvestment.htm, last visited on 05.08.2020.

956 The Organisation for Economic Cooperation and Development (OECD), Multilateral Agreement on Investment, available

https://www oecd org/investment/internationalinvestmentagreements/multilateralagreementoninvestment htm, visited on 05.08.2020.

957 Martin Khor, The "Singapore Issues" in the WTO: Evolution and Implications for Developing Countries, TWN Trade \& Development Series, Vol. 33, 2007, p. 15.
} 
features, the ICS goes further than the WTO Dispute Settlement System and rather resembles the EU's internal practice of the CJEU. ${ }^{958}$

Such a permanent court system can arguably ensure the development of jurisprudence and the rule of law. First, the permanent nature of the ICS would help to ensure more consistency in judgments. A court can naturally develop its jurisprudence by letting former cases have precedential effects on latter cases. Second, the high standard of specific requirements imposed on members of Tribunals and Appeal Tribunals reduce uncertainty as to the expected professional conduct of the adjudicators. It was argued that the ICS ensures that adjudicators understand their role as faithfully interpreting and applying the agreement that was concluded by the treaty parties. ${ }^{959}$ Furthermore, the predefined roster ensures the independence and democratic basis of the appointment of adjudicators. ${ }^{960}$ In addition to that, the security of tenure protects adjudicators from unnecessary influence. Third, the system's inherent high level of transparency guarantees the realization of a fair trial and due process. ${ }^{961}$ Last but not least, the inclusion of an appeal mechanism strengthens the jurisprudence of the ICS. Such an inclusion in fact is consistent with the suggestion to add investment to the WTO framework, where an Appellate Body would be available to supervise dispute resolution at the panel level. As shown by the Appellate Body in the WTO Dispute Settlement System, such an appeal mechanism could increase consistency, predictability and legitimacy. ${ }^{962}$ Although the pursuit of consistency and coherence may continue to face difficulties as long as investment law is characterized by a multitude of bilateral treaties, such an appeal structure could help to institutionalize the dispute settlement procedure, ${ }^{963}$ as well as encourage the adjudicative body to continue

\footnotetext{
958 The distinction between dispute settlement systems on institutional feature can be made between permanent tribunals such as the CJEU and the ad hoc arbitration tribunals, such as NAFTA Chapter 11 tribunals, or the combination of both, such as the WTO Dispute Settlement System. See: Yan Luo, Dispute Settlement in the Proposed East Asia Free Trade Agreement: Lessons Learned from the ASEAN, the NAFTA, and the EU, at: Lorand Bartels \& Federico Ortino (eds.), Regional Trade Agreements and the WTO Legal System, Oxford University Press, 2006, p. 431.

959 Comparing the situation where the disputing parties select the arbitrators ex post to one where the treaty parties select the adjudicators ex ante, the later was argued to help nudge states towards selecting balanced adjudicators. See: Anthea Roberts, Would a Multilateral Investment Court be Biased? Shifting to a Treaty Party Framework of Analysis, EJIL: Talk!, 28.04.2017, available at: https://www.ejiltalk.org/would-a-multilateral-investment-court-bebiased-shifting-to-a-treaty-party-framework-of-analysis/, last visited on 05.08.2020.

960 As pointed out, adjudicators are important to guarantee to jurisprudence and can safeguard the legitimacy of a system, since the effectiveness of an international tribunal depends on the quality of the individuals who sit on the bench in specific cases. See: Luis González García, Making Impossible Investor-State Reform Possible, at: Reshaping the Investor-State Dispute Settlement System: Journeys for the 21st Century, Brill | Nijhoff, 2015, p. 433. Mathias Wolkewitz, Transparency and Independence of Arbitrators in Investment Arbitration: Rule of Law Implications, European Investment Law and Arbitration Review, Vol. 1, 2016, p. 298.

${ }_{961}$ Mathias Wolkewitz, Transparency and Independence of Arbitrators in Investment Arbitration: Rule of Law Implications, European Investment Law and Arbitration Review, Vol. 1, 2016, pp. 295-296.

962 Thomas Wälde, Alternatives for Obtaining Greater Consistency in Investment Arbitration: An Appellate Institution after the WTO, Authoritative Treaty Arbitration or Mandatory Consolidation?, Transnational Dispute Management (TDM), 2005, available at: https://www.transnational-dispute-management.com/article.asp?key=421, last visited on 06.08.2020. Katia Yannaca-Small, Arbitration Under International Investment Agreements: A Guide to the Key Issues, Oxford University Press, 2010, p. 629. Anders Nilsson \& Oscar Englesson, Inconsistent Awards in Investment Treaty Arbitration: Is an Appeals Court Needed?, Journal of International Arbitration, Vol. 30, 2013, p. 576. Thomas Schultz, Against Consistency in Investment Arbitration, at: Zachary Douglas \& Joost Pauwelyn \& Jorge E. Viñuales (eds.), The Foundations of International Investment Law: Bringing Theory into Practice, Oxford University Press, 2014, pp. 5-6.

963 Doak Bishop, The Case for an Appellate Panel and its Scope of Review, 04.2005, available at: $\mathrm{https} / / / \mathrm{www}$. transnational-dispute-management.com/article.asp?key=403, p. 10, last visited on 30.07.2020.
} 
with the development of precedents and sound jurisprudence. ${ }^{964}$ At the same time, using a higher appellate body for the decision process could exert pressure on adjudicators at the lower level to bring their behaviour into alignment with the requirement of due process, which is an indispensable element of the rule of law. ${ }^{965}$ From the perspective of being a "self-contained" or "autonomous" system, the combination of a tribunal and an appeal tribunal creates a "public justice system", like those in the EU Member States' national legal systems and the EU internal practice in the CJEU. ${ }^{966}$ Therefore, it is reasonable to conclude that various procedural arrangements in the ICS could simultaneously contribute to the soundness of jurisprudence and compliance with the rule of law.

\section{(iii) Granting Treaty Parties a Significant Role to Stress the Public Law Nature of International Investment Law}

In the ICS, treaty parties are granted a significant role in ISDS. First, adjudicators within this system are to be selected by treaty parties, rather than disputing parties, which completely deprives private investors a role in the selection of adjudicators. Second, treaty parties have the power to unilaterally make submissions on treaty interpretation, and such submissions must be accepted by the adjudicators. At the same time, the states' interpretations of their domestic laws are required to be taken as fact in ISDS. In addition, the right of the joint committee to issue authoritative and binding interpretations of the IIA at issue further increases the influence of treaty parties.

Different approaches to ISDS originate in the diverse interpretations of the nature of ISDS. In this vein, the complete change from the traditional commercial arbitrationbased investor-state adjudication process to a model that is normally used in international public law indicates the understanding by the EU of ISDS as belonging to international public law, instead of international private law. The use of pre-selected adjudicators is typical evidence of this view, since such a practice can only be found in existing state-state DSMs. ${ }^{967}$ The public law understanding also explains the significant role given to the joint committee and treaty parties, as well as approaches to various detailed procedural issues, such as transparency. It arguably constitutes the theoretical foundation of the ICS. In fact, this international public law approach

\footnotetext{
964 Jaemin Lee, Introduction of an Appellate Review Mechanism for International Investment Disputes: Expected Benefits and Remaining Tasks, at: Jean E. Kalicki \& Anna Joubin-Bret (eds.), Reshaping the Investor-State Dispute Settlement System-Journeys for the 21st Century, Brill | Nijhoff, 2015, p. 481.

965 Richard L. Abel, A Comparative Theory of Dispute Institutions in Society, Law \& Society Review, Vol. 8, 1974, pp. 302-303. Howard Mann, Transparency and Consistency in International Investment Law: Can the Problems be Fixed by Tinkering?, at: Karl P. Sauvant \& Michael Chiswick-Patterson (eds.), Appeals Mechanism in International Investment Disputes, Oxford University Press, 2008, p. 214.

966 Cecilia Malmström, Proposing an Investment Court System, European Commission, 16.09.2015, available at: https://ec.europa.eu/commission/commissioners/2014-2019/malmstrom/blog/proposing-investment-courtsystem_en, last visited on 04.08.2020. Céline Lévesque, The European Union Commission Proposal for the Creation of an "Investment Court System": The $Q$ and A that the Commission Won't be Issuing, Kluwer Arbitration Blog, 06.04.2016, available at: http://arbitrationblog.kluwerarbitration.com/2016/04/06/the-european-union-commissionproposal-for-the-creation-of-an-investment-court-system-the-q-and-a-that-the-commission-wont-be-issuing/, last visited on 03.08.2020.

967 In addition to the ICJ and other international courts, the Iran-US Claims Tribunal established under the "Algiers Declaration" can be another example. The pre-selected members for adjudication refute disputing parties' rights in the appointment of the arbitrators that will hear their dispute, dismissing one of the essential features of arbitration.
} 
represents a new wave of ISDS practice in the world, moving away from a privateoriented approach to a more "State-like" public system. ${ }^{968}$

However, the corresponding radical changes to the procedural arrangements also raise reasonable concerns. For instance, adjudicators being selected by treaty parties instead of disputing parties creates the risk of appointing adjudicators for political reasons and may cause them to dismiss investors' claims. ${ }^{969}$ The joint committee's increased power to a certain extent brings state control into ISDS, or at least raises a fear of political interference. This could further result in the jurisprudence of the Tribunal being controlled by treaty parties. ${ }^{970}$ In addition, the Appeal Tribunal's "limitless" power of reviewing and remanding a dispute from the Tribunal may increase costs and result in other delayed implications ${ }^{971}$ and thus may make the use of ICS by some investors particularly difficult. Together with the established mechanisms for filtering claims, the balance between investors and host states seems to be adjusted excessively, from allegedly favouring investors now to benefitting states, deviating from the goal of building the ISDS system in a more balanced manner. ${ }^{972}$

\subsubsection{Proposing the Investment Court System in Multilateral Fora}

In addition to insisting on the ICS in IIA negotiations with third states, the EU has also promoted the ICS in multilateral fora and evidence of this can be found in the discussion in the UNCITRAL Working Group III on investor-state arbitration reform.

According to the documents submitted in preparation for the re-convention of the UNCITRAL Working Group III in April 2019, the EU stressed that the existing problems of ISDS require a systemic solution, which could be best found in a standing multilateral body, composed of a first instance and an appellate tribunal, staffed by fulltime adjudicators appointed in a carefully regulated process. ${ }^{973}$ This clearly derives from the practice in its ICS. The EU's promotion of the ICS in the ongoing UNCITRAL discussion can be taken as another attempt at establishing an international court for

\footnotetext{
968 Céline Lévesque, The European Union Commission Proposal for the Creation of an "Investment Court System": The $Q$ and $A$ that the Commission Won't be Issuing, Kluwer Arbitration Blog, 06.04.2016, available at: $\mathrm{http}: / /$ arbitrationblog.kluwerarbitration.com/2016/04/06/the-european-union-commission-proposal-for-thecreation-of-an-investment-court-system-the-q-and-a-that-the-commission-wont-be-issuing/, last visited on 03.08.2020.

969 Eduardo Zuleta, The Challenge of Creating a Standing International Investment Court, at: Reshaping the Investor-State Dispute Settlement System: Journeys for the 21st Century, 2015, p. 411. Tomáš Fecák, International Investment Agreements and EU Law, Kluwer Law International, 2016, p. 290.

970 Stephan W. Schill, The European Commission's Proposal of an '"Investment Court System" for TTIP: Stepping Stone or Stumbling Block for Multilateralizing International Investment Law?, American Society of International Law, 2016, available at: https://www.asil.org/insights/volume/20/issue/9/european-commissions-proposalinvestment-court-system-ttip-stepping, last visited on 05.08.2020.

971 Sophie Nappert, Escaping from Freedom? The Dilemma of an Improved ISDS Mechanism, at: European Investment Law and Arbitration Review (Volume 1), Brill | Nijhoff, 2016, p. 177.

972 Alex Mills, The Balancing (and Unbalancing?) of Interests in International Investment Law and Arbitration, at: Zachary Douglas \& Joost Pauwelyn \& Jorge E. Viñuales (eds.), The Foundations of International Investment LawBringing Theory into Practice, Oxford University Press, 2014, p. 437.

973 Although the EU viewed that only a two-tiered standing body could address the concerns expressed in relation to the current system, considering the difficulties in coordinating at a multilateral forum, it also envisaged an open architecture for states to opt-in for certain aspects of the standing body. See: Joel Dahlquist, As UNCITRAL InvestorState Arbitration Reform Enters Crucial Phase, We Preview Agenda for Upcoming Meeting, IAReporter, 27.03.2019, available at: https://www.iareporter.com/articles/as-uncitral-investor-state-arbitration-reform-enters-crucial-phasewe-preview-agenda-for-upcoming-meeting/, last visited on 31.07.2020.
} 
ISDS after the failure to do so in the OECD and the WTO, and it could be a concrete step further on the way to a multilateral ISDS system. The final result will be seen by the progress made at the UNCITRAL Working Group III in the near future.

\subsection{Conclusion}

The EU's approach to state-state trade and investment dispute settlement is mainly visible in three places: the DSMs in the IIAs and FTAs concluded by the EU, as well as the WTO Dispute Settlement System. After the Lisbon Treaty, the EU concluded three IIAs, CETA (2012), the EU-Singapore IPA (2018) and the EU-Vietnam IPA (2018). The state-state DSMs contained in these three agreements basically follow the design of the WTO Dispute Settlement System. In terms of the state-state DSMs laid out in the EU's FTAs, a shift from a diplomatic approach to a quasi-WTO dispute settlement panel proceedings model can be identified. By reviewing these DSMs chronologically, it is noticeable that more judicial features have been added gradually over time. No state-state cases have been brought under the EU's FTAs and IIAs, and therefore it is difficult to assess these DSMs in practice. The similarity between the DSMs in the EU's FTAs and IIAs, on the one hand, and the WTO DSU on panel proceedings, on the other, make it possible for the EU to take advantage of its successful experience in the WTO Dispute Settlement System. The EU has consistently been a frequent user of the WTO Dispute Settlement System, regarding this system as a normal tool to ensure the realization of its legitimate procedural and substantive rights. As evidenced by the relatively high success rate in dispute settlement, it is fair to say that the EU has largely been a system protector. Along with its supporting attitude towards alternative DSMs, the EU has shown a preference for the judicial characteristics of the WTO Dispute Settlement System not only by its frequent use of the system, but also from its reform proposal concerning the establishment of a permanent Panel Body and enhancing transparency. In brief, regarding state-state DSMs, adjudicative and compulsory DSMs have become the preferred choice and normal practice in the EU. ${ }^{974}$

Regarding ISDS, before 2009, it was EU Member States that enjoyed the competence to conclude IIAs with third states, and they had been quite active and productive in this area. Most of the IIAs provide for amicable DSMs, as well as arbitration for ISDS, and many cases have been brought under the latter, where EU investors were quite active in initiating investor-state arbitration but the EU/EU Member States were rarely challenged by non-EU investors. The Lisbon Treaty brought about a shift of competences in this area and, until now, three IIAs, CETA (2012), the EU-Singapore IPA (2018) and the EU-Vietnam IPA (2018) have been concluded. In these agreements,

\footnotetext{
974 This was argued as being evidence of the general trend of the evolution of DSMs in international economic law - heading towards more adjudicative and compulsory DSMs. See: Ignacio Garcia Bercero, Dispute Settlement in European Union Free Trade Agreements: Lessons Learned?, at: Regional Trade Agreements and the WTO System, Oxford University Press, 2006, p. 383. Edna Ramírez Robles, Political \& Quasi-Adjudicative Dispute Settlement Models in European Union Free Trade Agreements-Is the Quasi-adjudicative Model A Trend Or Is It Just Another Model?, World Trade Organization Economic Research and Statistics Division-Staff Working Paper ERSD-2006-09, 11.2006, available at: https://www.wto.org/english/res_e/reser_e/ersd200609_e.pdf, last visited on 05.08.2020
} 
the ground-breaking new approach to ISDS, the ICS, is consistently adopted, aiming at establishing an institution that "would address all the main issues which beset the current system". ${ }^{975}$ In the ICS, amicable DSMs, including negotiation, mediation and consultations are provided for and strengthened, acting as alternative ways to access justice. For adjudication, a standing two-tiered court-like mechanism is established with typical judicial characteristics, such as adjudicators with high qualifications, independence and impartiality, that are pre-selected by treaty parties and require great procedural transparency. At the same time, joint committees and treaty parties are granted significant roles in ISDS and available mechanisms for examining claims. This reshapes the balance between investors and states, and stresses the public law nature of international investment law. It seems clear that the ICS will be an essential element in the EU's position in its future negotiations for any prospective IIA and in multilateral fora.

The procedural designs of the DSMs in the ICS should keep the WTO Dispute Settlement System and the state-state DSMs in its FTAs and recently concluded IIAs in mind. At the same time, it deserves attention that the EU's most recent proposal on the WTO Dispute Settlement System reform, referring to strengthening the interaction between the Appellate Body and the WTO Members, resonates with its intention to strengthen the role of states in dispute settlement processes, as shown by the ICS. ${ }^{976}$ All of these points confirm the EU's persistent preference for a permanent two-tiered court-like system for dispute settlement in the area of international investment law and, more broadly, international economic law. In other words, from the proposal of a permanent Panel Body in the WTO, the gradually improved state-state DSMs in its FTAs and IIAs, to the proposal for an ICS, the EU's direction is clear and calls for building a multilateral, judicialized and permanent system that respects the international rule of law to resolve international economic disputes.

\footnotetext{
975 European Commission, A New System for Resolving Dispute between Foreign Investors and States in a Fair and Efficient Way, available at: http://trade.ec.europa.eu/doclib/docs/2017/september/tradoc_156042.pdf, last visited on 31.07.2020.

976 There are other points in the EU's WTO Dispute Settlement System reform proposal that recall those featured in its ICS, including changing the membership of the Appellate Body into a full time job; providing that "issues of law covered in the panel report and legal interpretations developed by the panel" do not include the meaning of the municipal measures.
} 


\section{Chapter 8 Comparison between China and the EU on International Investment}

\section{Dispute Settlement}

Based on the analysis in Chapters 6 and 7, this chapter compares the performance of China and the EU in international investment dispute settlement. This comparison is carried out from two perspectives. Section 8.1 focuses on the existing performance of both parties in SSDS and ISDS, evidenced by their concluded treaties, relevant cases and other measures. Section 8.2 considers the reflection of legal cultural characteristics in the performance of both parties in the field of international investment dispute settlement, in order to compare the influence of legal culture on the approaches to investment dispute settlement of China and the EU at the international level.

\subsection{Comparison between the Approaches of China and the EU to International Investment Dispute Settlement}

The approaches to international investment dispute settlement of China and the EU are reflected in two systems: SSDS and ISDS. In terms of the former, despite the different development process, recent practice by both parties similarly resulted in the adoption of a quasi-WTO dispute settlement panel proceedings model. In contrast, there is a clear divergence in the latter, where China and the EU have particularly different perceptions on the objective of ISDS and have a different focus regarding DSMs for resolving disputes between investors and states.

\subsubsection{State-State Dispute Settlement: Similar Trust in a quasi-WTO dispute settlement Panel Proceedings Model}

Both China's and the EU's most recent IIAs adopt a quasi-WTO dispute settlement panel proceedings model for state-state investment dispute settlement, although the extensiveness of the rules and detailed procedural arrangements are different. ${ }^{977}$ Such a model includes amicable and informal DSMs aiming at finding mutually satisfying solutions, as well as adjudicative and formal processes in order to resolve disputes fairly and effectively. In particular, the rules on adjudication resemble the WTO panel proceedings to a large extent, providing pre-established stages and binding decisions taken by a third authority on a legal basis. Such similar preference shown by China's and by the EU's practice presents their trust in the function of WTO Dispute Settlement System in resolving disputes between states, for not only international trade but international investment. It is also noted that at the same time, diverse arrangements of detailed procedural issues can be identified in their concluded treaties, which indicate their different preferences thereon. Take the rules on procedural transparency as an example. China has been quite cautious in requiring transparency in SSDS, so under its

\footnotetext{
977 For example, by comparing relevant articles in CETA (2012) and the China-Australia FTA (2015), it is clear that CETA (2012) covers several points that are not touched upon by the China-Australia FTA (2015) and often provides more detailed rules than the latter on the same issue.
} 
FTAs and IIAs, compared to the DSU, it either keeps the same level of transparency or retrieve to a certain extent. ${ }^{978}$ However, the EU has been a strong advocate for intensified transparency, so it moves further than the corresponding requirement contained in the DSU. ${ }^{979}$

Based on publicly available information, both China and the EU have not put their statestate DSMs in concluded IIAs or FTAs into practice, and therefore it is difficult to judge the real function of these measures. However, in this regard, the existing practice of both parties under the WTO should be illustrative, especially in terms of the treaties that have similar provisions to the DSU.

\subsubsection{Investor-State Dispute Settlement: Different Objectives and Focuses}

In contrast to the case of SSDS, where similarities can be easily identified in the recent treaties of both parties, differences have been clearly presented in the area of ISDS. Combining detailed rules on diverse procedural issues, overall, it is reasonable to conclude that China and the EU have presented different perceptions regarding the objective of ISDS, which is typically evidenced by their different concerning the various DSMs.

In China, although the acceptance of international arbitration from an early stage can be found in IIAs, the limited number of cases and the multiple amicable mechanisms for resolving investment disputes created in its domestic legal system indicate that great efforts have been made to resolve disputes with foreign investors amicably. At the same time, in its IIAs, China often requires exhausting administrative review procedures, which can further prevent disputes from being brought to international adjudication. Furthermore, under its OBOR Initiative, constructing a comprehensive system, in which amicable DSMs are expected to play a vital role, has been promoted for investment dispute settlement. Thus, China's focus in ISDS is arguably on efficient and effective dispute resolution, satisfying the needs of the disputing parties and restoring the problematic relationship to harmony. In contrast, although amicable mechanisms are also available, such as investor-state mediation, it is fair to say that the focus of the EU's ICS is on the two-tiered adjudicative mechanism with typical judicial features. Through such an adjudication process, access to justice, the development of jurisprudence and the international rule of law can be realized, which should be understood as the essential part of the ISDS's goal set by the EU.

The different perceptions of China and the EU are not absolute. In other words, many elements are being considered by both parties at the same time, including resolving specific disputes effectively and efficiently, realizing procedural and substantive justice, restoring the relationship between the disputing parties, and preserving the international rule of law. This could explain the fact that arrangements that do not align with the goal presented above also exist in the IIAs of both parties. The key difference lies in where the emphasis is. Thus, instead of one goal set against another, it is about which objective is considered primary and plays the key role.

\footnotetext{
978 For example, under the China-Australia FTA (2015), it is provided that hearings and the documents submitted to tribunals shall be confidential. See: the China-Australia FTA (2015), Annex 15-B, para. 17.

979 For example, under the EU-Vietnam IPA (2018), in SSDS, all hearings shall be open to the public unless otherwise provided. See: the EU-Vietnam IPA (2018), Art. 3.8.4.
} 


\subsection{Comparison between China and the EU on the Reflection of Legal Culture in International Investment Dispute Settlement}

Based on the exploration of the practice of China and the EU in international investment dispute settlement, this section compares the reflection of legal cultural characteristics in that practice, including the similarities and the differences in each jurisdiction.

\subsubsection{Similarities: Consistency between Internal and International Practice and Legal Culture}

The various preferences in international investment dispute settlement presented by China and by the EU, to a certain extent, resonate with their internal practice respectively. For example, China's focus on amicable settlement for ISDS points to the key role played by mediation in its domestic legal system; while for the EU, the courtlike adjudication process in the ICS can be taken as a reflection of its practice in the CJEU internally. In this sense, like internal DSMs, the practice at the international level also reflects the legal cultural characteristics of each jurisdiction. For instance, China's preference for amicable DSMs and its cautious attitude towards transparency can be read as being in line with its consistent pursuit of harmony and traditionally "saving face". Regarding the EU, it is reasonable to take the ICS as an example of its preference for resolving disputes through litigation in order to ensure the realization of due process and the rule of law.

In this regard, it deserves attention that, even when similar approaches have been adopted by both sides for international investment dispute settlement, they may be supported by various underlying motivations. A typical example is the promotion of mediation. The existing practice in China and the EU shows their similar intention to promote the use of mediation for ISDS. However, the main underpinnings are arguably different. With regard to China, the preference for mediation is that it is a tool used to resolve disputes in an amicable and mutually satisfying way, contributing to the construction of harmony. While, in the EU, promoting mediation is founded on the notion of access to justice, which is an indispensable element in the ultimate goal of the rule of law. Such differences regarding the underlying motivations can help to understand the differences in the mediation process, such as the rules on transparency and qualifications of mediators.

\subsubsection{Differences: Compromise vs. Intensification}

Along with the reflection of the legal culture of each jurisdiction in international investment dispute settlement, it should be noted that the extent of its influence is different from the influence at the internal level. In this vein, international practice unavoidably exerts an influence on shaping the practice of China and the EU on the international plane. In this sense, the case of China and that of the EU are arguably different. International practice, especially international adjudication, is far from China's traditional practice of dispute settlement. As a result, as evidenced by China's hesitation to internalize western practice and its slow acceptance of international adjudication, it is fair to say that international practice compromises and balances the 
influence from China's legal culture in the development of China's performance in international investment dispute settlement.

Compared to China, the features presented by the EU's case seem to be different. The preferences rooted in its legal culture seems to be further stressed and intensified in its international investment dispute settlement practice in many cases, a typical example of which the promotion of the ICS. This is because the current international practice of dispute settlement is primarily based on Western legal systems, where the EU is a main player. In addition, in contrast to implementing drastic measures internally, where unavoidably practical difficulties exist, the Union enjoys great freedom and often the Union's rules are also incorporated into the EU's international practice. As a result, for example, in the ICS, procedural designs that are in line with EU values and principles, but have not yet been realized internally, can be identified, such as opening all hearings in investor-state adjudication.

\subsection{Conclusion}

Comparing practice in international investment dispute settlement in China and the EU, both similarities and differences can be identified. For SSDS, both China's and the EU's most recent IIAs adopt a quasi-WTO dispute settlement panel proceedings model, although there are differences in their details. Regarding ISDS, both parties seem to have different perceptions regarding the objective of the whole system and the focus among various DSMs. China emphasises the amicable settlement of specific disputes and restoring harmonious relationships, while the EU cares more about realizing the international rule of law and developing jurisprudence through the system. Such differences should be in line with their internal practice and legal cultural characteristics, especially China's traditional preference for harmony and the EU's consistent pursuit of the rule of law. At the same time, each party's approach has been affected by its experience with international practice. In this sense, compared to China's situation, where there is more compromise and an acceptance of international practice, the preference in the EU's legal culture seems to be further stressed and intensified in its practice of international investment dispute settlement. 


\section{Part 4 Exploration of the Dispute Settlement System in the Prospective China-}

\section{EU Bilateral Investment Treaty}

\section{Introduction to Part 4}

Equipped with the knowledge of the legal cultural characteristics of dispute settlement in China and the EU and their relevant practice at the internal and international levels, the discussion in this Part explores the dispute settlement system in the prospective China-EU BIT.

This Part starts with a brief overview of the investment legal relationship between China and the EU, including its historical development, current status and, particularly, the dispute settlement systems in the existing IIAs between China and EU Member States. This constitutes the necessary basis to anticipate future developments. After that, Chapters 10-12 provide a detailed discussion on the comprehensive dispute settlement system in the prospective China-EU BIT, which is expected to be composed of two sub-systems: one for state-state dispute settlement and one for investor-state dispute settlement. Chapter 10 focuses on the former category, while the latter will be addressed in Chapter 11. Each of these two chapters covers the objective, jurisdiction and the DSMs contained in the sub-system. Instead of providing a thorough analysis of the detailed procedural designs of each mechanism or presenting possible treaty texts, the focus is on identifying the probably thorny issues that may stand in the way of a successful conclusion of the negotiations between China and the EU, and thereafter suggesting possible approaches to resolving the conflicts that may arise from their various proposals. Such an analysis is mainly based on the existing practice in both parties discussed in Part 3, supra, with due consideration for their legal cultural characteristics of dispute settlement explored in Part 2, supra, while bearing in mind the investment relationship between China and the EU, which is addressed in Chapter 8, supra. As a necessary further step, Chapter 12 assesses the relationship between the state-state and investor-state dispute settlement systems. This includes what separates them, connects them and a possible combination, with a view to ensuring these two systems function well and thus contributing to successful investment dispute resolution under the prospective China-EU BIT. 


\section{Chapter 9 The Legal Framework for China-EU Investment: Past and Present}

This Chapter provides an overview of the investment legal relationship between China and the EU, including its historical development, the current governing international legal framework and the state-state and the investor-state dispute settlement systems in the existing IIAs between China and EU Member States, with a view to providing the necessary background information to predict the future development of investment dispute settlement under a China-EU BIT.

\subsection{An Overview of the Development of the China-EU Investment Legal Relationship}

As introduced in Section 7.1, supra, before the Lisbon Treaty entered into force in 2009, the competence to conclude IIAs was shared by the Union and its Member States. As a result, both the Union and its Member States concluded treaties with China on investment. The power distribution was changed by the Lisbon Treaty to give the Union exclusive competence and thus, with respect to the prospective China-EU BIT, the negotiations have been undertaken between China and the Union.

\subsubsection{Before the Lisbon Treaty: General Agreements on Economic Cooperation and Bilateral Investment Treaties}

After the establishment of diplomatic ties between China and the EC in 1975, at an early stage, the EC-China Agreement on Trade and Economic Co-operation (1985) was concluded. Negotiations of this agreement began in 1983 and were concluded in 1985. It has four chapters, among which Chapter 2 defines various forms of economic cooperation, including investment. Specifically, Article 12 states that the two treaty parties shall agree "to promote and encourage greater and mutually beneficial investment" and undertake "to improve the existing favourable investment climate". ${ }^{980}$ It only expresses the intention for future cooperation without imposing any substantive obligation on treaty parties, and thus it has more of a symbolic rather than practical value. Nevertheless, this Agreement drew up a framework and laid down a general basis for future developments in the field of foreign investment. In fact, at the time this agreement was signed, there had been considerable EC investments in China, and seven out of ten EC Member States had signed BITs with China. ${ }^{981}$

Since then, the China-EC economic relationship has been developed by a series of actions. In 2003, China and the EC concluded a Framework Agreement for Establishing an Industrial Policy Dialogue in order to "strengthen and consolidate ties between the two Parties, promote and enhance mutual understanding and awareness of current and

\footnotetext{
980 The Agreement on Trade and Economic Co-operation between the European Community and the People's Republic of China (signed on 21.05.1985, entered into force on 22.09.1985), Art. 12.

981 Wenhua Shan, The Legal Framework of EU-China Investment Relations: A Critical Appraisal, Hart Publishing, 2005, p. 95.
} 
forthcoming policy approaches, legislation and related issues in the industrial sector". ${ }^{982}$ In the same year, both sides also launched the China-EC comprehensive strategic partnership, which deepened and broadened cooperation between the two parties in a wide range of areas, making China and the EU "highly interdependent as a result". ${ }^{983}$ This was followed by the Communication entitled "EU-China: Closer Partners, Growing Responsibilities" and a policy paper on Trade in 2006, which identified China's recent emergence as a major economic and political power. ${ }^{984}$ In 2007, negotiations were launched on a new China-EU Partnership and Cooperation Agreement, with a view to upgrading the 1985 Trade and Economic Cooperation Agreement and reflecting the full breadth and depth of the China-EU Comprehensive Strategic Partnership. The negotiations of this Agreement were regularly mentioned in subsequent joint statements of EU-China Summits, but, since 2009, there has been no further reference. ${ }^{985}$

It is noted that, alongside those general economic cooperation agreements with China, EU Member States were quite active in concluding BITs with China separately. Up to now, 26 BITs have been concluded and entered into force between China and $27 \mathrm{EU}$ Member States. ${ }^{986}$ These investment treaties contain more concrete provisions covering both substantive and procedural issues, including DSMs. They constitute an important part of the international legal framework governing the investment relationship between China and the EU, ${ }^{987}$ which are analysed in Section 9.3, infra.

\footnotetext{
982 According to this Framework Agreement, both sides aim to "contribute to the improvement of the competitiveness of businesses from both sides, by ensuring a business-friendly level playing field for industry operators". See: Framework Agreement Establishing Industrial Policy Dialogue between the Commission of the European Community and the Government of the People's Republic of China (signed on 30.10.2003).

983 Delegation of the European Union to China, EU-China 2020 Strategic Agenda for Cooperation, 23.11.2013, available at: https://eeas.europa.eu/delegations/china_en/15398/EUChina\%202020\%20Strategic\%20Agenda\%20for\%20Cooperation, p. 2, last visited on 04.08.2020. A more critical perspective was provided by Maher who argued that a more comprehensive partnership, beyond trade and investment, failed to materialize due to diverging values and interests. See: Richard Maher, The Elusive EU-China Strategic Partnership, International Affairs, Vol. 92, 2016.

984 Commission of the European Communities, Communication from the Commission to the Council and the European Parliament-EU-China: Closer Partners, Growing Responsibilities, COM(2006) 632 final, 24.10.2006, p. 2. Commission of the European Communities, Commission Working Document-Accompanying COM(2006) 631 Final: Closer Parterner, Growing Responsibilities-A Policy Paper on EU-China Trade and Investment: Competition and Partnership, $\operatorname{COM}(2006) 632$ final, 24.10.2006.

985 Since 2011, the negotiations of the new China-EU Partnership and Cooperation Agreement had been stalled due to divergences between the mandates and expectations of China and those of the EU. See: Chien-Huei $\mathrm{Wu}$, Reclaiming the Comprehensive Strategic Partnership Through the EU-China Partnership and Cooperation Agreement: Taking Stock and Moving Forward, at: Julien Chaisse (ed.), Sixty Years of European Integration and Global Power Shifts: Perceptions, Interactions and Lessons, Hart Publishing, 2020. European Commission, Overview of FTA and Other Trade Negotiations (Updated March 2018), available at: http://trade.ec.europa.eu/doclib/docs/2006/december/tradoc_118238.pdf, pp. 9-10, last visited on 27.05.2020.

986 The only EU Member State that has not concluded an IIA with China is Ireland. In addition, since Belgium and Luxembourg jointly signed one BIT with China, there are 27 EU Member States but only 26 BITs.

987 It is noted that there are other agreements between China and the EU in the pre-Lisbon period, such as the Textile Agreement. However, these agreements only focus on specific sectors or certain aspects of foreign investment, and are of quite limited relevance to the analysis of the DSMs in the prospective China-EU BIT. Therefore, they are not discussed in the present thesis. More discussion on these agreements can be found in: Wenhua Shan, The Legal Framework of EU-China Investment Relations: A Critical Appraisal, Hart Publishing, 2005, p. 93.
} 


\subsubsection{After the Lisbon Treaty: Heading towards a China-EU Bilateral Investment Treaty}

Concrete signs of a China-EU BIT date back to 2010. In the context of an Executiveto-Executive meeting in April 2010, European Commission President Manuel Barroso and then-Chinese Premier Wen Jiabao instructed their respective teams to study the options for enhancing the bilateral investment relationship between China and the EU. To this end, the considerations of a standalone China-EU BIT were expressly put forward with the "Joint EU-China Investment Task Force" for a deeper cooperation on investment. $^{988}$

In this context, the European Commission launched a broad public consultation in 2011 to gather views from stakeholders regarding the future EU-China investment relationship. ${ }^{989}$ The result revealed that China was regarded as one of the most strategic destinations for foreign direct investment by European companies - both at present and in the future, despite the fact that 80 per cent of the respondents pointed out a lack of transparency and consistency and the influence from political pressure in China's legal system. ${ }^{990}$ Thus, an investment agreement between China and the EU was strongly supported by the responses, especially because of its potential to increase the "clarity and predictability of the investment environment in China and the implementation of laws and commitments". ${ }^{991}$ In terms of investment DSMs, investor-state arbitration was seen by EU investors as a last resort, fearing a deterioration of their relationship with the Chinese government and illegal retaliatory actions by the government. ${ }^{992}$ When there is an investment-related dispute, the majority of the respondents mostly rely on amicable settlement.

In 2012, the prospect of negotiating an investment treaty between China and the EU became clearer. At the $14^{\text {th }}$ EU-China Summit in February 2012, leaders of both sides emphasized that a China-EU BIT "would promote and facilitate investment in both

\footnotetext{
988 European Commission, Communication from the Commission to the Council, the European Parliament, the European Economic and Social Committee and the Committee of the Regions: Towards a Comprehensive European

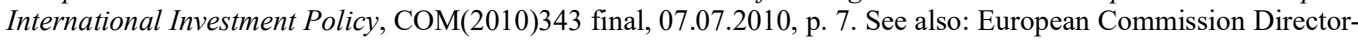
General for Trade, Consultation on the Future Investment Relationship between EU and China, 02.05.2011, available at: http://trade.ec.europa.eu/doclib/press/index.cfm?id=900, last visited on 27.05.2020.

989 This public consultation was open to all stakeholders both within the EU and in third states, running from 5 May to 5 July 2011 through an on-line questionnaire. The questionnaire mainly covered three topics: investment environment in China, investment environment in the EU, and the potential impacts of an EU-China investment agreement. In all, 57 answers were received from a wide range of respondents, including private companies, trade associations, trade union, governmental authorities, and NGOs. For more information, see: European CommissionDirector-General for Trade, Summary of Contributions to the European Commission's Public Consultation on "The Future Investment Relationship Between the EU and China", 2011, available at: http://trade.ec.europa.eu/doclib/docs/2011/december/tradoc_148394.pdf, last visited on 29.05.2020. European Commission, Recommendation for a Council Decision: Authorising the Opening of Negotiations for a Convention Establishing a Multilateral Court for the Settlement of Investment Disputes, COM(2017) 493 final, 13.09.2017, p. 3. The result of this public consultation resonates with those of some business surveys. See e.g. European Chamber of Commerce in China (EUCCC), Business Confidence Survey 2011.

990 European Commission-Director-General for Trade, Summary of Contributions to the European Commission's Public Consultation on "The Future Investment Relationship Between the EU and China", 2011, available at: http://trade.ec.europa.eu/doclib/docs/2011/december/tradoc_148394.pdf, last visited on 29.05.2020.

991 Id, p. 16.

992 Most of the respondents indicated that they would consider starting investment arbitration proceedings against China only in the case of complete expropriation. See: id, pp. 3-4.
} 
directions" and "[n]egotiations towards this agreement would include all issues of interest to either side". ${ }^{993}$ Later during the $15^{\text {th }}$ EU-China Summit in September 2012, the commitment to launch negotiations of a China-EU BIT was reconfirmed by both sides. ${ }^{994}$

The process towards a China-EU BIT accelerated in 2013. On 18 October 2013, the European Council authorized the European Commission to initiate negotiations for a comprehensive investment agreement with China. ${ }^{995}$ Negotiations for a China-EU BIT were formally launched at the $16^{\text {th }}$ EU-China Summit of 21 November 2013 in Beijing. Furthermore, both sides jointly adopted the EU-China 2020 Strategic Agenda for Cooperation, where an investment agreement was made central to the EU's long-term bilateral relationship with China. ${ }^{996}$ In fact, this was the first investment treaty that the Union started to negotiate after the Lisbon Treaty, ${ }^{997}$ which would replace the 26 existing BITs between EU Member States and China with one single comprehensive investment agreement and constitute "an opportune moment to set in place a uniform legal framework regulating investment protection in their respective territories". ${ }^{998}$

After the official initiation of negotiations, China and the EU have made concerted efforts in moving forward. In 2016, China and the EU negotiators reached clear conclusions on an ambitious and comprehensive scope for the prospective China-EU BIT and established a joint negotiating text. ${ }^{999}$ In the same year, the Council of the European Union released the "EU Strategy on China", which particularly expressed that the EU's engagement with China would stay true to its values and interests, and that the EU expects China "to assume responsibilities in line with its global impact and support the rules-based international order from which it, too, benefits". ${ }^{1000}$ On 16 July 2018, the EU and China held the $20^{\text {th }}$ summit in Beijing, where both sides agreed on a joint statement. In terms of investment, they committed to forging synergies between China's OBOR Initiative and the EU's Investment Plan and extended Trans-European

993 Leopoldo Rubinacci, EU-China Investment Relationship-Update on State of Play, DG TRADE Civil Society Dialogue, 07.03.2012.

994 European Commission, Commission Proposes to Open Negotiations for an Investment Agreement with China, Press Release, 23.05.2013, available at http://europa.eu/rapid/press-release_IP-13-458_en.htm, last visited on 05.08.2020.

995 European Commission, Overview of FTA and Other Trade Negotiations (Updated March 2018), available at: http://trade.ec.europa.eu/doclib/docs/2006/december/tradoc_118238.pdf, p. 9, last visited on 27.05.2020. This was based on the request of the European Commission on 23 May 2013 for a negotiating mandate to open official talks with China on a stand-alone BIT. See: European Commission, Commission Proposes to Open Negotiations for an Investment Agreement with China, Press Release, 23.05.2013, available at http://europa.eu/rapid/press-release_IP13-458_en.htm, last visited on 05.08.2020.

996 Delegation of the European Union to China, EU-China 2020 Strategic Agenda for Cooperation, 23.11.2013, available at: https://eeas.europa.eu/delegations/china_en/15398/EUChina\%202020\%20Strategic\%20Agenda\%20for\%20Cooperation, p. 5, last visited on 04.08.2020.

997 Marc Bungenberg \& Catharine Titi, The Evolution of EU Investment Law and the Future of EU-China Investment Relations, at: China and International Investment Law: Twenty Years of ICSID Membership, Brill | Nijhoff, 2015, pp. 297-298.

998 Id, p. 297.

999 This was described as "a major step forward in the EU-China talks launched at the end of 2013 and a direct response to the political commitment made by European and Chinese leaders at the June 2015 EU-China Summit". See: European Commission, EU and China Agree on Scope of the Future Investment Deal, 15.01.2016, available at: http://trade.ec.europa.eu/doclib/press/index.cfm?id=1435, last visited on 31.07.2020.

1000 Council of the European Union, EU Strategy on China-Council Conclusions (18 July 2016), 11319/16, 18.07.2016. 
Transport Networks. ${ }^{1001}$ In particular, the ongoing investment agreement negotiations were viewed as a "top priority and a key project towards establishing and maintaining an open, predictable, fair and transparent business environment for their respective investors". ${ }^{1002}$ According to the report of the $20^{\text {th }}$ round of negotiations for a ChinaEU BIT, which took place in February 2019, on ISDS, some progress was made "with some important policy discussions to follow", and on SSDS, relevant works "will need to be accelerated". ${ }^{1003}$ In the latest $28^{\text {th }}$ round of negotiations, it was reported that "[d]ecisive progress was made in the chapter on State-to-State Dispute Settlement". ${ }^{1004}$

\subsection{The Current International Legal Framework for the China-EU Investment Relationship}

The current legal framework regulating the investment relationship between China and the EU comprises both internal and international legal systems. The former involves China's domestic legal system and the EU's internal legal system, which is composed of EU law and EU Member States' domestic legal systems. These systems cover both substantive and procedural foreign investment related issues, including investment DSMs, which were introduced and analysed in Sections 3.2, 4.2 and 4.3, supra.

In addition to general international law, ${ }^{1005}$ more relevant rules of international law for the present analysis can be found in two groups of international agreements. First, as introduced in Section 9.1.1, supra, the 26 BITs between China and EU Member States constitute the main part of the legal framework regulating the investment relationship. Second, there are multilateral agreements to which China and the Union and/or EU Member States are contracting parties. These two groups are discussed in the following Section 9.2.1 and Section 9.2.2 respectively.

\subsubsection{Bilateral Investment Treaties between China and EU Member States}

Since the first BIT between China and an EU Member State was concluded in 1982, 26 BITs have been negotiated and came into force. TABLE 9.2.1 provides information on the conclusion and amendment of these BITs.

\footnotetext{
1001 Delegation of the European Union to China, Joint Statement of the 20th EU-China Summit, Press Release, 17.07.2018, available

https://eeas.europa.eu/delegations/china_en/48424/Joint\%20statement $\% 20$ of $\% 20$ the $\% 2020$ th\%20EUChina\%20Summit, last visited on 03.08.2020.

1002 Id, p. 3, para. 13.

1003 European Commission-Director-General for Trade, Report of the 20th Round of Negotiations for the EU-China

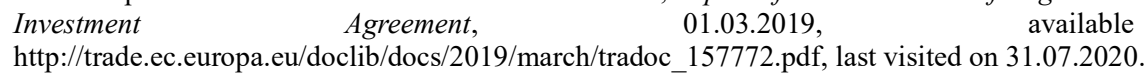

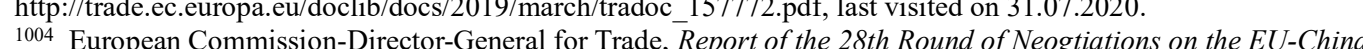
Comprehensive Agreement on Investment, 27.04.2020, available at: https://trade.ec.europa.eu/doclib/docs/2020/april/tradoc_158727.pdf, last visited on 01.08.2020.

${ }_{1005}$ The Statute of the International Court of Justice identifies five sources of international law: (a) treaties between States; (b) customary international law derived from the practice of States; (c) general principles of law recognized by civilized nations; and, as subsidiary means for the determination of rules of international law: (d) judicial decisions and the writings of the most highly qualified publicists. See: the Statute of the International Court of Justice, Art. 38.
} 
TABLE 9.2.1 The BITs between China and EU Member States ${ }^{1006}$

\begin{tabular}{|c|c|c|}
\hline No & EU Member States & Status \\
\hline 1 & Sweden & $\begin{array}{l}\text { Signed on } 29.03 .1982 \text {, entered into force on } 29.03 .1982 \text {, } \\
\text { amendment protocol signed on } 27.09 .2004\end{array}$ \\
\hline \multirow[t]{2}{*}{2} & Germany (terminated) & Signed on 07.10 .1983 , entered into force on 18.03 .1985 \\
\hline & Germany & Resigned on 01.12 .2003 , entered into force on 11.11 .2005 \\
\hline \multirow[t]{2}{*}{3} & France (terminated) & Signed on 30.05 .1984 , entered into force on 19.03 .1985 \\
\hline & France & Resigned in 26.11 .2007 , entered into force on 20.08 .2010 \\
\hline \multirow[t]{2}{*}{4} & $\begin{array}{l}\text { BLEU (Belgium-Luxembourg } \\
\text { Economic Union) (terminated) }\end{array}$ & Signed on 04.06 .1984 , entered into force on 05.10 .1986 \\
\hline & $\begin{array}{l}\text { BLEU (Belgium-Luxembourg } \\
\text { Economic Union) }\end{array}$ & Resigned on 06.06 .2005 , entered into force on 01.12 .2009 \\
\hline \multirow[t]{2}{*}{5} & Finland (terminated) & Signed on 04.09 .1984 , entered into force on 26.01 .1986 \\
\hline & Finland & Resigned on 15.11 .2004 , entered into force on 15.11 .2006 \\
\hline 6 & Italy & Signed on 28.01 .1985$, entered into force on 28.08 .1987 \\
\hline 7 & Denmark & Signed on 29.04.1985, entered into force on 29.04.1985 \\
\hline \multirow[t]{2}{*}{8} & The Netherlands (terminated) & Signed on 17.06 .1985$, entered into force on 01.02 .1987 \\
\hline & The Netherlands & Resigned on 26.11 .2001 , entered into force on 01.08 .2004 \\
\hline 9 & Austria & Signed on 12.09 .1985 , entered into force on 11.10 .1986 \\
\hline 10 & United Kingdom & Signed in 15.05 .1986$, entered into force on 15.05 .1986 \\
\hline 11 & Poland & Signed on 07.06.1988, entered into force on 08.01.1989 \\
\hline 12 & Bulgaria & $\begin{array}{l}\text { Signed on } 27.06 .1989 \text {, entered into force on } 21.08 .1994 \text {, } \\
\text { amendment protocol signed on } 26.06 .2007 \text {, entered into } \\
\text { force on } 10.11 .2007\end{array}$ \\
\hline 13 & Hungary & Signed on 29.05.1991, entered into force on 01.04 .1993 \\
\hline 14 & Slovakia & $\begin{array}{l}\text { Signed on } 04.12 .1991 \text {, entered into force on } 01.12 .1992 \text {, } \\
\text { amendment protocol signed on } 07.12 .2005 \text {, entered into } \\
\text { force on } 25.05 .2007\end{array}$ \\
\hline \multirow[t]{2}{*}{15} & Portugal (terminated) & Signed on 03.02.1992, entered into force on 01.12.1992 \\
\hline & Portugal & Resigned on 09.12.2005, entered into force on 26.07.2008 \\
\hline \multirow[t]{2}{*}{16} & Spain (terminated) & Signed on 06.02.1992, entered into force on 01.05 .1993 \\
\hline & Spain & Resigned on 14.11.2005, entered into force on 01.07 .2008 \\
\hline 17 & Greece & Signed on 25.06.1992, entered into force on 21.12.1993 \\
\hline 18 & Croatia & Signed on 07.06.1993, entered into force on 01.07.1994 \\
\hline 19 & Estonia & Signed on 02.09 .1993 , entered into force on 01.06 .1994 \\
\hline 20 & Slovenia & Signed on 13.09.1993, entered into force on 01.01 .1995 \\
\hline 21 & Lithuania & Signed on 08.11 .1993$, entered into force on 01.06 .1994 \\
\hline 22 & Romania & $\begin{array}{l}\text { Signed on 12.07.1994, entered into force on } 01.09 .1995 \text {; } \\
\text { amendment protocol signed on } 16.04 .2007 \text {, entered into } \\
\text { force on } 01.09 .2008\end{array}$ \\
\hline 23 & Cyprus & Signed on 15.01.2001, entered into force on 29.04.2002 \\
\hline 24 & Latvia & Signed on 15.04.2004, entered into force on 01.02.2006 \\
\hline \multirow[t]{2}{*}{25} & Czech Republic (terminated) & Signed on 04.12.1991, entered into force on 01.12.1992 \\
\hline & Czech Republic & Signed on 08.12.2005, entered into force on 01.09.2006 \\
\hline 26 & Malta & Signed on 22.02.2009, entered into force on 01.04.2009 \\
\hline
\end{tabular}

As mentioned in Section 7.3.2.2, supra, EU Regulation 1219/2012 establishes a transitional regime for the existing BITs concluded by EU Member States with third

1006 These BITs are listed according to the chronological sequence of their first signing dates. The information contained in this chart comes from: UNCTAD, International Investment Agreements Navigator_China, available at: https://investmentpolicy.unctad.org/international-investment-agreements/countries/42/china, last visited on 26.05.2020. The information here has been cross-checked with the information published on the official website of the Ministry of Commerce of the People's Republic of China (MOFCOM), see: Ministry of Commerce of the People's Republic of China-Department of Treaty and Law 中华人民共和国商务部条约法律司, The List of Bilateral Investment Treaties Concluded by China 我国对外签订双边投资协定一览表, 12.12.2016, available at: http://tfs.mofcom.gov.cn/article/Nocategory/201111/20111107819474.shtml, last visited on 04.08.2020. 
states, which also applies to those concluded with China. As a result, these 26 BITs will remain in force until a China-EU BIT comes into force, which means the latter "would streamline the existing bilateral investment protection agreements between China and most EU Member States into a single, coherent text". ${ }^{1007}$

\subsubsection{Other Applicable Multilateral International Agreements}

Alongside the BITs between China and EU Member States, there are multilateral international agreements to which China and the Union and/or EU Member States are contracting parties and thus also regulate the China-EU investment relationship. These mainly include the Convention on the Settlement of Investment Disputes between States and Nationals of Other States (the ICSID Convention), the Convention Establishing the Multilateral Investment Guarantee Agency (MIGA), as well as the General Agreement on Trade in Services (GATS), and the Agreement on Trade-related Investment Measures (TRIMs) under the WTO. ${ }^{1008}$ Considering the subject of the present thesis, the ICSID Convention is of more relevance.

As introduced in Section 2.2.2.2, supra, the ICSID Convention entered into force on 14 October 1966 and is ratified by 163 contracting states. ${ }^{1009}$ It does not set up a permanent body of judges or panel members to decide cases, as known in the context of the ICJ or the WTO Appellate Body, but it simply sets out the rules for resolving the disputes without providing substantive rights and obligations. Among other matters, this Convention establishes jurisdiction of the ICSID, authorizes conciliation and arbitration, as well as sets up an international institution, the International Centre for Settlement of Investment Disputes (ICSID), being available to administer investor-state and state-state disputes under IIAs, FTAs, investment laws and contracts. Until now, ICSID has become the world's leading institution devoted to international investment dispute settlement. ${ }^{1010}$

Due to the great number of investor-state arbitration cases brought to ICSID, the ICSID arbitration rules have been resorted to many times. This set of rules was adopted on 25 September 1967 and came into effect as of 1 January 1968, after which it was subsequently amended three times. In brief, under ICSID Arbitration Rules, the arbitration process starts with a request for arbitration by one disputing party. After going through screening and the registration of the request, arbitrators are appointed. Thereafter, there is both a written procedure and oral procedure and normally an award

1007 European Commission, Commission Proposes to Open Negotiations for an Investment Agreement with China, Press Release, 23.05.2013, available at http://europa.eu/rapid/press-release_IP-13-458_en.htm, last visited on 05.08.2020.

1008 Wenhua Shan, The Legal Framework of EU-China Investment Relations: A Critical Appraisal, Hart Publishing, 2005, pp. 96-104.

1009 International Centre for Settlement of Investment Disputes (ICSID), ICSID Convention, available at: https://icsid.worldbank.org/en/Pages/icsiddocs/ICSID-Convention.aspx, last visited on 03.08.2020. It has entered into force to China and all EU Member States.

1010 International Centre for Settlement of Investment Disputes (ICSID), Special Features of ICSID, available at: https://icsid.worldbank.org/en/Pages/about/Special-20Features-20of-20ICSID.aspx, last visited on 03.08.2020. Nathalie Bernasconi-Osterwalder, State-State Dispute Settlement in Investment Treaties, 10.2014, available at: https://www.iisd.org/sites/default/files/publications/best-practices-state-state-dispute-settlement-investmenttreaties.pdf, p. 17, last visited on 30.07.2020. 
is granted after the tribunal's deliberations. ${ }^{1011}$ Against the background of ISDS crisis, the past decades witnessed some development of ICSID arbitration practice, such as enhancing transparency and increasing efficiency.

In the IIAs concluded by China, EU Member States and the EU, ICSID arbitration and conciliation regularly appear as options for ISDS. China and most EU Member States as well as their investors also have experience in ICSID cases. In the latest ongoing amendment to the ICSID rules, China, EU Member States and the Union have participated actively, which proves the significance of these rules to them. ${ }^{1012}$

\subsection{The Dispute Settlement Systems in the Bilateral Investment Treaties between China and EU Member States}

Two groups of DSMs can be identified in the investment dispute settlement systems contained in the existing BITs between China and EU Member States: one for statestate disputes and one for investor-state disputes. In general, state-state DSMs exist in all the IIAs between China and EU Member States, while investor-state DSMs began to appear at a later stage. ${ }^{1013}$ These two categories are discussed respectively as follows.

\subsubsection{The State-State Dispute Settlement Mechanisms in the Bilateral Investment Treaties between China and EU Member States}

The procedural design of the state-state DSMs in the BITs between China and EU Member States have many similarities. For a comprehensive list of the provisions on state-state DSMs in these BITs, see TABLE 9.3.1.

The process to resolve disputes concerning the interpretation and application of provisions in these BITs between treaty parties starts with compulsory consultations through diplomatic channels. A six-month block of time for consultations is very often provided with variations. ${ }^{1014}$ If parties fail to settle the dispute through consultations, upon the request of either party, the dispute can be submitted to an ad hoc arbitral tribunal. It is noticeable that, in the BITs between China and Belgian-Luxembourg Economic Union, another try is required for amicable settlement before the joint committee consisting of representatives of treaty parties, as a precondition to submitting any dispute to international arbitration. ${ }^{1015}$

\footnotetext{
1011 For more information on ICSID arbitration, see: Meg Kinnear \& Geraldine R. Fischer \& Jara Minguez Almeida \& Luisa Fernanda Torres \& Mairée Uran Bidegain (eds.), Building International Investment Law: The First 50 Years of ICSID, Wolters Kluwer, 2015.

${ }^{1012}$ For the comments by China, the EU Member States and the EU on the proposed amendments to the ICSID rules, see: International Centre for Settlement of Investment Disputes (ICSID), State Input, available at: https://icsid.worldbank.org/en/amendments/state-input, last visited on 03.08.2020.

1013 The first BIT between China and an EU Member State which incorporated an investor-state DSM is the ChinaFrance BIT (1984-terminated).

1014 For example, the China-Denmark BIT (1985) provides for five months and the China-Netherlands BIT (1987) stipulates a reasonable lapse of time. There are also BITs which did not provide any minimum time requirement, such as the China-Sweden BIT (1982) and the China-United Kingdom BIT (1986).

1015 This extra precondition was incorporated into the China-BLEU BIT (1984-terminated) and the China-BLEU BIT (2005). See: the China-BLEU BIT (1984), Art. 12.1; the China-BLEU BIT (2005), Art. 9.2.
} 
Regarding the composition of an ad hoc tribunal, each party chooses its own arbitrator and the chairman, who is a national of a third state which has diplomatic relations with the two treaty parties, is to be selected by the two appointed arbitrators. It is noted that three BITs, two have been terminated and one is still in force, require the treaty parties' approval of the selection of the chairman. ${ }^{1016}$ If any position within the tribunal is not filled after the designated time limits, either party may invite the Secretary-General of the United Nations or the President of the International Court of Justice to make an appointment. ${ }^{1017}$ Tribunals enjoy general discretion over arbitration procedures. In each case, the tribunal is required to reach its award based on the provisions of the disputed IIA and principles of international law. Some IIAs further limit "principles of international law" to those "recognized by both contracting parties". ${ }^{1018}$ In decision making, a majority vote is required within the tribunal and the final award shall be final and binding upon disputing parties. Each party bears the cost of its appointed arbitrator and representation in arbitral proceedings. The cost of the chairman and the remaining costs are to be borne in equal parts by the disputing parties. Under some IIAs, tribunals are given broader discretion to change the rule on the equal allocation of costs. ${ }^{1019}$ No provision is provided for the implementation of awards.

In brief, for state-state disputes, the IIAs concluded between China and EU Member States provide for both amicable DSMs and ad hoc arbitration, with the former being a precondition to resorting to the latter. At the same time, rules are provided for certain procedural issues in ad hoc arbitration, such as the composition of tribunals, arbitration procedures, decision making, effect of arbitral awards, and allocation of costs. There are essential similarities among these IIAs, which are further in line with the general structure and some details in China Model BITs. In fact, such similarities can also be found in the BITs concluded by China or by EU Member States with third states. This is probably due to the preference for sticking to existing practices and the lack of real use of such DSMs in practice, and thus treaty parties did not take efforts to customize or reform what had already existed in their BITs.

\footnotetext{
1016 These three BITs are the China-Germany BIT (1983-terminated), the China-France BIT (1984-terminated) and the China-France BIT (2007).

1017 The BITs where the Secretary-General of the United Nations is used as the appointing authority are some old BITs that were terminated, with one exception, which include the China-Sweden BIT (1982-terminated), the ChinaGermany BIT (1983-terminated), the China-France BIT (1984-terminated), and the China-France BIT (2007).

${ }_{1018}$ For instance, the China-Bulgaria BIT (1989), Art. 8.5; the China-BLEU BIT (2005), Art. 9.3.

1019 The China-Lithuania BIT (1993), Art. 7.7; the China-Finland BIT (2004), Art. 8.7; the China-France BIT (2007), Art. 10.6.
} 


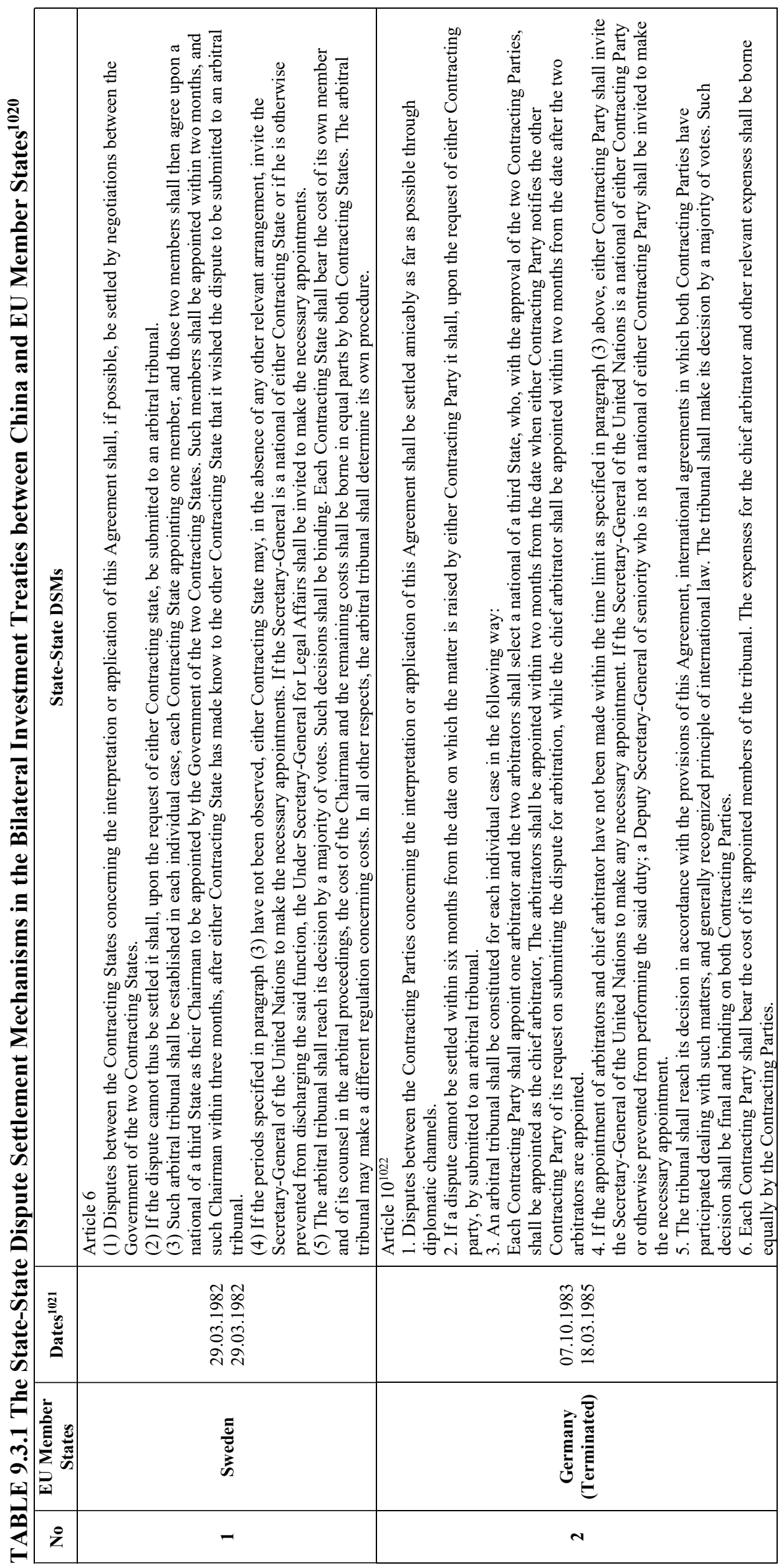

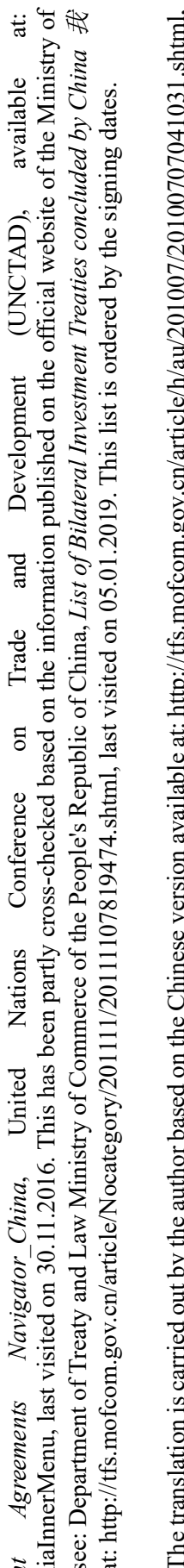

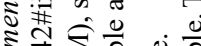

竞

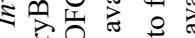

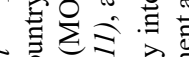

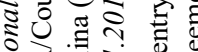

寻艺范

क्षे

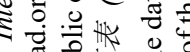

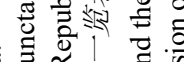

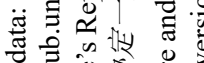

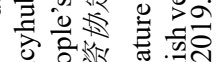

प응 可

盯败

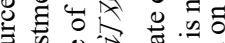

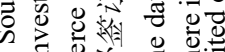

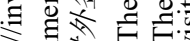

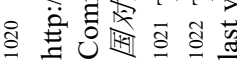




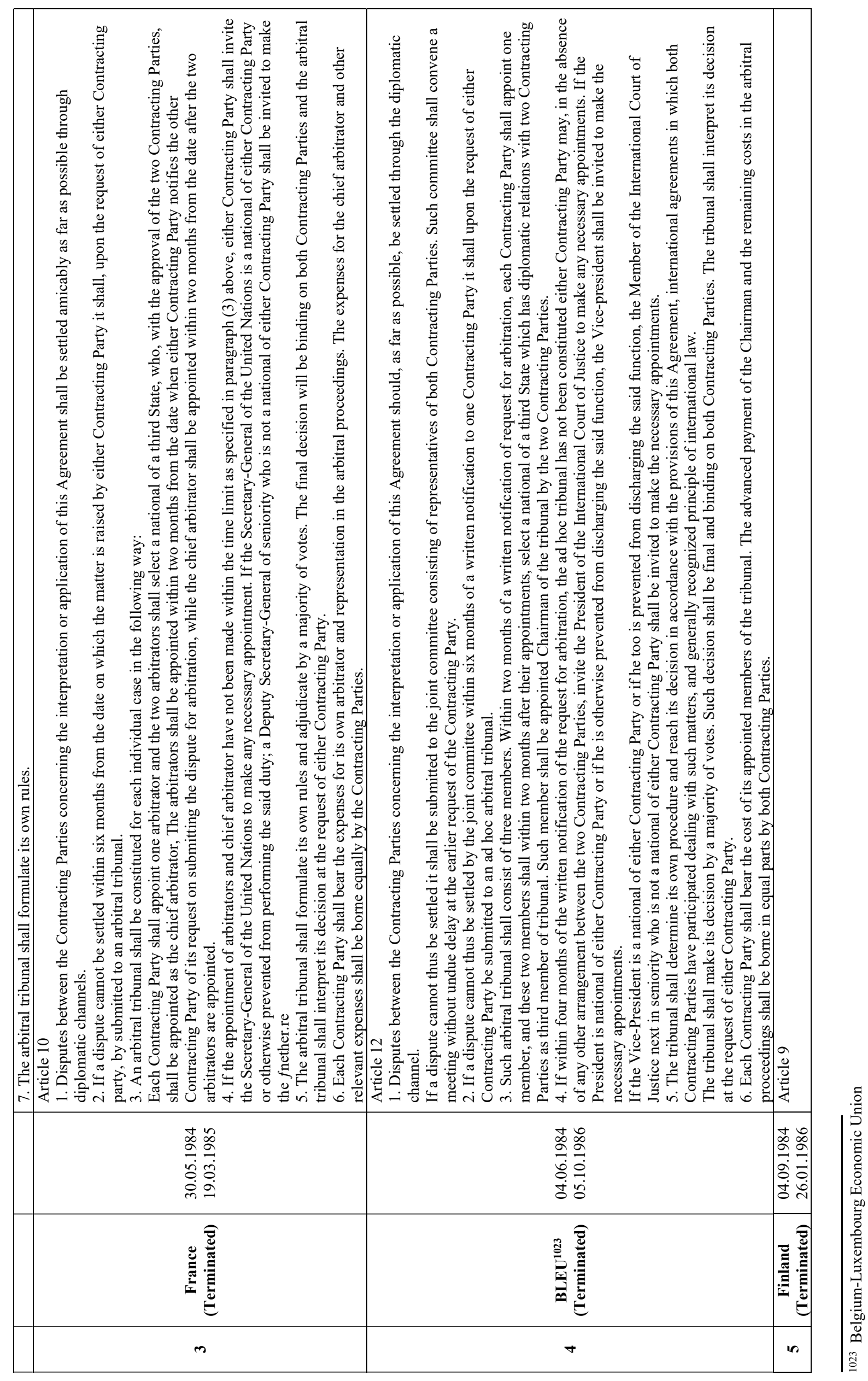




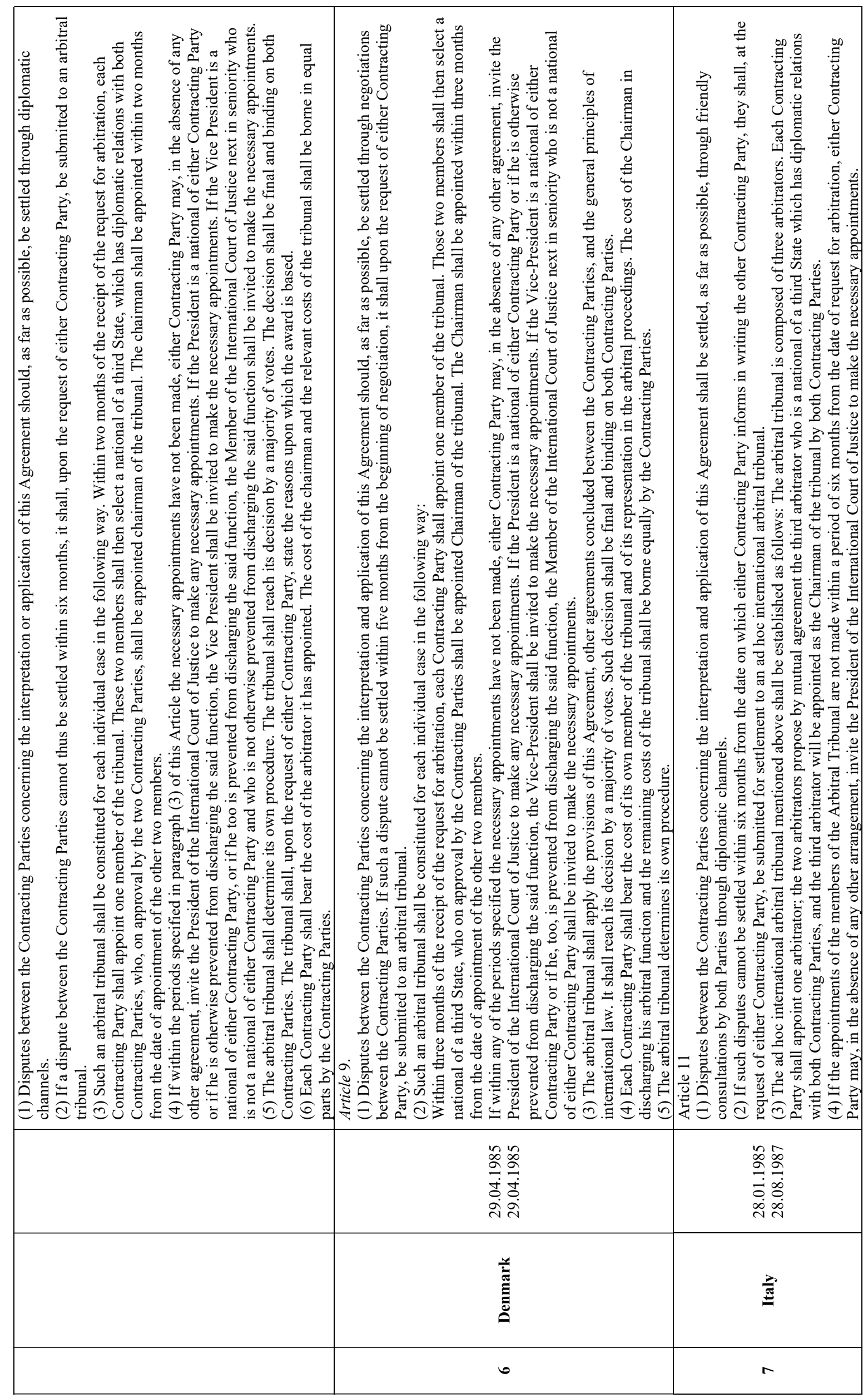




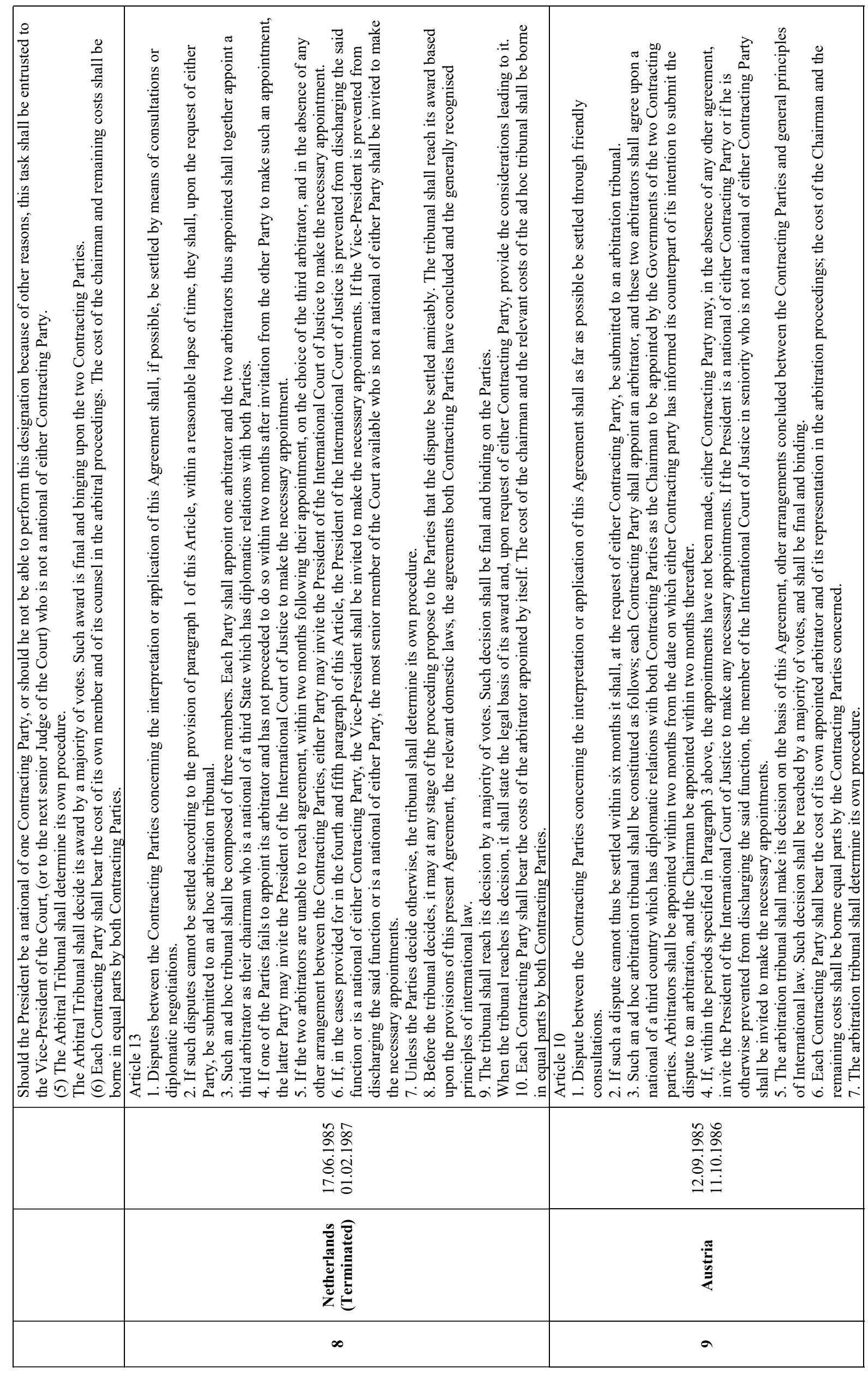




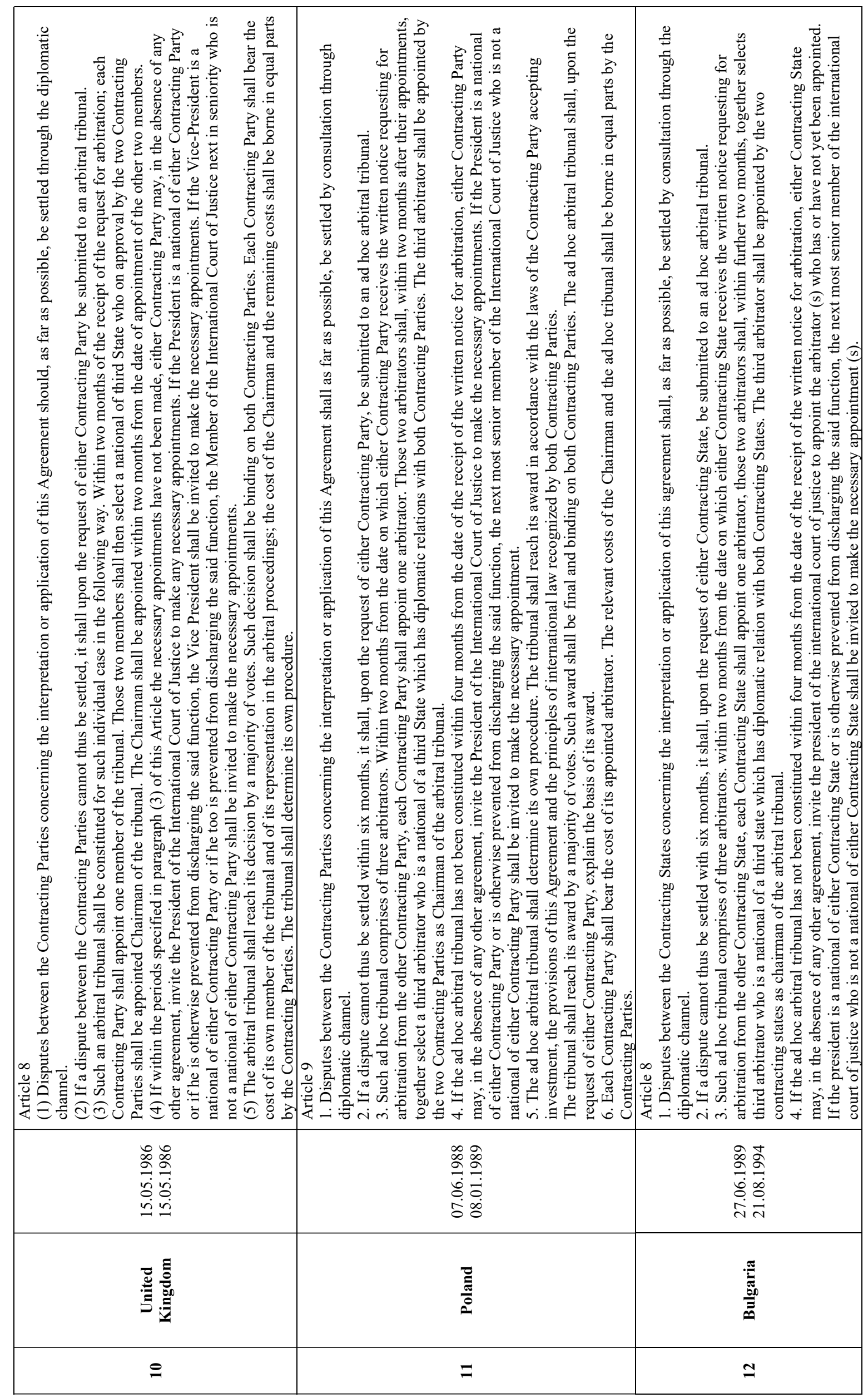




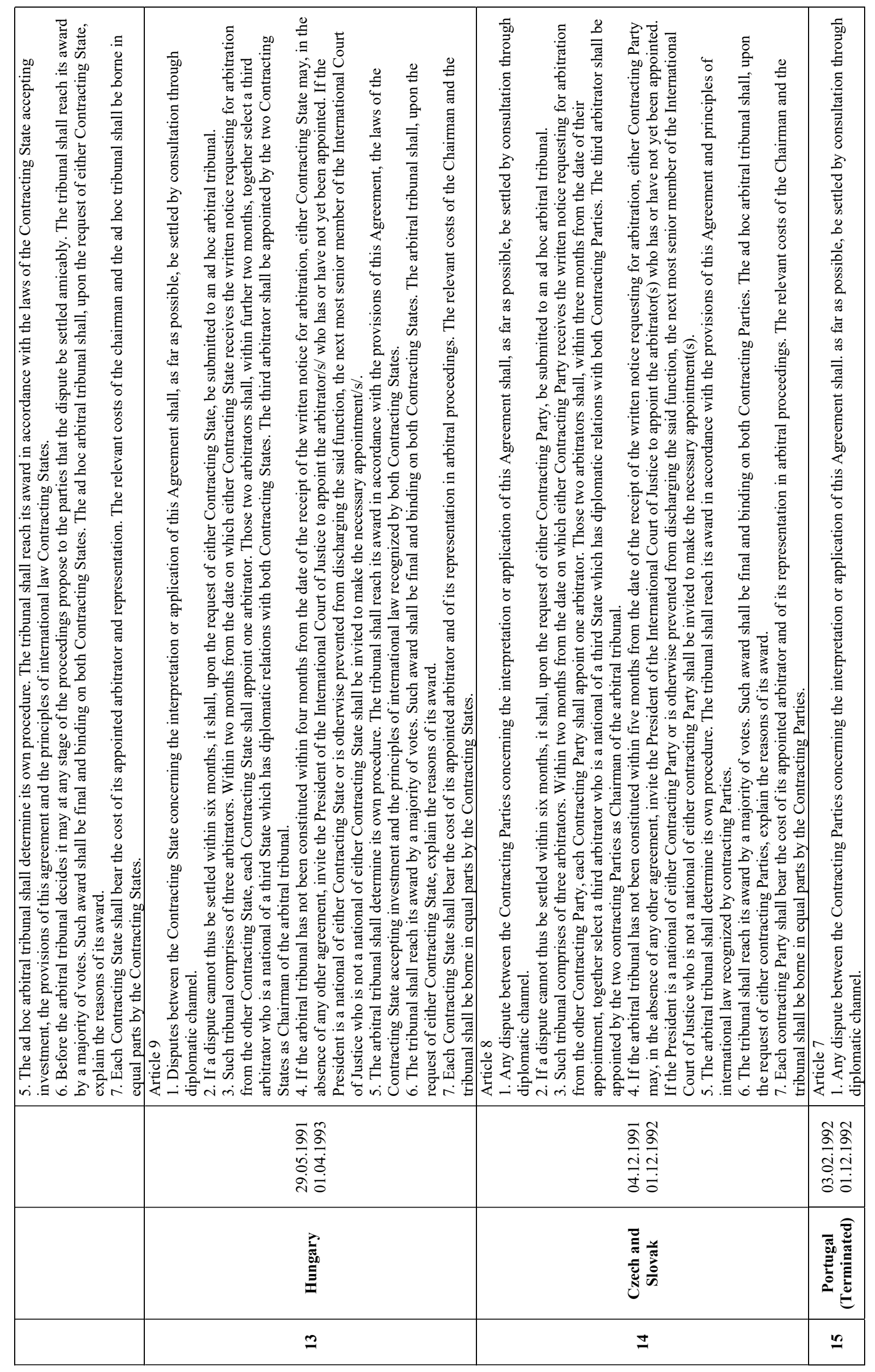




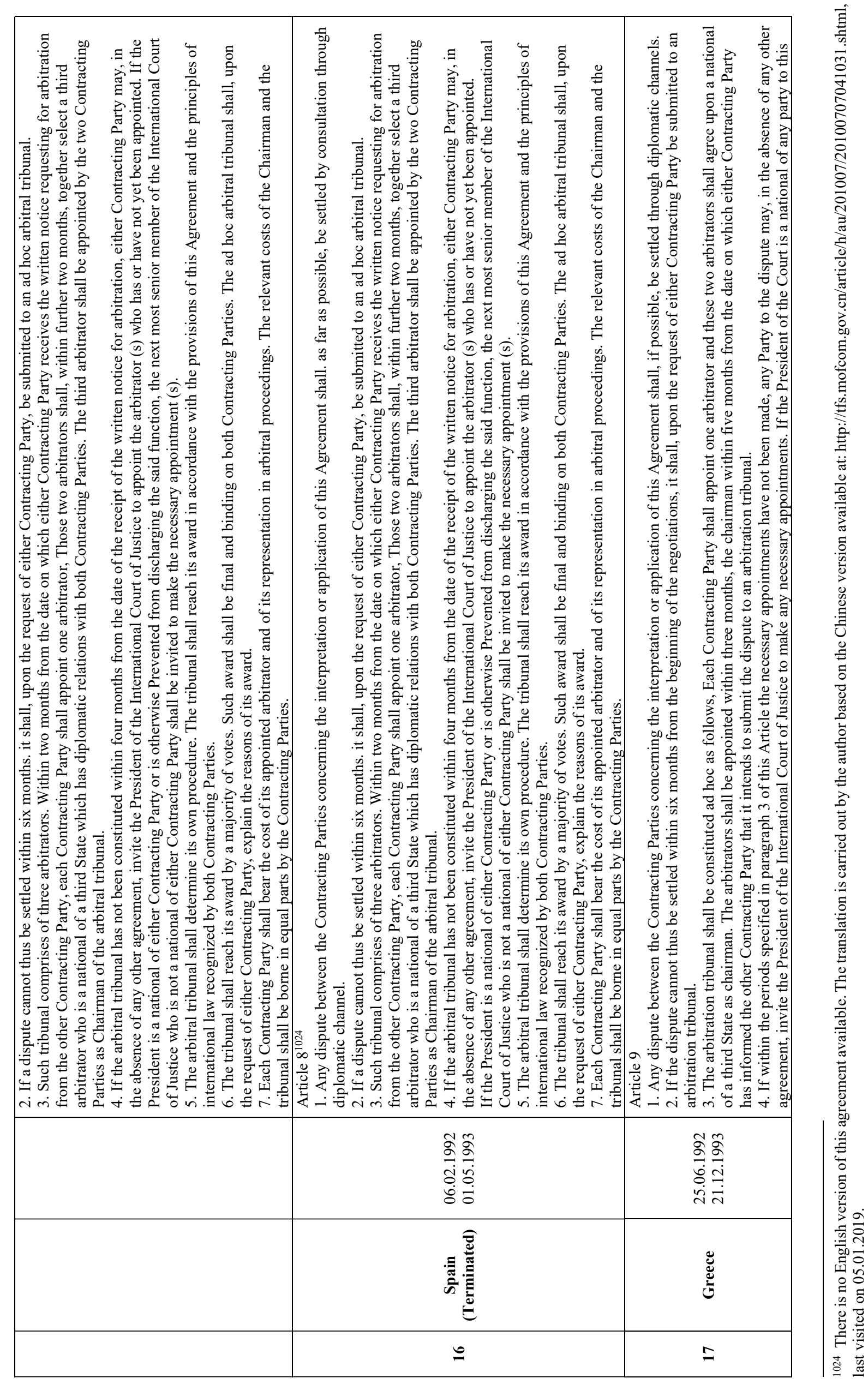




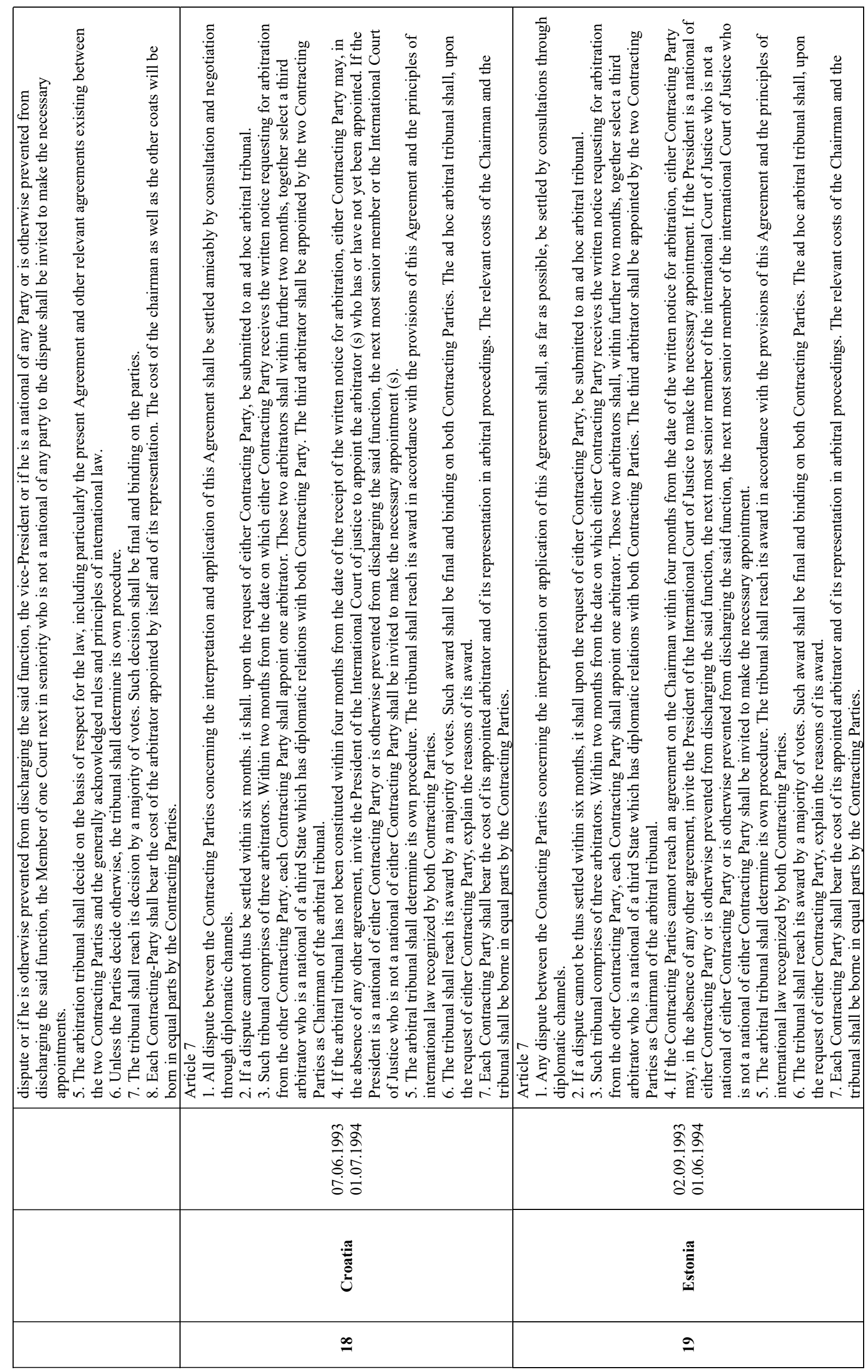




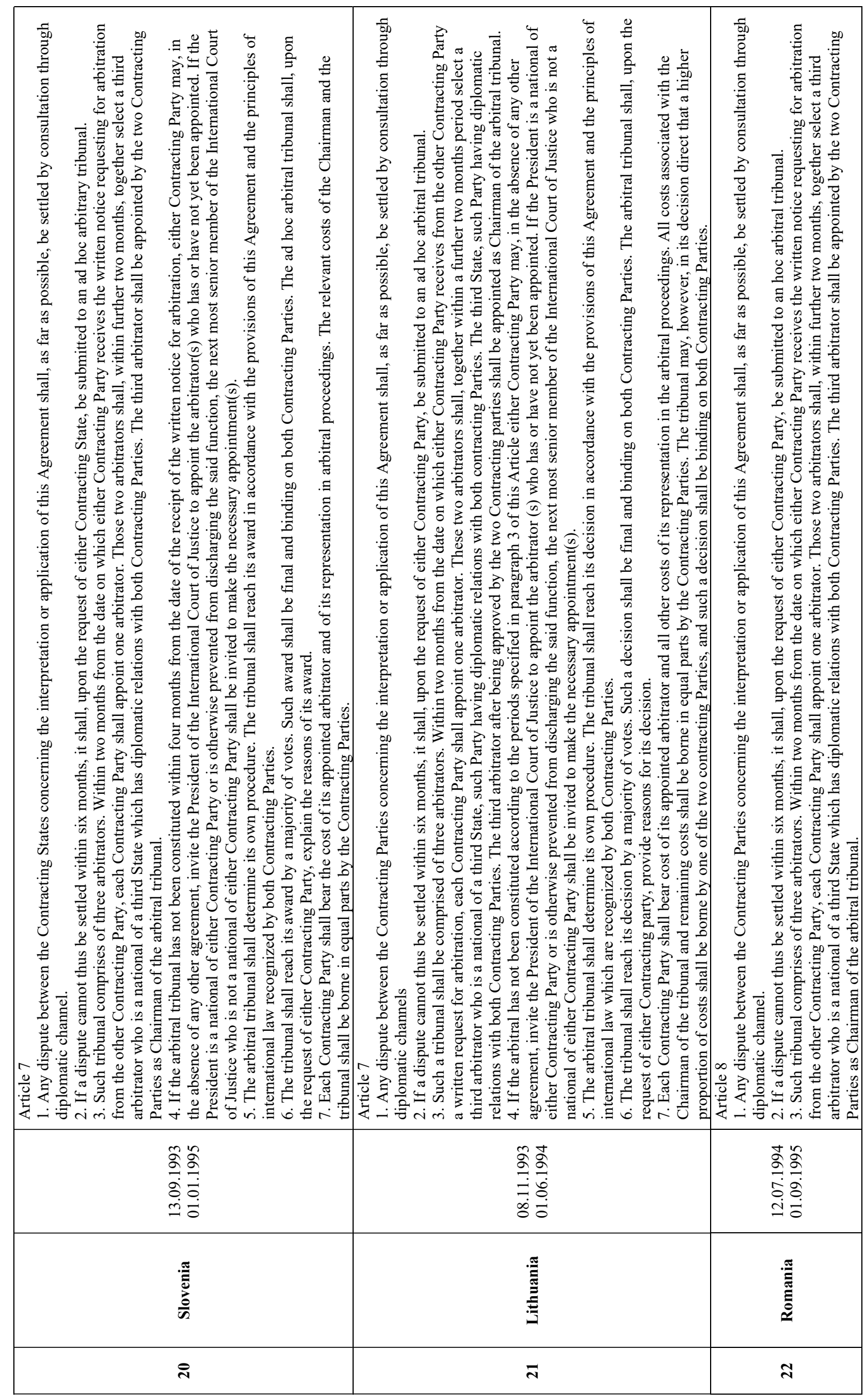




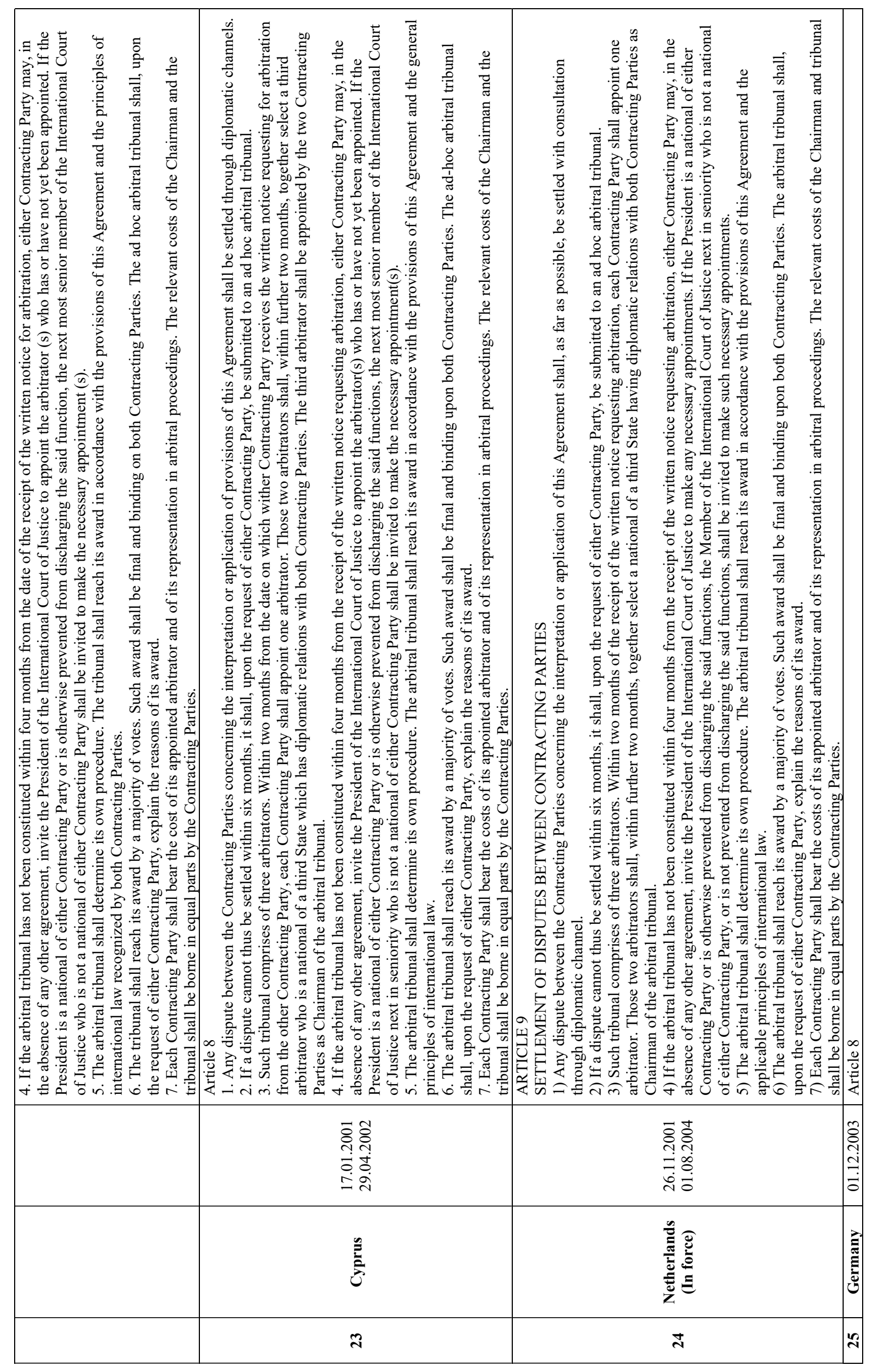




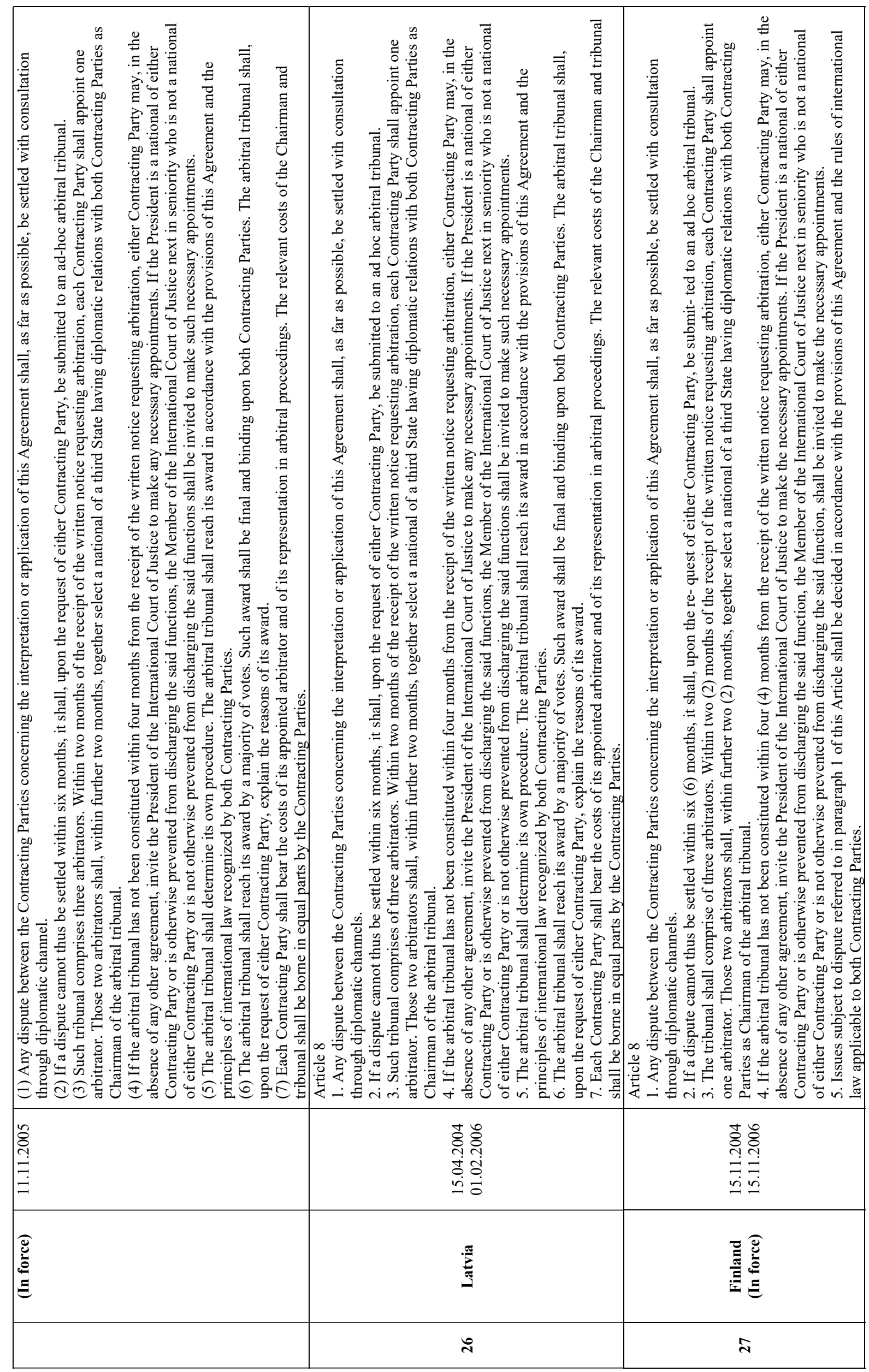




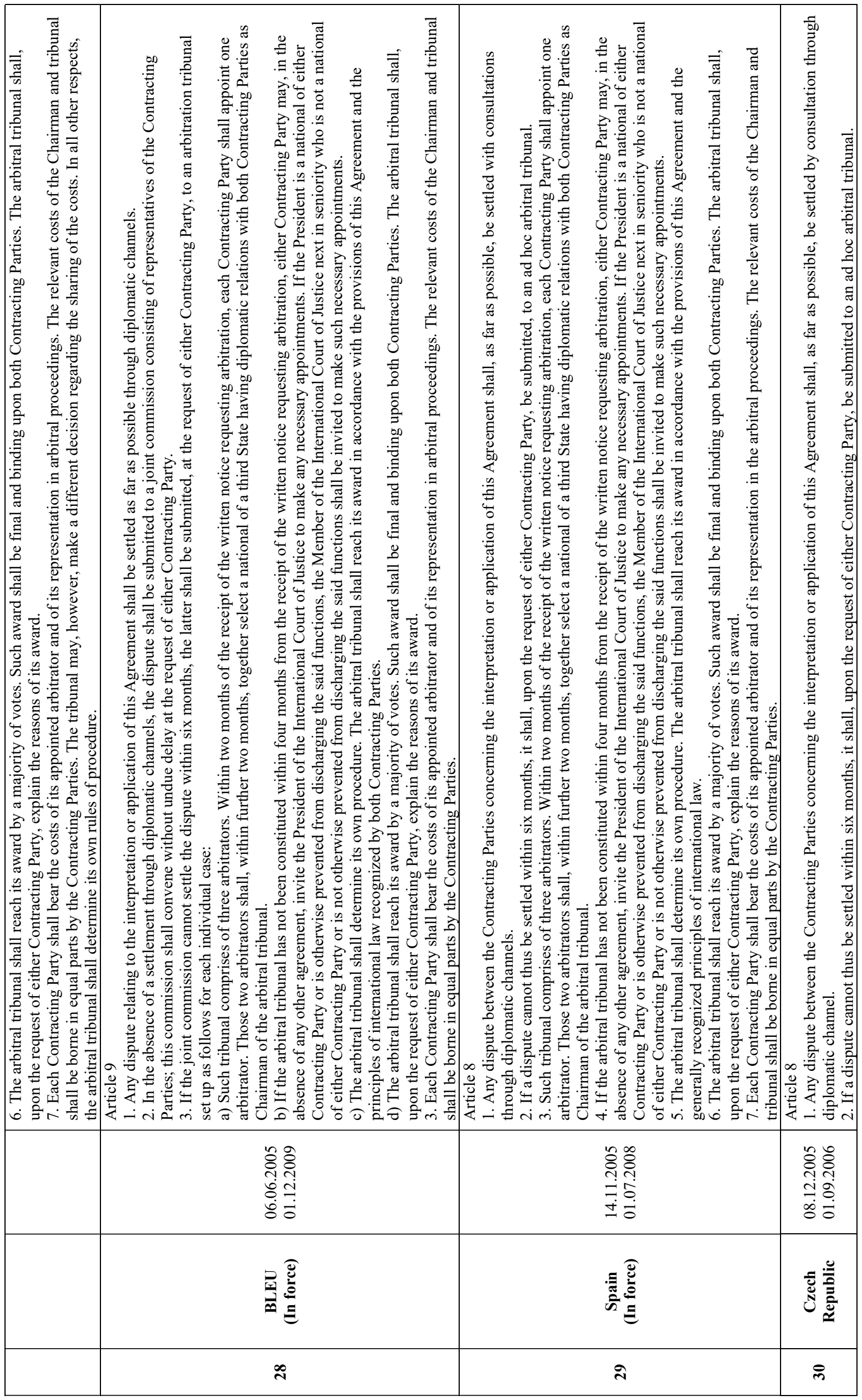




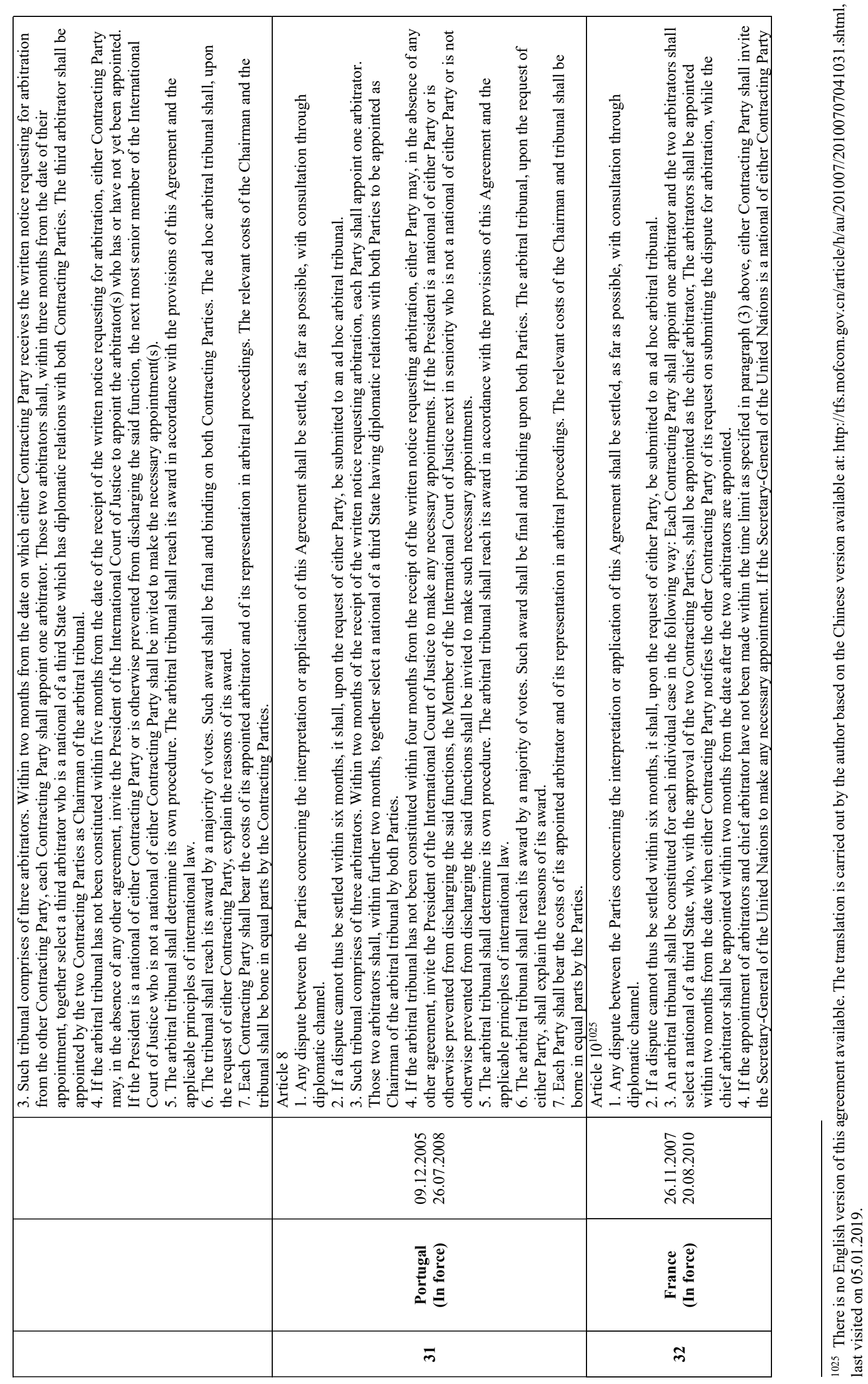




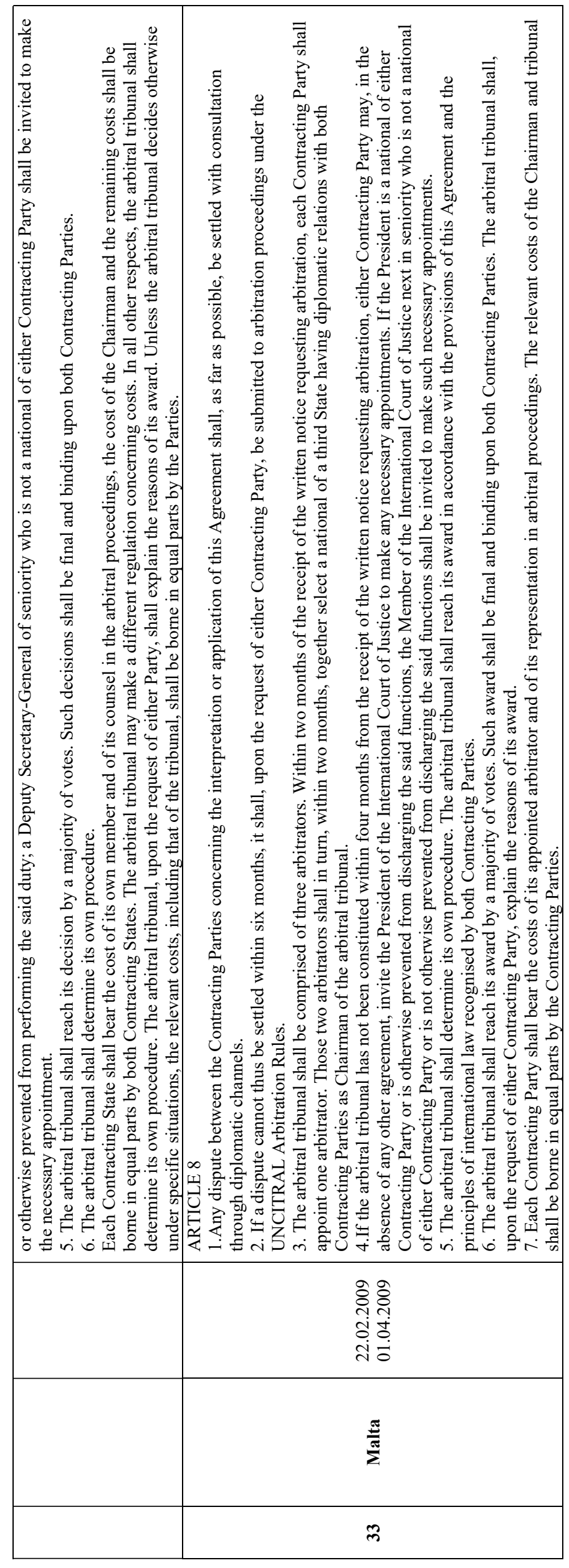




\subsubsection{The Investor-State Dispute Settlement Mechanisms in the Bilateral Investment Treaties between China and EU Member States}

In contrast to the similarities shared among the state-state DSMs, the investor-state DSMs contained in the BITs between China and EU Member States differ from each other. ${ }^{1026}$ As introduced in Section 6.2.3, supra, China's approach to investor-state dispute settlement changed over time, and the changes in its different investment development stages are also reflected in its BITs concluded with EU Member States. Thus, the discussion will address the division of the two previously identified stages and introduce the investor-state DSMs in the BITs signed between China and EU Member States before 1996 and from 1997 to 2009 respectively. ${ }^{1027}$

\subsubsection{Stage One: 1982-1996}

During the first stage (1982-1996), 22 BITs were signed between China and EU Member States. Among these agreements, two BITs, the China-Sweden BIT (1982) and the China-Germany BIT (1983-terminated), did not address the issue of ISDS. ${ }^{1028}$ The other 20 BITs provide for independent investor-state DSMs, including amicable and adjudicative DSMs, ${ }^{1029}$ which are introduced in turn. More details of these treaty provisions can be found in TABLE 9.3.2.1.

\section{(i) Amicable Dispute Settlement Mechanisms}

In 13 of these 20 BITs, using negotiations to settle the disputes between investors and host states is expressly provided for. Very often, it is stated that the investment disputes between an investor of one treaty party and the other treaty party shall, as far as possible, be settled amicably through negotiations between the parties to the dispute, and no further guidance is provided. ${ }^{1030}$ Three other BITs only state that a dispute can resort to an adjudication process only if it cannot be settled within six months. ${ }^{1031}$ The remaining four BITs did not touch upon this issue at all, which can be due to a lack of experience in treaty drafting at the early development stage of treaty parties. ${ }^{1032}$ The absence of such a provision should not be read as a negative attitude towards amicable

\footnotetext{
1026 Wenhua Shan, The Legal Framework of EU-China Investment Relations: A Critical Appraisal, Hart Publishing, 2005, p. 210

1027 As stated before, since the Lisbon Treaty came into force in 2009, the competence for negotiating and concluding IIAs has been transferred from the level of the EU Member States to that of the Union. At the same time, China and the EU started negotiations on a China-EU BIT since 2013. Thus, no agreement was concluded between China and EU Member States after 2009.

1028 The China-Sweden BIT (1982) does not contain any specific provision on ISDS, but a note of understanding was included at the end of the treaty, where Sweden acknowledged that China was currently not a signatory to the ICSID Convention and, if China acceded to the ICSID Convention in the future, a supplemental agreement would be signed to provide for binding dispute resolution.

1029 These include the China-France BIT (1984-terminated), the China-Finland BIT (1984-terminated), the ChinaBLEU BIT (1984-terminated), the China-Denmark BIT (1985), the China-Italy BIT (1984), the China-Netherlands BIT (1985-terminated), the China-Austria BIT (1985), the China-United Kingdom (1986), the China-Poland BIT (1988), the China-Bulgaria BIT (1989), the China-Hungary BIT (1991), the China-Czech and Slovak BIT (1991), the China-Portugal BIT (1992-terminated), the China-Spain BIT (1992-terminated), and the China-Greece BIT (1992).

1030 See e.g. the China-Czech and Slovak BIT (1991), Art. 9.1.

1031 These three BITs are the China-Italy BIT (1985), the China-United Kingdom BIT (1986), and the China-Spain BIT (1992-terminated).

1032 These four BITs are the China-Austria BIT (1985), the China-Poland BIT (1988), the China-Bulgaria BIT (1989) and the China-Hungary BIT (1991).
} 
settlement. In other words, amicable DSMs should always be available to disputing parties, as long as they consent to them, regardless whether there are relevant articles in the treaty texts or not. In addition, it is noted that independent conciliation is only addressed in the China-Czech and Slovak BIT (1991) by stating that investors "shall have the right to choose the conciliation procedure before the dispute is submitted for arbitration". 1033 The China-Greece BIT (1992) mentioned conciliation in the ICSID. ${ }^{1034}$

\section{(ii) Adjudicative Dispute Settlement Mechanisms}

For disputes that cannot be settled amicably, other mechanisms are available. Regarding forum selection, as a typical feature of the BITs concluded at this stage, the disputes about compensation for expropriation were treated differently from others, which is a reflection of the approach adopted by China's first and second Model BITs (1984 \& 1989). Specifically, any dispute between an investor and its host state can always resort to local remedies. ${ }^{1035}$ International arbitration is provided as an extra option for disputes about the amount of compensation, although specific prescriptions vary. ${ }^{1036}$ Two exceptions here are the China-United Kingdom BIT (1986) and the China-Spain BIT (1992-terminated), where a dispute concerning an amount of compensation shall be submitted to international arbitration, ${ }^{1037}$ which means that international arbitration is the only available forum for such disputes, instead of providing an additional option.

Where both local remedies and international arbitration are provided, different arrangements for how they interact can be found. Some BITs state that if the investor concerned has resorted to the host state's competent court, it cannot resort to international arbitration. ${ }^{1038}$ These provisions are similar to the so-called "fork-in-theroad" provisions. ${ }^{1039}$ It is not clear, if international arbitration has been referred to, whether domestic remedies can be used thereafter. Other BITs simply provide that investors are free to choose either domestic remedies or international arbitration, while

\footnotetext{
1033 The China-Czech and Slovak BIT (1991), Art. 9.3.

1034 The China-Greece BIT (1992), Art. 10.4.

1035 Differences exist in the description of local remedies. Some BITs prescribe "the competent court of the Contracting Party accepting the investment". See e.g. the China-Denmark BIT (1985), Art. 8(2). Some BITs choose "the competent court" or "the competent administrative authority". See e.g. the China-France (1984-terminated), Art. 8.2. There is also a BIT generally providing "local remedies of the Contracting Party in question". See: the China-Finland (1984-terminated), Protocol, Art. 3.

1036 The terms used include "amount of compensation", "the amount of compensation resulting from expropriation", "the amount of compensation for expropriation, nationalization or other similar measures" and "compensation for expropriation and any other dispute agreed by parties". For an example of each, see respectively: the China-United Kingdom BIT (1986), Art. 7(1); the China-Denmark BIT (1985), Art. 8(3); the China-BLEU (1984-terminated), Art. 10.3; the China-Czech and Slovak BIT (1991-terminated), Art. 9.2.

1037 The China-United Kingdom BIT (1986), Art. 7 (1); the China-Spain BIT (1992-terminated), Art. 9.1.

1038 These provisions include the China-Denmark BIT (1985), Art. 8(3); the China-Portugal BIT (1992-terminated), Art. 8.3; the China-Croatia BIT (1993), Art. 8.3; the China-Estonia BIT (1993), Art. 8.3; the China-Slovenia BIT (1993), Art. 8.3. The China-France BIT (1984-terminated) contained a variation of this, where international arbitration will become unavailable to an investor if it resorted to the procedures in the competent domestic court and the court made its final decision within one year from the date on which either related party filed a request for settlement. See: the China-France BIT (1984-terminated), Art. 8.3.

1039 For more information on "fork-in-the-road" provisions, see: August Reinisch, Fork-in-the-Road Provisions, at: Thomas Cottier \& Krista Nadakavukaren Schefer (eds.), Elgar Encyclopedia of International Economic Law, Edward Elgar Publishing, 2017, pp. 280-281.
} 
leaving the issue of whether choosing one option would prohibit investors from resorting to another option. ${ }^{1040}$

In the 20 BITs in which international arbitration is available for ISDS, procedural guidance is often provided, which covers applicable arbitration rules, constitution of tribunals, applicable law, decision making, enforcement, and allocation of costs. First, institutional or ad hoc arbitration is often provided for, while some BITs list both and the choice can be made based on the agreement of the disputing parties. ${ }^{1041}$ Members of tribunals are selected according to the tailored arbitration rules in institutional arbitration, while for ad hoc arbitration, UNCITRAL Arbitration Rules are often provided. If this is not the case, for the composition of tribunals, it is usually provided that each party should appoint one and the two designated arbitrators shall jointly appoint a third arbitrator whose nationality is of a third state which has diplomatic relations with the parties to the disputed BIT. If any member of the tribunal could not be appointed on time, a disputing party may request the Chairman of the Arbitration Institute of the Stockholm Chamber of Commerce or the President of the International Court of Justice to make the necessary appointments. ${ }^{1042}$ Tribunals are granted the power to establish the rules of procedure, for which they may use ICSID Arbitration Rules as guidance. ${ }^{1043}$

In the BITs in which the issue of applicable law is touched upon, eight of them require tribunals to adjudicate in accordance with the law of the treaty party to the dispute accepting the investment, including its rules on the conflict of laws, the provisions of the involved BIT, as well as the generally recognized principles of international law accepted by both treaty parties. ${ }^{1044}$ In another two BITs, only domestic law is mentioned as the applicable law. ${ }^{1045}$

The rules on decision making and the enforcement of awards are quite similar among the BITs. ${ }^{1046}$ Tribunals are required to reach any decision by a majority of votes. Such

\footnotetext{
1040 These provisions include the China-BLEU BIT (1984-terminated), Art. 10.3; the China-Finland BIT (1984terminated), Protocol Art. 2(3); the China-Italy BIT (1985), Art. 5(2)(i); the China-Netherlands BIT(1985terminated), Art. 9.3; the China-Austria BIT (1985), Art. 4.5; the China-Bulgaria BIT (1989), Art. 9.1; the ChinaHungary BIT (1991), Art. 10.1; the China-Czech and Slovak BIT (1991), Art. 9.2; the China-Greece BIT (1992), Art. 10.2; the China-Lithuania BIT (1993), Art. 8.2; and the China-Romania BIT (1994), Art. 9.2.

1041 For examples of each category, see respectively: the China-Romania BIT (1994), Art. 9.2; the China-Slovenia BIT (1993), Art. 8.3; the China-Greece BIT (1992), Art. 10.4. An exception of the third category is the ChinaLithuania BIT (1993), which provides investors a choice between the ICSID and ad hoc arbitration, instead of relying on the agreement of disputing parties. See: the China-Lithuania BIT (1993), Art. 8.2.

1042 Some BITs grant the power to the Chairman of the arbitration institute of the Stockholm Chamber of Commerce. See e.g. the China-Austria BIT (1985), Re Art. 4(2), Others choose the President of the International Court of Justice to make necessary appointments. See e.g. the China-Poland BIT (1988), Art. 10.2.

1043 See e.g. the China-Hungary BIT (1991), Art. 10.3.

1044 See e.g. the China-Bulgaria BIT (1989), Art. 9.5.

1045 The China-Greece BIT (1992), Art. 10.2; the China-Austria BIT (1985), Re Art. 4(2).

1046 There are 14 BITs where these two issues are regulated: the China-France BIT (1984-terminated), the ChinaBLEU BIT (1984-terminated), the China-Finland BIT (1984-terminated), the China-Italy BIT (1985), the ChinaDenmark BIT (1985), the China-Austria BIT (1985), the China-United Kingdom BIT (1986), the China-Bulgaria BIT (1989), the China-Czech and Slovak BIT (1991-terminated), the China-Portugal BIT (1992-terminated), the China-Croatia BIT (1993), the China-Estonia BIT (1993), the China-Slovenia BIT (1993), and the China-Lithuania BIT (1993). The China-Poland BIT (1988) only states that arbitral awards shall be final and binding on both sides, and the China-Greece BIT (1992) only states that awards shall be enforced in accordance with domestic law.
} 
a decision is final and binding, the enforcement of which shall be realized in accordance with the domestic law of the host state involved.

Most of these 20 BITs also stipulate rules on cost allocation by requiring each disputing party to bear the cost of its appointed arbitrator and representation. The cost of the chairman and the remaining cost in the arbitral proceedings shall be borne in equal parts by the parties to the dispute. 


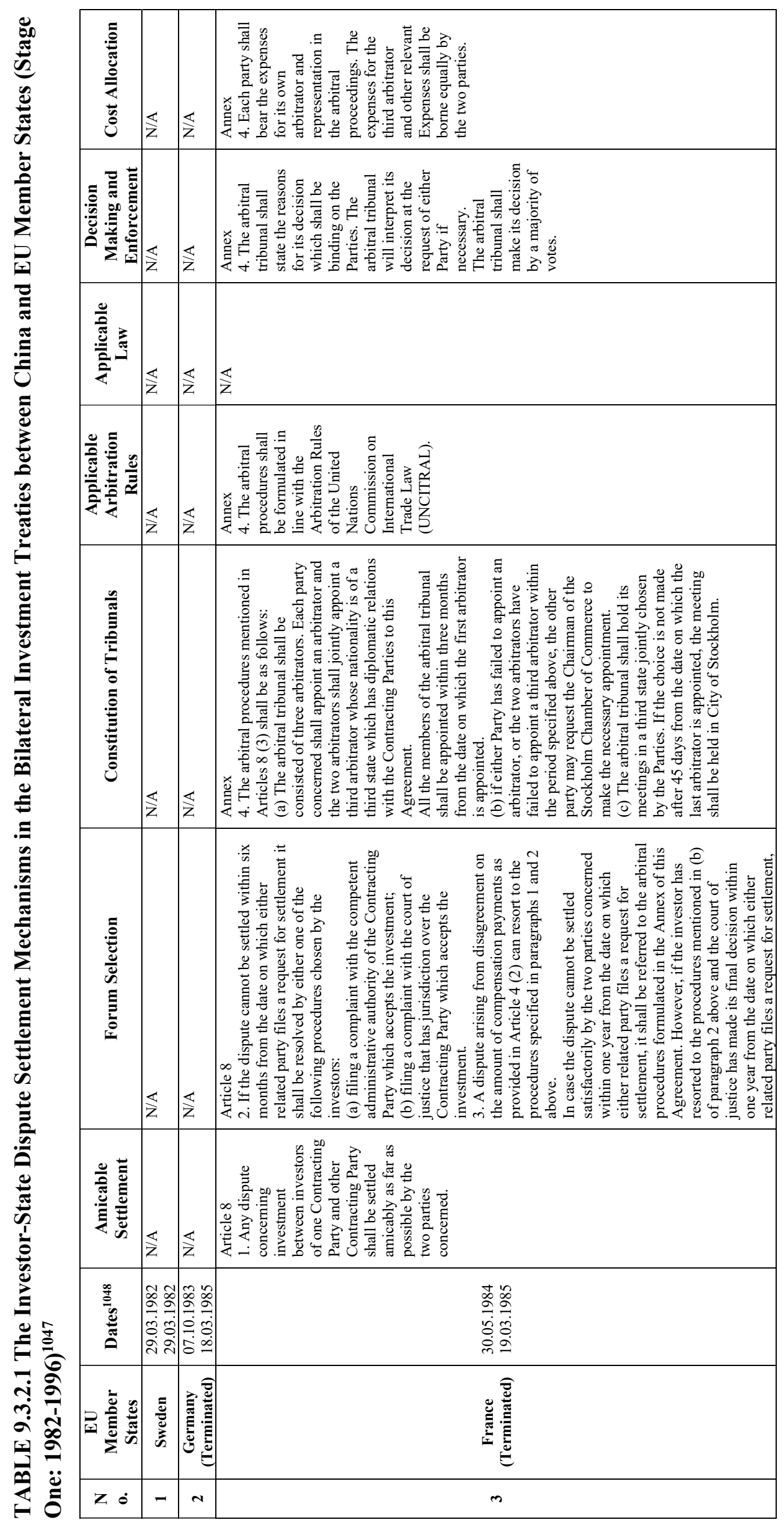

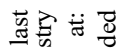

部言递

可

플

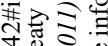

氙员

월

言总青

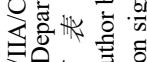

驾炮言

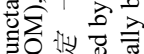

政

过汹

을

氙出

政

害要心

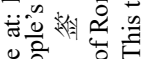

可

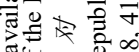

它週劳

这称

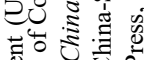

氖运

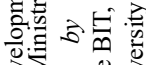

究

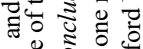

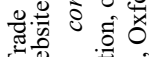

है

8.

牙

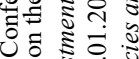

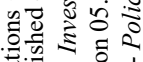

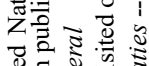

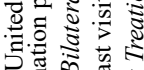

挐

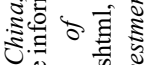

के

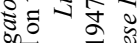

हิ

记

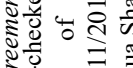

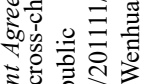

害虽

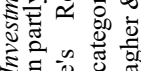

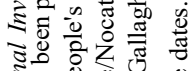

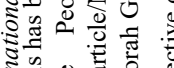

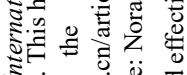

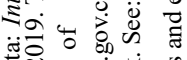

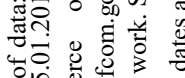

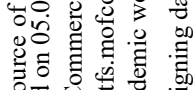

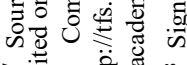

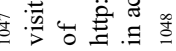




\begin{tabular}{|c|c|c|c|}
\hline 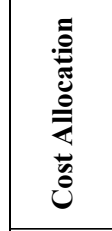 & & 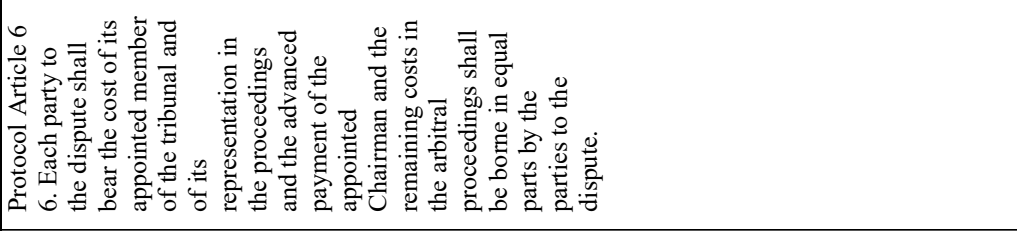 & 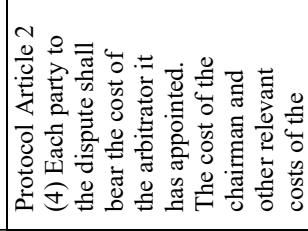 \\
\hline 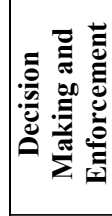 & & 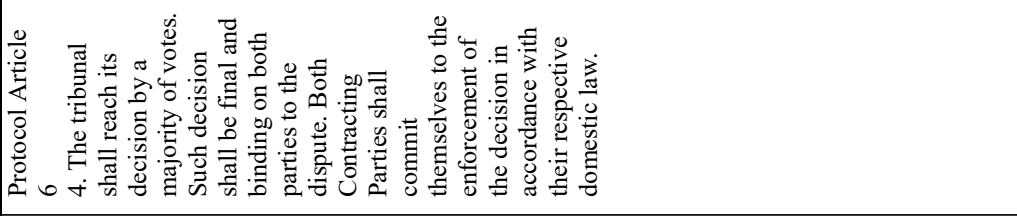 & 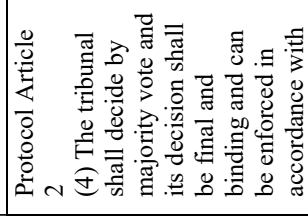 \\
\hline 产 & & 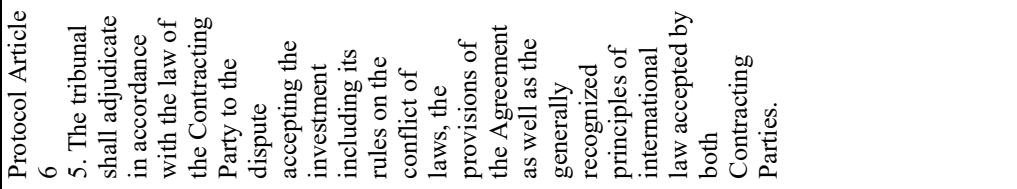 & $\overleftrightarrow{\mathrm{Z}}$ \\
\hline 竞: & & 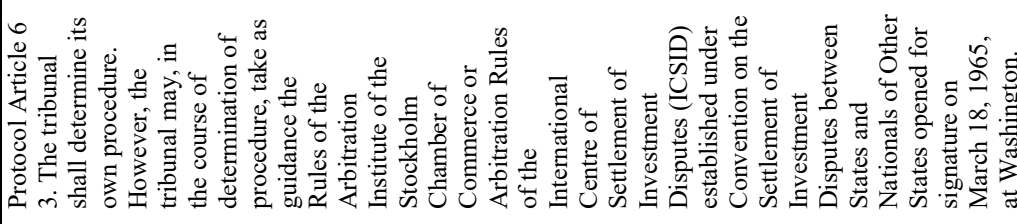 & 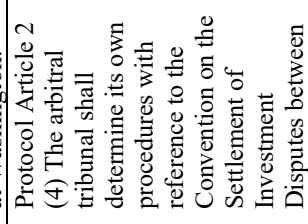 \\
\hline 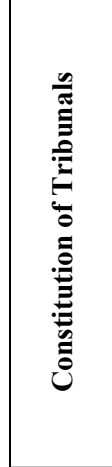 & & 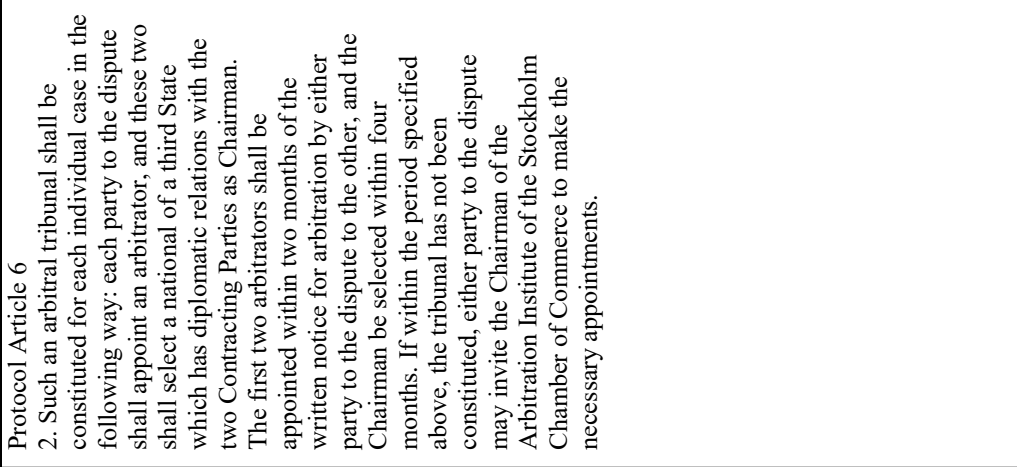 & 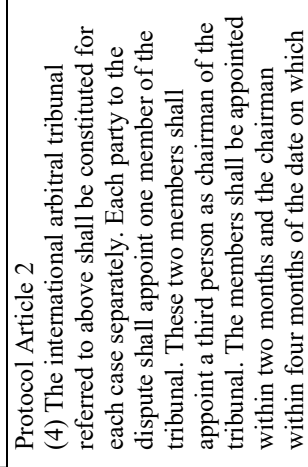 \\
\hline 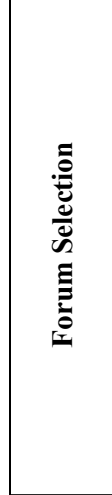 & 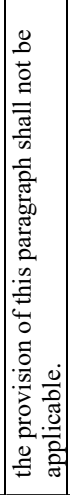 & 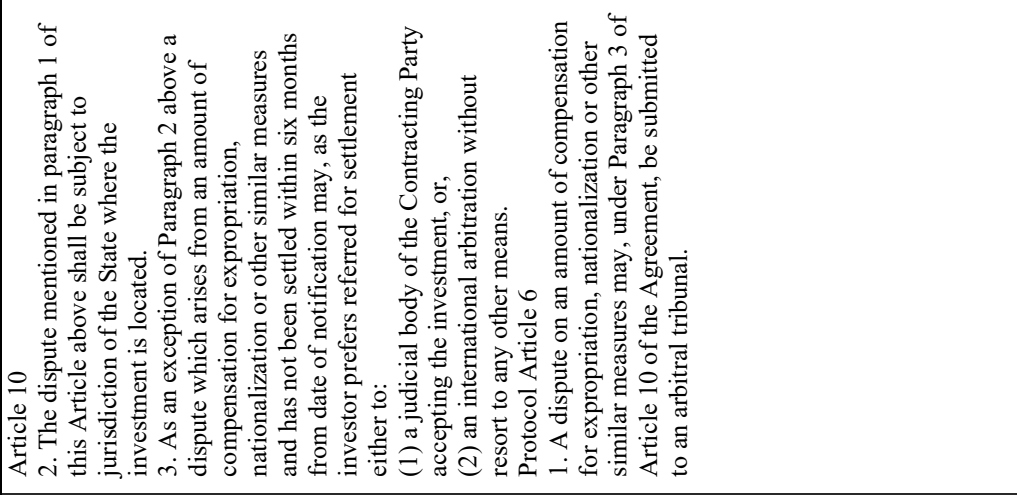 & 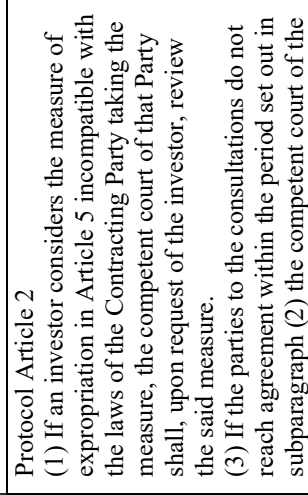 \\
\hline 冚 & & 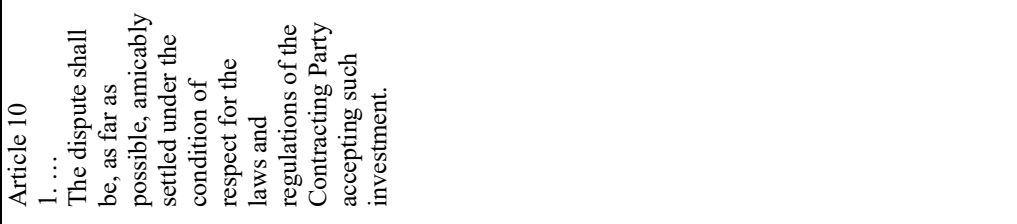 & 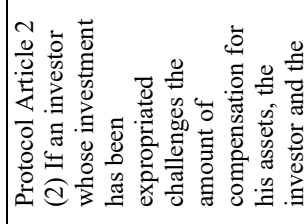 \\
\hline 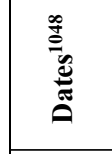 & & 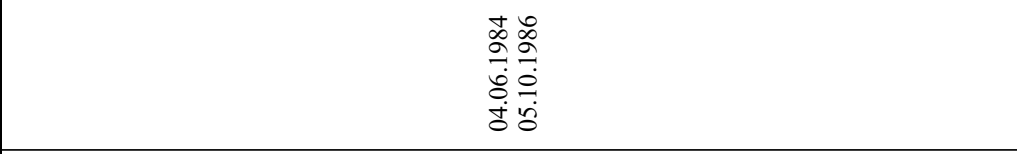 & 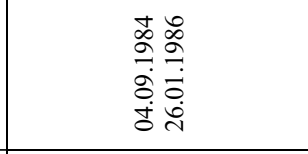 \\
\hline 位 & & 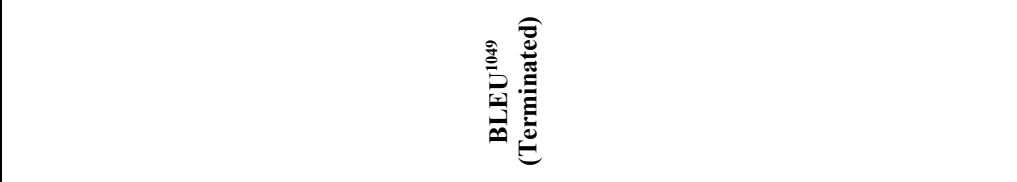 & 㺼 \\
\hline $\mathrm{z} \dot{0}$ & & $\sigma$ & in \\
\hline
\end{tabular}

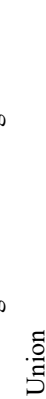




\begin{tabular}{|c|c|c|c|}
\hline 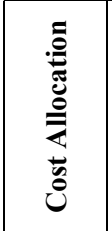 & 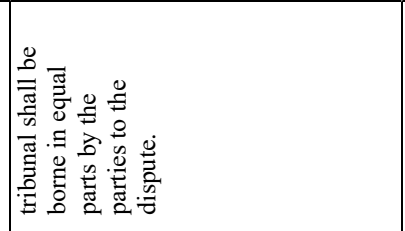 & 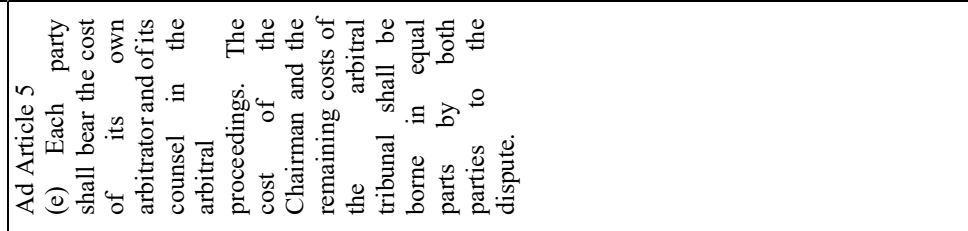 & 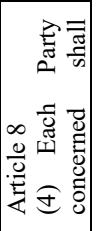 \\
\hline 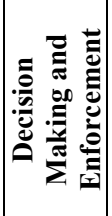 & 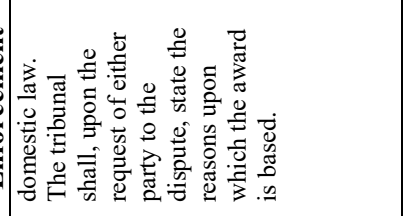 & 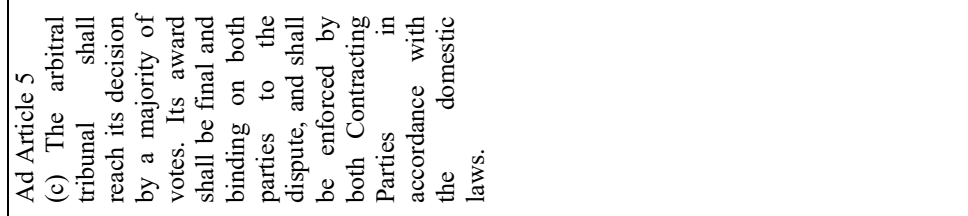 & 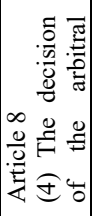 \\
\hline 吾 & & 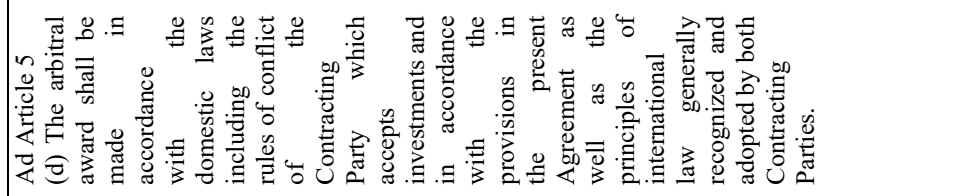 & $\frac{\varangle}{z}$ \\
\hline 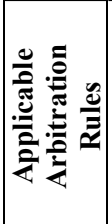 & 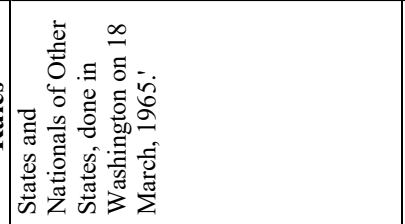 & 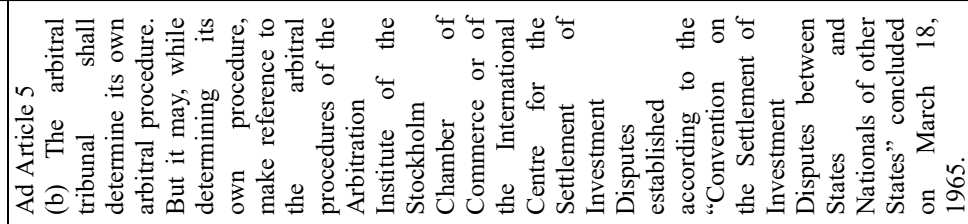 & 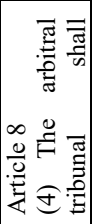 \\
\hline 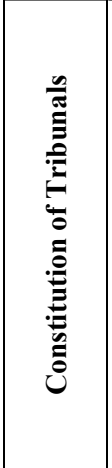 & 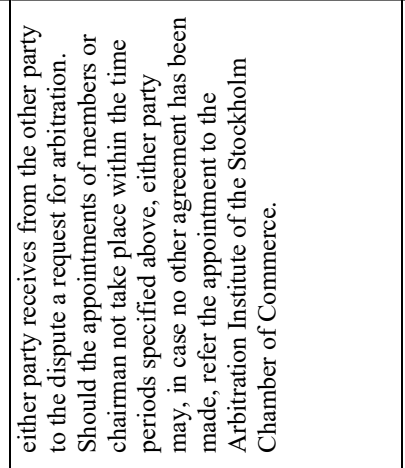 & 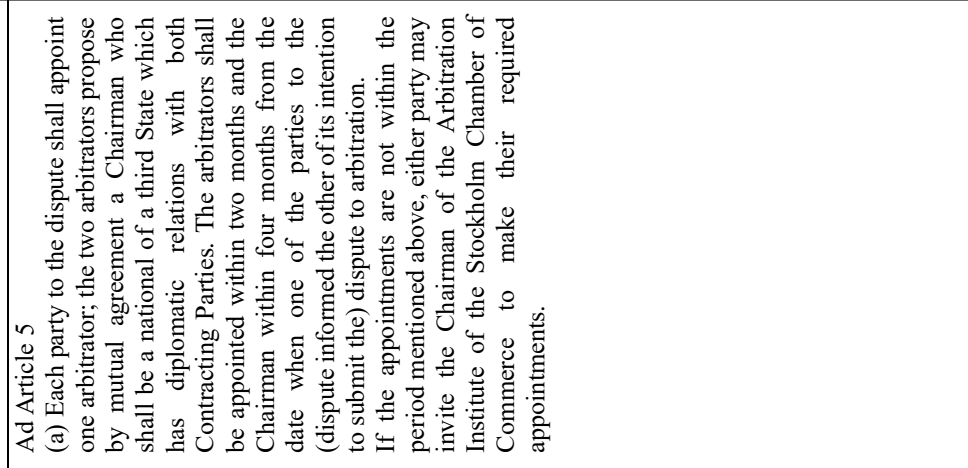 & 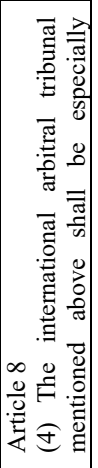 \\
\hline 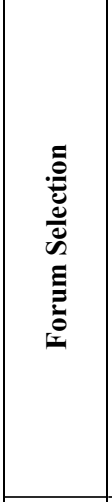 & 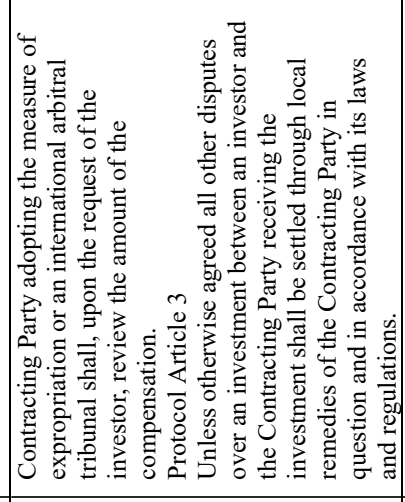 & 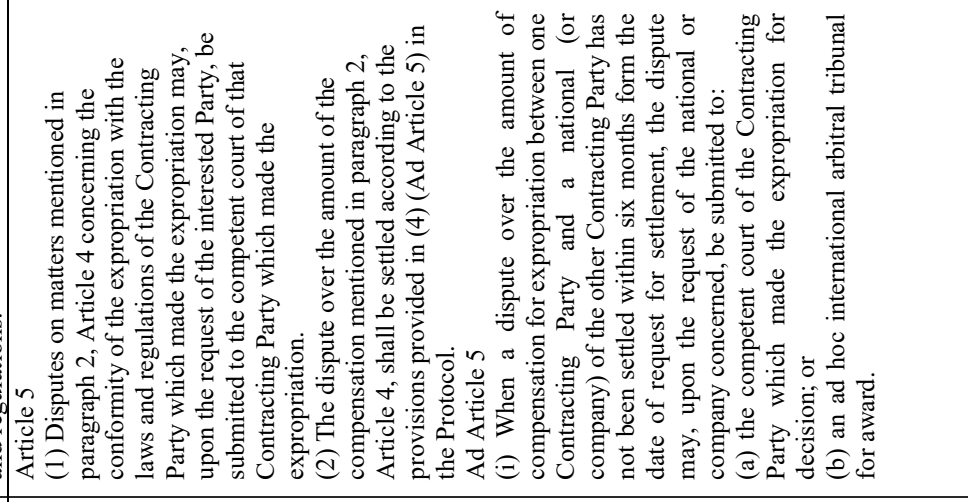 & 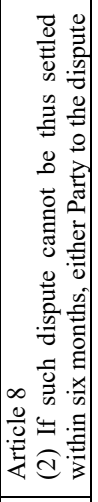 \\
\hline 总 & 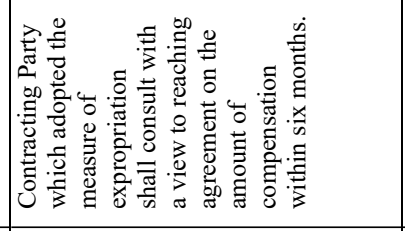 & 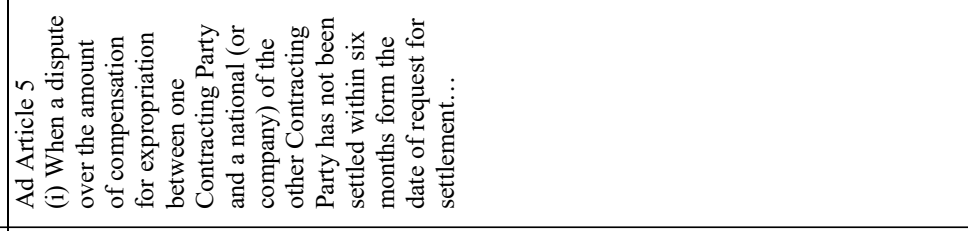 & 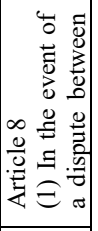 \\
\hline 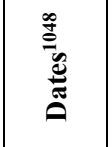 & & 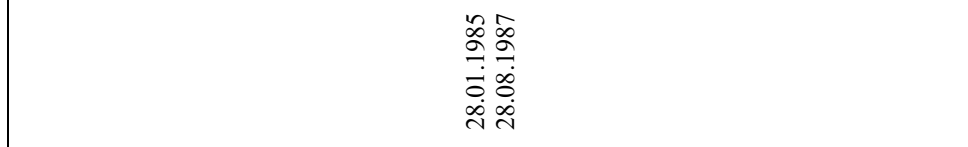 & 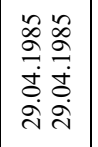 \\
\hline 它 & & $\frac{\mathrm{x}}{\mathrm{E}}$ & 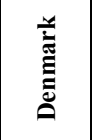 \\
\hline z $\dot{0}$ & & 0 & $r$ \\
\hline
\end{tabular}




\begin{tabular}{|c|c|c|}
\hline 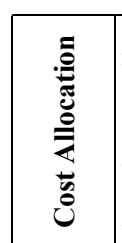 & 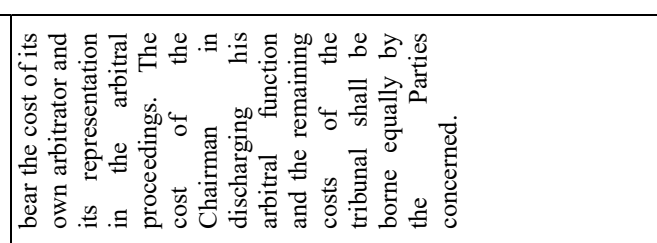 & $\frac{\widehat{z}}{z}$ \\
\hline 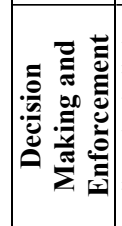 & 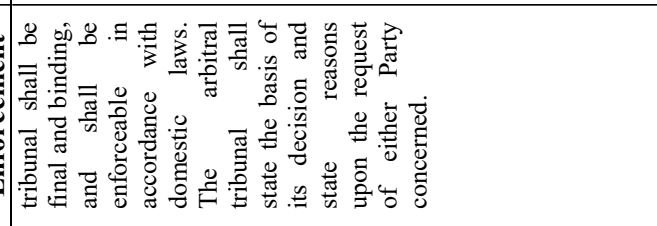 & $\frac{\widehat{z}}{\mathrm{z}}$ \\
\hline 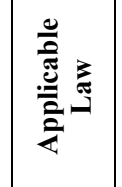 & & $\frac{\mathbb{z}}{z}$ \\
\hline 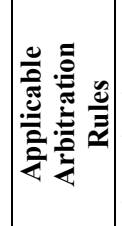 & 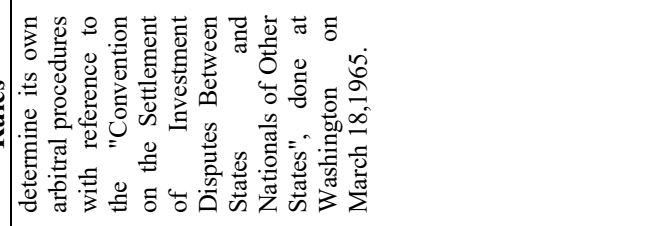 & $\frac{\pi}{z}$ \\
\hline 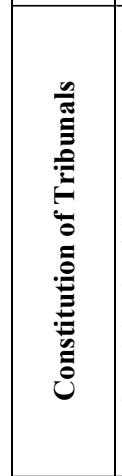 & 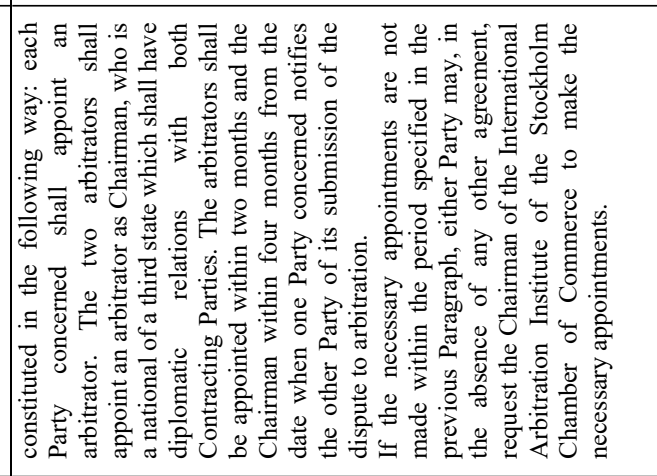 & $\frac{\mathbb{x}}{z}$ \\
\hline . & 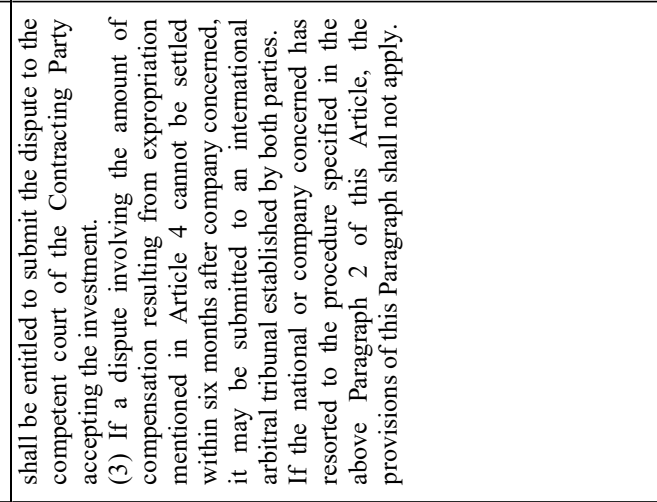 & 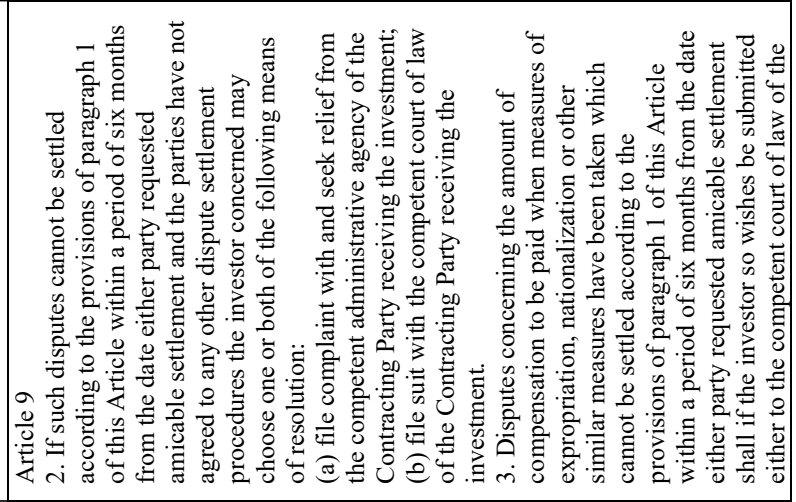 \\
\hline 要咅 & 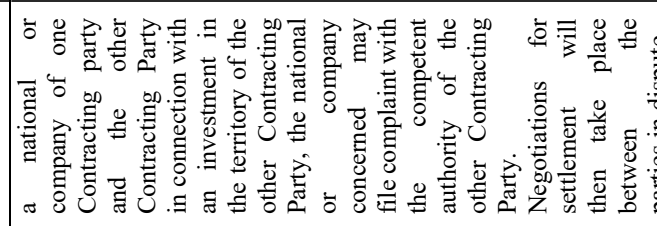 & 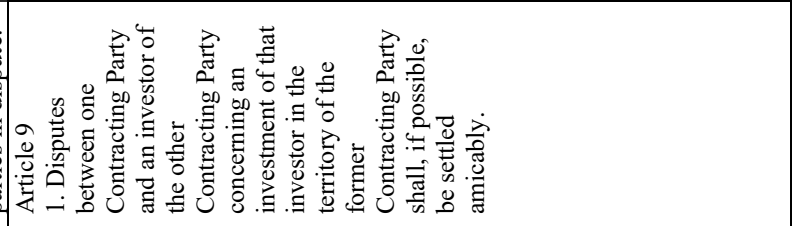 \\
\hline 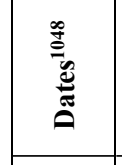 & & 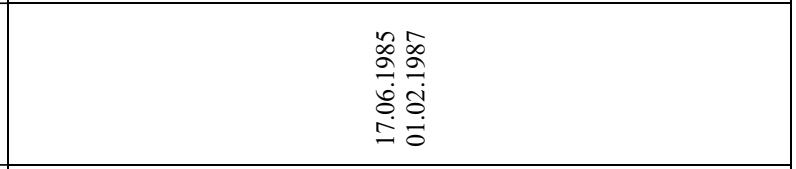 \\
\hline 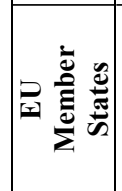 & & 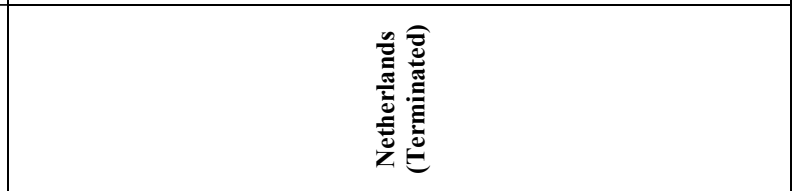 \\
\hline $\mathrm{z}^{\circ}$ & & $\infty$ \\
\hline
\end{tabular}




\begin{tabular}{|c|c|c|c|}
\hline 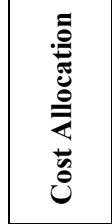 & & 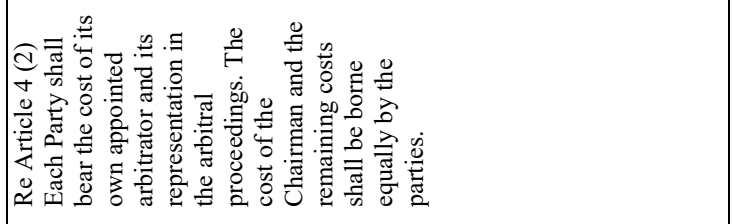 & 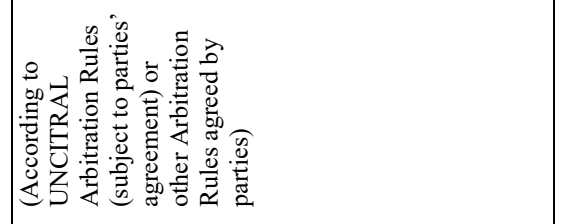 \\
\hline 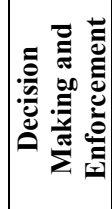 & & 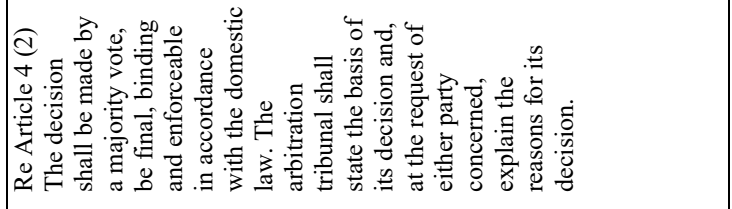 & 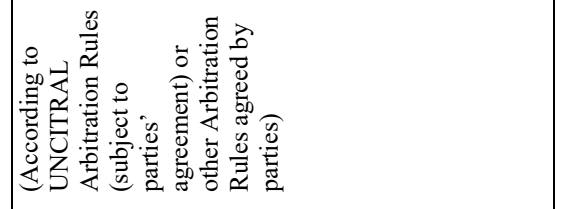 \\
\hline 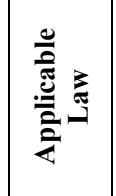 & & 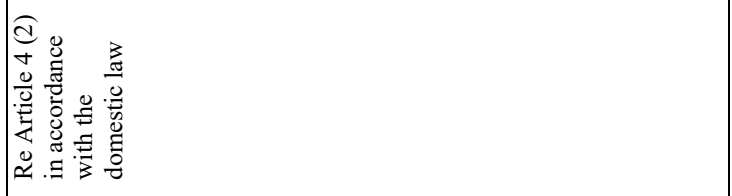 & 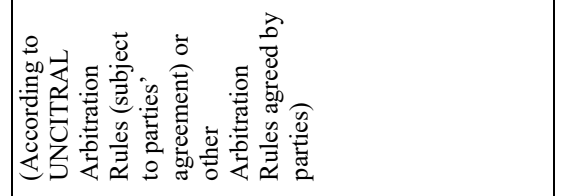 \\
\hline $\begin{array}{ll}0 \\
0\end{array}$ & & 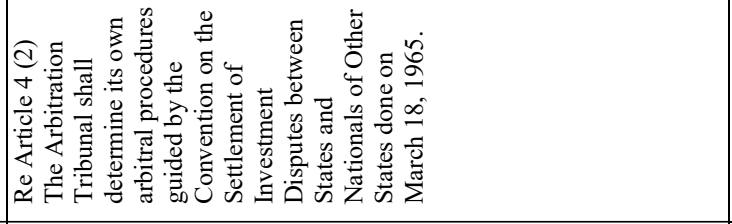 & 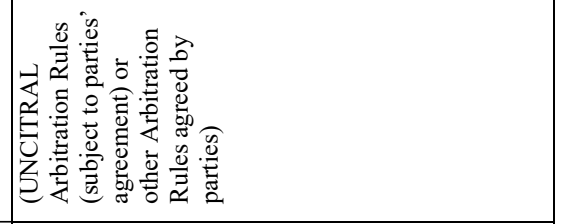 \\
\hline 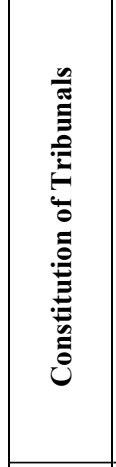 & & 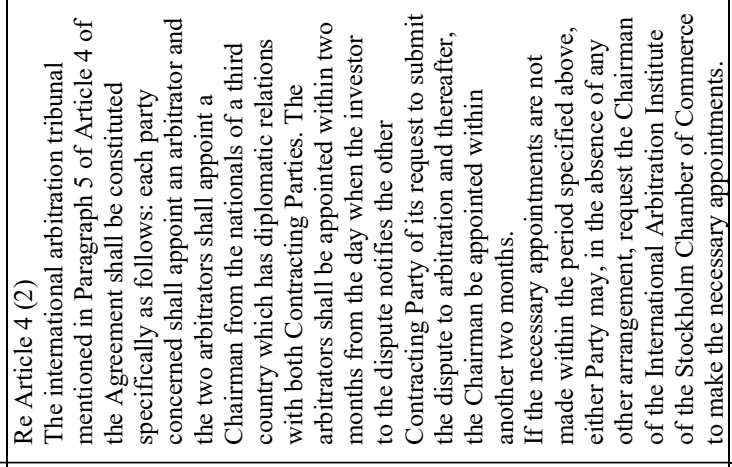 & 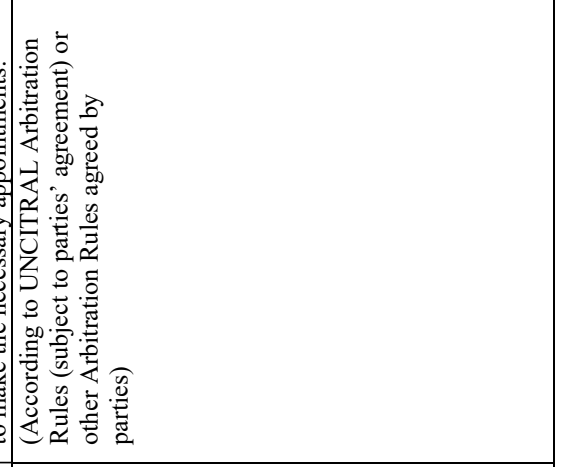 \\
\hline 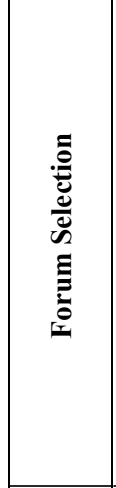 & 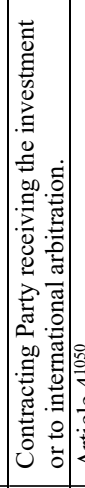 & 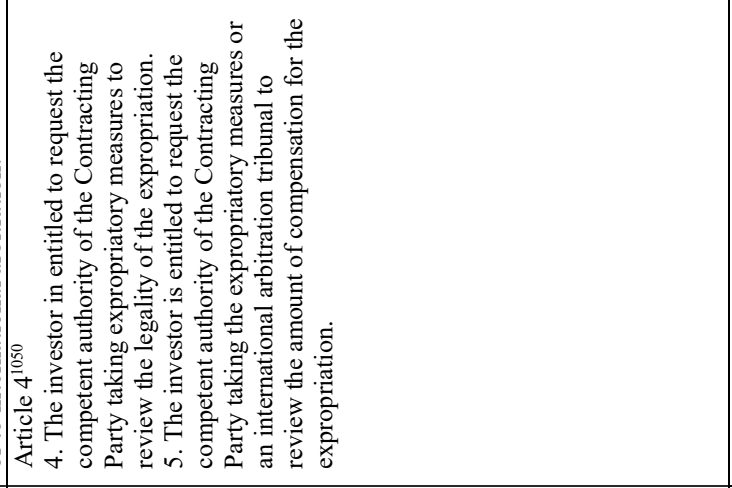 & 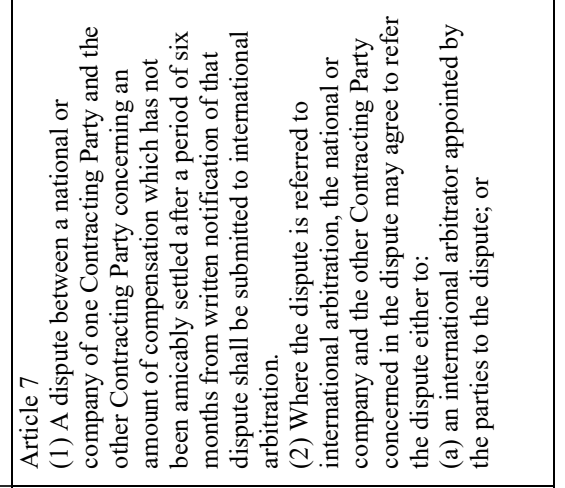 \\
\hline 号 & & $\overleftrightarrow{\mathrm{Z}}$ & 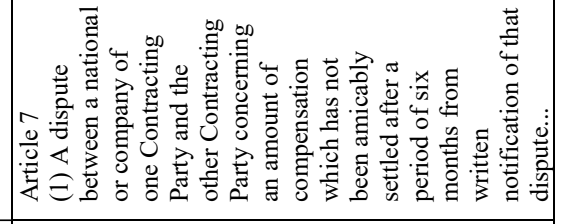 \\
\hline 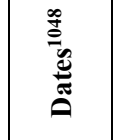 & & 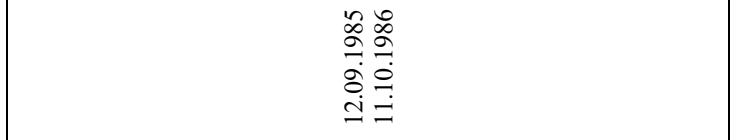 & 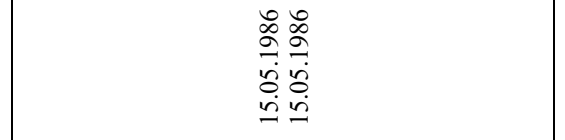 \\
\hline 宝产产 & & 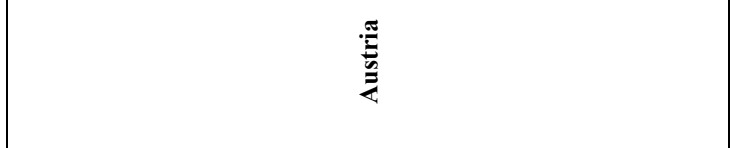 & 总言 \\
\hline Z 0 & & $a$ & $\Theta$ \\
\hline
\end{tabular}




\begin{tabular}{|c|c|c|c|}
\hline 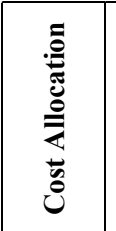 & & 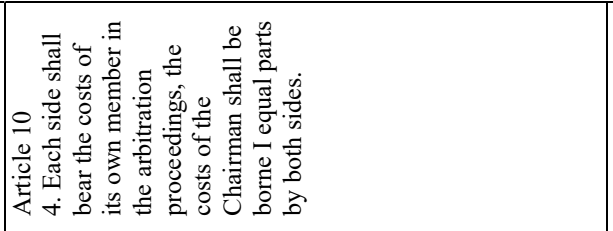 & 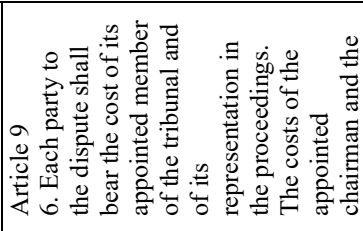 \\
\hline 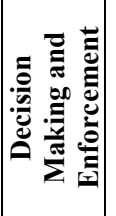 & & 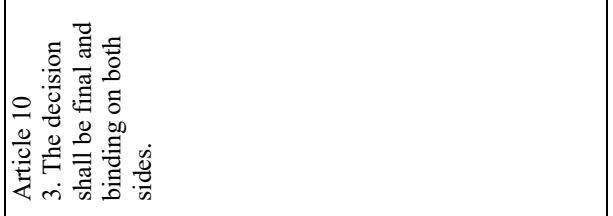 & 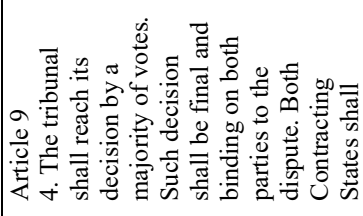 \\
\hline 吾 & & $\overleftrightarrow{Z}$ & 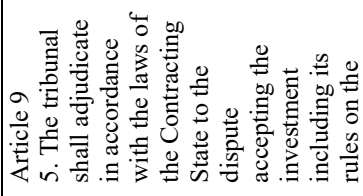 \\
\hline 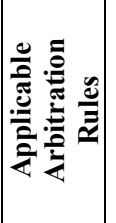 & & 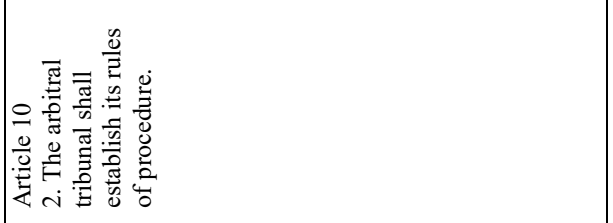 & 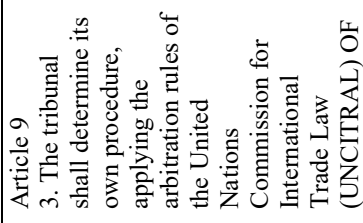 \\
\hline 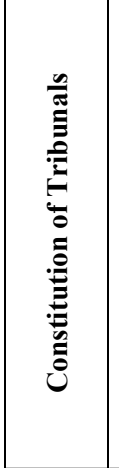 & & 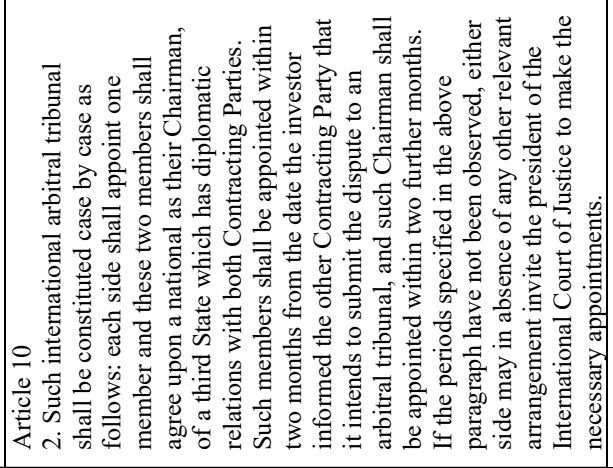 & 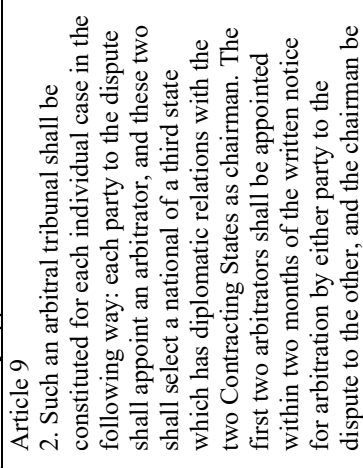 \\
\hline 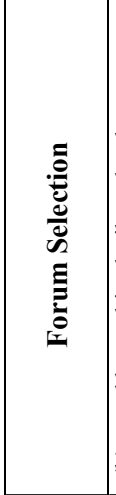 & 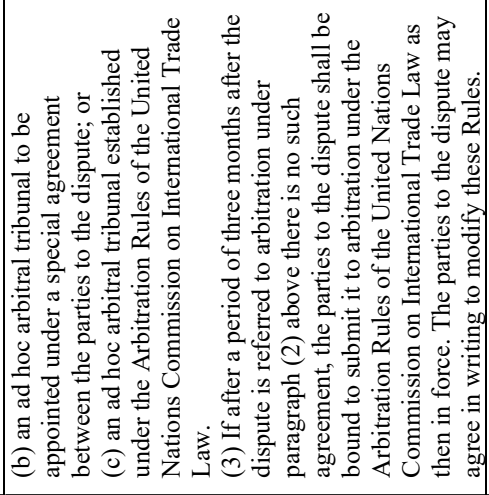 & 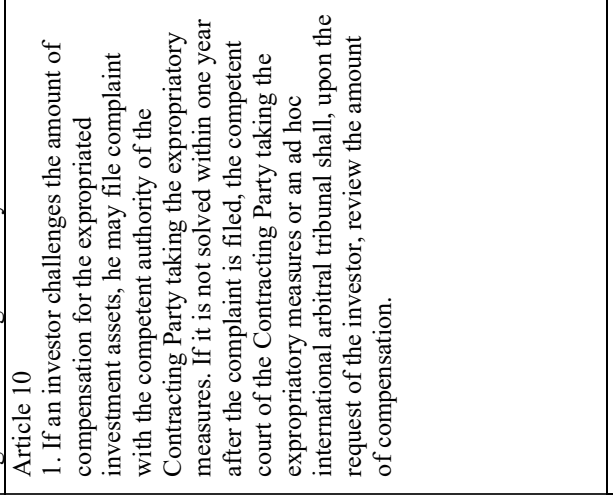 & 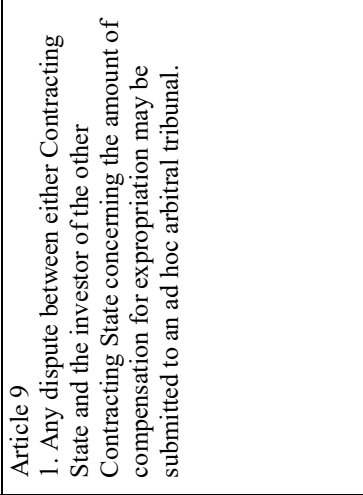 \\
\hline 哭 & & 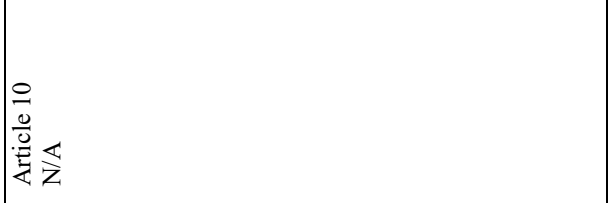 & $\overleftrightarrow{z}$ \\
\hline 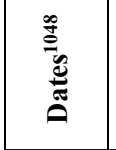 & & 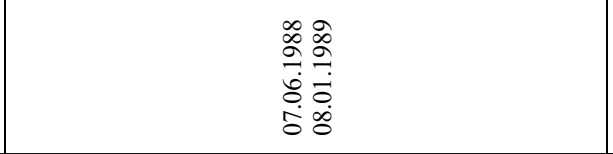 & 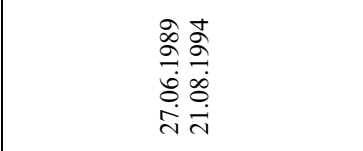 \\
\hline 完 & & $\begin{array}{l}\frac{5}{E} \\
\frac{\pi}{0} \\
\frac{\pi}{0}\end{array}$ & 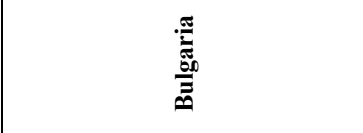 \\
\hline $\mathrm{z} \dot{0}$ & & $=$ & $\simeq$ \\
\hline
\end{tabular}




\begin{tabular}{|c|c|c|c|}
\hline 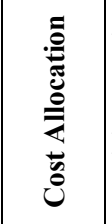 & 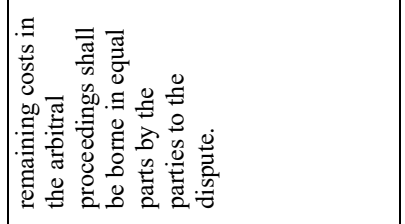 & 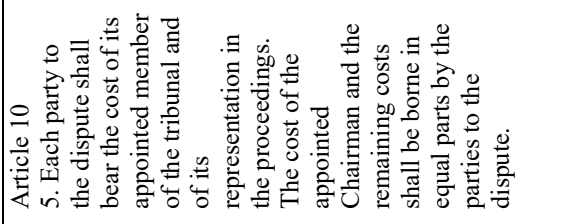 & 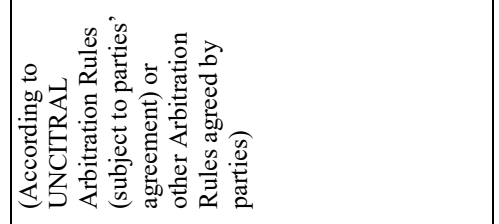 \\
\hline 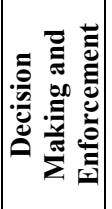 & 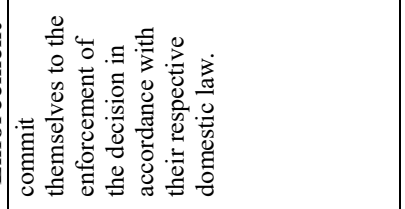 & 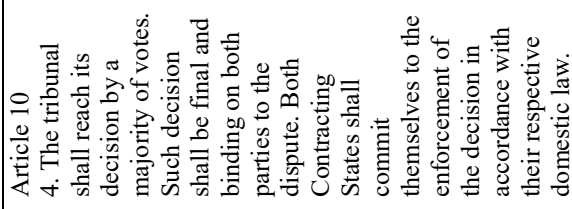 & 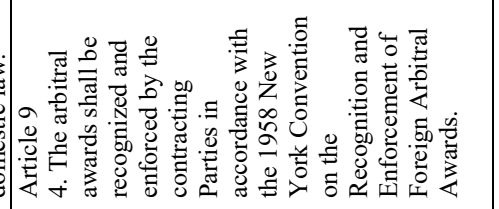 \\
\hline 黄 & 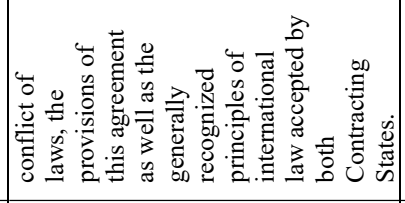 & 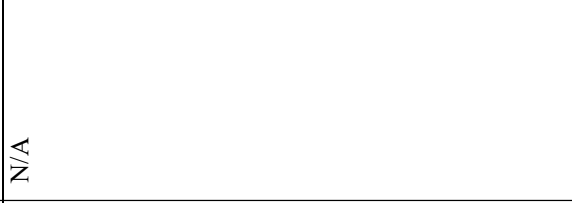 & 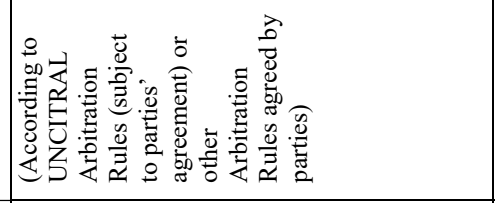 \\
\hline 竞言 & 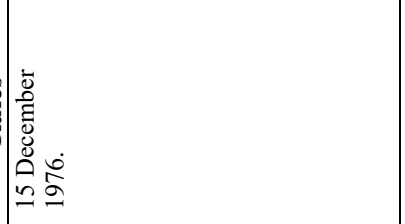 & 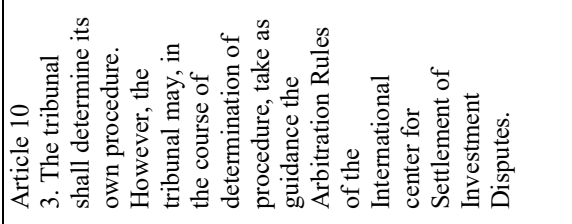 & 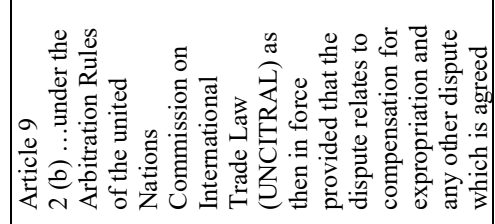 \\
\hline 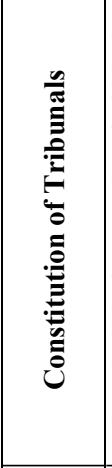 & 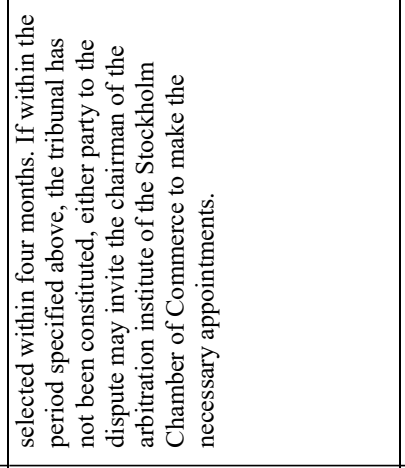 & 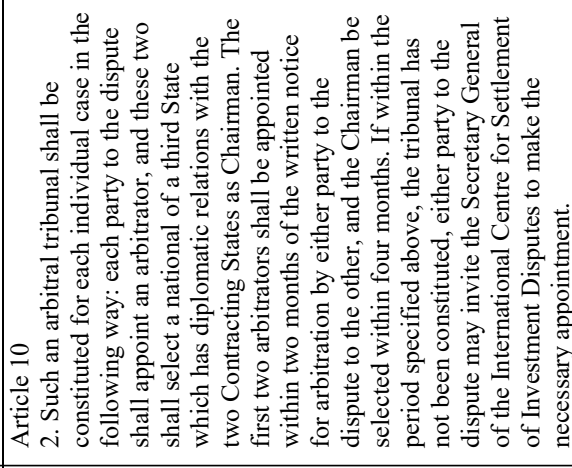 & 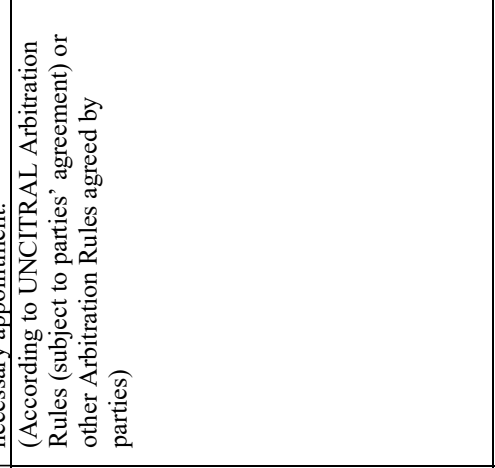 \\
\hline 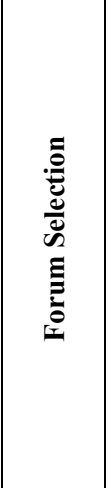 & & 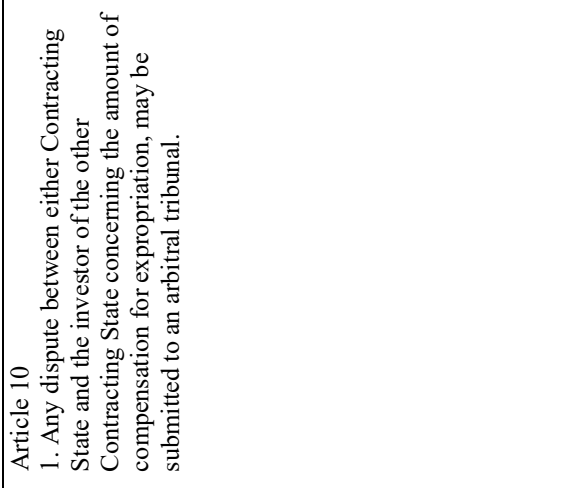 & 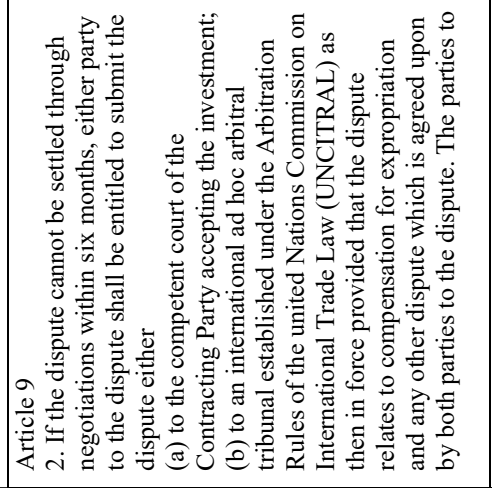 \\
\hline 竞 & & $\frac{\mathbb{z}}{z}$ & 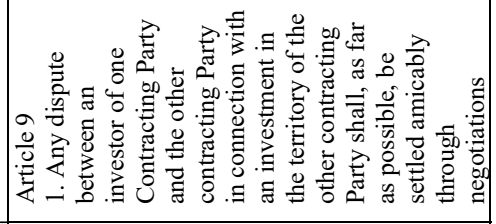 \\
\hline 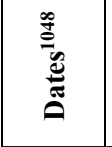 & & 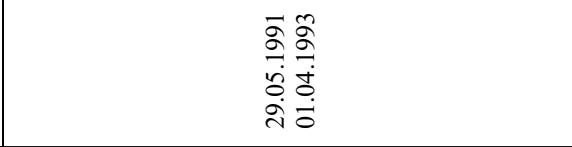 & 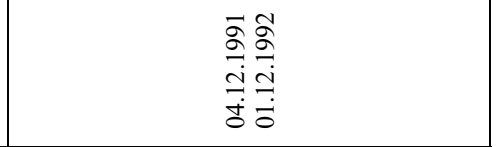 \\
\hline 空离 & & 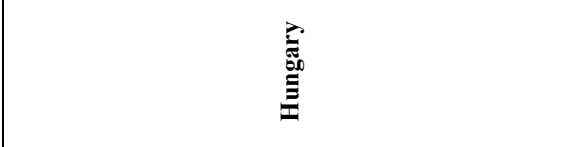 & 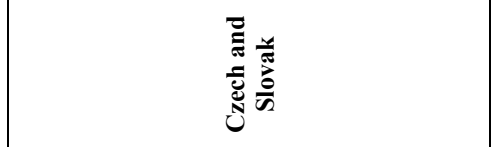 \\
\hline $\mathrm{z} \dot{0}$ & & 9 & \pm \\
\hline
\end{tabular}




\begin{tabular}{|c|c|c|}
\hline 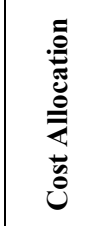 & & 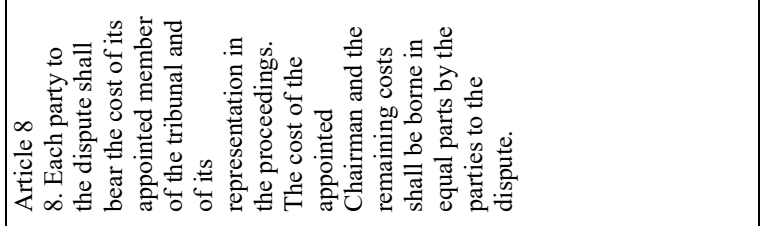 \\
\hline 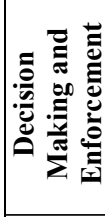 & & 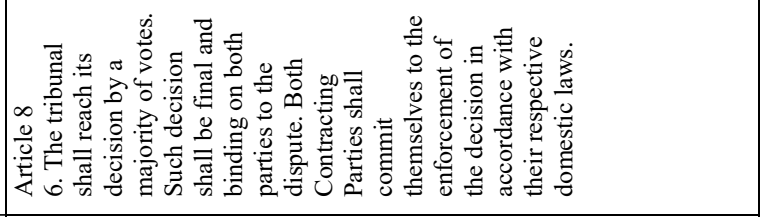 \\
\hline 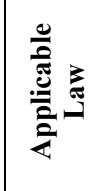 & & 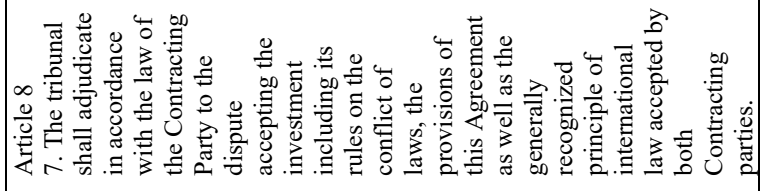 \\
\hline 跣 & 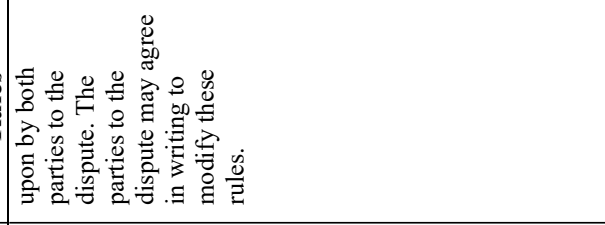 & 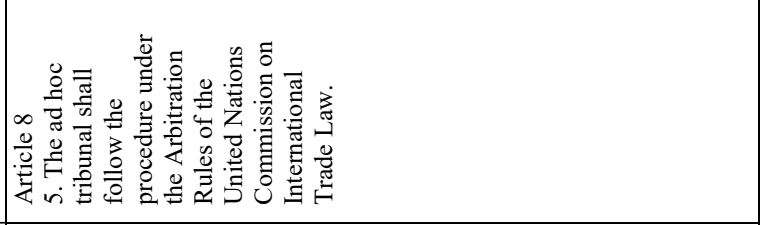 \\
\hline 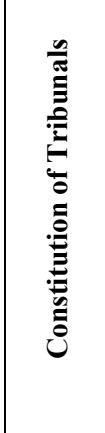 & & 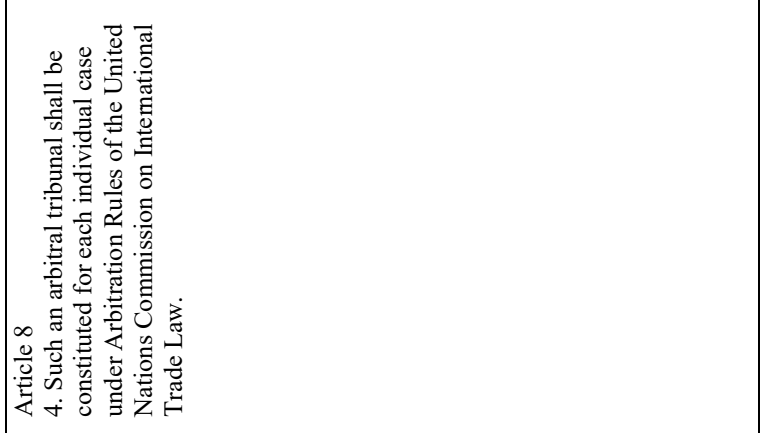 \\
\hline 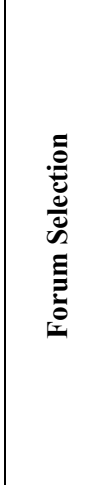 & 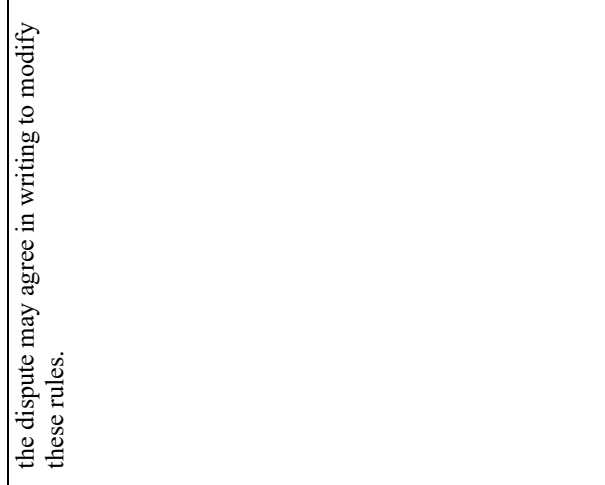 & 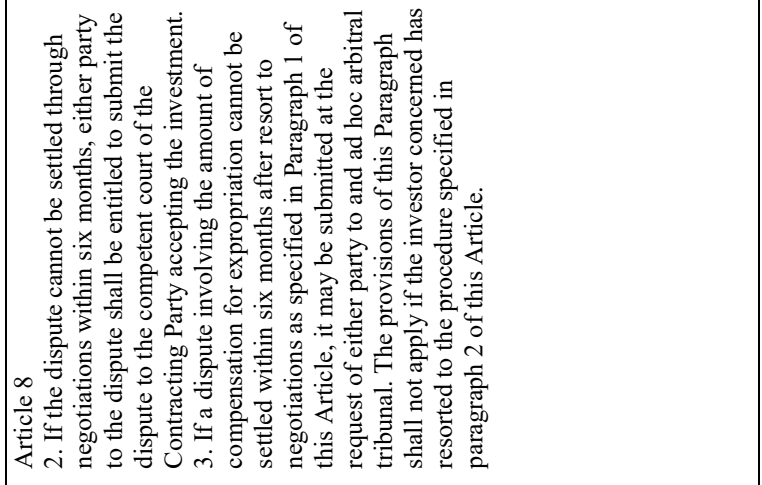 \\
\hline 焉 & 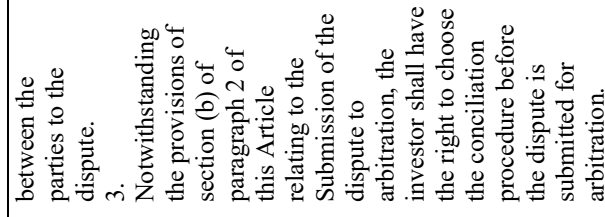 & 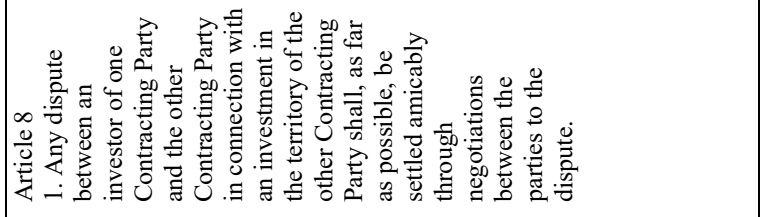 \\
\hline 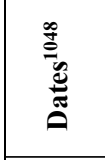 & & 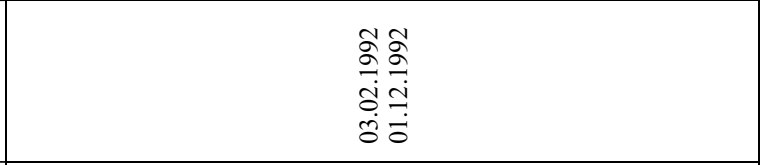 \\
\hline 离 & & 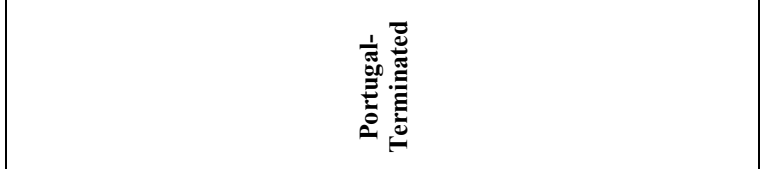 \\
\hline $\mathrm{z} \dot{0}$ & & 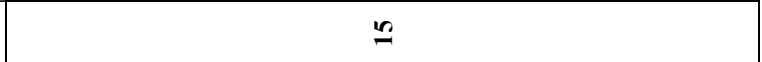 \\
\hline
\end{tabular}




\begin{tabular}{|c|c|c|}
\hline 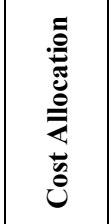 & 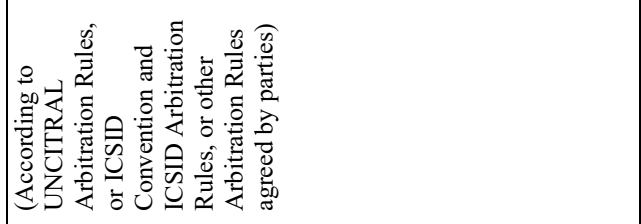 & 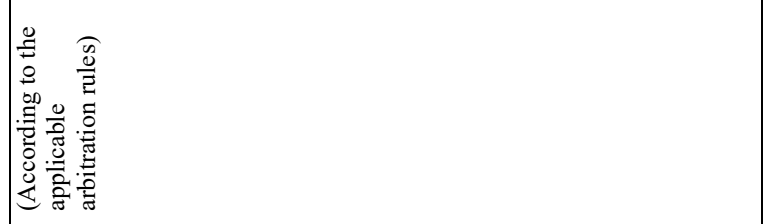 \\
\hline 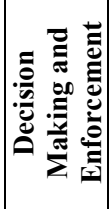 & 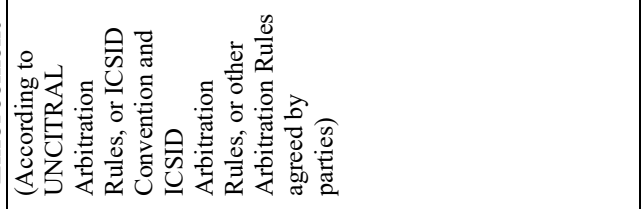 & 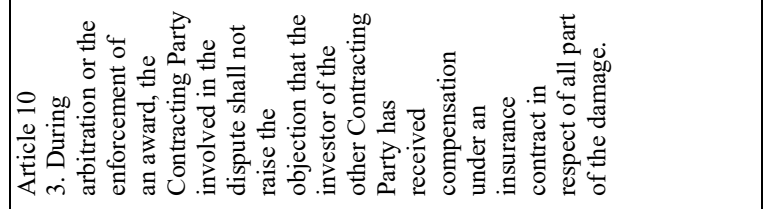 \\
\hline 总 & 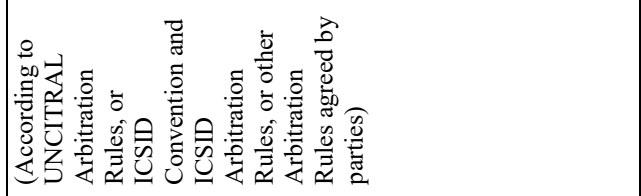 & 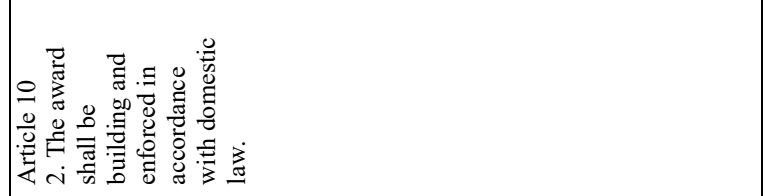 \\
\hline 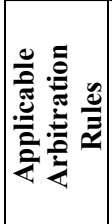 & 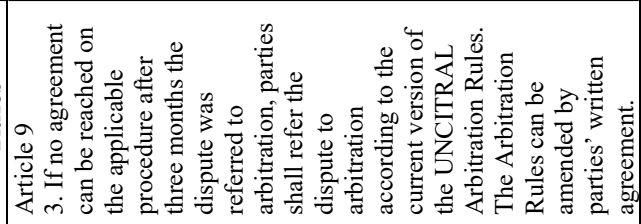 & 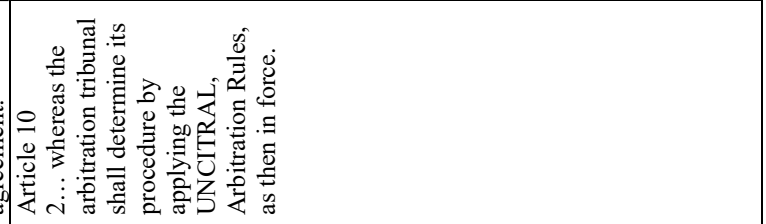 \\
\hline 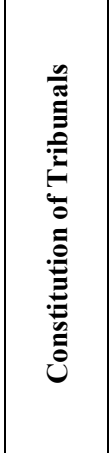 & 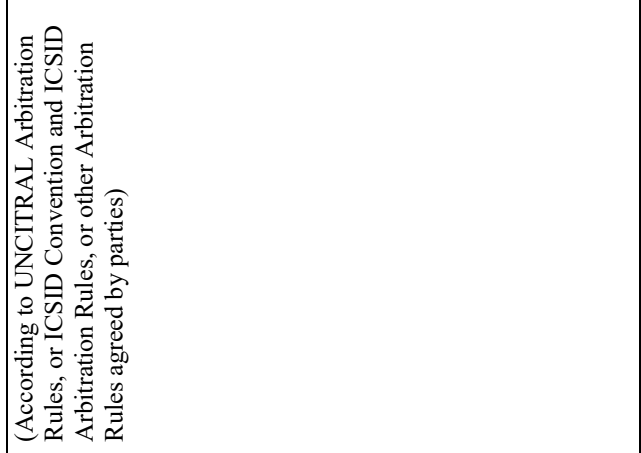 & 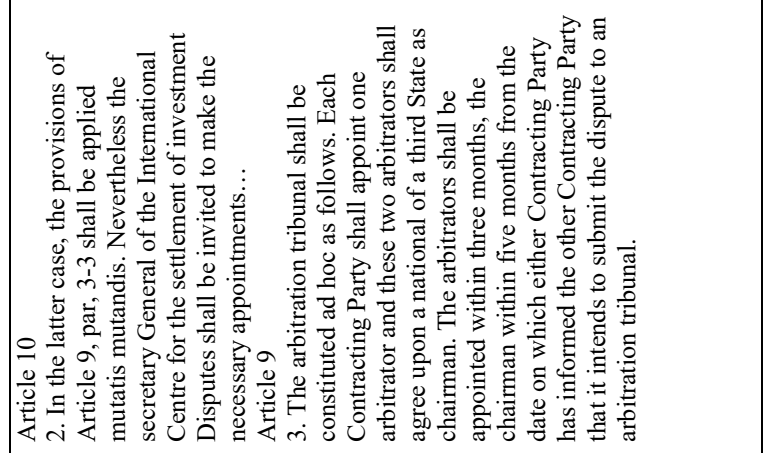 \\
\hline 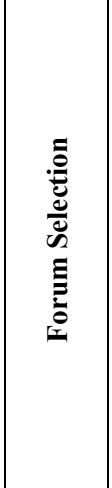 & 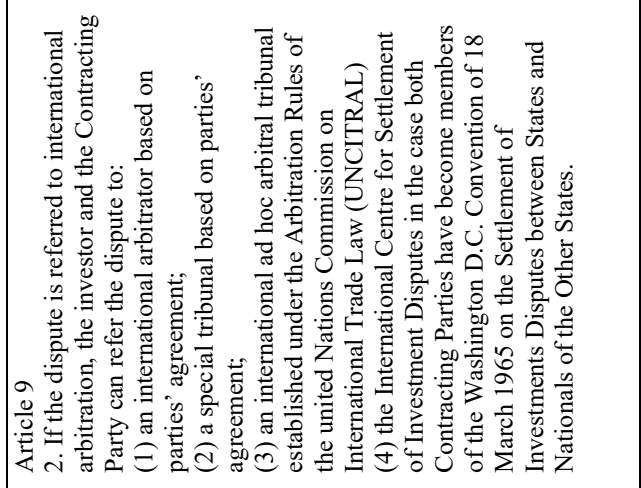 & 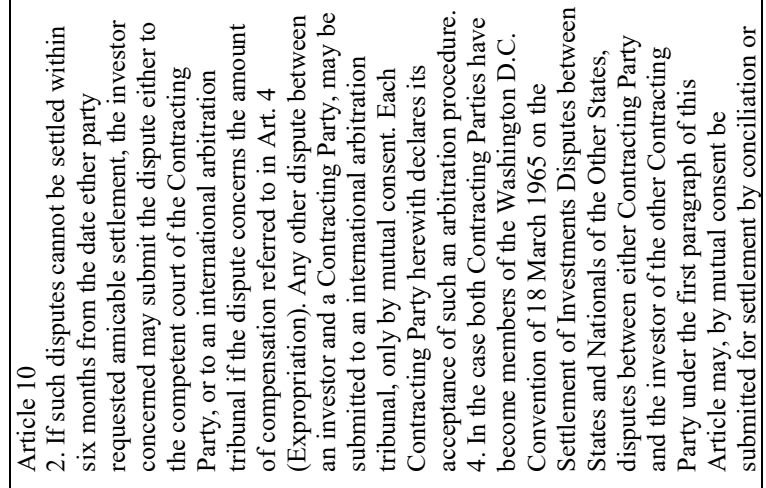 \\
\hline 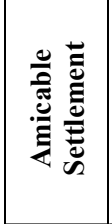 & 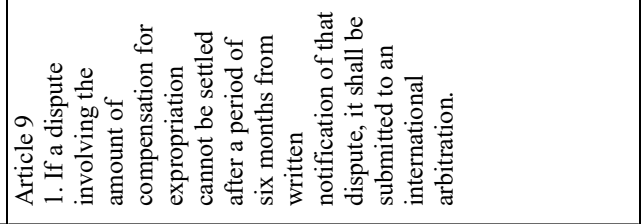 & 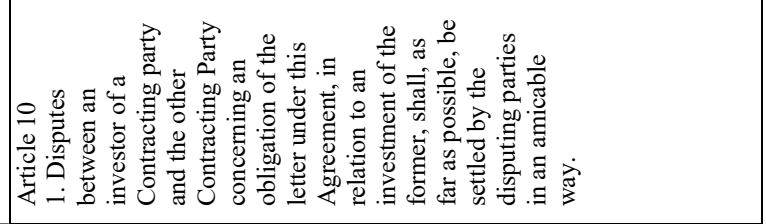 \\
\hline 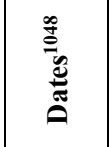 & 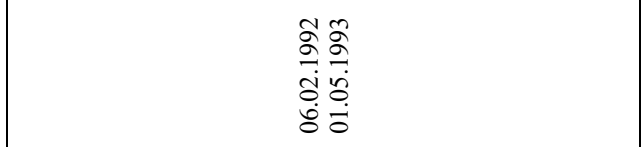 & 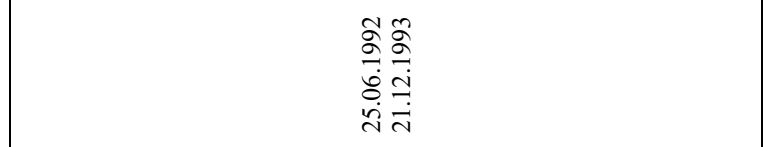 \\
\hline 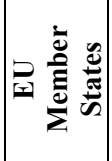 & 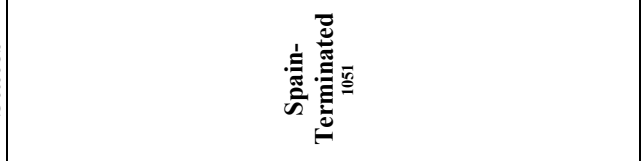 & 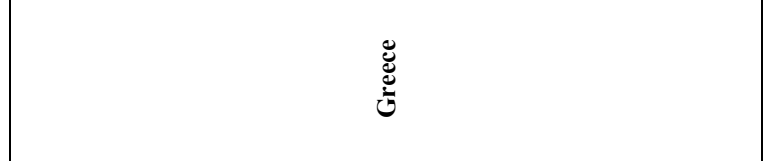 \\
\hline $\mathrm{z} \dot{0}$ & $\stackrel{\bullet}{\sim}$ & $\simeq$ \\
\hline
\end{tabular}




\begin{tabular}{|c|c|c|c|}
\hline 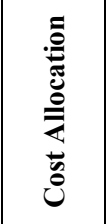 & & 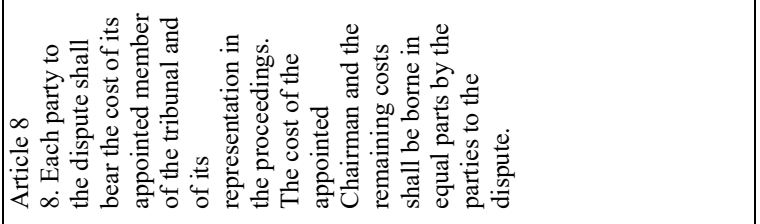 & 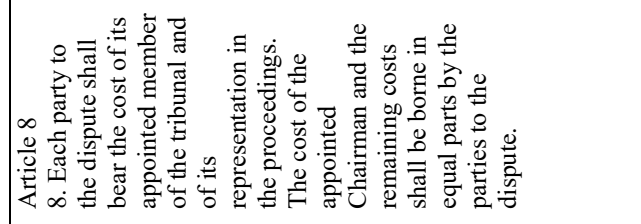 \\
\hline 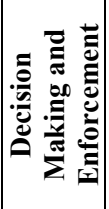 & & 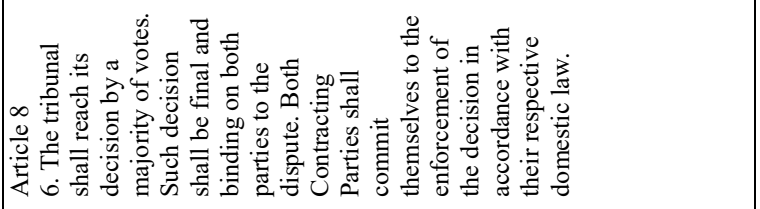 & 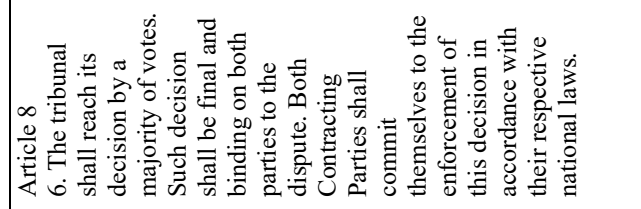 \\
\hline 产 & & 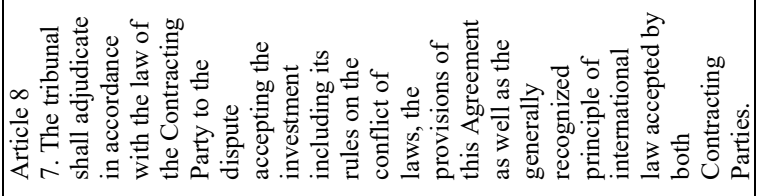 & 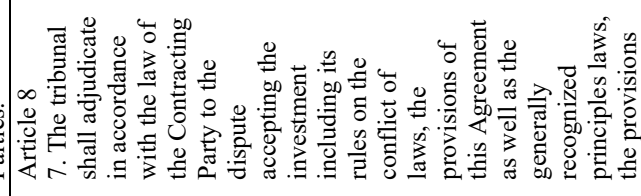 \\
\hline 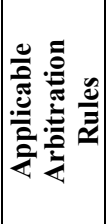 & & 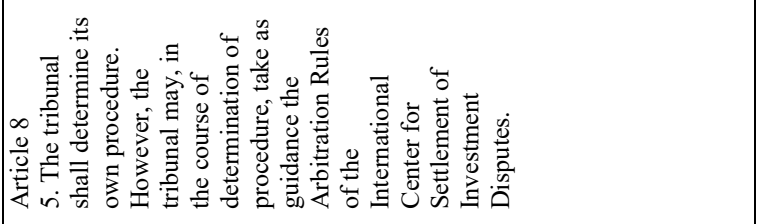 & 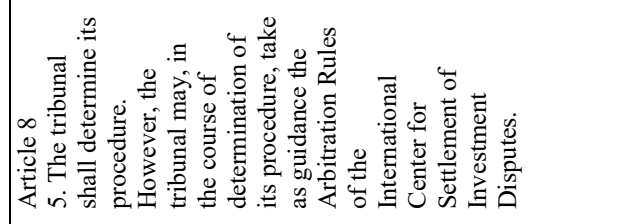 \\
\hline 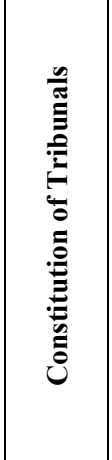 & & 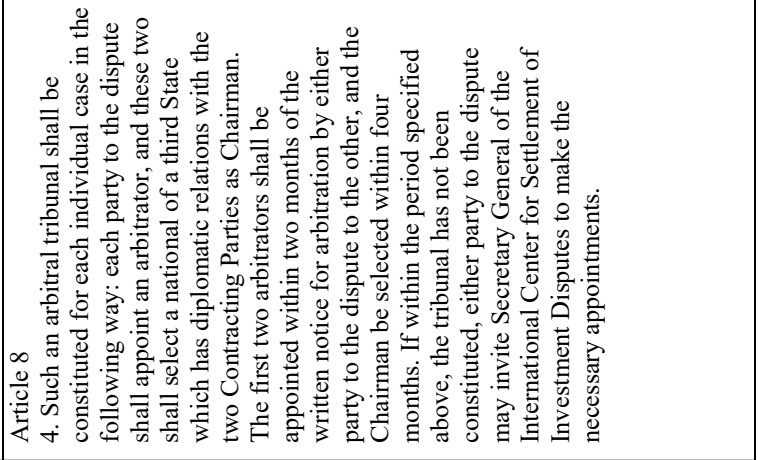 & 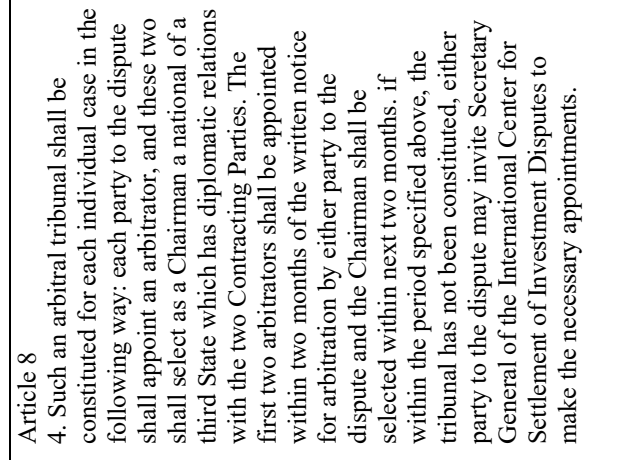 \\
\hline 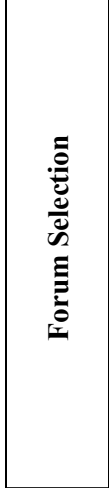 & 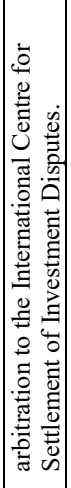 & 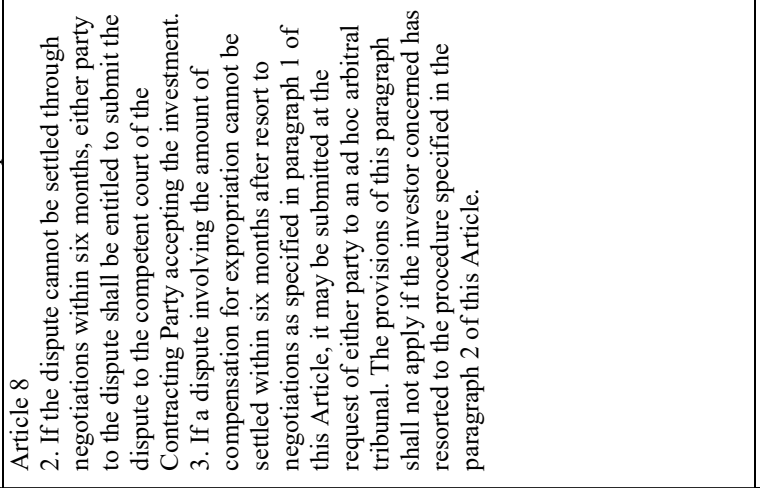 & 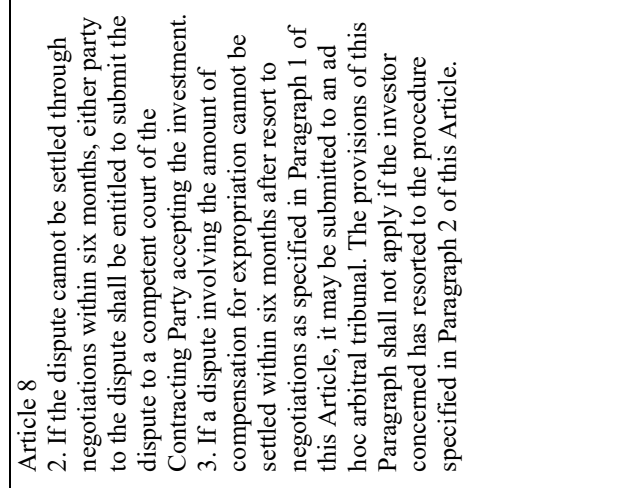 \\
\hline 资 & & 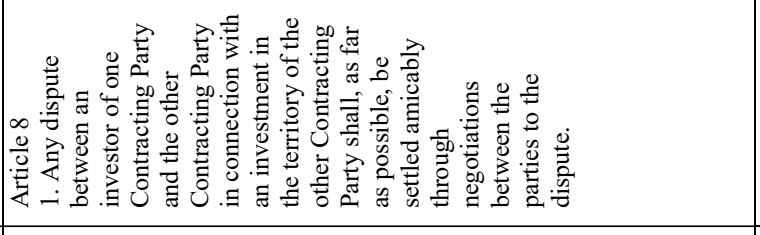 & 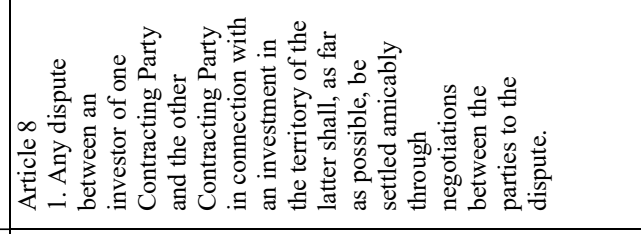 \\
\hline 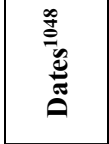 & & 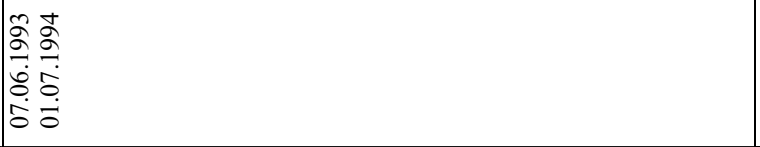 & 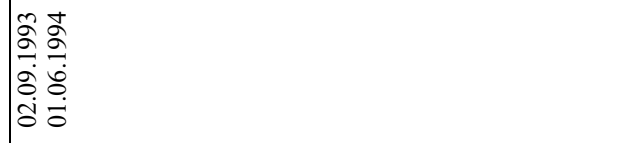 \\
\hline 厗 & & Uू & 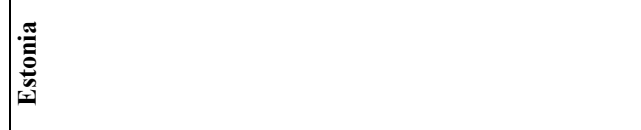 \\
\hline $\mathrm{z} \dot{0}$ & & 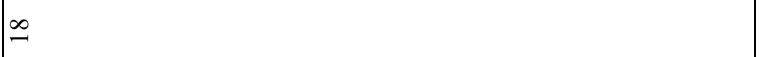 & 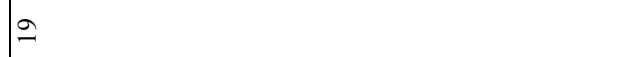 \\
\hline
\end{tabular}




\begin{tabular}{|c|c|c|c|}
\hline 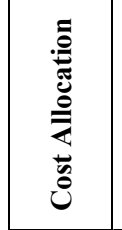 & & 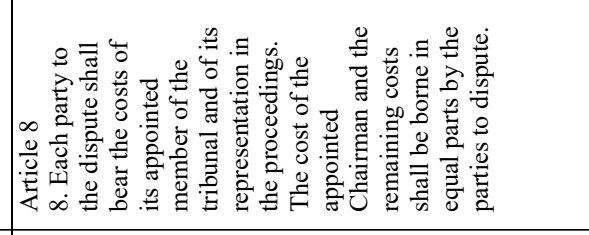 & 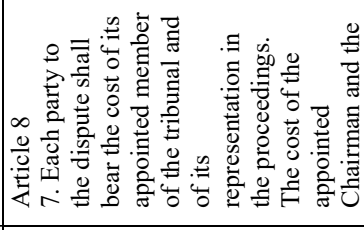 \\
\hline 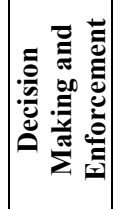 & & 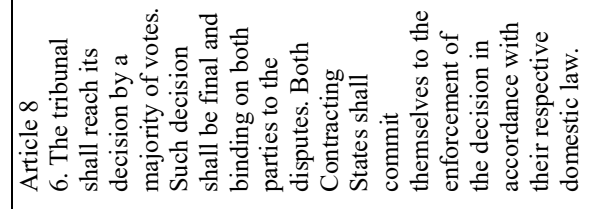 & 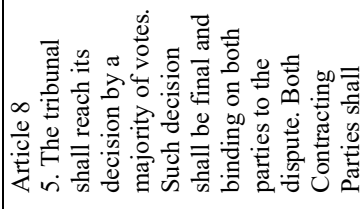 \\
\hline 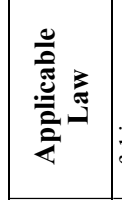 & 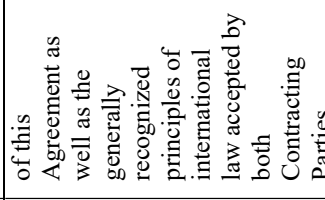 & 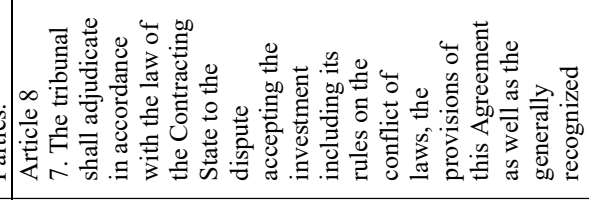 & 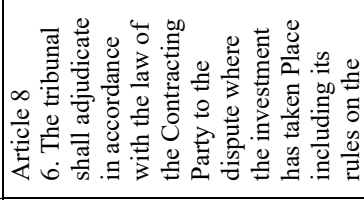 \\
\hline 量言 & & 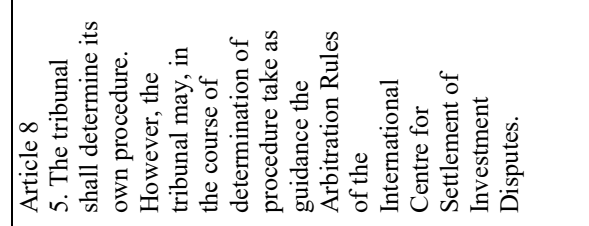 & 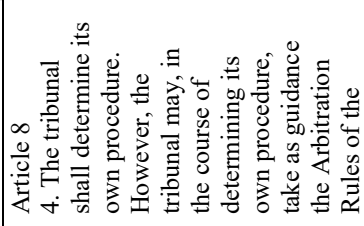 \\
\hline 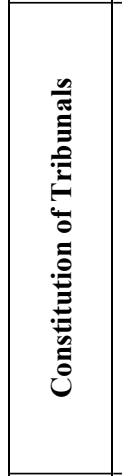 & & 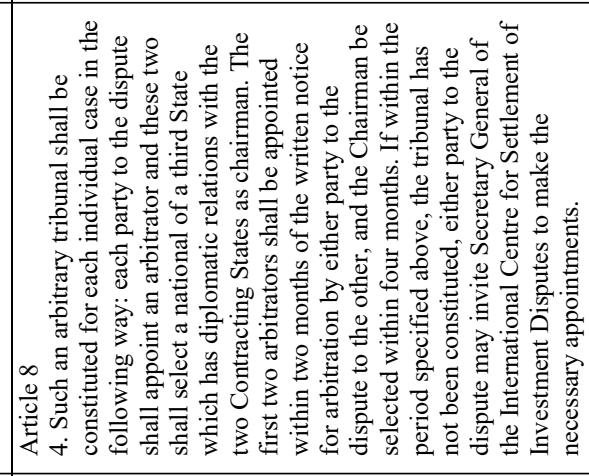 & 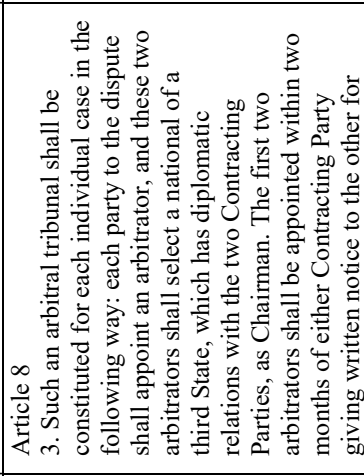 \\
\hline 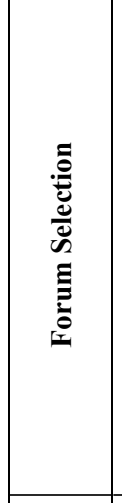 & & 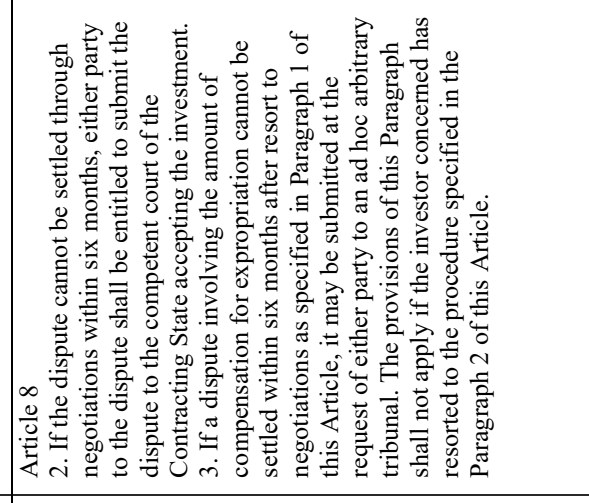 & 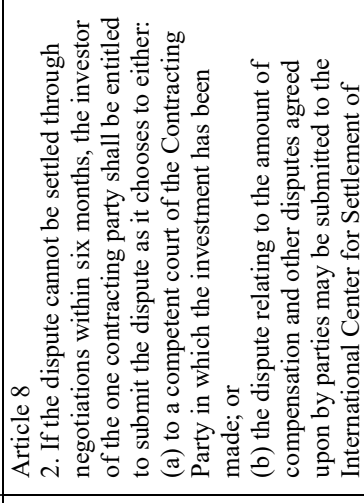 \\
\hline 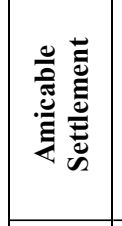 & & 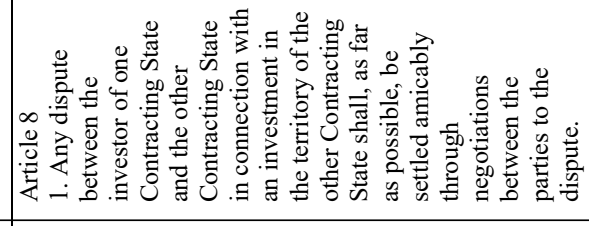 & 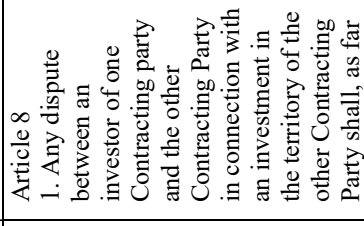 \\
\hline 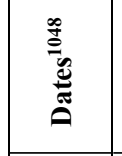 & & 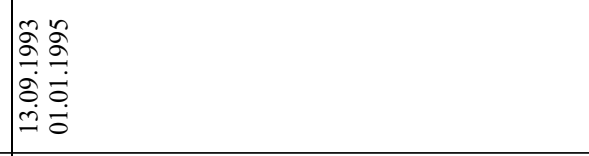 & 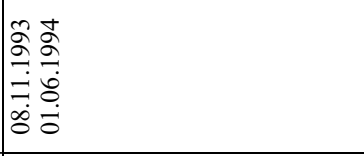 \\
\hline 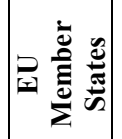 & & 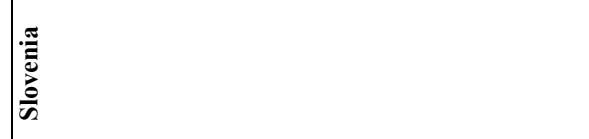 & 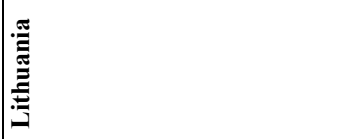 \\
\hline $\mathrm{z} \dot{0}$ & & i & $\vec{\lambda}$ \\
\hline
\end{tabular}




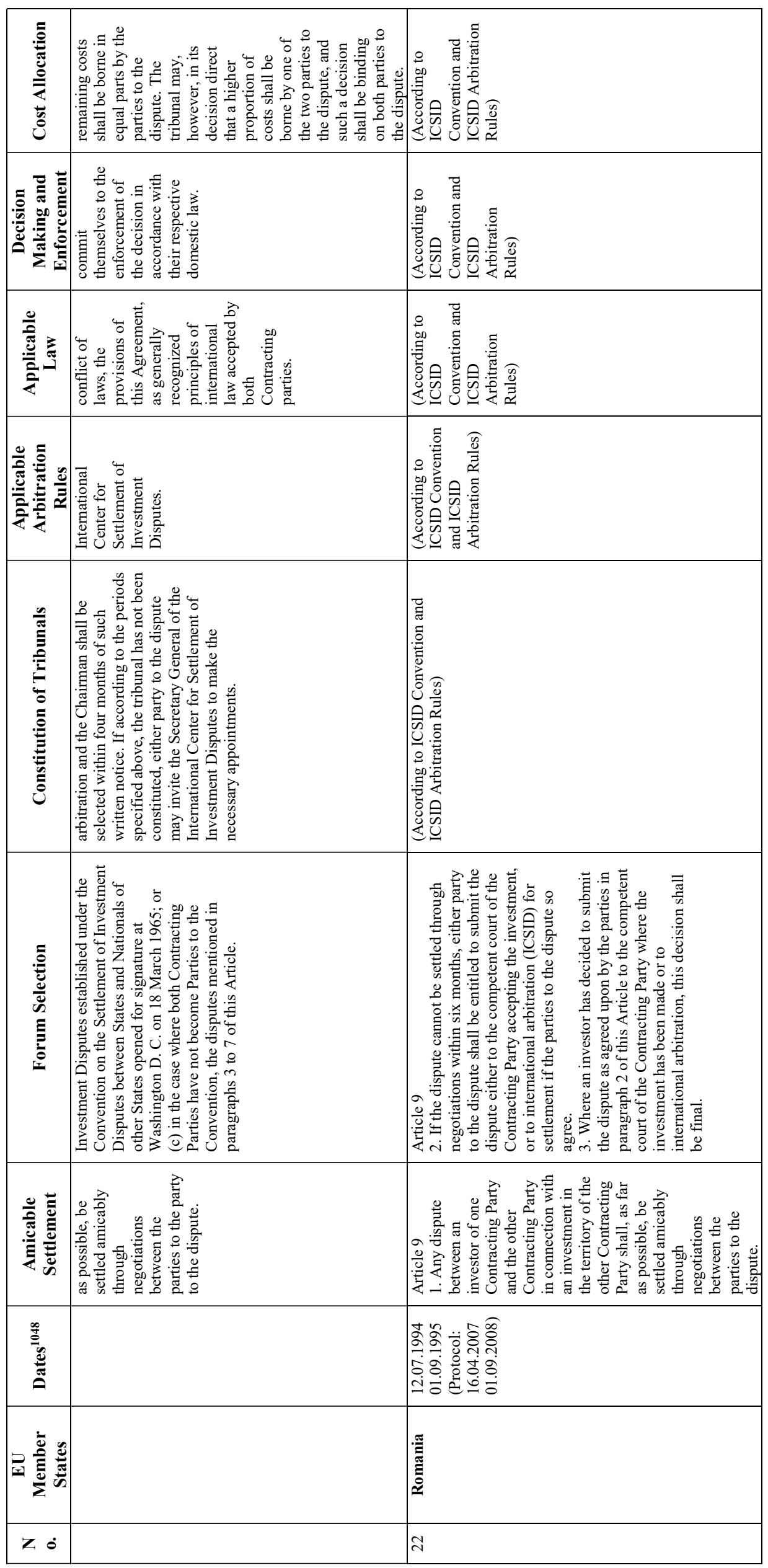




\subsubsection{Stage Two: 1997-2009}

During 1997-2009, four new BITs were concluded and seven BITs were updated between China and EU Member States. Compared to stage one, in line with the overall development of China's BITs, two big changes took place in these 11 treaties related to investor-state DSMs: the elimination of the restrictions on the subject matter of investor-state arbitration and the adoption of ICSID arbitration. These two changes are in line with the corresponding provisions in the China Model BIT (1997).

In general, as in the BITs concluded in Stage One, both amicable and adjudicative DSMs are provided for ISDS, which are introduced in the following. More details of relevant treaty provisions contained in these 11 BITs are provided in TABLE 9.3.2.2.

\section{(i) Amicable Dispute Settlement Mechanisms}

Different from the Stage One, amicable settlement through negotiation is expressly mentioned in each of these 11 BITs. These provisions often state that disputes concerning investment between a treaty party and an investor of the other treaty party "shall, as far as possible, be settled amicably through negotiations between the parties to the dispute". ${ }^{1052}$ Variations exist on three points. First, "legal dispute" instead of "dispute" is used in the China-Cyprus BIT (2001), the China-Latvia BIT (2004) and the China-BLEU BIT (2005), ${ }^{1053}$ although no definition is given to either term. Second, the China-Germany BIT (2003), the China-Finland BIT (2004) and the China-Portugal BIT (2005) use the word "should" instead of "shall". ${ }^{1054}$ Third, a notification from the investor in writing to the host state is required as the signal that the dispute settlement process is being initiated in China's BITs with Spain, the BLEU and Malta. ${ }^{1055}$ Of particular note here is that, in the China-Malta BIT (2009), the written notification shall be made to both the host state and the home state. ${ }^{1056}$ In addition to negotiation, in particular, the China-the Netherlands BIT (2001) mentions ICSID conciliation ${ }^{1057}$ and the China-BLEU BIT (2005) states the possibility of "seeking expert advice from a third party, or by conciliation between the Contracting Parties through diplomatic channels". ${ }^{1058}$ In addition, a minimum time requirement of six months is stipulated in most of these BITs for going through amicable settlement. ${ }^{1059}$

\section{(ii) Adjudicative Dispute Settlement Mechanisms}

If no settlement agreement can be reached, an investor may refer the dispute to the competent court of the host state or an international forum, which may require that local

\footnotetext{
1052 See e.g. the China-Cyprus BIT (2001), Art. 9.1.

1053 The China-Cyprus BIT (2001), Art. 9.1; the China-Latvia BIT (2004), Art. 9.1; the China-BLEU BIT (2005), Art. 8.1.

1054 The China-Germany BIT (2003), Art. 9 (1); the China-Finland BIT (2004), Art. 9.1; the China-Portugal BIT (2005), Art. 9.1.

1055 The China-Spain BIT (2005), Art. 9.1; the China-BLEU BIT (2005), Art. 8.1; the China-Malta BIT (2009), Art. 9.1 .

1056 The China-Malta BIT (2009), Art. 9.1.

1057 The China-the Netherlands BIT (2001), Art. 10.3.

1058 The China-BLEU BIT (2005), Art. 8.1.

1059 See e.g. the China-BLEU BIT (2005), Art. 8.2. An exception here is the China-Finland BIT (2004), where three months is required. See: the China-Finland BIT (2004), Art. 9.2.
} 
remedies are exhausted. ${ }^{1060}$ Regarding international fora, a key feature of these 11 BITs is that ICSID is provided as an option in each of them in addition to ad hoc arbitration, which reflects China's new membership of the ICSID Convention since 1993. In addition, the restriction on the subject matter of disputes about compensation for expropriation is eliminated. As a result, in the currently effective 26 BITs between China and EU Member States, there are various provisions on the jurisdiction of international arbitration, which can be divided into three categories: (i) only disputes about compensation for expropriation can be submitted to international arbitration; ${ }^{1061}$ (ii) only disputes about compensation for expropriation and other disputes agreed by disputing parties can be submitted to international arbitration; ${ }^{1062}$ (iii) any investment dispute is eligible to be referred to international arbitration. ${ }^{1063}$

Under most BITs, the choice among available internal and international fora is final. Some BITs made a differentiation between the choice of international arbitration and that of the competent court of the host state: the former is final, while the latter is not. Namely, an investor that chooses a domestic court can withdraw the filing and then refer the dispute to international arbitration. ${ }^{1064}$ In addition, some BITs set another precondition for using international arbitration: the host state may require the investor concerned to exhaust "the domestic administrative review procedure specified by the laws and regulations of that Contracting Party" before the dispute can be submitted to international arbitration. ${ }^{1065}$

Regarding international arbitration proceedings, these 11 BITs often provide two options, ICSID and ad hoc arbitration. If ICSID is chosen, the ICSID Convention and its arbitration rules will apply. When the dispute settlement process is under ad hoc arbitration, the UNCITRAL Arbitration Rules are often suggested or even required. ${ }^{1066}$ It is likely that these two sets of arbitration rules already contain comprehensive procedural regulations, because many of these BITs do not set out rules on issues such as the constitution of tribunals, decision making and cost allocation. Not all BITs concluded at this stage touch upon the issue of applicable law. Where it is regulated, the law of the host state, the provisions of the BIT at issue and generally recognized principles of international law are provided. ${ }^{1067}$ While the China-Romania BIT (1994) does not include any provision on the enforcement of awards, all the other 10 BITs

\footnotetext{
1060 See e.g. the China-BLEU BIT (2005), Protocol, Ad Art. 8.

1061 This category includes the China-Denmark BIT (1985), the China-Italy BIT (1985), the China-Austria BIT (1985), the China-United Kingdom BIT (1986), the China-Poland BIT (1988), the China-Hungary BIT (1991), the China-Croatia BIT (1993), the China-Estonia BIT (1993), and the China-Slovenia BIT (1993).

1062 This category includes the China-Greece BIT (1992) and the China-Lithuania BIT (1993).

1063 This category includes the China-Bulgaria BIT (1989), the China- Czech and Slovak BIT (2005), the ChinaRomania BIT (1994), the China-Cyprus BIT (2001), the China-the Netherlands BIT (2001), the China-Germany BIT (2003), the China-Finland BIT (2004), the China-Latvia BIT (2004), the China-Sweden BIT Amendment Protocol (2004), the China-BLEU BIT (2005), the China-Czech Republic BIT (2005), the China-Portugal BIT (2005), the China-Spain BIT (2005), the China-France BIT (2007), and the China-Malta BIT (2009).

1064 See e.g. the China-Czech Republic BIT (2005), Art. 9.4. In particular, under the China-Netherlands BIT (2001), Art. 10.2 provides that "[i]f a dispute concerns an investment in the territory of the Kingdom of the Netherlands an investor may choose to submit a dispute to international dispute settlement at any time". Thus, even successful withdrawing from a domestic court seems to be unnecessary.

1065 See e.g. the China-Cyprus BIT (2001), Art. 9.2.

1066 See e.g. the China-Portugal BIT (2005), Art. 9.2.

1067 See e.g. the China-Spain BIT (2005), Art. 9.3.
} 
incorporate articles stipulating that arbitration awards shall be final and binding upon parties to the dispute, and treaty parties shall commit themselves to the enforcement of the award. ${ }^{1068}$

1068 See e.g. the China-Malta BIT (2009), Art. 9.5. 


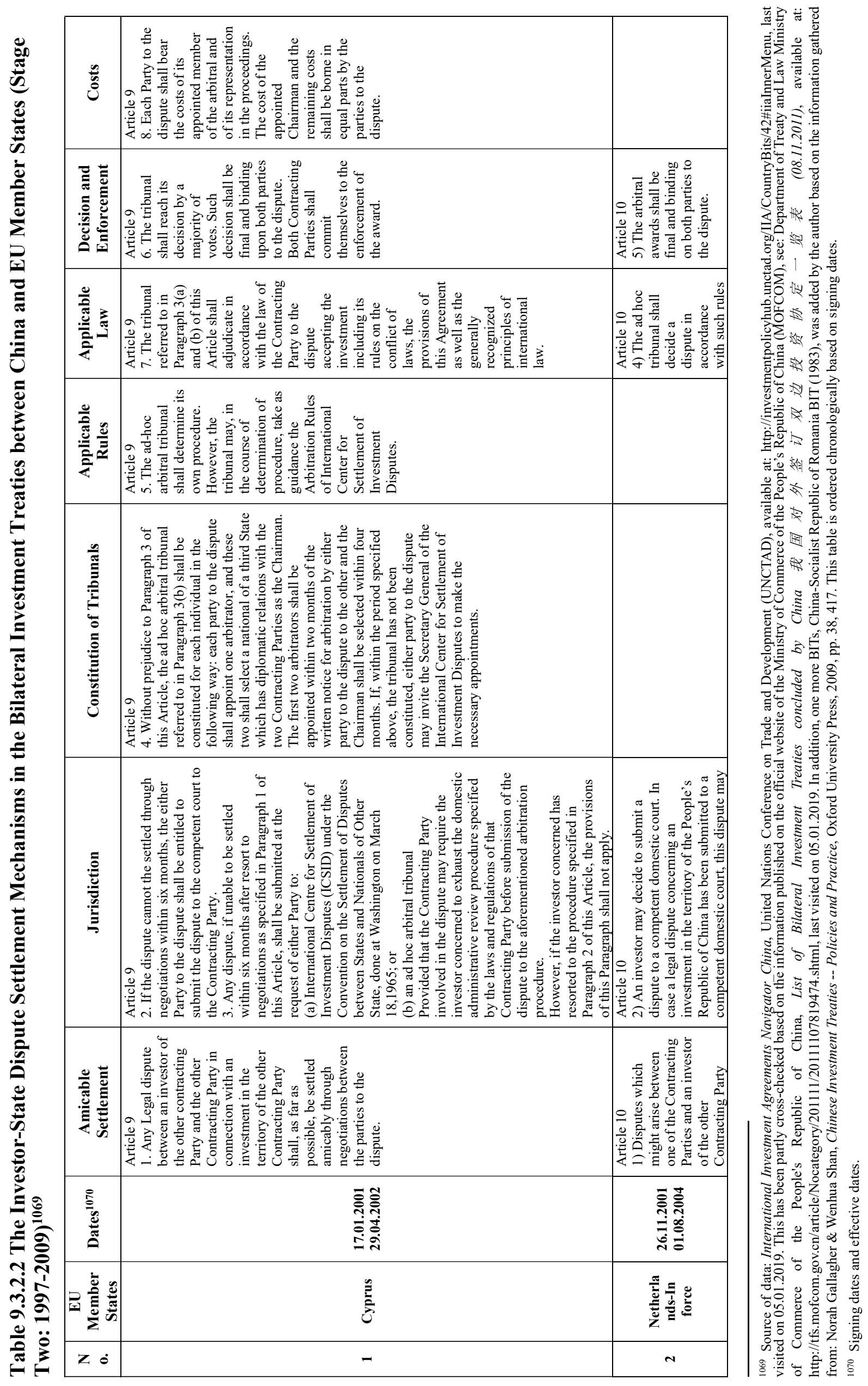




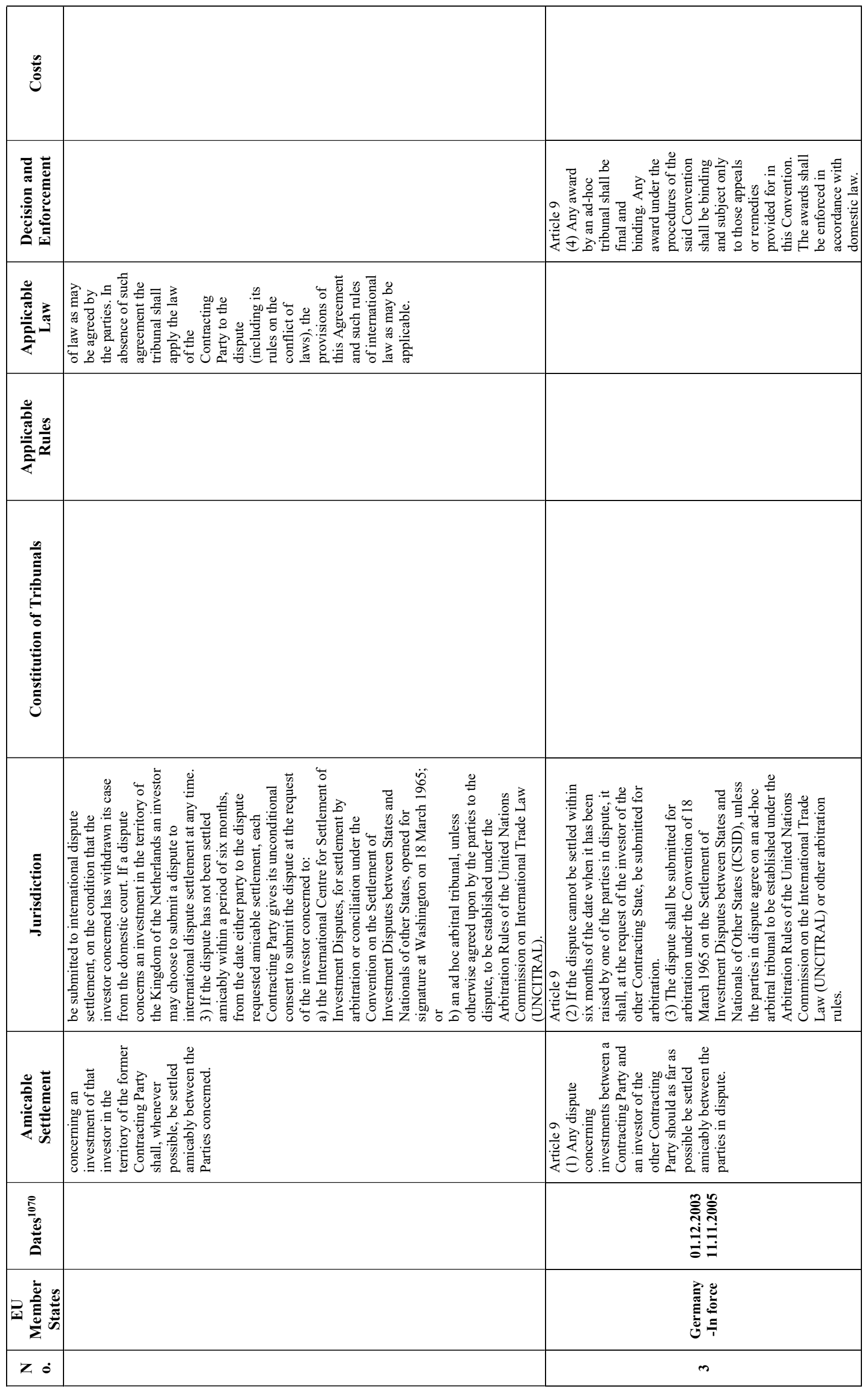




\begin{tabular}{|c|c|c|}
\hline 离 & & \\
\hline 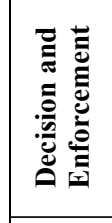 & 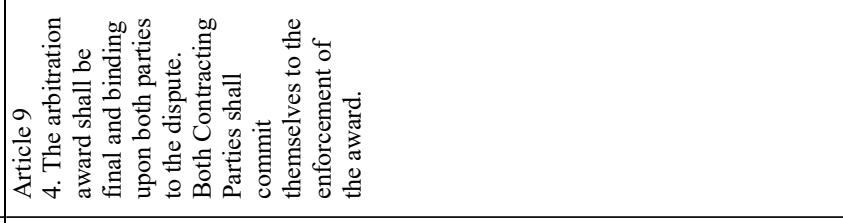 & 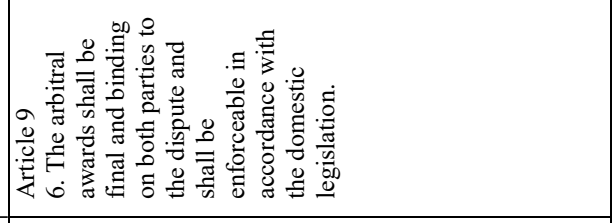 \\
\hline 冚 & 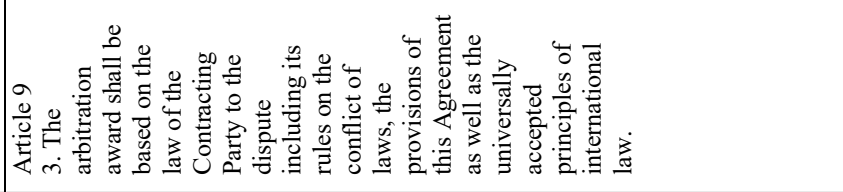 & 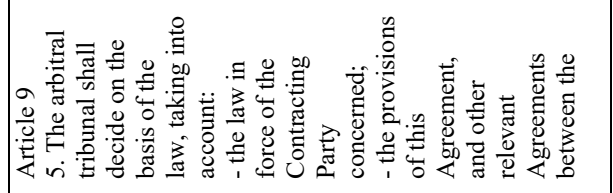 \\
\hline 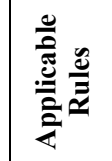 & & \\
\hline 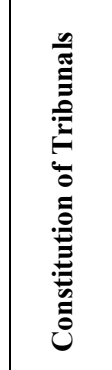 & & \\
\hline 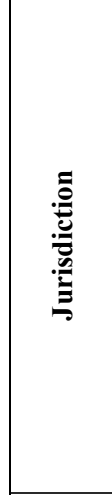 & 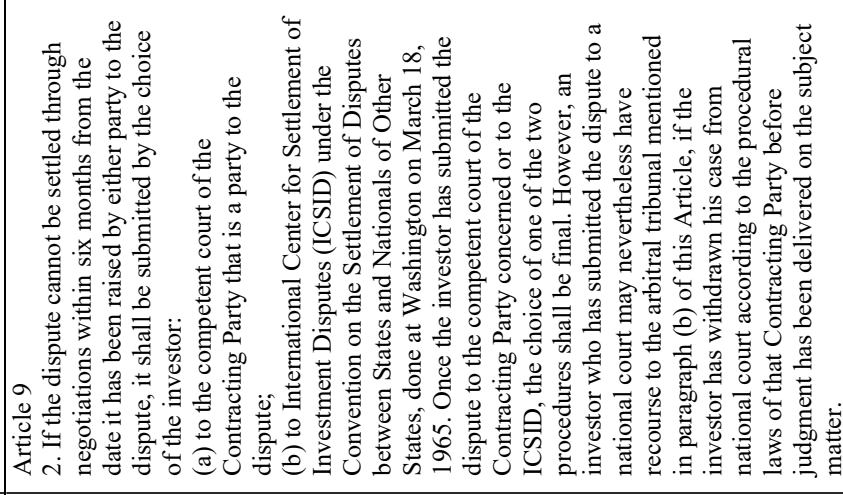 & 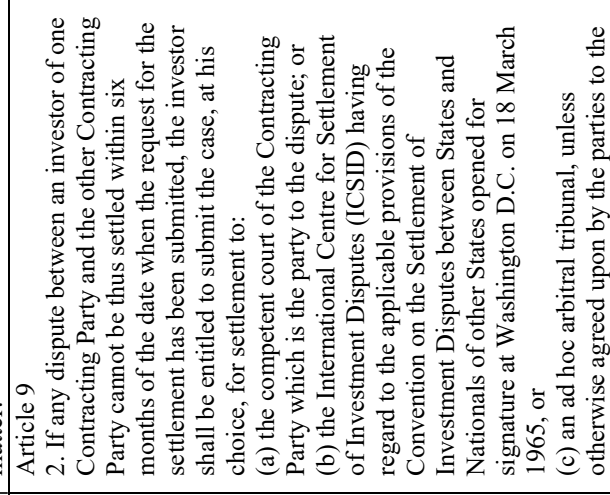 \\
\hline 哭苞 & 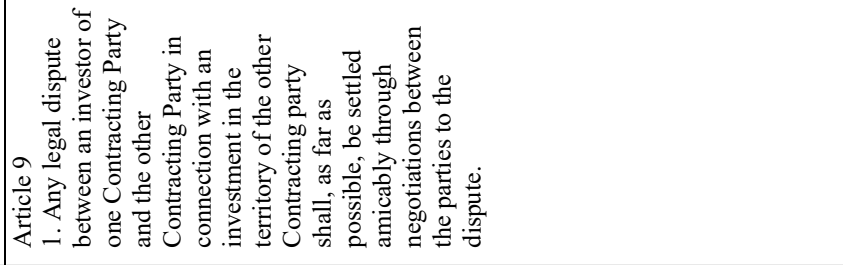 & 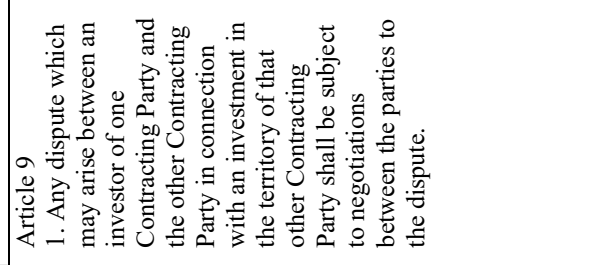 \\
\hline 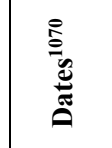 & 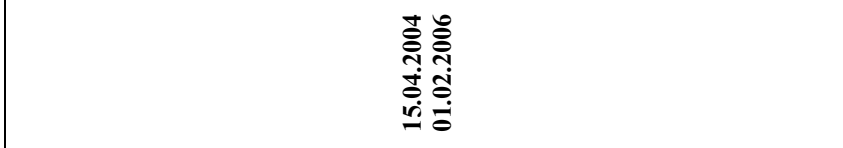 & 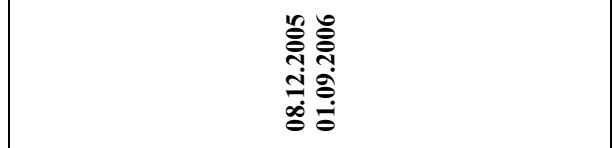 \\
\hline 它 & : & 总言 \\
\hline $\mathrm{z} \dot{0}$ & $\sigma$ & in \\
\hline
\end{tabular}




\begin{tabular}{|c|c|c|}
\hline 商 & & \\
\hline 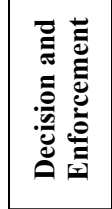 & & 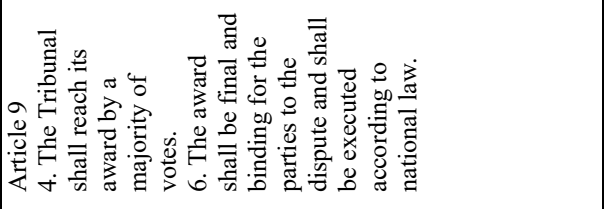 \\
\hline 窇 & 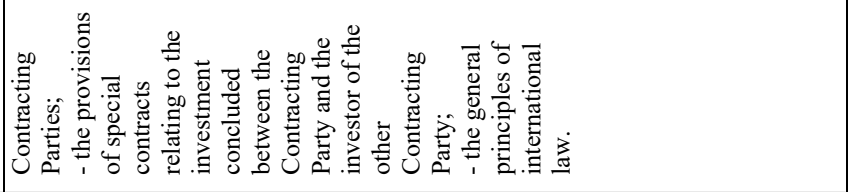 & 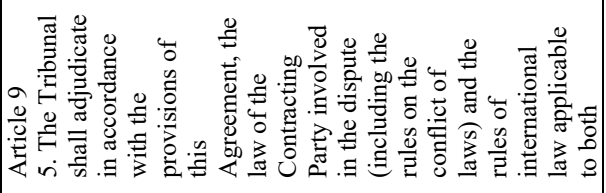 \\
\hline$\frac{0}{0}$ & & \\
\hline 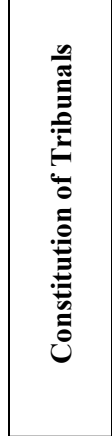 & & 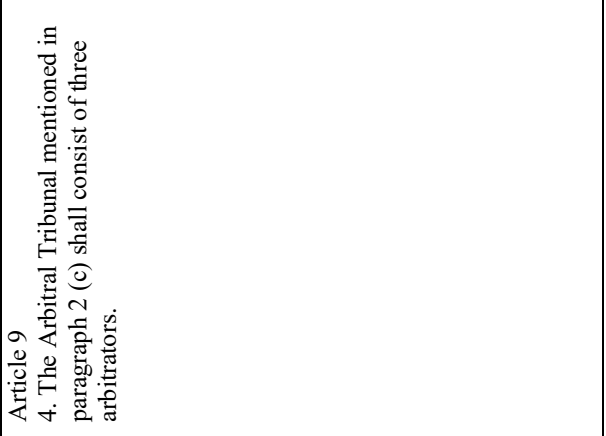 \\
\hline 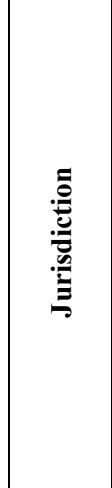 & 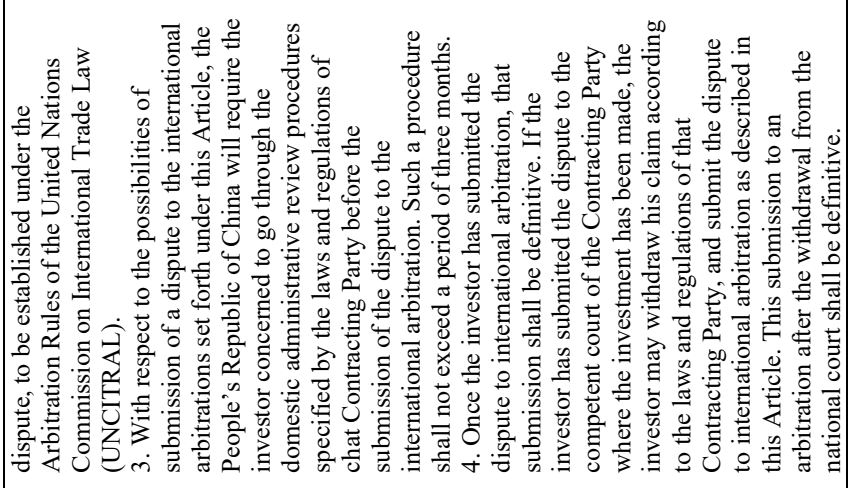 & 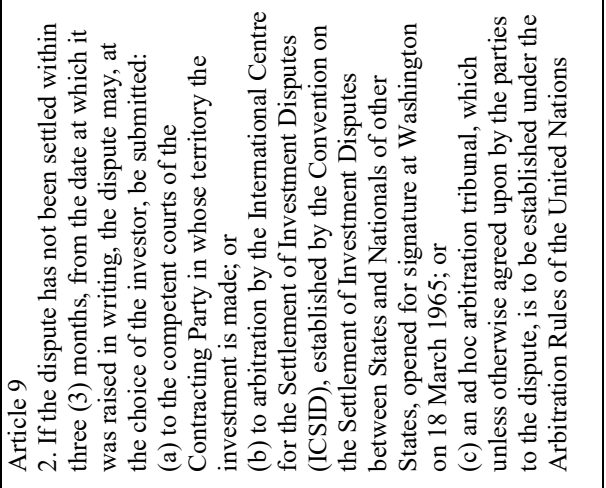 \\
\hline 竞 & & 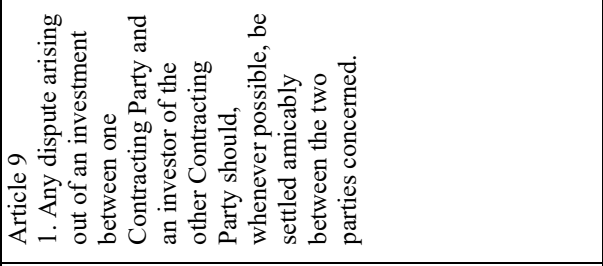 \\
\hline 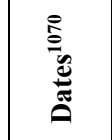 & & 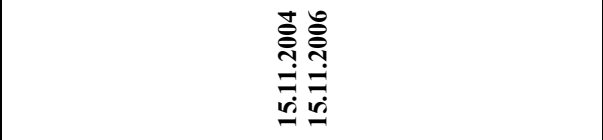 \\
\hline 它 & & 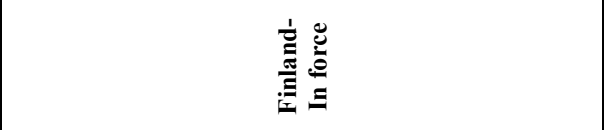 \\
\hline $\mathrm{z} \dot{0}$ & & 6 \\
\hline
\end{tabular}




\begin{tabular}{|c|c|c|c|}
\hline 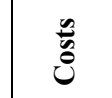 & & & \\
\hline 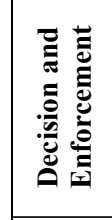 & & 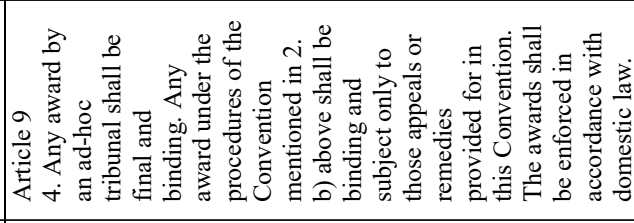 & 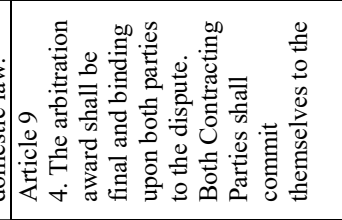 \\
\hline 窇 & 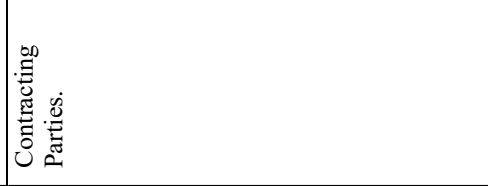 & & 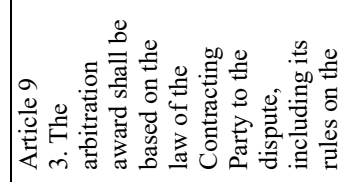 \\
\hline$\frac{0}{\frac{0}{2}}$ & & & \\
\hline 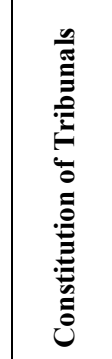 & & & \\
\hline 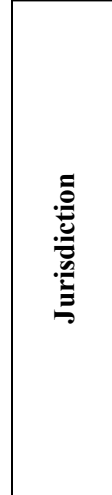 & 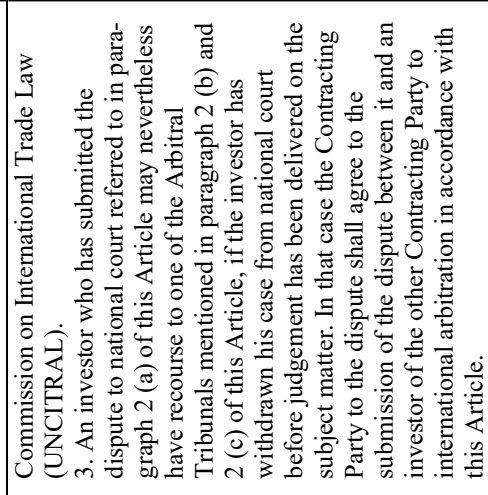 & 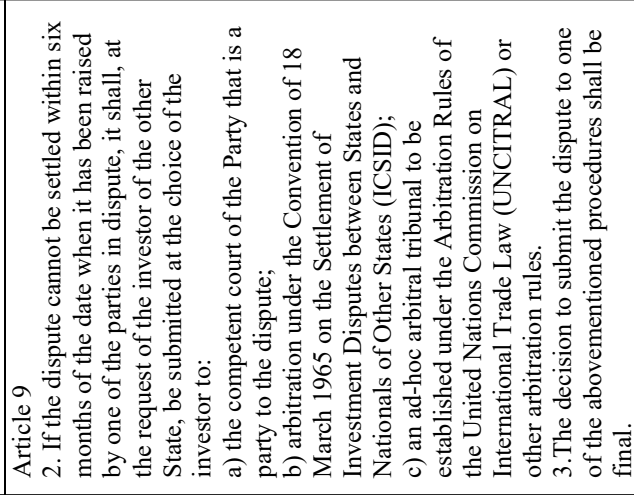 & 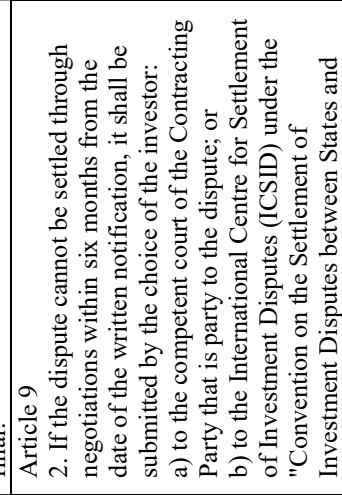 \\
\hline 总 & & 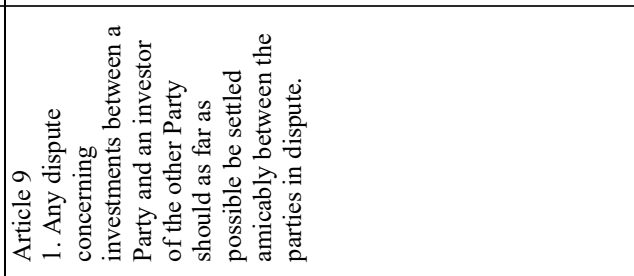 & 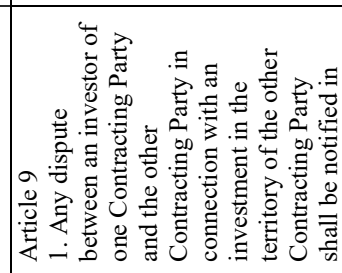 \\
\hline 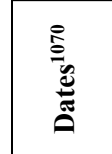 & & 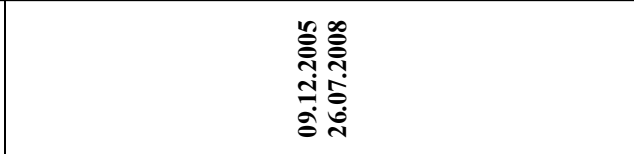 & 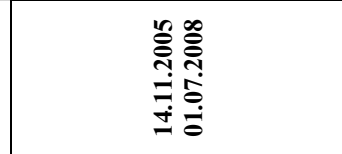 \\
\hline 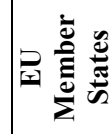 & & 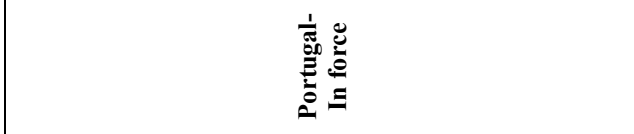 & 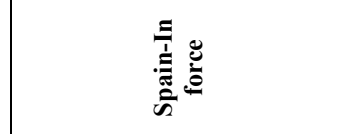 \\
\hline $\mathrm{z} \dot{0}$ & & $r$ & $\infty$ \\
\hline
\end{tabular}




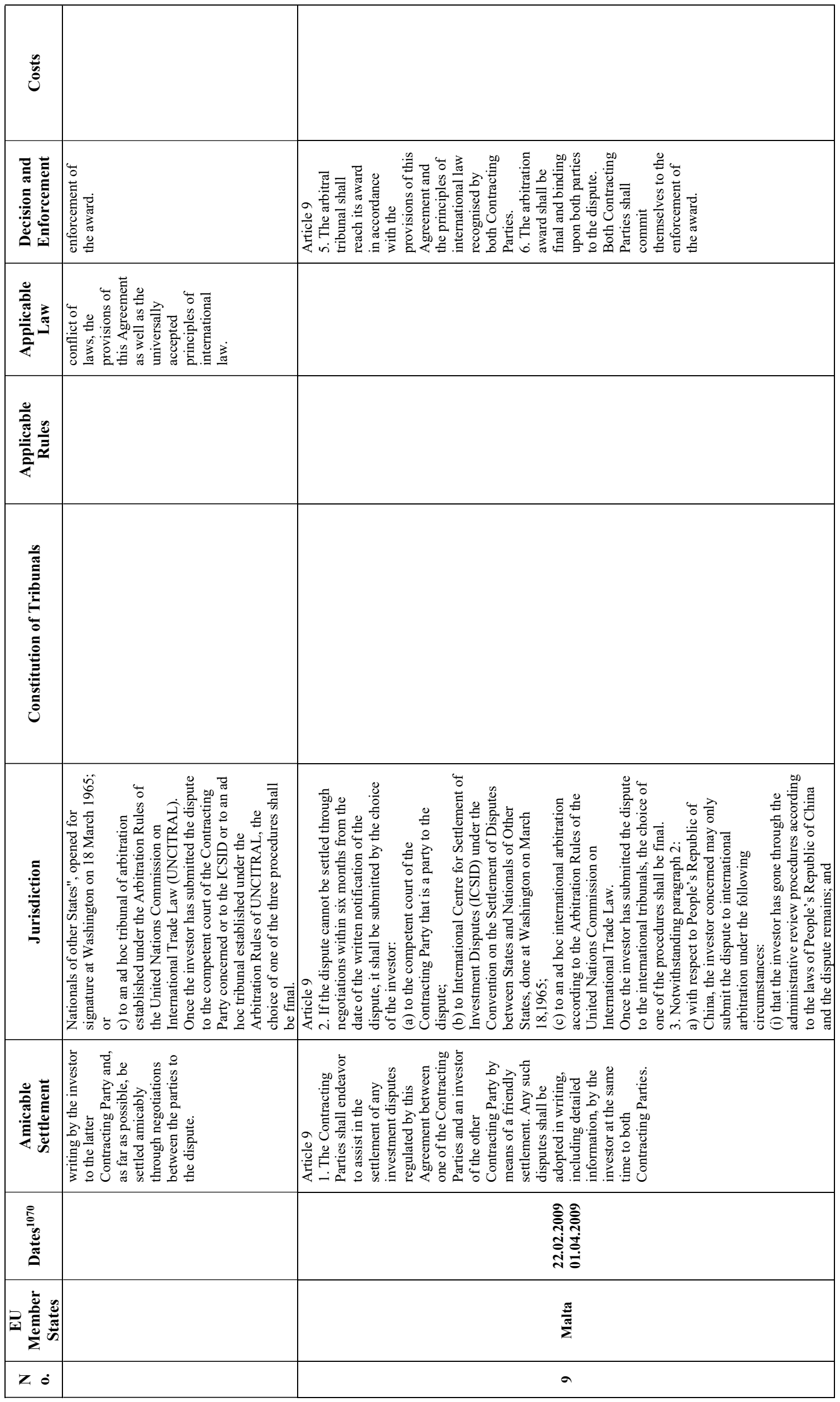




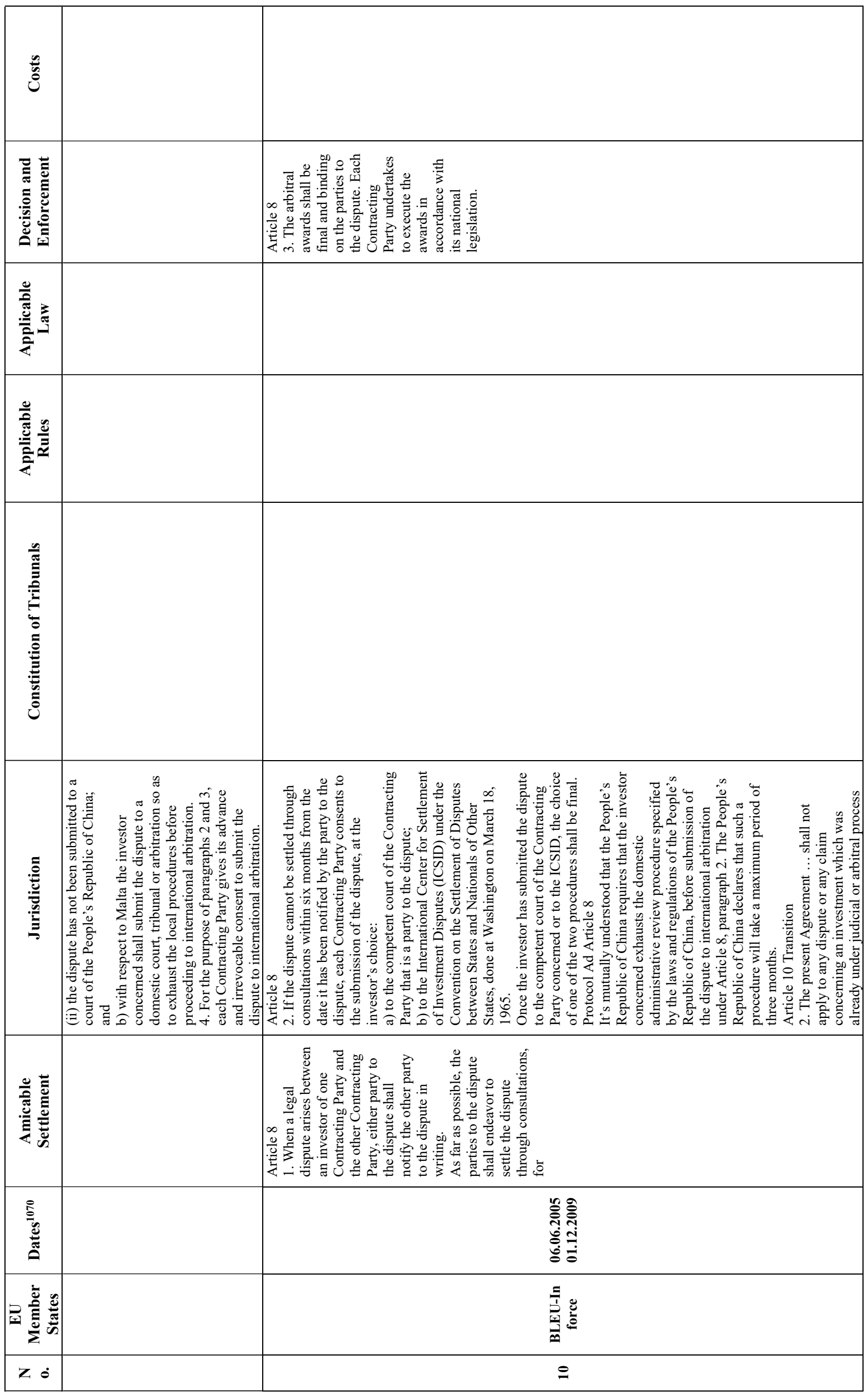




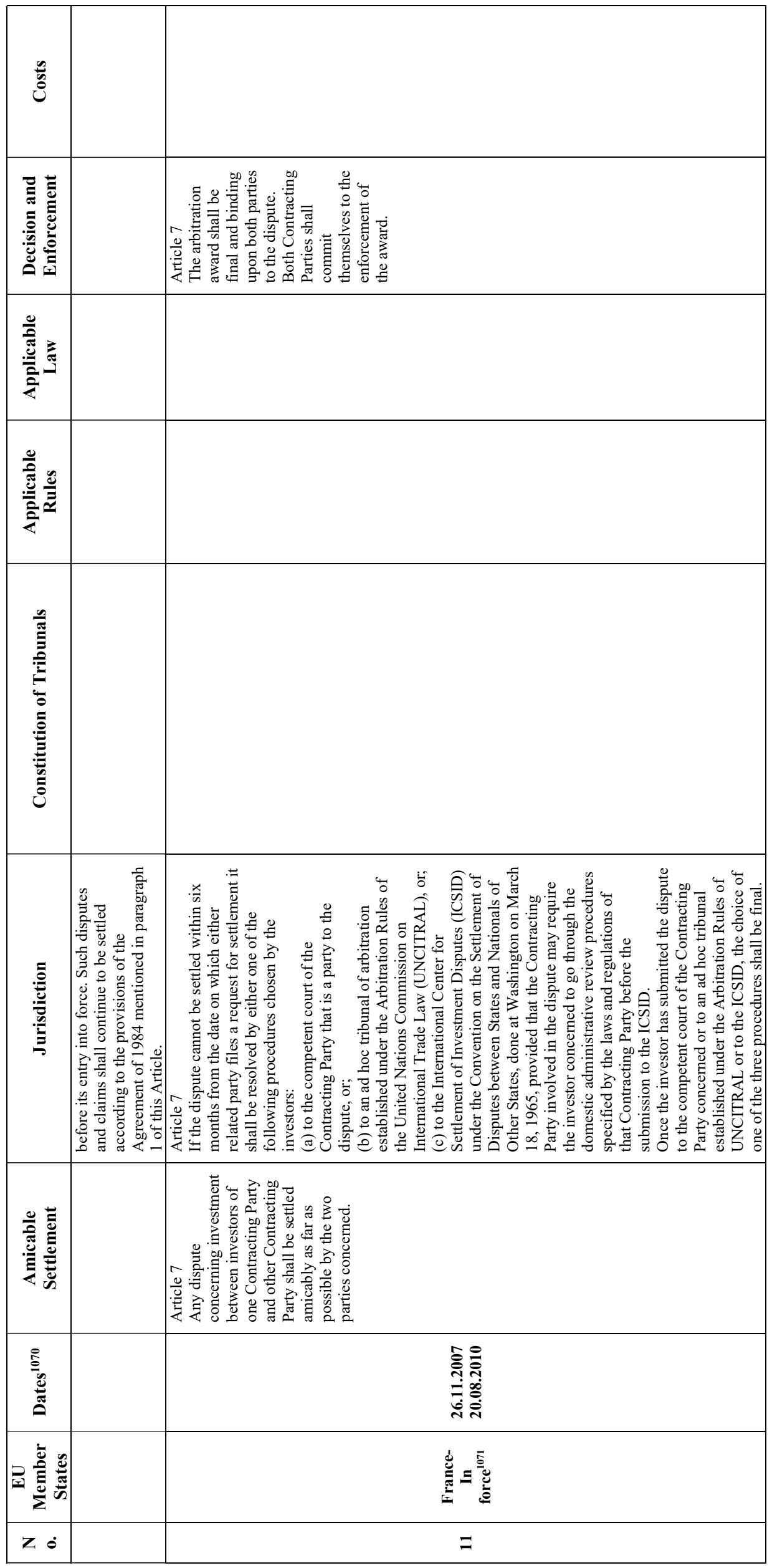

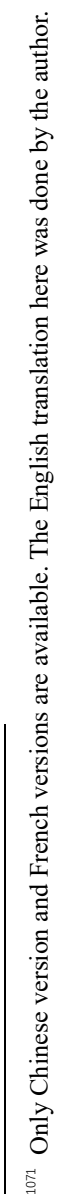




\subsubsection{Cases under the Bilateral Investment Treaties between China and EU Member States}

Until now, there have been only two cases brought under the BITs between China and the EU Member States. One was brought by Chinese investors, Ping An Life Insurance Company of China, Limited and Ping An Insurance (Group) Company of China, Limited, against the Kingdom of Belgium. The other one was brought by a German investor, Hela Schwarz GmbH, against China. Since these two cases were introduced in Section 6.2.3.3, supra, the discussion will not be repeated here.

Although the number of cases under the BITs between China and the EU Member States is very limited, as introduced in Section 7.3.1.1, supra, EU investors have been quite active in international investment arbitration. This is in stark contrast with the fact that only one case has been brought to date by an EU investor against China. Regarding the attitudes of EU investors towards ISDS with China, the public consultation on "The future investment relationship between the EU and China" provides some inspiration, ${ }^{1072}$ which helps to explain the very limited use of international arbitration to resolve disputes between EU investors and China. Regarding the ways of dealing with legal conflicts with the Chinese government on investment, amicable settlement has emerged as the most common approach. Only when this did not work out, some EU investors would consider "end of contract/cooperation" and recourse to local legal proceedings, international arbitration and diplomatic support. ${ }^{1073}$ Furthermore, although international arbitration is an option for at least unfair and discriminatory treatment or expropriation without compensation, only 40 per cent of investors would consider starting international arbitration proceedings on the basis of an investment treaty. In terms of the reasons for such a result, alongside the concerns about the time and costs of international arbitration, EU investors worried that international arbitration would seriously damage the relationship with the Chinese government, and thus would negatively impact other investments that they had made there and their business opportunities in China's significant market. In addition, EU investors generally lacked confidence in China's domestic legal system, and there local remedies were also not desired. Unfortunately, no similar public consultation report on Chinese investors' views on ISDS with the EU are available. The absence of such concrete empirical evidence makes it difficult to assess the reasons for the limited use of international arbitration between Chinese investors and EU Member States.

\subsection{Conclusion}

The Lisbon Treaty led to a ground-breaking change in the investment relationship between China and the EU. Before 2009, the Union only concluded general economic

\footnotetext{
1072 European Commission-Director-General for Trade, Summary of Contributions to the European Commission's Public Consultation on "The Future Investment Relationship Between the EU and China", 2011, available at: http://trade.ec.europa.eu/doclib/docs/2011/december/tradoc_148394.pdf, last visited on 29.05.2020.

1073 Id, p. 10.
} 
cooperation agreements with China. On the other hand, by exercising their treaty negotiating and concluding competences, EU Member States concluded 26 BITs with China. The Lisbon Treaty allocated the competence for foreign direct investment to the Union and, since 2013, a China-EU BIT has been under negotiation.

In addition to other applicable international law and rules, such as the ICSID Convention, the current international legal framework for the China-EU investment relationship is mainly constructed on the existing BITs between China and EU Member States. Two categories of DSMs exist in these BITs for investment dispute settlement: one for state-state and one for investor-state disputes. The provisions on state-state DSMs have been quite similar to each other. Compulsory consultations through diplomatic channels with a minimum time limit is required as the initial step. Only if this fails, disputes can be submitted to ad hoc arbitration. Rules on arbitration procedures, decision making, effect of arbitral awards, and allocation of costs are normally provided for. In general, diplomatic elements, such as the contracting parties' approval of the chairman, only exist in the BITs that were concluded in the early days. At the same time, the BITs negotiated recently often provide for more detailed procedural rules.

In contrast, the situation of investor-state DSMs is complex. In general, a division can be seen to have developed in 1997: the BITs concluded before this date are characterized by limited acceptance of investor-state arbitration, while, thereafter, the BITs signed in the second stage adopted an overall acceptance of international arbitration for ISDS. The BITs signed in both stages provide for amicable and adjudicative DSMs. Amicable DSMs are consistently stressed in these treaties and the BITs drafted as a later time are even more clear. In terms of adjudicative DSMs, the BITs signed at the first stage limit international arbitration to disputes about the amount of compensation for expropriation. Such a requirement disappeared in the BITs at the second stage. Another noticeable change which happened to the BITs later was the acceptance of ICSID arbitration. In addition, rules on key procedural issues are often provided for in the BITs in which international arbitration is provided.

Based on publicly available information, only two ISDS cases represent the real use of the DSMs in the BITs between China and EU Member States. The public consultation conducted by the European Commission indicates that EU investors prefer amicable settlement for investment disputes with the Chinese government, which was largely affected by concerns about China's domestic legal system and the preservation of the relationship with the Chinese government. 


\section{Chapter 10 The State-State Dispute Settlement System in the Prospective China-}

\section{EU Bilateral Investment Treaty}

This Chapter tackles the system for resolving investment disputes between treaty parties in the prospective China-EU BIT.

As explained in the Introduction to Part 4, the discussion in this chapter is based on the relevant practice of both parties as introduced in Part 3, supra, with due consideration for their legal cultural characteristics in dispute resolution as analysed in Part 2, supra, while bearing in mind the investment relationship between China and the EU, which was addressed in Chapter 8, supra. The discussion is also supplemented with the relevant practice of other states in the world, including treaties and relevant cases. The factors that are addressed in the present chapter do not strictly follow the analysis in previous chapters on the existing practice of both parties. This is mainly for two reasons. First, some procedural issues that have been regulated in their treaties are not likely to be problematic, because both parties have presented an established understanding and practice. Thus, for most of those issues, it is not worthwhile to repeat this in the present analysis. ${ }^{1074}$ Second, the existing practice in both parties does not necessarily touch upon all issues that deserve to be addressed in a China-EU BIT.

Specifically, this chapter starts with a discussion of the objective of the SSDS system, addressing the theme of the whole system and providing general guidance for the following discussion. This is followed by an analysis of the jurisdiction of the SSDS system, including the covered scope of disputes and acceptable claims. Thereafter it addresses the procedural designs of specific DSMs that are expected to be incorporated into a China-EU BIT for SSDS, including amicable options, negotiation/consultations and mediation, as well as adjudicative mechanisms. Regarding the latter, it selects and discusses three issues: adjudication model, transparency and third-party participation, and the effect of state-state adjudication decisions. Each of these DSMs is explored with a particular focus on identifying possible thorny issues that may stand in the way of the successful conclusion of negotiations in pursuit of potential mutually acceptable solutions for the both parties to consider.

\subsection{The Objective of the State-State Dispute Settlement System}

As analysed in Chapters 3, 4, 6 and 7, supra, the legal cultural characteristics in China and the EU, as well as their practice in dispute settlement at the internal and international levels, reveal their different perceptions in relation to the objective of dispute settlement. It is reasonable to expect that such differences would affect their

\footnotetext{
1074 However, there are also some issues where both sides had a similar practice but the possibility of being
} problematic in the future may make it necessary to be addressed and is thus covered in the following discussion. 
corresponding approaches in the context of the negotiations of a China-EU BIT, including each parties' proposals and their response to the proposals of each party.

Focusing on SSDS, from the failure to use state-state adjudication in the past experiences of both parties, it is clear that amicable DSMs in this system should have played and are expected to continue to play a role as the main method of resolving investment disputes between China and the EU. Therefore, it is appropriate to have a more modest objective in relation to settling disputes within the SSDS system. This does not refute the fact that a differentiation should be made between amicable and adjudicative DSMs within this system and the overall aim of settling disputes should not affect the rules-based nature of adjudicative DSMs. However, the general theme of the whole system will still have an influence on the choice where there is more than one available solution to a procedural issue in adjudication.

\subsection{The Jurisdiction of the State-State Dispute Settlement System}

The existing practice in both China and the EU consistently defines the scope of SSDS systems as concerning any dispute between the treaty parties related to the interpretation and/or application of provisions of the IIA at issue. ${ }^{1075}$ As evidenced by the case Ecuador v. the US, at least the term "dispute" can be problematic, since the jurisdiction of a tribunal may be frustrated by one treaty party's silence. ${ }^{1076}$ Based on this, in the prospective China-EU BIT, it is suggested to provide a further explanation for the covered situations, making it clear that one party's silence should not prohibit the tribunal from having jurisdiction as this does not confirm the absence of a dispute. To achieve this, treaty parties can, for instance, explicitly stipulate in the treaty texts that "dispute" is broadly understood as incorporating a situation in which one party refuses to take a position. Another option is to allow tribunals to issue an advisory opinion ${ }^{1077}$ or a preliminary ruling. ${ }^{1078}$ The difference between these two is that the former is binding while the latter is not. Both of them may help to avoid the problematic situation that arose in the Ecuador v. the US case, but it could be too great a step for China and the EU to take at the current stage of negotiations for their prospective BIT. Granting an adjudicative body the power to issue a preliminary ruling should not be completely unfamiliar in the EU, considering it is a common internal practice of the CJEU. This practice does not exist, however, in China's or the EU's concluded IIAs or FTAs. In particular, considering China's traditional reluctance to give up sovereignty to international adjudicative bodies, issuing advisory opinions or preliminary rulings,

\footnotetext{
1075 See, e.g. China Model BIT (1984, 1989, 1997, 2010), Art. 1; CETA (2012), Art. 29.2; the China-Netherlands BIT (2001), Art. 9.

1076 Republic of Ecuador v. United States of America, PCA Case No. 2012-5, Award, 29.09.2012.

1077 Nathalie Bernasconi-Osterwalder, State-State Dispute Settlement in Investment Treaties, 10.2014, available at: https://www.iisd.org/sites/default/files/publications/best-practices-state-state-dispute-settlement-investmenttreaties.pdf, pp. 20-21, last visited on 30.07.2020.

1078 When an EU Member State's national court is in doubt about the interpretation or validity of an EU law, or whether a national law or practice is compatible with EU law, it can ask the CJEU for clarification in the form of a preliminary ruling.
} 
which can be understood as a step furthering a tribunal's compulsory jurisdiction to resolve disputes, is very likely to face resistance from China.

Three categories of specific claims that can be brought through state-state DSMs are identified, as introduced in Section 2.3.1.2, supra: diplomatic protection claims brought by the home state seeking redress on behalf its investors, interpretive claims for decisions interpreting and applying investment treaty provisions, and declaratory relief claims regarding the conformity of host states' specific measures with the treaty at issue. Despite the scarcity, some lessons still can be learned from the limited existing cases under the dispute settlement systems in other IIAs to define the jurisdiction of the SSDS system for the prospective China-EU BIT better. As indicated by the tribunal in the Italy v. Cuba case, a diplomatic protection claim based on a SSDS clause in an IIA needs to adhere to the same conditions that are required for diplomatic protection under customary international law, namely having correct nationality status and exhausting local remedies, unless regulated otherwise in the treaty. Therefore, if the treaty parties wish to change these two conditions, specific provisions need to be introduced into the treaty texts. Problems mainly exist in relation to interpretive claims and declaratory relief claims in whether they can co-exist with ISDS procedures, as argued by the US in the case Mexico v. US. ${ }^{1079}$ This issue in the prospective China-EU BIT will be addressed in the discussion on separation and connection between the SSDS system and the ISDS system in Section 12.2, infra.

\subsection{Procedural Designs of State-State Dispute Settlement Mechanisms}

SSDS systems in IIAs often include amicable and adjudicative DSMs. Such an approach has also been followed by China and by the EU, including their most recently concluded IIAs. Thus, it is reasonable to expect that this will continue to be the case in the prospective China-EU BIT.

\subsubsection{Amicable Dispute Settlement Mechanisms}

Amicable settlement reached through mutually agreed solutions is normally provided at the beginning of the dispute settlement chapter of an IIA, with or without explicit reference to specific DSMs. In this regard, the mechanisms that are explicitly mentioned in China's and the EU's concluded treaties, negotiation or consultations and mediation, are expected to also be proposed for the prospective China-EU BIT. Considering both parties' increased emphasis on the amicable settlement of investment disputes, the proper procedural design of these DSMs can ensure that these amicable DSMs function in investment dispute settlement under the prospective BIT, and, in turn, increase their real use in practice.

\footnotetext{
1079 Mexico v. United States (in the Matter of Cross-Border Trucking Services), NAFTA Chapter 20 State-to-State Arbitration, Final Report of the Panel, 06.02.2001, paras. 147, 283. Although a positive confirmation was given by the tribunal in this case, it is uncertain whether such claims fall within the scope of state-state arbitration provisions outside the context of NAFTA.
} 


\subsubsection{Negotiation/Consultations}

Negotiation and consultations are often used interchangeably as SSDS mechanisms in IIAs. ${ }^{1080}$ They are the same in nature, being confidential, informal and bilateral processes for disputing parties to exchange opinions, which are normally resorted to by the disputing parties at the very beginning, with or without a reference in the underlying treaty. In this vein, IIAs often refer to either negotiations or consultations, with the possibility of making them a condition to initiating adjudication process, as evidenced by most of the BITs concluded between China and EU Member States. Such a reference is usually simple and does not provide detailed procedural rules.

It is noticeable, however, that consultations are different in the context of the ChinaAustralia FTA (2015) and the EU's ICS, where this DSM is not only set as a precondition to adjudication, but it provides detailed procedural requirements, such as a minimum time period, as well as the identification of the specific measure at issue and the legal basis for the complaint. This is in line with the provision on consultations in the DSU. Thus, the purpose of such consultations should be similar to allowing disputing parties "to exchange information, assess the strengths and weaknesses of their respective cases, narrow the scope of the differences between them and in many cases, reach a mutually agreed solution". 1081 Given that such a way of regulating consultations is adopted in the EU's ICS and China's recently concluded IIAs, it is very likely to be followed in a China-EU BIT. A further suggestion here is to incorporate a reference to the potential use of the joint committee's periodic meetings as the forum for holding consultations. Although it may happen without such a reference, a clear expression in the treaty texts would make the availability of the joint committee clearer and remind disputing parties of this possibility. This should not be faced with objections from either China or the EU, especially given that both sides have presented their intention to increase the role of a joint committee in investment dispute settlement.

\subsubsection{Mediation}

Similar to negotiations, mediation should be available to resolve disputes with or without explicit reference. Probably because of this, together with the difficulties in using this DSM in practice, not many IIAs have mentioned this option explicitly and state-state mediation seems to only have existed in theory.

Against such a background, the EU's recently concluded IIAs present some innovation. All of them, namely CETA (2012), the EU-Singapore IPA (2018), and the EU-Vietnam IPA (2018), incorporate separate sets of state-state mediation rules along with an explicit reference to state-state mediation in the main body of the treaty texts. These separate sets of rules cover issues like initiation of mediation, selection of the mediator,

\footnotetext{
${ }^{1080}$ It seems that the use of negotiation and consultations are different in SSDS and ISDS, since ISDS sometimes give negotiation and consultations different functions. For a further analysis on the use of negotiation and consultations in the context of ISDS in IIAs, see Sections 11.3.1 and 11.3.3, infra.

1081 This was used to describe the role of consultations in the WTO Dispute Settlement System. See: Mexico-AntiDumping Investigation of High-Fructose Corn Syrup (HFCS) from the United States, Recourse to Article 21.5 of the DSU by the United States, AB-2001-5, Appellate Body Report, para. 54. See also: Todd Allee \& Manfred Elsig, Dispute Settlement Provisions in PTAs: New Data and New Concepts, at: Trade Cooperation: The Purpose, Design and Effects of Preferential Trade Agreements, Cambridge University Press, 2015, p. 325.
} 
implementation of mutually agreed solutions, time limits, costs, all of which build the basic structure of state-state mediation, while leaving disputing parties and mediators much discretion in deciding procedural details. In particular, the mediators' role is defined as "bringing clarity to the measure and its possible adverse effects" and thus assist treaty parties in reaching a mutually agreed solution. ${ }^{1082}$ At the same time, they "shall not advise or give comments on the consistency of the measure at issue" with the treaty. ${ }^{1083}$ It is also noted that, although the process of mediation is confidential, mutually agreed solutions, if reached, "shall be made publicly available", excluding the information that a treaty party has designated as confidential. ${ }^{1084}$

On the side of China, neither its model BITs nor its IIAs with EU Member States explicitly referred to mediation for SSDS. Although this should not be read as prohibiting disputing parties from resorting to state-state mediation, it may decrease the real use of the mechanism, because it can lack procedural predictability. At the same time, this may indicate China's failure to consider it when it drafted or negotiated these IIAs or its lack of trust in resolving state-state investment disputes through mediation. The latter position may be further supported by its traditional distrust in international DSMs that have not been used very often, such as state-state mediation. In other words, without seeing its real function, it is likely that China hesitated to subject itself to using such a mechanism in order to avoid potential risks. ${ }^{1085}$ Although there is a general preference for amicable DSMs, and mediation is particularly taken by China as a representative of "oriental wisdom" in dispute resolution, ${ }^{1086}$ the fate of state-state mediation is different from commercial mediation, since China is quite familiar with the latter. It is noted that, in this regard, the China-Australia FTA (2015) is an exception, where mediation is explicitly referred to in treaty texts. ${ }^{1087}$

For a China-EU BIT, if state-state mediation is proposed by the EU in negotiations, the absence of such a reference or regulation in China's existing IIAs should not be strong enough to infer that China would reject an explicit incorporation of state-state mediation. This is particularly supported by its recently consistent emphasis on the amicable settlement of investment disputes and the use of mediation under its "One Belt One Road" Initiative. Furthermore, incorporating an explicit reference to statestate mediation in the main body of a China-EU BIT is suggested here strongly. This is mainly because such a reference would give a clear indication of the availability of this DSM and thus increase the possibility of it being used in practice. Attaching additional rules to state-state mediation in order to give necessary procedural guidance is also

\footnotetext{
1082 See e.g. the EU-Singapore IPA (2018), Annex 10, Art. 3.4.

1083 See e.g. the EU-Singapore IPA (2018), Annex 10, Art. 4.3.

1084 See e.g. the EU-Singapore IPA (2018), Annex 10, Art. 4.6.

1085 As previously argued in Section 5.2.2.4, supra, at least part of the reason for joining the WTO and accepting the jurisdiction of the WTO Dispute Settlement System is seeing its function in existing cases.

1086 Edna Sussman, Developing an Effective Med-Arb/Arb-Med Process, New York Dispute Resolution Lawyer, Vol. 2, 2009, pp. 71-74.

1087 Specifically, probably by copying the relevant article in the WTO DSU, good offices and conciliation are mentioned together with mediation in one article as alternative DSMs to adjudication. See: the China-Australia FTA (2015), Art. 15.6; DSU, Art. 5.
} 
desirable. For this, the state-state mediation rules in the treaties concluded by the EU could serve as the starting point for further negotiations between the two parties.

In this sense, it is noted that some provisions contained in the EU's current state-state mediation rules are likely to be faced with hesitation and even resistance from China, a typical example of which is the requirement to publish mutually agreed solutions. Although the settlement agreements disclosed to the public must exclude information that is designated as confidential by a disputing party, such a transparency requirement would mean that at least the existence of mediation and basic information about the concerned dispute are revealed to the public. Given the fact that this does not exist in China's relevant practice, together with the concern from the perspective of its traditional negative attitude towards disputes, it is possible that China will ask for complete confidentiality in relation to state-state mediation in the negotiations of a China-EU BIT.

In addition, by referring to the recent progress made by other entities around the world, such as the IBA Rules for Investor-State Mediation (2012), some issues are argued to be worth being considered in the negotiations of the prospective China-EU BIT. First, introducing the possible use of co-mediators can be useful to maximize mediators' skills and to address the concerns about equality in the process. Second, in order to create a forum for relevant stakeholders to engage in direct communication to resolve the whole dispute, the possible involvement of interested parties with the consent of the disputing parties may be an option in state-state mediation. ${ }^{1088}$ Such interested parties can include investors and industrial organizations which have substantial interests in the case at issue. This may undermine the chances of successful mediation, since it increases the number of possibly diverging interests. However, compared to its potential benefits, which is resolving the dispute by taking into account all key stakeholders' interests, such an arrangement still deserves a try.

In summary, an agreement is likely to be reached regarding amicable mechanisms for SSDS, providing for consultations with additional requirements for a certain amount of time as a precondition to initiating the adjudication process and encouraging the use of state-state mediation with some procedural guidance. Such an approach not only already exists in the existing practice of both China and the EU, but it goes along with China's legal cultural characteristic of preferring amicable DSMs and it does not go against the EU's legal tradition of respecting the rule of law for which alternative dispute resolution is another way of having access to justice. ${ }^{1089}$

\footnotetext{
1088 Chang-fa Lo et. al., Concept Paper on the Creation of a Permanent "Asia-Pacific Regional Mediation Organization" for State-to-State (Economy-to-Economy) Disputes, Comtemporary Asia Arbitration Journal, Vol. 10, 2017, p. 327.

1089 To further promote the use of amicable DSMs, additional inspiration may be found in the new Netherlands Model BIT (2018), where tribunals are explicitly allowed to propose to disputing states at any stage to settle the dispute amicably, which may be realized through the settlement of the dispute ex aequo et bono if disputing states agree. See: The Netherlands Model BIT (2018), Art. 25.5.
} 


\subsubsection{The Adjudicative Dispute Settlement Mechanism}

When amicable DSMs are not effective in settling state-state disputes, an adjudication mechanism can come into play to ensure the resolution of the dispute. Adjudication for state-state disputes in IIAs, and more broadly in FTAs and comprehensive economic agreements, is often built upon arbitration. A China-EU BIT may not follow such a practice, but it may adopt a quasi-WTO dispute settlement panel proceedings model as the basic structure. Despite such a possible consensus, the rules on transparency and third-party intervention, as well as the effect of state-state adjudication decisions are likely to be problematic, in particular. These three issues are thus addressed in turn as follows.

\subsubsection{A quasi-WTO dispute settlement Panel Proceedings Mechanism}

China's concluded IIAs and the EU's ICS present different practices of state-state adjudication: the former adopts ad hoc arbitration, while the latter uses a DSM that greatly resembles the WTO panel proceedings. In comparison, the adjudicative DSM in the EU's ICS further incorporates more judicial features than the design of panel proceedings in the WTO. A typical example is the pre-established list of adjudicators, from which the adjudicators for specific cases are selected. This resembles the practice of the WTO Appellate Body, although disputing parties may still enjoy some power to choose their own adjudicators from the list in the ICS. ${ }^{1090}$ At the same time, it is in line with the relevant operation in courts and thus shows a greater extent of judicialization. This is in clear contrast with the way in which adjudicators are selected in ad hoc arbitration, where each party is free to choose their preferred adjudicator according to the specific situation of each case. Although China's existing IIAs and FTAs mostly adopt ad hoc arbitration, the state-state adjudication mechanism in the China-Australia FTA (2015) also seems to have been inspired by the WTO DSU. This is evidenced by the general structure as well as detailed procedural designs contained in this Agreement. Such a change in China's practice might be based on Australia's insistence, but at least the conclusion of the final deal proves China's acceptance of the use of a quasi-WTO dispute settlement panel proceedings mechanism. This is probably due to China's positive experience in resolving trade disputes in the WTO and the lack of a real use of ad hoc state-state arbitration in practice. However, it deserves attention that, on the issue of the composition of tribunals, the approach used in ad hoc arbitration is still followed in the China-Australia FTA (2015), which indicates to the emphasis put on party autonomy in selecting adjudicators by treaty parties, including China.

Therefore, for a China-EU BIT, in general, the provisions on the panel proceedings in the WTO DSU are expected to be used as the reference for the adjudication process in the SSDS system. From initiation of arbitration, composition of tribunals, issuance of

\footnotetext{
1090 Under the EU-Singapore IPA (2018) and the EU-Vietnam IPA (2018), each disputing party can select one arbitrator from its proposed list and the chairman is to be chosen by the Chair of the Joint Committee by drawing a lot from the list of chairs. In contrast, under CETA (2012), all arbitrators are selected by drawing a lot from preestablished lists by the Chair of the Joint Committee, and thus disputing parties do not have a say in selecting adjudicators if no agreement can be reached. See: the EU-Singapore IPA (2018), Art. 3.29; the EU-Vietnam IPA (2018), Art. 3.7; CETA (2012), Art. 29.7.
} 
interim and final reports, to compliance proceedings, the prospective treaty would cover the whole process with detailed rules on specific issues. Although China has traditionally been hesitant to accept international judicialized systems, especially those that have been rarely used due to a fear of uncertainty, its experience in the WTO Dispute Settlement System is likely to have a positive effect on China accepting to participate in a similar system. It is important to note that China's positive experience in the WTO Dispute Settlement System also included appellate review, which is absent from the design of SSDS here. However, the procedural arrangements in the panel proceedings should undoubtedly also be an indispensable element that is seen to have contributed to China's trust in the whole dispute settlement system.

With regard to the potential problematic issue of selecting adjudicators, although a preestablished roster is not used in the China-Australia FTA (2015), in consideration of China's open attitude towards such an approach in ISDS, ${ }^{1091}$ changing the major approach in its concluded IIAs and accepting the EU's proposal on this issue is possible. In fact, if using pre-selected adjudicators is accepted by China for ISDS, it should be reasonable to expect that China would not reject it for SSDS, where the adjudicators are still in fact chosen by the disputing parties. The use of a pre-established roster is suggested to include a certain respect for party autonomy regarding the composition of the division for a specific case. Namely, each disputing party can select one arbitrator from its proposed list and the chairman is to be chosen by the Chair of the Joint Committee by drawing a lot from the list of chairs if no agreement can be reached between disputing parties. ${ }^{1092}$ This resembles China's existing practice in the sense that a division is still composed at the beginning of each dispute. At the same time, this was in fact adopted in the EU-Singapore IPA (2018) and the EU-Vietnam IPA (2018), although not in CETA (2012). Therefore, it is expected to be the option that is likely to be agreed upon by China and the EU.

\subsubsection{Transparency and Third-Party Participation}

Another innovation in the EU's ICS, which also constitutes a striking difference with China's practice, are the rules on transparency and third-party participation. In most of China's concluded IIAs, ad hoc arbitration is the basic mechanism and thus confidentiality of proceedings is a key feature. In particular, the requirement of holding hearings in closed session also exists in the China-Australia FTA (2015). In addition, no provision on third-party participation can be found in any of China's IIAs. However, in the EU-Singapore IPA (2018) and the EU-Vietnam IPA (2018), a public hearing is explicitly prescribed and the possibility of accepting amicus curiae submissions is addressed. Such changes in SSDS is probably a result of the spill-over effect of the increased transparency and openness in ISDS, mainly due to the public interests involved, which is also present in SSDS. In fact, examples of transparency being

\footnotetext{
1091 This can be evidenced by the newly released CIETAC Investment Arbitration Rules. See: CIETAC Investment Arbitration Rules (2017), Art. 11.1.

1092 The list of chairs is expected to be established by the Joint Committee composed of the representatives from treaty parties no later than a certain time after the date of the entry into force of a China-EU IIA, and this should be provided in the text of this treaty. This is based on the inspiration drawn from the EU's concluded IIAs. See: CETA (2012), Art. 29.8; the EU-Singapore IPA (2018), Art. 3.44; the EU-Vietnam IPA (2018), Art. 3.23.
} 
extended to state-state adjudication can be traced back to 2012. The 2012 US Model BIT provides that transparency rules in investor-state arbitration apply mutatis mutandis to interstate arbitration. ${ }^{1093}$ The WTO Dispute Settlement System also provides an example of the possibility of opening hearings and accepting amicus curiae briefs.

In terms of a China-EU BIT, transparency of state-state adjudication may be not acceptable to China. First, in the WTO Dispute Settlement System, procedural transparency has not received clear support from China. Second, different from ISDS, there is not a very strong support for transparency in SSDS, either at the international level or within in China. Third, ad hoc arbitration, which constitutes the main part of China's existing practice of state-state adjudication, is normally required to be held behind closed doors. Therefore, it is likely that the overall procedural transparency of state-state adjudication process will not be welcomed and may even be rejected by China. In terms of third-party participation, it is advised to open the door for accepting amicus curiae submissions in SSDS adjudication under a China-EU BIT. Although this does not exist in China's concluded IIAs either, the reasons for China to refuse this are not as strong as the reasons to accept transparency. ${ }^{1094}$ Furthermore, such an acceptance will particularly give interested investors an opportunity to have their opinions heard by state-state tribunals and thus may help to find a solution that is satisfying for diverse stakeholders and to settle all relevant disputes efficiently.

\subsubsection{The Effect of State-State Adjudication Decisions}

A crucial but controversial issue is the legal effect of decisions reached by state-state tribunals. Three possibilities have been categorized: the narrowest one is binding on treaty parties with respect to a particular dispute only; the intermediate construction is binding on the treaty parties generally rather than simply with regard to that dispute; while the broadest one was defined as binding in general, i.e., binding on the treaty parties, investors, and future state-state and investor-state tribunals. ${ }^{1095}$ From the perspective of ensuring certainty and consistency, the third option is clearly preferable. However, its suitability in the context of a China-EU BIT needs to be given a second thought. First, there seems to be no provision setting an overall rule on the effect of decisions of state-state tribunals in China's or the EU's relevant treaties. Second, based on the analysis in Section 10.3.2.1, supra, state-state adjudication in the prospective China-EU BIT is likely to adopt a quasi-WTO dispute settlement panel proceedings mechanism and, in the DSU, there is no discussion regarding the binding force of panel and Appellate Body reports adopted under the DSU for the parties to the dispute at issue. ${ }^{1096}$ In such a situation, a provision setting a clear boundary of the legal effect of

\footnotetext{
1093 The 2012 US Model BIT, Art. 37(4). Another example is the Investment Agreement for the Common Investment Area of the Common Market for Eastern and Southern Africa (COMESA), Art. 27(3)-(4) and Annex A, Art. 9.

1094 It is admitted that third parties will be able to submit an amicus curiae brief only when there is a certain degree of transparency in the proceedings. Relevant information can be disclosed by disputing parties to selected entities, such as potential third parties, to enable them to submit amicus curiae briefs.

1095 Anthea Roberts, State-to-State Investment Treaty Arbitration: A Hybrid Theory of Interdependent Rights and Shared Interpretive Authority, Harvard International Law Journal, Vol. 55, 2014, pp. 59-60.

1096 Nevertheless, there has been great consistency in the WTO Dispute Settlement System, mainly because of the requirement of the system to provide "security and predictability to the multilateral trading system". See: DSU, Art.
} 
decisions by tribunals may result in hesitation from both sides because of a lack of experience.

However, complete silence on this potentially problematic issue would leave it open to arguments and thus create uncertainty and unpredictability in future cases. ${ }^{1097}$ Thus, it is recommended that certain guidance be stated in treaty texts. In this regard, instead of formulating a provision setting out the clear scope, incorporating a provision similar to the DSU Article 3.2 is a preferable option. Such a provision could realize the goal of maintaining consistency, establishing jurisprudence and realizing the rule of law within the system to a large extent, while leaving a certain amount of flexibility. In particular, like the practice in the WTO Appellate Body, this can be realized through routine communications among the listed adjudicators. Furthermore, considering the fact that the adjudicators for any state-state adjudication case are chosen by treaty parties from the pre-established list and treaty parties can reach an agreement if any tribunal's decision is undesirable, the possible uncertainty created by this proposed general guidance should be acceptable. At the same time, considering China's and the EU's positive perception of the functioning of the WTO Dispute Settlement System, this is more likely to be accepted by both sides.

\subsection{Conclusion}

Evidenced by the absence of the real use of state-state adjudication in the past practice of both sides, amicable DSMs have probably played the main role in resolving statestate investment disputes for both China and the EU, which is expected to continue under the prospective China-EU BIT. Thus, it is appropriate to take settling disputes as the goal of the whole SSDS system.

In an IIA, a SSDS system is normally applicable to disputes about the interpretation and application of treaty provisions, based on which treaty parties can raise diplomatic protection claims, interpretive claims and claims for declaratory relief. Such an approach is likely to continue in a China-EU BIT. Within the SSDS system under this BIT, specific DSMs can be divided into two categories-amicable DSMs and adjudicative DSMs. The former normally comes into play in the first place, possibly through consultations and mediation. In particular, consultations are likely to be set as a precondition to initiating the state-state adjudication process.

Regarding adjudication, the most recent treaty practice of both China and the EU represents their interests in using a quasi-WTO dispute settlement panel proceedings mechanism, and this may also serve as the general structure under a China-EU BIT. Based on this, a problematic issue is likely to be the composition of tribunals. In this regard, China and the EU are likely to reach an agreement on pre-establishing a roster

\footnotetext{
3.2 .

1097 Aron Broches, The Convention on the Settlement of Investment Disputes between States and Nationals of Other States, Recueil des Cours, Vol. 136, 1972, p. 377. Anthea Roberts, State-to-State Investment Treaty Arbitration: A Hybrid Theory of Interdependent Rights and Shared Interpretive Authority, Harvard International Law Journal, Vol. 55, 2014, p. 29.
} 
of adjudicators and leave room for party autonomy in specific cases. Another issue that should be considered is procedural transparency. For a China-EU BIT, opening the whole process of adjudication to the public may be rejected by China, but third party participation, for example by submitting amicus curiae briefs is likely to be acceptable and even recommended. In terms of the effect of tribunals' decisions in state-state adjudication, a moderate approach, incorporating a provision similar to Article 3.2 of the DSU may be the most acceptable option. This means that the rulings would only have a precedential value, instead of being binding on all following cases.

Although state-state DSMs only played a minor role in investment dispute resolution in the past, this should not be the reason to underestimate its potential use under a China-EU BIT. Considering the clear intention behind increasing the states' role in investment dispute settlement evidenced by recent practice in China and the EU, it is reasonable to expect that, with proper procedural arrangements which satisfy practical needs of both sides and eliminate the concerns from the legal culture on dispute settlement, such a system in the prospective China-EU BIT is likely to make real contribution to investment dispute settlement. 


\section{Chapter 11 The Investor-State Dispute Settlement System in the Prospective}

\section{China-EU Bilateral Investment Treaty}

As addressed in Section 2.2, supra, international investment dispute settlement (ISDS) has two components. In addition to state-state DSMs, investor-state DSMs constitute another part of the whole system, and has been the most used in practice. As evidenced the concluded treaties of China and the EU, in the past decade, incorporating DSMs for investor-state dispute settlement in IIAs has been the common practice. Furthermore, with regard to the prospective China-EU BIT, there is no sign of a reluctance to have an ISDS system included in the BIT. ${ }^{1098}$ It is thus fair to say that there are no doubts about the intention to incorporate such a system in general; instead, potential problems may exist in relation to its procedural design.

Although the EU has not published a model BIT serving as a reference for future negotiations, ${ }^{1099}$ it has developed some strong ideas about the direction it wants to go in from its consistent practice in its concluded IIAs after the Lisbon Treaty. Specifically, the Investment Court System (hereinafter "the ICS") in CETA (2012), the EU-Vietnam IPA (2018) and the EU-Singapore IPA (2018) arguably constitutes a blueprint of the EU's proposal for investor-state dispute settlement provisions for its prospective IIAs. On the other hand, although China has published its model BITs, which are expected to be followed in general and thus help somewhat in achieving consistency, the practice in reality has not been as stable as the practice in the EU. In fact, China's various IIAs with different partners differ to a large extent. Against this background, for the purpose of the present chapter, which explores the procedural design of the ISDS system in the prospective China-EU BIT, it is reasonable to expect that using the EU's ICS as the basis and further predicting China's attitude thereto will deliver an effective and efficient result to the research question.

Although in the past in the field of international law China was largely a rule-taker rather than a rule-maker, it is noted that, with its increasing economic power and the corresponding enhanced position in international economic law, China has changed its role from being a partner that would easily agree to any ready-made proposal put on

\footnotetext{
1098 Unlike the situation for negotiating the Transatlantic Trade and Investment Partnership (TTIP), there seems to be no debate within the EU regarding the incorporation of an ISDS system in a China-EU BIT. In fact, having such a system in a China-EU BIT was even taken as an argument for incorporating one in the TTIP, by stating that the exclusion of the latter would hinder the way it would be incorporated into other prospective IIAs with other states, such as China. See: Axel Berger \& Lauge N. Skovgaard Poulsen, The Transatlantic Trade and Investment Partnership, Investor-State Dispute Settlement and China, Columbia FDI Perspectives, Vol. 140, 2015. Wolfgang Koeth, Can the Investment Court System (ICS) Save TTIP and CETA?, European Institute of Public Administration Working Paper, Vol. 2016/W/01, 2016, p. 8. Similarly, China has not shown any hesitation in relation to the incorporation of an ISDS system in its BIT with the EU.

1099 The EU Commission has steadfastly refused to publish a model investment treaty since receiving the competence for foreign direct investment from the Lisbon Treaty. See: Calamita N. Jansen, The Making of Europe's International Investment Policy: Uncertain First Steps, Legal Issues of Economic Integration, Vol. 39, 2012, pp. 316-322.
} 
the negotiation table. ${ }^{1100}$ As witnessed by the measures it has taken under the OBOR Initiative, China now seems to be willing to contribute "Chinese elements" to international law making. Thus, in the negotiations for a China-EU BIT, both parties should be in equal positions to negotiate an ISDS system that satisfies their respective needs. Previous discussions in Chapter 6 and Chapter 7 have revealed different preferences of China and the EU in investor-state dispute settlement on various procedural issues, which are likely to lead to difficulties in the negotiations for the prospective China-EU BIT. In particular, some features are rooted in the legal culture of dispute settlement in China and the EU respectively and relate to the fundamental values that one side intends to protect, making them difficult to abandon or even change.

Similar to Chapter 10, supra, this chapter focuses on anticipating the proposals that are likely to be brought to the negotiation table for the ISDS system by China and by the $\mathrm{EU}$, in order to see whether they are mutually complementary or contradictory and conflicting with each other. The discussion in this chapter is mainly based on the relevant practice of both parties addressed in Part 3, supra, with due consideration for their legal cultural characteristics in dispute resolution analysed in Part 2, supra, as well as their investment legal relationship discussed in Chapter 9, supra. Specifically, it covers the objective and jurisdiction of the ISDS system, as well as the amicable DSMs, the international adjudication mechanism and the local remedies contained therein. Considering the ongoing heated discussions on ISDS reform, which should be borne in mind by both parties, the present discussion is also supplemented by the status quo of the development of investment dispute settlement in the world and takes into account the relevant practice from other entities. It does not aim to provide a comprehensive analysis of all the details of each DSM contained in the ISDS system in a China-EU BIT; instead, it focuses on exploring the crucial but potentially thorny issues and offers reflections on the possible solutions thereto.

\subsection{The Objective of the Investor-State Dispute Settlement System}

The differences in the understanding of the general objective of a dispute settlement system between China and the EU is expected to also have an influence on their attitude towards ISDS. Resolving disputes amicably and restoring the relationship between disputing parties is taken as the key concern for China, while the EU puts more weight on access to justice, developing jurisprudence and preserving the rule of law. Such differences can be traced back to the traditional Chinese philosophies that still affect the current ideology in Chinese society and China's domestic legal system, as well as the constants in the EU's legal tradition and the Union's relevant internal measures.

Regarding the objective of having amicable ISDS mechanisms in a China-EU BIT, similar to SSDS, they must be differentiated from adjudicative mechanisms in the sense that they focus on settling disputes. Given the fact that investor-state adjudication has been considered to be the "teeth" of ISDS, as proven by the large number of existing

1100 Tomáš Fecák, International Investment Agreements and EU Law, Kluwer Law International, 2016, p. 291. 
cases, it should be an appropriate choice to take the developing jurisprudence and the international rule of law as the overall relevant theme in investor-state adjudication. Therefore, an adjudication mechanism that is independent, neutral and capable of producing binding decisions to enhance the legitimacy of the international treaty is indispensable. ${ }^{1101}$ Such an effective and legitimized DSM can also function as an important component of international cooperation by reducing the number of economic and political disputes. ${ }^{1102}$

\subsection{The Jurisdiction of the Investor-State Dispute Settlement System}

Like SSDS, rules on the ISDS system in an IIA normally start with a provision setting out the system's jurisdiction by identifying the types of covered disputes. The jurisdiction of the ISDS system is often defined as any dispute between a claimant of one treaty party and the other treaty party concerning treatment alleged to breach the provisions of investment protection provided by the IIA at issue and to cause loss or damage to the claimant or its locally established enterprise. ${ }^{1103}$ The exact scope of investment protection depends on treaty parties' agreement on the substantive obligations of host states, which goes beyond the scope of the present thesis. What deserves particular attention in this regard is that investor-state arbitration is limited to disputes about the amount of compensation for expropriation. This exists in China's early IIAs, but it basically disappeared in its IIAs concluded after 2000. Thus, such a provision is not likely to be supported by China in the China-EU BIT negotiation. Furthermore, as evidenced by the concluded IIAs of both parties, the normal practice that only monetary damages and returning the original property to investors are measures that can be awarded by tribunals is expected to continue in a China-EU BIT, and thus the applicable claims in investor-state adjudication are limited in this way.

\subsection{Amicable Dispute Settlement Mechanisms}

In general, the desire to settle disputes in a swift and cost-effective way and to preserve the long-term relationship between investors and host states were particularly viewed as the motivation for using amicable investor-state DSMs. ${ }^{1104}$ In addition, investment disputes are likely to be complex, involving both legal and non-legal issues, which requires a thorough consideration of the various elements. Therefore, solutions based on the interests of the parties, instead of strictly and solely interpreting legal provisions,

\footnotetext{
1101 Frank J. Garcia, New Frontiers in International Trade: Decision-making and Dispute Resolution in the Free Trade Area of the Americas: An Essay in Trade Governance, Michigan Journal of International Law, Vol. 18, 1997, pp. 365-367.

${ }^{1102}$ Edward D. Mansfield \& Brian M. Pollins (eds.), Economic Interdependence and International Conflict: New Perspectives on an Enduring Debate, The University of Michigan Press, 2003, p. 222.

1103 See e.g. the EU-Singapore IPA (2018), Art. 3.1.1. In China's model BITs, the description is simpler by describing the ISDS system's jurisdiction as "[a]ny dispute between an investor of one Contracting Party and the other Contracting Party in connection with an investment in the territory of the other Contracting Party". See: China Model BITs (1984, 1989, 1997), Arts. 9.1; China Model BIT (2010), Art. 13.1.

1104 Barton Legum \& Anna Joubin-Bret \& Inna Manassyan, Rules for Investor-State Mediation: Draft Prepared by the International Bar Association State Mediation Subcommittee, at: Roberto Echandi \& Pierre Sauvé, Prospects in International Investment Law and Policy-World Trade Forum, Cambridge University Press, 2013, pp. 265-266.
} 
should be preferred in many situations. Such solutions are easier to realize through amicable DSMs. In particular, considering the increasing recognition of the potential function of amicable mechanisms for investment dispute settlement for China and the $\mathrm{EU}$, it is reasonable to expect that such DSMs would gain the attention of both parties during their negotiations for a China-EU BIT.

By referring to the existing practice in China and the EU, the often-incorporated amicable DSMs for ISDS, negotiation, consultations and mediation, are expected to be referred to in a China-EU BIT. Considering that currently the use of amicable DSMs in practice is rare and the possible reasons for this, two questions are considered in particular to provide guidance for the following analysis: first, whether an amicable DSM should be mandated or recommended as the first-tier of dispute resolution; and second, whether and, if so, to what extent procedural guidance should be provided for the operation of these mechanisms in treaty texts.

\subsubsection{Negotiation}

Negotiation, or at least an attempt to negotiate, is usually the starting point of ISDS, which is affected by the trust of disputing parties in their bilateral relationship and the expectation of continuing cooperation in the investment project at issue. The negotiation process is bilateral, confidential and voluntary. In IIAs, including most existing BITs between China and EU Member States, this DSM is not explicitly referred to. A general statement is provided requiring that any dispute between an investor of one treaty party and the other treaty party "shall be settled amicably as far as possible by the two parties concerned". ${ }^{1105}$ On this point, it deserves attention that the EU's two most recently concluded IIAs, the EU-Singapore IPA (2018) and the EUVietnam IPA (2018), mention negotiation in particular as an available DSM for reaching amicable settlement in treaty texts. ${ }^{1106}$

Although it is difficult to assess the real use of negotiation in practice, because the required confidentiality, it was pointed out that negotiation is China's usual approach to resolving disputes with foreign investors as a host state, which was the major reason for its low numbers of ISDS cases. ${ }^{1107}$ This may come from China's intention to maintain its reputation as a desirable investment destination and its consistent proamicable DSMs attitude, which is also in line with its similar preferences in other relevant areas, such as international trade law.

For the prospective China-EU BIT, it is thus expected that amicable settlement through negotiation would be explicitly stated and encouraged in the treaty text. Procedural rules are not necessary for the negotiation process, since it is the least formal mechanism among all DSMs. In order to increase the possibility of amicable settlement, it is suggested that it should be made explicit in the treaty that, when negotiations

\footnotetext{
1105 See e.g. the China-France BIT (2007), Art. 7.

1106 The EU-Singapore IPA (2018), Art. 3.2; the EU-Vietnam IPA (2018), Art. 3.29.

1107 Peter Malanczuk, China and the Emerging Standard of Transparency in Investor-State Dispute Settlement (ISDS), New Zealand Association for Comparative Law, Vol. 19, 2015, pp. 90-91.
} 
between disputing parties are difficult, the joint committee can play a role to facilitate the process, similar to transforming negotiation into good offices.

\subsubsection{Consultations}

In addition to negotiation, consultations are another bilateral amicable DSM. Although, by nature, consultations are the same as negotiations, they are differentiated in the EU's ICS. Specifically, the ICS first stresses that disputes can be resolved amicably through negotiation. ${ }^{1108}$ It also provides explicit provisions on consultations. This DSM is established as a compulsory step before adjudication, which means that, unless it is not possible to settle disputes within the minimum amount of time through consultations, they cannot be brought to adjudication. This can be read as a guarantee that disputing parties make an effort to resolve disputes through bilateral communication, and thus it constitutes a necessary supplement to voluntary negotiations. At the same time, the EU's ICS provides detailed procedural requirements for the consultation process, such as the place of consultations, the content of requests for consultations and time limits. In particular, the content requirement of requests for consultations includes the treaty provisions alleged to have been breached, the legal and the factual basis for the claim, the relief sought and the estimated amount of damages claimed, which confirms the difference between consultations and negotiation. Another difference between negotiation and consultations is that requests for consultations are to be public, which does not apply to negotiation. All of these elements seem to be borrowed from the WTO DSU. In practice, disputing parties may start negotiations on the dispute at an early stage before identifying specific provisions of the IIA at issue or formulating legal and factual arguments to seek certain relief. In other words, when it is not possible to resolve the disputes using negotiation behind closed doors, disputing parties would publicly initiate consultations with a more solid legal basis.

Considering China's accumulated experience in the WTO, where consultations have been productive in settling disputes amicably, as well as amicable DSMs being in conformity with the Chinese approach to resolving disputes, such compulsory consultations in the EU's ICS should be acceptable to China. In fact, Chinese scholars even suggested that, under the OBOR Initiative, China should refine and specify the rules on consultations by learning from the corresponding regulations in the EU's ICS in order to ensure that consultations have a real function. ${ }^{1109}$ In this respect, it is noticeable that in investment arbitration cases, where going through negotiation and/or consultations is provided for in the IIAs at issue, some tribunals let investors proceed to arbitration without fulfilling such obligations. ${ }^{110}$ Thus, for a China-EU BIT, it is suggested that an explicit statement of the compulsory nature of and the minimum time

\footnotetext{
1108 See e.g. the EU-Singapore IPA (2018), Art. 3.2.

1109 Jingxia Shi \& Nuan Dong 石静霞、董暖, The Construction of Investment Dispute Settlement Mechanisms under 'One Belt One Road' Initiatives “一带一路” 倡议下投资争端解决机制的构建, Wuhan University International Law Review 武大国际法评论, Vol. 2, 2018, p. 5.

1110 See e.g. Ethyl Corporation v. The Government of Canada, UNCITRAL, Award on Jurisdiction, Reprinted in 38 I.L.M. 700, 729 (1999). For some academic discussion on this, see: Christoph Schreuer, Traveling the BIT Route of Waiting Periods, Umbrella Clauses and Forks in the Road, The Journal of World Investment \& Trade, Vol. 5, 2004, pp. 231-239.
} 
required for consultations should be added to treaty texts. In addition, one sensitive issue in consultations can be publishing the requests for consultations and the settlement agreement, if an agreement is reached. The process of consultations is widely recognized as confidential, and there seems to be no clear consensus on whether a right to know of other stakeholders would require disputing parties to publish their initial documents when initiating the dispute settlement process and their settlement agreements. It is explicitly required for the initial documents to be made public under the EU's ICS. ${ }^{1111}$ Regarding the latter, the EU's ICS does not explicitly touch upon this issue, and settlement agreements reached through consultations are not included in the list of documents that must be published. Considering China's less radical protransparency attitude, keeping not only the process but also at least the settlement agreements confidential is expected to be its preferred approach. In terms of the requests for consultations, considering the relevant requirement in the DSU, it may be acceptable to China to make such documents public.

\subsubsection{Mediation}

Mediation is available as another amicable mechanism for ISDS. In particular, recent years witnessed an increasing awareness and recognition of investor-state mediation. In particular, China and the EU have expressed clear intentions and have taken measures to develop mediation as one of the mechanisms to resolve investor-state disputes. Supporting evidence for this comes from the existing practice of both parties at the international as well as internal levels. ${ }^{1112}$

As introduced in Section 6.3, supra, China presented its interest in using investor-state mediation by explicitly incorporating it into the latest China Model BIT (2010) and some recently concluded IIAs. ${ }^{113}$ In these treaty documents, only a simple reference is provided without further guidance. Discussions on detailed investor-state mediation rules can be found in the academic works of Chinese scholars. ${ }^{1114}$ In China's domestic legal system, as introduced in Section 3.2, supra, as far as foreign investment is concerned, mediation plays a significant role in dispute resolution, where both independent and mixed mediation mechanisms are available. In particular, since 2006, a quasi-mediation process designed for foreign investment dispute resolution, "complaints coordination", has been promulgated. It is also noted that under the OBOR Initiative, using mediation for commercial dispute settlement has gained much attention and concrete progress has been made in this direction accordingly. ${ }^{115}$ Such efforts may

\footnotetext{
1111 See e.g. the EU-Singapore IPA (2018), Annex 8, Art. 1.1(a).

1112 In this regard, China's and the EU's internal legal systems not only prove their general approaches towards mediation, but they also indicate the elements that probably affect their investors' attitudes towards mediation. This is important in the sense that mediation as a familiar and possibly functional option in investors' home states' legal systems affects the real use of investor-state mediation.

1113 The most recent example is the Bilateral Agreement for the Promotion and Protection of Investments between the Government of the Republic of Colombia and the Government of the People's Republic of China (2013). A more comprehensive reflection can be found in Mainland China and Hong Kong Closer Economic Partnership Arrangement Investment Agreement (signed on 22.11.2008, entered into force on 02.07.2013).

1114 See e.g. Jingxia Shi \& Nuan Dong 石静霞、董暖, The Construction of Investment Dispute Settlement Mechanisms under 'One Belt One Road' Initiatives “一带一路” 倡议下投资争端解决机制的构建, Wuhan University International Law Review 武大国际法评论, Vol. 2, 2018.

1115 For instance, on 10 October 2018, 21 institutions from 12 states, including some EU Member States, signed the
} 
have certain spill-over effect on ISDS in the near future, and therefore a similar practice can be expected. In fact, mediation has been referred to as the "Oriental Experience" by China, which contains Chinese the traditional Confucius wisdom of prioritizing harmony. ${ }^{1116}$ As introduced in Section 7.2.4, supra, the intention of the EU to incorporate mediation in ISDS has been clearly and concretely shown in its recently concluded IIAs, which include separate investor-state mediation rules. It is expected that this will continue in the EU's proposals for other prospective IIAs in the near future. Internally, the EU has also promoted the use of mediation. ${ }^{1117}$

It is noticeable that, although mediation has been promoted by both China and the EU, the motivation for this seems to be different in each jurisdiction. Compared to adversarial adjudication, for China's perspective mediation can eliminate disputes and restore harmonious relationship, which is in line with its traditional ideologies. In this vein, procedural justice and other basic due process requirements under the rule of law may be overlooked. In fact, mediation is even argued to be a threat to the rule of law in China. ${ }^{1118}$ For the EU, on the other hand, mediation provides for a relative ease of access to justice with few formalities, technicality and jargon that might otherwise restrict access to justice for disputing parties. ${ }^{1119}$ Such differences in perspectives affect the general understanding of China and the EU of mediation and are reflected in their preferences for their different procedural arrangements in mediation.

Therefore, despite China's and the EU's recognition of mediation for ISDS, it is reasonable to predict that there would be some difficulties for them to reach an agreement on the procedural design of investor-state mediation. In addition to the issues that can be inferred from their distinctive existing practice, considering both parties' intention to promote a greater use of mediation, more innovative designs and thus more uncertainties can be expected. In particular, five crucial but controversial issues may stand in the way of concluding provisions on an investor-state mediation mechanism in

Rome Declaration on international commercial mediation with China to promote the use of mediation for dispute settlement under the "One Belt One Road" Initiative. See: www.legaldaily.com.cn 法制网, "One Belt One Road" International Commercial Mediation Forum Took Place in Rome and Issued Rome Declaration “一带一路” 国 际商事调解论坛在罗马召开并发布 《罗马宣言》, 11.10.2018, available at: http://www.legaldaily.com.cn/Lawyer/content/2018-10/11/content_7664185.htm, last visited on 07.08.2020.

1116 Edna Sussman, Developing an Effective Med-Arb/Arb-Med Process, New York Dispute Resolution Lawyer, Vol. 2, 2009, pp. 71-74.

1117 Typical examples include: European Parliament, Directive 2008/52/EC of the European Parliament and of the Council of 21 May 2008 on Certain Aspects of Mediation in Civil and Commercial Matters, Directive 2008/52/EC, 24.05.2008. European Parliament, Directive 2008/52/EC of the European Parliament and of the Council of 21 May 2008 on Certain Aspects of Mediation in Civil and Commercial Matters, Directive 2008/52/EC, 24.05.2008. European Parliament-Directorate-General for Internal Policies-Policy Department C: Citizens' Rights and Constitutional Affairs, 'Rebooting' the Mediation Directive: Assessing the Limited Impact of Its Implementation and Proposing Measures to Increase the Number of Mediations in the EU, 2014, available at: http://www.europarl.europa.eu/RegData/etudes/etudes/join/2014/493042/IPOL-JURI_ET(2014)493042_EN.pdf, last visited on 31.07.2020.

1118 Knut B. Pissler, Mediation in China: Threat to the Rule of Law?, at: Klaus J. Hopt \& Felix Steffek (eds.), Mediation: Principles and Regulation in Comparative Perspective, Oxford University Press, 2013, pp. 959-1009.

1119 Laurence Boulle, Mediation: Principles, Process, Practice (3rd ed), LexisNexis Butterworths, 2011, Sections 3.51, 6.15. See also: Jean R. Sternlight, Is Alternative Dispute Resolution Consistent with the Rule of Law? Lessons from Abroad, DePaul Law Review, Vol. 56, 2006, p. 570. It was also argued that mediation was not compatible with and supportive of the traditional rule of law values associated with adjudication. See: Sundaresh Menon, Mediation and the Rule of Law, The Law Society Mediation Forum, Singapore, 10.03.2017. 
a China-EU BIT: voluntariness, selection of mediators, mediation styles, transparency, and enforcement of settlement agreements, which are addressed in turn in the following.

\subsubsection{Voluntariness}

A preliminary question is the voluntariness of initiating investor-state mediation: should this DSM be a compulsory or a voluntary stop on the way to adjudication? Arguments supporting each position exist. On the one hand, to increase the possibility of an amicable settlement, robust engagement in mediation is preferred. Namely, mediation is compulsory and accompanied by a minimum time period, in order to push the disputing parties to try to resolve the dispute using this amicable mechanism. On the other hand, voluntariness is one of the fundamental features of mediation. Even if a disputing party is free to terminate its participation at any point, the compulsory initiation of mediation prolongs the dispute resolution process. On this issue, the existing practice of both China and the EU supports voluntariness.

For a China-EU BIT, adhering to voluntariness in mediation is thus considered to be the suitable choice, but some procedural adjustments can be made to realize a greater use of investor-state mediation. As pointed out by the International Bar Association, the use of investor-state mediation was largely affected by a lack of awareness of the disputing parties and practitioners. ${ }^{1120}$ Therefore, it is suggested that, under the prospective China-EU BIT, if it is not chosen spontaneously, mediation should be offered to disputing parties by the adjudicators at the beginning of the adjudication process. Any party that rejects mediation can then choose to opt out but must demonstrate why mediation would duplicate earlier efforts, be unlikely to be productive or might even cause harm. ${ }^{1121}$ Such an arrangement can be productive from the perspective that it ensures a clear understanding and concrete consideration of investorstate mediation by the parties, and thus it promotes its use without prejudicing party autonomy. When the dispute is not suitable for mediation, compared to compulsory mediation, it minimizes the time wasted.

\subsubsection{Selection of Mediators}

Once disputing parties decide to use mediation to resolve their disputes, the next crucial step is to select the proper person to act as the mediator. In the EU's ICS, disputing parties are expected to reach an agreement on the selection of mediators, who "shall not be a national of either Party, unless the disputing parties agree otherwise". ${ }^{122}$ It is indicated in particular that "such agreement may include appointing a mediator from the Members of the Tribunal". ${ }^{1123}$ If the disputing parties cannot agree on the mediator,

1120 Herbert Smith Freehills LLP, International Bar Association Launches Investor-State Mediation Rules, 23.10.2012, available at: http://hsfnotes.com/adr/2012/10/23/international-bar-association-launches-investor-statemediation-rules/, last visited on 04.08.2020. See also: Barton Legum \& Anna Joubin-Bret \& Inna Manassyan, Rules for Investor-State Mediation: Draft Prepared by the International Bar Association State Mediation Subcommittee, at: Prospects in International Investment Law and Policy-World Trade Forum, Cambridge University Press, 2013, p. 266.

1121 Bobbi McAdoo \& Nancy Welsh, Court-Connected General Civil ADR Programs: Aiming for Institutionalization, Efficient Resolution and the Experience of Justice, at: Donna Stienstra \& Susan Yates (eds.), ADR Handbook For Judges, American Bar Association, 2004, pp. 16-17.

1122 The EU-Singapore IPA (2018), Annex 6, Art.3.3.

1123 The EU-Singapore IPA (2018), Annex 6, Art.3.1. 
either of them may request the President of the Tribunal to draw the mediator by lot from the Members of the Tribunal. Based on this, it seems that, in the EU's ICS, the selection standard for mediators is quite similar to the standard used for adjudicators. In fact, a code of conduct for mediators is attached to CETA, which is the same for arbitrators. This code particularly stresses the disclosure obligations for mediators, as well as their independence and impartiality. China has not included a rule on the selection of mediators in any of its IIAs or FTAs. Analysing this issue from a legal cultural perspective,

Against this background, in the prospective China-EU BIT, it is likely to be difficult for treaty parties to reach an agreement on the qualifications required for mediators, especially related to independence and impartiality. In this regard, it is suggested that this issue should not be regulated in the treaty texts explicitly; instead, it is suggested to leave it to be determined by the disputing parties in specific cases. Such an arrangement would give priority to party autonomy and necessary freedom to choose the best person to act as a mediator in a particular case. In addition, considering the different functions of mediation and adjudication, it is also justifiable to apply different standards for adjudicators and mediators.

\subsubsection{Mediation Styles}

As introduced in Section 2.3.2.2, supra, mediation can be interest-based or rule-based. Although interest-based mediation is arguably preferable for ISDS, rule-based mediation also has its value, especially when disputing parties prefer this option. Regarding this issue, in its ICS, the EU chooses to explicitly prevent mediators from giving advice or comments on the consistency of the measure at issue with the applicable IIA, ${ }^{1124}$ which means that only interest-based mediation is allowed. There has been no concrete procedural rule in China's concluded IIAs or its model BITs on mediation and its domestic legislation also does not give useful clues on the mediation style. Some scholars described the dominant approach in practice as evaluative and rights-based, ${ }^{1125}$ while others argue that Chinese mediation joins together the Western concepts of mediation, arbitration, and litigation. ${ }^{1126}$

Therefore, a combined model is recommended for a China-EU BIT, taking interestbased mediation as the default type and rule-based mediation as a supplement. ${ }^{1127}$ In other words, non-evaluative mediation based on the interests of the parties is the normal practice. When disputing parties reach a different agreement, it is possible to change to

\footnotetext{
1124 See e.g. the EU-Vietnam IPA (2018), Annex 10, Art. 4.3.

1125 See e.g. Peter Chi Hin Chan, The Position of Mediation in Contemporary Chinese Civil Justice: A Proceduralist Perspective, to obtain the Doctoral Degree at Mastricht University, 2016, p. 224. In this doctoral thesis, the author explored the features of mediation in China' s contemporary legal system based on a doctrinal analysis and empirical legal research.

1126 See e.g. Donald C. Clarke, Dispute Resolution in China, at: Tahirih V. Lee (ed.), Contract, Guanxi, and Dispute Resolution in China, Garland Publishing, Inc., 1997, pp. 369-422.

1127 A similar arrangement was argued by Nancy Welsh and Andrea Kupfer Schneider for investor-state mediation in general. Specifically, the authors suggested that the process should begin in a facilitative manner. Discussions of relevant legal norms and evaluations by the mediator are supposed to be permitted at a later stage. See: Nancy A. Welsh \& Andrea K. Schneider, The Thoughtful Integration of Mediation into Bilateral Investment Treaty Arbitration, Harvard Negotiation Law Review, Vol. 18, 2013, p. 71.
} 
an evaluative rule-based type. In addition to taking the preferences of the disputing parties into account in each case, such a combination ensures that mediation is an interest-based process to a large extent, which is beneficial for trust-building and information exchange. It also gives necessary freedom to mediators to customize the style as the process evolves. Specifically, mediators can make a proposal to change the mediation style, if a change is deemed appropriate at any point during the process. ${ }^{1128}$ As argued, mediation is "most likely to be helpful when it includes both legal analysis and probing for interests". ${ }^{1129}$ In Particular, when complex disputes are involved, disputing parties possibly prefer a type of mediation that can uncover their extra-legal interests as well as discuss applicable laws and litigation realities. ${ }^{1130}$

This combined model is recommended to be prescribed explicitly in the prospective China-EU BIT, in order to give disputing parties clear information, increase the predictability of the process and to decrease undue influence from elements such as the peculiarities of mediators. ${ }^{1131}$ Other detailed procedural arrangements, such as the number of mediators, whether to convene or not and time management, can be left to disputing parties and mediators to decide on a case-by-case basis, ${ }^{1132}$ but these agreements should always be clearly specified at the beginning of the mediation process. ${ }^{1133}$ In order to realize this, a checklist that lists key procedural issues and describes possible choices or offers some guidelines, which parties are free to choose from, can be attached to the provided mediation rules. In this regard, a reference to the International Bar Association Investor-Mediation Rules can be another option, subject to the provisions in the prospective China-EU BIT and disputing parties' agreements. The overarching guiding principle here should be make the investor-state mediation

${ }^{1128}$ For example, a mediator may start with an interest-based approach, then propose to transit to a rule-based style of reaching a settlement agreement.

1129 Nancy A. Welsh \& Andrea K. Schneider, The Thoughtful Integration of Mediation into Bilateral Investment Treaty Arbitration, Harvard Negotiation Law Review, Vol. 18, 2013, p. 114.

1130 Nancy A. Welsh \& Andrea K. Schneider, Becoming "Investor-State Mediation", Penn State Journal of Law \& International Affairs, Vol. 1, 2012, p. 94.

${ }^{1131}$ It was argued that the existence of different types of legal-cultural idiosyncrasies would call for rules should clarify the models that may be used if mediation is added to the investment context. See: A. Timothy Martin, International Mediation: An Evolving Market, at: Arthur W. Rovine (ed.), Contemporary Issues in International Arbitration and Mediation: The Fordham Papers (2010), Martinus Nijhoff Publishers, 2011, p. 415.

${ }_{1132}$ In this regard, some innovative designs in the IBA Rules for Investor-State Mediation can be good references, such as co-mediators and mediation management conferences. See: IBA Rules for Investor-State Mediation (2012), Art. 4.1 and 9. For some comments on these innovations, see: Munir Maniruzzaman, A Rethink of Investor-State Dispute Settlement, Kluwer Arbitration Blog, 30.05.2013, available at: http://kluwerarbitrationblog.com/2013/05/30/a-rethink-of-investor-state-dispute-settlement/, last visited on 04.08.2020. Herbert Smith Freehills LLP, International Bar Association Launches Investor-State Mediation Rules, 23.10.2012, available at: http://hsfnotes.com/adr/2012/10/23/international-bar-association-launches-investor-statemediation-rules/, last visited on 04.08.2020. Barton Legum \& Anna Joubin-Bret \& Inna Manassyan, Rules for Investor-State Mediation: Draft Prepared by the International Bar Association State Mediation Subcommittee, at: Prospects in International Investment Law and Policy-World Trade Forum, Cambridge University Press, 2013, p. 269.

${ }_{1133}$ As pointed out, on procedural arrangements of international mediation, "difficulties could easily be addressed by providing clear guidelines and definitions on mutually identified parameter", which would "at least inform disputants of differences and how they may have an impact on the process or the outcome to their dispute". See: Manon Schonewille \& Jeremy Lack, Mediation in the European Union and Abroad: 60 States Divided by a Common Word?, at: The Variegated Landscape of Mediation: A Comparative Study of Mediation Regulation and Practices in Europe and the World, Eleven International Publishing, 2014, p. 21. 
process accessible to a wide range of end-users by balancing procedural flexibility and predictability.

\subsubsection{Transparency}

Transparency has been discussed extensively and increasingly realized in investor-state arbitration in the past decades. Although most of the characteristics also exist in mediation, ${ }^{1134}$ confidentiality is one of the core advantages of mediation which is different from arbitration. It creates a desirable environment for parties to negotiate freely, without the fear of their positions being disclosed or being used against them in future dispute resolution proceedings. Consequently, mediators are can gather the necessary information to help parties to reach a satisfying settlement. If transparency would be required, disputing parties would probably reconsider their approaches and be more cautious about their interactions, and thus the possibility of resolving the dispute with a settlement agreement could be negatively affected.

Under the EU's investor-state mediation rules in the ICS, at least the existence of cases and final settlement agreements are made available to the public. ${ }^{1135}$ This may have been inspired by the IBA Rules for Investor-State Mediation (2012), which provide similar provisions. ${ }^{1136}$ Such a practice helps to ensure that settlement agreements are consistent with the IIA at issue, which is in line with the EU's perception of mediation as a way of having access to justice and the rule of law in its legal culture. However, such a deviation from confidentiality can raise concerns from China. Various reasons contribute to such a speculation. First, the confidentiality of the proceedings and outcomes is recognized as one of the advantages of mediation over arbitration, in the sense that a litigated dispute with a major investor "can have negative consequences for international perceptions of the investment climate in the host country", ${ }^{1137}$ which has been one of China's main concerns. Second, mediation is prescribed as confidential in the Chinese mediation rules, unless the disputing parties agree otherwise. ${ }^{1138}$ This is affected by the fact that confidential nature of mediation is in line with the Chinese legal cultural tradition of "no litigation" (Wúsòng, 无讼). ${ }^{1139}$ Such a tradition means that disputes are expected to be avoided, and resolving a dispute in a transparent way is similar to washing the dirty linen in public. Making the existence and some elements of parties' disputes public would cause discomfort for the disputing parties and thus reduce the attractiveness of mediation. Third, mediation is considered by China as the DSM with Chinese characteristics, and therefore the prospect of accepting a practice that deviates from one of the fundamental features of Chinese mediation looks bleak. In this vein, it deserves attention that the newly published Arbitration Rules of the

\footnotetext{
1134 This refers to the involvement of public interest and the requirement for the accountability of the host state's government.

${ }^{1135}$ See e.g. the EU-Singapore IPA, Annex 6, Arts. 4.6, 6.3.

1136 IBA Rules for Investor-State Mediation (2012), Arts. 10.1, 10.3.

1137 Jeswald W. Salacuse, Is There a Better Way? Alternative Methods of Treaty-Based, Investor-State Dispute Resolution, Fordham International Law Journal, Vol. 31, 2007, p. 177.

1138 See e.g. China Council for the Promotion of International Trade (CCPIT)/China Chamber of International Commerce (CCOIC), CCPIT/CCOIC Mediation Rules (enforced on 01.05.2012), Art. 22.

1139 Jinfan Zhang, The Tradition and Modern Transition of Chinese Law, Springer, 2014, pp. 429-456.
} 
China International Economic and Trade Arbitration Commission for International Investment Disputes (2017) create the possibility of engaging in investor-state mediation and it is clearly stated that such mediation shall be confidential. ${ }^{1140}$ Furthermore, although it seems that China has changed its attitude towards transparency in investor-state arbitration from first rejecting it now to acceptance, ${ }^{1141}$ this is not the same story for mediation. There is no sign of an increase in transparency in investorstate mediation domestically in China or in the international community. Therefore, it is reasonable to expect that the transparency requirement of investor-state mediation, albeit limited to the existence of a case and the settlement agreement reached in the end, would be difficult for China to accept. Furthermore, even if it is accepted in the prospective China-EU BIT, it is likely to diminish the attractiveness of mediation and become a big hurdle in its use in practice by China or Chinese investors.

For a China-EU BIT, confidentiality is proposed to be respected as a rule, but an exception can be created for party autonomy. Namely, disputing parties can disclose the existence of mediation, certain aspects of their settlement agreement or other details of the process, if this is agreed upon. ${ }^{1142}$ In this way, the confidential nature of mediation is largely maintained and the possibility of other arrangements is not excluded. In addition, considering the fact that transparency would very likely exist in investor-state adjudication, maintaining confidentiality in mediation as the default rule should be preferred in order to provide disputing parties with different levels of procedural transparency in various DSMs within the ISDS system. ${ }^{1143}$

\subsubsection{Enforcement of Settlement Agreements}

The enforcement of settlement agreements is a practical issue that may lead to mediation being faced with scepticism as a way of resolving investor-state disputes. Successful mediation leads to a new agreement between disputing parties, the implementation of which is not guaranteed, since it is not readily enforceable as an arbitral award which benefits from the enforcement regimes under the ICSID Convention or the 1958 New York Convention. As a result, mediation may simply prolong the dispute resolution process without any reliable result. Although resolving a dispute through mediation implies an expectation of a high level of voluntary compliance, disputing parties would likely prefer to have a certain guarantee of compliance. Therefore, providing a sufficient guarantee of the implementation of

\footnotetext{
1140 Arbitration Rules of the China International Economic and Trade Arbitration Commission for International Investment Disputes (enforced on 01.10.2017), Art. 43(2).

1141 Peter Malanczuk, China and the Emerging Standard of Transparency in Investor-State Dispute Settlement (ISDS), New Zealand Association for Comparative Law, Vol. 19, 2015, pp. 91-93.

1142 There have been several examples of non-confidential public sector resource mediations, which demonstrate the possibility of transparency in investor-state mediation cases to various extents. See e.g. Francis McGovern, Mediation of the Snake River Basin Adjudication, Idaho Law Review, Vol. 42, 2006, pp. 548-553.

1143 In this regard, another possible way of compromising diverse preferences of both parties may be the intermediate approach taken by ICSID in its newly proposed investor-state mediation rules, where only the disclosure of the fact that the parties are mediating, or have mediated, is required, and all other information related to mediation, including any settlement agreement, shall be kept confidential. See: ICSID Mediation Rules, Rule 8. See: International Centre for Settlement of Investment Disputes (ICSID), Proposals for Amendment of the ICSID Rules-Working Paper \#2-Volume 1, 03.2019, available at: https://icsid.worldbank.org/en/Documents/Vol_1.pdf, last visited on 03.08.2020.
} 
settlement agreements is of significance, which would increase the attractiveness of investor-state mediation and thus contribute to the amicable settlement of investor-state disputes.

Neither China nor the EU explicitly dealt with this issue in their existing IIAs, where relevant provisions only stress that "each disputing party shall endeavour to take the measures necessary to implement the mutually agreed solution within the agreed timeframe" and "[t]he implementing disputing party shall inform the other disputing party in writing of any steps or measures taken to implement the mutually agreed solution". ${ }^{1144}$ While internally both parties have created mechanisms to ensure the enforceability of settlement agreements resulting from mediation, ${ }^{1145}$ it is difficult to transpose such domestic arrangements to the international level.

In this regard, lessons can be learned from international commercial arbitration: if a settlement agreement is reached through mediation, disputing parties can refer to arbitration, asking an arbitral tribunal to transform the settlement into an award by consent. ${ }^{1146}$ As a result, the enforceability of a final award under the ICSID Convention or the 1958 New York Convention would be available. ${ }^{1147}$ This is also possible in the context of the EU's ICS, by incorporating settlement agreements into the decisionmaking stage of the adjudication process and thus the realization of settlement agreements is guaranteed by the enforcement system. ${ }^{1148}$ Another possible arrangement can be found in the EU's proposal for TTIP, where a mutually agreed solution shall be notified to the non-disputing treaty party and the joint committee shall keep the implementation of the settlement under surveillance with disputing parties' regular report. ${ }^{1149}$

\footnotetext{
1144 See e.g. EU-Singapore IPA (2018), Annex 6, Arts. 5.1, 5.2.

1145 Regarding the EU, see: European Parliament, Directive 2008/52/EC of the European Parliament and of the Council of 21 May 2008 on Certain Aspects of Mediation in Civil and Commercial Matters, Directive 2008/52/EC, 24.05.2008, Art. 6. In terms of China' s legal system, there are different ways to add an enforcement effect to a settlement agreement from mediation. For example, parties may make an application to the competent people's court to confirm their settlement agreement. See: Civil Procedure Law of the People's Republic of China (enforced on 09.04.1991, as amended on 31.08.2012), Art. 26.

1146 In fact, there have been at least 15 ICSID cases where the arbitral tribunals were asked to transform parties' settlements into consent awards. See: Jean Kalicki, Mediation of Investor-State Disputes: Revisiting the Prospects, Kluwer Arbitration Blog, 14.06.2013, available at: http://kluwerarbitrationblog.com/2013/06/14/mediation-ofinvestor-state-disputes-revisiting-the-prospects/, last visited on 03.08.2020.

1147 As mentioned in academic discussions, another more straightforward option could be to grant the settlement agreements reached through mediation the same effect as adjudicators' decisions. See: Jingxia Shi \& Nuan Dong 石静霞、董暖, The Construction of Investment Dispute Settlement Mechanisms under 'One Belt One Road' Initiatives “一带一路” 倡议下投资争端解决机制的构建, Wuhan University International Law Review 武大 国际法评论, Vol. 2, 2018, p. 22.

1148 It is noticeable that this does not deal with the unavoidable weakness of the EU's ICS that its judgments may not be enforced in states which are not subject to this system. For a further analysis on this point, see: Stockholm Chamber of Commerce-ISDS BLOG, Just Published: Analysis of EU'S "Investment Court System", available at: $\mathrm{http}$ ://isdsblog.com/2016/10/27/just-published-analysis-of-eus-investment-court-system/, last visited on 05.08.2020. 1149 The EU's TTIP proposal (tabled for discussion with the United States and made public on 12.11.2015), Chapter II Section 3 Art. 2. From a procedural arrangement perspective, such surveillance and report mechanisms should recall a similar report mechanism for mutually agreed solutions to disputes reached between WTO Members to the WTO Dispute Settlement Body with sufficient information for other WTO Members. See: DSU, Art. 21.
} 


\subsection{The International Adjudication Mechanism}

Various amicable DSMs provide investors and states with an opportunity to resolve their disputes in a friendly environment. However, they are not enough to guarantee the effective resolution of investor-state disputes. The real "teeth" of an ISDS system is often from the international adjudication mechanisms.

This sub-section discusses the adjudication mechanism for ISDS in the prospective China-EU BIT, by identifying the potential thorny issues that may cause difficulties in the negotiations and by proposing possible procedural arrangements that could serve as the solutions. This exploration is arranged under five headings: adjudication forum, selection of adjudicators, the role of the joint committee in dispute settlement, procedural transparency and, finally, the appeal process.

\subsubsection{Adjudication Forum: Arbitration or an Investment Court?}

At the first glance, China and the EU seem to have different preferences regarding the forum for adjudicating investor-state disputes. In all of China's IIAs where international adjudication is provided, arbitration is the consistent and only choice. Investors are often granted the right to choose arbitration under the framework of ICSID or ad hoc arbitration under other rules. In the EU, despite arbitration being the common practice in the Member States' existing IIAs, it is quite clear that the intention is to insist on the proposed ICS for the IIAs to be concluded in the near future. ${ }^{1150}$ This will likely also be the case for its prospective investment agreement with China. However, as introduced in Section 6.1, supra, traditionally China is resistant to engaging with international courts, particularly because of not having control over, or even an impact on, the constitution of the tribunals and their decisions. Therefore, an initial and fundamental question that needs to be dealt with here is whether the ICS proposed by the EU would face a hostile attitude from China at the negotiation table for a China-EU BIT.

As noted previously, recent decades have witnessed the softening of China's traditional resistance towards international adjudication, such as joining the WTO which includes a compulsory quasi-judicial dispute settlement system. In this vein, it is more appropriate to predict China's possible attitude towards the ICS on the basis of the system's specific features. In addition, although the EU's proposal is widely referred to as a "court" system, ${ }^{1151}$ its real differences from investment arbitration deserves a

${ }^{1150}$ It was stated by the EU that the reformed system for investment dispute settlement was to be included in its ongoing and future negotiations with other states. See: European Commission, Establishment of a Multilateral Investment Court for Investment Dispute Resolution, DG Trade - F2, 01.08.2016, p. 3. In particular, during the recent investment treaty negotiations between Japan and the EU, the European Commission stressed that "anything less ambitious, including coming back to the old investor-to-state dispute settlement, is not acceptable". See: European Commission, A New EU Trade Agreement with Japan, 07.2018, available at: http://rade.ec.europa.eu/doclib/docs/2017/july/tradoc_155684.pdf, last visited on 31.07.2020.

1151 The reference to "Investment Court System (ICS)" can be found in the EU's official documents as well as academic discussions. See e.g. European Parliament-Directorate General for External Policies-Policy Department, In Pursuit of an International Investment Court-Recently Negotiated Investment Chapters in EU Comprehensive Free Trade Agreements in Comparative Perspective, 2017, available at: http://www.europarl.europa.eu/thinktank/en/document.html?reference=EXPO_STU\%282017\%29603844, last visited on 01.08.2020. Szilárd Gáspár-Szilágyi, A Standing Investment Court under TTIP from the Perspective of the Court of Justice of the European Union, Journal of World Investment \& Trade, Vol. 17, 2016. Shixi Huang 黄世席, 
second thought. As was occasionally pointed out, the EU's proposal is different from a typical standing international court. ${ }^{1152}$ In fact, the use of "court" and "judge" is only used in the EU's proposal for the TTIP, ${ }^{1153}$ but not in its three concluded IIAs and other treaty proposals. More importantly, the resemblance of the ICS to investment arbitration is evidenced in various aspects. First, both of them are adjudicative by nature, where disputes are decided by a third independent and impartial body according to applicable laws. Second, institutionally, the ICS does not establish a permanent secretariat for the adjudication body, which can be seen in other international courts like the ICJ. The costs of the adjudication process are still mostly paid by disputing parties, which means that ad hoc features still exist. Third, procedurally, the adjudication process in the ICS uses existing arbitration rules, like those of UNCITRAL and ICSID. ${ }^{1154}$ Furthermore, regarding enforcement, the ICS partly relies on the ICSID Convention and the 1958 New York Convention. Therefore, it is arguable that many similarities exist between the EU's ICS and investor-state arbitration. Considering China has accepted the latter, for its prospective BIT with the EU, incorporating an international adjudication mechanism for ISDS that does not deviate much from its existing practice of arbitration should not face hesitation from China. Although the nomenclature of a "court" system may raise certain concerns considering China's traditional resistance to subjecting its sovereignty to an international court, at least from the perspective of the adjudicative nature of the ICS, institutional arrangements, applicable procedural rules, and enforcement process, such worries do not seem to be justifiable.

In addition, two features of the ICS are even argued to be desirable for China. First, compared to the existing practice of investor-state arbitration, the level of institutionalization of the ICS is enhanced. Despite some remaining ad hoc arrangements, in general, the ICS is supposed to be a permanent institution staffed with standing adjudicators pre-selected by treaty parties using autonomous rules. Moreover, a joint committee composed of representatives from treaty parties is established with a broad range of functions, including supervising the treaty's daily operation, issuing the interpretation of treaty provisions and delivering supplement agreements. Considering

\footnotetext{
The Origin of and the Response to the EU's Investment Court System 欧盟国际投资仲裁法庭制度的缘起与因应, Studies in Law and Business 法商研究, Vol. 4, 2016.

1152 See: e.g. Céline Lévesque, The European Union Commission Proposal for the Creation of an "Investment Court System": The $Q$ and A that the Commission Won't be Issuing, Kluwer Arbitration Blog, 06.04.2016, available at: http://arbitrationblog.kluwerarbitration.com/2016/04/06/the-european-union-commission-proposal-for-thecreation-of-an-investment-court-system-the-q-and-a-that-the-commission-wont-be-issuing/, last visited on 03.08.2020.

1153 The EU's proposal for the Transatlantic Trade and Investment Partnership (tabled for discussion with the United States and made public on 12.11.2015), Chapter II Section 3.

1154 In this regard, it deserves attention that the recent reform proposal for ICSID rules includes revising the Additional Facility rules so that a regional economic integration organization can be a party to Additional Facility proceedings. This appears to "open a more straightforward path for the European Union-a non-party to the ICSID Convention-to be a party to some form of ICSID-based arbitration". See: Luke Eric Peterson, A First Look at ICSID's Proposed Rules Changes, Including in Relation to Provisional Measures, Third-party Funding, Security for Costs, and Arbitrator Disqualification, IAReporter, 03.08.2018, available at: https://www.iareporter.com/articles/afirst-look-at-icsids-proposed-rules-changes-including-in-relation-to-provisional-measures-third-party-fundingsecurity-for-costs-and-arbitrator-disqualification/, last visited on 05.08.2020.
} 
China's preference for institutionalization rather than ad hoc arrangements, ${ }^{1155}$ such intensified institutionalization is likely to be welcomed by China. Second, the adjudication function of the ICS is realized under great influence from the treaty parties. As introduced in Section 7.3.3.2, supra, this is particularly reflected in the joint committee's power to issue binding treaty interpretations, as well as the treaty parties' right to make individual submissions on treaty interpretation and binding domestic law interpretation. It is admitted that this will not determine the ultimate interpretation adopted by the adjudicators, but it confirms the right of treaty parties to make submissions on treaty interpretation before the adjudicators make a decision and the binding effect of a domestic law interpretation given by treaty parties. Such arrangements decrease the delegation to the adjudication body and reserve more control for treaty parties over the adjudication process of ISDS. ${ }^{1156}$ In fact, the enhancement of the treaty parties' role in ICS in ISDS mainly aims at responding to the criticism against the investment arbitration decisions where IIAs were interpreted as going against the treaty parties' domestic law, deviating from their alleged intention, or conflicting with other cases, which was also supported by China. ${ }^{1157}$ It is arguable that the increased power for treaty parties in the EU's ICS should at least partly reduce China's anxiety about not having an influence on the result of international adjudication. In addition, the involvement of investors' home states in the ICS may increase the chance of an amicable settlement of disputes, considering the possible strong intention of states to settle disputes amicably, which is in line with China's consistent preference for maintaining harmonious relationships.

In brief, regarding the adjudication forum, the approach of China and that of the EU can be reconciled, since they do not deviate much from each other. Furthermore, considering the enhanced institutionalization and the treaty parties' increased influence on adjudicators, the general structure of the EU's ICS should not be a stumbling block for both parties to reach an agreement. It is also suggested that China should not reject the ICS as a whole only because of its novelty and China's unfamiliarity with it. ${ }^{1158}$ However, one point that China may resist is the exclusive jurisdiction of the ICS. As has been suggested by many Chinese scholars, China will need to argue for adding the

\footnotetext{
1155 This can be typically evidenced by China's different attitudes towards institutional commercial arbitration and ad hoc commercial arbitration. At the beginning, only the awards from the former were recognized and enforceable in China. Furthermore, until now, ad hoc commercial arbitration is still not allowed to be conducted in China.

1156 Two issues, who selects adjudicators and whether there is any standing body composed of treaty parties, were argued to be the two elements relevant to the degree of delegation. See: Todd Allee \& Manfred Elsig, Dispute Settlement Provisions in PTAs: New Data and New Concepts, at: Trade Cooperation: The Purpose, Design and Effects of Preferential Trade Agreements, Cambridge University Press, 2015, pp. 341-342.

1157 Anthea Roberts \& Zeineb Bouraoui, UNCITRAL and ISDS Reforms: Concerns about Arbitral Appointments, Incentives and Legitimacy, EJIL: Talk!, 06.06.2018, available at: https://www.ejiltalk.org/uncitral-and-isds-reformsconcerns-about-arbitral-appointments-incentives-and-legitimacy/, last visited on 05.08.2020. On this issue, it deserves attention that the newly released CIETAC Investment Arbitration Rules explicitly stipulate the nondisputing state party's right to make submissions on treaty interpretation. See: The CIETAC Investment Arbitration Rules, Art. 44.1.

1158 It was argued that, as evidenced by the development of the ICSID, the positive effect of an institution may only be noticed gradually with its development after the establishment. See: Thomas Wälde, Alternatives for Obtaining Greater Consistency in Investment Arbitration: An Appellate Institution after the WTO, Authoritative Treaty Arbitration or Mandatory Consolidation?, Transnational Dispute Management (TDM), 2005, available at: $\mathrm{https} / / / \mathrm{www}$. transnational-dispute-management.com/article.asp?key=421, last visited on 06.08.2020.
} 
possibility of submitting disputes to any arbitration institution agreed upon by the disputing parties, in order to include Chinese arbitration institutions, such as the CIETAC, for them to play a role in potential ISDS cases. ${ }^{1159}$ In addition to the familiarity of using its own arbitration institutions and the comfort afforded by this, there are some typical features of the procedural rules of Chinese arbitration institutions that China may have strong preference for. A typical example would be the practice of combining mediation and arbitration, which reflects China's consistent preference for mediation; it is an approach that it is proud of. However, this approach may be rejected by the EU. In addition to its unfamiliarity with such a practice, the mix of informal settings and arbitration brought by "Arb- Med" may violate the EU's perception of procedural justice and the rule of law. ${ }^{1160}$ Furthermore, considering the consistent practice of using the ICS as the only forum for investor-state adjudication in the EU's concluded IIAs, even if accepted in a China-EU BIT, the possibility of involving other arbitration institutions based on the consent of the disputing parties is likely to happen only in the case of EU investors going up against the Chinese government. This is because, when the Union acts as the respondent, it would prefer to resort to the ICS. When EU investors are involved, the Union may have a more open attitude towards the choice of forum.

\subsubsection{Selection of Adjudicators: by Disputing Parties or by Treaty Parties?}

In China's IIAs, investor-state adjudication normally takes the form of arbitration, where disputing parties enjoy the right to select the adjudicators in their own cases. Specifically, a tribunal is often composed of three arbitrators, one appointed by the claimant, one appointed by the respondent and the chair being chosen based on the agreement of the disputing parties or the two selected arbitrators. In the EU's ICS, members of the Tribunal and the Appeal Tribunal are pre-selected by treaty parties. The members of a division for a specific case are appointed randomly and unpredictably by the President of the Tribunal or the Appeal Tribunal from the pre-established rosters, composed of one national of a Member State of the EU, one national of the other treaty party and one national of a third state. As a result, no room is left for party autonomy, and investors do not have a say in the composition of the tribunals of their own cases.

The difference in the selection of adjudicators between the practice of the two parties relates to the different adjudication fora adopted. With regard to arbitration, party autonomy is a top concern, as reflected in the arbitrators being selected by the disputing parties, while in a court-type system, the role played by disputing parties in the selection of adjudicators is limited. Similar to the practice in a domestic court or the EU's internal adjudication body, the CJEU, the EU's ICS does not give the right to disputing parties to decide or exert any influence on the composition of adjudicators.

\footnotetext{
1159 See e.g. Jingxia Shi \& Nuan Dong 石静霞、董暖, The Construction of Investment Dispute Settlement Mechanisms under 'One Belt One Road' Initiatives “一带一路” 倡议下投资争端解决机制的构建, Wuhan University International Law Review 武大国际法评论, Vol. 2, 2018.

1160 "Med-Arb" refers to combining mediation and arbitration by conducting mediation during the arbitration process when there is the consent of the disputing parties. For a further explanation of such a practice, see Section 3.2.2.4, supra.
} 
The impetus for changing the existing practice in investment arbitration to selecting adjudicators in advance is considered to ensuring that tribunals would be particularly mindful of the intentions of the treaty parties. ${ }^{161}$ In addition, compared to selecting adjudicators after a case is filed, where disputing parties would seek to appoint adjudicators that they believe are broadly sympathetic to their positions, pre-selection by treaty parties is more likely to result in having a balance of adjudicators. ${ }^{1162}$ From this perspective, China seems to share similar ideas. During the meetings of the UNCITRAL Working Group III sessions on states' concerns about ISDS, China pointed out that it was concerned about adjudicators making a decision which went against the treaty parties' original intent. ${ }^{1163}$ China also recognized that ensuring the independence and impartiality of arbitrators was a systemic issue, which required an integral approach. ${ }^{164}$ In this regard, the new CIETAC Investment Arbitration Rules are noticeable, where the practice of determining a pre-established roster of arbitrators was introduced. However, party autonomy is still preserved by allowing the disputing parties in a specific case to select their adjudicators from the roster. ${ }^{165}$ This is also the practice adopted in the China-Australia FTA (2015), where the establishment of a list of potential arbitrators for investor-state arbitration is envisaged, while party autonomy is still respected. ${ }^{166}$ Furthermore, China also presented such a preference during the discussion of ISDS reform at the UNCITRAL Working Group III. ${ }^{1167}$ Thus, it is fair

1161 As pointed out by the EU, treaty parties are likely to choose the ones that would "best respect the balance of interest that has been struck during the negotiations of the substantive rules of the underlying treaties" especially when adjudicators are expected to serve long term. See: Anthea Roberts \& Zeineb Bouraoui, UNCITRAL and ISDS Reforms: Concerns about Arbitral Appointments, Incentives and Legitimacy, EJIL: Talk!, 06.06.2018, available at: https://www.ejiltalk.org/uncitral-and-isds-reforms-concerns-about-arbitral-appointments-incentives-andlegitimacy/, last visited on 05.08.2020. In this sense, it deserves attention that being in favour of the treaty parties does not mean being pro-investor or pro-state; instead, it is about honouring the deal and adhering to the bargain that treaty parties have reached. See: Anthea Roberts, Would a Multilateral Investment Court be Biased? Shifting to a Treaty Party Framework of Analysis, EJIL: Talk!, 28.04.2017, available at: https://www.ejiltalk.org/would-amultilateral-investment-court-be-biased-shifting-to-a-treaty-party-framework-of-analysis/, last visited on 05.08.2020.

1162 Julian Donaubauer \& Eric Neumayer \& Peter Nunnenkamp, Winning or Losing in Investor-to-State Dispute Resolution: The Role of Arbitrator Bias and Experience, Kiel Working Paper, Vol. 2074, 2017. On the other hand, it was also argued that the presumption that an investor-appointed arbitrator is biased in favour of the appointing investor had been proven untrue by empirical statistics and the allegation that party-appointed commercial arbitrators were unable to handle disputes involving public interest was equally unfounded. See: Chi-Chung Kao, The Inclusion of Investment Court System into the EU-China BIT: Innovations, Prospects and Problems, at: Julien Chaisse (ed.), China-European Union Investment Relationships: Towards a New Leadership in Global Investment Governance?, Edward Elgar Publishing, 2018, p. 265.

1163 Anthea Roberts \& Zeineb Bouraoui, UNCITRAL and ISDS Reforms: Concerns about Arbitral Appointments, Incentives and Legitimacy, EJIL: Talk!, 06.06.2018, available at: https://www.ejiltalk.org/uncitral-and-isds-reformsconcerns-about-arbitral-appointments-incentives-and-legitimacy/, last visited on 05.08.2020.

1164 Id.

1165 If disputing parties want to nominate someone outside the roster, subject to the fulfilment of qualifications set forth in the rules, a further confirmation by the Chairman of CIETAC is needed. See: CIETAC Investment Arbitration Rules (2018), Art. 11.1.

1166 According to Art. 9.15 of the China-Australia FTA (2015), the Committee on Investment "shall, no later than 2 years after the entry into force of this Agreement, establish a list of individuals who are willing and able to serve as arbitrators". In a dispute, "[u]nless the disputing parties have agreed to appoint a sole arbitrator, the tribunal shall comprise three arbitrators, one arbitrator appointed by each of the disputing parties and the third, who shall be the chairperson, appointed by agreement of the disputing parties". When "a tribunal has not been constituted within 90 days from the date that a claim is submitted to arbitration under this Section, the appointing authority, on the request of a disputing party, shall appoint, in his or her discretion, the remaining arbitrators from the list established".

1167 China indicated that it did not necessarily believe there was a problem with the party appointment mechanism itself. See: Anthea Roberts, UNCITRAL and ISDS Reforms: Moving to Reform Options...the Politics, EJIL: Talk!, 08.11.2018, available at: https://www.ejiltalk.org/uncitral-and-isds-reforms-moving-to-reform-options-the-process/, 
to say that China and the EU have the same intention to ensure the impartiality of the tribunals and adherence to the original intent of the treaty parties reflected in IIAs. They have diverse views, however, on the issue of respecting party autonomy. Specifically, party autonomy has been a key concern for China, which should not be changed even when systemic reform of ISDS is called for. This can be understood from the point of view that China uses DSMs as a way of providing a service to disputing parties to resolve their disputes. In other words, disputing parties are seen as the customers and adjudicators are service providers. Thus, satisfying the disputing parties' needs takes priority and can be taken even further as realizing "justice". However, to the EU, resolving disputes is just part of the result of the dispute settlement process. More importantly, dispute settlement, especially adjudication, bears the responsibility of realizing the rule of law, and thus due process and developing jurisprudence come before the disputing parties' needs. Thus, from the EU's perspective, respecting the rule of law should be indispensable in realizing "justice" in dispute settlement.

Therefore, the problematic issue here for a China-EU BIT is how to acknowledge party autonomy. Regarding this, it should be borne in mind that the recognition by both states and investors of an investor-state DSM is key to its function in practice. The possible perception of adjudicators lacking impartiality and fairness by investors would affect the system's efficacy and use in practice. Thus, satisfying not only the treaty parties' but also investors' needs is necessary. In this vein, completely disregarding party autonomy in the composition to tribunals is argued to be undesirable for investors and, in fact, unnecessary to reach the EU's goal of guaranteeing the independence, impartiality and qualification adjudicators. In the ICS, before composing the division for a specific case, there are already two levels of safeguards. The first level comes from the fact that the Tribunal and the Appeal Tribunal are composed of members appointed by the treaty parties. In exercising their power of selecting members from the roster, treaty parties would balance their diverse interests and select impartial adjudicators that would not always be pro-investors or pro-states. The second safeguard is the qualification requirements stated in the body of the treaty text and the attached binding Code of Conduct for adjudicators. These two safeguards would guarantee the professional and ethical qualifications of the adjudicators. As a result, in specific cases, letting disputing parties choose their own adjudicators respectively from the preestablished roster would not negatively affect the functioning of the system. In fact, this is the practice that was adopted in the EU's IIAs for state-state adjudication. ${ }^{1168}$

If no agreement can be reached between disputing parties on the selection of the chair of a tribunal, the president of the Tribunal or the Appeal Tribunal can designate a chair from the roster of adjudicators of third states by a random draw. Such an approach is argued to be acceptable and even desirable for China, since it leaves room for party autonomy and is to some extent similar to how panels are composed in the WTO Dispute Settlement System, which has already been accepted by China and China has

last visited on 05.08.2020

1168 See e.g. the EU-Singapore IPA (2018), Art. 3.29. 
gotten used to it. ${ }^{1169}$ Although the disputing parties do not have rights to select adjudicators at the WTO Appellate Body level, before China's accession, existing practice had proven the functioning of the WTO Appellate Body, which is not yet the case for the EU's ICS, since there has been no real use of this system. More concrete support for China's possible preference for the approach recommended here comes from relevant practice under the CIETAC Investment Arbitration Rules and the ChinaAustralia FTA (2015). Last but not least, the discretion given to disputing parties would contribute to the attractiveness of the ICS for potential users and correspondingly increases their satisfaction with the system. It could also constitute a proper adjustment to the criticism of the ICS being "a setback in the de-politicization of investor-state dispute settlement". 1170

In brief, regarding the selection of adjudicators for investor-state adjudication, letting treaty parties compose the roster of adjudicators and allowing disputing parties to select the decision makers for their own cases from the pre-established list is argued to result in a proper balance between treaty parties' and investors' rights, as well as a balance between China's and the EU's preferred practice and correspondingly preserved values.

\subsubsection{The Role of the Joint Committee in Dispute Settlement: Influential or Decisive?}

Despite the academic debate about the weight of joint agreements on treaty interpretation, ${ }^{1171}$ many IIAs expressly grant them binding effect. When it comes to certain specified matters, tribunals are even required to suspend the ongoing proceedings and resort to treaty parties for binding joint decisions. ${ }^{1172}$ Some of China's concluded IIAs provide that treaty interpretations reached through joint committees are binding on ISDS tribunals. ${ }^{173}$ In the EU's ICS, the joint committee is afforded great power, particularly on treaty interpretation. During the adjudication process of ISDS, the joint committee can issue binding interpretations of the IIA at issue, which must be respected by the tribunals. This aims at ensuring that the treaty parties' real intentions are reflected and presented in specific cases and can contribute to a "more harmonious, authoritative and linear development" of treaty interpretation. ${ }^{1174}$ The ICS goes even

\footnotetext{
1169 It is admitted that it is different in the sense that in the WTO Dispute Settlement System, while there is an indicative list of panelists, parties and the Director General are free to select a person not on that list.

1170 Chi-Chung Kao, The Inclusion of Investment Court System into the EU-China BIT: Innovations, Prospects and Problems, at: China-European Union Investment Relationships: Towards a New Leadership in Global Investment Governance?, Edward Elgar Publishing, 2018, p. 265.

1171 Disagreement generally exists in whether an "authentic" interpretation by treaty parties is binding or simply very persuasive. See, e.g. Anthea Roberts, Power and Persuasion in Investment Treaty Interpretation: The Dual Role of States, American Journal of International Law, Vol. 104, 2010, pp. 75-76. Mark E. Villiger, Commentary on the 1969 Vienna Convention on the Law of Treaties, Martinus Nijhoff Publishers, 2009, p. 429. Richard Gardiner, Treaty Interpretation, Oxford University Press, 2008, p. 32.

1172 Sheng Zhang 张生, Study on Treaty Parties' Interpretation under the Framework of International Investment Law 国际投资法制框架下的缔约国解释研究, Modern Law Science 现代法学, Vol. 37, 2015, pp. 167-168.

1173 See e.g. the China-Canada BIT (2012), Art. 18. For a further discussion on such provisions in China's concluded IIAs, see: Norah Gallagher, China's BIT's and Arbitration Practice: Progress and Problems, at: China and International Investment Law: Twenty Years of ICSID Membership, Brill | Nijhoff, 2014, p. 212.

1174 Sophie Nappert, Escaping from Freedom? The Dilemma of an Improved ISDS Mechanism, at: European Investment Law and Arbitration Review (Volume 1), Brill | Nijhoff, 2016, p. 189.
} 
further in this direction by giving the joint committee the power to determine the effective dates for its interpretations, which may open the door for retroactivity. ${ }^{1175}$

Although the possibility of reaching a joint interpretation during certain investor-state dispute settlement processes is low in practice, ${ }^{1176}$ how the joint committee's role as a treaty interpreter can be defined during ISDS deserves a second thought. As was pointed out, while acknowledging the inevitable tensions resulting from the coexistence of states and tribunals, an investment treaty system aims at developing "a hybrid theory", which recognizes and values their independent and shared interpretive authorities. ${ }^{1177}$ Joint interpretations are preferred, since they reflect the treaty parties' true intentions, and especially in some difficult or sensitive cases, joint interpretations can work as the "safety valve". ${ }^{1178}$ However, the blurring line between interpretations and amendments can cause difficulties and risks. A joint declaration reached after a dispute arises can take the form of an interpretation explaining the meaning of existing words in the treaty, or an amendment which changes the original deal and thus should just constitute an element in the holistic method of interpretation. ${ }^{1179}$ As a result, granting any joint committee's declaration reached at any time the status of a binding interpretation may violate the principle of non-retroactivity, when it in fact amends the IIA at issue. ${ }^{1180}$ Possible retroactive interpretations from the joint committee also conflict with the rule of law if the rights and obligations in the treaty are changed ${ }^{1181}$ and, further, if they go against the original intent of depoliticizing the investment dispute settlement process. However, at the same time, it is admitted that making a difference between treaty interpretations and treaty amendments is not an easy job. ${ }^{1182}$

\footnotetext{
1175 On this point, a draft text on ISDS for the EU's IIAs negotiation that was leaked in June 2012 adopted a narrower approach by limiting interpretive agreements to be prospective only. See: The European Commission, Note for the Attention of the Trade Policy Committee (Services and Investment)-Text on Investor State Dispute Settlement for EU agreements (05.06.2012), 69/12, Art. 9(2). Such a statement seems to have been abandoned and does not exist in any of the EU's concluded IIAs.

1176 As has been pointed out, coordinating interpretation mechanisms are significantly underutilized in ISDS. See: Michael Waibel, International Investment Law and Treaty Interpretation, at: Rainer Hofmann \& Christian J. Tams (eds.), International Investment Law and General International Law: From Clinical Isolation to Systemic Integration?, Nomos Publishers, 2011, p. 30. For example, so far, the NAFTA Free Trade Commission has called for light to be shed on the meaning of a treaty provision only once. See: North American Free Trade Agreement, Notes of interpretation of Certain Chapter 11 Provisions, NAFTA Free Trade Commission (31.07.2001).

1177 Anthea Roberts, State-to-State Investment Treaty Arbitration: A Hybrid Theory of Interdependent Rights and Shared Interpretive Authority, Harvard International Law Journal, Vol. 55, 2014, p. 28.

1178 Anthea Roberts, Power and Persuasion in Investment Treaty Interpretation: The Dual Role of States, American Journal of International Law, Vol. 104, 2010, p. 215.

1179 Sheng Zhang 张生, Study on Treaty Parties' Interpretation under the Framework of International Investment Law 国际投资法制框架下的缔约国解释研究, Modern Law Science 现代法学, Vol. 37, 2015, p. 171.

${ }_{1180}$ Gabrielle Kaufmann-Kohler, Interpretive Powers of the Free Trade Commission and the Rule of Law, at: Emmanuel Gaillard \& Frédéric Bachand (eds.), Fifteen Years of NAFTA Chapter 11 Arbitration, JurisNet, 2011, p. 152. It was also argued that a delicate differentiation between interpretations and amendments was particularly compelling when dealing with treaties that create rights or benefits for and legitimate expectations of third parties, like investors, which should curb the ability of the treaty parties to reinterpret the treaty at will. See: Anthea Roberts, Power and Persuasion in Investment Treaty Interpretation: The Dual Role of States, American Journal of International Law, Vol. 104, 2010, p. 104. Anthea Roberts, Subsequent Agreements and Practice: The Battle Over Interpretive Power, at: Georg Nolte (ed.), Treaties and Subsequent Practice, Oxford University Press, 2013, pp. 101102.

1181 Based on the principle of the rule of law, law should be certain and prospective. A retroactive interpretation would conflict with the rule of law to the extent that it negatively affects investors' rights and legal interests.

1182 It was even argued that a clear line between these two did not exist. See: Charles H. Brower II, Why the FTC Notes of Interpretation Constitute a Partial Amendment of NAFTA Article 1105, Virginia Journal of International Law, Vol. 46, 2006, pp. 347-363. Anthea Roberts, Power and Persuasion in Investment Treaty Interpretation: The
} 
In existing investment arbitration cases, tribunals have presented different attitudes towards joint interpretations by treaty parties, especially those issued after certain investor-state disputes had arisen. ${ }^{1183}$ When the relevant document is defined as a subsequent agreement or subsequent practice, its effect changes from being "binding" to "persuasive". ${ }^{1184}$ Probably because of such uncertainty, the EU's ICS takes a rigorous approach to ensuring decisive power of treaty parties in relation to treaty interpretation, by providing that a joint interpretation is always binding and treaty parties may even decide its effective date. In this regard, it deserves particular attention that the CJEU's Opinion 1/17 seems to correct this practice. In this Opinion, the CJEU clearly stated that the requirement of independence of the ICS presupposed that the body concerned exercised its functions "wholly autonomously" and "without taking orders or instructions from any source whatsoever, thus being protected against external interventions or pressure". ${ }^{185}$ Based on this, it should be reasonable to expect that similar provisions granting joint committees the power to decide the effective dates of their joint interpretations would not appear in the EU's future IIAs. At the same time, in practice, any joint interpretation, including those under the three concluded IIAs, is likely to be considered as being binding on future cases only.

In spite of the doubts about its legitimacy introduced above, giving the joint committee a decisive role in ISDS may not face harsh objection from China. This inference is particularly based on China's experience in the case Sanum Investments Limited v. Lao People's Democratic Republic, where the treaty parties' joint interpretation was not recognized by the tribunal as an interpretation but an amendment, and thus it was not granted binding effect. ${ }^{186}$ At the same time, supporting elements may also come from China's legal culture. A joint committee uses diplomatic cooperation, which means the resolution and implementation of many matters are realized through informal bilateral negotiations, instead of formal legal procedures. This should work well with China's

Dual Role of States, American Journal of International Law, Vol. 104, 2010, pp. 212-215. Rahim Moloo, When Actions Speak Louder Than Words: The Relevance of Subsequent Party Conduct to Treaty Interpretation, Berkeley Journal of International Law, Vol. 31, 2013, pp. 75-76.

1183 For example, in Mondev International Ltd. v. the US, the tribunal accepted the NAFTA Free Trade Commission's statement on treaty interpretation and respected the binding effect thereof. See: Mondev Internaional Ltd. v. United States of America, ICSID Case No. ARB(AF)/99/2, Award, 11.10.2002, para. 121. A similar attitude was also taken by the tribunal in the cases ADF Group Inc. v. the US and Chemtura Corp. v. Canada. See: ADF Group Inc. v. United States of America, ICSID Case No. ARB(AF)/00/1, Award, 09.01.2003, para. 177; Chemtura Corp. v. Government of Canada, ad hoc arbitration under UNCITRAL Rules, Award, 02.08.2010, para. 120.

On the other hand, in Pope \& Talbot Inc. v. Canada, the tribunal challenged the joint statement issued by the NAFTA Free Trade Commission, deeming it as "amendment" of the treaty instead of "interpretation". See: Pope \& Talbot Inc. v. Government of Canada, NAFTA Chapter 11 Arbitration, Award in Respect of Damages, 31.05.2002, para. 23. Support for such a position can also be found in cases such as Merrill \& Ring Forestry LP v. Canada. See: Merrill and Ring Forestry L.P. v. Canada, ICSID Case No. UNCT/07/1, Award, 31.03.2010, para. 192.

1184 See e.g. Interpretation of the Air Transport Services Agreement between the United States of America and Italy, Award of 17 July 1965, 16 RIAA 75, 99. It was addressed here that the subsequent practice of treaty parties is not "in itself decisive for the interpretation of the disputed text; it can however serve as additional evidence as regards the meaning to be attributed to the text". See also: International Status of South-West Africa, Advisory Opinion of 11 July 1950, ICJ, paras. 135-136.

1185 Opinion 1/17 of the Court (Full Court), 30.04.2019, para. 202.

${ }^{1186}$ In response to a jurisdictional challenge, the Singapore Court of Appeal took a decision where it determined the joint statement of China and Lao did not constitute a treaty interpretation, but a subsequent agreement. See: The Government of the Law People's Democratic Republic v. Sanum Investments Limited, the Court of Appeal of the Republic of Singapore, [2016]SGCA 57, 29.09.2016, paras. 116-118. 
legal cultural characteristic of relying heavily on relationships ("guānxi", 关系). In other words, in a general sense it corresponds to China's popular legal culture of the system depending on people instead of rules. ${ }^{1187}$

In the context of the prospective China-EU BIT, if the EU changes its existing practice under the influence of the CJEU's Opinion 1/17, agreement is expected to be reached that the joint committee's treaty interpretations have binding force on future cases only. Although China may also prefer to at least let joint interpretations be binding in any ongoing case, this may not be acceptable to the EU and, even if accepted, the EU may resist concluding a joint interpretation with China in future cases.

\subsubsection{Procedural Transparency: Default or Exceptions?}

The default of confidentiality in investment arbitration has been harshly criticized for excluding the public and thus being undemocratic. ${ }^{1188}$ Recent decades witnessed transparency in investment arbitration being one of the most topical issues in different fora, 1189 and great efforts have been made to increase transparency correspondingly. ${ }^{1190}$ This was motivated by various concerns, including public interests and the accountability requirement of the host states' government, ${ }^{1191}$ the need of developing consistent case law, development of jurisprudence and legal certainty, ${ }^{1192}$ as well as improving understanding and engagement by stakeholders. ${ }^{1193}$ It is also noted that, on the other hand, there are elements that support confidentiality,

1187 Colin B. Picker, China, Global Governance \& Legal Culture: The Example of China \& the WTO, at: China and Global Economic Governance: Ideas and Concepts, The University of Tokyo-Institute of Social Science (ISS) Research Series No.45, 2011, pp. 86-87.

1188 Pia Eberhardt \& Cecilia Olivet with contributions from Tyler Amos \& Nick Buxton, Profiting from Injustice: How Law Firms, Arbitrators and Financiers are Fueling an Investment Arbitration Boom, Corporate Europe Observatory and the Transnational Institute, 2012. See also: Stephan W. Schill, International Investment Law and the Rule of Law, at: Rule of Law Symposium 2014: The Importance of the Rule of Law in Promoting Development, Singapore: Academy Publishing, 2015, pp. 81, 84.

1189 In particular, in the context of UNCITRAL, in 2013, Working Group II agreed to higher levels of transparency in disputes on the basis of future investment agreements. See: United Nations Commission on International Trade Law (UNCITRAL), Report of Working Group II (Arbitration and Conciliation) on the Work of Its Fifty-eighth Session, United Nations Commission on International Trade Law Forty-sixth session, New York, 4-8.02. 2013. For some academic discussions on this, see: Marc Bungenberg \& Catharine Titi, Developments in International Investment Law, at: Christoph Herrmann \& Markus Krajewski \& Joerg Philipp Terhechte (eds.), European Yearbook of International Economic Law 2014, Springer, 2013, pp. 425-442. Catharine Titi, International Investment Law and Good Governance, at: Marc Bungenberg \& Jörn Griebel \& Stephan Hobe \& August Reinisch (eds.), International Investment Law, C.H. Beck·Hart·Nomos, 2015, pp. 1817-1832.

1190 The development of the ICSID Arbitration rules is a typical example. According to the current ICSID Arbitration Rules (2006), even without the parties' consent, excerpts of legal reasoning of tribunals shall be published by the ICSID. See: ICSID Arbitration Rules (2006), Rule 48(4). Now the ICSID is undertaking a new round of amendments of the rules, where the transparency of proceedings is suggested to be further enhanced. For more information, see: International Centre for Settlement of Investment Disputes (ICSID), ICSID Rules and Regulations Amendment Process, 2018, available at: https://icsid.worldbank.org/en/amendments, last visited on 03.08.2020. Luke Eric Peterson, An In-depth Look at ICSID's Proposed Transparency Changes (Including Non Disputing Party Participation), IAReporter, 06.08.2018, available at: https://www.iareporter.com/articles/an-in-depth-look-at-icsidsproposed-transparency-changes-including-non-disputing-party-participation/, last visited on 05.08.2020.

1191 Public interest considerations mainly arise where foreign investments involve public utilities or legislative or administrative acts that are directed at preserving public interests. See: Dominik Horodyski, Democratic Deficit of Investment Arbitration in the View of Rules on Transparency and Mauritius Convention on Transparency, US-China Law Review, Vol. 13, 2016, pp. 166-167.

1192 Note: Mediation of Investor-State Conflicts, Harvard Law Review, Vol. 127, 2014, p. 2556.

1193 Marc Bungenberg \& Catharine Titi, The Evolution of EU Investment Law and the Future of EU-China Investment Relations, at: China and International Investment Law: Twenty Years of ICSID Membership, Brill | Nijhoff, 2015, p. 339. 
such as the need to protect business secrets and governmental information, as well as prevent politicizing cases. ${ }^{1194}$

In the EU's ICS, as assessed in Section 7.3.3.2, supra, by adopting the UNCITRAL Rules on Transparency or incorporating similar provisions, procedural transparency in the ISDS process has been greatly intensified. Almost all documents produced during the adjudication process must be public. In particular, exhibits, which are excluded from being public under the UNCITRAL Transparency Rules, may also be published under the ICS. ${ }^{1195}$ Hearings are also supposed to be transparent, except for the situation in which the tribunal determines that it is necessary to protect confidential or protected information. At the same time, third parties are explicitly permitted to submit amicus curiae briefs, provided that these parties have submitted their status and their interests in the proceedings to the Tribunal. In particular, regarding the prospective China-EU BIT, the "European Parliament's resolution on the EU-China negotiations for a bilateral investment agreement" states that the investor-state DSMs contained therein should be established "within a suitable legal framework and subject to strict transparency criteria". ${ }^{1196}$ In China, most of its IIAs respect the confidentiality feature of arbitration and none of the 26 BITs concluded by EU Member States with China contain any transparency obligation in ISDS. It deserves attention that, in line with the recent global trend of increasing transparency, China's attitude to this issue has gone through a change: its public statement in 2013 showed that China is moving towards accepting greater procedural transparency in ISDS, ${ }^{1197}$ which can be further proven by its recently signed IIAs with the states that have a strong intention to adopt transparency, such as the China-Canada BIT (2012) and the China-Australia FTA (2015). However, it is noted that, even under these two treaties, the extent of procedural transparency in investor-state adjudication is relatively limited. ${ }^{1198}$

The different practices in relation to transparency respectively resonates each party's legal cultural characteristics and protected values. China traditionally prefers confidential dispute settlement processes, since resolving disputes transparently causes disputing parties to "lose face". This should be the same with ISDS. As was pointed out, by accepting transparency, China will have to "manage lay opinions and media

\footnotetext{
1194 It was pointed out that, in some quarters, transparency in ISDS may particularly be contrary to the interests of investors. See: Christina Knahr \& August Reinisch, Transparency Versus Confidentiality in International Investment Arbitration-The Biwater Gauff Compromise, The Law \& Practice of International Courts and Tribunals, Vol. 6, 2007, p. 111. Klaus Peter Berger, The International Arbitrators' Application of Precedents, Journal of International Arbitration, Vol. 9, 1992, pp. 5-22. Geoffrey Gertz \& Srividya Jandhyala \& Lauge N. Skovgaard Poulsen, Legalization, Diplomacy, and Development: Do Investment Treaties De-politicize Investment Disputes?, World Development, Vol. 107, 2018, p. 243.

1195 CETA (2012), Art. 8.36.3. A similar provision is also available in the EU-Vietnam IPA (2018), Art. 3.46.3. The EU-Singapore IPA (2018) does not contain such a provision.

1196 European Parliament resolution of 9 October 2013 on the EU-China negotiations for a bilateral investment agreement 2013/2674(RSP), P7_TA(2013)0411, 09.10.2013, para. 43.

1197 Statement by Mr Shang Zhen, Chinese Delegate at the 68th Session of the UN General Assembly on Agenda Item 79 Report of UNCITRAL on the Work of Its 46th Session, 14.10.2013, available at: http://www.chinaun.org/eng/chinaandun/legalaffairs/sixthcommittee1/t1091525.htm, last visited on 13.02.2017.

1198 The extent of transparency under these two treaties is much lower than those under the EU's concluded IIAs. As analysed in Section 6.2.3.4, supra, under these two treaties, the realization of transparency is largely in the hand of the disputing parties and especially host states.
} 
reactions to the state's legal case, decisions to settle and perceived loss of face". ${ }^{1199}$ In the EU, transparency is considered to guide both its internal and external actions, which is required and supported by its core protected values of the rule of law and due process.

It is, therefore, reasonable to expect that transparency in investor-state adjudication would be accepted by both China and the EU in general, and the UNCITRAL Rules on Transparency could be adopted as the default rules subject to specific treaty provisions. However, the unavoidable difference in the practice of both sides regarding the level of transparency and detailed arrangements may still constitute stumbling blocks for China and the EU in reaching an agreement. In addition, although Chinese scholars support China in accepting greater transparency in prospective IIAs in principle, they also caution the Chinese government to reduce the speed of development so that China's relevant legislation to protect national secrecy information is comprehensive first. ${ }^{1200}$ Thus, to what extent China would accept the extensive levels of transparency in the ICS is uncertain, and it is essential to contemplate a way of realizing transparency to an appropriate level under a China-EU BIT. As introduced above, there are tenable arguments for both requiring and rejecting transparency in ISDS. In specific cases, investors and states may also have particular reasons to argue for keeping the process transparent or confidential. Thus, it is suggested to leave room for disputing parties to agree on the level of public disclosure under the default rule of transparency. The final say could be left to tribunals in the case an agreement would potentially disrupt the proceedings or unduly prejudice or burden any party. Such a compromise of transparency and party autonomy would not only balance the existing practice and preferences in China and the EU, but it would be a way of showing respect to their respective legal cultural characteristics and preserved values. Specifically, the default rule of transparency should ensure that the publication of documents and open hearings would be realized to a large extent, which is in line with the EU's preference, while the exceptions created for party autonomy would make it easier for China to accept this at the current stage, for both practical and legal cultural reasons.

\subsubsection{An Appeal Mechanism: Necessary for Consistency and Correctness?}

The inconsistency and unpredictability in the current investor-state arbitration system have been criticized greatly, especially considering the tribunals' divergent decisions on similar legal and factual issues. ${ }^{1201}$ In comparison to the two-tiered system in the WTO for international trade dispute settlement, the absence of an appeal mechanism

\footnotetext{
1199 Sophie Nappert, The Other Side of Transparency, Columbia FDI Perspectives, Vol. 141, 2015.

1200 See e.g. Jun Zhao \& Yun Liu 赵骏、刘芸, The Reform of Transparency in International Investment Arbitration and China's Response 国际投资仲裁透明度改革及我国的应对, Journal of Zhejiang University (Humanities and Social Science) 浙江大学学报 (人文社会科学版), Vol. 44, 2014, pp. 159, 161.

${ }^{1201}$ Evidence of this can typically be found in the series of CME and Lauder v. Czech Republic awards. The two simultaneous arbitration cases dealt with the same facts, while in the end one tribunal dismissed the claim and the other tribunal awarded $\$ 353$ million to the investor. See: CME v. Czech Republic, Partial Award of 13 September 2001, reprinted in World Trade and Arbitration Materials (2002), p. 109 et seq.; Lauder v. Czech Republic, Award of 3 September 2001, reprinted in World Trade and Arbitration Materials (2002), p. 35 et seq. For some academic discussion on this issue, see e.g. Susan D. Franck, The Legitimacy Crisis in Investment Treaty Arbitration: Privatizing Public International Law Through Inconsistent Decisions, Fordham Law Review, Vol. 73, 2005. Thomas Wälde, Introductory Note to Svea Court of Appeals: Czech Republic v. CME Czech Republic B.V., Internatioanl Legal Materials, Vol. 42, 2003.
} 
has been considered to be an important reason. ${ }^{1202}$ An appeal mechanism in ISDS is expected to resolve the problem of zigzagging decisions of different ad hoc tribunals, to strengthen the legal correctness of arbitral awards, to ensure consistency and coherence in jurisprudence, to re-establish stakeholders' trust in ISDS, and thus make the whole international investment legal system more sustainable. ${ }^{1203}$ On the other hand, it is also noted that inserting another tier of adjudication may extend the duration of the dispute settlement process, increase costs, and erode the principle of the finality of investment awards. ${ }^{1204}$ The necessity of an appeal mechanism is also doubted in the sense that most decisions have been consistent with each other ${ }^{1205}$ and, even in the situations where there has been a divergence of opinions, certain legal interpretations would stand out and become more acceptable, which results in supporting further consistency. ${ }^{1206}$

In addition to heated academic debate, the idea of creating an appeal mechanism for ISDS has also been put into treaty-making practice. As early as 2004, a provision envisaging a multilateral agreement on establishing an appellate body was incorporated into the US Model BIT (2004). ${ }^{1207}$ More concrete efforts in this trend were made by the EU through creating an Appeal Tribunal in its ICS. This Appeal Tribunal is established in a permanent manner with a fixed number of pre-ordained members who are nationals of treaty parties and third states for a fixed term. Recourse to appeal is intended to be had on prescribed grounds and, in the end, an Appeal Tribunal can maintain, modify or reverse the legal findings and conclusions in the provisional award

1202 Marc Bungenberg \& Catharine Titi, The Evolution of EU Investment Law and the Future of EU-China Investment Relations, at: China and International Investment Law: Twenty Years of ICSID Membership, Brill | Nijhoff, 2015, p. 344. Christian J. Tams, An Appealing Option? The Debate about an ICSID Appellate Structure, Essays in Transnational Economic Law, Vol. 57, 2006. Karl P. Sauvant \& Michael Chiswick-Patterson (eds.), Appeals Mechanism in International Investment Disputes, Oxford University Press, 2008.

${ }_{1203}$ Audley Sheppard \& Hugo Warner, Appeals and Challenges to Investment Treaty Awards: Is It Time for an International Appellate System?-Editorial Note, Transnational Dispute Management (TDM), 04.2005, available at: https://www.transnational-dispute-management.com/article.asp?key=399, last visited on 06.08.2020. Doak Bishop, The Case for an Appellate Panel and its Scope of Review, 04.2005, available at: https://www.transnational-disputemanagement.com/article.asp?key=403, last visited on 30.07.2020.

In this regard, it is noted that the function of an appeal mechanism cannot be realized by the existing review mechanisms, such as the ICSID annulment proceedings, reviewing or setting aside mechanisms under the lex arbitri in domestic courts, or the recognition and enforcement process under the 1958 New York Convention. A more detailed analysis of why existing review mechanisms are not able to function appeal process can be found in the literature. See e.g. Noah Rubins, Judicial Review of Investment Arbitration Awards, at: Federico Ortino \& Audley Sheppard \& Hugo Warner (eds.), Investment Treaty Law: Current Issues, Volume I, British Institute of International and Comparative Law, 2006, pp. 75-81. Sun Liu 刘笋, Discussion on Establishing an Appellate Mechanism of International Investment Arbitration 建立国际投资仲裁的上诉机制问题析评, Modern Law Science 现代法学, Vol. 5, 2009.

1204 A comprehensive summary of the advantages and disadvantages of an appeal mechanism in ISDS can be found in a study prepared for the European Parliament. See: Stephen Woolcock, The EU Approach to International Investment Policy after the Lisbon Treaty, European Parliament-Directorate-General for External Policies of the Union, 2010, available at: http://www.europarl.europa.eu/RegData/etudes/etudes/join/2010/433854/EXPOINTA_ET(2010)433854_EN.pdf, last visited on 05.08.2020.

1205 Guido Tawil, An international Appellate System: Progress or Pitfall, at: Federico Ortino \& Audley Sheppard \& Hugo Warner (eds.), Investment Treaty Law: Current Issues (Volume 1), British Institute of International and Comparative Law, 2006, p. 23. In other words, "soft precedent" had been followed to a great extent. See: Ian Laird \& Rebecca Askew, Finality Versus Consistency: Does Investor-State Arbitration Need an Appellate System?, Journal of Appellate Practice and Process, Vol. 7, 2005, p. 301.

1206 Judith Gill, Inconsistent Decisions: An Issue to be Addressed or a Fact of Life?, at: Federico Ortino \& Audley Sheppard \& Hugo Warner (eds.), Investment Treaty Law-Current Issues, British Institute of International and Comparative Law, 2006, pp. 23-28.

1207 The US Model BIT (2004), Art. 28.10. 
by a Tribunal in whole or in part. With regard to China's relevant practice, the ChinaAustralia FTA (2015) is the only treaty which contains a provision dealing with the issue of appellate procedures and it simply envisages future negotiations. ${ }^{1208}$ Although such a provision was argued as somewhat presenting supportive attitude from China, or at least an open mind towards having appeal in ISDS, ${ }^{1209}$ it is still the only piece of evidence in this regard.

In terms of a China-EU BIT, both parties recognize the need to increase systemic consistency and predictability in ISDS, and therefore the key issue here should be whether an appeal mechanism is necessary to reach this goal. In the context of the EU's ICS, it is argued here that consistency within the system and correctness of the tribunals' decisions can be ensured by other arrangements, and thus the contribution of an additional appeal mechanism seems to be limited. First, the requirements for expertise, independence and impartiality of adjudicators ensures the quality of their decisions. Second, consistency in jurisprudence under the treaty at issue could be realized through effective communication among members of the Tribunal, like the way in which the WTO Appellate Body works. In this regard, a provision similar to Article 3.2 of the DSU could be added to a China-EU BIT, setting "providing security and predictability" as a guiding principle, to create a de facto precedent system. ${ }^{1210}$ In other words, adjudicators are mandated to pursue the general goal of developing the consistency of the dispute settlement system with such an expression. In addition, the systemic consistency could also benefit from the power granted to the joint committee on issuing binding interpretations. All of these can work together to realize a satisfactory level of consistency in jurisprudence and the correctness of the tribunals' decisions, without an additional appeal mechanism. In addition, overall consistency and predictability in a coherent legal system in international investment adjudication "may solely be envisaged in a future multilateral system, or at least a plurilateral or regional one". ${ }^{1211}$ Considering the positive progress that has been achieved by the UNCITRAL Working Group III on ISDS reform, it is better for China and the EU to negotiate the possibility of establishing an appeal mechanism in this plurilateral forum. ${ }^{1212}$

Even if the EU succeeds in persuading China to incorporate an appeal mechanism under a China-EU BIT, relevant procedural arrangements in the ICS could also be viewed as

1208 The China-Australia FTA (2015), Art. 9.23.

1209 Jun Xiao 肖军, A Study on the Feasibility of Building an Appeal Mechanism in International Investment Arbitration: Starting with the Negotiations on a China-US Bilateral Investment Treaty 建立国际投资仲裁上诉机 制的可行性研究——从中美双边投资条约谈判说起, Studies in Law and Business 法商研究, Vol. 2, 2015.

1210 This has also been suggested for the SSDS system in a China-EU BIT. See: Section 10.3.2.3, supra. If such a provision is accepted by China and the EU for both SSDS and ISDS, it can be set as the guidance for the overall comprehensive dispute settlement system under a China-EU BIT, which is composed of a SSDS system and an ISDS system.

1211 Marc Bungenberg \& Catharine Titi, The Evolution of EU Investment Law and the Future of EU-China Investment Relations, at: China and International Investment Law: Twenty Years of ICSID Membership, Brill | Nijhoff, 2015, p. 345. Barry Appleton, The Song Is Over: Why It's Time to Stop Talking About an International Investment Arbitration Appellate Body, International Law in a Multipolar World, Vol. 107, 2013, pp. 23-24.

1212 There are scholars that expect that China would feel comfortable with developing an appellate mechanism in general because of its experience in the WTO. See: Anthea Roberts, The Shifting Landscape of Investor-State Arbitration: Loyalists, Reformists, Revolutionaries and Undecideds, EJIL: Talk!, 15.06.2017, available at: https://www.ejiltalk.org/the-shifting-landscape-of-investor-state-arbitration-loyalists-reformists-revolutionariesand-undecideds/, last visited on 05.08.2020. 
problematic by China. For example, the scope of appeal is not limited to questions of law, as China accepted in the China-Australia FTA (2015), but it includes questions of fact. Such a broad basis of appeal does not exist in either China's IIAs or any other existing international review mechanisms. ${ }^{1213}$ Furthermore, this has been criticized by scholars as making the appeal mechanism a second chance to seek remedies, instead of ensuring consistency. ${ }^{1214}$ It is noted that, in contrast to the Appellate Body in the WTO, in the ICS, an Appeal Tribunal is granted the power to refer the case back to the Tribunal without specific guidance, which may lead to divergent practices. ${ }^{1215}$ Therefore, it is more likely that China would argue to eliminate the appeal mechanism found in the EU's ICS for the prospective China-EU BIT, and it is suggested here that such a mechanism is not necessary in realizing the EU's goal of creating systemic consistency and ensuring the correctness of decisions.

\subsection{Local Remedies}

About 60 per cent of the currently effective IIAs in the world provide for international DSMs and local remedies, through domestic administrative or judicial procedures in parallel, as possible ways to address investor-state disputes. ${ }^{1216}$ This is particularly the case for most of the BITs between China and EU Member States. Although they are not mentioned in IIAs, local remedies are often available in the host states' domestic legal systems, which mainly serve the goal of reserving the right of host states to try to resolve the disputes internally.

Detailed regulations on local remedies come from the host states' domestic legal systems, while IIAs usually focus on their relationship with international fora. Focusing on the BITs between China and EU Member States, the rules on this issue can be categorized into three groups. ${ }^{1217}$ First, only the disputes about the amount of

1213 The grounds of annulment under the ICSID and the basis for refusing recognition and enforcement under the New York Convention only focus on violating fundamental procedural principles. In specific, under the ICSID Convention, the grounds of an annulment request include that: (a) the Tribunal was not properly constituted; (b) the Tribunal has manifestly exceeded its powers; (c) there was corruption on the part of a member of the Tribunal; (d) there has been a serious departure from a fundamental rule of procedure; or (e) the award has failed to state the reasons on which it is based. See: ICSID Convention, Art. 52(1). Under New York Convention, denying recognition and enforcement should be based on no valid arbitration agreement, violation of due process, exceeding the scope of jurisdiction, pathological composition of the tribunal, and no binding award. See: New York Convention (1985), Art. V.1.

${ }_{1214}$ See e.g. Luca Pantaleo, Lights and Shadows of the TTIP Investment Court System, CLEER Paper Series, Vol. 1, 2016. Tingting Deng 邓婷婷, The Investor-State Dispute Settlement Mechanism in a China-EU Bilateral Investment Treaty: From the Perspective of the EU's Investment Court System 中欧双边投资条约中的投资者一国家争端解 决机制——以欧盟投资法庭制度为视角, Politics and Law 政治与法律, Vol. 4, 2017, p. 108.

1215 Tingting Deng 邓婷婷, The Investor-State Dispute Settlement Mechanism in a China-EU Bilateral Investment Treaty: From the Perspective of the EU'S Investment Court System 中欧双边投资条约中的投资者一国家争端解 决机制——以欧盟投资法庭制度为视角, Politics and Law 政治与法律, Vol. 4, 2017, p. 108.

1216 Jingxia Shi \& Nuan Dong 石静霞、董暖, The Construction of Investment Dispute Settlement Mechanisms under 'One Belt One Road' Initiatives “一带一路” 倡议下投资争端解决机制的构建, Wuhan University International Law Review 武大国际法评论, Vol. 2, 2018, p. 10.

1217 There are other procedural arrangements regarding the relationship between local remedies and international DSMs in existing IIAs in the world. For a further discussion on this, see: United Nations Conference on Trade and Development (UNCTAD), Dispute Settlement: Investor-State (UNCTAD Series on Issues in International Investment Agreements), 2003, available at: https://unctad.org/en/Docs/iteiit30_en.pdf, last visited on 06.08.2020. Jayoung Jeon, Drafting an Optimal Dispute Resolution Clause in Investment Treaties, Peking University 
compensation for expropriation which have not been brought to any domestic court may be referred to international arbitration. For other types of disputes, local remedies are the only choice. ${ }^{1218}$ Second, complaints about any kind of disputes can be brought to international arbitration if they have not been filed in a domestic court. This is the so-called "fork-in-the-road" or "no U-turn" approach, which means that investors have the right to choose between local remedies or international arbitration, and the choice of one forum would exhaust other possibilities. ${ }^{1219}$ Third, international arbitration is available in disputes that have not been brought to any domestic court or have been withdrawn from the court before a decision concerning the same treatment as that alleged to be inconsistent with the underlying IIA is delivered. This can be described as a variant of the "fork-in-the-road" approach, which can be found, in particular, in several IIAs between China and EU Member States signed after 2000, such as ChinaNetherlands BIT (2001). ${ }^{1220}$ At the same time, this has been the EU's consistent approach in its three concluded IIAs. ${ }^{1221}$ Regarding the prospective China-EU BIT, an agreement is likely to be reached on the third option - the variant of the "fork-in-theroad" approach. Such an arrangement can encourage the use of domestic courts, while keeping the door to international adjudication open, reduce the concern that national courts may hinder the advancement and realization of the international rule of law and prevent investors from resorting to both domestic and international fora as well as being subject to redress respectively. ${ }^{1222}$

Another relevant issue here is the requirement to exhaust administrative reconsideration procedures. This is a typical feature of most of China's IIAs, where investors are required to "go through the appropriate domestic administrative review process before seeking to arbitrate". ${ }^{1223}$ However, it is noticeable that only five BITs concluded between China and EU Member States incorporated this requirement. ${ }^{1224}$ At the same time, although the European Parliament's Resolution of 6 April 2011 seems to suggest that exhausting local remedies is required where those remedies are "reliable enough to

Transnational Law Review, Vol. 4, 2016. In the interest of the present thesis, only the BITs between China and EU Member States are focused on.

1218 See e.g. the China-Italy BIT (1985), Protocol Ad Art. 5(i).

1219 See e.g. the China-Denmark BIT (1985), Art. 8.2.

1220 The China- Netherlands BIT (2001), Art. 10.2.

1221 See e.g. CETA (2012), Art. 8.22.1.

1222 European Commission, Reading Guide-Draft Text on Investment Protection and Investment Court System in the Transatlantic Trade and Investment Partnership (TTIP), 16.09.2015, available at: http://europa.eu/rapid/pressrelease_MEMO-15-5652_en.htm, last visited on 31.07.2020.

In reality, there have been many investor-state arbitration cases where investors resorted to the domestic courts of host states to challenge the legality of certain domestic legislation before, after or at the same time as resorting to international arbitration. For example, in the case Vattenfall AB and others v. Federal Republic of Germany, the investor initiated arbitration against Germany before the ICSID and filed a lawsuit before the Federal Constitutional Court of Germany. See: Vattenfall AB and others v. Federal Republic of Germany, ICSID Case No. ARB/12/12, Decision pursuant to ICSID Arbitration Rule 41(5), 2 July 2013; Judgment of the Federal Constitutional Court of Germany, 06.12.2016. See also: Nathalie Bernasconi-Osterwalder \& Martin Dietrich Brauch, The State of Play in Vattenfall v. Germany II: Leaving the German Public in the Dark, 10.2014, available at: https://www.iisd.org/sites/default/files/publications/state-of-play-vattenfall-vs-germany-II-leaving-german-publicdark-en.pdf, p. 2, last visited on 30.07.2020.

1223 Wenhua Shan \& Sheng Zhang, The Potential EU-China BIT: Issues and Implications, at: EU and Investment Agreements: Open Questions and Remaining Challenges, Hart Publishing, 2013, p. 117.

1224 These five BITs and relevant articles are: the China-Cyprus BIT (2001), Art. 9.3(b); the China-Czech Republic BIT (2005), Art. 9.3; the China-BLEU BIT (2005), Art. 8.2; the China-France BIT (2007), Art. 7; and the ChinaMalta BIT (2009), Art. 9.3. 
guarantee due process", ${ }^{1225}$ until now, the EU's practice has not adopted and appears unlikely to adopt such an approach in the near future. ${ }^{1226}$ In particular, considering the general distrust of EU investors in relation to China's legal system, ${ }^{1227}$ the EU probably would argue against having such a compulsory procedure. Considering the absence of the requirement to exhaust administrative reconsideration procedures in China's recently concluded relevant treaties, such as the China-Australia FTA (2015), China may change its predominant practice if this is proposed by the EU, and thus such a requirement would not appear in a China-EU BIT. In fact, this is also in line with what Chinese scholars have strongly advised the Chinese government to do in China's prospective IIAs. $^{1228}$

\subsection{Conclusion}

In the ISDS system under the prospective China-EU BIT, a differentiation should be made between the objective of amicable DSMs and that of the adjudication process. The former is intended to focus on settling disputes amicably. Considering investorstate adjudication has played and would continue to play the role as being the real "teeth" of the ISDS system, the aim of the adjudication process is suggested to be developing jurisprudence and realizing the international rule of law.

Regarding the jurisdiction of the ISDS system, any dispute between an investor of one treaty party and the other treaty party concerning treatment alleged to breach a provision of investment protection and to cause damages should be covered. Within this broad scope, two issues must be pointed out: first, the limit on the scope of investorstate adjudication to disputes about the amount of compensation for expropriation is not likely to be argued by China; second, only monetary damages and returning the original property would be allowed to be claimed by investors in investor-state adjudication and issued by tribunals as remedies.

Specific DSMs within this system can be divided into three categories: amicable mechanisms, adjudication mechanisms and local remedies. Amicable DSMs are valuable in the context of ISDS, since very often there is a need for restoring the relationship and ensuring further cooperation between investors and the host state. In this regard, the prospective China-EU BIT is expected to include voluntary negotiation and mediation, as well as compulsory consultations as a precondition to adjudication. Among these three DSMs, given the intention presented by both sides to increase the

\footnotetext{
1225 European Parliament, European Parliament Resolution of 6 April 2011 on the Future European International Investment Policy (2010/2203(INI)), P7_TA(2011)0141, 06.04.2011, para. 31.

1226 The Arif Report (2011) showed that the EU Parliament once contemplated the re-introduction of the obligation to exhaust local remedies in the EU's future IIAs. However, in its Resolution on EU-China negotiations (2013), effective ISDS was listed as a "key priority", but nothing was mentioned on the local remedies requirement.

${ }^{1227}$ It was further argued that, for a Chinese investor, to bring a dispute before an EU court "might be less of a risk and easier to put up with than the other way round". See: Wolfgang Koeth, Can the Investment Court System (ICS) Save TTIP and CETA?, European Institute of Public Administration Working Paper, Vol. 2016/W/01, 2016, p. 2.

1228 See e.g. Jingxia Shi \& Nuan Dong 石静霞、董暖, The Construction of Investment Dispute Settlement Mechanisms under 'One Belt One Road' Initiatives “一带一路” 倡议下投资争端解决机制的构建, Wuhan University International Law Review 武大国际法评论, Vol. 2, 2018, p. 13.
} 
use of mediation for ISDS, the procedural design of this mechanism, especially in relation to five issues, deserves attention. First, the basic principle of voluntariness should be adhered to. In addition to that, if disputing parties do not choose mediation spontaneously, it should be offered at the beginning of adjudication process. Second, the qualification of potential mediators should be left to the disputing parties' autonomy, and it is appropriate to establish different rules for mediators and adjudicators. Third, interest-based mediation is suggested to be prescribed as the default DSM, unless the disputing parties have agreed otherwise. Fourth, it is better to keep confidentiality as a fundamental feature of investor-state mediation, except if parties reach a different agreement. Finally, in terms of the enforcement of settlement agreements, a possible solution is to incorporate such agreements into the decision-making stage of adjudication to trigger the enforcement system.

In international adjudication, China's attitude towards the EU's ICS is expected to be modestly positive. First, regarding the type of forum, the adjudicatory nature of the ICS would be generally acceptable, but China may argue to eliminate the system's exclusive jurisdiction to open the door for other arbitration institutions, such as CIETAC. Second, a pre-established roster of adjudicators selected by treaty parties can be the preferred way for both parties, but this is suggested to come with the disputing parties' right to choose the adjudicators from the roster for their own cases. Third, both parties are compatible in their shared intention to strengthen the treaty parties' role in ISDS by increasing the joint committee's power. A possible agreement is likely to be reached on the prospective binding force of the joint committee's treaty interpretations. Fourth, procedural transparency should be respected in general, but it is better to allow a reasonable degree of party autonomy to prevent public disclosure. Last but not least, it does not seem to be necessary to have an appeal mechanism in a China-EU BIT. Instead, it is better for both parties to consider this in a plurilateral forum.

Regarding the relationship between local remedies and international DSMs, the prospective China-EU BIT may incorporate an article adopting the variant of the "forkin-the-road" approach. This means that international adjudication is available for the disputes that have not been brought to any domestic court or have been withdrawn from the domestic court before a decision has been delivered. In addition, exhausting local remedies would not be required as a precondition to international adjudication.

In brief, it is fair to say that, in general, China's and the EU's proposals for the ISDS system would probably be mutually complementary, although they may have some unavoidable contradictory and conflicting points. Taking into account the preferred practice and legal cultural characteristics of both parties, a system comprising both amicable and adjudicative and both compulsory and voluntary DSMs is suggested for the prospective China-EU BIT. With thoughtful procedural designs, such a system would be palatable to the treaty parties and attractive to potential users, contributing to successful investment dispute settlement and the sustainable development of a ChinaEU BIT. 


\section{Chapter 12 The Relationship between the State-State Dispute Settlement System}

\section{and the Investor-State Dispute Settlement System}

In the prospective China-EU BIT, a SSDS system and an ISDS system are very likely to exist in parallel with each other. The IIAs concluded by China and by the EU respectively, especially the most recent ones, confirm their support for incorporating both state-state and investor-state dispute settlement systems in one IIA. Therefore, it is very likely that, in a China-EU BIT, these two tracks for investment dispute settlement will co-exist with each other.

Keeping SSDS mechanisms would not negatively affect the sufficiently powerful procedural rights of investors and the power of investor-state tribunals in ISDS. ${ }^{122}$ At the same time, the combination of SSDS and ISDS systems provides different stakeholders with various options to address their complaints under an IIA, and thus this increases the possibility of successful investment dispute settlement. However, it should also be noted that such coexistence creates potential conflicts. In particular, the compulsory and enforceable state-state and investor-state adjudication mechanisms, which are the "teeth" in enforcing the obligations under an IIA, ${ }^{1230}$ bring with them the possibility of competing jurisdiction, conflicting decisions and other potential problems. As there are rows of teeth, if these two tracks of DSMs work together well, it can "chew up" the disputes; however, if they are not properly positioned in relation to each other, they may attack each other and thus leave the disputes unresolved and even more blurred. Therefore, establishing proper rules regarding the relationship between statestate and investor-state adjudication is necessary, especially for their respective jurisdiction and its effects. Unfortunately, in both theory and practice, this relationship has gained little attention, despite the long-time dual nature of state-state and investorstate investment adjudication. Some recent cases bring this problem into view and demonstrate the need for a careful examination.

With the increasing attention paid by China and the EU to the states' role in investment dispute settlement, the potential conflicts between SSDS system and ISDS system, especially the adjudication mechanisms therein, could probably arise more frequently and cause more controversies under their investment agreements in the future. Therefore, the importance of a proper arrangement is ever more pronounced. The present section explores the relationship between these two dispute settlement systems under the prospective China-EU BIT, in an attempt to answer the following two basic

1229 This can be arguably proven by the long-term co-existence of SSDS and ISDS mechanisms. In addition, such duality demonstrates that investment protection and de-politicizing ISDS are important, but they are not absolute. See: Anthea Roberts, State-to-State Investment Treaty Arbitration: A Hybrid Theory of Interdependent Rights and Shared Interpretive Authority, Harvard International Law Journal, Vol. 55, 2014, p. 28.

${ }^{1230} \mathrm{Shu} \mathrm{Xv}$ 徐树, The Conflicts and Coordination between the Dule Tracks of the Enforcement Mechanisms of International Investment Agreements 国际投资条约 “双轨” 执行机制的冲突及协调, Studies in Law and Business 法商研究, Vol. 2, 2017, p. 149. 
but controversial questions: first, what are the situations subject to the jurisdiction of state-state adjudication and that of investor-state adjudication respectively, and what situations are subject to both? Second, regarding the situations that can resort to both, how should these two dispute settlement systems cooperate with each other? Bearing this in mind, the relationship between the SSDS system and the ISDS system in a ChinaEU BIT is explored from the perspectives of their separation, connection and possible combination. Thoughtful pre-established rules would not only prevent one dispute settlement system from stalling or thwarting the other, minimizing the side effects brought about by the hybridity, but rather facilitate that they complement and cooperate with each other to realize the settlement of investment disputes, maximizing the advantages of a comprehensive investment dispute settlement system.

\subsection{The Separation and Connection between the State-State Dispute Settlement System and the Investor-State Dispute Settlement System}

Although the general practice defines the scopes of SSDS and ISDS respectively as the interpretation and application of any provision in the IIA at issue and any alleged violation of specific commitments by host states, as explained in Section 2.2.3, supra, these two elements are nonetheless connected with each other. This connection results in a dual-track jurisdictional regime with different disputes being assigned exclusively to one or the other being difficult and even impracticable. Regarding this, the EU's ICS incorporates a provision similar to the ICSID Convention Article 27, providing that an investor's home state is prevented from giving diplomatic protection or bringing a case against the other treaty party if the investor and the other treaty party have consented to submitting to or have submitted to investor-state adjudication, unless this treaty party has failed to abide by and comply with the award rendered in ISDS. ${ }^{1231}$ It also stipulates that, even if a specific investment dispute has been submitted to an investorstate tribunal, SSDS is not precluded in respect of a measure of general application. ${ }^{1232}$ On the part of China, existing practice has included importing the ICSID Convention Article $27,{ }^{1233}$ and generally stipulating that investor-state arbitration is without prejudice to SSDS where a dispute concerns the interpretation and application of the same provision at issue. ${ }^{1234}$ Thus, China and the EU seem to at least have a clear idea on the prohibition of diplomatic claim after ISDS has been resorted to by investors, as stated in the ICSID Convention Article 27. For other types of claims in SSDS, the EU explicitly allows treaty parties to bring declaratory relief claims while China chooses interpretive claims instead. It is not clear whether the other types of claims that are left unmentioned in the practice of each party are allowed or not. At the same time, whether

\footnotetext{
1231 See e.g. the EU-Singapore IPA (2018), Art. 3.23.1

1232 See e.g. the EU-Singapore IPA (2018), Art. 3.23.2.

1233 See e.g. the Investment Agreement of the ASEAN-China FTA (2009), Art. 14(8).

1234 See e.g. the China-Singapore BIT (1985), Art. 13(12); the China-Sri Lanka BIT (1986), Art. 13.11; the China-

New Zealand BIT (1988), Art. 13.12. These articles seem to allow parallel proceedings under ISDS and SSDS respectively without providing further guidance. However, if the investor-state arbitration is conducted under ICSID Convention, Art. 27 applies and thus later SSDS is prevented.
} 
ISDS can be resorted to by investors if any related SSDS proceeding exists is also left untouched.

Given the distinct purposes of the three types of claims in SSDS, except for diplomatic protection claims which have the same goal as ISDS, both declaratory relief claims concerning a measure of general application and interpretive claims regarding the interpretation and application of the same provision in the related ISDS process should to be allowed within a relevant ISDS proceeding. Such SSDS proceedings can help to resolve the disputed situation more completely by having a concrete idea of the meaning of the disputed treaty provisions and/or the compliance of a measure of general application. However, this does not warrant the permitting simultaneous SSDS and ISDS proceedings. The existing practice in China and the EU seems to generally allow ISDS and SSDS proceedings not only in sequence but also in parallel, except for explicitly prohibited situations. This makes sense from the perspective that interpretive claims and declaratory relief claims normally do not overlap with the claims in ISDS. However, it does not deal with the issue brought about by the unavoidably related disputes in these two types of proceedings, which results in the fact that the decisions reached by different tribunals are necessarily relevant for each other. In this regard, considering the possible complicated situations brought about by parallel proceedings and the potential tension arising from the co-existence of a SSDS tribunal and an ISDS tribunal, it is better to explicitly prohibit parallel proceedings concerning the same challenged measure.

In terms of relevant SSDS and ISDS cases raised in sequence, especially the effect of the decisions reached therein, it is widely accepted that a decision made for a specific dispute is binding on the disputing parties, but there are different opinions about whether previous decisions should have any influence on the decisions of tribunals in later cases. Some view jurisprudence as persuasive, rather than authoritative. ${ }^{1235}$ Some argue that relevant decisions made in previous cases should be binding on treaty parties as well as for subsequent cases under the same IIA. ${ }^{1236}$ In this regard, under the prospective China-EU BIT, for the sake of systemic consistency and predictability, it is suggested to incorporate a provision stressing the key role of the overall dispute settlement system, covering both SSDS and ISDS, in providing security and predictability in relation to the treaty. In this vein, Article 3.2 of the DSU provides a good example. Such a provision would result in adjudicators with a general obligation to at least take existing decisions into account, as is the practice in the WTO Dispute Settlement System. ${ }^{1237}$ Instead of creating detailed rules trying to cover all possible

1235 See e.g. Jamal Seifi, Investor-State Arbitration v. State-State Arbitration in Bilateral Investment Treaties, Transnational Dispute Management (TDM), 2004, available at: https://www.transnational-disputemanagement.com/article.asp?key=112, last visited on 05.08.2020. Michele Potestà, State-to-State Dispute Settlement Pursuant to Bilateral Investment Treaties: Is there Potential?, at: Nerina Boschiero \& Tullio Scovazzi \& Cesare Pitea \& Chiara Ragni (eds.), International Courts and the Development of International Law-Essays in Honour of Tullio Treves, T.M.C. Asser Press, 2013, p. 341.

1236 See e.g. Anthea Roberts, State-to-State Investment Treaty Arbitration: A Hybrid Theory of Interdependent Rights and Shared Interpretive Authority, Harvard International Law Journal, Vol. 55, 2014, pp. 61-66.

1237 This is greatly contested by some WTO Members and in particular by the United States. See e.g. United States Trade Representative, Report on the Appellate Body of the World Trade Organization, February 2020. 
situations, this is arguably a more appropriate and acceptable approach to both China and the EU, at least for the current stage.

\subsection{Combining the State-State Dispute Settlement System and the Investor-State Dispute Settlement System}

As explained above, investment disputes are very often complex and, during the settlement of such disputes, it is not only expected to resolve the disputes but also to restore the relationship for further cooperation. In addition, regardless of whether a dispute arises between an investor and its host state, or the host state and the investor's home state, the interests of these three parties are often all involved at the same time. Such a complex situation is further intensified by the inter-related investor-state and state-state disputes and the shared interpretive authorities of state-state and investorstate tribunals. Taking all these features of investment dispute settlement into consideration, this section makes innovative proposals of combining SSDS and ISDS, with a view to exploring the possibility of resolving state-state and investor-state disputes in a single forum. Such innovations are expected to address the comprehensive settlement of investment disputes and create greater certainty, consistency and predictability under the prospective China-EU BIT.

\subsubsection{State-Investor-State Mediation}

An amicable mechanism that is able to include the three stakeholders, the investor, its home state and the host state, in direct negotiations is arguably effective and beneficial for complex investment dispute settlement. Such a trilateral arrangement can offer a unique opportunity to accommodate the diverse interests of the three involved parties. It could also resolve the long-standing issue that one stakeholder's rights and interests are neglected in any available bilateral DSM. In this vein, a state-investor-state mediation mechanism is suggested as a suitable option. It can give the three parties a pre-established forum to discuss existing disputes with professional assistance from a mediator to ensure the proper conduct of negotiations. Furthermore, as was analysed in Chapters 6, 7 and 9, supra, both parties recently showed interest in using mediation for international investment dispute settlement and this proves that the prospective ChinaEU BIT can be a suitable starting point to put this innovation into practice.

In a bilateral mediation process, a non-disputing party may also get involved in the confidential process, with the disputing parties' consent, but this has only existed as an exceptional case and the role of such a non-disputing party in mediation is not clear or, needless to say, guaranteed. That is far from the suggested pre-established stateinvestor-state mediation here, which enjoys greater procedural predictability in which three parties are put on an equal footing. If accepted by the treaty parties, it can be realized through explicitly stipulating the possibility of having trilateral mediation or pointing out the possibility of transforming bilateral mediation into a trilateral mediation when necessary. Applicable procedural rules can be borrowed from statestate mediation and investor-state mediation, but more discretion is suggested to be left 
to the parties through party autonomy and mediators, especially considering the need to coordinate the three parties.

\subsubsection{Combining the Rosters of Adjudicators for State-State and Investor-State Dispute Settlement}

A further step to pre-selecting adjudicators for both SSDS and ISDS can be combining the two separate rosters. This means that the same group of adjudicators selected by treaty parties would be available for both SSDS and ISDS. As a result, a fixed small group would be in place to provide judicial authority. Such an institutional design should be acceptable, and even arguably desirable, for China and the EU, especially considering that the existing practice of both parties already adopts quite similar qualification requirements for SSDS and ISDS adjudicators. Furthermore, such an approach could reduce the institutional costs of the dispute settlement system under their prospective BIT and, more importantly, help realize better communication among adjudicators and thus contribute to the system's consistency.

\subsubsection{Granting Investors Procedural Rights in State-State Dispute Settlement}

The possibility of sequential correlated SSDS and ISDS proceedings may create a race to adjudication. Although, until now, this problem has rarely occurred, the recent reassertion of the states' role in investment dispute settlement should bring this important but untested issue back to the table. In particular, the race to adjudication between an investor and its home state may lead to negatively affecting investor's interests by settling relevant disputes through SSDS without their knowledge. ${ }^{1238}$ Even when investors are informed, it is likely that they are bound by the result of state-state awards without having the opportunity to present opinions during adjudication. ${ }^{1239}$ In response to this, it is suggested that directly affected investors should be treated as thirdparties in SSDS, if no objection is raised by the disputing parties. This goes further than granting investors the right to submit amicus curiae briefs, ${ }^{1240}$ since investors not only enjoy the right to submit their opinions but also to have their views considered by SSDS tribunals. Namely, this would ensure state-state tribunals actually consider the impact of their decisions on affected investors. Considering the non-disputing treaty party's interest in treaty interpretation, both China's and the EU's recently concluded IIAs grant the non-disputing treaty party the right to make submissions on treaty interpretation during ISDS. Given the fact that investors may also be stakeholders in SSDS, a similar arrangement should also be considered for investors in SSDS proceedings.

\footnotetext{
1238 There are different positions on whether investors' consent needs to be achieved before their home states represent them to resolve relevant disputes through SSDS. See: Kate Parlett, The Individual in the International Legal System: Continuity and Change in International Law, Cambridge University Press, 2011, pp. 53, 82.

1239 Ecuador v. United States, PCA Case No. 2012-5, Expert Opinion with Respect to Jurisdiction in the Interstate Arbitration Initiated by Ecuador Against the United States (W. Michael Reisman), 24.04.2012, pp. 19-20.

1240 Some model treaties have granted investors the right to submit amicus curiae briefs. See e.g. the US Model BIT (2012), Arts. 37(2), 28(3). In the absence of such a provision, tribunals could accept such an intervention by exercising their general power in relation to procedural arrangements.
} 


\subsection{Conclusion}

In the prospective China-EU BIT, it is highly likely that a SSDS system and an ISDS system will co-exist with each other. The unavoidably related SSDS and ISDS could bring about potential conflicts between these two aspects of the comprehensive investment dispute settlement system under this treaty. Therefore, it is suggested that both sides consider proper separation, connection and a combination between the SSDS system and the ISDS system.

Existing practice in China and the EU has presented a specific idea on the prohibition of pursuing diplomatic claims in SSDS after ISDS has been resorted to by investors, as stipulated in the ICSID Convention Article 27. Considering their different aims from those in ISDS, interpretive claims and declaratory relief claims should be generally allowed in SSDS. However, because of the possible complicated situations brought by parallel proceedings and the potential tension brought by the co-existence of a SSDS tribunal and an ISDS tribunal, it is recommended to explicitly prohibit parallel proceedings concerning the same challenged measure. In order to preserve the system's consistency and predictability, for sequential relevant SSDS and ISDS cases, it is necessary to incorporate a provision stressing the role of the dispute settlement system in providing security and predictability.

As a step further, an innovative combination of SSDS and ISDS deserves consideration, which may be realized through the establishment of state-investor-state mediation, combining the rosters of adjudicators for SSDS and ISDS and granting relevant investors procedural rights in SSDS proceedings.

Thoughtfully-designed procedural arrangements regarding the relationship between SSDS and ISDS systems is essential in realizing the goal of establishing a comprehensive system under the prospective China-EU BIT. Without much existing practice, how the suggestions provided in the present chapter would function admittedly remains to be seen. Nevertheless, theoretically well-founded innovative procedural designs deserve a try, not only to avoid potential problematic situations, but also to ensure that the two dispute settlement systems for SSDS and ISDS function cooperatively and coherently, heading towards successful investment dispute settlement under a China-EU BIT. 


\section{Part 5 Conclusion}

\section{Chapter 13 Summary of Conclusions}

Since the formal launch of the negotiations for a China-EU BIT at the $16^{\text {th }}$ EU-China Summit of November 2013, as of April 2020, 28 rounds of negotiations were held between the two parties. This prospective BIT will replace the 26 existing BITs between China and EU Member States with one single comprehensive agreement, with a view to removing market access barriers to investment, promoting economic transactions and cooperation between China and the EU in the field of international investment and providing a high level of protection to investors and investment in the EU and the Chinese markets.

Based on the fact that China and the EU have different preferences in various issues in investment dispute resolution, the disagreement about what constitutes appropriate dispute settlement systems in the prospective China-EU BIT is expected to be one of the major stumbling blocks in the negotiations. This thesis analyses the proper procedural design of the investment dispute settlement mechanisms in the prospective China-EU BIT, tackling this issue by exploring the mechanisms for both state-state and investor-state disputes respectively. In general, anticipating the possible proposals of both parties, the analysis focuses on the potential thorny issues that may become the stumbling blocks in concluding this prospective investment agreement and recommends possible solutions to overcome those obstacles.

Among the various factors that are expected to affect each parties' proposals and the reactions to the proposals of the parties, this thesis focuses on two essential aspects: the negotiating parties' existing practice and their legal culture in dispute settlement. The former includes the state-state dispute settlement systems and the investor-state dispute settlement systems in the concluded IIAs by China and the EU and the cases brought thereunder, the state-state dispute settlement systems in their Free Trade Agreements, as well as relevant practice under the WTO Dispute Settlement System. All of these provide direct evidence to predict each party's possible proposal regarding the design of the investment dispute settlement systems in future treaty negotiations. The latter concerns the legal tradition and internal practice in dispute settlement for China and the EU respectively. Some underlying reasons for certain dispute resolution approaches reveals the ideological predilections of the treaty parties, and it helps to identify the procedural arrangements that are difficult to change because they reflect the values and principles embedded in the party's legal culture. Three main research questions, are raised and answered in the present thesis, namely:

- Whether, and if so to what extent, differences in legal culture determine China's and the EU's respective approaches to investment dispute settlement at the internal level? 
- Whether, and if so to what extent, differences in legal culture determine China's and the EU's respective approaches to investment dispute settlement at the international level?

- What would/could the dispute settlement system in the prospective China-EU BIT look like?

\subsection{Comparison between the Legal Culture in Dispute Settlement of China and the EU}

The first research question concerns the legal cultural characteristics of China and those of the EU in dispute settlement and, in order to answer this question, the legal cultural features influenced by the legal tradition and their internal dispute settlement systems are discussed respectively. With regard to China, traditional philosophies, especially Confucianism, constituted the ideological foundation of Chinese legal culture and, instead of law, the values and teachings advocated by these philosophies played a significant role in regulating ancient Chinese society. Under Confucianism, community came before individuals, social responsibility was more important than freedom and, most importantly, harmony was prioritized and took the central position. As a result, dispute settlement focused on restoring a harmonious relationship through amicable informal DSMs. Bringing a dispute to a formal DSM, like litigation, was not desired and was even disapproved of. The core values of traditional Chinese philosophies have been arguably inherited by contemporary Chinese ideology, as reflected in the goal of constructing a harmonious socialist society. Thus, non-adjudicated solutions to disputes through amicable mechanisms are consistently preferred. Moving from traditional Chinese philosophies to contemporary Chinese ideology, the core values have been insisted on and, in particular, the amicable settlement of disputes has been the consistent preference. Different from traditional philosophies, law is seen by China in modern times as an indispensable part of socialist construction and the socialist rule of law is established, which is, however, subject to the overall objective of socialist harmony. Concerning dispute settlement in the Chinese legal system, six DSMs act as the main avenues for disputes arising from foreign investment, including negotiation, mediation, arbitration, complaints coordination for foreign investment, administrative review, and litigation. Among these DSMs, there is a preference for amicable ones, especially mediation, is clear. When examining the procedural design of these DSMs and the general structure of China's dispute settlement system, which is composed of those DSMs, from a legal cultural perspective, elements from Chinese ideologies can be identified: the promotion of amicable DSMs aims at restoring harmony between disputing parties as well as in the society; the extensive use of mediation is in line with the requirements of various legal cultural elements; and even the construction of the socialist rule of law is combined with the pursuit of harmony. All of these elements nudge the disputing parties in the same direction of retaining a harmonious socialist society. 
Regarding the traditional values preserved in European legal history, three constantspersonalism, legalism and intellectualism - in particular formed the basis of the European legal culture of dispute settlement. Against this background, law is taken as the guarantor of justice, fairness and legal rights; the insistence on the rule of law ensures the supremacy of law; as a normal way of resolving disputes, litigation focuses on preserving substantive rights and procedural justice and, correspondingly, judges must make decisions according to law following due process. With regard to the commonly available DSMs for investment disputes in EU Member States, mediation, arbitration and litigation are identified. First, partly contributed to by the various legal traditions of the EU Member States, the current legislative situation related to mediation is quite different among the EU Member States in terms of their general attitude and the detailed procedural rules. Legislation on arbitration is less diversified and consensus has been generally reached on certain basic principles, such as due process and equal treatment, which was inherited from the European legal tradition and is a reflection of European legal culture. In addition to its Member States' relevant rules, the Union has also taken actions to regulate DSMs, which include primary law, secondary legislation, the CJEU's practice on procedural justice, and other efforts like the Joint ELIUNIDROIT Project "From Transnational Principles to European Rules of Civil Procedure". The common underlying motivation here is to preserve individuals' rights to access to justice, effective remedies and fair trial, which reflect the common values and principles arising from the constitutional tradition shared by the EU Member States. In other words, it is fair to say that the value-oriented identity of the EU acts as one of the driving forces in the Union in relation to regulating DSMs. Taking a legal cultural perspective to analyse the DSMs in the EU Member States and the Union's relevant regulating measures, three points deserve attention. First, a consistent pursuit of the rule of law can be identified in dispute settlement. Second, litigation has been commonly used, which focuses on realizing substantive and procedural justice. Third, recently, increased attention on mediation is based on the recognition of its function in ensuring access to justice. Therefore, the relevant practice of EU Member States and the Union to a large extent reflects the EU's legal cultural characteristics in dispute settlement, which, in turn, arguably reinforce the underlying values and principles.

By comparison, the diverse features of dispute resolution employed by China and by the EU are typically reflected within legal culture, the perception of law, the role of law, and the objective of dispute settlement. In general, Chinese legal culture stresses the society's overall goal of preserving harmony and, as a result, the interests of individuals are secondary to this goal. In contrast, the legal culture of the EU shows clear signs of individualism, where individuals' rights are respected and protected as constitutional rights and democratic principles. Regarding the perception of law, despite the negative influence coming from the traditional understanding of law as a tool of punishment, contemporary Chinese ideology recognizes the importance of law in setting rules and protecting individuals' legal rights. It deserves attention that the "socialist rule of law" combines law with, and even takes law as a tool of realizing, extrinsic social values, with a view to constructing a harmonious socialist society. On the side of the EU, law 
is separated from morality, enjoying its own value and fundamental importance, protecting individuals' rights and balancing the power of the ruler. The rule of law constitutes part of "Europe's DNA" and guarantees the supremacy of law. With regard to dispute settlement, in Chinese legal culture, the objective can be described as resolving disputes, restoring the relationship between disputing parties and preserving social harmony, while the EU's corresponding practice seems to focus more on realizing individual procedural and substantive justice and developing jurisprudence. Furthermore, the legal cultural characteristics of dispute settlement in China and those of the EU have affected their legal systems, respectively. In particular, China's dispute settlement system shows a strong preference for amicable DSMs, while in the EU the focus is on the use of litigation, especially its conformity with the rule of law. In addition, China arguably adopts a service-based doctrine of dispute settlement, with DSMs providing a service to disputing parties. This seems to be different from the approach of the EU, where DSMs are used to realize justice and to serve a justice-based doctrine. Influence from legal culture is particularly reflected in approaches to mediation in China and the EU: both parties have made efforts to enhance the use of mediation in dispute settlement, but the underlying motivation is different. China's preference for mediation is based on the pursuit of social harmony, while the EU uses this DSM as an alternative way of realizing access to justice. In short, there are clear differences between China and the EU regarding the legal culture in dispute settlement and the design of internal DSMs, which is likely to lead to difficulties when they try to reach an agreement on relevant issues.

\subsection{The Approaches of China and the $\mathrm{EU}$ in International Investment Dispute Settlement}

Based on the analysis in the first part, in response to the second research question, the thesis explores how the differences in the legal cultural characteristics in dispute settlement in China and the EU, as reflected in their internal legal systems, determine each party's approach to investment dispute settlement at the international level. It first looks at what China and the EU have done to date regarding international investment dispute settlement, including state-state mechanisms for resolving disputes about treaty application and implementation as well as investor-state mechanisms for investors to bring cases against host states regarding complaints related to specific investments. As a further step, it compares the legal cultural characteristics of China and the EU with their performance in international investment dispute settlement, in order to examine how the former has affected the latter.

With regard to China's engagement in investment dispute settlement, for state-state dispute settlement, a hybrid approach combining diplomatic consultations and ad hoc arbitration has been consistently adopted in China's Model BITs and most of its concluded IIAs. By examining the state-state DSMs in China's IIAs chronologically, it is noted that, first, the treaties concluded at a later stage often contain more detailed procedural rules. Second, certain diplomatic elements in the early treaties disappeared 
from those concluded at a later stage, which can be taken as evidence showing China's increasing confidence in international adjudication. In addition, China's most recent treaty practice adjusts this hybrid approach to a quasi-WTO dispute settlement panel proceedings model, which in fact has been the practice of the state-state DSMs under its FTAs. In general, China's FTAs emphasized amicable DSMs and mutually satisfactory solutions, which is the practice that is expected to be continued. At the same time, the adoption of a system similar to the WTO panel proceedings can indicate its confidence in this system and the intention to learn from relevant experience in international trade dispute settlement. In the WTO, generally speaking, China has transformed from being reluctant and even afraid to use the Dispute Settlement System to being confident and using the system regularly. The features of its performance in this system present a combination of practical concerns and influence from its legal culture on dispute settlement. Regarding ISDS, both the China Model BITs and its concluded IIAs witnessed the changes of China's approach over time. These changes are particularly evidenced by the attitude towards investor-state arbitration: in the first stage (1982-1996), there was no acceptance of investor-state arbitration or acceptance of international arbitration only for disputes about the amount of compensation for expropriation; in the second stage (1997-2009), an overall acceptance of investor-state arbitration was the choice; in the third stage (2010-), the acceptance of investor-state arbitration is being carefully revised. In addition, since signing the ICSID Convention in 1993, it has become China's normal practice to incorporate ICSID arbitration for ISDS into its IIAs. Detailed procedural designs of the DSMs for ISDS in China's IIAs vary between each other, which shows China's flexibility and open attitude. Until now, there have been eight ISDS arbitration cases brought under the IIAs concluded by China. Compared to its large number of IIAs and ever-increasing investment flows, this number is relatively small. Possible underlying reasons for this include the Chinese government's preference for the amicable settlement of investment disputes to preserve harmony and its political image as a friendly host state, together with foreign investors' worries about the Chinese government's retaliation and the lucrativeness of the Chinese market. In addition, China has joined the worldwide ongoing reform of ISDS, presenting its perceptions on specific issues in different international fora and adopting new practices in its IIAs. In brief, China's practice in both SSDS and ISDS resonate with some of its legal cultural characteristics in dispute settlement, such as the preference for amicable settlements and confidentiality in the dispute settlement process, as already shown at its domestic level. However, at the same time, from accepting the jurisdiction of an international adjudication body to actively participating in discussions on the reform of international dispute settlement, it is also clear that China has increasingly recognized the function of international adjudication in statestate and investor-state dispute settlement.

Similarly, the EU's approach to state-state trade and investment dispute settlement is mainly reflected in its IIAs, while at the same time, the FTAs concluded by the EU and its performance in the WTO Dispute Settlement System is also of relevance here. After the Lisbon Treaty, the EU concluded three IIAs, CETA (2012), the EU-Singapore IPA 
(2018) and the EU-Vietnam IPA (2018). The state-state DSMs contained in these three agreements basically follow the design of the WTO panel proceedings. In terms of the state-state DSMs laid out in the EU's FTAs, chronologically, a shift from a diplomatic approach to a quasi-WTO dispute settlement panel proceedings model can be identified. In addition, more judicial features were gradually added to these DSMs. The resemblance between the DSMs in the EU's FTAs and IIAs, on the one hand, and the WTO DSU on panel proceedings, on the other, may have been inspired by the EU's positive experience in the WTO Dispute Settlement System. The EU has consistently been a frequent user of this system for resolving disputes between states, taking it as a normal tool to ensure the realization of its legitimate substantive and procedural rights. Along with its supportive attitude towards alternative DSMs, the EU has shown a preference for the judicial characteristics of the WTO Dispute Settlement System by not only its frequent use of the adjudication proceedings, but also in its reform proposal for the establishment of a permanent Panel Body and enhancing procedural transparency. Regarding ISDS, before 2009, EU Member States had the competence to conclude IIAs with third states, and they were quite active and productive in this regard. Most of these IIAs provide for amicable DSMs as well as arbitration for ISDS, and many cases have been heard under the latter, in which mostly EU investors initiated investor-state arbitration but the EU was rarely challenged by non-EU investors. The Lisbon Treaty brought about a shift in competence to conclude IIAs from the EU Member States to the Union. In the three IIAs that have been concluded by the Union since 2009, a ground-breaking approach to ISDS - the Investment Court System (ICS) - has been adopted consistently, which also represents the EU's position in its future negotiations for any prospective IIA in bilateral and multilateral fora. In the ICS, amicable DSMs, including negotiation, mediation and consultations are provided and strengthened, acting as alternative ways to have access to justice. For adjudication, the ICS establishes a standing two-tiered court-like mechanism with typical judicial characteristics. For example, the pool of arbitrators who may be appointed to adjudicate a particular dispute in a specific case is supposed to be pre-selected by treaty parties, and the dispute settlement proceedings are to be operated with great procedural transparency, with a view to enhancing the system's soundness of jurisprudence. At the same time, the joint committee and treaty parties are afforded significant roles in ISDS and mechanisms for scrutinizing claims are created in particular, which to some extent reshapes the balance between investors and states as well as stresses the public law nature of international investment law. The procedural designs of the DSMs in the ICS echoes the WTO Dispute Settlement System and the state-state DSMs in the EU's FTAs. At the same time, it deserves attention that the EU's most recent proposal on the WTO Dispute Settlement System reform, such as strengthening the interaction between the Appellate Body and the WTO Members, is in line with its increasing intention of strengthening the role of the states in the dispute settlement process, as shown in the ICS. All of this confirms the EU's persistent preference for a permanent two-tiered court-like system for dispute settlement in the area of international investment law and, more broadly, international economic law. In other words, from the proposal to reform the WTO Dispute Settlement System, the gradually improved state-state DSMs in its 
FTAs and IIAs, to the ICS, the EU's direction is clear and calls for building a multilateral, judicialized and permanent system that respects the international rule of law to resolve international economic disputes.

Comparing China's and the EU's practice in international investment dispute settlement, both similarities and differences can be identified. For SSDS, China's and the EU's most recent IIAs similarly adopt a quasi-WTO dispute settlement panel proceedings model, although there are differences in the details. Regarding ISDS, the two parties seem to have different perceptions on the objective of the whole system and the focus among the various DSMs. China puts its emphasis on settling disputes amicably and restoring harmonious relationships, while the EU cares more about realizing the international rule of law and developing jurisprudence through the system. Such differences correspondingly resonate with their internal practice and legal cultural characteristics, especially China's traditional preference for harmony and the EU's consistent pursuit of the rule of law. At the same time, each party's approach has been affected by its interaction with international practice. Compared to the situation in China, where there is more emphasis on compromise and the acceptance of international practice, the EU's practice in international investment dispute settlement seems to further stress and intensify its preferences that are rooted in its legal culture.

\subsection{Exploration of the Dispute Settlement System in a China-EU Bilateral Investment Treaty}

Equipped with the knowledge of China's and the EU's legal cultural characteristics in dispute settlement and their relevant practice at the internal and international levels, the discussion addresses the exploration of the dispute settlement system in the prospective China-EU BIT. To build a necessary basis for exploration, a brief overview of the investment legal relationship between China and the EU, including its historical development, current status and, particularly, the dispute settlement systems in the existing IIAs between China and EU Member States are provided in the first place. Before 2009, the Union only concluded general economic cooperation agreements with China. While, at the same time, by exercising their treaty negotiating and concluding competence, China and EU Member States concluded 26 IIAs. In addition to other applicable international law, such as the ICSID Convention, the current international legal framework of the China-EU investment relationship is constructed mainly on these IIAs. Two categories of DSMs exist in these Agreements for investment dispute settlement: one for state-state and one for investor-state dispute settlement. The provisions on state-state DSMs are quite similar to each other. First, compulsory consultations through diplomatic channels is required. Only if this fails, disputes can be submitted to ad hoc arbitration. Rules on arbitration procedures, decision making, the effect of arbitral awards and allocation of costs are normally provided for. In particular, diplomatic elements, such as approval by the contracting parties of the chairman of a tribunal, only exist in the BITs concluded in the early days. At the same time, the BITs negotiated more recently often set out more detailed procedural rules. In 
contrast, the situation of investor-state DSMs is more complex. A division can be drawn in 1997: at the first stage (1982-1996), the IIAs are characterized by a limited acceptance of investor-state arbitration, while the IIAs signed in the second stage (1997-2009) reflect an overall acceptance of international arbitration for ISDS. All of these treaties provide for amicable and adjudicative DSMs simultaneously. Amicable DSMs are usually stressed in these treaties and, in particular, the BITs drafted at later time have explicit provisions in the treaty texts. In terms of the adjudicative mechanisms, the IIAs signed at the first stage limit international arbitration to disputes about the amount of compensation for expropriation. Such a requirement disappears in the IIAs at the second stage. Another noticeable change is the acceptance of ICSID arbitration. In addition, in the IIAs where international arbitration is provided for, rules on key procedural issues are provided. Regarding the real use of these DSMs, based on publicly available information, there have only been two ISDS arbitration cases. The public consultation conducted by the European Commission indicated the preference of EU investors for the amicable settlement for investment disputes with the Chinese government, which was largely affected by concerns about China's domestic legal system and the preservation of the relationship with the Chinese government.

As mentioned above, the Lisbon Treaty led to a ground-breaking change in the investment relationship between China and the EU by allocating competence for foreign direct investment to the Union and, since 2013, a China-EU BIT has been under negotiation. The overall dispute settlement system in the prospective China-EU BIT is expected to be composed of two sub-systems - one for state-state dispute settlement and one for investor-state dispute settlement. In terms of the former, as evidenced by the absence of any real use of state-state adjudication in the past practice of both parties, amicable DSMs have probably played a main role in resolving state-state investment disputes for both China and the EU, which is expected to continue under the prospective China-EU BIT. Thus, it is appropriate to take the amicable resolution of disputes as the core objective of the SSDS system. Regarding jurisdiction, disputes about the interpretation and application of treaty provisions are expected to be allowed, based on which, treaty parties can raise diplomatic protection claims, interpretive claims and claims for declaratory relief. Specific DSMs within the SSDS system can be divided into two categories - amicable DSMs and adjudicative DSMs. The former normally comes into play in the first place possibly through negotiation/consultations and/or mediation. In particular, consultations are likely to be required as a precondition for initiating a state-state adjudication process. In relation to adjudication, the most recent treaty practice of both parties reflects their interest in using a quasi-WTO dispute settlement dispute settlement panel proceedings mechanism, and this may also serve as the general structure for state-state adjudication under a China-EU BIT. In this regard, a problematic issue may be the composition of tribunals, for which China and the EU are likely to reach an agreement on pre-establishing a roster of adjudicators while leaving some room for party autonomy in specific cases. Another issue that deserves attention is procedural transparency. For a China-EU BIT, opening the whole process of adjudication to the public may be rejected by China, but third-party participation by 
submitting amicus curiae briefs is likely to be acceptable and even recommended. In terms of the effect of the decisions of tribunals in state-state adjudication, a moderate approach, incorporating a provision similar to Article 3.2 of the DSU, is anticipated to be the most acceptable option. This means the rulings would only have a precedential value, instead of being binding on all following cases. Although state-state DSMs played a minor role in investment dispute resolution in the past, this should not be the reason to underestimate their potential use under a China-EU BIT. Considering the clear intention of both parties to increase the states' role in investment dispute settlement, it is reasonable to expect that, with proper procedural arrangements which satisfy practical needs and the concerns coming from legal culture on dispute settlement of both parties, such a system in the prospective China-EU BIT is likely to make a real contribution to the settlement of investment disputes.

Regarding the ISDS system under the prospective China-EU BIT, first, a differentiation should be made between the objective of amicable DSMs and that of adjudication. The former should focus on settling disputes amicably. In comparison, considering investorstate adjudication has played and would continue to play the role of the real "teeth" in ISDS, the key objective of investor-state adjudication is suggested to be the development of jurisprudence and the realization of the international rule of law. Both amicable DSMs and the adjudication process should cover disputes between an investor of one treaty party and the other treaty party concerning treatment alleged to breach a provision of investment protection and to cause damages. Within this broad scope, two issues deserve attention: first, the limit on the scope of investor-state adjudication to disputes about the amount of compensation for expropriation is not likely to be argued by China; second, only monetary damages and returning the original property to investors would be allowed to be claimed by investors in investor-state adjudication and thereby possibly issued by tribunals as remedies. Specific DSMs within this system can be divided into three categories: amicable mechanisms, adjudication mechanisms and local remedies. Amicable DSMs are valuable in the context of ISDS, since very often there is a need to restore the relationship and to ensure further cooperation between investors and the host state. In this regard, the prospective China-EU BIT is expected to include voluntary negotiation and mediation, as well as compulsory consultations as a precondition to adjudication. Among these three DSMs, given the intention presented by both parties to increase the use of mediation for ISDS, the procedural design of this mechanism, especially with respect to five issues, deserves attention. First, the basic principle of voluntariness should be adhered to. In addition to that, if disputing parties do not choose mediation spontaneously, it should be offered to disputing parties by the adjudicators at the beginning of the adjudication process. Second, the qualification of potential mediators should be based upon the agreement of disputing parties, and it is appropriate to establish various standards for mediators and adjudicators. Third, interest-based mediation should be prescribed as the default type of mechanism, unless disputing parties agree otherwise. Fourth, it is better to keep confidentiality as a fundamental feature of investor-state mediation, unless disputing parties reach a different agreement. Finally, the settlement agreements reached in 
mediation can be incorporated into the decision-making stage of adjudication, in order to trigger the enforcement system. In international adjudication, China's attitude towards the EU's ICS is expected to be modestly positive. First, regarding the type of forum, the adjudicatory nature of the ICS would be generally acceptable, but China may argue for eliminating the system's exclusive jurisdiction to open the door for other arbitration institutions, such as CIETAC. Second, a pre-established roster of adjudicators selected by treaty parties could be preferred by both parties. However, this is suggested to come with the disputing parties' right to choose the adjudicators from the roster. Third, the perception of both parties of strengthening the treaty parties' role in ISDS by increasing the power of the joint committee are compatible with each other. A possible agreement is likely to be reached on the prospective binding force of the joint committee's treaty interpretations. Fourth, procedural transparency should be respected in general, but it is better to allow for a reasonable degree of party autonomy to prevent public disclosure. Last but not least, it does not seem to be necessary to have an appeal mechanism in a China-EU BIT. Instead, both sides should consider appeal within a plurilateral forum. Regarding the relationship between local remedies and international DSMs, the prospective China-EU BIT may incorporate an article adopting the variant of the "fork-in-the-road" approach. This means that international adjudication is available in the disputes that have not been brought to any domestic court or have been withdrawn from the domestic court procedure before a decision is delivered. In addition, exhausting local remedies would not be required as a precondition to international adjudication. In brief, it is fair to say that, in general, the proposals by China and the EU for the ISDS system would probably be mutually complementary, although with some unavoidable contradictory and conflicting points. Taking into account both parties' preferred practice and legal cultural characteristics, a system comprising both amicable and adjudicative and both compulsory and voluntary DSMs is suggested for the prospective China-EU BIT.

As a necessary further step, the relationship between the state-state and investor-state dispute settlement systems in the prospective China-EU BIT, including their separation, connection and possible combination, are assessed. Existing practice in China and the EU presented a concerted idea on the prohibition of diplomatic claims in SSDS after ISDS has been resorted to by investors, as stipulated in the ICSID Convention Article 27. Considering their different aims from those in ISDS, interpretive claims and declaratory relief claims should be generally allowed in SSDS. However, because of the possible complicated situations brought about by parallel proceedings and the potential tension coming from the co-existence of a SSDS tribunal and an ISDS tribunal, it is recommended to explicitly prohibit parallel proceedings concerning the same challenged measure. In order to preserve the system's consistency and predictability, for sequential relevant SSDS and ISDS cases, it is necessary to incorporate a provision stressing the role of the dispute settlement system in providing security and predictability. Furthermore, an innovative combination of SSDS and ISDS may be realized through establishing state-investor-state mediation, combining the rosters of adjudicators for SSDS and ISDS and granting relevant investors procedural rights in 
SSDS proceedings. Without much existing practice, how these suggestions would function in practice admittedly remains to be seen. Nevertheless, theoretically wellfounded innovative procedural designs deserve a try, not only to avoid potential problematic situations, but also to ensure that the dispute settlement systems for statestate disputes and investor-state disputes function cooperatively and coherently.

In short, this thesis tackles the comprehensive dispute settlement system in the prospective China-EU BIT by exploring its procedural design, including the systems for both state-state and investor-state disputes. Based on the exploration of the legal cultural characteristics in China's and the EU's dispute settlement mechanisms and the influence thereof on their relevant internal and international practice, as well as their current investment legal relationship, it anticipates both parties' possible proposals, discusses the potential thorny issues and recommends solutions that are worthy of consideration. It is believed that, with thoughtfully-designed procedural arrangements, this comprehensive dispute settlement system would be palatable to the treaty parties and attractive to potential users and, more importantly, may contribute to successful investment dispute settlement under, and sustainable development of, the prospective China-EU BIT. 


\section{Bibliography}

\section{Cases}

AES Summit Generation Limited and AES-Tisza Erömü Kft v. The Republic of Hungary, No. ICSID Case No. ARB/07/22 (23.09.2010)

Dieter Krombach v. André Bamberski, No. Case C-7/98 (28.03.2000)

Jean-E. Humblet v. Belgian State, No. Case C-6/60 (16.12.1960)

Joined Cases C-317/08, C-318/08, C-319/08 and C-320/08, Rosalba Alassiniv. Telecom Italia SpA (C-317/08), Filomena Califano v. Wind SpA (C-318/08), Lucia Anna Giorgia Iacono v. Telecom Italia SpA (C-319/08) and Multiservice Srl v Telecom Italia SpA (C-320/08), Judgment of the Court (Fourth Chamber) (18.03.2010)

Joined Cases C-514/07 P, C-528/07 P and C-532/07 P, Kingdom of Sweden v. Association de la presse international ASBL (API) and European Commission (C514/07 P), Association de la presse internationale ASBL (API) v European Commission (C-528/07 P) and European Commission v Association de la presse internationale ASBL (API) (C-532/07 P) (21.09.2010)

Jungbunzlauer AG v. Commission of the European Communitie (Case T-43/02) (27.09.2006)

Nuova Agricast Srl and Cofra Srl v. European Commission (Case C-67/09 P) (14.10.2010)

Parti écologiste "Les Verts" v. European Parliament (Case 294/83) (23.04.1986)

Paula Gomez-Rivero v. Bundesanstalt für Arbeit (Case C-211/97) (03.06.1999)

Regina v. Kent Kirk (Case 63/83) (10.07.1984)

Salzgitter Mannesmann GmbH v. Commission of the European Communities (Case C411/04) (25.01.2007)

Samuel Sidney Evans v. The Secretary of State for the Environment, Transport and the Regions and The Motor Insurers' Bureau (Case C-63/01) (04.12.2003)

Siemens v. European Commission (Case T-110/07) (03.03.2011)

Southern Bluefin Tuna (New Zealand v. Japan, Australia v. Japan) (39 ILM 1359) (04.08.2000)

\section{Legislation and Policy Documents}

Commission of the European Communities, A Level Playing Field for Direct Investment World-Wide, COM(95) 42 final (01.03.1995)

Charter of Fundamental Rights of the European Union, OJ C 326 (18.12.2000)

European Commission, Communication from the Commission to the Council, the European Parliament, the European Economic and Social Committee and the 
Committee of the Regions: Towards a Comprehensive European International Investment Policy, COM(2010)343 final (07.07.2010)

Commission of the European Communities, Commission Working DocumentAccompanying COM(2006) 631 Final: Closer Parterner, Growing Responsibilities-A Policy Paper on EU-China Trade and Investment: Competition and Partnership, $\operatorname{COM}(2006) 632$ final (24.10.2006)

Commission of the European Communities, Communication from the Commission to the Council and the European Parliament-EU-China: Closer Partners, Growing Responsibilities, COM(2006) 632 final (24.10.2006)

Commission of the European Communities, Green Paper on Alternative Dispute Resolution in Civil and Commercial Law (presented by the Commission), COM(2002) 196 final (19.04.2002)

Council of the European Union, EU Strategy on China-Council Conclusions (18 July 2016), 11319/16 (18.07.2016)

Council of the European Union \& Commission of the European Communities, Council and Commission Decision of 23 September 1997 on the Conclusion, by the European Communities, of the Energy Charter Treaty and the Energy Charter Protocol on Energy Efficiency and Related Environmental Aspects, 98/181/EC, ECSC, Euratom (23.09.1997)

Council of the European Union-General Secretariat, WTO-EU's proposals on WTO Modernisation, WK 8329/2018 INIT (05.07.2018)

Court of Justice of the European Union-the Court of Justice, Rules of Procedure of the Court of Justice (29.09.2012)

European Commission, Establishment of a Multilateral Investment Court for Investment Dispute Resolution, DG Trade - F2 (01.08.2016)

European Commission, Reflection Paper on Harnessing Globalisation, COM(2017) $240(10.05 .2017)$

European Commission, Commission Staff Working Papter-Report: Online Public Consultation on Investment Protection and Investor-to-State Dispute Settlement (ISDS) in the Transatlantic Trade and Investment Partnership Agreement (TTIP), SWD(2015) 3 final (13.01.2015)

European Commission, Communication from the Commission to the European Parliament, the Council, the European Central Bank, the European Economic and Social Committee and the Committee of the Regions-The 2017 EU Justice Scoreboard, COM(2017) 167 final (2017)

European Commission, Communication from the Commission to the European Parliament, the Council, the European Economic and Social Committee and the Committee of the Regions: Trade for All-Towards a More Responsible Trade and Investment Policy, COM(2015) 497 final (14.10.2015) 
European Commission, Recommendation for a Council Decision: Authorising the Opening of Negotiations for a Convention Establishing a Multilateral Court for the Settlement of Investment Disputes, COM(2017) 493 final (13.09.2017)

European Parliamanet, Directive 2008/52/EC of the European Parliament and of the Council of 21 May 2008 on Certain Aspects of Mediation in Civil and Commercial Matters, Directive 2008/52/EC (24.05.2008)

European Parliament, European Parliament Recommendation to the Council and to the European Council on the Future of the Area of Freedom, Security and Justice as well as on the Measures Required to Enhance the Legitimacy and Effectiveness Thereof (2004/2175(INI)), P6_TA(2004)0022 (07.07.2005)

European Parliament, European Parliament Resolution of 6 April 2011 on the Future European International Investment Policy (2010/2203(INI)), P7_TA(2011)0141 (06.04.2011)

European Parliament \& Council of the European Union \& European Commission, Explanations Relating to the Charter of Fundamental Rights of the European Union, 2007/C 303/02 (12.12.2007)

List of the Bilateral Investment Agreements Referred to in Article 4(1) of Regulation (EU) No 1219/2012 of the European Parliament and of the Council Establishing Transitional Arrangements for Bilateral Investment Agreements between Member States and Third Countries, 2013/C 131/02, 08.05.2013

List of the Bilateral Investment Agreements Referred to in Article 4(1) of Regulation (EU) No 1219/2012 of the European Parliament and of the Council of 12 December 2012 Establishing Transitional Arrangements for Bilateral Investment Agreements between Member States and Third Countries, 2016/C 149/01, 27.04.2016

The EC/Mexico Joint Council, Decision 2/2000 of the EC-Mexico Joint Council of 23 March 2000 (Covering Trade in Goods, Government Procurement, Cooperation for Competition, Consultation on Intellectual Property Rights, Dispute Settlement), CEMX 3854/00 (23.03.2000)

The Sixth Plenary Session of the Sixteenth Central Committee of the Communist Party of China 中国共产党第十六届中央委员会第六次全体会议, Decision of the Central Committee of the Communist Party of China on Several Major Issues of Building a Harmonious Socialist Society 中共中央关于构建社会主义和谐社会若干重大问题 的决定 (11.10.2006)

The Third Plenary Session of the 18th Central Committee of the Communist Party of China 中国共产党第十八届中央委员会第三次全体会议, Decision of the Central Committee of the Communist Party of China on Some Major Issues Concerning Comprehensively Deepening the Reform 中共中央关于全面深化改革若干重大问 题的决定 (12.11.2013) 
United Nations Commission on International Trade Law Working Group II (Arbitration and Conciliation), Settlement of Commercial Disputes-Transparency in Treaty-based Investor-State Arbitration-Compilation of Comments by Governments-Note by the Secretariat-Addendum, A/CN.9/WG.II/WP.159/Add.1 (04.08.2010)

United Nations, Treaties and International Agreements Registered or Filed and Recorded with the Secretariat of the United Nations, I. Nos. 34026-34034 (1997)

World Trade Organization-Dispute Settlement Body-Special Session, Contribution of the European Communities and its Member States to the Improvement of the WTO Dispute Settlement Understanding, TN/DS/W/1 (13.03.2002)

\section{Other Publications}

\section{Books}

Aaron Broches, The Convention on the Settlement of Disputes between States and Nationals of Other States, at: Collected Courses of the Hague Academy of International Law (Volume 136), Brill | Nijhoff, 1972

Abram Chayes \& Antonia Handler Chayes, The New Sovereignty: Compliance with International Regulatory Agreements, Harvard University Press, 1998

Adrian A. S. Zuckerman, Court Adjudication of Civil Disputes: A Public Service to be Delivered with Proportionate Resources, within a Reasonable Time and at Reasonable Cost, at: C.H. van Rhee \& D. Heirbaut \& M. Storme (eds.), The French Code of Civil Procedure (1806) after 200 Years: the Civil Procedure Tradition in France and Abroad, Kluwer, 2008

Adrian A. S. Zuckerman (ed.), Justice in Crisis: Comparative Dimensions of Civil Procedure, Oxford University Press, 1999

Alan Uzelac, Reforming Mediterranean Civil Procedure: Is There a Need for Shock Therapy?, at: C. H. van Rhee \& Alan Uzelac (eds.), Civil Justice between Efficiency and Quality: From Ius Commune to the CEPEJ, Intersentia, 2008

Alasdair R. Young, Effective Multilateralism on Trial: EU Compliance with WTO Law, at: Spyros Blavoukos \& Dimitris Bourantonis (eds.), The EU Presence in International Organizations, Routledge, 2011

Alasdair R. Young \& John Peterson, Parochial Global Europe: 21st Century Trade Politics, Oxford University Press, 2014

Albert Hung-yee Chen, An Introduction to the Legal System of the People's Republic of China (1st edition), Butterworths Asia, 1992

Alex Mills, The Balancing (and Unbalancing?) of Interests in International Investment Law and Arbitration, at: Zachary Douglas \& Joost Pauwelyn \& Jorge E. Viñuales (eds.), The Foundations of International Investment Law-Bringing Theory into Practice, Oxford University Press, 2014 
Allen Carlson, More Than Just Saying No: China's Evolving Approach to Sovereignty and Intervention Since Tiananmen, at: Alastair Iain Johnston \& Robert S. Ross (eds.), New Directions in the Study of China’s Foreign Policy, Stanford University Press, 2006

An Chen, CHEN's Papers on International Economic Law (two volumes) (Vol. 1), Peking University Press, 2005

Andrew Newcombe \& Lluís Paradell, Law and Practice of Investment Treaties: Standards of Treatment Kluwer Law International, 2009

Anna Joubin-Bret, Admission and Establishment in the Context of Investment Protection, at: August Reinisch (ed.), Standards of Investment Protection, Oxford University Press, 2008

Anthea Roberts, Subsequent Agreements and Practice: The Battle Over Interpretive Power, at: Georg Nolte (ed.), Treaties and Subsequent Practice, Oxford University Press, 2013

Ari Afilalo \& Dennis Patterson \& Kai Purnhagen, Statecraft, the Market State and the Development of European Legal Culture, at: Geneviève Helleringer \& Kai Purnhagen (eds.), Towards a European Legal Culture, Hart Publishing, 2014

Armand de Mestral, NAFTA Dispute Settlement: Creative Experiment or Confusion?, at: Lorand Bartels \& Federico Ortino (eds.), Regional Trade Agreements and the WTO Legal System, Oxford University Press, 2006

Åse B. Grødeland \& William L. Miller, European Legal Cultures in Transition, Cambridge University Press, 2015

August Reinisch, Fork-in-the-Road Provisions, at: Thomas Cottier \& Krista Nadakavukaren Schefer (eds.), Elgar Encyclopedia of International Economic Law, Edward Elgar Publishing, 2017

A. Timothy Martin, International Mediation: An Evolving Market, at: Arthur W. Rovine (ed.), Contemporary Issues in International Arbitration and Mediation: The Fordham Papers (2010), Martinus Nijhoff Publishers, 2011

Bart Kerremans, The European Commission in the WTO's DDA negotiations-A Tale of an Agent, a Single Undertaking and Twenty-seven Nervous Principals, at: Spyros Blavoukos \& Dimitris Bourantonis (eds.), The EU Presence in International Organizations, Routledge, 2011

Bart Wauters \& Marco de Benito, The History of Law in Europe: An Introduction, Edward Elgar Publishing, 2017

Barton Legum \& Anna Joubin-Bret \& Inna Manassyan, Rules for Investor-State Mediation: Draft Prepared by the International Bar Association State Mediation Subcommittee, at: Roberto Echandi \& Pierre Sauvé, Prospects in International Investment Law and Policy-World Trade Forum, Cambridge University Press, 2013

Bertrand Wägenbaur, Court of Justice of the European Union: Commentary on Statue and Rules of Procedure, C.H. Beck•Hart•Nomos, 2013 
Bobbi McAdoo \& Nancy Welsh, Court-Connected General Civil ADR Programs: Aiming for Institutionalization, Efficient Resolution and the Experience of Justice, at: Donna Stienstra \& Susan Yates (eds.), ADR Handbook For Judges, American Bar Association, 2004

Buyun Li 李步云, Discussion on The Rule of Law 论法治, Social Sciences Academic Press 社会科学文献出版社, 2008

Catharine Titi, International Investment Law and Good Governance, at: Marc Bungenberg \& Jörn Griebel \& Stephan Hobe \& August Reinisch (eds.), International Investment Law, C.H. Beck•Hart•Nomos, 2015

Carrie J. Menkel-Meadow \& Lela Porter Love \& Jean R. Sternlight \& Andrea Kupfer Schneider, Dispute Resolution: Beyond the Adversarial Model (Second Edition), Aspen Publishers, 2010

Chad Damro \& Alberta M. Sbragia, The New Framework of Transatlantic Economic Governance: Strategic Trade Management and Regulatory Conflict in Multilateral Global Economy, at: Miriam L. Campanella \& Sylvester C.W. Eijffinger (eds.), EU Economic Governance and Globalization, Edward Elgar, 2003

Charles de Secondat baron de Montesquieu-The Spirit of Law (Volume I), Thomas Ruddingman, 1793

Chiara Ragni, The Role of Amicus Curiae in Investment Disputes: Striking a Balance Between Confidentiality and Broader Policy Considerations, at: Tullio Treves \& Francesco Seatzu \& Seline Trevisanut (eds.), Foreign Investment, International Law and Common Concerns, Routledge, 2014

China International Economic and Trade Arbitration Commission 中国国际经济贸易 仲裁委员会, Selected Works of China International Economic and Trade Arbitration Commission Awards (1963-1988) 中国国际经济贸易仲裁裁决书选编 (1963-1988), China Renmin University Press 中国人民大学出版社, 1993

Chien-Huei Wu, Reclaiming the Comprehensive Strategic Partnership Through the EU-China Partnership and Cooperation Agreement: Taking Stock and Moving Forward, at: Julien Chaisse (ed.), Sixty Years of European Integration and Global Power Shifts: Perceptions, Interactions and Lessons, Hart Publishing, 2020

Chi-Chung Kao, The Inclusion of Investment Court System into the EU-China BIT: Innovations, Prospects and Problems, at: Julien Chaisse (ed.), China-European Union Investment Relationships: Towards a New Leadership in Global Investment Governance?, Edward Elgar Publishing, 2018

Clifford Geertz, The Interpretation of Clutures: Selected Essays, Basic Books, 1973

Colin B. Picker, China, Global Governance \& Legal Culture: The Example of China \& the WTO, at: Junji Nakagaw (ed.), China and Global Economic Governance: Ideas and Concepts, The University of Tokyo-Institute of Social Science (ISS) Research Series No.45, 2011 
Colin B. Picker, International Investmnet Law: Some Legal Cultural Insights, at: Leon Trakman \& Nick Ranieri (eds.), International Trade and Investment Law: Developments and Directions, Oxford University Press, 2012

Dainian Zhang \& Yishan Cheng 张岱年 \& 程宜山, Cultural Spirits of China 中国 文化精神, Joint Publishing (Hong Kong) 三联书店（香港）, 2016

Danae Azaria, The European Union's Contribution to the Law on Standing and Jurisdiction in International Dispute Settlement, at: Marise Cremona \& Anne Thies \& Ramses A Wessel (eds.), The European Union and International Dispute Settlement, Hart Publishing, 2017

David Shambaugh, China Goes Global: The Partial Power, Oxford University Press, 2013

Davydenko Dmitry Leonidovich, Amicable Dispute Resolution in the European Legal Tradition, Infotropic Media Publishing House, 2013

Derek Heater, A Brief History of Citizenship, Edinburgh University Press, 2004

Detlev Brauns \& Tomas Baert, The European Union in the World Trade Organization Post-Lisbon: No Single Change to the Single Voice?, at: Christine Kaddous (ed.), The European Union in International Organisations and Global Governance, Hart Publishing, 2017

Donald C. Clarke, Dispute Resolution in China, at: Tahirih V. Lee (ed.), Contract, Guanxi, and Dispute Resolution in China, Garland Publishing, Inc., 1997

Edger Bodenheimer, Jurisprudence-The Philosophy and Method of the Law, Harvard University Press, 1974

Eduardo Zuleta, The Challenge of Creating a Standing International Investment Court, at: Jean E. Kalicki \& Anna Joubin-Bret (eds.), Reshaping the Investor-State Dispute Settlement System: Journeys for the 21st Century, 2015

Edward D. Mansfield \& Brian M. Pollins (eds.), Economic Interdependence and International Conflict: New Perspectives on an Enduring Debate, The University of Michigan Press, 2003

Emmerich de Vattel, The Law of Nations or the Principles of Natural Law Applied to the Conduct and to the Affairs of Nations and Sovereigns (1758) (Translated by Charles G. Fenwick), Carnegie Institution of Washington, 1916

Eva Storskrubb, Civil Procedure and EU Law: A policy Area Uncovered, Oxford University Press, 2008

Federico Ortino, Transparency of Investment Awards: External and Internal Dimensions, at: Junji Nakagawa (ed.), Transparency in International Trade and Investment Dispute Settlement, Routledge, 2013 
Fernández Arroyo DP, Exorbitant and Exclusive Grounds of Jurisdiction in European Private International Law: Will They Ever Survive?, at: Heinz P Mansel et al. (eds.), Festschrift für Erik Jayme, Sellier, 2004

Francesco Pesce, International and EU Perspective on Mediation: Mediation and Fundamental Right of Access to Justice, at: Francesco Pesce \& Dana Rone, Mediation to Foster European Wide Settlement of Disputes, Aracne, 2016

Francis Snyder, The Creation of New Sites of Governance: China, Regional Trade Agreements and WTO Law, at: The EU, the WTO and China: Legal Pluralism and International Trade Regulation, Hart Publishing, 2010

Frank Hoffmeister, The European Union in the World Trade Organization-A Model for the EU's Status in International Organisations?, at: Christine Kaddous (ed.), The European Union in International Organisations and Global Governance, Hart Publishing, 2015

Frank Hoffmeister \& Güneş Ünüvar, From BITS and Pieces Towards European Investment Agreements, at: Marc Bungenberg \& August Reinisch \& Christian Tietje (eds.), EU and Investment Agreements: Open Questions and Remaining Challenges, Nomos/Hart Publishing, 2013

Franz Leopold Neumann, The Rule of Law: Political Theory and the Legal System in Modern Society, Berg Publishers Ltd., 1986

Fu Hualing \& Richard Cullen, From Mediatory to Adjudicatory Justice: The Limits of Civil Justice Reform in China, at: Margaret Y. K. Woo \& Mary E. Gallagher (eds.), Chinese Justice: Civil Dispute Resolution in Contemporary China, Cambridge University Press, 2011

Gabrielle Kaufmann-Kohler, Interpretive Powers of the Free Trade Commission and the Rule of Law, at: Emmanuel Gaillard \& Frédéric Bachand (eds.), Fifteen Years of NAFTA Chapter 11 Arbitration, JurisNet, 2011

Gary B. Born, International Commercial Arbitration (2nd edition), Kluwer Law International, 2014

Gottfried Dietze, Two Concepts of the Rule of Law, Liberty Fund, 1973

Guido Tawil, An international Appellate System: Progress or Pitfall, at: Federico Ortino \& Audley Sheppard \& Hugo Warner (eds.), Investment Treaty Law: Current Issues (Volume 1), British Institute of International and Comparative Law, 2006

Guohua Yang \& Xiaoli Shi (eds.) 杨国华、史晓丽 编, We Are Practicing in the WTO: Collection of Essaies on Participation in the WTO Hearings 我们在 WTO 打官司一 一参加 WTO 听证会随笔集, Intellectual Property Publishing House 知识产权出版 社, 2014

Gus Van Harten, Investment Treaty Arbitration and Public Law, Oxford University Press, 2008 
Hanqin Xue, Chinese Perspectives on International Law: History, Culture and International Law, Martinus Nijhoff Publishers, 2012

Hans W. Micklitz, The (Un)-Systematics of (Private) Law as an Element of European Culture, at: Geneviève Helleringer \& Kai Purnhagen (eds.), Towards a European Legal Culture, Hart Publishing, 2014

Harold J. Berman, Law and Revolution: The Formation of the Western Legal Tradition, Harvard University Press, 1983

Heather M. Campbell (ed.), The Britannica Guide to Political and Social Movements That Changed the Modern World, Britannica Educational Publishing, 2010

Heinrich A. Rommen (translated by Thomas R. Hanley \& Russell Hittinger), The Natural Law: A Study in Legal and Social History and Philosophy, Liberty Fund Inc, 1998

Henry G. Schermers \& Denis Waelbroeck, Judicial Protection in the European Communities (Fourth Edition), Kluwer Law and Taxation Publishers, 1987

Howard Mann, Transparency and Consistency in International Investment Law: Can the Problems be Fixed by Tinkering?, at: Karl P. Sauvant \& Michael ChiswickPatterson (eds.), Appeals Mechanism in International Investment Disputes, Oxford University Press, 2008

Hualing Fu, Mediation and the Rule of Law: The Chinese Landscape, at: Joachim Zekoll \& Mortiz Bälz \& Iwo Amelung (eds.), Formalisation and Flexibilisation in Dispute Resolution, Brill Nijhoff, 2014

H. Patrick Glenn, Comparative Legal Families and Comparative Legal Traditions, at: Mathias Reimann \& Reinhard Zimmermann (eds.), The Oxford Handbook of Comparative Law, Oxford University Press, 2006

H. Patrick Glenn, Legal Traditions of the World: Sustainable Diversity in Law (Fifth Edition), Oxford University Press, 2014

Ignacio Garcia Bercero, Dispute Settlement in European Union Free Trade Agreements: Lessons Learned?, at: Lorand Bartels \& Federico Ortino (eds.), Regional Trade Agreements and the WTO System, Oxford University Press, 2006

Jacques Martain (translated by Doris C. Anson), The Rights of Man and Natural Law, Gordian Press, 1971

Jaemin Lee, Introduction of an Appellate Review Mechanism for International Investment Disputes: Expected Benefits and Remaining Tasks, at: Jean E. Kalicki \& Anna Joubin-Bret (eds.), Reshaping the Investor-State Dispute Settlement SystemJourneys for the 21st Century, Brill | Nijhoff, 2015

James E. Sheridan, China in Disintegration: The Republican Era In Chinese History 1912-1949, The Free Press, 1975 
James V. Feinerman, The History and Development of China's Dispute Resolution System, at: Chris Hunter (ed.), Dispute Resolution in the PRC-A Practical Guide to Litigation and Arbitration in China, Asia Law \& Practice Ltd., 1995

Jan Wouters \& Matthieu Burnay, China and the European Union in the World Trade Organization: Living Apart Together?, at: Jan Wouters \& Tanguy de Wilde \& Pierre Defraigne \& Jean-Christophe Defraigne, China, the European Union and the Restructuring of Global Governance, Edward Elgar, 2012

Jan Paulsson, Avoiding Unintended Consequences, at: Karl P. Sauvant \& Michael Chiswick-Patterson (eds.), Appeals Mechanism in International Investment Disputes, Oxford University Press, 2008

János Volkai, The European Union and its Member States' Participation in the World Trade Organization: A WTO Perspective, at: Christine Kaddous (ed.), The European Union in International Organisations and Global Governance, Hart Publishing, 2015

Jean Yves Heurtebise, Understanding Non-Trade Concerns Through Comparative Chinese and European Philosophy of Law, at: Paolo Davide Farah \& Elena Cima (eds.), China's Influence on Non-Trade Concerns in International Economic Law, Routledge, 2016

Jeremy Lack, Appropriate Dispute Resolution (ADR): the Spectrum of Hybrid Techniques Available to the Parties, at: Arnold Ingen-Housz (ed.), ADR in Business: Practice and Issues Across Countries and Cultures-Volume II, Kluwer Law International, 2011

Jeswald W. Salacuse, Is There a Better Way? Alternative Methods of Treaty-Based, Investor-State Dispute Resolution, Fordham International Law Journal, Vol. 31, 2007

Jiachu K. \& Shifi Z. \& Li L., International Business Negotiations in the People's Republic of China, at: James R. Silkenat \& Jeffrey M. Aresty (eds.), The ABA Guide to International Business Negotiations-A Comparison of Cross-Cultural Issues and Successful Approaches (3rd Edition), ABA Publishing, 2000

Jianfu Chen, Chinese Law: Context and Transformations, Martinus Nijhoff Publishers, 2008

Jinfan Zhang, The Tradition and Modern Transition of Chinese Law, Springer, 2014

Jingzhou Tao, Arbitration in China, at: Philip J. McConnaughay \& Thomas B. Ginsburg (eds.), International Commercial Arbitration in Asia (Second Edition), Juris Publishing, 2006

John Finnis, Natural Law and Natural Right, Clarendon Press, 1980

John Howard Jackson, The European Community and World Trade: The Commercial Policy Dimension, at: William James Adams (ed.), Singular Europe: Economy and Polity of the European Community After 1992, University of Michigan Press, 1993

John H. Jackson, The World Trading System: Law and Policy of International Economic Relations (2nd Edition), The MIT Press, 1997 
Joost Pauwelyn \& Manfred Elsig, The Politics of Treaty Interpretation: Variations and Explanations Across International Tribunals, at: Jeffrey Dunoff \& Mark Pollack (eds.), Interdisciplinary Perspectives on International Law and International Relations, Cambridge University Press, 2012

Joseph Chan, Confucian Perfectionism: A Political Philosophy for Modern Times, Princeton University Press, 2014

Judith Gill, Inconsistent Decisions: An Issue to be Addressed or a Fact of Life?, at: Federico Ortino \& Audley Sheppard \& Hugo Warner (eds.), Investment Treaty LawCurrent Issues, British Institute of International and Comparative Law, 2006

Jürgen Kurtz, Building Legitimacy Through Interpretation in Investor-State Arbitration: On Consistency, Coherence, and the Identification of Applicable Law, at: Zachary Douglas \& Joost Pauwelyn \& Jorge Vinuales (eds.), The Foundations of International Investment Law: Bridging Theory Into Practice, Oxford University Press, 2014

Karl P. Sauvant \& Michael Chiswick-Patterson (eds.), Appeals Mechanism in International Investment Disputes, Oxford University Press, 2008

Kate Parlett, The Individual in the International Legal System: Continuity and Change in International Law, Cambridge University Press, 2011

Katia Yannaca-Small, Arbitration Under International Investment Agreements: A Guide to the Key Issues, Oxford University Press, 2010

Knut B. Pissler, Mediation in China: Threat to the Rule of Law?, at: Klaus J. Hopt \& Felix Steffek (eds.), Mediation: Principles and Regulation in Comparative Perspective, Oxford University Press, 2013

Kristina Anđeli, Why ICSID Doesn't Need an Appellate Procedure, and What to Do Instead, at: Jean E. Kalicki \& Anna Joubin-Bret (eds.), Reshaping the Investor-State Dispute Settlement System, Brill, 2015

Kun Fan, Arbitration in China: A Legal and Cultural Analysis, Hart Publishing, 2013

Kyung Kwak \& Gabrielle Marceau, Overlaps and Conflicts of Jurisdiction between the World Trade Organization and Regional Trade Agreements, at: Lorand Bartels \& Federico Ortino (eds.), Regional Trade Agreements and the WTO Legal System, Oxford University Press, 2007

Lai Chen 陈来, The Core Values of Chinese Civilization 中华文明的核心价值, Joint Publishing (H.K.) 三联书店（香港）, 2016

Laurence Boulle, Mediation: Principles, Process, Practice (3rd ed), LexisNexis Butterworths, 2011

Lawrence M. Friedman, The Legal System: A Social Science Perspective, Russell Sage Foundation, 1975 
Leon E. Trakman, Geopolitics, China, and Investor-State Arbitration, at: Lisa Toohey \& Colin Picker \& Jonathan Greenacre (eds.), China in the International Economic Order: New Directions and Changing Paradigms, Cambridge University Press, 2015

Leonardo Morlino \& Gianluigi Palombella (eds.), Rule of Law and Democracy: Inquiries into Internal and External Issues, Brill, 2010

Lin Li 李林, The Role of People's Congress System in the Building of the Harmonious Society 人民代表大会制度在建设和谐社会中的作用, at: Lin Li (ed.) 李林（编）， Ruling Country According to Law and the Building of Harmonious Society 依法治国 与和谐社会建设, China Legal Publishing House 中国法制出版社, 2007

Lisa J. Conant, Justice Contained: Law and Politics in the European Union, Cornell University Press, 2002

Liyong Jiang, WTO Dispute Settlement Mechanism and China's Participation, at: Henry Gao \& Donald Lewis (eds.), China's Participation in the WTO, Cameron May, 2005

Liyu Han \& Henry Gao, China's Experience in Utilizing the WTO Dispute Settlement Mechanism, at: Gregory C. Shaffer \& Ricardo Meléndez-Ortiz (eds.), Dispute Settlement at the WTO: The Developing Country Experience, Cambridge University Press, 2010

Lon L. Fuller, Collective Bargaining and the Arbitrator, at: Mark L. Kahn (ed.), Collective Bargaining and the Arbitrator's Role: Proceedings of the Fifteenth Annual Meeting-National Academy of Arbitrators, Bureau of National Affairs Inc., 1962

Lon L. Fuller, The Morality of Law, Yale University Press, 1969

Luis González García, Making Impossible Investor-State Reform Possible, at: Jean E. Kalicki \& Anna Joubin-Bret (eds.), Reshaping the Investor-State Dispute Settlement System: Journeys for the 21st Century, Brill | Nijhoff, 2015

Luke Nottage \& Romesh Weeramantry, Investment Arbitration in Asia: Five Perspectives on Law and Practice, at: Vivienne Bath \& Luke Nottage (eds.), Foreign Investment and Dispute Resolution Law and Practice in Asia, Routledge, 2011

Ma Pía Calderón Cuadrado \& José Luis Iglesias Buhigues, Mediation as an 'Alternative' to Jurisdiction: Directive 2008/52, at: European Civil Procedure, Thomoson Reuters, 2011

Manon Schonewille \& Jeremy Lack, Mediation in the European Union and Abroad: 60 States Divided by a Common Word?, at: Manon Schonewille \& Fred Schonewille (eds.), The Variegated Landscape of Mediation: A Comparative Study of Mediation Regulation and Practices in Europe and the World, Eleven International Publishing, 2014

Marc Bungenberg \& Stephan Hobe, The Relationship of International Investment Law and European Union Law, at: Marc Bungenberg \& Jörn Griebel \& Stephan Hobe \& 
August Reinisch (eds.), International Investment Law: A Handbook, C.H.Beck-HartNomos, 2015

Marc Bungenberg \& Catharine Titi, Developments in International Investment Law, at: Christoph Herrmann \& Markus Krajewski \& Joerg Philipp Terhechte (eds.), European Yearbook of International Economic Law 2014, Springer, 2013

Marc Bungenberg \& Catharine Titi, The Evolution of EU Investment Law and the Future of EU-China Investment Relations, at: Wenhua Shan \& Jinyuan Su (eds.), China and International Investment Law: Twenty Years of ICSID Membership, Brill | Nijhoff, 2015

Marc L. Busch \& Krzysztof J. Pelc, Does the WTO Need a Permanent Body of Panelists?, Journal of International Economic Law, Vol. 12, 2009

Marcel L. Storme (ed.), Rapprochement du droit judiciaire de l'Union Européenne/Approximation of Judiciary Law in the European Union, Kluwer Law International, 1994

Marcia Don Harpaz, China and International Tribunals: Onward from the WTO, at: Lisa Toohey \& Colin B. Picker \& Jonathan Greenacre (eds), China in the International Economic Order: New Directions and Changing Paradigms, Cambridge University Press, 2015

Mark A. Pollack \& Gregory C. Shaffer, When Cooperation Fails: The International Law and Politics of Genetically Modified Foods, Oxford University Press, 2009

Mark C. Murphy, Natural Law in Jurisprudence and Politics, Cambridge University Press, 2006

Mark E. Villiger, Commentary on the 1969 Vienna Convention on the Law of Treaties, Martinus Nijhoff Publishers, 2009

Mark Juergensmeyer, Religion in Global Civil Society, Oxford University Press, 2005

Mark Kantor, The Transparency Agenda for UNCITRAL Investment Arbitrations: Looking in all the Wrong Places, New York University Investment Law Forum, New York, 07.02.2011

Mary Ann Glendon \& Paolo G. Carozza \& Colin B. Picker, Comparative Legal Traditions in a Nutshell (4th Edition), West Academic Publishing, 2016

Meg Kinnear \& Geraldine R. Fischer \& Jara Minguez Almeida \& Luisa Fernanda Torres \& Mairée Uran Bidegain (eds.), Building International Investment Law: The First 50 Years of ICSID, Wolters Kluwer, 2015Marc Bungenberg, The Division of Competences Between the EU and Its Member States in the Area of Investment Politics, at: Marc Bungenberg et al. (eds.), International Investment Law and EU Law, Springer, 2011

Michael D.A. Freeman, Legal Theory at the End of the Millennium, Oxford University Press, 1998 
Michael Waibel, International Investment Law and Treaty Interpretation, at: Rainer Hofmann \& Christian J. Tams (eds.), International Investment Law and General International Law: From Clinical Isolation to Systemic Integration?, Nomos Publishers, 2011

Michele Potestà, State-to-State Dispute Settlement Pursuant to Bilateral Investment Treaties: Is there Potential?, at: Nerina Boschiero \& Tullio Scovazzi \& Cesare Pitea \& Chiara Ragni (eds.), International Courts and the Development of International LawEssays in Honour of Tullio Treves, T.M.C. Asser Press, 2013

Ministry of Commerce of the People' s Republic of China \& National Bureau of Statistics of the People' $\mathrm{s}$ Republic of China \& State Administration of Foreign Exchange 中华人民共和国商务部\&中华人民共和国国家统计局\&国家外汇管理 局, 2014 Statistical Bullentin of China's Outward Foreign Direct Investment 2014 年 度中国对外直接投资统计公报, China Statistics Press 中国统计出版社, 01.09.2015

Mortimer Sellers, What Is the Rule of Law and Why Is It So Important?, at: Flora A.N.J. Goudappel \& Ernst M.H. Hirsch Ballin (eds.), Democracy and Rule of Law in the European Union-Essays in Honour of Jaap W. de Zwaan, T.M.C. Asser Press, 2016

Natalie Klein, Dispute Settlement in the UN Convention on the Law of the Sea, Cambridge University Press, 2005

Neil J. Smelser \& Paul B. Baltes (eds.), International Encyclopaedia of the Social and Behavioural Sciences, Pergamon Press, 2001

Nigel Blackaby \& Constantine Partasides \& Alan Redfern \& Martin Hunter (eds.), Redfern and Hunter on International Arbitration (Sixth Edition), Oxford University Press, 2015

Nilaratna Xuto, Thailand: Conciliating a Dispute on Tuna Exports to the EC, at: Peter Gallagher \& Patrick Low \& Andrew L. Stoler (eds.), Managing the Challenges of WTO Participation: 45 Case Studies, Cambridge University Press, 2005

Noah Rubins, Judicial Review of Investment Arbitration Awards, at: Federico Ortino \& Audley Sheppard \& Hugo Warner (eds.), Investment Treaty Law: Current Issues, Volume I, British Institute of International and Comparative Law, 2006

Norah Gallagher, China's BIT's and Arbitration Practice: Progress and Problems, at: Wenhua Shan \& Jinyuan Su (eds.), China and International Investment Law: Twenty Years of ICSID Membership, Brill | Nijhoff, 2014

Norah Gallagher \& Wenhua Shan, China, at: Chester Brown (ed.), Commentaries on Selected Model Investment Treaties, Oxford University Press, 2013

Norah Gallagher \& Wenhua Shan, Chinese Investment Treaties: Policies and Practice, Oxford University Press, 2009

Paolo Davide Farah, L'influenza Della Concezione Confuciana Sulla Costruzione del Sistema Giuridico e Politico Cinese (The Influence of Confucianism on the 
Construction of the Chinese Political and Juridical System), at: Giovanni Bombelli \& Bruno Montanari (eds.), Identità Europea e Politiche Migratorie, Vita e Pensiero, 2008

Paul Craig \& Gráinne de Búrca, EU Law-Text, Cases, and Materials (Sixth Edition), Oxford University Press, 2015

Paul R. Goldin, Confucianism, Routledge, 2014

Peter Malanczuk, Hong Kong, at: Rüdiger Wolfrum (ed.), The Max Planck Encyclopedia of Public International Law, Oxford University Press, 2012

Peter N. Stearns, Periodization in World History: Challenges and Opportunities, at: Weller R. Charles (ed.), 21st-Century Narratives of World History: Global and Multidisciplinary Perspectives, Palgrave Macmillan, 2017

Philip Strik, Shaping the Single European Market in the Field of Foreign Direct Investment, Hart Publishing, 2016

Pia Eberhardt \& Cecilia Olivet with contributions from Tyler Amos \& Nick Buxton, Profiting from Injustice: How Law Firms, Arbitrators and Financiers are Fueling an Investment Arbitration Boom, Corporate Europe Observatory and the Transnational Institute, 2012

Pieter Jan Kuijper \& Frank Hoffmeister, WTO Influence on EU Law: Too Close for Comfort?, at: Ramses A. Wessel \& Steven Blockmans (eds.), Between Autonomy and Dependence: The EU Legal Order under the Influence of International Organisations, T.M.C. Asser Press, 2013

Pitman B. Potter, The Chinese Legal System-Globalization and Local Legal Culture, Routledge, 2001

Porges Amelia, Dispute Settlement, at: Jean-Pierre Chauffour \& Jean-Christophe (eds.), Preferential Trade Agreement Policies for Development: A Handbook, The World Bank, 2011

P. Brooker \& A. Lavers, Perceptions of the Role of Alternative Dispute Resolution in the Settlement of Construction Disputes: Lessons from the UK and US Experience, at: P. In Fenn (ed.), Proceedings of CIB TG15 Meeting: Construction Conflict: Management and Resolution, E. \& F. N. Spon, 1994

Randall Lesaffer, European Legal History: A Cultural and Political Perspective, Cambridge University Press, 2009

Randall Peerenboom, China's Long March Toward Rule of Law, Cambridge University Press, 2002

Randall P. Peerenboom, Law and Morality in Ancient China: The Silk Manuscripts of Huang-Lao, State University of New York Press, 1993

Richard Gardiner, Treaty Interpretation, Oxford University Press, 2008

Richard Happ, Why Investment Arbitration Contributes to the Rule of Law: Without Konwing Where We Came from We Cannot Know Where We are Heading, at: Loukas 
Mistelis \& Nikos Lavranos (eds.), European Investment Law and Arbitration Review, Brill | Nijhoff, 2016

Robert A. Baruch Bush \& Joseph P. Folger, The Promise of Mediation: Responding to Conflict through Empowerment and Recognition, Jossey-Bass, 1994

Robert B. Davidson, Initiating an International Mediation, at: Richard Chernick \& Daniel M. Kolkey \& Barbara Reeves Neal (eds.), Practitioner's Handbook on International Arbitration and Mediation (Third Edition), JurisNet, LLC, 2012

Robert P. George, The Autonomy of Law: Essays on Legal Positivism, Oxford University Press, 1999

Roberto Echandi, Complementing Investor-State Dispute Resolution: A Conceptual Framework for Investor-State Conflict Management, at: Roberto Echandi \& Pierre Sauvé (eds.), Prospects in International Investment Law and Policy: World Trade Forum, Cambridge University Press, 2013

Robin White, Lawyers and the Courts, at: Robert Blackburn (ed.), Rights of Citizenship, Mansell Publishing, 1993

Roger Cotterrell, The Concept of Legal Culture, at: David Nelken (ed.), Comparing Legal Cultures, Routledge, 1997

Roger T. Ames \& Henry Rosemont Jr. (Translators), The Analects of Confucius: A Philosophical Translation, Random House Publishing Group, 2010Armand de Mestral C.M., The Lisbon Treaty and the Expansion of EU Competence Over Foreign Direct Investment and the Implications for Investor-State Arbitration, at: Karl P. Sauvant (ed.), Yearbook on International Investment Law \& Policy 2010-2011, Oxford University Press, 2012

Ronald Dworkin, Law's Empire, Belknap Press of Harvard University Press, 1986

Rudolf Dolzer \& Christoph Schreuer, Principles of International Investment Law (Second Edition), 2nd edition, Oxford University Press, 2012

Santiago Montt, State Liability in Investment Treaty Arbitration-Global Constitutional and Administrative Law in the BIT Generation, Hart Publishing, 2009

Scott Barclay \& Susan S. Silbey, Understanding Regime Change: Public Opinion, Legitimacy, and Legal Consciousness, at: Gregory A. Caldeira \& R. Daniel Kelemen \& Keith E. Whittington (eds.), The Oxford Handbook of Law and Politics, Oxford University Press, 2008

Shahla Ali, Prospects of Utilizing Investor-State Mediation and UNCITRAL Rules on Transparency for Polycentric Environmental Disaster-Related Disputes: The Case of Vattenfall v. Germany, at: Muruga Perumal Ramaswamy \& Jodo Ribeiro (eds.), Trade Development through Harmonization of Commercial Law, New Zealand Association of Comparative Law, 2015 
Shengchang Wang 王生长, The Theory and Practice of Combining Arbitration with Mediation 仲裁与调解相结合的理论与实务, Publishing House of Law 法律出版社, 2001

Shuliang Wang, Introduction to International Trade Dispute Settlement in China, at: Pitman B. Potter \& Ljiljana Biuković, Globalization and Local Adaptation in International Trade Law, UBC Press, 2011

Sophie Nappert, Escaping from Freedom? The Dilemma of an Improved ISDS Mechanism, at: Loukas Mistelis \& Nikos Lavranos (eds.), European Investment Law and Arbitration Review (Volume 1), Brill | Nijhoff, 2016

Stanley B. Lubman, Bird in a Cage-Legal Reform in China after Mao Standford University Press, 2000

Stephen Goldstein, On Comparing and Unifying Civil Procedural Systems, at: Roger Cotterrell (ed.), Butterworth Lectures 1994: Process and Substance, Butterworths, 1995

Stephen M. Schwebel, Introduction, at: Ulf Franke \& Annette Magnusson \& Joel Dahlquist (eds.), Arbitrating for Peace: How Arbitration Made a Difference, Kluwer Law International, 2016

Stephan W. Schill, International Investment Law and the Rule of Law, at: Jeffrey Lowell \& J. Christopher Thomas \& Jan van Zyl Smit (eds.), Rule of Law Symposium 2014: The Importance of the Rule of Law in Promoting Development, Singapore: Academy Publishing, 2015

Stephan W. Schill, Ordering Paradigms in international Investment Law: BilateralismMultilateralism-Multilateralization, at: Zachary Douglas \& Joost Pauwelyn \& Jorge E. Viñuales (eds.), The Foundations of international Investment Law: Bringing Theory into Practice, Oxford Univresity Press, 2014

Stephen Woolcock, A Framework for Assessing Regional Trade Agreements: WTOPlus, at: Gary P. Sampson \& Stephen Woolcock (eds.), Regionalism, Multilateralism and Economic Integration: the Recent Experience, United Nations University Press, 2003

Thomas Bernauer, Genes, Trade and Regulation: The Seeds of Conflict in Food Biotechnology, Princeton University Press, 2003

Thomas Schultz, Against Consistency in Investment Arbitration, at: Zachary Douglas \& Joost Pauwelyn \& Jorge E. Viñuales (eds.), The Foundations of International Investment Law: Bringing Theory into Practice, Oxford University Press, 2014

Thomas Wälde, Introductory Note to Svea Court of Appeals: Czech Republic v. CME Czech Republic B.V., Internatioanl Legal Materials, Vol. 42, 2003

Tim Josling \& Tim Taylor, Conclusion, at: Timothy Josling \& Timothy Taylor (eds.), Banana Wars: The Anatomy of a Trade Dispute, CABI Publishing, 2003 
Timothy Webster, China's Implementation of WTO Decisions, at: Lisa Toohey \& Colin B. Picker \& Jonathan Greenacre (eds.), China in the International Economic Order: New Directions and Changing Paradigms, Cambridge University Press, 2015

Todd Allee \& Manfred Elsig, Dispute Settlement Provisions in PTAs: New Data and New Concepts, at: Andreas Dür \& Manfred Elsig (eds.), Trade Cooperation: The Purpose, Design and Effects of Preferential Trade Agreements, Cambridge University Press, 2015

Valentina Vadi, Converging Divergences: The Rise of Chinese Outward Foreign Investment and its Implications for International (Investment) Law, at: Karl P. Sauvant (ed.), Yearbook on International Investment Law \& Policy 2011-2012, Oxford University Press, 2013

Victoria Donaldson \& Simon Lester, Dispute Settlement, at: Simon Lester \& Bryan Mercurio (eds.), Bilateral and Regional Trade Agreements: Commentary and Analysis, Cambridge University Press, 2009

Wenhua Shan, The Legal Framework of EU-China Investment Relations: A Critical Appraisal, Hart Publishing, 2005

Wenhua Shan \& Sheng Zhang, The Potential EU-China BIT: Issues and Implications, at: Marc Bungenberg \& August Reinisch \& Christian Tietje (eds.), EU and Investment Agreements: Open Questions and Remaining Challenges, Hart Publishing, 2013

Werner Menski, Comparative Law in a Global Context: The Legal Systems of Asia and Africa (2nd Edition), Cambridege University Press, 2009

William J. Davey, Dispute Settlement in the WTO and RTAs: A Comment, at: Lorand Bartels \& Federico Ortino (eds.), Regional Trade Agreements and the WTO Legal System, Oxford University Press, 2006

William Theodore de Bary, The Trouble with Confucianism, Harvard University Press, 1996

Won L. Kidane, The Culture of International Arbitration, Oxford University Press, 2017

W. J. Waluchow, Inclusive Legal Positivism, Clarendon Press, 1994

Yan Luo, Dispute Settlement in the Proposed East Asia Free Trade Agreement: Lessons Learned from the ASEAN, the NAFTA, and the EU, at: Lorand Bartels \& Federico Ortino (eds.), Regional Trade Agreements and the WTO Legal System, Oxford University Press, 2006

Yang Shang (translated and noted by J.J.L. Duyvendak), The Book of Lord Shang: A Classic of the Chinese School of Law, The Lawbook Exchange, Ltd., 1963

Ying Tao, Recognize the True Face of Bourgeois International Law from a Few Basic Concepts, at: Jerome Alan Cohen \& Hungdah Chiu (eds.), People's China And International Law: A Documentary Study, Princeton University Press, 1974 
Yongjie Li, Factors to be Considered for China's Future Investment Treaties, at: Wenhua Shan \& Jinyuan Su (eds.), China and International Investment Law-Twenty Years of ICSID Membership, Brill | Nijhoff, 2015

\section{Journal Articles}

Alan Watson, Legal Change: Sources of Law and Legal Culture, University of Pennsylvania Law Review, Vol. 131, 1983

Albert H.Y. Chen, Toward a Legal Enlightenment: Discussions in Contemporary China on the Rule of Law, Pacific Basin Law Journal, Vol. 17, 1999

Anders Nilsson \& Oscar Englesson, Inconsistent Awards in Investment Treaty Arbitration: Is an Appeals Court Needed?, Journal of International Arbitration, Vol. 30, 2013

Anna Spain Bradley, Integration Matters: Rethinking the Architecture of International Dispute Resolution, University of Pennsylvania Journal of International Law, Vol. 32, 2010

Anne Judith Farina, "Talking Disputes into Harmony" China Approaches International Commercial Arbitration, American University International Law Review, Vol. 4, 1989

Anthea Roberts, Clash of Paradigms: Actors and Analogies Shaping the Investment Treaty System, American Journal of International Law, Vol. 107, 2013

Anthea Roberts, Power and Persuasion in Investment Treaty Interpretation: The Dual Role of States, American Journal of International Law, Vol. 104, 2010

Anthea Roberts, State-to-State Investment Treaty Arbitration: A Hybrid Theory of Interdependent Rights and Shared Interpretive Authority, Harvard International Law Journal, Vol. 55, 2014

Anthony Ogus, Competition between National Legal Systems: A Contribution of Economic Analysis to Comparative Law, The International and Comparative Law Quarterly, Vol. 48, 1999

Audley Sheppard \& Hugo Warner, Appeals and Challenges to Investment Treaty Awards: Is It Time for an International Appellate System?-Editorial Note, Transnational Dispute Management (TDM), 04.2005, available at: https://www.transnational-dispute-management.com/article.asp?key=399, last visited on 06.08 .2020

August Reinisch, The Use and Limits of Res Judicata and Lis Pendens as Procedural Tools to Avoid Conflicting Settlement Outcomes, The Law and Practice of International Courts and Tribunals, Vol. 3, 2004

Axel Berger, Investment Rules in Chinese Preferenctial Trade and Investment Agreements: Is China Following the Global Trend Towards Comprehensive Agreements, German Development Institute Discussion Paper, Vol. 7, 2013 
Axel Berger \& Lauge N. Skovgaard Poulsen, The Transatlantic Trade and Investment Partnership, Investor-State Dispute Settlement and China, Columbia FDI Perspectives, Vol. 140, 2015

Barbara Koremenos, If Only Half of International Agreements Have Dispute Resolution Provisions, Which Half Needs Explaining?, The Journal of Legal Studies, Vol. 36, 2007

Barry Appleton, The Song Is Over: Why It's Time to Stop Talking About an International Investment Arbitration Appellate Body, International Law in a Multipolar World, Vol. 107, 2013

Bernard Kishoiyian, The Utility of Bilateral Investment Treaties in the Formulation of Customary International Law, Northwestern Journal of International Law \& Business, Vol. 14, 1993

Bryan Mercurio, Improving Dispute Settlement in the World Trade Organization: The Dispute Settlement Understanding Review-Making it Work?, Journal of World Trade, Vol. 38, 2004

Cai Congyan, China-US BIT Negotiations and the Future of Investment Treaty Regime: A Grand Bilateral Bargain with Multilateral Implications, Journal of International Economic Law, Vol. 12, 2009

Caifen Jiang 姜彩芬, The Origin and Social Function of Mianzi Culture 面子文化产 生根源及社会功能, Guangxi Social Science 广西社会科学, Vol. 3, 2009

Calamita N. Jansen, The Making of Europe's International Investment Policy: Uncertain First Steps, Legal Issues of Economic Integration, Vol. 39, 2012

Carl F. Minzner, China's Turn against Law, American Journal of Comparative Law, Vol. 59, 2011

Carlos de Vera, Arbitrating Harmony: "Med-Arb" and the Confluence of Culture and Rule of Law in the Resolution of International Commercial Disputes in China, Columbia Journal of Asian Law, Vol. 18, 2004

Catharine Titi, The Arbitrator as a Lawmaker: Jurisgenerative Processes in Investment Arbitration, Journal of World Investment \& Trade, Vol. 14, 2013

Chang-fa Lo et. al., Concept Paper on the Creation of a Permanent "Asia-Pacific Regional Mediation Organization" for State-to-State (Economy-to-Economy) Disputes, Comtemporary Asia Arbitration Journal, Vol. 10, 2017

Charles H. Brower II, Why the FTC Notes of Interpretation Constitute a Partial Amendment of NAFTA Article 1105, Virginia Journal of International Law, Vol. 46, 2006

Christian J. Tams, An Appealing Option? The Debate about an ICSID Appellate Structure, Essays in Transnational Economic Law, Vol. 57, 2006 
Christina Knahr \& August Reinisch, Transparency Versus Confidentiality in International Investment Arbitration-The Biwater Gauff Compromise, The Law \& Practice of International Courts and Tribunals, Vol. 6, 2007

Christoph Schreuer, Traveling the BIT Route of Waiting Periods, Umbrella Clauses and Forks in the Road, The Journal of World Investment \& Trade, Vol. 5, 2004

Chunlei Zhao, Investor-State Mediation in a China-EU Bilateral Investment Treaty: Talking About Being in the Right Place at the Right Time, Chinese Journal of International Law, Vol. 16, 2018

Clovis J. Trevino, State-to-State Investment Treaty Arbitration and the Interplay with Investor-State Arbitration Under the Same Treaty, Journal of International Dispute Settlement, Vol. 5, 2014

Colin B. Picker, Comparative Legal Cultural Analyses of International Economic Law: A New Methodological Approach, The Chinese Journal of Comparative Law, Vol. 1, 2013

Cris Currie, Mediating off the Grid, Dispute Resolution Journal, Vol. 59, 2004

David Nelken, Using the Concept of Legal Culture, Australian Journal of Legal Philosophy, Vol. 29, 2004

Derk Bodde, Evidence for "Laws of Nature" in Chinese Thought, Harvard Journal of Asiatic Studies, Vol. 20, 1957

Dominik Horodyski, Democratic Deficit of Investment Arbitration in the View of Rules on Transparency and Mauritius Convention on Transparency, US-China Law Review, Vol. 13, 2016

Edna Sussman, Developing an Effective Med-Arb/Arb-Med Process, New York Dispute Resolution Lawyer, Vol. 2, 2009

Edwin H. W. Chan, Amicable Dispute Resolution in the People's Republic of China and Its Implications for Foreign-related Construction Disputes, Construction Management and Economics, Vol. 15, 1997

Ehhard Blankenburg, Patterns of Legal Culture: The Netherlands Compared to Neighboring Germany, The American Journal of Comparative Law, Vol. 46, 1998

Ernst-Ulrich Petersmann, Trade and Investment Adjudication Involving 'Silk Road Projects': Legal Methodology Challenges, European University Institute Working Papers, Vol. 2, 2018

Francis McGovern, Mediation of the Snake River Basin Adjudication, Idaho Law Review, Vol. 42, 2006

Francis M. Burdick, What Is the Law Merchant?, Columbia Law Review, Vol. 2, 1902

Frank J. Garcia, Evaluating International Economic Law Dispute Resolution Mechanisms, South Texas Law Review, Vol. 42, 2001 
Frank J. Garcia, New Frontiers in International Trade: Decision-making and Dispute Resolution in the Free Trade Area of the Americas: An Essay in Trade Governance, Michigan Journal of International Law, Vol. 18, 1997

Frank J. Garcia \& Hyun Ju Cho \& Tara Santosuosso \& Randall Scarlett \& Rachel Denae Denae Thrasher, The Case Against Third-Party Funding in ISDS: Executive Summary, Boston College Law School Faculty Papers, Vol. 4-23, 2018

Franz Wieacker \& Edgar Boenheimer, Foundations of European Legal Culture, The American Journal of Comparative Law, Vol. 38, 1990

Frauke Nitschke, The IBA's Investor-State Mediation Rules and the ICSID Dispute Settlement Framework, ICSID Review, Vol. 29, 2014

Frederick Tse-shyang Chen, The Confucian View of World Order, Indiana International \& Comparative Law Review, Vol. 1, 1991

Gabrielle Kaufmann-Kohler \& Fan Kun, Integrating Mediation into Arbitraiton: Why It Works in China, Journal of International Arbitration, Vol. 25, 2008

Geoffrey Gertz \& Srividya Jandhyala \& Lauge N. Skovgaard Poulsen, Legalization, Diplomacy, and Development: Do Investment Treaties De-politicize Investment Disputes?, World Development, Vol. 107, 2018

Gerald Aksen, Ad Hoc Versus Institutional Arbitration, the ICC International Court of Arbitration Bulletin, Vol. 10, 1991

Gloria Maria Alvarez et al., A Response to the Criticism Against ISDS by EFILA, Journal of International Arbitration, Vol. 33, 2016

Guiguo Wang, Chinese Mechanisms for Resolving Investor-State Disputes, Jindal Journal of International Affairs, Vol. 1, 2011

Guiguo Wang, Consent in Investor-State Arbitration: A Critical Analysis, Chinese Journal of International Law, Vol. 13, 2014

Gus Van Harten, Comments on the European Commission's Approach to InvestorState Arbitration in TTIP and CETA, Osgoode Legal Studies Research Paper No. 59/2014, Vol. 10, 2014

Haiwen Zhou, Confucianism and the Legalism: A Model of the National Strategy of Governance in Ancient China, Munich Personal RePEc Archive (MPRA) Paper, Vol. 81944, 2017

Hanqin Xue, Chinese Contemporary Perspectives on International Law: History, Culture and International Law, The Pocket Books of the Hague Academy of International, Vol. 15, 2012

Henry Gao, China's Participation in the WTO: A Lawyer's Perspective, Singapore Year Book of International Law, Vol. 11, 2007 
Heqisheng Research Group 何其生课题组, Discussion on the Construction of China International Commercial Court 论中国国际商事法庭的构建, Wuhan University International Law Review 武大国际法评论, Vol. 3, 2018

Holger Spamann, Contemporary Legal Transplants: Legal Families and the Diffusion of (Corporate) Law, Brigham Young University Law Review, Vol. 1813, 2009

Horatia Muir Watt, Evidence of an Emergent European Legal Culture: Public Policy Requirements of Procedural Fairness under the Brussels and Lugano Conventions, Texas International Law Journal, Vol. 36, 2001

Hugh Collins, European Private Law and the Cultural Diversity, European Review of Private Law, Vol. 3, 1995

Hyeran Jo \& Hyun Namgung, Dispute Settlement Mechanisms in Preferential Trade Agreements: Democracy, Boilerplates, and the Multilateral Trade Regime, Journal of Conflict Resolution, Vol. 56, 2012

Ian Laird \& Rebecca Askew, Finality Versus Consistency: Does Investor-State Arbitration Need an Appellate System?, Journal of Appellate Practice and Process, Vol. 7,2005

Ignacio Garcia Bercero \& Paolo Garzotti, DSU Reform: Why Have Negotiations to Improve WTO Dispute Settlement Failed so far and What Are the Underlying Issues?, The Journal of World Investment \& Trade, Vol. 6, 2005

Jack J. Coe, Toward a Complementary Use of Conciliation in Investor-State DisputesA Preliminary Sketch, UC Davis Journal of International Law and Policy, Vol. 12, 2005

James A. R. Nafziger \& Ruan Jiafang, Chinese Methods of Resolving International Trade, Investment and Maritime Disputes, Willamette Law Review, Vol. 23, 1987

James K. Lockett, Dispute Settlement in the People's Republic of China: The Developing Role of Arbitration in Foreign Trade and Maritime Disputes, George Washington Journal of International Law and Economics, Vol. 16, 1982

James McCall Smith, The Politics of Dispute Settlement Design: Explaining Legalism in Regional Trade Pacts, International Organization, Vol. 54, 2000

Jan Kleinheisterkamp, The Next 10 Year ECT Investment Arbitration: A Vision for the Future-From a European Law Perspective, London School of Economics Legal Studies Working Paper, Vol. 7, 2011

Janne Nijman, A Universal Rule of Law for a Pluralist World Order: Leibniz's Universal Jurisprudence and his Praise of the Chinese Ruler, Amsterdam Center for International Law (ACIL) Research Paper, Vol. 16, 2016

Jansen N. Calamita, Dispute Settlement Transparency in Europe's Evolving Investment Treaty Policy, The Journal of World Investment \& Trade, Vol. 15, 2014

Jarrod Wong, The Subversion of State-to-State Investment Treaty Arbitration, Columbia Journal of Transnational Law, Vol. 53, 2014 
Jason Webb Yackee, Conceptual Difficulties in the Empirical Study of Bilateral Investment Treaties, Brooklyn Journal of International Law, Vol. 33, 2008

Jayoung Jeon, Drafting an Optimal Dispute Resolution Clause in Investment Treaties, Peking University Transnational Law Review, Vol. 4, 2016

Jean R. Sternlight, Is Alternative Dispute Resolution Consistent with the Rule of Law? Lessons from Abroad, DePaul Law Review, Vol. 56, 2006

Jeremy Lack \& François Bogacz, The Neurophysiology of ADR and Process Design: A New Approach to Conflict Prevention and Resolution?, Cardozo Journal of Conflict Resolution, Vol. 4, 2012

Jingxia Shi \& Nuan Dong 石静霞、董暖, The Construction of Investment Dispute Settlement Mechanisms under 'One Belt One Road' Initiatives “一带一路” 倡议下 投资争端解决机制的构建, Wuhan University International Law Review 武大国际 法评论, Vol. 2, 2018

Jinping Xi 习近平, Accelerating the Establishment of Socialist Rule of Law in China 加快建设社会主义法治国家, Qiu Shi 求是, Vol. 1, 2015

Joachim Pohl \& Kekeletso Mashigo \& \& Alexis Nohen, Dispute Settlement Provisions in International Investment Agreements-A Large Sample Survey, OECD Working Papers on International Investment, Vol. 2, 2012

Joel Sobel, A Theory of Credibility, Review of Economic Studies, Vol. 52, 1985

John Farina, The Study of Spirituality: Some Problems and Opportunities, US Catholic Historian, Vol. 8, 1989

José E. Alvarez, The Return of the State, Minnesota Journal of International Law, Vol. 20, 2011

José E. Alvarez \& Kenneth J. Vandevelde, The BIT Program: A Fifteen-Year Appraisal, Proceedings of the Annual Meeting (American Society of International Law), Vol. 86, 1992

Judith Resnik, Due Process: A Public Dimension, The University of Florida Law Review, Vol. 39, 1987

Judith Resnik, For Owen M. Fiss: Some Reflections on the Triumph and the Death of Adjudication, University of Miami Law Review, Vol. 10, 2003

Judith Resnik, Whither and Whether Adjudication, Boston University Law Review, Vol. 86, 2006

Julian Donaubauer \& Eric Neumayer \& Peter Nunnenkamp, Winning or Losing in Investor-to-State Dispute Resolution: The Role of Arbitrator Bias and Experience, Kiel Working Paper, Vol. 2074, 2017

Julian D.M. Lew, Expert Report of Dr. Julian D.M. Lew (in Esso/BHP v. Plowman), Arbitration International, Vol. 11, 1995 
Julian $\mathrm{Ku}$, China and the Future of International Adjudication, Maryland Journal of International Law, Vol. 27, 2012

Julian Ku, Enforcement of ICSID Awards in the People's Republic of China, Contemporary Asia Arbitration Journal, Vol. 6, 2013Junwu Pan, Chinese Philosophy and International Law, Asian Journal of International Law, Vol. 1, 2011

Juliane Kokott \& Christoph Sobotta, Investment Arbitration and EU Law, Cambridge Yearbook of European Legal Studies, Vol. 18, 2016

Jun Xiao, How Can a Prospective China-EU BIT Contribute to Sustainable Investment: In Light of the UNCTAD Investment Policy Framework for Sustainable Development, Journal of World Energy Law and Business, Vol. 8, 2015

Jun Xiao 肖军, A Study on the Feasibility of Building an Appeal Mechanism in International Investment Arbitration: Starting with the Negotiations on a China-US Bilateral Investment Treaty 建立国际投资仲裁上诉机制的可行性研究一一从中美 双边投资条约谈判说起, Studies in Law and Business 法商研究, Vol. 2, 2015

Jun Xiao 肖军, The Investor-State Dispute Settlement Mechanism in a China-EU BIT: A Comparative Analysis Based on the China-Canada BIT and CETA 中欧 BIT 的投 资者-东道国争端解决机制——基于中加 BIT 与 CETA 的比较分析, Journal of Xidian University (Social Science Edition) 西安电子科技大学学报(社会科学版), Vol. 25, 2015

Jun Zhao \& Timothy Webster, Taking Stock: China's First Decade of Free Trade, University of Pennsylvania Journal of International Law, Vol. 33, 2011

Jun Zhao \& Yun Liu 赵骏、刘芸, The Reform of Transparency in International Investment Arbitration and China's Response 国际投资仲裁透明度改革及我国的应 对, Journal of Zhejiang University (Humanities and Social Science) 浙江大学学报 (人文社会科学版) , Vol. 44, 2014

Justice Robert F. Utter, Dispute Resolution in China, Washington Law Review, Vol. 62,1987

Jürgen Kurtz, Australia's Rejection of Investor-State Arbitration: Causation, Omission and Implication, ICSID Review, Vol. 27, 2012

Karen J. Alter \& Sophie Meunier, Nested and Overlapping Regimes in the Transatlantic Banana Dispute, Journal of European Public Policy, Vol. 13, 2007

Karl P. Sauvant \& Michael D. Nolan, China's Outward Foreign Direct Investment and International Investment Law, Journal of International Economic Law, Vol. 18, 2015

Kenneth J. Vandevelde, A Brief History of International Investment Agreements, U.C.Davis Journal of International Law \& Policy, Vol. 12, 2005

Kenneth J. Vandevelde, Bilateral Investment Treaties: History, Policy, and Interpretation, Thomas Jefferson School of Law Research Paper, Vol. 3022249, 2010 
Kenneth Winston, The Internal Morality of Chinese Legalism, Singapore Journal of Legal Studies, Vol. 12, 2005

Klaus Peter Berger, The International Arbitrators' Application of Precedents, Journal of International Arbitration, Vol. 9, 1992

Konstantinos D. Kerameus, Procedural Harmonization in Europe, American Journal of Comparative Law, Vol. 43, 1995

Kuik Cheng-Chwee, Multilateralism in China's ASEAN Policy: Its Evolution, Characteristics, and Aspiration, Contemporary Southeast Aisa, Vol. 27, 2005

Laurence R. Helfer \& Anne-Marie Slaughter, Why States Create International Tribunals: A Response to Professors Posner and Yoo, California Law Review, Vol. 93, 2005

Laurent Pech, Rule of Law as a Guiding Principle of the European Union's External Action, Centre for the Law of EU External Relations (CLEER) Working Papers, Vol. 3,2012

Leon E. Trakman, China and Foreign Direct Investment: Does Distance Lend Enchantment to the View?, The Chinese Journal of Comparative Law, Vol. 2, 2014

Leon E. Trakman, Investor-State Arbitration: Evaluating Australia's Evolving Position, The Journal of World Investment \& Trade, Vol. 15, 2014

Leon E. Trakman, "Legal Traditions" and international Commercial Arbitration, The American Review of International Arbitration, Vol. 17, 2007

Lester Nurick \& Stephen J. Schnably, The First ICSID Conciliation: Tesoro Petroleum Corporation v. Trinidad and Tobago, ICSID Review, Vol. 1, 1986

Li Liao 廖丽, Innovative Study on the Dispute Settlement Mechanism under the 'One Belt One Road' Initiative: From International Law and Comparative Law Perspectives “一带一路” 争端解决机制创新研究——国际法与比较法的视角, Law Review 法 学评论, Vol. 2, 2018

Lijun Cao, CIETAC as a Forum for Resolving Business Disputes, The Foundation for Law, Justice and Society, 24.01.2008, available at: http://www.fljs.org/sites/www.fljs.org/files/publications/FLJ\%2BS\%20Cao\%20pb_c. pdf, last visited on 03.08.2020

Liming Wang 王利明, A Harmonious Society Should be a Rule of Law Society 和谐 社会应当是法治社会, Legal Science 法学, Vol. 5, 2005

Low Sui Pheng, The Influence of Chinese Philosophies on Mediation and Conciliation in the Far East, Arbitration, Vol. 61, 1996

Luca Pantaleo, Lights and Shadows of the TTIP Investment Court System, CLEER Paper Series, Vol. 1, 2016 
Marcia Don Harpaz, Sense and Sensibilities of China and WTO Dispute Settlement, Journal of World Trade, Vol. 44, 2010

Mathias Wolkewitz, Transparency and Independence of Arbitrators in Investment Arbitration: Rule of Law Implications, European Investment Law and Arbitration Review, Vol. 1, 2016

Matthieu de Boisséson, La Soft Law dans l'arbitrage, Les Cahiers de l'Arbitrage, Vol. 3,2014

Martin Khor, The "Singapore Issues" in the WTO: Evolution and Implications for Developing Countries, TWN Trade \& Development Series, Vol. 33, 2007

Martins Paparinskis, Investment Arbitration and the Law of Countermeasures, British Yearbook of International Law 2008, Vol. 79, 2008

Martins Paparinskis, The Limits of Depoliticisation in Contemporary Investor-State Arbitration, Select Proceedings of the European Society of International Law, Vol. 3, 2010

Mehmet Ruhi Demiray, Natural Law Theory, Legal Positivism, and the Normativity of Law, The European Legacy, Vol. 20, 2015

Michele Potestá, Republic of Italy v. Republic of Cuba, American Journal of International Law, Vol. 106, 2012

Mo Zhang, The Socialist Legal System with Chinese Characteristics: China's Discourse for the Rule of Law and a Bitter Experience, Temple International \& Comparative Law Journal, Vol. 24, 2010

M. Scott Donahey, Seeking Harmony: Is the Asian Concept of the Conciliator/Arbitrator Applicable in the West?, Dispute Resolution Journal, Vol. 50, 1995

Nadja Alexander, The Mediation Meta Model: Understanding Practice Around the World, Conflict Resolution Quarterly, Vol. 26, 2008

Nancy A. Welsh \& Andrea K. Schneider, Becoming "Investor-State Mediation", Penn State Journal of Law \& International Affairs, Vol. 1, 2012

Nancy A. Welsh \& Andrea K. Schneider, The Thoughtful Integration of Mediation into Bilateral Investment Treaty Arbitration, Harvard Negotiation Law Review, Vol. 18, 2013

Ndapwilapo Shimutwikeni, The Impact of Culture in International Business Negotiations: Special Reference to China and United States of America, CEPMLP Annual Review, Vol. 14, 2009

Note: Mediation of Investor-State Conflicts, Harvard Law Review, Vol. 127, 2014

OLO De Witt Wijnen, ADR, the Civil Law Approach, Arbitration, Vol. 61, 1995

Owen M. Fiss, Against Settlement, Yale Law School Legal Scholarship Repository, Vol. 1, 1984 
Pasha L. Hsieh, China's Development of International Economic Law and WTO Legal Capacity Building, Journal of International Economic Law, Vol. 13, 2010

Peter Malanczuk, China and the Emerging Standard of Transparency in Investor-State Dispute Settlement (ISDS), New Zealand Association for Comparative Law, Vol. 19, 2015

Peter Malanczuk, State-State and Investor-State Dispute Settlement in the OECD Draft Multilateral Investment Agreement, Journal of International Economic Law, Vol. 3, 2000

Pierre Legrand, European Legal Systems Are Not Converging, International and Comparative Law Quarterly, Vol. 45, 1996

Pierre Legrand, On the Unbearable Localness of the Law: Academic Fallacies and Unseasonable Observations, European Review of Private Law, Vol. 1, 2002

Qingjiang Kong, China's Uncharted FTA Strategy, Journal of World Trade, Vol. 46, 2012

Qinglin Zhang 张庆麟, An Analysis of the EU's Reform of the Investor-State Dispute Settlement Mechanism 欧盟投资者-国家争端解决机制改革实践评析, Studies in Law and Business 法商研究, Vol. 3, 2016

Rachel Brewster, Rule-Based Dispute Resolution in International Trade Law, Virginia Law Review, Vol. 92, 2006

Rahim Moloo, When Actions Speak Louder Than Words: The Relevance of Subsequent Party Conduct to Treaty Interpretation, Berkeley Journal of International Law, Vol. 31, 2013

Rajesh Sharma, China-India FTA: Is the Future Imperfect?, Journal of World Trade, Vol. 48, 2014

Raymond Shonholtz, A General Theory on Disputes and Conflicts, Journal of Dispute Resolution, Vol. 2003, 2003

Richard L. Abel, A Comparative Theory of Dispute Institutions in Society, Law \& Society Review, Vol. 8, 1974

Richard Maher, The Elusive EU-China Strategic Partnership, International Affairs, Vol. 92, 2016

Robert Mnookin, Alternative Dispute Resolution, Harvard Law School John M. Olin Center for Law, Economics and Business Discussion Paper Series, Vol. 232, 1998

Rong Liu 刘嵘, Establishing the Idea of the Judiciary Serves the People and Implementing the Theme of Justice and Efficiency: Note of the National Conference for Presidents of the Higher Courts 树立司法为民思想，践行公正与效率主题—— 记全国高级法院院长座谈会, People's Judicature 人民司法, Vol. 9, 2003 
Sebastiaan Princen, EC Compliance with WTO Law: The Interplay of Law and Politics, European Journal of International Law, Vol. 15, 2004

Shahla F. Ali \& Odysseas G. Repousis, Investor-State Mediation and the Rise of Transparency in International Investment Law: Opportunity or Threat?, Denver Journal of International Law and Policy, Vol. 45, 2016-2017

Shaotang Wang 王少棠, Legetimacy Crisis Resolved? Reconsideration of the EU's Reform of Investment Court System 正当性危机的解除?一一欧盟投资争端解决机 制改革再议, Studies in Law and Business 法商研究, Vol. 2, 2018

Sheng Zhang 张生, Study on Treaty Parties' Interpretation under the Framework of International Investment Law 国际投资法制框架下的缔约国解释研究, Modern Law Science 现代法学, Vol. 37, 2015

Shixi Huang 黄世席, The Investor-State Dispute Settlement Mechanisms in the EU's Investment Agreements: Together with the Discussion on Relevant Issues in a ChinaEU Bilateral Investment Treaty 欧盟投资协定中的投资者一国家争端解决机制一 一兼论中欧双边投资协定中的相关问题, Global Law Review 环球法律评论, Vol. 5,2015

Shixi Huang 黄世席, The Origin of and the Response to the EU's Investment Court System 欧盟国际投资仲裁法庭制度的缘起与因应, Studies in Law and Business 法商研究, Vol. 4, 2016

Shu Xv 徐树, The Conflicts and Coordination between the Dule Tracks of the Enforcement Mechanisms of International Investment Agreements 国际投资条约 “双 轨” 执行机制的冲突及协调, Studies in Law and Business 法商研究, Vol. 2, 2017

Sophie Nappert, The Other Side of Transparency, Columbia FDI Perspectives, Vol. 141, 2015

Stanley B. Lubman \& Gregory C. Wajnowski, International Commercial Dispute Resolution in China: A Practical Assessment, The American Review of International Arbitration, Vol. 4, 1993

Stephanie Smith \& Jan Martinez, An Analytic Framework for Dispute Systems Design, Harvard Negotiation Law Review, Vol. 14, 2009

Sun Liu 刘笋, Discussion on Establishing an Appellate Mechanism of International Investment Arbitration 建立国际投资仲裁的上诉机制问题析评, Modern Law Science 现代法学, Vol. 5, 2009

Susan D. Franck, Integrating Investment Treaty Conflict and Dispute Systems Design, Minnesota Law Review, Vol. 92, 2007

Susan D. Franck, The Legitimacy Crisis in Investment Treaty Arbitration: Privatizing Public International Law Through Inconsistent Decisions, Fordham Law Review, Vol. 73, 2005 
Szilárd Gáspár-Szilágyi, A Standing Investment Court under TTIP from the Perspective of the Court of Justice of the European Union, Journal of World Investment \& Trade, Vol. 17, 2016

Thomas J. Stipanowich et al., East Meets West: An International Dialogue on Mediation and Med-Arb in the United States and China, Pepperdine Dispute Resolution Law Journal, Vol. 9, 2009

Thomas Wälde, Efficient Management of Transnational Disputes: Mutual Gain by Mediation or Joint Loss in Litigation, Arbitration International, Vol. 22, 2006

Timothy A. Steinert, If the BIT Fits: The Proposed Bilateral Investment Treaty between the United States and the People's Republic of China, Columbia Journal of Asian Law, Vol. 2, 1988

Tingting Deng 邓婷婷, The Investor-State Dispute Settlement Mechanism in a ChinaEU Bilateral Investment Treaty: From the Perspective of the EU's Investment Court System 中欧双边投资条约中的投资者一国家争端解决机制——以欧盟投资法庭 制度为视角, Politics and Law 政治与法律, Vol. 4, 2017

Todd Allee \& Paul K. Huth, Legitimizing Dispute Settlement: International Adjudication as Domestic Political Cover, American Political Science Review, Vol. 100,2006

Tom Ginsburg, The Culture of Arbitration, Vanderbilt Journal of Transnational Law Vol. 36, 2003

Tong Qi, How Exactly Does China Consent to Investor-State Arbitration: On the First ICSID Case against China, Contemporary Asia Arbitration Journal, Vol. 5, 2012

Tony Burns, Aristotle and Natural Law, History of Political Thought, Vol. 19, 1998

Tony Fang, Negotiation: the Chinese Style, Journal of Business \& Industrial Marketing, Vol. 21, 2006

Tyler Cohen \& David Schneiderman, The Political Economy of Chinese Bilateral Investment Treaty Policy, Chinese Journal of Comparative Law, Vol. 5, 2017

Ucheora O. Onwuamaegbu, The Role of ADR in Investor-State Dispute Settlement: The ICSID Experience, Transnational Dispute Management (TDM) in Mediation \& ADR, Vol. 1, 2007

Urs Martin Lauchli, Cross-cultural Negotiations, With a Special Focus on ADR with the Chinese, William Mitchell Law Review, Vol. 26, 2000

Weiping Zhang 张卫平, Court Mediation: Analysis and Reflection of the Current Situation 诉讼调解: 时下态势的分析与思考, Law Science 法学, Vol. 5, 2007

Weiping Zhang 张卫平, Reflection on Returning Back to Xiwu Ma 回归马锡五的思 考, Modern Law Science 现代法学, Vol. 31, 2009 
Weixia Gu, The Delicate Art of Med-Arb and its Future Institutionalisation in China, UCLA Pacific Basin Law Journal, Vol. 31, 2014

Wenhua Ji \& Cui Huang, China's Path to the Center Stage of WTO Dispute Settlement: Challenges and Responses, Global Trade and Customs Journal, Vol. 5, 2010

Wenhua Shan \& Lu Wang, The China-EU BIT: The Emerging "Global BIT 2.0"?, ICSID Review, Vol. 30, 2015

Wenhua Shan \& Norah Gallagher \& Sheng Zhang, National Treatment for Foreign Investment in China: A Changing Landscape, ICSID Review, Vol. 27, 2012

Xiantao Wen 温先涛, Discussion on "China Model Bilateral Investment Treaty (Draft)" 《中国投资保护协定范本》(草案)论稿, Journal of International Economic Law 国际经济法学刊, Vol. 18 \& 19, 2011

William J. Davey, Compliance Problems in WTO Dispute Settlement, Cornell International Law Journal, Vol. 42, 2009

Wolfgang Koeth, Can the Investment Court System (ICS) Save TTIP and CETA?, European Institute of Public Administration Working Paper, Vol. 2016/W/01, 2016

Won Kidane, China-Africa Dispute Settlement: The Law, Economics and Culture of Arbitration, Seattle University School of Law Legal Research Paper Series, Vol. 12-16, 2011

Xingzhong Yu, Legal Pragmatism in the People's Republic of China, Cornell Law Faculty Publications, Vol. 993, 1989

X. Jiang \& S. Tan, Non-litigation Tradition in China, Legal System and Society, Vol. 4,2008

Zhiping Liang, Explicating "Law": A Comparative Perspective of Chinese and Western Legal Culture, Journal of Chinese Law, Vol. 3, 1989

Zhiping L., The Past, the Present and the Future of Chinese Law: A Critical Retrospect of a Kind of Culture, Study of Comparative Law, Vol. 17, 1987

Zhongying Cheng 成中英, The Concept of "Face" and Its Confucian Origin 脸面观 念及其儒学根源, Chinese Social Psychological Review 中国社会心理学评论, Vol. 2, 2006

\section{Internet Sources}

ADR Center for Development, The Costs of Non ADR-Surveying and Showing the Actual Costs of intra-Community Commercial Litigation, Project Timeline: 12.200804.2010, available at: https://www.adrcenterfordevelopment.com/2018/06/08/eumember-states-the-costs-of-non-adr-surveying-and-showing-the-actual-costs-of-intracommunity-commercial-litigation/, last visited on 31.07.2020 
Alasdair Young, The European Union's Use of the World Trade Organization's Dispute

Resolution Process, 2004, available at: https://www.gla.ac.uk/media/media_36176_en.pdf, last visited on 07.08.2020

Alison Ross, Belgium Prevails Against Chinese Investor, Global Arbitration Review (GAR), 05.05.2015, available at: https://globalarbitrationreview.com/article/1034431/belgium-prevails-against-chineseinvestor, last visited on 05.08.2020

Alison Ross \& Lacey Yong, China Faces Second ICSID Claim, Global Arbitration Review (GAR), 07.11.2014, available at: https:/globalarbitrationreview.com/article/1033850/china-faces-second-icsid-claim, last visited on 05.08 .2020

Andreas Fischer-Lescano (Translation into English by Elisabeth Schmalen), The Limits of EU and Constitutional Law for the Comprehensive Economic and Trade Agreement between the EU and Canada (CETA)-Legal Opinion on Behalf of attac/Munich, 10.2014, available at: https://blog.campact.de/wpcontent/uploads/2014/12/Gutachten_CETA_engl_final_27112014.pdf, last visited on 05.08.2020

Anne Isabel Kraus, Chinese-European Dispute Resolution in China: Towards Culturally Matching Procedures, Centrum für angewandte Politikforschung $(C \cdot A \cdot P)$, 09.2007, available at: https://css.ethz.ch/en/services/digitallibrary/publications/publication.html/39874, last visited on 03.08.2020

Anthea Roberts, The Shifting Landscape of Investor-State Arbitration: Loyalists, Reformists, Revolutionaries and Undecideds, EJIL: Talk!, 15.06.2017, available at: https://www.ejiltalk.org/the-shifting-landscape-of-investor-state-arbitration-loyalistsreformists-revolutionaries-and-undecideds/, last visited on 05.08.2020

Anthea Roberts, UNCITRAL and ISDS Reforms: Moving to Reform Options...the Politics, EJIL: Talk!, 08.11.2018, available at: https://www.ejiltalk.org/uncitral-andisds-reforms-moving-to-reform-options-the-process/, last visited on 05.08.2020

Anthea Roberts, Would a Multilateral Investment Court be Biased? Shifting to a Treaty Party Framework of Analysis, EJIL: Talk!, 28.04.2017, available at: https://www.ejiltalk.org/would-a-multilateral-investment-court-be-biased-shifting-toa-treaty-party-framework-of-analysis/, last visited on 05.08.2020

Anthea Roberts \& Zeineb Bouraoui, UNCITRAL and ISDS Reforms: Concerns about Arbitral Appointments, Incentives and Legitimacy, EJIL: Talk!, 06.06.2018, available at: https://www.ejiltalk.org/uncitral-and-isds-reforms-concerns-about-arbitralappointments-incentives-and-legitimacy/, last visited on 05.08.2020

Anthea Roberts \& Zeineb Bouraoui, UNCITRAL and ISDS Reforms: Concerns about Costs, Transparency, Third Party Funding and Counterclaims, 06.06.2018, available at: https://www.ejiltalk.org/uncitral-and-isds-reforms-concerns-about-costs-transparencythird-party-funding-and-counterclaims/, last visited on 06.08.2020 
Ashurst Australia, Bull in a China Shop? The Investor-State Dispute Settlement Provisions of the China-Australia Free Trade Agreement, 23.06.2015, available at: https://www.ashurst.com/en/news-and-insights/legal-updates/bull-in-a-china-shop/, last visited on 30.07.2020

Beijing Arbitration Commission \& Beijing International Arbitration Center 北京仲裁 委员会 \& 北京国际仲裁中心, The Conference on BIAC 2019 Report Was Successfully Held 北仲 “2019 年工作报告会” 成功举办, 20.01.2020, available at: http://www.bjac.org.cn/news/view?id=3653, last visited on 31.07.2020.

Cecilia Malmström, Proposing an Investment Court System, European Commission, 16.09.2015, available at: https://ec.europa.eu/commission/commissioners/20142019/malmstrom/blog/proposing-investment-court-system_en, last visited on 04.08.2020

Center for Effective Dispute Resolution, EU Launches Code of Conduct for Mediators, 21.07.2004, available at: https://www.cedr.com/news/?item=EU-launches-Code-ofConduct-for-Mediators, last visited on 05.08.2020

Céline Lévesque, The European Union Commission Proposal for the Creation of an "Investment Court System": The Q and A that the Commission Won't be Issuing, Kluwer Arbitration Blog, 06.04.2016, available at: http://arbitrationblog.kluwerarbitration.com/2016/04/06/the-european-unioncommission-proposal-for-the-creation-of-an-investment-court-system-the-q-and-athat-the-commission-wont-be-issuing/, last visited on 03.08.2020

China Academy of Arbitration Law 中国仲裁法学研究会, China International Commercial Arbitration Annual Report (2014) 中国国际商事仲裁年度报告 (2014), 2015, available at: http:/www.cietac.org/Uploads/201602/56cbb883901f0.pdf, last visited on 07.08.2020

China Council for the Promotion of International Trade (CCPIT)/China Chamber of International Commerce (CCOIC) Mediation Center 中国国际贸易促进委员会/中国 国际商会调解中心, Introduction of the Center 中心简介, 05.03.2019, available at: https://adr.ccpit.org/articles/25, last visited on 07.08.2020

China International Commercial Court, A Brief Introduction of China International Commercial Court, 28.06.2018, available at: http://cicc.court.gov.cn/html/1/219/193/195/index.html, last visited on 31.07.2020

China International Economic and Trade Arbitration Commission 中国国际经济贸易 仲裁委员会, China International Commercial Arbitration Annual Report 2016 中国 国 际 商 事 仲裁 年 度报 告 2016, 2017, available at: http://www.cietac.org/Uploads/201710/59df3824b2849.pdf, last visited on 07.08.2020

Christian Tietje \& Freya Baetens, The Impact of Investor-State-Dispute Settlement (ISDS) in the Transatlantic Trade and Investment Partnership (Study prepared for: Minister for Foreign Trade and Development Cooperation, Ministry of Foreign Affairs, 
The Netherlands), 2014, available at: http://media.leidenuniv.n1/legacy/the-impact-ofinvestor-state-dispute-settlement-isds-in-the-ttip.pdf, last visited on 30.07.2020

cn.chinadaily.com.cn 中国日报网, Foreign Media: Keqiang Li Promoted China-EU Negotiations on Solar to Achieve Success 外媒: 李克强促使中欧光伏谈判取得成 功 , 05.08.2013, available at: http://caijing.chinadaily.com.cn/201308/05/content_16870071.htm, last visited on 07.08.2020

Damien Charlotin, Chinese Investors Launch Bilateral Investment Treaty Arbitration against Greece, IAReporter, 10.06.2019, available at: https://www.iareporter.com/articles/chinese-investors-launch-bilateral-investmenttreaty-arbitration-against-greece/, last visited on 31.07.2020

Damien Charlotin, Chinese Miner Files BIT Notice Complaining of JudiciallyEmbargoed Material and Frozen Accounts, 05.10.2018, available at: https://www.iareporter.com/articles/chinese-miner-files-bit-notice-complaining-ofjudicially-embargoed-material-and-frozen-accounts/, last visited on 03.08.2020

Damien Charlotin \& Luke Eric Peterson, BIT Dispute Involving Chinese State-owned Investors Leads Government to Hire Lawyers, IAReporter, 04.12.2017, available at: https://www.iareporter.com/articles/bit-dispute-involving-chinese-state-ownedinvestors-leads-government-to-hire-lawyers/, last visited on 05.08.2020

David Gaukrodger \& Kathryn Gordon, Investor-State Dispute Settlement: A Scoping Paper for the Investment Policy Community, 2012, available at: www.oecd.org/daf/investment/workingpapers, last visited on 02.08.2020

Deborah Ruff \& Julia Belcher \& Charles Golsong, Energy Charter Treaty Coming up for 20 years, 2014, available at: http://www.nortonrosefulbright.com/files/energycharter-treaty-115911.pdf, last visited on 27.05.2020

Delegation of the European Union to China, EU-China 2020 Strategic Agenda for Cooperation, 23.11.2013, available at: https://eeas.europa.eu/delegations/china_en/15398/EUChina\%202020\%20Strategic\%20Agenda\%20for\%20Cooperation, last visited on 04.08.2020

Delegation of the European Union to China, Joint Statement of the 20th EU-China Summit, Press Release, 17.07.2018, available at https://eeas.europa.eu/delegations/china_en/48424/Joint\%20statement $\% 20$ of $\% 20$ the $\% 2020$ th\%20EU-China\%20Summit, last visited on 03.08.2020

Deming Chen 陈德铭, An In-depth Implementation of the Seventeenth Party Congress' s Spirits and a Comprehensive Inauguration of the Commercial Cause: Report by the Minister of Commerce Chen Deming at the 2008 National Business Working Conference (Exerpt) 深入贯彻党的十七大精神 全面开创商务工作新局面一一商 务部部长陈德铭在 2008 年全国商务工作会议上的报告（摘要）, Ministry of Commerce of the People's Republic of China 中华人民共和国商务部, 21.01.2008, 
available at: http://www.mofcom.gov.cn/aarticle/ae/ai/200801/20080105344851.html, last visited on 07.08.2020

Despite Our Differences-A Blog about EU Law and Other Creatures by Daniel Sarmiento, The Singapore Silver Bullet, 17.05.2017, available at: $\mathrm{https}$ ://despiteourdifferencesblog.wordpress.com/2017/05/17/the-singapore-silverbullet/, last visited on 30.07.2020

Directorate General for Internal Policies-Policy Department C: Citizens' Rights and Constitutional Affairs, The European Law Institute/UNIDROIT Civil Procedure Projects as a Soft Law Tool to Resolve Conflicts of Law, 2016, available at: http://www.europarl.europa.eu/RegData/etudes/IDAN/2017/556972/IPOL_IDA(2017 )556972_EN.pdf, last visited on 30.07.2020

Doak Bishop, The Case for an Appellate Panel and its Scope of Review, 04.2005, available at: https://www.transnational-dispute-management.com/article.asp?key=403, last visited on 30.07.2020

Ecorys Nederland \& Oxford Intelligence \& TNO \& Reichwein China Consult, Sustainability Impact Assessment (SIA) in Support of an Investment Agreement between the European Union and the People's Republic of China, 06.2016, available at: http://trade.ec.europa.eu/doclib/docs/2016/july/tradoc_154778.pdf, last visited on 05.08.2020

Edna Ramírez Robles, Political \& Quasi-Adjudicative Dispute Settlement Models in European Union Free Trade Agreements-Is the Quasi-adjudicative Model A Trend Or Is It Just Another Model?, World Trade Organization Economic Research and Statistics Division-Staff Working Paper ERSD-2006-09, 11.2006, available at: https://www.wto.org/english/res_e/reser_e/ersd200609_e.pdf, last visited on 05.08.2020

Elena Conde Pérez \& Zhaklin Valerieva Yaneva, Unequal Treaties in International Law, Oxford Bibliographies, 25.03.2020, available at: https://www.oxfordbibliographies.com/view/document/obo-9780199796953/obo9780199796953-0131.xml, last visited on 06.08.2020

Elisabeth Talbourdet, The EU's Investment Court System-A Possible Solution to Conflicts of Interest in Investment Arbitration, EU Law Blog-King's Student Law Review (KSLR) Blog on European Law, 10.04.2017, available at: https://blogs.kcl.ac.uk/kslreuropeanlawblog/?p=1121\#.Wr9dZJNuZE4, last visited on 05.08.2020

Elodie Dulac, The Emerging Third Generation of Chinese Investment Treaties, Transnational Dispute Management, 2010, available at: https://www.transnationaldispute-management.com/article.asp?key=1636, last visited on 01.08 .2020

Esmé Shirlow, The Rising Interest in the Mediation of Investment Treaty Disputes, and Scope for Increasing Interaction between Mediation and Arbitration, Kluwer Arbitration Blog, 29.09.2016, available at: 
http://kluwerarbitrationblog.com/2016/09/29/the-rising-interest-in-the-mediation-ofinvestment-treaty-disputes-and-scope-for-increasing-interaction-between-mediationand-arbitration/, last visited on 05.08.2020

Ethan Michelson, Popular Attitudes Towards Dispute Processing in Urban and Rural China, The Foundation for Law, Justice and Society, 24.01.2008, available at: $\mathrm{http}$ //www.fljs.org/content/popular-attitudes-towards-dispute-processing-urban-andrural-china, last visited on 04.08.2020

europa.eu, The European Judicial Network in Civil and Commercial mMatters, available at: http://ec.europa.eu/civiljustice/index_en.htm, last visited on 06.08.2020

europa.eu, Regulations, Directives and Other Acts, available at: https://europa.eu/european-union/eu-law/legal-acts_en, last visited on 01.08.2020

European Commission, A New EU Trade Agreement with Japan, 07.2018, available at: http://trade.ec.europa.eu/doclib/docs/2017/july/tradoc_155684.pdf, last visited on 31.07.2020

European Commission, A New System for Resolving Dispute between Foreign Investors and States in a Fair and Efficient Way, available at: http://trade.ec.europa.eu/doclib/docs/2017/september/tradoc_156042.pdf, last visited on 31.07 .2020

European Commission, CETA: EU and Canada Agree on New Approach on Investment in Trade Agreement, Press Release, 29.02.2016, available at http://europa.eu/rapid/press-release_IP-16-399_en.htm, last visited on 31.07.2020

European Commission, Commission Proposes to Open Negotiations for an Investment Agreement with China, Press Release, 23.05.2013, available at http://europa.eu/rapid/press-release_IP-13-458_en.htm, last visited on 05.08.2020

European Commission, Countries and Regions-China, available at: http://ec.europa.eu/trade/policy/countries-and-regions/countries/china/, last visited on 31.07.2020

European Commission, Dispute Settlement, available at: http://ec.europa.eu/trade/policy/accessing-markets/dispute-settlement/, last visited on 31.07.2020

European Commission, EU and China Agree on Scope of the Future Investment Deal, 15.01.2016, available at: http://trade.ec.europa.eu/doclib/press/index.cfm?id=1435, last visited on 31.07 .2020

European Commission, EU and China Begin Investment Talks, Press Release, 20.01.2014, available at http://europa.eu/rapid/press-release_IP-14-33_en.htm, last visited on 31.07 .2020

European Commission, EU Finalises Proposal for Investment Protection and Court System for TTIP, 12.11.2015, available at: http://europa.eu/rapid/press-release_IP-156059_en.htm, last visited on 29.07.2019 
European Commission, EU welcomes first opening of WTO Appellate Body hearing to the public, Press Release, 11.07.2008, available at http://trade.ec.europa.eu/doclib/docs/2008/july/tradoc_139603.pdf, last visited on 27.09.2019

European Commission, European Commission Welcomes Parliament's Support of Trade Deal with Canada, 15.02.2017, available at: http:/europa.eu/rapid/pressrelease_IP-17-270_en.htm, last visited on 31.07.2020

European Commission, EU-Japan Economic Partnership Agreement: Texts of the Agreement, 18.04.2018, available at: http://trade.ec.europa.eu/doclib/press/index.cfm?id=1684, last visited on 31.07.2020

European Commission, Investment, available at: $\mathrm{http} / /$ ec.europa.eu/trade/policy/accessing-markets/investment/, last visited on 31.07.2020

European Commission, Investment in TTIP and Beyond-the Path for Reform: Enhancing the Right to Regulate and Moving from Current Ad Hoc Arbitration towards an Investment Court, 05.05.2015, available at: http://trade.ec.europa.eu/doclib/docs/2015/may/tradoc_153408.PDF, last visited on 29.07.2020

European Commission, Investment Provisions in the EU-Canada Free Trade Agreement (CETA), 25.09.2014, available at: http://data.parliament.uk/DepositedPapers/Files/DEP2015-

0877/Lord_Livingston_to_Sir_William_Cash_MP_05.03.15_Annex_B.PDF, last visited on 31.07.2020

European Commission, Investor-to-State Dispute Settlement (ISDS)-Some Facts and Figures, 12.03.2015, available at: http://trade.ec.europa.eu/doclib/docs/2015/january/tradoc_153046.pdf, last visited on 27.07.2020

European Commission, Justice-Building a European Area of Justice, Rule of Law, available at: http://ec.europa.eu/justice/effective-justice/rule-of-law/index_en.htm, last visited on 30.05 .2020

European Commission, Negotiations and Agreements, available at: http://ec.europa.eu/trade/policy/countries-and-regions/negotiations-andagreements/\#_in-place, last visited on 31.07.2020

European Commission, New EU-Mexico Agreement: The Agreement in Principle and its Texts, available at: http://ec.europa.eu/trade/policy/in-focus/eu-mexico-tradeagreement/, last visited on 30.07.2020

European Commission, Overview of FTA and Other Trade Negotiations (Updated March 2018), available at: http://trade.ec.europa.eu/doclib/docs/2006/december/tradoc_118238.pdf, last visited on 27.05 .2020 
European Commission, Press Release Database, available at: $\mathrm{http}: / /$ europa.eu/rapid/press-release_MEMO-94-75_en.htm?locale=EN, last visited on 26.05.2020

European Commission, Reading Guide-Draft Text on Investment Protection and Investment Court System in the Transatlantic Trade and Investment Partnership, 16.09.2015, available at: http://europa.eu/rapid/press-release_MEMO-15-5652_en.htm, last visited on 29.07.2020

European Commission, The Multilateral Investment Court Project, 07.06.2019, available at: http://trade.ec.europa.eu/doclib/press/index.cfm?id=1608, last visited on 31.07.2020

European Commission Director-General for Trade, Consultation on the Future Investment Relationship between EU and China, 02.05.2011, available at: $\mathrm{http} / /$ trade.ec.europa.eu/doclib/press/index.cfm?id=900, last visited on 27.05.2020

European Commission-Director-General for Trade, Report of the 20th Round of Negotiations for the EU-China Investment Agreement, 01.03.2019, available at: $\mathrm{http}$ ://rade.ec.europa.eu/doclib/docs/2019/march/tradoc_157772.pdf, last visited on 31.07.2020

European Commission-Director-General for Trade, Report of the 28th Round of Neogtiations on the EU-China Comprehensive Agreement on Investment, 27.04.2020, available at: https://trade.ec.europa.eu/doclib/docs/2020/april/tradoc_158727.pdf, last visited on 01.08 .2020

European Commission-Director-General for Trade, Summary of Contributions to the European Commission's Public Consultation on "The Future Investment Relationship Between the EU and China", 2011, available at: http://trade.ec.europa.eu/doclib/docs/2011/december/tradoc_148394.pdf, last visited on 29.05 .2020

European Court of Human Rights, Accession of the European Union, available at: http://www.echr.coe.int/Pages/home.aspx?p=basictexts/accessionEU\&c=, last visited on 05.08 .2020

European Court of Human Rights, Guide on Article 6 of the European Convention on Human Rights, 30.04.2013, available at: http://www.echr.coe.int/Documents/Guide_Art_6_ENG.pdf, last visited on 23.08.2016 EUR-Lex, Final Act of the Energy Charter Conference, 31.12.1994, available at: https://eur-lex.europa.eu/legal-

content/EN/TXT/PDF/?uri=CELEX:21994A1231(51)\&from=EN, last visited on 30.07.2020

EUR-Lex, Sources of European Union Law, available at: https://eurlex.europa.eu/legal-content/EN/TXT/?uri=LEGISSUM\%3A114534, last visited on 01.08.2020 
European Parliament, Prospects for a Multilateral Investment Court, 06.2017, available at:

http://www.europarl.europa.eu/RegData/etudes/ATAG/2017/607252/EPRS_ATA(201 7)607252_EN.pdf, last visited on 05.08.2020

European Parliament-Directorate General for External Policies-Policy Department, In Pursuit of an International Investment Court-Recently Negotiated Investment Chapters in EU Comprehensive Free Trade Agreements in Comparative Perspective, 2017, available at: http://www.europarl.europa.eu/thinktank/en/document.html?reference=EXPO_STU\% $282017 \% 29603844$, last visited on 01.08 .2020

European Parliament-Directorate General for Internal Policies-Policy Department C: Citizens' Rights and Constitutional Affairs, Legal Instruments and Practice of Arbitration in the EU, 2014, available at: http://www.europarl.europa.eu/RegData/etudes/STUD/2015/509988/IPOL_STU(2015 )509988_EN.pdf, last visited on 01.08.2020

European Parliament-Directorate-General for Internal Policies-Policy Department C: Citizens' Rights and Constitutional Affairs, 'Rebooting' the Mediation Directive: Assessing the Limited Impact of Its Implementation and Proposing Measures to Increase the Number of Mediations in the EU, 2014, available at: http://www.europarl.europa.eu/RegData/etudes/etudes/join/2014/493042/IPOLJURI_ET(2014)493042_EN.pdf, last visited on 31.07.2020

Felix Steffek, Mediation in the European Union: An Introduction, Europa.eu, 06.2012, available at: https://e-justice.europa.eu/fileDownload.do?id=b3e6a432-440d-4105b9d5-29a8be95408f, last visited on 05.08.2020

Financial Times, Germany Expresses Concerns about US and Canada Trade Deals, 25.09.2015, available at: https://www.ft.com/content/671841da-44c1-11e4-bce800144feabdc0, last visited on 06.08.2020

Financial Times, Ping An in Arbitration Claim over Fortis, 24.09.2012, available at: www.ft.com/intl/cms/s/0/87437290-0620-11e2-bd29-

00144feabdc0.html\#axzz3bPhlPP5e, last visited on 06.08.2020

Global Arbitration Review (GAR), Chinese Investor Takes on Yemen at ICSID, 09.12.2014, available at: https://globalarbitrationreview.com/article/1033938/chineseinvestor-takes-on-yemen-at-icsid, last visited on 31.07.2020

Guillaume Croisant, Opinion 1/17-The CJEU Confirms that CETA's Investment Court System is Compatible with EU Law, Kluwer Arbitration Blog, 30.04.2019, available at: http://arbitrationblog.kluwerarbitration.com/2019/04/30/opinion-117-the-cjeuconfirms-that-cetas-investment-court-system-is-compatible-with-eu-law/, last visited on 31.07.2020

Herbert Smith Freehills LLP, International Bar Association Launches Investor-State Mediation Rules, 23.10.2012, available at: 
http://hsfnotes.com/adr/2012/10/23/international-bar-association-launches-investorstate-mediation-rules/, last visited on 04.08.2020

IAReporter, Chinese Miner Files BIT Notice Complaining of Judicially-Embargoed Material and Frozen Accounts, 05.10.2018, available at: https://www.iareporter.com/articles/chinese-miner-files-bit-notice-complaining-ofjudicially-embargoed-material-and-frozen-accounts/, last visited on 26.05.2020

ICSID Secretariat, Possible Improvements of the Framework for ICSID Arbitration, International Centre for Settlement of Investment Disputes (ICSID), 26.10.2014, available at: http://icsid.worldbank.org/news-and-events/news-releases/possibleimprovements-framework-icsid-arbitration, last visited on 05.08.2020

International Centre for Settlement of Investment Disputes (ICSID), Database of ICSID Member States, available at: https://icsid.worldbank.org/en/Pages/about/Database-ofMember-States.aspx, last visited on 03.08.2020

International Centre for Settlement of Investment Disputes (ICSID), ICSID Convention, available at: https://icsid.worldbank.org/en/Pages/icsiddocs/ICSID-Convention.aspx, last visited on 03.08 .2020

International Center for Settlement of Investment Disputes (ICSID), ICSID Membership-Designations and Notifications_China, available at: https://icsid.worldbank.org/en/Pages/about/MembershipStateDetails.aspx?state=ST30, last visited on 31.07.2020

International Centre for Settlement of Investment Disputes (ICSID), ICSID Rules and Regulations Amendment Process, 2018, available at: https://icsid.worldbank.org/en/amendments, last visited on 03.08.2020

International Centre for Settlement of Investment Disputes (ICSID), Proposals for Amendment of the ICSID Rules-Working Paper \#2-Volume 1, 03.2019, available at: https://icsid.worldbank.org/en/Documents/Vol_1.pdf, last visited on 03.08.2020

International Centre for Settlement of Investment Disputes (ICSID), Special Features of ICSID, available at: https://icsid.worldbank.org/en/Pages/about/Special-20Features20of-20ICSID.aspx, last visited on 03.08.2020

International Centre for Settlement of Investment Disputes (ICSID), State Input, available at: https://icsid.worldbank.org/en/amendments/state-input, last visited on 03.08.2020

Internatioanl Centre for Settlement of Investment Disputes (ICSID), The ICSID Caseload-Statistics, available at: https://icsid.worldbank.org/en/Pages/resources/ICSID-Caseload-Statistics.aspx, last visited on 03.08.2020

International Centre for Settlement of Investment Disputes (ICSID), The ICSID Caseload-Statistics (Issue 2016-1), 2016, available at: 
https://icsid.worldbank.org/en/Documents/resources/ICSID\%20Web\%20Stats\%2020

16-1\%20(English)\%20final.pdf, last visited on 03.08.2020

International Centre for Settlement of Investment Disputes (ICSID), The ICSID Caseload-Statistics (Issue 2017-1), 2017, available at: https://icsid.worldbank.org/en/Documents/resources/ICSID\%20Web\%20Stats\%2020 17-1\%20(English)\%20Final.pdf, last visited on 03.08.2020

International Centre for Settlement of Investment Disputes (ICSID), The ICSID Caseload-Statistics-Special Focus-European Union, 04.2017, available at: https://icsid.worldbank.org/en/Documents/resources/ICSID\%20Web\%20Stats\%20EU (English)April\%202017.pdf, last visited on 03.08.2020

International Energy Charter, Dispute Settlement, available at: https://energycharter.org/what-we-do/dispute-settlement/overview/, last visited on 31.07.2020

International Institute for the Unification of Private Law (UNIDROIT), Study LXXVIA - Transnational Civil Procedure - Formulation of Regional Rules: ELI - UNIDROIT Transnational Rules of Civil Procedure, available at: https:/www.unidroit.org/workin-progress-eli-unidroit-european-rules, last visited on 06.08.2020

italaw, Other Investment Cases, available at: https://www.italaw.com/otherinvestment-cases, last visited on 03.08.2020

Jamal Seifi, Investor-State Arbitration v. State-State Arbitration in Bilateral Investment Treaties, Transnational Dispute Management (TDM), 2004, available at: https://www.transnational-dispute-management.com/article.asp?key=112, last visited on 05.08 .2020

Jarrod Hepburn, Chinese State-Owned Investor Settles Treaty Claim After 2017 Jurisdictional Ruling That Took Generous View of Treaty's Scope for Arbitration of Claims, IAReporter, 12.06.2018, available at: https://www.iareporter.com/articles/chinese-state-owned-investor-settles-treaty-claimafter-2017-jurisdictional-ruling-that-took-generous-view-of-treatys-scope-forarbitration-of-claims-recent-ruling-in-libya-case-adopted-differing-a/, last visited on 01.08.2020

Jarrod Hepburn \& Luke Eric Peterson, US-Ecuador Inter-State Investment Treaty Award Released to Parties, 30.10.2012, available at: https://www.iareporter.com/articles/us-ecuador-inter-state-investment-treaty-awardreleased-to-parties-tribunal-members-part-ways-on-key-issues/, last visited on 05.08.2020

Jean Kalicki, Mediation of Investor-State Disputes: Revisiting the Prospects, Kluwer Arbitration Blog, 14.06.2013, available at: http://kluwerarbitrationblog.com/2013/06/14/mediation-of-investor-state-disputesrevisiting-the-prospects/, last visited on 03.08.2020 
Jinping Xi 习近平, Secure a Decisive Victory in Building a Moderately Prosperous Society in All Respects and Strive for the Great Success of Socialism with Chinese Characteristics for a New Era 决胜全面建成小康社会 夺取新时代中国特色社会主 义伟大胜利, www.xinhuanet.com 新华网，27.10.2017, available at: http://www.xinhuanet.com//politics/19cpcnc/2017-10/27/c_1121867529.htm, last visited on 07.08.2020

Jinping Xi 习近平, Sticking to the Combination of the Rule of Law and the Rule of Virtue 坚持依法治国和以德治国相结合, www.xinhuanet.com 新华网, 10.12.2016, available at: http://www.xinhuanet.com//politics/2016-12/10/c_1120093133.htm, last visited on 07.08 .2020

Joel Dahlquist, As UNCITRAL Investor-State Arbitration Reform Enters Crucial Phase, We Preview Agenda for Upcoming Meeting, IAReporter, 27.03.2019, available at: https://www.iareporter.com/articles/as-uncitral-investor-state-arbitration-reformenters-crucial-phase-we-preview-agenda-for-upcoming-meeting/, last visited on 31.07.2020

José Manuel Durão Barroso, The Rule of Law as Inspiration and Aspiration, Press Release, European Commission, 28.05.2013, available at https://ec.europa.eu/commission/presscorner/detail/en/SPEECH_13_469, last visited on 30.07.2020

Joseph Fewsmith, Promoting the Scientific Development Concept The China Leadership Monitor, 2004, available at: http://media.hoover.org/sites/default/files/documents/clm11_jf.pdf, last visited on 01.08.2020

Kyriaki Karadelis, Peru Fails to Annul Chinese Treaty Award, Global Arbitration Review (GAR), 04.03.2015, available at: https://globalarbitrationreview.com/article/1034270/peru-fails-to-annul-chinesetreaty-award, last visited on 03.08 .2020

Lei Zhao 赵蕾, The Biggest Controversy over Judicial Reform: the Revival of Xiwu $\mathrm{Ma}$ 司法改革最热争议 马锡五复活, infzm.com 南方周末网, 10.06.2009, available at: http://www.infzm.com/content/29885, last visited on 07.08.2020

Leon E. Trakman, Enter the Dragon IV: China's Proliferating Investment Treaty Program, UNSW Centre for Law, Markets and Regulation, 2011, available at: https://clmr.unsw.edu.au/article//enter-the-dragon-iv\%3A--china\%27s-proliferatinginvestment-treaty-program, last visited on 06.08.2020

Liming Wang 王利明, Discussion on Procedural Justic from the Perspective of Socrates 从苏格拉底之死谈程序正义, aisixiang.com 爱思想, 08.07.2014, available at: http://www.aisixiang.com/data/76135.html, last visited on 07.08.2020

Lin Zhang 张琳, The New Developments in China' s FTAs 中国区域自由贸易协定 的新发展 , 10.02.2015, available at: 
http:/fta.mofcom.gov.cn/article/ftazixun/201502/20454_1.html, last visited on 07.08.2020

Ling Zhang 张玲, Qianhai “One Belt One Road” Docking Center for International Commercial Litigation and Mediation Inaugurated on January 7 前海”一带一路” 国 际商事诉调对接中心 1 月 7 日揭牌, Qianhai News 前海新闻, 08.01.2018, available at: http://iqianhai.sznews.com/content/2018-01/08/content_18209556.htm, last visited on 07.08 .2020

Lise Johnson, The Mauritius Convention on Transparency: Comments on the Treaty and Its Role in Increasing Transparency of Investor-State Arbitration, Columbia Center on Sustainable Investment, 09.2014, available at: http://ccsi.columbia.edu/files/2013/08/Mauritius-Convention-Transparency-Paperformatted-FINAL.pdf, last visited on 04.08.2020

Luke Eric Peterson, A First Look at ICSID's Proposed Rules Changes, Including in Relation to Provisional Measures, Third-party Funding, Security for Costs, and Arbitrator Disqualification, IAReporter, 03.08.2018, available at: https://www.iareporter.com/articles/a-first-look-at-icsids-proposed-rules-changesincluding-in-relation-to-provisional-measures-third-party-funding-security-for-costsand-arbitrator-disqualification/, last visited on 05.08.2020

Luke Eric Peterson, An In-depth Look at ICSID's Proposed Transparency Changes (Including Non Disputing Party Participation), IAReporter, 06.08.2018, available at: https://www.iareporter.com/articles/an-in-depth-look-at-icsids-proposed-

transparency-changes-including-non-disputing-party-participation/, last visited on 05.08.2020

Luke Eric Peterson, Analysis: A Closer Look at the Dispute Settlement Provisions of the China-Canada Investment Treaty, Including Its State-to-State Mechanism, 26.09.2012, available at: https://www.iareporter.com/articles/analysis-a-closer-lookat-the-dispute-settlement-provisions-of-the-china-canada-investment-treaty-includingits-state-to-state-mechanism/, last visited on 05.08.2020

Luke Eric Peterson, Canada Announces Conclusion of Investment Treaty with China, but There's an Asterisk, 16.02.2012, available at: https://www.iareporter.com/articles/canada-announces-conclusion-of-investmenttreaty-with-china-but-theres-an-asterisk/, last visited on 05.08.2020

Luke Eric Peterson, China-Canada Bilateral Investment Treaty Unveiled: A First Look at the Provisions of Long-delayed Pact, 26.09.2012, available at: https://www.iareporter.com/articles/china-canada-bilateral-investment-treatyunveiled-a-first-look-at-the-provisions-of-long-delayed-pact/, last visited on 05.08.2020

Luke Eric Peterson, ICSID Tribunal Declines to Halt Investor Arbitration in Deference to State-to-State Arbitration, International Institute for Sustainable Development (IISD), 19.12.2003, available

at: 
http://www.iisd.org/pdf/2003/investment_investsd_dec19_2003.pdf, last visited on 05.08.2020

Luke Eric Peterson, In an Apparent First, Investor and Host-State Agree to Try Mediation under IBA Rules to Resolve an Investment Treaty Dispute, IAReporter, 14.04.2016, available at: https://www.iareporter.com/articles/in-an-apparent-firstinvestor-and-host-state-agree-to-try-mediation-under-iba-rules-to-resolve-aninvestment-treaty-dispute/, last visited on 05.08.2020

Luke Eric Peterson, Mongolia Prevails in Long-Running Chinese BIT Arbitration, as Arbitrators Distinguish Their Reading of Constricted Jurisdiction Clause From More Generous Readings in Prior Cases, IAReporter, 07.07.2017, available at: https://www.iareporter.com/articles/mongolia-prevails-in-long-running-chinese-bitarbitration-as-arbitrators-distinguish-their-reading-of-constricted-jurisdiction-clausefrom-more-generous-readings-in-prior-cases/, last visited on 05.08.2020

Luke Eric Peterson, United States Defeats Ecuador's State-to-State Arbitration, IAReporter, 02.09.2012, available at: https://www.iareporter.com/articles/unitedstates-defeats-ecuadors-state-to-state-arbitration-will-outcome-dissuade-argentinecopycat-case/, last visited on 05.08 .2020

Marcin Orecki, State-to-State Arbitration Pursuant to Bilateral Investment Treaties: the Ecuador-US Dispute, YoungICCA Blog, 2013, available at: http://www.youngiccablog.com/state-to-state-arbitration-pursuant-to-bilateral-investment-treaties-theecuador-us-dispute/, last visited on 05.08.2020

Maria Beatrice Deli \& Maria Laura Marceddu, Is the European Commission Issuing a Dismissal Letter to Arbitrators?, Kluwer Arbitration Blog, 19.10.2015, available at: http://arbitrationblog.kluwerarbitration.com/2015/10/19/the-investment-court-systemfor-ttip-is-the-european-commission-issuing-a-death-certificate-for-arbitrators/, last visited on 04.08.2020

Matthew Gearing, The Dangers of Arb-Med, Allen \& Overy, 20.04.2011, available at: $\mathrm{http}$ ://www.allenovery.com/publications/en-gb/Pages/The-dangers-of-arb-med-.aspx, last visited on 05.08.2020

Ministry of Commerce of the People's Republic of China, China FTA Network, available at: http://fta.mofcom.gov.cn/english/index.shtml, last visited on 31.07.2020

Ministry of Commerce of the People's Republic of China, Interpretation of ChinaCanada Bilateral Investment Protection Agreement by An Official from the Department of Treaty and Law of MOFCOM, 13.09.2012, available at: http://English.mofcom.gov.cn/article/policyrelease/Cocoon/201209/20120908359187. shtml, last visited on 31.07.2020

Ministry of Commerce of the People's Republic of China-Department of Treaty and Law 中华人民共和国商务部条约法律司, The List of Bilateral Investment Treaties Concluded by China 我国对外签订双边投资协定一览表, 12.12.2016, available at: 
http://tfs.mofcom.gov.cn/article/Nocategory/201111/20111107819474.shtml, last visited on 04.08.2020

Munir Maniruzzaman, A Rethink of Investor-State Dispute Settlement, Kluwer Arbitration Blog, 30.05.2013, available at: http://kluwerarbitrationblog.com/2013/05/30/a-rethink-of-investor-state-disputesettlement/, last visited on 04.08.2020

Nathalie Bernasconi-Osterwalder, Analysis of the European Commission's Draft Text on Investor-State Dispute Settlement for EU Agreements, 19.07.2012, available at: https://www.iisd.org/itn/2012/07/19/analysis-of-the-european-commissions-draft-texton-investor-state-dispute-settlement-for-eu-agreements/, last visited on 30.07.2020

Nathalie Bernasconi-Osterwalder, State-State Dispute Settlement in Investment Treaties, 10.2014, available at: https://www.iisd.org/sites/default/files/publications/best-practices-state-state-disputesettlement-investment-treaties.pdf, last visited on 30.07.2020

Nathalie Bernasconi-Osterwalder \& Lise Johnson, Transparency in the Dispute Settlement Process: Country Best Practices, Internatioanl Institute for Sustainable Development (IISD), 02.2011, available at: https://www.iisd.org/sites/default/files/publications/transparency_dispute_settlement_ processes.pdf, last visited on 03.08.2020

Nathalie Bernasconi-Osterwalder \& Martin Dietrich Brauch, The State of Play in Vattenfall v. Germany II: Leaving the German Public in the Dark, 10.2014, available at: https://www.iisd.org/sites/default/files/publications/state-of-play-vattenfall-vsgermany-II-leaving-german-public-dark-en.pdf, last visited on 30.07.2020

Norton Rose Fulbright, Fork-in-the-Road Clauses-Divergent Paths in Recent Decisions, 10.2015, available at: https://www.nortonrosefulbright.com/en/knowledge/publications/0bd10ad8/fork-inthe-road-clauses, last visited on 01.08.2020

Oceans \& Law of the Sea-United Nations, United Nations Convention on the Law of the Sea: Declarations Made Upon Signature, Ratification, Accession or Succession or Anytime Thereafter, 13.02.2020, available at: http://www.un.org/depts/los/convention_agreements/convention_declarations.htm\#Ch ina after ratification, last visited on 04.08.2020

Opinion of Advocate General Poiares Maduro in Joined Cases C-514/07 P, C-528/07 $\mathrm{P}$ and $\mathrm{C}-532 / 07 \mathrm{P}$, Kingdom of Sweden v. Association de la presse internationale ASBL (API), Association de la presse internationale ASBL (API) v. Commission of the European Communities, Commission of the European Communities v. Association de la presse internationale ASBL (API), 01.09.2009, available at: http://curia.europa.eu/juris/document/document_print.jsf?doclang=EN\&text=\&pageIn $\mathrm{dex}=0 \&$ part $=1 \&$ mode $=1$ st $\&$ docid $=72663 \&$ occ $=$ first $\&$ dir $=\& \operatorname{cid}=1210687$, last visited on 30.07.2020 
Rhodium Group LLC, EU-China FDI Monitorr-3Q 2017 Update: Public Version, 2017, available at: http://trade.ec.europa.eu/doclib/docs/2018/january/tradoc_156572.pdf, last visited on 01.08.2020

Robert Wisner \& Neil Campbell, Bringing the Home State Back in: the Case for Home State Control in Investor-State Dispute Settlement, International Bar Association, 14.02.2018, available at: https://www.ibanet.org/Article/NewDetail.aspx?ArticleUid=522de4cb-caa3-46568236-f1e13f261b86, last visited on 31.07.2020

Sébastien Billioud, Confucianism, "Cultural Tradition" and Official Discourses in China at the Start of the New Century, 2007, available at: http://journals.openedition.org/chinaperspectives/2033, last visited on 30.07.2020

Statement by Mr Shang Zhen, Chinese Delegate at the 68th Session of the UN General Assembly on Agenda Item 79 Report of UNCITRAL on the Work of Its 46th Session, 14.10.2013, available at: http://www.chinaun.org/eng/chinaandun/legalaffairs/sixthcommittee1/t1091525.htm, last visited on 13.02.2017

Stefan Szepesi, Comparing EU Free Trade Agreements: Dispute Settlement, European Centre for Development Policy Management (ECDPM), 01.2004, available at: https://ecdpm.org/wp-content/uploads/2013/11/IB-6G-Comparing-EU-Free-Trade-

Agreements-Dispute-Settlement-2004.pdf, last visited on 05.08.2020

Stefanie Schacherer, Can EU Member States Still Negotiate BITs with Third Countries?, International Institute for Sustainable Development (IISD), 10.08.2016, available at: https://www.iisd.org/itn/2016/08/10/can-eu-member-states-stillnegotiate-bits-with-third-countries-stefanie-schacherer/\#_edn11, last visited on 03.08.2020

Stephan W. Schill, Reforming Investor-State Dispute Settlement (ISDS): Conceptual Framework and Options for the Way Forward, The E15Initiative (E15), 2015, available at: http://e15initiative.org/publications/reforming-investor-state-dispute-settlementisds-conceptual-framework-and-options-for-the-way-forward/, last visited on 05.08.2020

Stephan W. Schill, The European Commission's Proposal of an '"Investment Court System" for TTIP: Stepping Stone or Stumbling Block for Multilateralizing International Investment Law?, American Society of International Law, 2016, available at: https://www.asil.org/insights/volume/20/issue/9/european-commissions-proposalinvestment-court-system-ttip-stepping, last visited on 05.08.2020

Stephen Woolcock, The EU Approach to International Investment Policy after the Lisbon Treaty, European Parliament-Directorate-General for External Policies of the Union, 2010, available at: http://www.europarl.europa.eu/RegData/etudes/etudes/join/2010/433854/EXPOINTA_ET(2010)433854_EN.pdf, last visited on 05.08.2020 
Stockholm Chamber of Commerce-ISDS BLOG, Just Published: Analysis of EU's "Investment Court System", available at: http://isdsblog.com/2016/10/27/justpublished-analysis-of-eus-investment-court-system/, last visited on 05.08.2020

Szilárd Gáspár-Szilágyi, A Follow-up to the EU Commission's Decision to 'Split' Trade and Investment Protection, International Economic Law and Policy Blog, 14.09.2017, available at: http://worldtradelaw.typepad.com/ielpblog/2017/09/guestpost-a-follow-up-to-the-eu-commissions-decision-to-split-trade-and-investmentprotection.html, last visited on 01.08.2020

Tariana Turia, Government Moves Forward with Plain Packaging of Tobacco Products, Beehive.govt.nz, 20.02.2013, available at: https://www.beehive.govt.nz/release/government-moves-forward-plain-packagingtobacco-products, last visited on 06.08.2020

The EU Network of Independent Experts on Fundamental Rights, Commentary of the Charter of Fundamental Rights of the European Union, 2006, available at: $\mathrm{http}$ //ec.europa.eu/justice/fundamental-rights/files/networkcommentaryfinal_en.pdf, last visited on 05.08 .2020

The Organisation for Economic Cooperation and Development (OECD), Multilateral Agreement on Investment, available at: https://www.oecd.org/investment/internationalinvestmentagreements/multilateralagre ementoninvestment.htm, last visited on 05.08.2020

The State Council-The People's Republic of China, Communique of the Sixth Plenum of the 16th CPC Central Committee, 11.10.2006, available at: http://www.gov.cn/english/2006-10/11/content_410436.htm, last visited on 22.05.2020

Thomas Wälde, Alternatives for Obtaining Greater Consistency in Investment Arbitration: An Appellate Institution after the WTO, Authoritative Treaty Arbitration or Mandatory Consolidation?, Transnational Dispute Management (TDM), 2005, available at: https://www.transnational-dispute-management.com/article.asp?key=421, last visited on 06.08.2020

Transnational Dispute Management, TDM Special Issue on "Reform of Investor-State Dispute Settlement (ISDS): In Search of a Roadmap", 2014, available at: https://www.transnational-dispute-management.com/journal-browse-issuestoc.asp?key=52, last visited on 30.07.2020

Tyler Cohen \& David Schneiderman, The Political Economy of Chinese Bilateral Investment Treaty Policy, The Chinese Journal of Comparative Law, Vol. 5, 2017

United Nations Commission on International Trade Law (UNCITRAL), Working Group III: Investor-State Dispute Settlement Reform, available at: https://uncitral.un.org/en/working_groups/3/investor-state, last visited on 06.08.2020

United Nations Conference on Trade and Development (UNCTAD), Dispute Settlement: Investor-State (UNCTAD Series on Issues in International Investment 
Agreements), 2003, available at: https://unctad.org/en/Docs/iteiit30_en.pdf, last visited on 06.08 .2020

United Nations Conference on Trade and Development (UNCTAD), Dispute Settlement: State-State (UNCTAD Series on Issues in International Investment Agreements), 2003, available at: http://unctad.org/en/docs/iteiit20031_en.pdf, last visited on 06.08 .2020

United Nations Conference on Trade and Development (UNCTAD), Investor-State Dispute Settlement: An Informationa Note on the United States and the European Union, 06.2014, available at: http://unctad.org/en/PublicationsLibrary/webdiaepcb2014d4_en.pdf, last visited on 06.08.2020

United Nations Conference on Trade and Development (UNCTAD), Investor-State Dispute Settlement: Review of Developments in 2016, 2017, available at: http://unctad.org/en/PublicationsLibrary/diaepcb2017d1_en.pdf, last visited on 06.08.2020

United Nations Conference on Trade and Development (UNCTAD), Investor-State Disputes: Prevention and Alternatives to Arbitration, 2010, available at: http://unctad.org/en/docs/diaeia200911_en.pdf, last visited on 06.08.2020

United Nations Conference on Trade and Development (UNCTAD), Interpretation of IIAs: What States Can Do?, 2011, available at: http://unctad.org/en/Docs/webdiaeia2011d10_en.pdf, last visited on 06.08.2020

United Nations Conference on Trade and Development (UNCTAD), Latest Developments in Investor-State Dispute Settlement, IIA MONITOR No. 4, 2006, available at: http://www.unctad.org/en/docs//webiteiit20052_en.pdf, last visited on 06.08.2020

United Nations Conference on Trade and Development (UNCTAD), Recent Trends in IIAs and ISDS, 2015, available at: http://unctad.org/en/PublicationsLibrary/webdiaepcb2015d1_en.pdf, last visited on 06.08.2020

United Nations Conference on Trade and Development (UNCTAD), Reform of the IIA Regime: Four Paths of Action and a Way Forward, 2014, available at: https://unctad.org/en/PublicationsLibrary/webdiaepcb2014d6_en.pdf, last visited on 06.08.2020

United Nations Conference on Trade and Development (UNCTAD), World Investment Report 2015: Reforming International Investment Governance, 2015, available at: http://unctad.org/en/PublicationsLibrary/wir2015_en.pdf, last visited on 06.08.2020

United Nations Conference on Trade and Development (UNCTAD), World Investment Report 2016: Investor Nationality: Policy Challenges, 2016, available at: https://unctad.org/en/PublicationsLibrary/wir2016_en.pdf, last visited on 06.08.2020 
United Nations Conference on Trade and Development (UNCTAD), World Investment Report 2017: Investment and the Digital Economy, 2017, available at: http://unctad.org/en/PublicationsLibrary/wir2017_en.pdf, last visited on 06.08.2020

United Nations Conference on Trade and Development (UNCTAD), World Investment Report 2018: Investment and New Industrial Policies, 2018, available at: https://unctad.org/en/PublicationsLibrary/wir2018_en.pdf, last visited on 06.08.2020

United Nations Conference on Trade and Development (UNCTAD), World Investment Report 2019: Special Economic Zones, 2019, available at: https://unctad.org/en/PublicationsLibrary/wir2019_en.pdf, last visited on 06.08.2020

United Nations Conference on Trade and Development (UNCTAD) Investment Policy Hub, China, available at: https://investmentpolicy.unctad.org/international-investmentagreements/countries/42/china?type=bits, last visited on 06.08.2020

United Nations Conference on Trade and Development (UNCTAD) Investment Policy Hub, IIAs by Economy_Ireland, available at: http://investmentpolicyhub.unctad.org/IIA/CountryBits/100\#iiaInnerMenu, last visited on 06.08 .2020

Uniview (UNV), The Belt and Road Initiative, 29.09.2018, available at: http://en.uniview.com/News/News/201809/804999_169683_0.htm, last visited on 06.08 .2020

US Department of State, CANACAR v. United States of America, 04.02.2009, available at: http://www.state.gov/s/l/c29831.htm, last visited on 21.05.2017

Viviane Reding, Strengthening Mutual Trust: Towards a True European Area of Civil Justice, 25.03.2014, available at: https://www.mpi.lu/fileadmin/mpi/medien/news/2014/4/Speech_VP_Reding.pdf, last visited on 05.08.2020

Wenhua Shan, Toward a Multilateral or Plurilateral Framework on Investment, The E15 Initiative, 11.2015, available at: http://e15initiative.org/publications/toward-amultilateral-or-plurilateral-framework-on-investment/, last visited on 05.08.2020

World Trade Organization, Dispute Settlement Without Recourse to Panels and the Appellate Body, available at: https://www.wto.org/english/tratop_e/dispu_e/disp_settlement_cbt_e/c8s1p1_e.htm, last visited on 05.08.2020

World Trade Organization, Disputes by Member, available at: https://www.wto.org/english/tratop_e/dispu_e/dispu_by_country_e.htm, last visited on 05.08.2020

World Trade Organization, DS320: United States-Continued Suspension of Obligations in the EC-Hormones Dispute, available at: https://www.wto.org/english/tratop_e/dispu_e/cases_e/ds320_e.htm, last visited on 05.08.2020 
World Trade Organization, Hong Kong Briefing Notes-Briefing Notes on the Ministerial and the Main Issues, 2005, available at: https://www.wto.org/english/thewto_e/minist_e/min05_e/brief_e/brief00_e.htm, last visited on 05.08 .2020

World Trade Organization, Regional Trade Agreements, available at: https://www.wto.org/english/tratop_e/region_e/region_e.htm, last visited on 05.08.2020

World Trade Organization, Regional Trade Agreements Database, available at: http://rtais.wto.org/UI/PublicMaintainRTAHome.aspx, last visited on 26.05.2020

World Trade Organization, The European Union and the WTO, available at: https://www.wto.org/english/thewto_e/countries_e/european_communities_e.htm, last visited on 05.08.2020

World Trade Organization, WTO Disputes Reach 400 Mark, Press Release, 06.11.2009, available at https://www.wto.org/english/news_e/pres09_e/pr578_e.htm, last visited on 05.08.2020

www.chinanews.com 中国新闻网, The Ministry of Commerce (MOFCOM) Researches on the Request for Consultations from the US and the Dispute Regarding Subsidy May Take Two Years 商务部研究美方磋商请求 补贴争端可能耗时两年, 06.02.2007, available at: http:/www.chinanews.com/cj/gncj/news/2007/0206/868895.shtml, last visited on 07.08.2020

www.china.com.cn 中国网, Beijing Industry and Commerce Bureau Xicheng Branch: Connecting Administrative Mediation of Contract Disputes and Judicial Confirmation 北京市工商局西城分局合同纠纷行政调解对接司法确认, 29.10.2012, available at: http://finance.china.cn/roll/20121029/1098465.shtml, last visited on 06.08.2020

www.cpcnews.cn 中国共产党新闻网, Jinping Xi: Deepen Partnership and Promote Prosperity in Asia-Pacific 习近平：深化伙伴关系 共促亚太繁荣, 20.11.2015, available at: http://cpc.people.com.cn/n/2015/1120/c64094-27835631.html, last visited on 04.08 .2020

www.legaldaily.com.cn 法制网, "One Belt One Road" International Commercial Mediation Forum Took Place in Rome and Issued Rome Declaration “一带一路” 国 际商事调解论坛在罗马召开并发布《罗马宣言》, 11.10.2018, available at: http://www.legaldaily.com.cn/Lawyer/content/2018-10/11/content_7664185.htm, last visited on 07.08.2020

www.legaldaily.com.cn 法制网, The Blossom of the Oriental Flower: The Current Status, Problems and Solutions Regarding Mediation in China 东方之花的绽放—— 调解在中国的发展现状、问题及对策，21.11.2018, available at: http://www.legaldaily.com.cn/Arbitration/content/2018-11/21/content_7690176.htm, last visited on 07.08.2020 
Xin Hua News Agency, China Publishes Resolution on Building Harmonious Society, Press Release, 18.10.2006, available at https://chinadigitaltimes.net/2006/10/chinapublishes-resolution-on-building-harmonious-society-xinhua/, last visited on 22.07.2018

Zoe Williams, Chinese Mining Giant Puts State on Notice of BIT Claim, IAReporter, 10.09.2018, available at: https://www.iareporter.com/articles/chinese-mining-giantputs-state-on-notice-of-bit-claim/, last visited on 06.08.2020

\section{Others Materials}

Alessia Azzini \& Alban Heron, The Meaning of the Rule of Law, Seminar Towards European Constitutionalism, 23-24.05.2016

Cecilia Malmström, Remarks at the European Parliament on Investment in TTIP and Beyond, Meeting of the International Trade Committee of the European Parliament, Brussels, 06.05.2015

David Morgan, Dispute Settlement under PTAs: Political or Legal?, Melbourne Law School Legal Studies Research Paper No. 341, 2008, available at: http://ssrn.com/abstract $=1203022$, last visited on 31.07.2020

European Commission, The European Union and the Rule of Law, Keynote speech at Conference on the Rule of Law, Tilburg University, 31.08.2015

European Commission for Democracy Through Law (Venice Commission), Rule of Law Checklist, Adopted by the Venice Commission at its 106th Plenary Session, Venice, 11-12.03.2016

Guiguo Wang, China's FTA Practices and Prospects, Asian WTO Research Network Seoul Meeting 2010, Seoul, 22.05.2010

Guo-Ming Chen \& Jensen Chung, The Impact of Confucianism on Organizational Communication, The Annual Meeting of the Speech Communication Association (79th), Miami, 18-21.11.1993

Jianlong $\mathrm{Yu}$ 于健龙, Discussion on the Chinese Legal System of Commercial Mediation 论中国商事调解法律制度, to obtain the Doctor Degree at University of International Business and Economics 对外经济贸易大学, 2013

Leopoldo Rubinacci, EU-China Investment Relationship-Update on State of Play, DG TRADE Civil Society Dialogue, 07.03.2012

Lisa C. Toohey, Rule of Law Discourse and the Accession of Transitional Economies to the World Trade Organization, to obtain the PhD Degree at The University of Queensland, 2008

Lorenza Mola, Which Role for the EU in the Development of International Investment Law?, Society of International Economic Law (SIEL) Inaugural Conference 2008, Geneva, 15-17.07.2008 
Michael Cohen, Alternative Dispute Resolution, EuroExpert Symposium, Estoril/Portugal, 2003

Opinion of Mr Advocate General Ruiz-Jarabo Colomer, Judicial Cooperation in Civil Matters - Preliminary References - Jurisdiction of the Court - Definition of 'Dispute' Regulation (EC) No 1348/2000 - Service of extrajudicial documents in the absence of legal proceedings - Notarial act, 05.03.2009

Opinion 2/13 of the Court (Full Court), Opinion pursuant to Article 218(11) TFEU Draft International Agreement - Accession of the European Union to the European Convention for the Protection of Human Rights and Fundamental Freedoms Compatibility of the Draft Agreement with the EU and FEU Treaties, 18.12.2014

Peter Chi Hin Chan, The Position of Mediation in Contemporary Chinese Civil Justice: A Proceduralist Perspective, to obtain the Doctoral Degree at Maastricht University (2016)

Shuchao Henry Gao, China's Strategy for Free Trade Agreements: Political Battle in the Name of Trade, Asian Regional Workshop on Free Trade Agreements: Towards Inclusive Trade Policies in Post-crisis Asia, Bangkok, 08-09.12.2009

Sundaresh Menon, Mediation and the Rule of Law, The Law Society Mediation Forum, Singapore, 10.03.2017

Thomas Johnson, ICSID Annulment: Factual Review, The Second Conference of the British Institute of International and Comparative Law's Investment Treaty ForumAppeals and Challenges to Investment Treaty Awards: Is it Time for an International Appellate System, London, 07.05.2004

United Nations Commission on International Trade Law (UNCITRAL), Report of Working Group II (Arbitration and Conciliation) on the Work of Its Fifty-eighth Session, United Nations Commission on International Trade Law Forty-sixth session, New York, 4-8.02. 2013

Weidong Zhu, The Dispute Settlement Mechanism of ASEAN Free Trade Area (AFTA) and Its Implications for SADC, The first International Conference on Regional Integration and SADC Law, Maputo, 23-25.04.2008

Xuan Gu, The Combination of Arbitration and Mediation in China, to obtain the Master Degree at University of Geneva \& University of Lausanne, 2008 


\section{Summary}

China and the EU are two of the biggest players in international investment. With the proliferation of international investment agreements throughout the world, China and the EU have also made concerted efforts to negotiate a China-EU Bilateral Investment Treaty. This prospective bilateral investment treaty (hereinafter "BIT") will replace the 25 existing BITs between China and 27 EU Member States with one single comprehensive investment agreement. Since China and the EU have presented conflicting attitudes regarding various issues in investment dispute resolution, disagreements regarding what constitutes appropriate dispute settlement systems in the prospective China-EU BIT is expected to be one of the major stumbling blocks in the negotiations. Based on the exploration of the legal cultural characteristics in China's and the EU's dispute settlement mechanisms (hereinafter "DSMs") and the influence thereof on their relevant internal and international practice, as well as their current investment legal relationship, the present thesis anticipates both parties' possible proposals, discusses the potential thorny issues and recommends solutions that are worthy of consideration.

The legal cultural features influenced by the legal traditions of China and the EU and presented in their internal dispute settlement systems are discussed respectively in the first place. In China, traditional philosophies, especially Confucianism, constituted the ideological foundation of Chinese legal culture. Under Confucianism, harmony was particularly prioritized and took the central position. As a result, dispute settlement focused on restoring a harmonious relationship through amicable informal DSMs. The core values of traditional Chinese philosophies have been arguably inherited by contemporary Chinese ideology, and non-adjudicated solutions to disputes through amicable mechanisms are consistently preferred. Different from traditional philosophies, the socialist rule of law is established, but it is subject to the overall objective of socialist harmony. Concerning dispute settlement in the Chinese legal system, six DSMs act as the main avenues for disputes arising from foreign investment, including negotiation, mediation, arbitration, complaints coordination for foreign investment, administrative review, and litigation. Examining the procedural design of these DSMs and the general structure of China's dispute settlement system from a legal cultural perspective, elements from Chinese ideologies can be identified: the promotion of amicable DSMs aims at restoring harmony between disputing parties as well as in the society; the extensive use of mediation is in line with the requirements of various legal cultural elements; and even the construction of the socialist rule of law is combined with the pursuit of harmony. 
Regarding the traditional values preserved in European legal history, three constantspersonalism, legalism and intellectualism-in particular formed the basis of the European legal culture of dispute settlement. Law is taken as the guarantor of justice, fairness and legal rights; the insistence on the rule of law ensures the supremacy of law; as a normal way of resolving disputes, litigation focuses on preserving substantive rights and procedural justice and, correspondingly, judges must make decisions according to law following due process. With regard to the commonly available DSMs for investment disputes in EU Member States, mediation, arbitration and litigation are identified. In addition to EU Member States' relevant rules on these DSMs, the Union has also taken actions to regulate DSMs. The common underlying motivation here is to preserve individuals' rights to access to justice, effective remedies and fair trial, which reflect the common values and principles arising from the constitutional tradition shared by the EU Member States. Taking a legal cultural perspective to analyse the DSMs in the EU Member States and the Union's relevant regulating measures, three points deserve attention: a consistent pursuit of the rule of law can be identified in dispute settlement; litigation has been commonly used, which focuses on realizing substantive and procedural justice, and; the increased attention on mediation is based on the recognition of its function in ensuring access to justice.

By comparison, the diverse features of dispute resolution employed by China and by the EU are typically reflected within legal culture, the perception of law, the role of law, and the objective of dispute settlement. The legal cultural characteristics of dispute settlement in China and those of the EU have further affected their legal systems, respectively. China's dispute settlement system shows a strong preference for amicable DSMs, while in the EU the focus is on the use of litigation. In addition, China arguably adopts a service-based doctrine of dispute settlement, but in the EU, DSMs are used to realize justice and to serve a justice-based doctrine. Furthermore, both China and the EU have made efforts to enhance the use of mediation in dispute settlement, but China's preference is based on the pursuit of social harmony, while the EU uses this DSM as an alternative way of realizing access to justice.

In terms of the approaches in international investment dispute settlement, two DSMs, state-state mechanisms for resolving disputes about treaty application and implementation as well as investor-state mechanisms for investors to bring cases against host states regarding complaints related to specific investments, are discussed. For state-state dispute settlement, a hybrid approach combining diplomatic consultations and ad hoc arbitration has been consistently adopted in China's Model BITs and most of its concluded International Investment Agreements (hereinafter "IIAs"). In addition, China's most recent treaty practice adjusts this hybrid approach to a quasi-WTO dispute settlement panel proceedings model, which in fact has been the 
practice of the state-state DSMs under its FTAs. Regarding investor-state dispute settlement, both the China Model BITs and its concluded IIAs witnessed the changes of China's attitude towards investor-state arbitration over time: from no acceptance of investor-state arbitration or acceptance of international arbitration only for disputes about the amount of compensation for expropriation, to an overall acceptance of investor-state arbitration, and now the acceptance of investor-state arbitration is being carefully revised. Until now, there have been eight investor-state dispute arbitration cases brought under the IIAs concluded by China. Possible underlying reasons for this relatively small number include the Chinese government's preference for the amicable settlement of investment disputes to preserve harmony and its political image as a friendly host state, together with foreign investors' worries about the Chinese government's retaliation and the lucrativeness of the Chinese market. In brief, China's practice resonates with some of its legal cultural characteristics in dispute settlement, such as the preference for amicable settlements and confidentiality in the dispute settlement process. At the same time, it is also clear that China has increasingly recognized the function of international adjudication in state-state and investor-state dispute settlement.

Similarly, the EU's approach to state-state trade and investment dispute settlement is mainly reflected in its FTAs and IIAs, and performance in the WTO Dispute Settlement System. The state-state DSMs laid out in the EU's FTAs and IIAs has chronologically shifted from a diplomatic approach to a quasi-WTO dispute settlement panel proceedings model. Along with its supportive attitude towards alternative DSMs, the EU has shown a preference for the judicial characteristics of the WTO Dispute Settlement System. Regarding investor-state dispute settlement, before 2009, EU Member States had the competence to conclude IIAs with third states, and they were quite active and productive in this regard. Most of these IIAs provide for amicable DSMs as well as arbitration, and many cases have been heard under the latter. The Lisbon Treaty brought about a shift in competence to conclude IIAs from the EU Member States to the Union. In the three IIAs that have been concluded by the Union since 2009, a ground-breaking approach to investor-state dispute settlement- the Investment Court System (ICS) - has been adopted consistently. In the ICS, amicable DSMs, including negotiation, mediation and consultations are provided and strengthened, acting as alternative ways to have access to justice. For adjudication, the ICS establishes a standing two-tiered court-like mechanism with typical judicial characteristics. The pool of arbitrators who may be appointed to adjudicate a particular dispute in a specific case is supposed to be pre-selected by treaty parties, and the dispute settlement proceedings are to be operated with great procedural transparency. At the same time, the joint committee and treaty parties are afforded significant roles and 
mechanisms for scrutinizing claims are created in particular. It can be said that from the proposal to reform the WTO Dispute Settlement System, the gradually improved state-state DSMs in its FTAs and IIAs, to the ICS, the EU's direction is clear: it calls for building a multilateral, judicialized and permanent system that respects the international rule of law to resolve international economic disputes.

Comparing China's and the EU's practice in international investment dispute settlement, both similarities and differences can be identified. For state-state dispute settlement, China's and the EU's most recent IIAs similarly adopt a quasi-WTO dispute settlement panel proceedings model, although there are differences in the details. Regarding investor-state dispute settlement, the two parties seem to have different perceptions on the objective of the whole system and the focus among the various DSMs. China puts its emphasis on settling disputes amicably and restoring harmonious relationships, while the EU cares more about realizing the international rule of law and developing jurisprudence through the system. Such differences correspondingly resonate with their internal practice and legal cultural characteristics, especially China's traditional preference for harmony and the EU's consistent pursuit of the rule of law.

Taking a particular look at the investment legal relationship between China and the EU, before 2009, the Union only concluded general economic cooperation agreements with China. While, at the same time, by exercising their treaty negotiating and concluding competence, China and EU Member States concluded 26 IIAs. Two categories of DSMs exist in these Agreements for investment dispute settlement: one for state-state and one for investor-state dispute settlement. The provisions on state-state DSMs are quite similar to each other: compulsory consultations through diplomatic channels is required as the first step; only if this fails, disputes can be submitted to ad hoc arbitration. In contrast, the situation of investor-state DSMs is more complex. Before 1997, the IIAs are characterized by a limited acceptance of investor-state arbitration, while the IIAs signed thereafter reflect an overall acceptance of investor-state arbitration. There have only been two investor-state arbitration cases under these Agreements.

The dispute settlement system in the prospective China-EU BIT is expected to be composed of two sub-systems - one for state-state dispute settlement and one for investor-state dispute settlement. In terms of the former, it is appropriate to take the amicable resolution of disputes as the core objective. Disputes about the interpretation and application of treaty provisions should be allowed, based on which, treaty parties can raise diplomatic protection claims, interpretive claims and claims for declaratory relief. Specific DSMs within the state-state dispute settlement system can be divided into two categories - amicable and adjudicative ones. The former normally comes into play in the first place possibly through negotiation/consultations and/or mediation. A quasi-WTO dispute settlement panel proceedings mechanism serves as the general 
structure for the latter. In this regard, a problematic issue may be the composition of tribunals, for which China and the EU are likely to reach an agreement on preestablishing a roster of adjudicators while leaving some room for party autonomy in specific cases. Another issue that deserves attention is procedural transparency. For a China-EU BIT, opening the whole process of adjudication to the public may be rejected by China, but third-party participation by submitting amicus curiae briefs is likely to be acceptable and even recommended. Regarding the effect of the decisions of tribunals, incorporating a provision similar to Article 3.2 of the DSU is anticipated to be the most acceptable option, which means the rulings would only have a precedential value instead of being binding on all following cases.

Regarding the investor-state dispute settlement system under the prospective China-EU BIT, amicable DSMs should focus on settling disputes amicably, while the aim of adjudication is supposed to be the development of jurisprudence and the realization of the international rule of law. Both amicable DSMs and the adjudication process cover disputes between an investor of one treaty party and the other treaty party concerning treatment alleged to breach a provision of investment protection and to cause damages. Specific DSMs within this system can be divided into three categories: amicable mechanisms, adjudication mechanisms and local remedies. Amicable DSMs are expected to include voluntary negotiation and mediation, as well as compulsory consultations as a precondition to adjudication. In particular, five issues regarding the procedural design of mediation deserve attention: first, the basic principle of voluntariness should be adhered to; second, the qualification of potential mediators should be based upon the agreement of disputing parties, and it is appropriate to establish various standards for mediators and adjudicators; third, interest-based mediation should be prescribed as the default type of mechanism, unless disputing parties agree otherwise; fourth, it is better to keep confidentiality as a fundamental feature, unless disputing parties reach a different agreement, and; finally, in order to trigger the enforcement system, the settlement agreements reached in mediation can be incorporated into the decision-making stage of adjudication. In international adjudication, China's attitude towards the EU's ICS is expected to be modestly positive. The adjudicatory nature of the ICS would be generally acceptable, but China may argue for eliminating the system's exclusive jurisdiction to open the door for other arbitration institutions. A pre-established roster of adjudicators selected by treaty parties could be preferred by both parties, but this is suggested to come with the disputing parties' right to choose the adjudicators from the roster. In addition, a possible agreement is likely to be reached on the prospective binding force of the joint committee's treaty interpretations. Procedural transparency should be respected in general, but it is better to allow for a reasonable degree of party autonomy to prevent public disclosure. 
Furthermore, it does not seem to be necessary to have an appeal mechanism in a China-EU BIT. Regarding the relationship between local remedies and international DSMs, the prospective China-EU BIT may incorporate an article adopting the variant of the "fork-in-the-road" approach, and exhausting local remedies would not be required as a precondition to international adjudication.

Finally, the relationship between the state-state and investor-state dispute settlement systems in the prospective China-EU BIT are assessed. Diplomatic claims in statestate dispute settlement would be prohibited after investor-state dispute settlement has been resorted to by investors, while interpretive claims and declaratory relief claims should be generally allowed. At the same time, it is recommended to explicitly prohibit parallel proceedings concerning the same challenged measure. In order to preserve the system's consistency and predictability, for sequential relevant state-state dispute settlement and investor-state dispute settlement cases, it is necessary to incorporate a provision stressing the role of the dispute settlement system in providing security and predictability. Innovative combinations of state-state and investor-state dispute settlement are particularly suggested to be realized through three ways: establishing state-investor-state mediation, combining the rosters of adjudicators for state-state and investor-state dispute settlement and, granting relevant investors procedural rights in state-state dispute settlement proceedings.

It is believed that, with thoughtfully-designed procedural arrangements, the comprehensive dispute settlement system in the prospective China-EU BIT would be palatable to the treaty parties and attractive to potential users and, more importantly, may contribute to successful investment dispute settlement under, and sustainable development of, the prospective China-EU BIT. 


\section{Valorisation Addendum}

\section{Social Relevance}

In order to to predict the form the dispute settlement system in a China-EU BIT would take, this thesis examines the legal cultures of China and that of the EU, which play a vital role in their respective dispute settlement practices. By examining the effect of the legal traditions and contemporary legal ideologies of China and the EU on the current dispute settlement systems in their legal systems, and by explaining how those systems are are culturally imbedded and socially constructed, this thesis helps society understand and recognize the inter-relationship between legal culture and a country's practice in dispute settlement. Since legal cultural characteristics are closely tied to the legal system they exist in and are deeply rooted within their communities, the legal cultural analysis of the approaches of China and the EU to dispute settlement helps investors from one side to run their investment in the other side's territory. At the same time, legal culture undoubtedly also reflects relevant features of individuals in the society, so the research result of this thesis enriches the capacity to understand the underlying reasons for particular behaviours in dispute settlement of individuals from China and the EU.

\section{Target Groups}

The target groups of this thesis include legal academics, scholars and students from different legal specializations, particularly in international investment law, international trade law and dispute settlement. This thesis may also be interesting to audiences outside the academic community. First, since this thesis addresses the design of the dispute settlement system in the prospective China-EU BIT, policy makers, government officials, public policy experts and political scientists that are involved with foreign affairs, trade, commerce and investment departments would be interested in it. Second, legal practitioners, like lawyers, who want to understand the dispute settlement systems in China and in the EU, especially for foreign investment related issues, may also find some useful discussions in this thesis. Third, considering one of the innovative features of this thesis_— analyzing dispute settlement from a legal cultural perspective, this thesis is of interest to people who work in the fields of law and social science. Last but not least, the general public can also find this thesis useful in order to gain an understanding of the legal systems and general legal culture of China and the EU.

\section{Activities/Products}


The concrete products of this thesis include a presentation of the approaches taken by China and by the EU in internal and international investment dispute settlement. It also examines the legal culture in China and that in the EU regarding dispute settlement in general.

Topics related to this thesis have been presented in several conferences. The following are some of the presentations:

- "The Investor-State Dispute Settlement System in a China-EU Comprehensive Agreement on Investment: Setting a Sample of Integration", presented at the International Conference of "Multilateral Reform of Investor-State Dispute Resolution: A Dialogue among Different Approaches" in September 2019 in Xi'an, China

- 'The EU's Proposal for Investor-State Dispute Settlement: Adding 'EU-elements' to the International Rule of Law", presented at the 23rd Ius Commune Annual Conference in November 2018 in Amsterdam, the Netherlands

- "Resolving Foreign Direct Investment-Related Disputes in China's Legal System: What to Expect and How to Understand?", published in Vesna Lazić \& Steven Stuij (eds.), International Dispute Resolution-Selected Issues in International Litigation and Arbitration, Springer/Asser Press (2018), 109-127

- "Alternative Dispute Resolution for Investor-State Dispute Settlement Mechanism in a China-EU Bilateral Investment Treaty", presented at the 7th Conference of the Postgraduate and Early Professionals/Academics Network of the Society of International Economic Law (PEPA/SIEL) in April 2018 in Nicosia, Cyprus

- "Investor-State Mediation in a China-EU Bilateral Investment Treaty: Talking About Being in the Right Place at the Right Time", published in Chinese Journal of International Law (SSCI), 2018(17), 111-135

- "Promoting Mediation to Restore Trust in Investor-State Dispute Settlement", presented at the 22nd Ius Commune Annual Conference in November 2017 in Utrecht, the Netherlands

- “China's Approach to Trade and Investment Dispute Resolution: from Domestic Mechanisms to International Platforms", presented at the 2nd Annual PhD Colloquium of International Economic Law in January 2017 in Brussels, Belgium

- “Tribunals' Discretion in Realizing Transparency in Investment Arbitration”, presented at the Max Planck Institute Luxembourg Guest Forum in February 2017 in Luxembourg, Luxembourg

- "Jurisdiction Ratione Temporis in Successive International Investment AgreementsWhat Can China and Chinese Investors Learn from the Ping An Case?", published in China and WTO Review, 2017(3), 61-90 
- “Tribunals' Discretion in Realizing Transparency in Investment Arbitration”, presented at the 21st Ius Commune Annual Conference in November 2016 in Maastricht, the Netherlands

- "The Dispute Settlement Mechanisms in a China-EU Free Trade and Investment Agreement", at the 1st Annual PhD Colloquium of Young Researchers on A New Architecture for International Economic Law in April 2016 in Antwerp, Belgium

\section{Innovativeness}

This thesis is innovative in at least two respects:

First, this thesis conducts a legal cultural analysis by focusing on the manner in which the legal culture of China and that of the EU has shaped their performance in resolving investment disputes. Such an analysis is instructive in terms of predicting how it would affect the current negotiations on a China-EU BIT. In existing literature, legal cultural analysis is used more often when one legal system is being examined. The legal cultural analysis in this thesis takes into account the practice on dispute settlement by China and by the EU respectively at both internal and international levels. Specifically, it identifies both parties' legal cultural characteristics in dispute settlement as influenced by their legal traditions at the first step. It then assesses the DSMs in the internal legal systems from a legal cultural perspective. In this regard, internal dispute settlement systems can be taken as formally reflecting and confirming legal cultural characteristics. In other words, certain arrangements in DSMs reflect and help to maintain the deeply held normative values of the society. Third, a legal cultural analysis is also conducted of the performance of both parties in international investment dispute settlement.

Second, this thesis adopts and applies a systemic analysis in two aspects. First, dispute resolution is discussed by combining the practice of a state in international trade and investment in the system of international economic law. In other words, in order to understand a state's practice in the past and forecast its attitude to international investment dispute settlement in the future, a related area, international trade dispute resolution, which is another constituent of the field of international economic law, is examined for inspiration, especially for the analysis of state-state investment dispute settlement. Second, various DSMs are viewed as a whole constituting a comprehensive dispute settlement system. Different DSMs, such as negotiation, mediation, consultations, and adjudication, are normally considered and examined separately. However, a systemic view is necessary for designing a coherent and comprehensive dispute settlement system composed of various DSMs. Such a systemic approach has the potential to improve the functioning of investment dispute settlement. However, this approach seems to have been unfortunately overlooked in literature and treaty practice. 


\section{Schedule \& Implementation}

Valorisation can be achieved in the following ways. Firstly, the author will continue doing research on this topic. This thesis contributes to research regarding the possible design of the dispute settlement system in the prospective China-EU BIT based on their legal cultural characteristics and practice in dispute settlement. However, more research remains to be carried out. For example, whether and if so, how an entity's approach to resolving disputes in other relevant areas, such as international maritime law, affects the entity's performance in international economic law. The author aims to obtain an academic position in relation to international dispute resolution in a Chinese university, where there is good access to latest news and publications to facilitate the future research. At the same time, cooperation with the supervisors and other researchers will continue. Secondly, the author will seek opportunities to participate and present on the topics derived from this thesis at events that aim to communicate the up-to-date issues regarding international dispute settlement. Thirdly, some topics that are touched upon in this thesis will be further developed with the aim to publish in journals. For instance, the combination of and interaction between state-state and investor-state dispute settlement system. Fourthly, this thesis is planned to be further improved and published in a book in order to reach a wider audience. 


\section{Curriculum Vitae}

Chunlei Zhao (born in Qingdao, China in 1990) started her PhD project in 2016 at the Institute for Globalisation and International Regulation (IGIR), Faculty of Law, Maastricht University.

This project was undertaken in Maastricht University in 2016, 2018 and 2019, at the Max Planck Institute Luxembourg for International, European and Regulatory Procedural Law in 2017, and at the Max Planck Institute for Comparative Public Law and International Law in 2019 (from June to August). She has published and presented on the topic of her thesis at various workshops/conferences and in various journals. During the project, she also conducted internships at the International Centre for Settlement of Investment Dispute (ICSID) in Washington DC, the US, and the Permanent Court of Arbitration (PCA) in the Hague, the Netherlands.

She received her master's degree in Chinese Civil and Commercial law from China University of Political Science and Law (Beijing, China) in 2015, and a LLM degree in International and European Law from Hamburg University (Hamburg, Germany) in 2015. Before joining Maastricht University, she had various working experience in Chinese and foreign law firms, arbitration commissions, judicial organs, etc. She is a qualified lawyer in mainland China. 